\title{
The regulation of architects in Belgium and the Netherlands: a comparative analysis
}

Citation for published version (APA):

Schoenmaekers, S. L. T. (2010). The regulation of architects in Belgium and the Netherlands: a comparative analysis. [Doctoral Thesis, Maastricht University]. Datawyse / Universitaire Pers Maastricht. https://doi.org/10.26481/dis.20101014ss

Document status and date:

Published: 01/01/2010

DOI:

10.26481/dis.20101014ss

Document Version:

Publisher's PDF, also known as Version of record

\section{Please check the document version of this publication:}

- A submitted manuscript is the version of the article upon submission and before peer-review. There can be important differences between the submitted version and the official published version of record.

People interested in the research are advised to contact the author for the final version of the publication, or visit the DOI to the publisher's website.

- The final author version and the galley proof are versions of the publication after peer review.

- The final published version features the final layout of the paper including the volume, issue and page numbers.

Link to publication

\footnotetext{
General rights rights.

- You may freely distribute the URL identifying the publication in the public portal. please follow below link for the End User Agreement:

www.umlib.nl/taverne-license

Take down policy

If you believe that this document breaches copyright please contact us at:

repository@maastrichtuniversity.nl

providing details and we will investigate your claim.
}

Copyright and moral rights for the publications made accessible in the public portal are retained by the authors and/or other copyright owners and it is a condition of accessing publications that users recognise and abide by the legal requirements associated with these

- Users may download and print one copy of any publication from the public portal for the purpose of private study or research.

- You may not further distribute the material or use it for any profit-making activity or commercial gain

If the publication is distributed under the terms of Article $25 \mathrm{fa}$ of the Dutch Copyright Act, indicated by the "Taverne" license above, 
The Regulation of Architects in

Belgium and the Netherlands

A Comparative Analysis 


\section{(c) Copyright, Sarah Schoenmaekers Maastricht 2010}

No part of this book may be reproduced in any form, by print, photocopy, microfilm or any other means, without written permission from the author.

A commercial edition of this $\mathrm{PhD}$ thesis will be published by Intersentia in the Ius Commune Europaeum Series, No. 89 under ISBN 978-94-000-0125-1

Graphic make up Datawyse / Universitaire Pers Maastricht 


\title{
The Regulation of Architects in Belgium and the Netherlands
}

A Comparative Analysis

\author{
DISSERTATION \\ to obtain the degree of Doctor at the Maastricht University, \\ on the authority of the Rector Magnificus, Prof. dr. G.P.M.F. Mols \\ in accordance with the decision of the Board of Deans, \\ to be defended in public \\ on Thursday 14 October 2010 at 12:00 hours
}

by

Sarah Schoenmaekers 


\section{Supervisors}

Prof. dr. M.G. Faure

Prof. dr. H.E.G.S. Schneider

Assessment Committee

Prof. dr. E. Vos (Chair)

Prof. dr. A.I. Ogus (University of Manchester)

Dr. N.J. Philipsen 


\section{ACKNOWLEDGEMENTS}

When I studied at the European Law School of Maastricht University I learnt to compare different national legal systems and to analyze them within a broader European context. I was determined to use this knowledge in practice and to become a fully fledged lawyer in my home state Belgium. Even though I was aware that I would have to take an aptitude test before I would be able to register, it was only by practising that I discovered that the exercise of the profession in both countries differed. I wondered whether this would also be the case for other professions which were not directly dependent upon the precise content of laws and regulations. I never imagined that a few years later I would have written a $\mathrm{PhD}$ comparing the regulation of architects in Belgium and the Netherlands.

This manuscript is the result of many personal efforts. However, it would never have been possible without the guidance of my supervisors Prof. Dr. Michael Faure and Prof. Dr. Hildegard Schneider. Even though I was for most of the time an external researcher, they have always kept a close eye on my progress. They are a great source of inspiration and I want to thank them for their criticism and assessments of my writings. I am particularly grateful for the freedom they gave me in conducting this research.

I also want to express my deepest gratitude towards the members of my reading committee, Prof. Dr. Ellen Vos, Prof. Dr. Anthony Ogus and Dr. Niels Philipsen, for their willingness to read my work and their useful comments. I want to thank Niels for his detailed feedback on an earlier draft.

I am grateful to Prof. Dr. Lode Vereeck of Hasselt University who was the supervisor of my master thesis and never stopped encouraging me in pursuing my goals. I want to thank him for the motivation and support.

I would like to thank all my colleagues of the Faculty of Law, in particular the department of International and European law. I am particularly indebted to Dr. Stefan Weishaar. He was the first one who filled my mind with the idea of writing a PhD. I am grateful for the many hours we spent in the library where he taught me, with much enthusiasm, important insights in macro- and microeconomic theory, even before this 
project started. I am also indebted to Mrs. Cathérine Burdorf for commenting upon my French summary.

My 'confraters' of the law firm Omnius should also be mentioned for the interest they have shown in my research and their support. I am thankful that they have given me the opportunity to continue working on the field while also pursuing an academic career.

I am very grateful to my paranymphs Ton Roseboom and Koenraad Vanschoren. Since the beginning of this project they believed in me and have continued supporting and reassuring me ever since. They are truly the best friends ever.

Finally and most importantly I want to thank my parents and my partner Stefan. Even though they were often confronted with someone who had 'no time' or was just 'too busy', they never stopped filling my world with love and joy. Words cannot express my sincerest gratitude, appreciation and love for them. Thank you opa for your positive spirit and for your famous and inspriring slogan: 'Even if you lose a battle, that doesn't mean you lose the war'. With this book I have won a battle. I'm looking forward to the next one. 
When we mean to build,

We first survey the plot, then draw the model.

And when we see the figure of the house,

Then must we rate the cost of the erection,

Which if we find outweighs ability,

What do we then but draw anew the model

In fewer offices, or at least desist

To build at all?

William Shakespeare,

King Henry the Fourth, Part II

(Lord Bardolph at I, iii) 



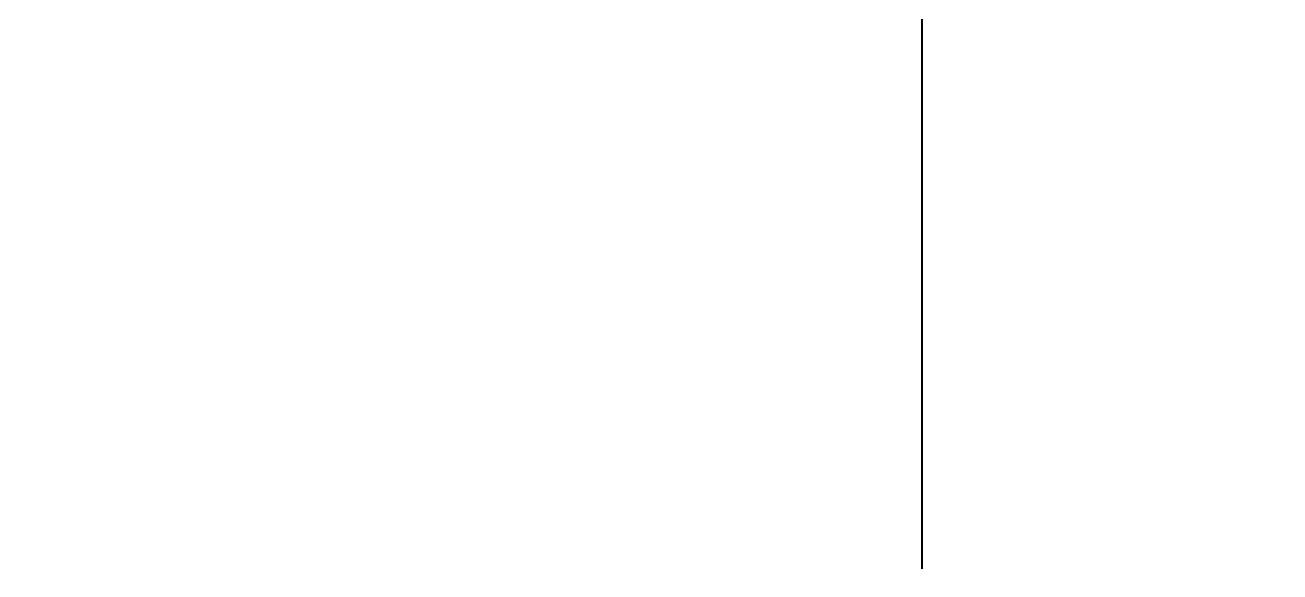

\section{OUTLINE CONTENTS}

ACKNOWLEDGEMENTS................................................................................... V

LIST OF ABBREVIATIONS ……………………………………………………….XIX

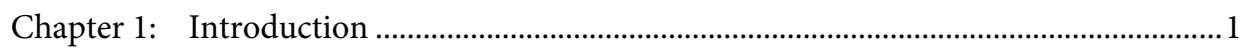

Chapter 2: The Architect.............................................................................................13

PART I: THE REGULATION OF ARCHITECTS IN THE EUROPEAN UNION.....43

Chapter 3: Public regulation of architects at European Union level.................................45

PART II: THE REGULATION OF ARCHITECTS ON A NATIONAL LEVEL..........201

Chapter 4: The Regulation of Architects in The Low Countries ....................................203

A. THE REGULATION OF ARCHITECTS IN BELGIUM ..............................................207

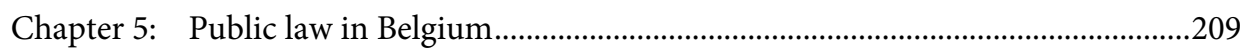

Chapter 6: Contract law in Belgium ............................................................................261

B. THE REGULATION OF ARCHITECTS IN THE NETHERLANDS ..........................303

Chapter 7: Public Law in the Netherlands...................................................................305

Chapter 8: Contract law in the Netherlands....................................................................337

C. THE REGULATION OF ARCHITECTS IN BELGIUM VS. THE

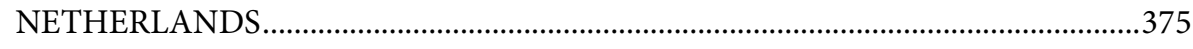

Chapter 9: Comparison of the situation of architects in both countries........................377 
Chapter 10: Comparison of the situation of Dutch and Belgian architects with other EU architects

PART III: ECONOMIC ANALYSIS OF THE REGULATION OF ARCHITECTS.....393

Chapter 11: The architectural profession: an economic approach 395

Chapter 12: Final conclusions

RESUMÉ 507

BIBLIOGRAPHY .513

CURRICULUM VITAE.. 541

IUS COMMUNE EUROPAEUM 543 

2.2.1. Introduction

2.2.2. Third-country national family members of EU citizens who made use of their free movement rights: Directive 2004/38/EC

2.2.3. Family members of Union citizens who have not made use of their free movement rights

2.2.4. Association and Partnership agreements............................................................... 72

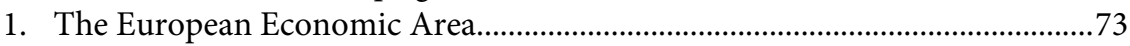

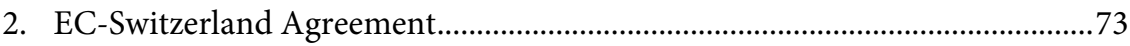

3. The EEC-Turkey Association Agreement.................................................................74

4. Partnership and Cooperation Agreements with Russia and other ex-

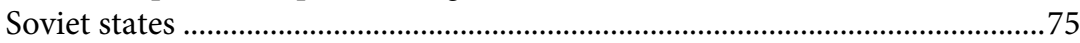

5. The Euro-Mediterranean Association Agreement ............................................76

6. The ACP states and Latin American countries .................................................76

7. Stabilization and Association Agreement with the Balkan states ......................77

2.2.5. Non-privileged third-country nationals: Directives on legal migration of

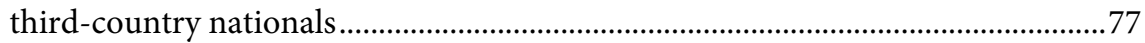

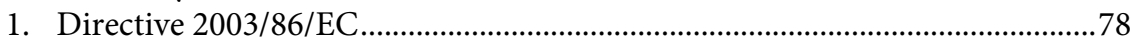

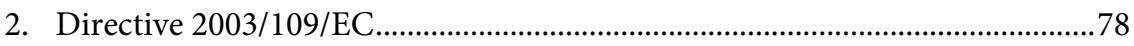

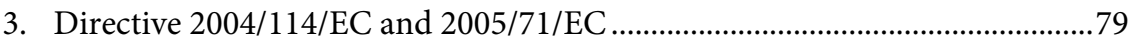

4. Directive 2009/50/EC..............................................................................................

5. Draft Directive on a single permit and a common set of rights.........................81

3. Free movement of architects through the recognition of professional

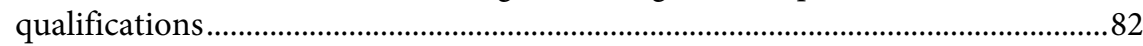

3.1. Architects holding the nationality of an EU Member State...................................83

3.1.1. Vertical approach towards the recognition of architectural qualifications ...........85

3.1.2. Horizontal approach towards the recognition of professional qualifications.......89

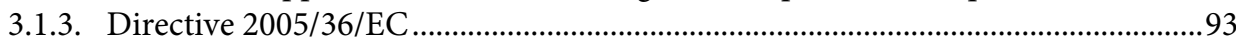

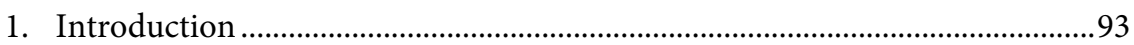

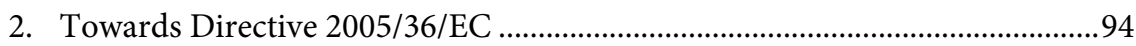

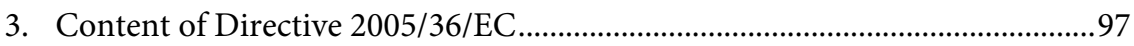

a. General provisions (Title I) .......................................................................98

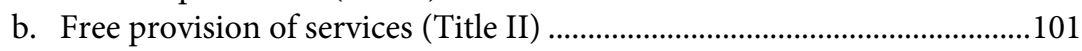

c. Freedom of establishment (Title III) .............................................................105

d. Procedure and consequences of recognition .............................................115

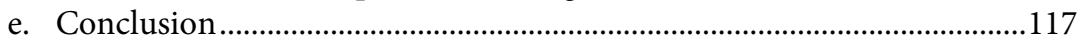

3.2. Architects not holding the nationality of an EU Member State............................121

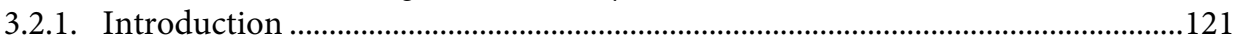

3.2.2. Third-country national family members of EU citizens who made use of their free movement rights: Directive 2004/38/EC ........................................................121

3.2.3. Family members of Union citizens who have not made use of their free movement rights

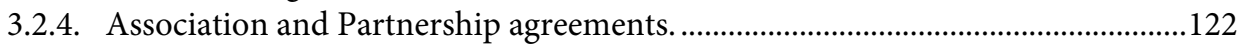

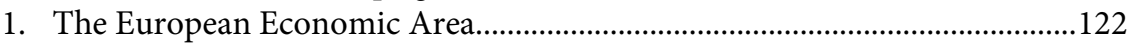

2. EEC-Switzerland Agreement ........................................................................123

3. The EEC-Turkey Association Agreement.....................................................123 
4. Partnership and Cooperation Agreements with Russia and other exSoviet states

5. The Euro-Mediterranean Association Agreements.............................................124

6. The ACP states Latin American countries.......................................................124

7. Stabilization and Association Agreement with the Balkan states ...................124

3.2.5. Non-privileged third-country nationals: Directives on legal migration of third-country nationals.

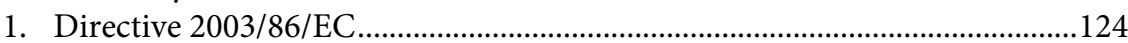

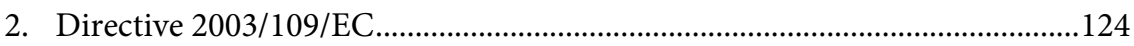

3. Directive 2004/114/EC and 2005/71/EC ............................................................125

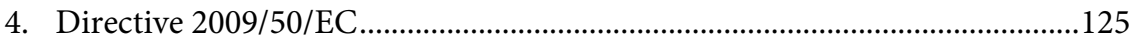

5. Draft Directive on a single permit and a common set of rights.....................125

3.3. Case law on the recognition of architectural qualifications...................................126

4. Directive 2006/123/EC on services in the internal market.....................................140

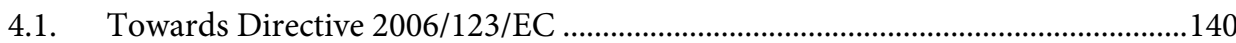

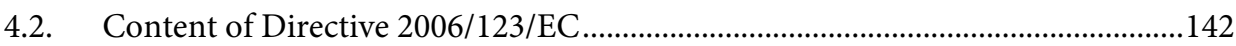

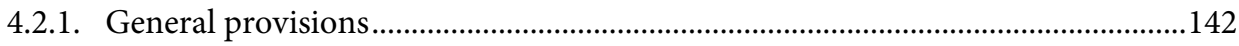

4.2.2. Administrative simplification ................................................................................. 143

4.2.3. Measures relating to the freedom of establishment for service providers ............145

4.2.4. Measures relating to the free provision of services ...............................................146

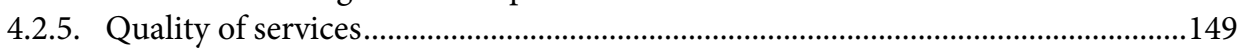

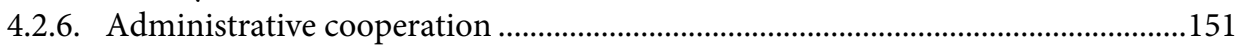

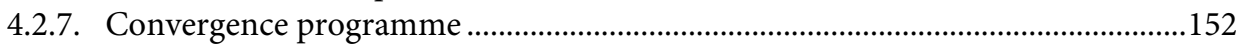

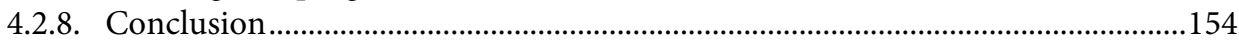

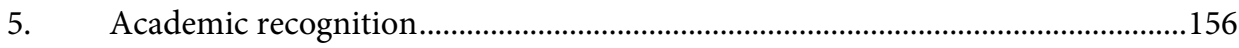

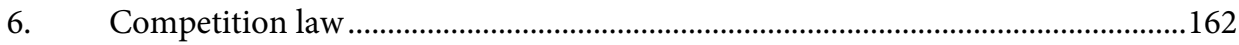

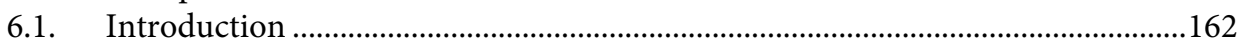

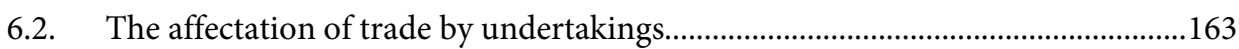

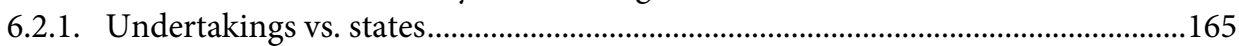

6.2.2. Agreements - Decisions - Concerted practices ..................................................168

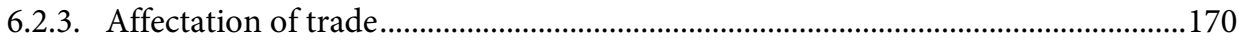

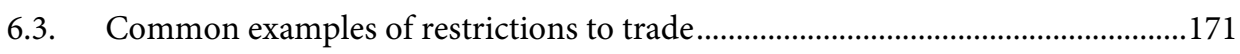

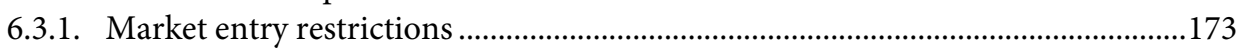

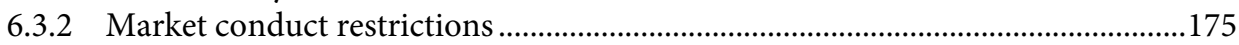

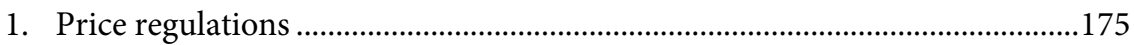

a. Fixed prices ................................................................................................... 175

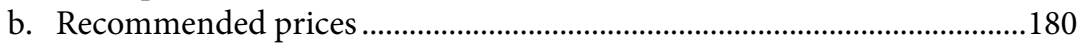

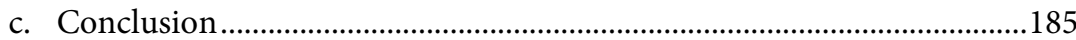

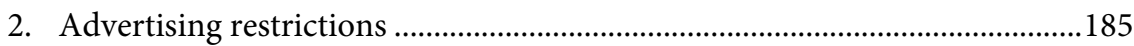

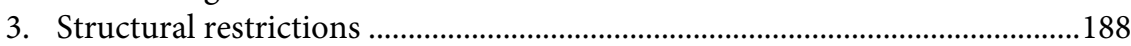

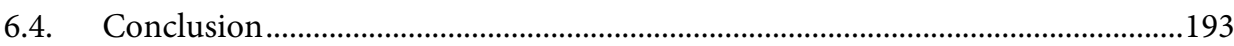

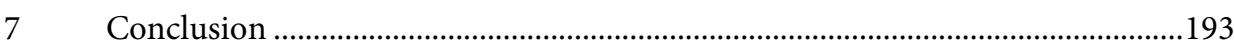




\section{PART II: THE REGULATION OF ARCHITECTS ON A NATIONAL}

\section{LEVEL}

CHAPTER 4: THE REGULATION OF ARCHITECTS IN THE LOW COUNTRIES.203

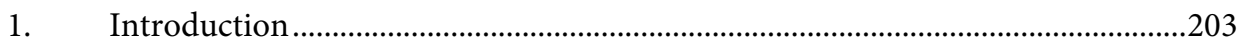

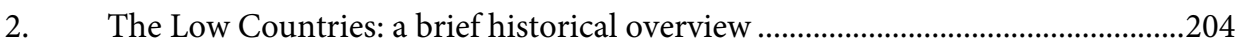

A.THE REGULATION OF ARCHITECTS IN BELGIUM …............................................207

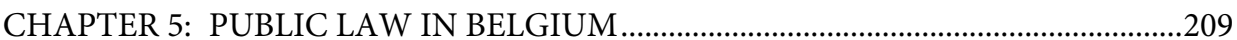

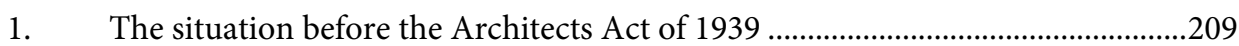

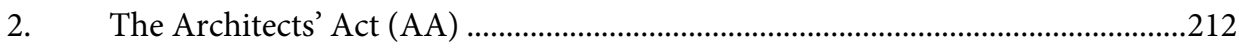

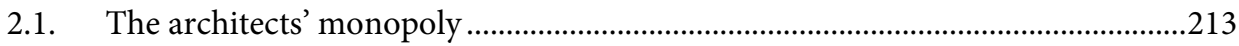

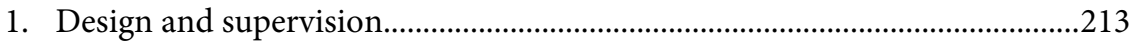

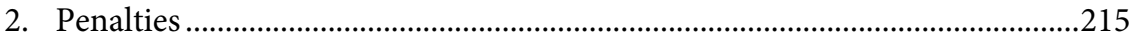

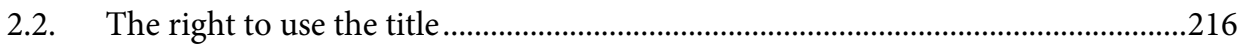

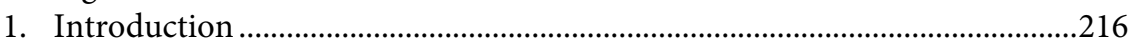

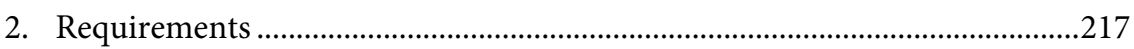

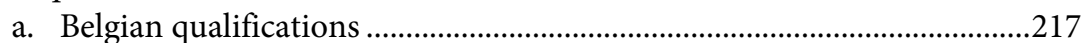

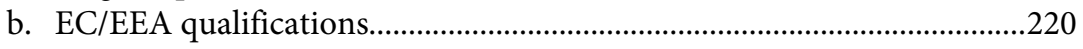

c. Non EC/EEA qualifications......................................................................222

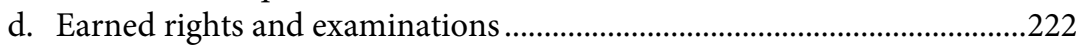

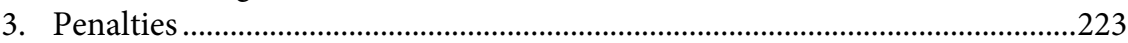

4. Academic titles...................................................................................................22

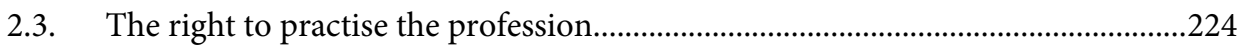

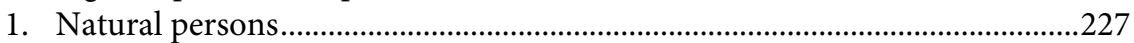

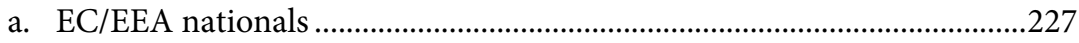

b. Non EC-EEA nationals ..................................................................................2229

2. Natural persons practising the profession within the framework of a company or association ..............................................................................2230

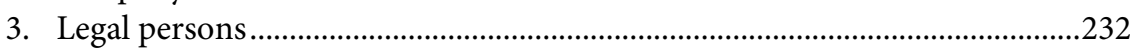

a. Situation before the Laruelle Act .............................................................232

b. The Laruelle Act.....................................................................................233

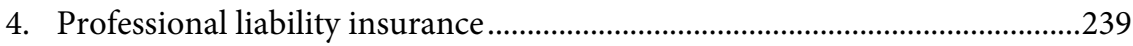

a. Deontological insurance obligation .........................................................239

b. Insurance obligation laid down by the Laruelle Act .................................242

c. The Royal Decree Laruelle............................................................................247

3. The Architects' Order and the Architects' Order Act ............................................250

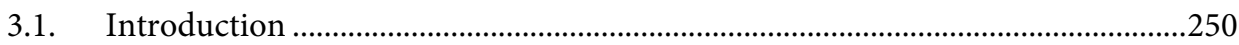

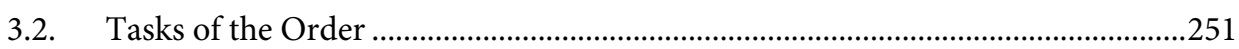

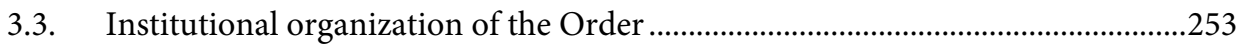

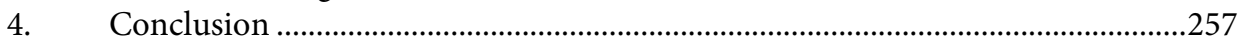




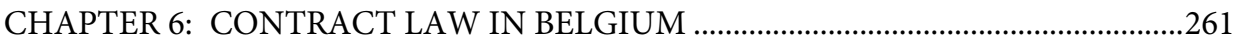

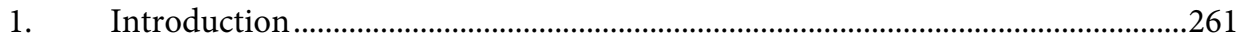

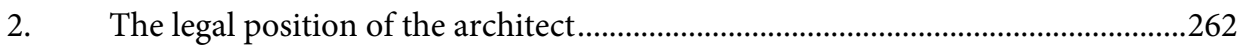

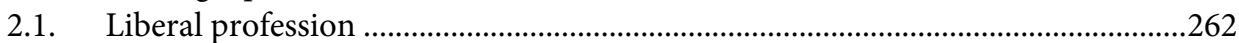

2.2. The legal classification of the architectural contract................................................263

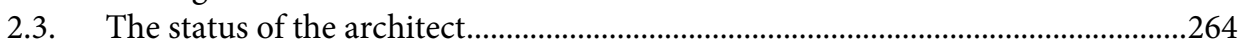

2.3.1. The contract of the self-employed architect: rent of labour .................................265

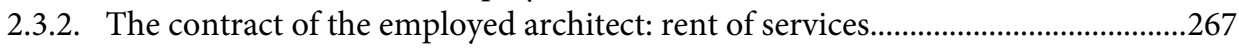

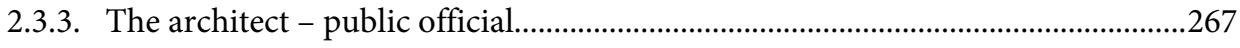

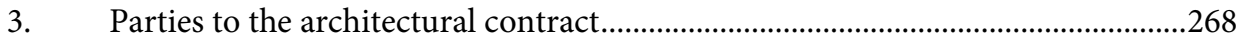

4. Content of the architectural contract ....................................................................271

4.1. Obligations of the architect ...................................................................................2. 273

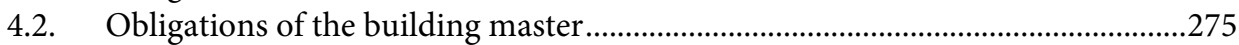

5. Liabilities and risks of the architect and the entrepreneur ....................................280

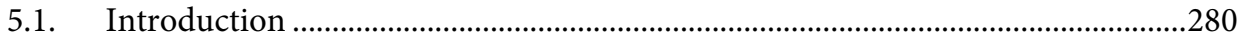

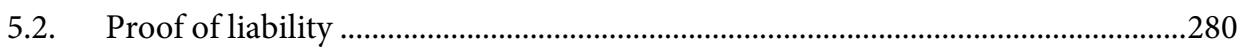

5.3. Liability before and after reception of the building works.....................................285

5.3.1. Liability before the reception of the building works ..............................................287

5.3.2. Liability after reception of the building work ......................................................28

1. In principle: no liability of the architect/entrepreneur after reception..........288

2. Exception 1: Hidden defects ........................................................................291

3. Exception 2: Perishing of the building due to serious defects........................293

a. Article 1792 CC:

b. Article 2270 CC ...........................................................................................299

4. Exception 3: Deceit..........................................................................................299

5.4. The liability of the architect for subordinates and sub-entrepreneurs..................300

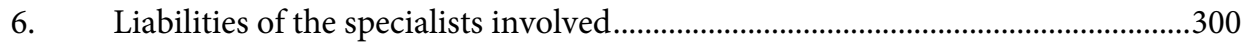

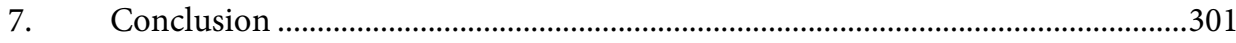

B. THE REGULATION OF ARCHITECTS IN THE NETHERLANDS .........................303

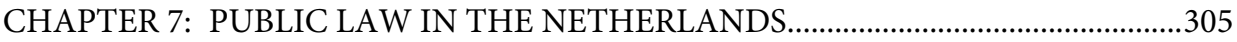

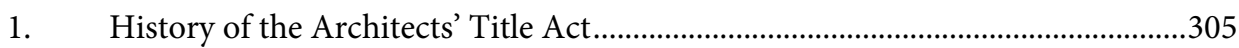

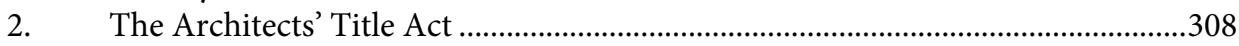

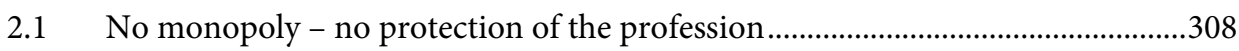

2.2. Title protection: natural persons and legal persons ...............................................309

2.2.1. Registration by the Foundation Bureau Architect's Register ..................................312

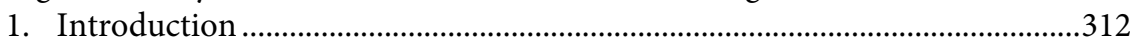

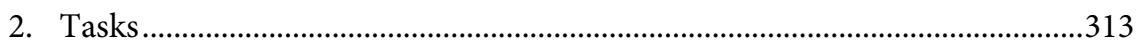

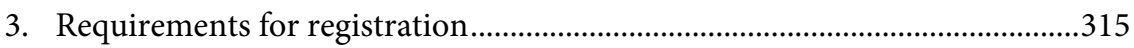

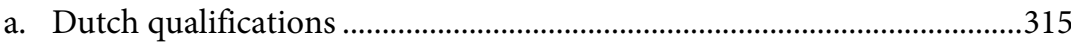

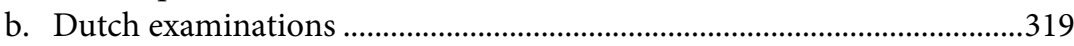

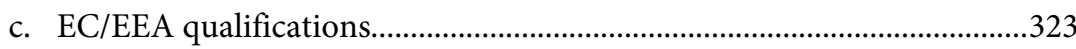

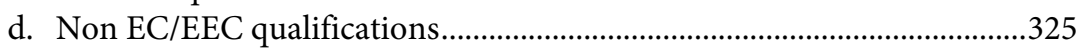




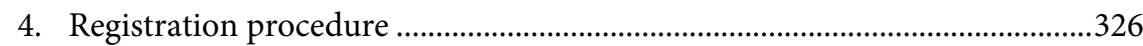

2.2.2. Turning the Architects' Title Act into a more powerful quality instrument........328

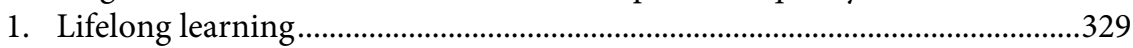

2. Two year period of practical experience ….........................................................329

3. Professional liability insurance .............................................................................330

4. Complaint procedures and a deontological code.............................................331

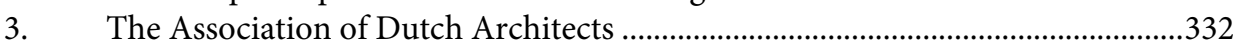

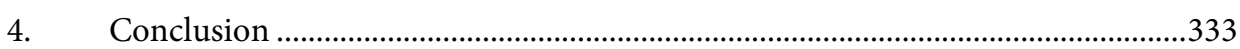

CHAPTER 8: CONTRACT LAW IN THE NETHERLANDS ..........................................337

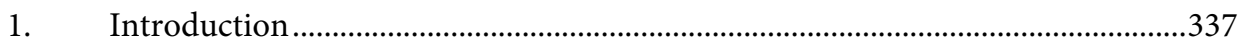

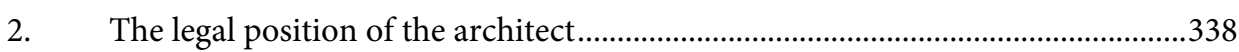

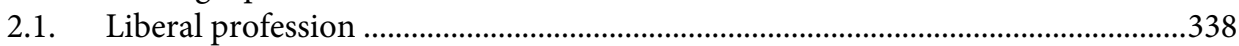

2.2. The legal classification of the architectural contract.............................................338

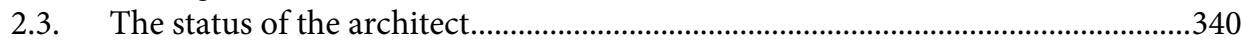

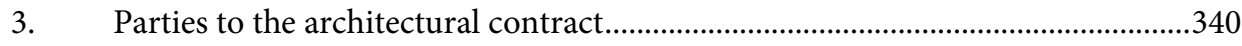

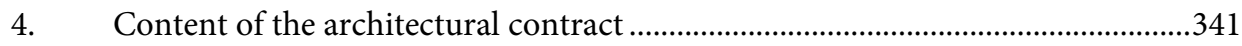

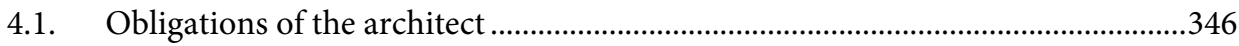

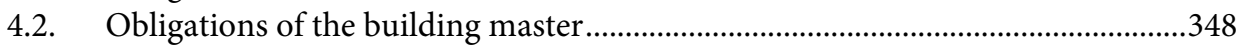

5. Liabilities and risks of the architect and the entrepreneur ...................................350

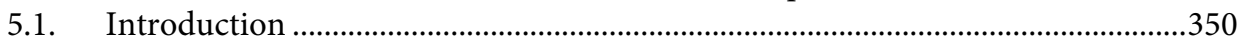

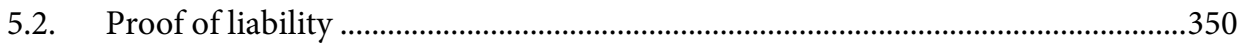

5.3. Liability before and after reception of the building work .....................................353

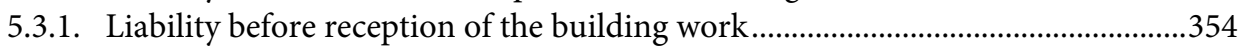

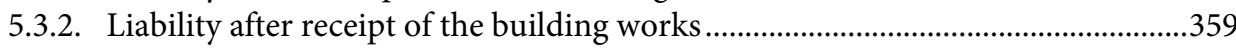

1. In principle: the architect can be held liable for five years after

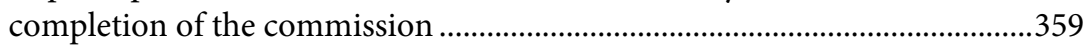

2. The entrepreneur is in principle not liable for defects after delivery of the

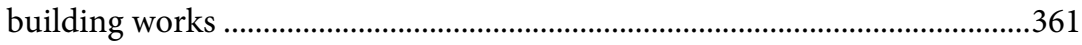

3. The entrepreneur is liable for hidden defects after delivery .............................365

4. The entrepreneur is liable after delivery for damage caused by the perishing of the building due to serious defects..................................................369

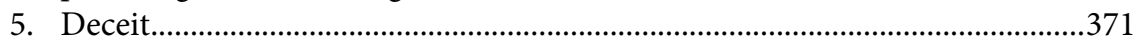

5.4. The liability of the architect for subordinates and sub-entrepreneurs..................372

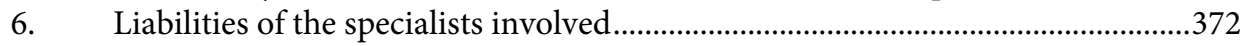

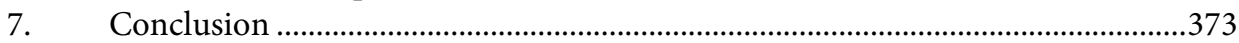

C. THE REGULATION OF ARCHITECTS IN BELGIUM VS. THE NETHERLANDS.

CHAPTER 9: COMPARISON OF THE SITUATION OF ARCHITECTS IN

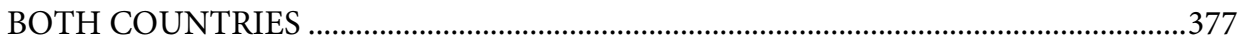

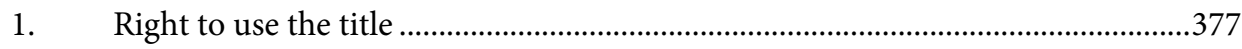

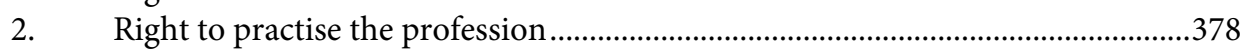

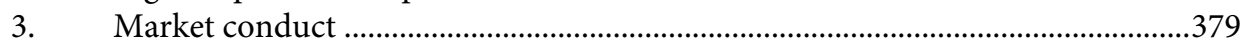




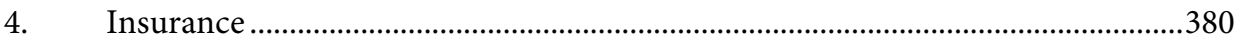

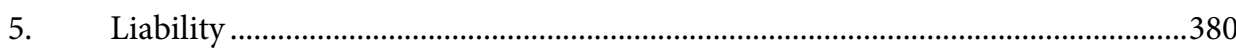

D. REGULATION OF ARCHITECTS IN OTHER EU MEMBER STATES...................383

CHAPTER 10: COMPARISON OF THE SITUATION OF DUTCH AND BELGIAN ARCHITECTS WITH OTHER EU ARCHITECTS ...........................................385

1. Studies conducted by the OTB Research Institute for Housing, Urban and

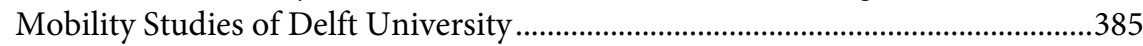

2. Study conducted by the Institute for Advanced Studies in Vienna .......................389

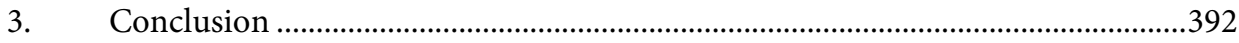

\section{PART III: ECONOMIC ANALYSIS OF THE REGULATION OF} ARCHITECTS.

\section{CHAPTER 11: THE ARCHITECTURAL PROFESSION: AN ECONOMIC}

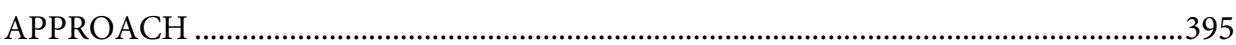

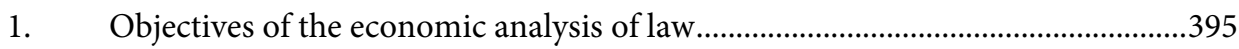

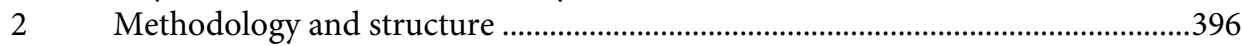

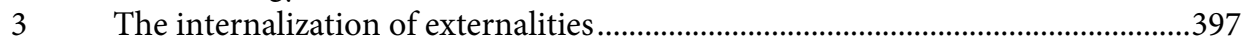

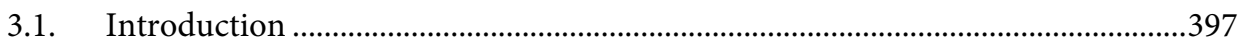

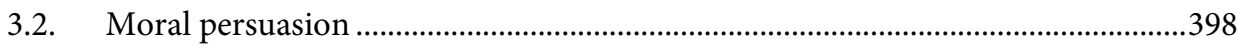

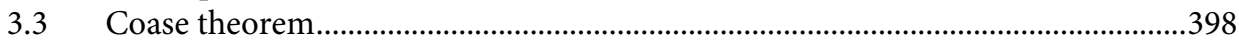

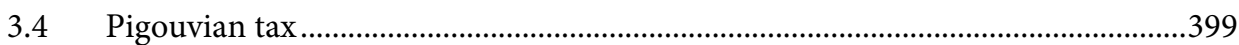

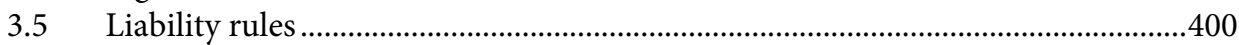

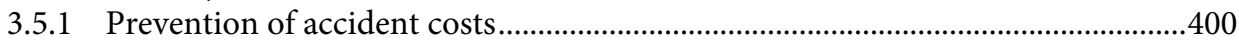

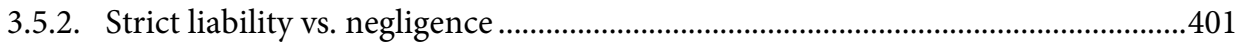

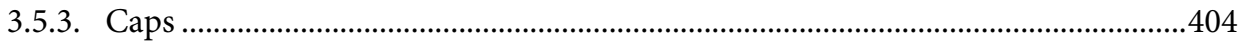

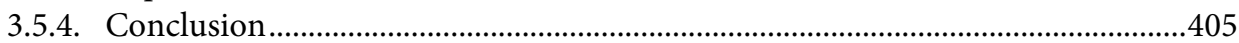

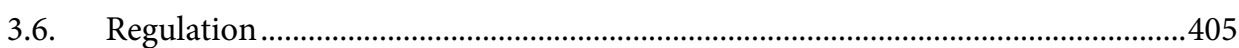

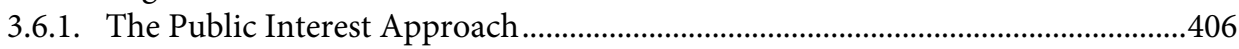

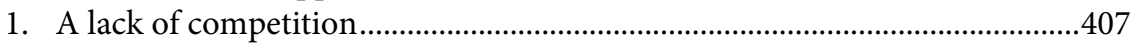

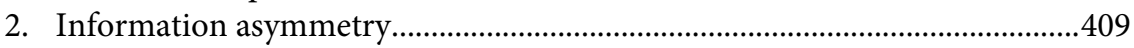

a. Experienced clients vs. professionals ......................................................409

b. Adverse selection ........................................................................................4 411

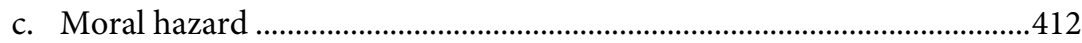

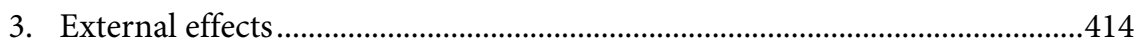

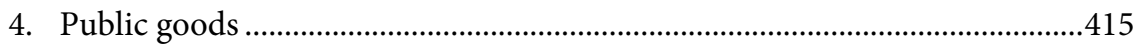

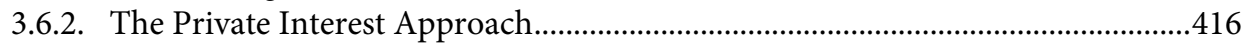

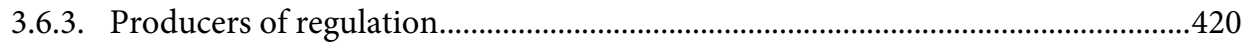

1. Public regulation vs. self-regulation...............................................................420

a. Public interest arguments in favour of self-regulation ..............................421

b. Private interest arguments against self-regulation ......................................422

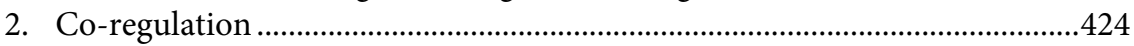

3. Competitive self-regulation..........................................................................425 
4. Authors of regulation in Belgium and the Netherlands.................................426

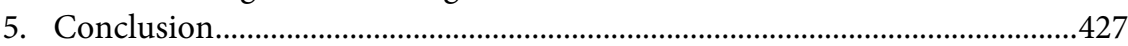

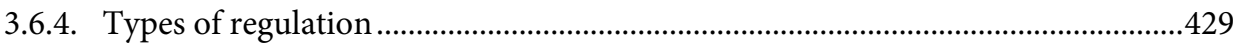

1. Market entry regulation...............................................................................429

a. Educational requirements, registration or membership of a professional association, nationality and establishment requirements, numerus clauses, etc..............................................................429

b. Information regulation and quality standards.........................................429

c. Reserved rights: certification and licensing..................................................431

d. Market entry regulation in Belgium and the Netherlands ........................433

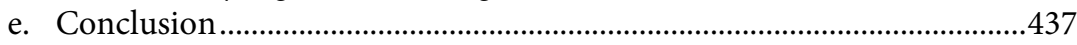

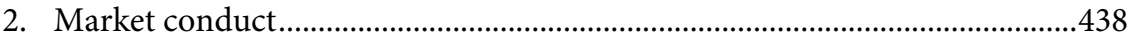

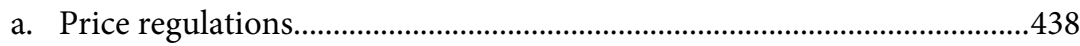

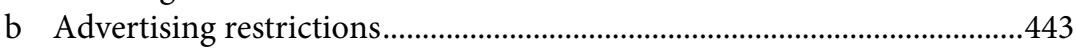

c. Structural restrictions................................................................................446

d. Market conduct regulation in Belgium and the Netherlands ..................448

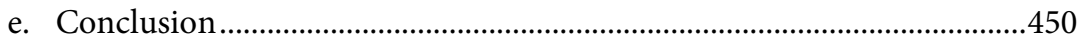

3. Findings of the European Commission..........................................................451

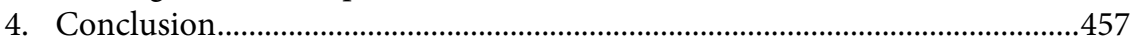

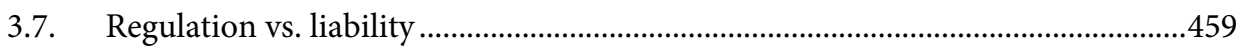

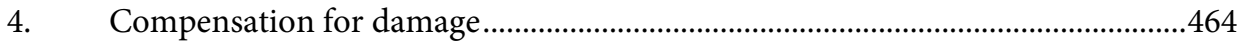

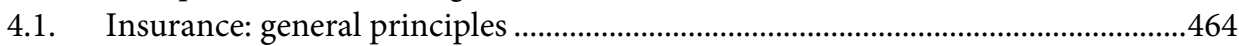

4.2. Professional liability insurance in Belgium and the Netherlands ........................466

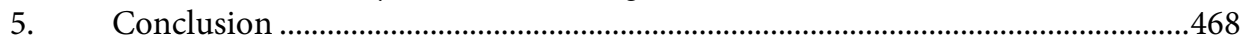

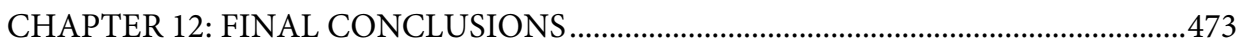

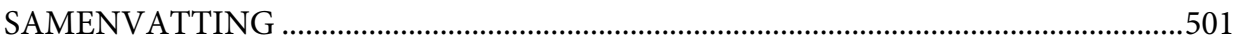

RÉSUMÉ

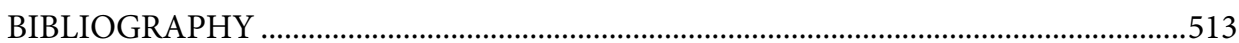

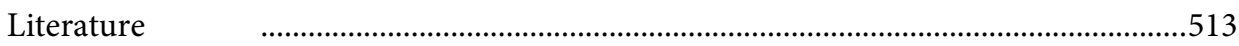

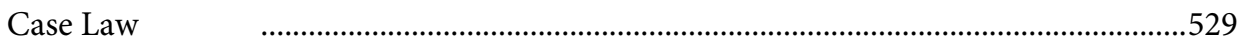

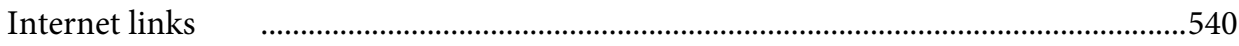

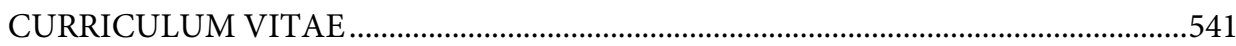

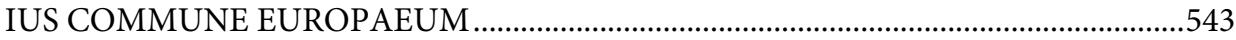




\section{LIST OF ABBREVIATIONS}

AA

ACE

ACP

A.J.T.

Ann.dr.Lg.

Ann.Parl.

A.P.M.

Arr.Cass.

Arr. GwH

Arr.R.v.St.

$\mathrm{AO}$

Arob

ATA

AVA

Ba-Ma

B.J.

BNA

BR

B.R.H.

BUA

Bull.

BVA

Cah.dr.immo.

CC

CEDIC

CEPES

DCFR

Doc.Parl.

EAAE

EC
Architects Act

Architects' Council of Europe

African, Carribean and Pacific countries associated with the

Community by the Lomé Convention

Algemeen Juridisch Tijdschrift

Annales de droit de Liège

Annales Parlementaires

Administration publique (Mensuel): revue du droit public et des sciences administratives

Arresten van het Hof van Cassatie

Arresten Grondwettelijk Hof

Verzameling van arresten van de Raad van State

Architects' Order Act

Administratieve rechtspraak overheidsbeslissingen

Architects' Title Act

Algemene voorwaarden voor aannemingen in het bouwbedrijf

Bachelor-Master

La Belgique judiciaire: gazette des tribunaux belges et étrangers

Bond der Nederlandse Architecten

Bouwrecht

Belgische rechtspraak in handelszaken

Beroepsunie der Architecten

Bulletin des arrêts de la Cour de Cassation

Bond van Vlaamse Architecten

Cahiers de droit immobilier

Civil Code

Comité Européen des Ingénieurs Conseils

Centre européen pour l'enseignment supérieur

Draft Common Frame of Reference

Documents parlementaires

European Association of Architectural Education

European Community 


\begin{tabular}{|c|c|}
\hline ECJ & Court of Justice of the European Union \\
\hline ECR & European Court Reports \\
\hline EEA & European Economic Area \\
\hline EEC & European Economic Community \\
\hline EFTA & European Free Trade Association \\
\hline ECHR & European Court of Human Rights \\
\hline ENHSA & European Network of Heads of School of Architecture \\
\hline ENIC & European Network of Information Centres \\
\hline EU & European Union \\
\hline FQS & Flexible quality standard \\
\hline FYROM & Former Yugoslavian Republic of Macedonia \\
\hline GATS & General Agreement on Trade in Services \\
\hline Gedr. St. & Gedrukt Stuk \\
\hline GMA & General Measure of Administration \\
\hline GURI & Gazzetta Ufficiale della Repubblica Italiana \\
\hline HEI & Higher Education Institutions \\
\hline IHS & Institut für Höhere Studien \\
\hline JAR & Jurisprudentie Arbeidsrecht \\
\hline Jb.Hand.Med. & Jaarboek handelspraktijken en mededinging \\
\hline J.C.B. & Jurisprudence commerciale de Belgique \\
\hline J.C.Fl. & Jurisprudence commerciale des Flandres \\
\hline J.L. & Jurisprudence de Liège \\
\hline J.L.M.B. & Revue de jurisprudence de Liège, Mons et Bruxelles \\
\hline J.T. & Journal des Tribunaux \\
\hline J.T.T. & Journal des tribunaux du travail \\
\hline LA & Laruelle Act \\
\hline Limb.Rechtsl. & Limburgs Rechtsleven \\
\hline MDP & Multi-disciplinary partnerships \\
\hline MQS & Minimum quality standard \\
\hline NAFTA & North American Free Trade Agreement \\
\hline NARIC & National Academic Recognition Information Centre \\
\hline NAV & Nationale Architectenvereniging \\
\hline NJ & Nederlandse jurisprudentie \\
\hline N.J.W. & Nieuw Juridisch Weekblad \\
\hline NR & Nieuwe Regeling 2005 \\
\hline OJ & Official Journal \\
\hline ONRI & Organisatie van advies- en ingenieursbureaus \\
\hline OTB & Onderzoeksinstituut technische bestuurskunde \\
\hline Pas. & Pasicrisie belge \\
\hline PEL SC & Principles of European Law on Service Contracts \\
\hline PPP & Purchasing Power Parity \\
\hline PSC & Points of Single Contact \\
\hline R.A.B.G. & Rechtspraak Antwerpen Brussel Gent \\
\hline R.A.C.E. & Receuil des arrêts du Conseil d'État \\
\hline R.C.J.B. & Revue critique de jurisprudence belge \\
\hline
\end{tabular}


RDL Royal Decree Laruelle

Rev.dr.Commun. Revue de droit communal

Rev.not.b. Revue du notariat belge

RGAR Revue générale des assurances et des responsabilités

R.J.D.A. Recueil de jurisprudence du droit administratif et du Conseil d'état

R.J.I. Res et Jura Immobilia

R.R.D. Revue régional de droit

Rvdw Rechtspraak van de week

R.W. Rechtskundig Weekblad

SAF Sociétés des Architectes Francophones

SIA State Insurance Act

SIM Services in the Internal Market

SLIM Simpler Legislation for the Internal Market

SR Standaardvoorwaarden Rechtsverhouding Opdrachtgever-Architect

Stb. Staatsblad

Stcrt Staatscourant

T.Aann. Tijdschrift voor aannemingsrecht

T.App. Tijdschrift voor appartements- en immorecht

T.B.B.R. Tijdschrift voor Belgisch burgerlijk recht

T.B.H. Tijdschrif voor Belgisch handelsrecht

T.B.O. Tijdschrift voor bouwrecht en onroerend goed

T.B.P. Tijdschrift voor bestuurswetenschappen en publiekrecht

TEU Treaty on the European Union

TFEU Treaty on the Functioning of the European Union

TOGOR Tijdschrift voor onroerendgoedrecht

T.R.V. Tijdschrift voor rechtspersoon en vennootschap

T.S.R. Tijdschrift voor social recht

TU Technical University

TvA Tijdschrift voor arbitrage

UAV Uniforme administratieve voorwaarden voor de uitvoering van werken

UAV-GC Uniforme administratieve voorwaarden voor de uitvoering van werken - geïntegreerde contracten

UIA Union Internationale des Architectes

UK United Kingdom

UNESCO United Nations Educational, Scientific and Cultural Organization

UPA Union Royale Professionnelle des Architectes

VROM Volkshuisvesting, Ruimtelijke Ordening en Milieubeheer

W Weekblad voor het recht 



\section{Chapter 1}

\section{INTRODUCTION}

\section{Background to the research project}

In today's world, states worldwide have become more and more economically interdependent due to the increasing volume and variety of cross-border transactions in goods and services, free international capital flows, and the increasingly rapid and widespread diffusion of technology. The International Monetary Fund has called this phenomenon 'economic globalization'. 'The concept of globalization refers to a complex series of economic, social, technological, cultural and political changes that have increased interdependence, integration and interaction between people and companies in disparate locations. The term 'liberalization' on the other hand refers to the unimpeded flow of products between economic jurisdictions. This has led to the specialization of nations in terms of exports, and the pressure to end protective tariffs and other barriers to trade. Liberalization does not only concern the free movement of goods and capital, but also the free movement of persons and the freedom of establishment, the two latter being applicable to architects.

In the $20^{\text {th }}$ Century, the impact of globalization in the field of architecture is reflected by the impact of the international style of the 1930s, when many architects designed buildings all over the world: Le Corbusier in India, Kahn in Bangladesh, Foster in Japan, Wright in Japan, Utzon in Australia, etc. ${ }^{2}$ The international style was based on systematization and standardization, mass production, economies of scale, functional logic and aesthetic composition devoid of both ornament and sentiment. Given a similar functional program, the design of a building in southern Asia could be similar to one in South America. For several decades after World War II, this style greatly influenced the design of office buildings, schools, hospitals, laboratories and multifamily housing. ${ }^{3}$ The common characteristics are easy to identify: a radical simplification of form, a rejection of ornament, the adoption of glass, steel and concrete as preferred materials, the trans-

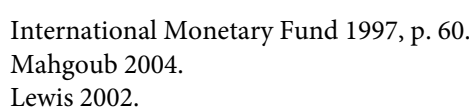


parency of buildings and therefore of the construction (called the honest expression of structure), the acceptance of industrialized mass-production techniques and the machine aesthetic, acceptance of the automobile, design decisions that logically support the function of the building, and a vague but exciting sense of the future. ${ }^{4}$

Nevertheless, architects have been practicing internationally for centuries. The ancient Romans established the first example of global architectural hegemony, spreading their ideals across the empire. ${ }^{5}$ However, an extremely rapid expansion in the provision of cross-border services only started in the early 1990s. This was generated in large part by the globalization of businesses, investments and interests of what had historically been domestic clients, but also by the increasing use of architectural competitions to select and award major public and private commissions. ${ }^{6}$ In this way architects have domestic projects with international clients while they are increasingly becoming involved in European or international projects as well.

Notwithstanding the process of globalization and the creation of the European Union which contributed significantly to the liberalization of trade and the free moment of professionals, the $20^{\text {th }}$ Century has also been characterized by nation states imposing all sorts of requirements on 'foreign' products and professionals before they are allowed to enter their territory. In this regard, restrictions were often imposed on architects because of their (lack of) professional qualifications and the absence of uniformity with regard to architectural regulations. In several EU states anyone can perform the work of an architect while the use of the title is reserved for qualified professionals. In other states the title, as well as the practice of the profession, is regulated. When one is considered to be a qualified professional also differs. Some states require a degree in architecture while other states only demand some years of training in an architectural office followed by an examination. Some countries do not require any qualifications whatsoever, and only demand that the building accords with the building specifications. In addition, the professions themselves have created a substantial number of rules with which their members have to comply. Next to these limitations on the entry to the profession and with regard to professional conduct, architectural liabilities and responsibilities also differ. It follows that once a professional wants to provide services outside his/her national territory, s/he is often confronted with a whole set of different rules which are liable to hinder his/her free movement and to restrict competition as well.

This thesis discusses the free movement rights of architects as laid down in the Treaty on the Functioning of the European Union, and as interpreted by the Court of Justice of the European Union, by studying secondary EU legislation which contains rather technical requirements that need to be met before architects are allowed to work in another EU state. It aims to determine whether architects who meet all these requirements are really free to engage in architectural activities in another Member State, or whether they

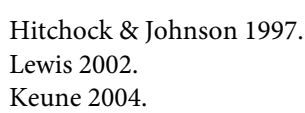


might still be hampered by all sorts of other requirements which are not covered by EU legislation. In addition to a high level of public regulation, free professionals are generally subject to self-regulation by professional associations which may not only limit the entry to the profession, but also the competition within the profession itself and the competition with other professions (conduct regulation). Furthermore, private law principles and obligations arising from contract law may also discourage architects from working outside their familiar national territory. On the other hand however, (self- and liability rules may also improve the quality of the services provided by the architect.

On a national level, this thesis specifically examines the regulation of architects in two neighbouring countries: Belgium and the Netherlands. Not only do I discuss the public law requirements which need to be fulfilled before one can enter the profession, but also the private law responsibilities and liabilities of architects in the event that a building has a defect. The reason why I have chosen these two states lies in the fact that the regulation of the architectural profession in both countries differs to a large extent as far as the use of the title and the practice of the profession is concerned. Moreover, the contractual liability period which is, in principle, laid down in the Civil Codes of both states, varies considerably. Since both countries used to be part of the United Kingdom of the Netherlands after the French domination which introduced the Napoleonic Code and since even today the Belgian Civil Code is still a direct translation/copy of the Code Napoleon of 1804 (although it contains several amendments) which also forms the basis of the new Dutch Civil Code, this development is of great interest.

Since the tasks performed by architects are complicated, and since their responsibilities are substantial, it is important that their designs provide for safe and secure buildings. States and professional associations argue that regulations are needed to safeguard quality since the architectural market is characterized by market failure. ${ }^{7}$ This is the public interest approach towards regulation. The private interest approach, on the other hand, indicates that regulation is merely a result of rent-seeking behaviour by individuals or associations who want to maximize their profits. ${ }^{8}$ In this regard I will examine whether there is indeed market failure in the architectural market which may justify the current regulations.

It should be noted that my conclusions with regard to the architectural profession have also relevance for other liberal professions, since states and professional associations often use the same types of restrictions with regard to entry to a range of regulated professions such as professional qualifications, a professional monopoly, a numerus clausus, advertising restrictions and price fixing.

This concept will be discussed in Chapter 11.

The public interest approach as well as the private interest approach towards regulation will be discussed in Chapter 11. 
By providing a legal and economic analysis, I hope to inspire lawyers, economists, architects and politicians to think about the regulation of architects in their countries, to aim for a more efficient regulation of the profession.

\section{Problem definition and research questions}

In the light of the legal analysis of the regulation of architects in Belgium and the Netherlands, the question arises as to whether these regulations are needed to cure possible market failures, and whether they increase social welfare. Since the regulation of architects is quite different in each country, the regulations will be compared in terms of their efficiency. The problem definition (central research question) is therefore as follows: Is the Dutch or the Belgian combination of regulations and contract law provisions most cost-efficient from an economic point of view?

In order to answer this question, several other questions have to be answered first.

The first question concerns the regulation of architects at the EU level, and aims to determine what requirements the European Union imposes upon individuals who want to access or pursue the profession of an architect. The first research question is: Is there legislation or case law at EU level that determines who should be allowed to use the title of architect or to practise the profession and how the profession should be practised?

Since the provisions of the Treaty on the European Union (TEU) and the Treaty on the Functioning of the European Union (TFEU) and regulations are directly applicable in the Member States, it is important to study EU law as well. As the Court of Justice of the European Union (ECJ) has established in Van Gend en Loos', 'The European Union is a legal order of international law for the benefit of which the States have limited their sovereign rights and the subjects of which comprise not only Member States but also their nationals, obligations imposed upon member states by the treaties can be enforced by individuals, in the form of individual legal rights, before national courts.' Furthermore, in Costa, it was held that 'Community law must be given primacy by national courts over any incompatible national law'10. This is highly relevant, since architects can in principle directly rely upon provisions of EU legislation against Member States before their national courts, at least, if these provisions confer specific rights upon them and are sufficiently clear and precise and unconditional. Even Directives, which are not directly applicable, can be invoked by individuals against a Member State that has failed to implement them on time or has implemented them incorrectly if the abovementioned conditions are fulfilled. Moreover, certain provisions even have horizontal direct effect which encompasses that these can be invoked against individuals or other private actors as well.

9 Case C-26/62 NV Algemene Transport en Expeditie Onderneming van Gend en Loos v. Nederlandse Administratie der Belastingen [1963] ECR 1.

10 Case C-6/64 Flaminio Costa v. ENEL [1964] ECR 585, 593. In Simmenthal, it was held that national courts should even disapply conflicting provisions of national law. See Case C-106/77 Amministrazione delle Finanze dello Stato $v$ Simmenthal S.p.A. [1978] ECR 629. 
Since the Court of Justice of the European Union ruled in Simmenthal that national courts should disapply provisions of national law that conflict with Community law, EU legislation and case law is highly relevant with regard to determining the exact rights and obligations of EU architects and the exact scope of the Belgian and Dutch regulations.

In this thesis it will be discussed in how far Member States are free to determine who is allowed to practise the profession of architect and use the title on their territory, specifically in the light of the process of globalization and the ever increasing movements of professionals in and to the European Union. Part I of the thesis will thus whether other EU (and non EU) nationals are or should be allowed to practise the profession of architect in Belgium and the Netherlands and which conditions needs to be fulfilled for this. The free movement of architects in and to the European Union will thus be discussed.

Furthermore, EU competition policy is also highly relevant with regard to the architectural profession. Not only states but also private undertakings such as professional associations can create rules on who is allowed to practise a profession and how this profession should be practised. This might have an effect on trade in the European Union as well. $\mathrm{n}$ evaluation of EU competition law principles will contribute to determining the lawfulness and scope of national law rules and self-regulatory rules.

The second research question is: Which national regulations and self-regulatory measures issued by professional associations exist in Belgium and the Netherlands with regard to the architectural profession? Without a discussion of the legislation that is currently in force, it will be impossible to determine whether or not the national legislations are in conformity with EU legislation and economic (cost) efficiency. In this regard it has to be determined whether or not architectural associations have also issued rules that regulate the profession. Their content, scope and legal value (i.e. are these rules enforceable) has to be discussed. Such analysis is required to determine whether the Belgian or the Dutch combination of regulatory and non-regulatory options will be most efficient from an economic point of view. If it turns out that the national regulations are incompatible with EU legislation, the free movement of architects in the EU might be restricted.

Next to a discussion of the requirements imposed upon architects by public law, a discussion of the obligations and responsibilities imposed by private law seems to be warranted to achieve a sound understanding of what the practice of the profession exactly entails. In this regard it should be noted that it is possible that not only public regulations issued by the Belgian and Dutch governments and the rules created by architectural associations are able to restrict the free movement of architects, but also differences in contractual obligations and liability regimes. For this reason I will also examine their private law responsibilities. The third research question is therefore: What are the tasks, obligations and liabilities of architects in Belgium and the Netherlands?

After this legal analysis, an economic analysis will be presented of the regulation of architects in both states. In this way I will first determine why such regulations are created 
in the first place and whether there are alternatives to changing the behaviour of legal subjects. My fourth question is: What does economic theory teach us about(self-) regulation in the professions? In this regard it is important to demonstrate why regulation might be needed in the first place. The different approaches towards regulation will have to be discussed. The public interest approach to regulation stipulates that regulation is a correction for market failure which might be present due to the fact that consumers have less information at their disposal than service providers, while the private interest approach indicates that regulation is merely or predominantly the result of rent seeking behaviour by individuals or associations. It has to be determined whether and why regulation might be needed with regard to the architectural profession. If regulation is created to ensure a certain level of quality, it should be determined whether or not liability rules are sufficient to obtain this objective.

The fifth research question is: Is there any market failure in the Belgian and Dutch markets for architectural services which might justify regulation? The economic theory which was discussed to answer question four will be applied to the markets under consideration. In this way I aim to determine to what extent the Belgian and Dutch regulations are really necessary and proportional to achieve the goals set.

Hence, I come to the sixth question: Is the intensity of public regulation related to the intensity of the contractual obligations and liabilities of architects in Belgium and the Netherlands? In this thesis I aim to determine whether there is a link between the amount and level of public regulation, and the amount and level of contract law by which the architectural obligations and liabilities are determined. By interpreting the results of the previous questions, I will try to determine whether the system which imposes heavier regulatory requirements upon architects in terms of entry to the profession or professional conduct, is characterized by softer contractual liabilities and vice versa.

Finally, after having determined the differences in regulations in both states and their economic consequences, an answer to the central research question will be formulated. By answering this question I hope to provide law and policy makers, architects and all interested parties with an insight regarding the particularities of these systems, and their possible efficiency gains and losses. This may inspire the legislators and the architectural associations of Belgium and the Netherlands, but also those of other states, to adapt or perhaps preserve their current systems.

\section{Research methodologies}

The research methodologies used in this thesis consist of a legal analysis of EU legislation and case law with regard to the public regulation of architects and a comparative legal analysis of the public regulation of the profession by the governments and architectural associations concerned, and of the contractual obligations and liabilities of architects in Belgium and the Netherlands. An economic analysis will be undertaken of the regulation of professions in general, which will be applied to the architectural profession 
in both states. In addition to studying the relevant legislation, considering the abundance of case law and all sorts of legal and economic literature, I also had several meetings and telephone conversations with members of the profession, lawyers specialized in 'building' or 'construction' law, and insurance companies.

Part I of the book focuses upon the regulation of architects in the European Union on a public law level. This discusses the requirements which need to be fulfilled before an EU architect is allowed to practise his profession in another Member State. Generally it must be stated that the freedom of movement of workers in the EU is secured, and that restrictions on the freedom of establishment and the freedom to provide services on the part of nationals of a Member State in the territory of another Member State, is prohibited. This entails that discrimination based on nationality between professionals of the Member States has to be abolished, and that measures which are liable to affect the free movement of such professionals should be eliminated. By introducing the concept of EU citizenship, the Treaty of Maastricht established that non economically active persons holding the nationality of an EU Member State can, subject to certain limitations and conditions, move and reside freely within the Union. Since their freedom of movement would be impaired if certain family members, even if they hold a third-country nationality, were not allowed to join or accompany them, in addition third-country national architects are allowed to practise their profession in the EU if they are a family member of a Union citizen and certain conditions are fulfilled. To be complete, this thesis will also refer to the other possibilities of third-country national architects working in the Union. By referring to the relevant provisions of the Treaty on the Functioning of the European Union (TFEU) and the Treaty on the European Union (TEU), as well as to relevant secondary legislation and case law, the possibilities for EU and non EU architects moving in, or to, the European Union will be discussed in detail. This thesis will not include a discussion of European private law since there is currently no European Civil Code that is binding upon EU Member States and/or its citizens.

In Part II of this thesis a presentation and examination of the regulation of architects in Belgium and the Netherlands will be undertaken, both on a public law and a contract law level. I will investigate which requirements architects have to fulfil before they can enter the profession, and will emphasize the difference between 'the right to use the title' and 'the right to practise the profession'. In this regard, the Belgian and Dutch public legislation which is specifically applicable to those who are allowed to use the architectural title and the relevant national legislation that implements the EU policy discussed in Part I, will be discussed, as well as professional rules regulating architectural conduct. By studying the Civil Codes of both states, as well as the relevant literature and case law, the tasks, responsibilities and liabilities of architects will be analyzed and I will also discuss whether these professionals have the obligation to buy professional liability insurance. In this regard the relevant Standard Conditions which are often used in the Netherlands to regulate these issues in a general way, will also be reflected upon.

The economic analysis in Part III provides an objective method for evaluating the efficiency of the regulation of architects in Belgium and the Netherlands. It contains an 
economic analysis of the (self-)regulation of liberal professions with an application to the specific case of the architectural market. The legal rules which were presented in Part II will be scrutinized from an efficiency point of view to determine whether the Dutch or Belgian regime which is applicable to the architectural profession corresponds better to the predictions of the economic model. To be able to reach such a conclusion, the objectives of regulation and the different approaches towards regulation in general will be discussed by focusing upon the economic literature. In this regard possible alternatives or complements to regulation such as liability rules, will also be discussed. In this way I aim to establish the effects of the regulations and to what extent the Belgian and Dutch regulations are really necessary. Furthermore, the regulatory instruments will be compared to liability rules. The legal analysis of contract law in Part II will be used to determine whether the intensity of public regulation is linked to the intensity of the contractual obligations and liabilities of architects in Belgium and the Netherlands. By applying all the information obtained, I will finally try to determine which combination of regulations or private law provisions is most likely to lead to more efficient outcomes, and whether the Dutch or the Belgian regime which is applicable to the architectural profession corresponds best to the predictions of the economic model.

\section{Scope - limits - points for further research}

The central goal of this thesis is to determine whether the Dutch or the Belgian regime which are applicable to the architectural profession is more efficient from a public and private interest perspective. Furthermore, I also aim to establish whether EU law furthers or hinders market access.

In this thesis the public regulation of architects in the EU, Belgium and the Netherlands will be discussed as well as their contractual tasks, obligations and liabilities within the traditional building process in both Member States. Since the responsibilities and tasks of architects are, in principle, determined by contract, and since it has been demonstrated by case law that architects are, in the vast majority of cases, held liable on the basis of their contractual obligations, I will not discuss the liability in tort of architects, or their criminal liability.

In this regard it should be noted that this thesis only concerns architects stricto sensu, meaning that it only deals with architects who have, as their main task, the design of buildings and the supervision of the erection of building works. It does not discuss the situation of town planners, interior architects or garden and landscape architects.

This thesis does not include a discussion of European private law since there is currently no European Civil Code that is binding upon the EU Member States and/or its citizens. In this regard, the Draft Common Frame of Reference (DCFR) prepared by the Study Group on a European Civil Code and the Research Group on European Private Law as well as the PEL SC (Principles of European Law on Service Contracts) which is a research project initiated by the Study Group on a European Civil Code with the aim of drafting common European principles for the most important aspects of the law of obligations and for certain parts of the law of property in movables, should be mentioned. The PEL SC contain a number of principles for different service contracts, under 
which is included design contracts, and reflects on the current approach to legal problems in the area of service contracts. Due to the fact that this thesis already covers an extensive analysis of the obligations and liabilities of architects in Belgium and the Netherlands, and since parties are allowed to deviate from the PEL SC, the private regulation of architects at EU level is not discussed separately. For a discussion of the European harmonisation of construction law I refer the reader to Jansen's dissertation, Towards a European Building Contract Law ${ }^{11}$ and Kohl's article, European Construction Law and the Draft Common Frame of Reference: Selected Topics ${ }^{12}$.

With regard to the economic analysis, it should be noted that this thesis aims to demonstrate that a law and economics approach towards regulation can be a useful method for analysing architectural law and policy. The economic analysis is provided to determine whether, and to what extent, it is efficient to regulate the architectural profession from a public interest and a private interest perspective. The public and private interest approach towards regulation will be discussed from a theoretical point of view, and I will try to determine whether there is any market failure with regard to the architectural profession in Belgium and the Netherlands in the light of the public and the private interest model. In this regard it should be noted however, that I will not look for empirical evidence to establish any market failure. First of all, this is not necessary in order to answer my central research question, and secondly the existence of a certain degree of market failure is highly probable due to problems of information asymmetry. The acquisition of empirical evidence would require extensive research which would go beyond the scope of this thesis. My theoretical approach will thus provide certain important indications but more extensive and econometric research is needed to concretize these and to put these to the test. Further research is also needed to determine in more detail whether and in how far the respective regulations are really necessary to protect the general interest or whether they rather protect the professionals.

In this thesis I will not discuss whether it is better (i.e. more efficient) to have EU legislation to uniformly regulate (harmonize) the architectural profession. Reference can be made again to the Draft Common Frame of Reference and the PEL SC, neither of which are legally enforceable, and to the legal analysis of the regulation of architects in the European Union provided for in Part I of this thesis, which contains an effectiveness study to determine whether architects can practise their profession in other EU states without unjustified impediments. The economics of federalism provides a method to determine whether or not it would be more efficient to uniformly regulate the profession. ${ }^{13}$ However, this goes beyond the scope of this research which aims to establish whether EU legislation furthers the free movement of architects.

Janssen 1998

Kohl, 2009.

See for example Heremans 2010, pp. 73-96; Kerber \& Van den Bergh 2008, pp. 447-465; Faure 2008; Van Boom 2008, p. 17; Faure 2003; Marciano \& Josselin 2002, p. 288; Van den Bergh 1998, pp. 129-152; Ribstein \& Kobayashi 1996, pp. 131-199; Buchanan 1995, pp. 19-27; Van den Bergh 1994, pp. 337-366; Tullock 1969, pp. 19-29. 
Finally it should be noted that this thesis describes the situation of architects up to $31^{\text {st }}$ December, 2009. Developments after that date could only be taken into account to a limited extent.

\section{Structure}

The structure of this thesis is based on the research questions described above.

In Chapter 2, the architectural profession in all its component parts and its development over the years is defined. The reader will be provided with tables and charts to allow a thorough understanding of how many professionals are covered by this thesis, their main occupations, their type of clients, etc. It will be demonstrated that for centuries, architects have practised their profession outside their country of origin.

Part I (Chapter 3) contains the regulation of architects in the European Union. Since EU architects should be able to move freely within the Union in order to practise their profession, any restrictions that are liable to prohibit or otherwise impede the activities of an architect in another Member State, violate EU law. To be complete, this chapter will also refer to the rights of third-country nationals to practise as an architect in the EU. In Part I, research question one will be answered.

Part II of this thesis (Chapters 4-10) discusses the regulation of architects in Belgium (Section A) and the Netherlands (Section B) from a public and a contract law perspective. To answer research question two, the requirements which are imposed upon architects to enter the profession will be discussed in Chapters 5 and 7. The tasks, responsibilities and liabilities of architects in both states will be analysed in Chapters 6 and 8 which aim to provide an answer to research question 3. While Chapter 9 provides for a comparison between the public regulations and contract law of both states (Section C), Chapter 10 contains an overview of the public regulation of architects in fifteen EU Member States so that it can be determined whether or not the Belgian and Dutch public regulations are particularly strict or lenient on a European level (Section D). An overview of contractual obligations and liabilities in these fifteen states is not given since obtaining all relevant information would be a complex task because contractual liabilities are generally provided for in the contract itself, and parties are often allowed to deviate from the applicable governmental legislation.

Within the light of research question four, Part III (Chapter 11) contains an economic analysis of the regulation of liberal professions. The private and public interest approach towards regulation will be presented, and different regulatory instruments will be discussed. Since the public interest approach towards regulation indicates that regulation is needed to correct market failure, I will attempt to provide an answer to research question five, whether, or to what extent, there is any market failure in the Belgian and the Dutch architectural markets. In this way I try to determine to what extent the Belgian and Dutch ex-ante regulations are necessary to ensure high quality, or whether ex-post liability rules are sufficient to achieve this goal. The legal analysis of contract law in Part 
II will be used to determine whether the intensity of public regulations is linked to the intensity of the contractual obligations and the liabilities of architects in Belgium and the Netherlands (research question six). By applying all the information obtained, this thesis will conclude with an answer to the central research question, and will establish which of the Dutch or the Belgian regimes that are applicable to the architectural profession are most likely to be most cost-efficient from an economic point of view. 



\section{Chapter 2}

\section{THE ARCHITECT}

This thesis deals with the regulation of architects in the European Union in general, and two of its Member States in particular. Before discussing these regulations it is useful to have an understanding of what the architectural profession exactly entails and how it has developed throughout history. Furthermore, it is also interesting to know whether the subjects under consideration (architects) are many in number, how the professional group is exactly composed, whether their turnover is considerable, etc. In this way one can get a clear view of whom and what is covered by this research. .

In this chapter the history and development of the profession will be discussed in paragraph 2.1. Paragraph 2.2. will elaborate on the different tasks that architects perform, while paragraph 2.3. will provide the reader with relevant tables and charts which provide him/her with some interesting facts about the composition of the profession and how architects practise it.

\section{History and development of the profession}

European architecture is founded on the astonishing geometric and mathematical mental development peculiar to the ancient civilizations, which flourished around the eastern Mediterranean: ancient Egyptian, Semitic, Babylonian and Arab peoples, and more prominently, the ancient Greeks. ${ }^{1}$ For centuries, the architect was the keystone to every large construction project. He was a master builder with responsibility for both the design and the construction of a building. ${ }^{2}$ In fact, the word "architect" is derived from the Latin archi-tectus or the Greek arkhi-tekton. Originally it was used to describe the leading stone mason of the ancient Greek temples of 500 B.C..'; "Arkhi" - meaning "head, chief, master" / "Tekton" meaning "worker, builder". It is related to "Tekhne" which means "art, skill". ${ }^{4}$

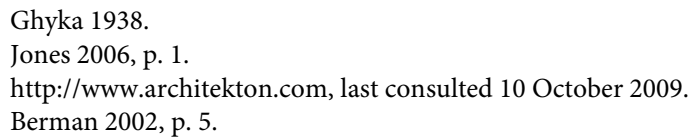


In Timaeus, Plato described the starting point of architecture and held that empty space is 'the mother and receptacle of all created and visible and in any way sensible things'. All architecture begins with empty space; it is the art of distinctions within the continuum of space, for example between solid and void, interior and exterior, light and dark, or warm and cold. ${ }^{6}$ In this way, one can say that 'Architecture began when cave dwellers first hung skins in front of their caves to keep out the cold. By so doing they enclosed space, and thus they created space, rather than merely discovering it. But the discovery preceded the creation in their imagination. The cave was already there, along with the hill and the valley or the plain which the hill enclosed, and the fact that it was there to begin with was essential to the creation."7

As held by Jones, 'Prior to 500 B.C., there were virtually no structures that existed above the ground floor. Building construction was basic and did not require a high level of expertise. The Greek civilization changed this pattern and provided revolutionary changes in building and provided revolutionary changes in building and architecture. The Greeks introduced a stationary dominance that brought an end to nomadic life

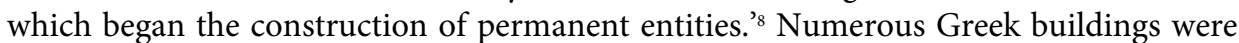
temples which were an expression of their religious beliefs. The 'master builder'9 was typically the head carpenter or head mason on the project, depending on the primary materials used for construction. ${ }^{10}$

The lifestyle of the wealthy Ancient Romans was characterised by luxury. Next to buildings which were designed in terms of their belief, aqueducts and roads were created for their practical use, while fountains, the forum and the Coliseum served mainly cultural purposes. The architect Vitruvius ( $1^{\text {st }}$ century B.C.) who is held to be the author of De Architectura, the oldest surviving document related to European Architecture, known today as The Ten Books of Architecture, described himself as a 'client' of the emperor. The book is a treatise written in Latin and Greek on architecture and dedicated to his 'patron', emperor Augustus. Vitrunius. In those days the patrons were drawn mainly from the social, political and religious aristocracy, from the papacy and the monarchy, through the various ranks of church and state down to the minor nobility and gentry to bankers and, latterly, to the prosperous bourgeoisie. ${ }^{11}$ It does not come as a surprise that a high level of expertise was required to create the desired buildings. Often the master masons alone did not have this expertise, meaning that the new levels of complexity triggered a shift in the role of the architect towards individuals with different backgrounds, such as military engineers, civil servants and private persons. ${ }^{12}$ They all cooperated with the master masons to have the building erected.

5 Plato, Timaeus. See: The Dialogues of Plato, trans. Jowett, 1937, vol. 2, p. 31. Timaeus is a theoretical treatise of Plato expressing his main ideas about the nature of the physical world.

Mitchell 1990.

Greenbie 1993, p. 82.

Jones 2006, p. 10.

An individual (or nowadays a full service team) that performs all facets of the construction process, including design, engineering and construction.

10 Jones 2006, p. 9.

11 Allsopp 1993, p. 33.

12 Jones 2006, p. 10. 
While in the Middle Ages, which were characterized by the need for strong and fortified buildings without eloquent details or complex designs, master masons could generally lead the erection of a construction, beauty became important once again during the Renaissance. As suggested by Jones, 'The knowledge of antique forms and artwork was possessed by the goldsmiths, sculptors and painters such as Brunelleschi, Michelozzo, Bramante, Raphael and Michelangelo who were called the 'architects' yet did not belong to construction guilds and were not masons or stone cutters. It was at this time that the titles of architect and master builder first became separated. While some form of an architect had been around since the first edifice was ever built, it was in this period of time that the profession of the architect as a designer, independent from the builder, began to be defined as an integral and mandatory part of the construction process. ${ }^{13}$

In 1753, Laugier beautifully described the complexity and the nobility of the architectural profession:

'When one speaks of the art of building, the chaotic mess of clumsy debris, immense piles of shapeless materials, a dreadful noise of hammers, perilous scaffolding, a fearful grinding of machines and an army of dirty and mudcovered workmen - all this comes to the mind of ordinary people, the unpleasant outer cover of an art whose intriguing mysteries, noticed by few people, excite the admiration of all those who penetrate them. There they discover inventions of a boldness that proclaims a great and fertile genius, proportions of a stringency that indicates severe and systematic precision, and ornaments of an elegance that tells of a delicate and exquisite feeling. Whoever is able to grasp true beauty to this extent will, far from confounding architecture with the lesser arts, be inclined to range it among the more profound sciences. The sight of a building, perfect as a work of art, causes a delightful pleasure which is irresistible. It stirs in us noble and moving ideas and that sweet emotion and enchantment which works of art carrying the imprint of a superior mind arouse in us. A beautiful building speaks eloquently for its architect.' ${ }^{14}$

It can be seen that the profession of architect was held in high esteem and was considered to be one of the highest arts. As construction projects grew in complexity and scale, this led to specialisation, and the design of buildings was, for the first time, held to be separated from the construction process at a cultural, legal, functional and economic level. The architect was deemed to be the intellectual, while the builder was the executive with muscular strengths. The architect was seen as a true professional. In 1819, the first school of architecture was established in 1819: the Ecole des Beaux-Arts. ${ }^{15}$ Those who

Jones 2006, p. 12; Coble \& Blatter 1999, pp. 44-48; Woods 1999.

14 Laugier 1753.

15 "École des Beaux-Arts" (School of Fine Arts) refers to a number of influential Art schools in France. The most famous is located in Paris. The "Académie des Beaux-Arts" was founded in 1648 by Cardinal Mazarin and developed studies in architecture, drawing, painting, sculpture, engraving, modelling, and gem cutting. It was brought under control of the government by Louis XIV, originally to guarantee a pool of artists available to decorate the palaces and paint the Royalty, but was made independent by Napoléon III in 1863. Beaux Arts style was modelled on classical "antiquities", preserving these idealized forms and passing 
studied at this establishment -and later also those who went to other educational institutions- started to unite themselves in professional organisations, and some of them opened architectural offices together. The creation of guilds as confraternities of craftsmen had emerged much earlier however, and flourished in the Middle Ages.

While, from the Renaissance onwards, architecture was regarded as an art, $20^{\text {th }}$ Century modernism destroyed the aesthetic importance. Architects worked for clients who spent a lot of money (for example banks, insurance companies, bureaucracies) but who did not have any aesthetic interest in the building whatsoever. This caused the architect to become an anonymous and obscure face in the building process. It followed that the word 'patron' obtained a pejorative undertone. Accordingly, the role of both parties has changed over time and become the exact opposite to what it once was: nowadays architects refer to their employers as their 'clients'. The $20^{\text {th }}$ Century is characterised by industrialisation and specialisation. Architects had to respond to increased project size and work complexity. Prior to the Industrial Revolution, there was a substantial identity of values between sponsors and their architects. Their shared social and educational backgrounds, through shared class origins, and the well-established traditions of the few building types in existence, ensured that there was little risk of hidden agendas not being fulfilled. ${ }^{16}$ There was also little need to lay down the programmes (today's "briefs") in detail. However, as held by Tiesdell and Oc, 'The supersedence of craft-based trades by industrial rationalization led to the relative estrangement of the sponsor, the designer and the eventual user of the built environment. Such an estrangement made the architect's precise role in the process confused. The architect has to deal with the goals and aspirations of both the sponsor, which may increasingly include the ability to negotiate and manage a conflict-ridden, litigious construction process ${ }^{17}$ and the ultimate achievement of profit, and those of the users, who may be simply unknown. ${ }^{18}$ Since both sponsors and architects came from a much wider social background, the identity of class interest could no longer be assumed. Moreover, users of buildings began to develop their own voices. 'In theory, architects were given freedom over the form of specific projects. They were, thenceforward, to absorb all their energy in stylistic debate. They were to be artists; their workplaces 'studios', their education in art institutions based on the Ecole des Beaux-Arts. They were to exhibit framed drawing in the Academies, today even those drawn by computers. The media, textbooks and professional institutions were committed to architecture-as-art. However, the sponsors, the selfsame elites, took control of the resources for architectural education, the media, publishing and exhibitions. Form could be censored at an institutional level, without destroying the apparent freedom of architects. Of course sponsors could not afford to be so cavalier. So they explicitly and elaborately prescribed it in a text -the brief- which was presented as 'neutral', 'technical' or 'objective' and thus beyond argument. By means of specific briefs, general design guides, Codes, Standards and legislation, a battery of written and graphic prescriptions were produced. These texts became powerful prescrip-

the style on to future generations. See http://www.jssgallery.org/Essay/Ecole_des_Beaux-Arts/Ecole_des_Beaux-Arts.htm, last consulted 11 October, 2009.

16 Markus 1993, p. 20.

17 Montgomery 1989, pp. 260-281.

18 Tiesdell \& Oc 1993, p. 44. 
tions which, in many important ways, designed a building long before a so-called designer appeared on the scene. ${ }^{19}$

As noted above, next to the changing relationship between the architect and his client due to changing backgrounds and the increasing influence of clients on the building process, specialisation and increased complexity characterise the $20^{\text {th }}$ Century. This meant that the responsibilities of architects became enormous. Traditionally architects advised their clients on the budget and the schedule, made the design and supervised the building work. Over the centuries, the role of the architect has constantly been modified to suit the needs and requirements of their time. Where traditional methods were shown to be inadequate, new approaches were developed to take their place. As stipulated in the Beijing Charter, 'Without exception, each redefinition pushes the boundary of architecture outwards for a wider coverage, as well as inwards for higher degrees of specialisation in the component parts. ${ }^{20}$ 'A wider coverage of the contents of the architectural profession and finer degrees of specialisation have empowered the $20^{\text {th }}$ and $21^{\text {st }}$ Century architect with unprecedented professional opportunities and potential, yet at a personal level, an expanding profession with growing specialisation can seem elephantine.' ${ }^{21}$ In this regard, the Beijing Charter holds that 'In a sense, the architects' Tower of Babel appears to have fallen: it is increasingly difficult for one architect to grasp the expertise of a fellow colleague; although the body of knowledge has grown collectively, the outlook of any single designer tends to become paradoxically narrow and fragmented. ${ }^{22}$ To cope with new technologies, building contractors (hereinafter: entrepreneurs) began to introduce sub-contracts. Furthermore, the architect went through the same process as the builder with his sub-contractors. All sorts of other professionals, consultants and managers have come to the fore, who assume responsibility for various areas of specialisation. These sub-contractors can be hired by the building master but also by the architects themselves. Moreover, practices have arisen which offer design as well as building services, so that the profession of 'master builder' has revived, especially with regard to turn-key projects. This results in a power struggle between these professionals. It can be asked whether the growth of such firms and the involvement of more specialists who consequently gain more authority and responsibility, can be found in the fact that architects may have taken a backseat due to liability concerns (risk-aversion) and the fact that they might not be able to keep up with modern trends in the construction industry. We can also ask whether the precise role of the architect is still clear. The construction industry is constantly growing and developing into an increasingly professional, white collar industry. ${ }^{23}$ More educated professionals, more complexity, new technologies, more lawsuits, higher compensation and more turn-key projects have influenced the

19 Markus 1993, p. 20.

20 Article 3.1 Beijing Charter. In 1999 more than 6,000 people, of whom 2,500 were architectural students, met in Beijing to take part in the activities of the XX World Congress of Architects organised by the Architectural Society of China. The ambitious Congress theme 'Architecture of the 21st Century' was thoroughly and pragmatically dealt with by the international community of architects during the congress. The papers presented were published in three reference works, as well as the Beijing Charter which was a general synthesis.

21 Beijing Charter, Article 3.1.

22 Ibid.

23 Jones 2006, p. 76. 
architectural profession. Nevertheless, the architects' primary function has remained constant: the design of buildings. ${ }^{24}$

It can thus be concluded that for centuries the architect was a 'master builder' who was responsible for the design and the construction of buildings. Due to new technologies and higher complexity, more specialised professionals were needed, leading to the separation of the designer and the building contractor. While the building contractor takes care of the execution of the building, the architect advises his client on the project and the budget, designs the building and supervises the building works. However, due to the ever increasing complexity, even architects may have difficulty keeping up with all new technologies. Specialists are involved and turn-key projects have gained in popularity. This has caused the exact role of the architect to become unclear, and means that architects are losing their previously prominent role.

\section{Content of the profession}

'In architecture, as in all other Operative Arts, the end must direct the Operation. The end is to build well. Well building hath three Conditions: Commodity, Firmness, and Delight. ${ }^{25}$ These words of Sir Henry Wotton, were inspired by the writings of the Roman architect, Vitruvius, who saw "durability, convenience and beauty" as the conditions to be met by an architect, emphasising the complexity of the building art. ${ }^{26}$ The function of architecture is to shelter human activity (utilitas or commodity), to durably challenge gravity and the elements (firmitas or firmness) and to be an object of beauty (venustas or delight). The art of architecture lies in knowing how to establish the appropriate relations between the three conditions.

Throughout history, the most important function of architecture has been the provision of shelter. Architecture creates an artificial climate to secure the survival of mankind and to protect individuals against the climate, animals, enemies, etc. and this lies at the heart of most architectural activities. By designing buildings, architects create the environment in which persons spend their lives. After the struggle for survival had been won, investment could be made in work that had spiritual, symbolic or enriching significance. ${ }^{27}$ As held by Nuttgens, 'The need of people was no longer simply for shelter; there was a requirement for something more permanent, more lasting and more emotionally significant. In that sense the story of great architecture can be seen as the astonishing story of how individuals and groups have taken the structures, groupings, plans, access and service arrangements originally evolved to satisfy basic human needs, and transformed them into one of the greatest manifestations of the human spirit. ${ }^{28}$ Today, buildings have importance on an economic, social, political and cultural level. As suggested by King, 'Economically, they house activities, occupy land, create work and, in modern market societies, they provide for investment and capital. Socially, buildings

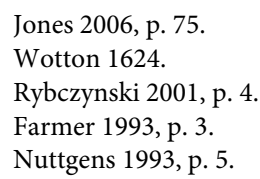


house institutions, provide shelter, support relationships, express social division, permit hierarchies, embody property relations and enable the expression so status, identity and authority. Culturally, they store sentiment, symbolize meaning, embody history and express identity. Politically, buildings represent authority, symbolize power, become an arena for conflict and are a political resource. ${ }^{29}$ It is therefore clear that buildings have a myriad of functions and that the importance of architecture has always been acknowledged.

To achieve all these aims, architects provide a broad selection of services such as the planning of buildings and developments, interior and exterior design, planning permission applications, preparation and monitoring of construction, technical control and certification, feasibility studies, procurement of building materials, topographical determination, demarcation and land surveying. ${ }^{30}$ Usually, architects start their task with the examination of the building site. They advise their clients on the selection of building materials, the applicable laws and rules, and the construction costs. Drawing a plan is the essential factor in the creation of a work of architecture; it is the organization of areas and spaces to accommodate and link together the needs -or functions- for which the building is erected. ${ }^{31}$ As indicated by Le Corbusier, 'The plan is the generator'. ${ }^{32}$ The drawings, specifications and other construction documentation are prepared and administered by the architect during construction. In this regard it should be mentioned that the transfer of information between the participants and the processing of this information by these same participants, is of the utmost importance. The design by the architect combines and converts numerous items of information into a coherent design proposal, represented in a form that communicates with other participants, such as those from whom planning permission must be sought, or those who will eventually construct the building. ${ }^{33}$ After the design is complete, architects can be hired to supervise the construction of the building works by the builder. It can be said that no one can control a project better than the one who devised the concept and who has studied the methods needed to realize the design since s/he knows the difficulties. Architects have to guide their clients, who often expect to have the latest innovations in their buildings, as to what approaches are the best for a new building project, the best models, the best materials and the best methods to make their project come alive. Architects are therefore coordinators, and have to unify various formal, technical, social and economic problems that arise in connection with their building. ${ }^{34}$ Since architecture is held to be a discipline which 'draws knowledge from the humanities, the social and the physical sciences, technology, environmental sciences, the creative arts and the liberal arts ${ }^{35}$, architects have to unify knowledge from different complex fields which they cannot

29 King 1991, p. 11.

30 See also Stocktaking Exercise on Regulation of Professional Services: Overview of Regulation in the New EU Member States, European Commission, Competition DG, COMP/D3/MK/D(2004), paragraph 82.

Nuttgens 1993, p. 6

2 Le Corbusier 1927, pp. 35-36

3 Day \& Powell 1993, p. 166.

Gropius 1965, p. 98

5 Skolimowski 1993, p. 498. 
master all by themselves. It follows that architects are, in general, specialized in a particular field, and collaborate with different specialists such as landscape architects, engineers, quantity surveyors, interior designers, builders and subcontractors. Their potential is therefore no longer valued in the first instance in terms of their artistic abilities, but in terms of their technical knowledge..$^{36}$ It follows that, due to their specialisation which necessarily brings about a reduction of competence in general, specialists are often intruding on the traditional areas of the architects' responsibilities, such as their management function.

It has become obvious that the tasks of an architect comprise much more than is at first expected. The profession embraces a myriad of skills, abilities and know-how, and demonstrates a multi-layered proficiency. It has numerous facets and is challenging for everyone who practices it.

\section{The architectural profession in Europe: facts and figures}

In this section I will present some data which are interesting within the ambit of this thesis. These data were collected by other researchers, Eurostat and my own contacts with architectural associations and registration offices. In this chapter I will not try to explain these data. Where data are important with regard to the national regulations under consideration, they will be discussed in more detail in Part II, where reference will be made to this chapter if necessary.

In 2008 a Sector Study ${ }^{37}$ was commissioned by the Architects' Council of Europe (ACE). This is a professional organisation whose members are the national representatives and regulatory bodies of the profession in all EU Member States, Accession States, Norway and Switzerland. It is claimed to be the first comprehensive study of the architectural profession carried out in Europe. All 32 countries (hereinafter: Europe 32) from which the ACE drew its membership at the time of the study in 2008, were invited to participate and 17 countries $^{38}$ (hereinafter: Europe 17) fully participated. Additionally, several other countries, which had recently carried out national studies, shared the results of these studies with the ACE and hence could also be considered. The research was conducted in two phases and was the first comprehensive study of the architectural profession in Europe. In phase I, Member Organisations were addressed by means of a written questionnaire. Since the researchers felt that the ACE was seeking data which simply did not exist in many countries, they addressed in phase II a certain number of architects directly. In this way, a total of 8,083 architects replied. It should be noted however, that the response rate for Belgium was only $15 \%$ and for the Netherlands $10 \%$. Only persons

36 This also has its influence on architectural education systems. The oldest educational establishments were attached to art academies since architecture was seen as a mixture of art and craft. Now, most architectural schools are faculties of technical universities because they were started at around the turn of the $20^{\text {th }}$ Century when the technical aspects of the discipline were regarded as decisive. See Lund 1993, pp. 477-480.

37 Mirza \& Nacey 2008.

38 Austria, Belgium, Denmark, Estonia, Finland, France, Germany, Greece, Ireland, Luxembourg, Malta, Netherlands, Romania, Slovenia, Sweden, Turkey, United Kingdom. 
qualifying as real 'architects', i.e. persons who were professionally and academically qualified and generally registered/licensed/certified to practise architecture in the jurisdiction in which they resided and were responsible for advocating the fair and sustainable development, welfare, and cultural expression of society's habitat in terms of space, forms and historical context, were invited to take part. Since this study is only a first attempt and might, on certain points, not be representative of the whole profession due to the limited number of participants, some caution should be taken when looking at the results.

According to the study, Europe 32 has an estimated 483,000 architects. One quarter (25\%) of architects are based in just one country: Italy. A reason for this density is not given but can certainly not be found in an indolent liability regime since Italy is the only state of the old EU 15 in which architects cannot limit their personal liability by the creation of a company. The second highest number of architects is recorded in Germany, accounting for $20 \%$ of the European total. Third highest is Spain, with 45,000 architects and three countries - Turkey, the UK and France - have around 30,000 architects each (between 6 and $7 \%$ of the European total). It follows that these six countries together account for $74 \%$ of all of Europe's architects. The 27 Member States of the European Union account for 436,280 of these architects.

A comparison between the numbers of registered architects in different European countries shows that there are significant differences in the volume of architects per country. When comparing the number of architects with the general population, the study reveals that there are approximately 0.8 architects per 1,000 population in Europe. The highest density of architects occurs in Italy (2.1 architects per 1,000 population), the Former Yugoslavian Republic of Macedonia and Portugal. The lowest density of architects is recorded in Eastern Europe -Slovakia, Latvia, Czech Republic and Romaniawith each recording 0.3 or fewer architects per 1,000 population. The range in the density statistic across Europe is huge: in Italy there is one architect for every 485 people while in Slovakia the ratio is nearly ten times lower at one architect for every 4,155 people. According to the 2008 study, in Belgium there are 11,500 architects ${ }^{39}$ and the density is 1.1 per 1,000 persons while in the Netherlands 9,100 were counted, representing a density of 0.6. There are therefore fewer 'real' architects in the Netherlands than in Belgium.

It may be that distinctions in cultural patterns, in the standing of the profession, in building practice and in legislation, are accountable for such differences. ${ }^{40}$ An overview can be found in Table 1 and Chart $1 .^{41}$

39 In a telephone conversation held on $17^{\text {th }}$ September, 2009, the Belgian Order of Architects revealed that on that date there were 7,060 architects registered in the Flemish Region and 5,654 in the Walloon and German Region. Every year the number of professional extends considerably. I did not receive more recent data from the Dutch Foundation Bureau Architects Register (SBA) nor from the Association of Dutch Architects (BNA). The latter held that information was only available to its members.

40 The Bond der Nederlandse Architecten (a Dutch architectural association) indicates that differences in the quality of the built environment are less sharp than the disparities in architect numbers would suggest: Bond der Nederlandse Architechten, The Architectural Profession in the Netherlands, leaflet, August 2006, p. 4. See http://www.bna.nl/binaries/bna-downloads-3/infoblad-the-architectural-profession-in-nl.pdf, last consulted 23 December 2009. 
The Architect

Table 1

Estimated number of architects in each country and number of architects per 1,000 population

\begin{tabular}{|c|c|c|c|}
\hline & $\begin{array}{c}\text { Number of } \\
\text { architects }\end{array}$ & Population & $\begin{array}{c}\text { Architects per } \\
1000 \text { population }\end{array}$ \\
\hline Austria & 3,800 & $8,331,930$ & 0.5 \\
\hline Belgium & 11,500 & $10,666,866$ & 1.1 \\
\hline Bulgaria & 3,500 & $7,640,238$ & 0.5 \\
\hline Croatia & 3,000 & $4,435,383$ & 0.7 \\
\hline Cyprus & 430 & 794,580 & 0.5 \\
\hline Czech Republic & 3,000 & $10,381,130$ & 0.3 \\
\hline Denmark & 7,000 & $5,475,791$ & 1.3 \\
\hline Estonia & 700 & $1,340,935$ & 0.5 \\
\hline Finland & 3,600 & $5,300,484$ & 0.7 \\
\hline France & 29,400 & $63,753,140$ & 0.5 \\
\hline FYROM & 3,000 & $2,045,117$ & 1.5 \\
\hline Germany & 95,000 & $82,221,808$ & 1.2 \\
\hline Greece & 15,000 & $11,214,992$ & 1.3 \\
\hline Hungary & 4,000 & $10,045,000$ & 0.4 \\
\hline Ireland & 3,500 & $4,419,859$ & 0.8 \\
\hline Italy & 123,000 & $59,618,114$ & 2.1 \\
\hline Latvia & 700 & $2,270,894$ & 0.3 \\
\hline Lithuania & 2,000 & $3,366,357$ & 0.6 \\
\hline Luxembourg & 600 & 483,799 & 1.2 \\
\hline Malta & 500 & 410,584 & 1.2 \\
\hline Netherlands & 9,100 & $16,404,282$ & 0.6 \\
\hline Norway & 3,600 & $4,737,171$ & 0.8 \\
\hline Poland & 13,500 & $38,115,641$ & 0.4 \\
\hline Portugal & 16,300 & $10,617,575$ & 1.5 \\
\hline Romania & 5,500 & $21,528,627$ & 0.3 \\
\hline Slovakia & 1,300 & $5,400,998$ & 0.2 \\
\hline Slovenia & 1,350 & $2,025,866$ & 0.7 \\
\hline Spain & 45,000 & $45,283,259$ & 1.0 \\
\hline Sweden & 5,400 & $9,182,927$ & 0.6 \\
\hline Switzerland & 5,300 & $7,591,414$ & 0.7 \\
\hline Turkey & 32,300 & $70,586,256$ & 0.5 \\
\hline United Kingdom & 31,600 & $61,185,981$ & 0.5 \\
\hline Europe- 32 & 483,480 & $586,877.058$ & 0.8 \\
\hline
\end{tabular}

Population source: Eurostat. Population as at $1^{\text {st }}$ January 2008. Copyright (c) Eurostat

Architects source: Various sources. The starting point was the research publication produced by COAC Architectural Practice Around the World by the Collegi d'Arquitectes de Catalunya (COAC), based on information supplied by national institutes and associations of architects of the individual countries. Further data was collected by ACE in Phase I of the research. The Mirza \& Nacey researchers attempted to verify all figures using a mixture of primary and secondary sources including Member Organisation websites, telephone/email. Very often different sources produced conflicting figures, sometimes substantially different. The researchers hold that final figures are their best estimates based on these several different sources.

41 The tables and charts are those which are provided by the Mirza \& Nacey 2008 
Chart 1

Estimated number of architects in each European country

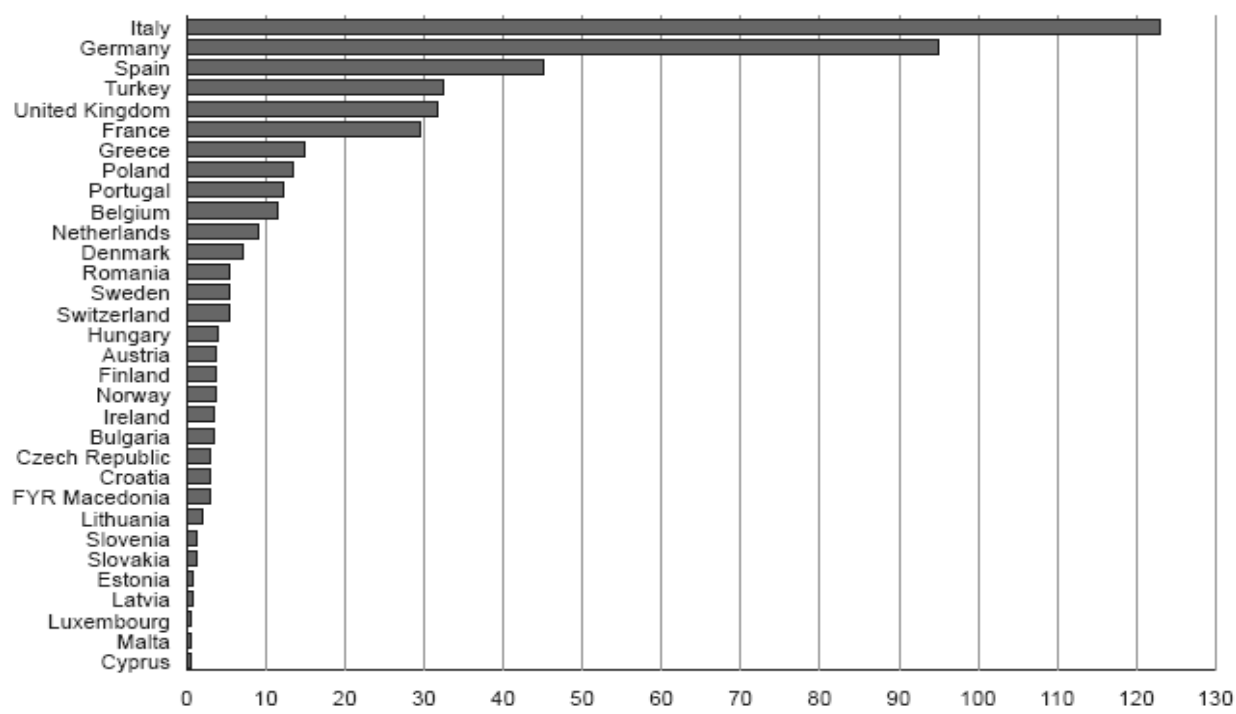

number of architects, 000's

$16 \%$ of all architects in Europe are not economically active. They are retired, unemployed, or not working for other reasons. In Belgium only $2 \%$ is not economically active while in the Netherlands this number is $6 \%$.

The study also revealed that the vast majority of architects (93\%) work or reside in the same country as they are registered in. $4.2 \%$ of Belgian architects are working or residing in a different country from the one in which they are registered. With regard to Dutch architects, this number is $6.7 \%$. In this regard it should be noted that these figures arestimations based upon questionnaires to which only a small percentage of architects have responded, so that more detailed research is necessary. Furthermore, this does not necessarily mean that architects do not make use of their freedom of movement: one can, for example, also be registered in a Member State in which one did not study. This was not covered by the study. The number of cases which were dealt with by the Court of Justice of the European Union with regard to the free movement of architects suggests that the architectural profession is characterised by mobile professionals. The free movement rights of architects will be elaborated on in Part I of this thesis. 
The Architect

Table 2

\begin{tabular}{lc}
\hline & $\begin{array}{l}\text { Architects working/resident in } \\
\text { different country from the one in } \\
\text { which registered (per cent) }\end{array}$ \\
\hline Austria & 12.5 \\
Belgium & 4.2 \\
Denmark & 3.3 \\
Estonia & $<1$ \\
Finland & $<1$ \\
France & 8.3 \\
Germany & 7.9 \\
Greece & 6.0 \\
Ireland & 18.2 \\
Luxembourg & 11.1 \\
Malta & 14.3 \\
Netherlands & 6.7 \\
Romania & 6.3 \\
Slovenia & $<1$ \\
Sweden & 5.9 \\
Turkey & 6.4 \\
United Kingdom & 6.3 \\
Europe-17 & 7.0 \\
\hline
\end{tabular}

${ }^{*}$ EUROPE -17 figure is a weighted average and takes account of the number of architects in each participating country.

It was further demonstrated that a significant proportion of architects operate alone as sole principals ${ }^{42}(24 \%)$ and as freelancers ${ }^{43}(9 \%)$ which is typical for the liberal professions. Including sole principals, private practice dominates, and accounts for more than two thirds of the profession (67\%). One quarter (27\%) of architects work in private practice as salaried architects (including associates), while the remainder are principals, partners or directors with an equity stake in the practice. Next to private practice, the principal employers are governments and local authorities. 5\% of architects work for a municipal local authority, $1 \%$ for a regional local authority and $1 \%$ for central government or its agencies. Taken together, the public sector employs $13 \%$ of the profession. Private practice is the largest employment field in most countries. Fewer architects are employed in the public sector than in the private sector in all countries. According to the study, in Belgium 21\% work as a sole principal, $12 \%$ are partners or directors in a company, $3 \%$ are salaried architects, $22 \%$ work as freelance architects and $6 \%$ work for local public authorities. In the Netherlands, $31 \%$ work as a sole principal, $45 \%$ as a partner or director, $9 \%$ are salaried and $2 \%$ work for local public authorities. The remaining architects are associates, or work in educational or other establishments. For more details see Tables 3 and 4.

42 An architect, working independently, who provides a full range of architectural services to clients.

43 An architect who contracts his/her services to an architectural practice or organisation (i.e. the form of structure through which architects practise the architectural profession. It includes sole principals, partnerships and limited companies) and does not accept commissions directly from clients. 
Table 3

\begin{tabular}{lc}
\hline & Per cent architects working \\
\hline Sole Principal & 24 \\
Partner/Director & 16 \\
Associate & 5 \\
Private Practice Salaried & 22 \\
In-House & 3 \\
Agency & 6 \\
Freelance & 9 \\
Other Private & 4 \\
Local Authority-Municipal & 5 \\
Local Authority-Regional & 1 \\
Central Government & 1 \\
Education & 2 \\
Health & $<1$ \\
Other Public & 3 \\
Chef De Project & $<1$ \\
Europe-17 & 100 \\
\hline
\end{tabular}

${ }^{*}$ weighted to reflect the total architectural population in all 17 countries

Table 4

Architects' field of employment by country (per cent)

\begin{tabular}{|c|c|c|c|c|c|c|c|c|c|c|c|c|}
\hline & 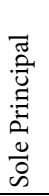 & 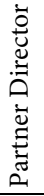 & 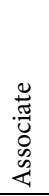 & 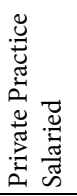 & 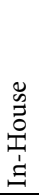 & 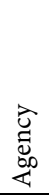 & 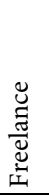 & 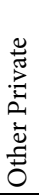 & 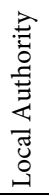 & 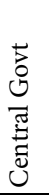 & 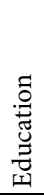 & 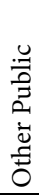 \\
\hline Austria & 66 & 30 & 1 & 2 & 0 & 0 & 0 & 1 & 0 & 0 & 0 & 0 \\
\hline Belgium & 21 & 12 & 5 & 3 & 0 & 23 & 22 & 5 & 6 & 0 & 0 & 3 \\
\hline Denmark & 11 & 7 & 6 & 26 & 4 & 4 & 2 & 6 & 21 & 3 & 4 & 6 \\
\hline Estonia & 16 & 56 & 8 & 12 & 0 & 4 & 4 & 0 & 0 & 0 & 0 & 0 \\
\hline Finland & 12 & 12 & 0 & 31 & 1 & 5 & 2 & 3 & 21 & 4 & 4 & 4 \\
\hline France & 23 & 5 & 12 & 6 & 1 & 23 & 25 & 1 & 1 & 1 & 1 & 3 \\
\hline Germany & 40 & 14 & 1 & 19 & 5 & 3 & 3 & 4 & 7 & 0 & 1 & 3 \\
\hline Greece & 14 & 15 & 6 & 13 & 1 & 3 & 23 & 4 & 7 & 1 & 6 & 8 \\
\hline Ireland & 16 & 23 & 14 & 26 & 1 & 1 & 2 & 3 & 6 & 2 & 1 & 3 \\
\hline Luxembourg & 31 & 14 & 8 & 7 & 1 & 15 & 16 & 1 & 5 & 0 & 0 & 1 \\
\hline Malta & 9 & 15 & 4 & 31 & 1 & 2 & 12 & 3 & 5 & 13 & 1 & 4 \\
\hline Netherlands & 31 & 45 & 5 & 9 & 3 & 0 & 3 & 0 & 2 & 0 & 2 & 1 \\
\hline Romania & 14 & 23 & 12 & 25 & 1 & 6 & 10 & 3 & 2 & 1 & 3 & 2 \\
\hline Slovenia & 18 & 13 & 10 & 23 & 2 & 5 & 18 & 2 & 5 & 0 & 1 & 2 \\
\hline Sweden & 8 & 10 & 5 & 30 & 1 & 4 & 6 & 2 & 22 & 3 & 6 & 3 \\
\hline Turkey & 10 & 20 & 2 & 33 & 1 & 2 & 13 & 2 & 6 & 1 & 6 & 5 \\
\hline United Kingdom & 8 & 17 & 13 & 43 & 4 & 0 & 1 & 7 & 5 & 0 & 1 & 2 \\
\hline Europe-17 $7^{\circ}$ & 24 & 16 & 5 & 22 & 3 & 6 & 9 & 4 & 6 & 1 & 2 & 3 \\
\hline
\end{tabular}

* weighted to reflect the total architectural population in all 17 countries 
The total value of the European construction market (Europe 32) is estimated to be worth in excess of 1,65 billion Euros per year. ${ }^{44}$ This includes civil engineering and infrastructure work. There are four significant players, who together account for $54 \%$ of total construction output: the UK, France, Germany and Italy. In Belgium, the construction market's size amounted in 2007 to 52.987 million Euros, representing 4,967 Euros construction output per head of population. In the Netherlands this number amounted to 78.648 million Euros representing 4,794 Euros construction output per head of population. See Tables 5 and 6.

Table 5

Size of construction market Million of Euros (or ECU up to 31.12.1998)

\begin{tabular}{|c|c|c|c|c|c|c|c|c|c|c|}
\hline & 1997 & 1998 & 1999 & 2000 & 2001 & 2002 & 2003 & 2004 & 2005 & 2006 \\
\hline ustr & 26.487 & 27.037 & 27.834 & 28.590 & 28.211 & 28.591 & 30.510 & 31.622 & 32.669 & 34.973 \\
\hline Belgium & 30.368 & 30.691 & 33.761 & 35.862 & 36.688 & 36.394 & 37.680 & 40.126 & 42.659 & 48.680 \\
\hline Bulg & 738 & 1.205 & 1.396 & 1.507 & 1.727 & 1.813 & 2.088 & 2.866 & 3.999 & 5.321 \\
\hline Croatia & $\mathrm{n} / \mathrm{a}$ & $\mathrm{n} / \mathrm{a}$ & $\mathrm{n} / \mathrm{a}$ & $\mathrm{n} / \mathrm{a}$ & $\mathrm{n} / \mathrm{a}$ & $\mathrm{n} / \mathrm{a}$ & $\mathrm{n} / \mathrm{a}$ & $\mathrm{n} / \mathrm{a}$ & $\mathrm{n} / \mathrm{a}$ & $\mathrm{n} / \mathrm{a}$ \\
\hline yprus & 1.103 & 1.149 & 1.192 & 1.234 & 1.324 & 1.453 & 1.599 & 1.834 & 2.117 & 2.273 \\
\hline Czecl & 11.805 & 12.426 & 12.182 & 12.880 & 14.255 & 17.011 & 17.904 & 18.686 & 21.101 & 25.665 \\
\hline Denmark & 18.167 & 18.997 & 19.553 & 20.550 & 21.408 & 21.550 & 22.492 & 23.337 & 25.140 & 28.552 \\
\hline stonia & 819 & 1.075 & 998 & 938 & 1.058 & 1.252 & 1.352 & 1.503 & 1.992 & 2.569 \\
\hline Finland & 11.922 & 13.665 & 15.099 & 17.077 & 17.709 & 17.457 & 17.667 & 18.859 & 20.867 & 22.665 \\
\hline rance & $\mathrm{n} / \mathrm{a}$ & $\mathrm{n} / \mathrm{a}$ & 141.002 & 157.605 & 165.638 & 170.250 & 177.465 & 190.175 & 204.994 & 228.674 \\
\hline YROM & $\mathrm{n} / \mathrm{a}$ & $\mathrm{n} / \mathrm{a}$ & $\mathrm{n} / \mathrm{a}$ & $\mathrm{n} / \mathrm{a}$ & $\mathrm{n} / \mathrm{a}$ & $\mathrm{n} / \mathrm{a}$ & $\mathrm{n} / \mathrm{a}$ & $\mathrm{n} / \mathrm{a}$ & $\mathrm{n} / \mathrm{a}$ & $\mathrm{n} / \mathrm{a}$ \\
\hline Germany & 232.295 & 224.543 & 229.880 & 225.270 & 214.460 & 199.390 & 195.730 & 189.440 & 184.480 & 196.690 \\
\hline reece & 1.033 & 14.900 & 16.327 & 21.214 & 23.107 & 24.331 & 27.295 & 29.244 & 30.247 & 31.263 \\
\hline Hungary & 4.258 & 4.130 & 4.553 & 5.430 & 6.592 & 8.177 & 8.021 & 8.892 & 9.776 & 9.948 \\
\hline Ireland & $\mathrm{n} / \mathrm{a}$ & $\mathrm{n} / \mathrm{a}$ & $\mathrm{n} / \mathrm{a}$ & 17.587 & 19.926 & 21.294 & 23.820 & 27.595 & 31.556 & $\mathrm{n} / \mathrm{a}$ \\
\hline aly & 122.206 & 123.471 & 129.065 & 138.840 & 148.197 & 156.842 & 163.900 & 173.415 & 181.237 & 192.843 \\
\hline Latvia & 572 & 869 & 1.047 & 1.224 & 1.426 & 1.627 & 1.841 & 2.575 & 3.167 & 4.604 \\
\hline Lithuania & 1.182 & 1.484 & 1.396 & 1.348 & 1.465 & 1.713 & 2.131 & 2.434 & 2.897 & 3.873 \\
\hline Luxer & 2.041 & 2.311 & 2.559 & 2.810 & 3.067 & 3.511 & 3.671 & 3.701 & 4.007 & 4.290 \\
\hline Malta & 278 & 271 & 273 & 339 & 328 & 399 & 361 & 362 & 376 & 415 \\
\hline Netherlands & 7.043 & 49.839 & 55.027 & 60.287 & 64.656 & 64.880 & 63.650 & 63.675 & 66.284 & 72.085 \\
\hline Norway & 15.942 & 16.251 & 17.220 & 18.154 & 19.291 & 21.625 & 20.663 & 21.921 & 25.847 & 29.448 \\
\hline Poland & 20.925 & 25.513 & 27.084 & 31.790 & 34.928 & 31.244 & 26.164 & 27.280 & 35.680 & 43.749 \\
\hline Portu & 19.056 & 20.848 & 22.019 & 24.376 & 26.226 & 26.912 & 25.708 & 27.167 & 27.940 & 27.260 \\
\hline Romania & $\mathrm{n} / \mathrm{a}$ & 4.226 & 3.671 & 4.491 & 5.486 & 6.171 & 6.811 & 8.114 & 11.319 & 15.882 \\
\hline Slovakia & 4.018 & 3.969 & 3.127 & 3.939 & 4.012 & 4.605 & 4.774 & 5.318 & 6.300 & 6.613 \\
\hline Slovenia & 3.209 & 3.353 & 3.980 & 3.741 & 3.645 & 3.972 & 4.346 & 4.716 & 5.191 & 8.947 \\
\hline Spain & 81.376 & 88.001 & 93.696 & 127.335 & 146.380 & $\mathrm{n} / \mathrm{a}$ & $\mathrm{n} / \mathrm{a}$ & $\mathrm{n} / \mathrm{a}$ & $\mathrm{n} / \mathrm{a}$ & $\mathrm{n} / \mathrm{a}$ \\
\hline Sweden & 15.970 & 16.217 & 17.240 & 18.981 & 19.143 & 19.842 & 20.148 & 22.097 & $\mathrm{n} / \mathrm{a}$ & $\mathrm{n} /$ \\
\hline
\end{tabular}

44 Source of all data except for Turkey: Eurostat, National Accounts by 31 branches - aggregates at current prices. For Turkey the data are provided by TurkStat, the Turkish Statistical Institute. 
Chapter 2

\begin{tabular}{lrrrrrrrrrr}
\hline & 1997 & 1998 & 1999 & 2000 & 2001 & 2002 & 2003 & 2004 & 2005 & 2006 \\
\hline Switzerland & 25.147 & 25.689 & 26.649 & 28.585 & 29.730 & 31.912 & 31.181 & 32.289 & 33.944 & 34.534 \\
Turkey (1) & $\mathrm{n} / \mathrm{a}$ & 1.478 & 3.096 & 5.301 & 13.440 & 24.802 & 33.858 & 39.182 & 45.590 & 66.696 \\
$\begin{array}{l}\text { United King- } \\
\text { dom }\end{array}$ & 147.515 & 161.920 & 177.002 & 201.818 & 214.421 & 230.849 & 227.986 & 250.884 & 245.458 & $\mathrm{n} / \mathrm{a}$ \\
$\begin{array}{l}\text { Europe- 32 } \\
(€ 000 \text { millions) }\end{array}$ & 858 & 895 & 1.092 & 1.219 & 1.287 & 1.326 & 1.347 & 1.415 & 1.475 & 1.596 \\
\hline
\end{tabular}

Source of all data except Turkey: Eurostat, National Accounts by 31 branches - aggregates at current prices Copyright (C) Eurostat. All Rights Reserved.

(1) Source: Derived from raw data sourced from TurkStat, the Turkish Statistical Institute. Raw data (not reproduced here) is Copyright (c) TURKSTAT. Raw data converted from New Turkish Lira to Euros using conversion rates as at 31.12 each year. NB, conversion rates changed significantly over the period 1997 to 2001, and have been more stable since 2002.

(2) Note: some countries which provided data for previous years are marked n/a for 2007 (and occasionally for 2005 and 2006) so the 'total' figure has been adjusted to include the latest available figure for those missing years. Data for Spain is n/a since 2002, here too the latest (2001) figure has been added by the Mirza \& Nacey 2008 to Europe's 'total' figure for those missing years. It was decided to use the latest available data sourced from Eurostat rather than to research missing data direct from national statistical offices, as it proved hard to reconcile data between different sources. Construction output includes civil engineering and infrastructure work.

Table 6

Estimated size of construction market, 2007 (or latest available year) by country, and comparative values.

\begin{tabular}{|c|c|c|c|c|}
\hline & $\begin{array}{c}\text { Construction } \\
\text { output } \\
\text { (€m’s) }\end{array}$ & $\begin{array}{c}\text { Population (num- } \\
\text { ber as at } \\
01.01 .2008)\end{array}$ & $\begin{array}{c}\text { Construction } \\
\text { output per head } \\
\text { of population ( }(€ \text { 's) }\end{array}$ & $\begin{array}{c}\text { Architects (est. } \\
\text { number) }\end{array}$ \\
\hline Austria & 37,544 & $8,331,930$ & 4,506 & 3,800 \\
\hline Belgium & 52,987 & $10,666,866$ & 4,967 & 11,500 \\
\hline Bulgaria & 5,321 & $7,640,238$ & 696 & 3,500 \\
\hline Croatia & $\mathrm{n} / \mathrm{a}$ & $4,435,383$ & $\mathrm{n} / \mathrm{a}$ & 3,000 \\
\hline Cyprus & 2,273 & 794,580 & 2,861 & 430 \\
\hline Czech Republic & 27,934 & $10,381,130$ & 2,691 & 3,000 \\
\hline Denmark & 28,552 & $5,475,791$ & 5,214 & 7,000 \\
\hline Estonia & 2,569 & $1,340,935$ & 1,916 & 700 \\
\hline Finland & 26,077 & $5,300,484$ & 4,920 & 3,600 \\
\hline France & 228,674 & $63,753,140$ & 3,587 & 29,400 \\
\hline FYROM & $\mathrm{n} / \mathrm{a}$ & $2,045,177$ & $\mathrm{n} / \mathrm{a}$ & 3,000 \\
\hline Germany & 212,890 & $82,221,808$ & 2,589 & 95,000 \\
\hline Greece & 32,969 & $11,214,992$ & 2,940 & 15,000 \\
\hline Hungary & 10,436 & $10,045,000$ & 1,039 & 4,000 \\
\hline Ireland & 31,556 & $4,419,859$ & 7,140 & 3,500 \\
\hline Italy & 203,428 & $59,618,114$ & 3,412 & 123,000 \\
\hline Latvia & 6,533 & $2,270,894$ & 2,877 & 700 \\
\hline Lithuania & 5,338 & $3,366,357$ & 1,586 & 2,000 \\
\hline Luxembourg & 4,585 & 483,799 & 9,477 & 600 \\
\hline Malta & 415 & 410,584 & 1,011 & 500 \\
\hline Netherlands & 78,648 & $16,404,282$ & 4,794 & 9,100 \\
\hline Norway & 35,003 & $4,737,171$ & 7,389 & 3,600 \\
\hline Poland & 43,749 & $38,115,641$ & 1,148 & 13,500 \\
\hline
\end{tabular}


The Architect

\begin{tabular}{lrcrr}
\hline & $\begin{array}{c}\text { Construction } \\
\text { output } \\
\left.(€ \mathrm{~m})^{\prime}\right)\end{array}$ & $\begin{array}{c}\text { Population (num- } \\
\text { ber as at } \\
01.01 .2008)\end{array}$ & $\begin{array}{c}\text { Construction } \\
\text { output per head } \\
\text { of population }(€ \text { 's })\end{array}$ & $\begin{array}{c}\text { Architects (est. } \\
\text { number) }\end{array}$ \\
\hline Portugal & 27,260 & $10,617,575$ & 2,567 & 16,300 \\
Romania & 15,882 & $21,528,627$ & 738 & 5,500 \\
Slovakia & 8,401 & $5,400,998$ & 1,555 & 1,300 \\
Slovenia & 10,718 & $2,025,866$ & 5,291 & 1,350 \\
Spain & 146,380 & $45,283,259$ & 3,233 & 45,000 \\
Sweden & 22,097 & $9,182,927$ & 2,406 & 5,400 \\
Switzerland & 34,534 & $7,591,414$ & 4,549 & 5,300 \\
Turkey & 70,156 & $70,585,256$ & 994 & 32,300 \\
United Kingdom & 245,458 & $61,185,981$ & 4,012 & 31,600 \\
Europe- 32 & $1,658,367$ & $586,877,058$ & 2,826 & 483,480 \\
\hline
\end{tabular}

Source: Construction output and population data - Eurostat Copyright (c) Eurostat. All Rights Reserved.

Construction output includes civil engineering and infrastructure work.

The total value of the architectural market in the 17 surveyed countries is estimated to be 11.6 billion Euros. This relates to the total value of the revenue generated by the profession. However, the Mirza \& Nacey research indicates that this figure is very much an estimate, and relies on survey data from which it has been grossed up. Any other published data on the size of the European architectural market were not found, so this estimate is very much a first attempt at establishing the market size and will have to be refined. If this figure is grossed up to reflect all 32 European countries, the total estimated value of the architectural market in Europe is 22 billion Euros.

Analysed per architect, the highest values are recorded by architects in Ireland, the Netherlands and the UK. The average market size per architect in these three countries is 95,000 Euros or more. By comparison, the average market size per architect is under 25,000 Euros in Finland, Greece, Romania and Turkey. In the Netherlands, the market size (the architectural market as measured as the sum of the revenues earned by private architectural practices in each country) is 901,558,000 Euros, representing 99,072 Euros per architect and 54,959 Euros per 1,000 population. The architectural market constitutes $1.1 \%$ of the whole construction market. In Belgium, the market size is only $327,108,000$ Euros, representing a value of 28,444 Euros per architect and 30,666 Euros per 1,000 population. This architectural market is $0.6 \%$ of the construction market. The architectural market is thus larger in the Netherlands than in Belgium. See Table 7 and Chart 2. 
Table 7

Estimated size of architectural market, by country, and comparative values

\begin{tabular}{lrccc}
\hline & $\begin{array}{c}\text { Market size } \\
\left(€ 000^{\prime} s\right)\end{array}$ & $\begin{array}{c}\text { Value per } \\
\left.\text { architect( } €^{\prime} s\right)\end{array}$ & $\begin{array}{c}\text { Value per 1000 } \\
\text { population }\left(€^{\prime} s\right)\end{array}$ & $\begin{array}{c}\text { Architectural market as } \\
\text { per cent construction } \\
\text { market }\end{array}$ \\
\hline Austria & 296,789 & 78,102 & 35,621 & 0.8 \\
Belgium & 327,108 & 28,444 & 30,666 & 0.6 \\
Denmark & 356,228 & 50,890 & 65,055 & 1.2 \\
Estonia & 27,524 & 39,320 & 20,526 & 1.1 \\
Finland & 42,580 & 11,828 & 8,033 & 0.2 \\
France & $1,103,778$ & 37,543 & 17,313 & 0.5 \\
Germany & $3,988,103$ & 41,980 & 48,504 & 1.9 \\
Greece & 294,149 & 19,610 & 26,228 & 0.9 \\
Ireland & 408,855 & 116,816 & 92,504 & 1.3 \\
Luxembourg & 31,828 & 53,047 & 65,788 & 0.7 \\
Malta & 13,320 & 26,641 & 32,443 & 3.2 \\
Netherlands & 901,558 & 99,072 & 54,959 & 1.1 \\
Romania & 112,659 & 20,484 & 5.233 & 0.7 \\
Slovenia & 40,501 & 30,001 & 19,992 & 0.4 \\
Sweden & 145,073 & 26,865 & 15,798 & 0.7 \\
Turkey & 726,778 & 22,501 & 10,296 & 1.0 \\
United kingdom & $2,800,042$ & 88,609 & 45,763 & 1.1 \\
Europe-17 & $11,616,874$ & 45,405 & 31,017 & 1.1 \\
\hline
\end{tabular}

'Market size' refers to the architectural market as measured by the sum of the revenues earned by private architectural practices in each country. Data refers to 2007.

Chart 2

Estimated value of Architectural Market

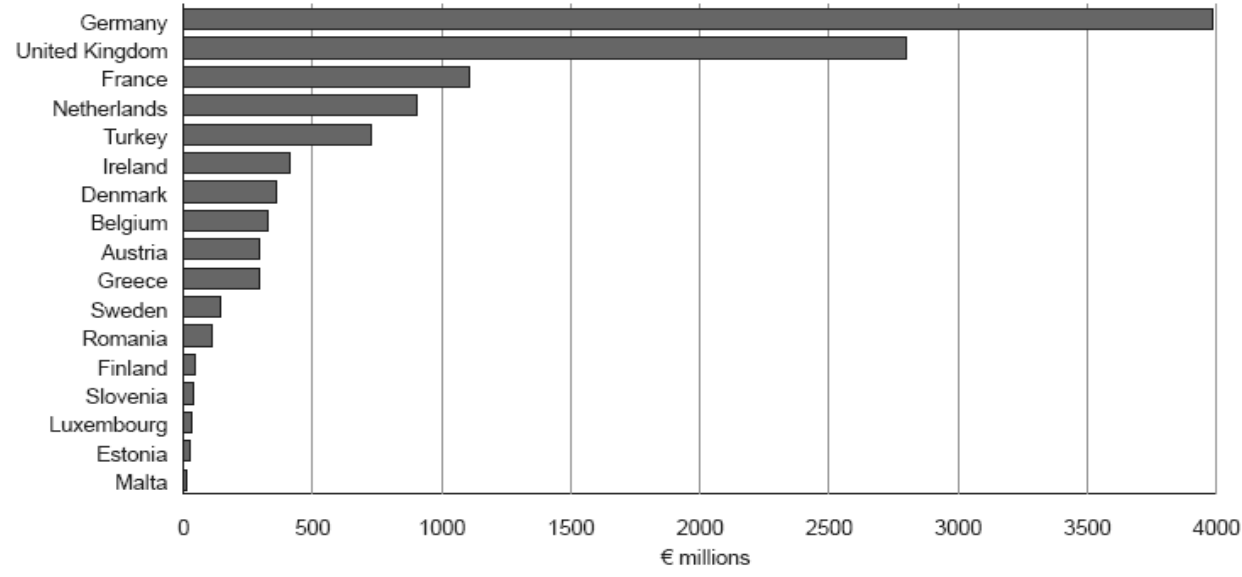


The largest single sector of the market is work with regard to individual houses. These account for an estimated $31 \%$ of the architectural market. Other private housing work which will include flats and housing developments - account for a further $14 \%$. So, in total, $45 \%$ of the architectural market is private housing. Add in the public housing share, and housing in total accounts for $49 \%$. $18 \%$ of the market is commercial work, while public works (including public housing) accounts for $24 \%$. Over half of the work in Belgium is private housing (59\%). This is the highest number within Europe 17. In the Netherlands this is $30 \%$. Not only is private housing the dominant source of revenue, more architectural practices are involved in private housing than in any other sector. $76 \%$ of architectural practices had, in the past 12 months before the study was published, derived revenue from work on individual houses; while $48 \%$ had undertaken other private housing work. $42 \%$ have been involved in the office sector. An overview is presented in Charts 3 and 4 and Tables 8 and 9.

Chart 3

Proportion of market by building sector

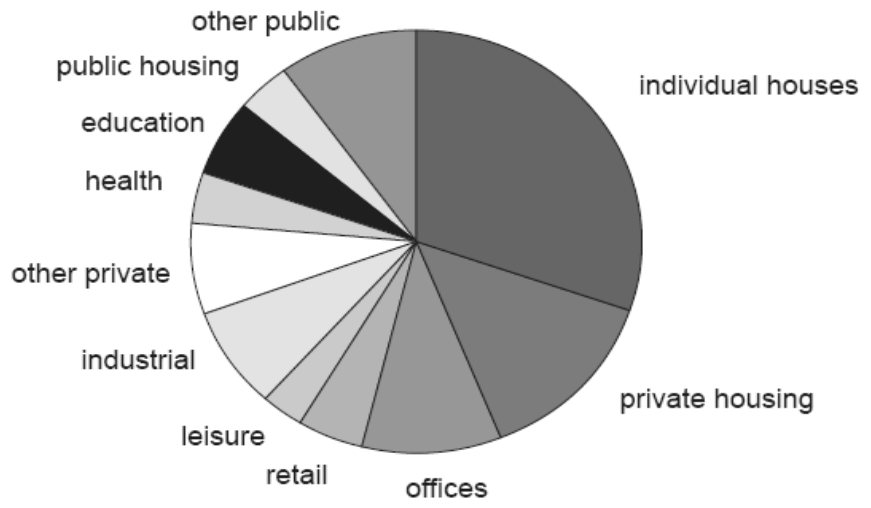

Table 8

Comparison of the proportion of the market accounted for by different building sectors, and the proportion of practices involved in these building sectors

\begin{tabular}{lcc}
\hline & Per cent of market & Per cent of practices involved \\
\hline Individual houses & 31 & 76 \\
Other private housing & 14 & 48 \\
Offices & 10 & 42 \\
Retail & 5 & 26 \\
Leisure and the arts & 3 & 14 \\
Industrial & 8 & 32 \\
Health & 4 & 14 \\
Education & 6 & 22 \\
Public housing & 4 & 13 \\
Other private & 7 & 29 \\
Other public & 10 & 30 \\
\hline
\end{tabular}


Table 9

Proportion of work undertaken by the building sector, analysed by country (per cent)

\begin{tabular}{|c|c|c|c|c|c|c|c|c|c|c|c|c|}
\hline & 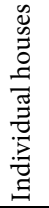 & 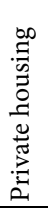 & $\underbrace{\mathscr{\sharp}}_{0}$ & 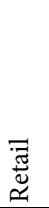 & 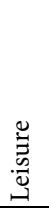 & 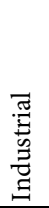 & $\begin{array}{l}\text { 声 } \\
\text { 芯 } \\
\text { 吾 }\end{array}$ & 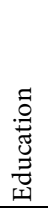 & 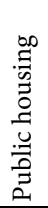 & 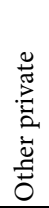 & 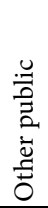 & $\stackrel{\vec{\pi}}{0}$ \\
\hline Austria & 20 & 8 & 11 & 3 & 4 & 7 & 7 & 7 & 13 & 8 & 11 & 100 \\
\hline Belgium & 44 & 15 & 7 & 4 & 2 & 5 & 4 & 3 & 5 & 2 & 10 & 100 \\
\hline Denmark & 20 & 11 & 12 & 5 & 5 & 8 & 5 & 6 & 10 & 8 & 11 & 100 \\
\hline Estonia & 18 & 8 & 24 & 6 & 1 & 2 & 3 & 9 & 13 & 8 & 7 & 100 \\
\hline Finland & 18 & 8 & 13 & 13 & 4 & 7 & 4 & 6 & 8 & 5 & 14 & 100 \\
\hline France & 24 & 14 & 7 & 4 & 4 & 3 & 7 & 8 & 7 & 6 & 16 & 100 \\
\hline Germany & 30 & 13 & 10 & 4 & 2 & 11 & 4 & 7 & 2 & 7 & 11 & 100 \\
\hline Greece & 42 & 15 & 7 & 6 & 3 & 4 & 1 & 3 & 3 & 5 & 11 & 100 \\
\hline Ireland & 29 & 11 & 8 & 9 & 4 & 3 & 8 & 7 & 8 & 10 & 4 & 100 \\
\hline Luxembourg & 43 & 13 & 8 & 3 & 3 & 4 & 2 & 7 & 2 & 3 & 11 & 100 \\
\hline Malta & 28 & 18 & 10 & 10 & 4 & 10 & 3 & 1 & 1 & 9 & 8 & 100 \\
\hline Netherlands & 18 & 12 & 14 & 4 & 6 & 8 & 8 & 8 & 13 & 4 & 5 & 100 \\
\hline Romania & 34 & 11 & 13 & 8 & 3 & 9 & 1 & 3 & 4 & 8 & 6 & 100 \\
\hline Slovenia & 27 & 9 & 9 & 2 & 6 & 9 & 2 & 8 & 11 & 4 & 14 & 100 \\
\hline Sweden & 19 & 14 & 14 & 4 & 5 & 6 & 3 & 7 & 11 & 7 & 10 & 100 \\
\hline Turkey & 30 & 23 & 7 & 10 & 2 & 8 & 2 & 2 & 2 & 8 & 5 & 100 \\
\hline United kingdom & 38 & 16 & 8 & 4 & 3 & 2 & 2 & 11 & 3 & 8 & 6 & 100 \\
\hline Europe- 17 & 31 & 14 & 10 & 5 & 3 & 8 & 4 & 6 & 4 & 7 & 10 & 100 \\
\hline
\end{tabular}

Chart 4

Proportion of work undertaken for each main building sector, ranked in order of highest private housing work

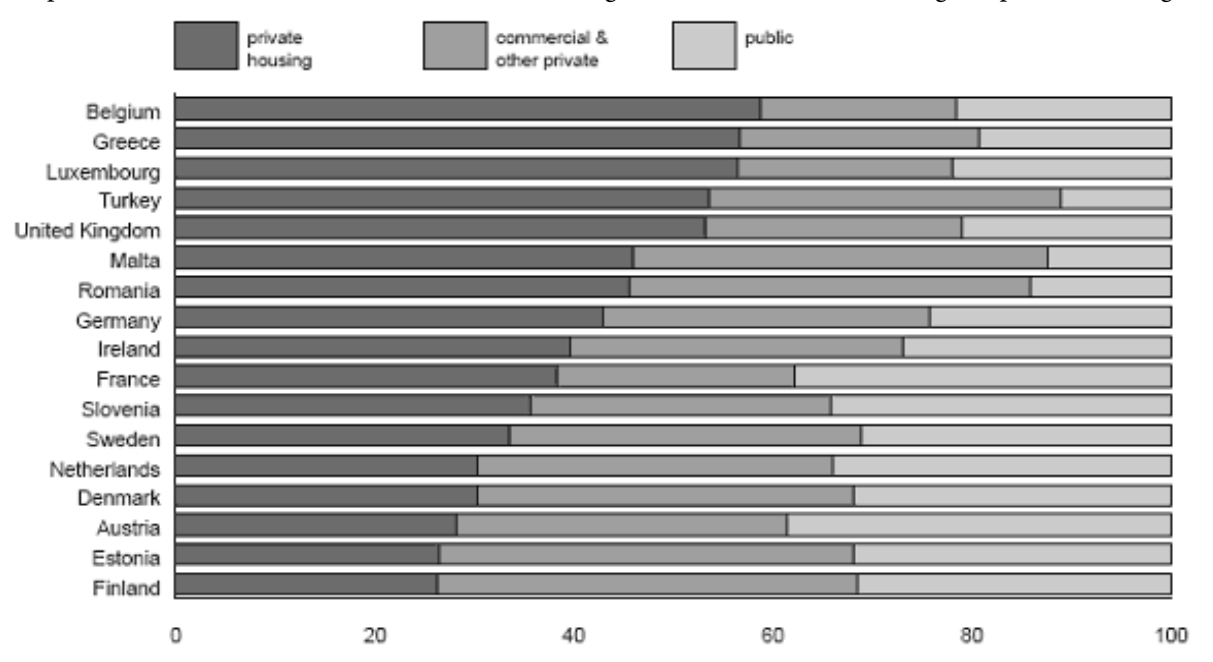

per cent total market 
Private individuals are architects' principal client type, accounting for almost half (47\%) of architectural practices' revenue. This clearly mirrors the importance of individual housing as the largest market sector. Public sector clients account for $22 \%$ of revenue, while $10 \%$ of revenue comes from developers and $14 \%$ from private companies. See Chart 5 and Table 10.

\section{Chart 5}

Proportion of market by client type

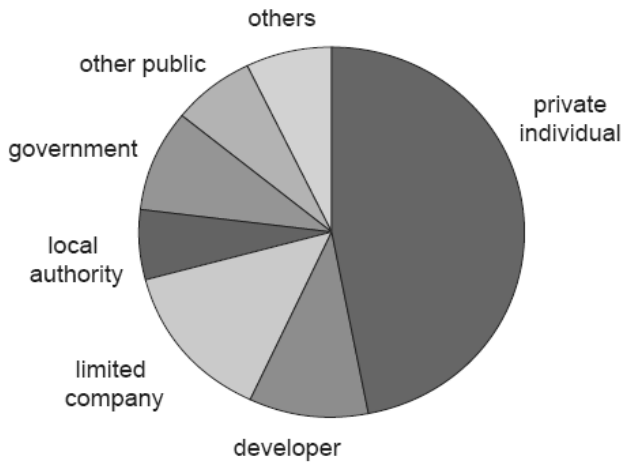

Table 10

Proportion of work undertaken for different clients, analysed by country

\begin{tabular}{|c|c|c|c|c|c|c|c|c|c|}
\hline Per cent & 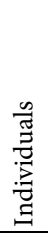 & 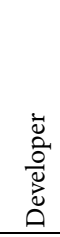 & 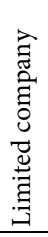 & 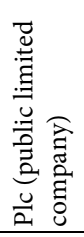 & 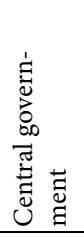 & 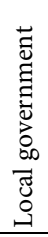 & 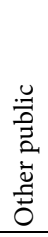 & 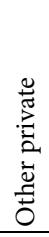 & $\begin{array}{l}\text { 픔 } \\
\stackrel{0}{0}\end{array}$ \\
\hline Austria & 40 & 9 & 18 & 0 & 13 & 10 & 4 & 6 & 100 \\
\hline Belgium & 54 & 13 & 11 & 0 & 3 & 2 & 13 & 5 & 100 \\
\hline Denmark & 39 & 19 & 10 & 0 & 3 & 15 & 7 & 8 & 100 \\
\hline Estonia & 25 & 34 & 16 & 0 & 3 & 16 & 6 & 1 & 100 \\
\hline Finland & 24 & 15 & 25 & 0 & 3 & 12 & 18 & 2 & 100 \\
\hline France & 34 & 13 & 6 & 0 & 2 & 1 & 35 & 8 & 100 \\
\hline Germany & 49 & 6 & 13 & 0 & 7 & 13 & 5 & 8 & 100 \\
\hline Greece & 56 & 13 & 9 & 0 & 5 & 7 & 4 & 5 & 100 \\
\hline Ireland & 35 & 21 & 9 & 0 & 4 & 9 & 6 & 14 & 100 \\
\hline Luxembourg & 48 & 19 & 4 & 0 & 9 & 3 & 16 & 1 & 100 \\
\hline Malta & 34 & 34 & 16 & 0 & 4 & 0 & 4 & 7 & 100 \\
\hline Netherlands & 35 & 27 & 10 & 0 & 3 & 11 & 8 & 5 & 100 \\
\hline Romania & 44 & 22 & 18 & 0 & 2 & 3 & 5 & 4 & 100 \\
\hline Slovenia & 37 & 20 & 12 & 0 & 9 & 14 & 7 & 2 & 100 \\
\hline Sweden & 32 & 23 & 14 & 0 & 4 & 12 & 9 & 4 & 100 \\
\hline Turkey & 53 & 8 & 22 & 0 & 1 & 4 & 5 & 7 & 100 \\
\hline United kingdom & 48 & 22 & 13 & 0 & 3 & 4 & 1 & 10 & 100 \\
\hline Europe- 17 & 47 & 10 & 14 & 0 & 6 & 9 & 7 & 7 & 100 \\
\hline
\end{tabular}


Building design is very clearly the principal revenue generating activity, accounting for two thirds $(66 \%)$ of the total market. The only other significant service type is interior design, which accounts for $9 \%$ of total architectural revenue. The remainder of the market is split between several types of service, for example planning, project management, feasibility studies, landscape design, each of which accounts for $5 \%$ or less of the total. In Belgium, building design constitutes $74 \%$ of the architects' work. In the Netherlands, this is $69 \%$.

There are an estimated 69,800 private architectural practices in the 17 responding countries. Grossing-up this figure to reflect all 32 European countries produces an estimate of 130,000 private architectural practices in Europe. More than half (54\%) of these practices are one person firms. A further 35\% have between 2 and 5 architectural staff. $8 \%$ of practices have between 6 and 10 architectural staff and 3\% have 11 and 30. Only 1\% of architectural practices have more than 30 staff. It follows that architectural practices are skewed very heavily towards small firms ('micro-enterprises'). However, large firms employ a significant number of architects. The researchers estimate that in the Europe 17 countries, $12 \%$ of the total private practice workforce is employed in firms of more than 50 architectural staff. Hence, 19,000 architects are employed in 350 firms. At the other end of the scale, the 37,000 one person firms employ $21 \%$ of all private practice architects. In Belgium 2.403 out of 3.894 architectural practices have only 1 member of staff. In the Netherlands, this is 1.896 out of 3.304 .

Over half of the principals work in 'independent architect practices'. This may include freelance architects and architects working on their own as a sole principal. The independent architect practices model is most common in Austria, Belgium France, Germany and Luxembourg. In each of these countries it accounts for over $50 \%$ of architectural practices. In the Netherlands this is $38 \% .18 \%$ of principals work in partnerships and $22 \%$ are directors in limited companies. See Chart 6 and Table 11.

Chart 6

Type of architectural businesses

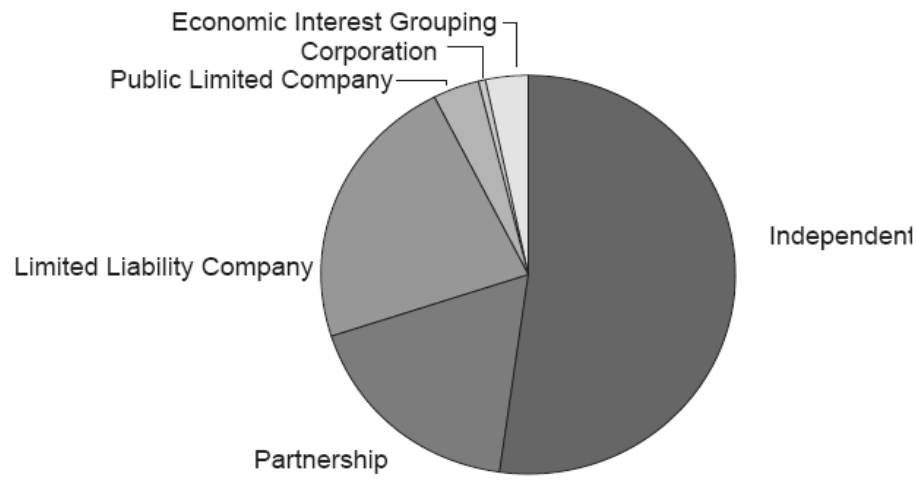


The Architect

Table 11

Legal formation of architectural practices - based on type of practice in which principals work (per cent)

\begin{tabular}{|c|c|c|c|c|c|c|}
\hline & 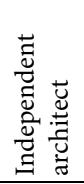 & 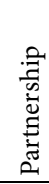 & 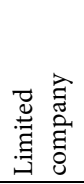 & 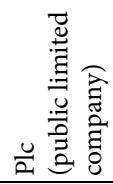 & 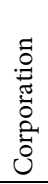 & 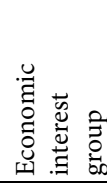 \\
\hline Austria & 59 & 9 & 29 & 3 & 0 & 0 \\
\hline Belgium & 52 & 12 & 25 & 7 & 2 & 2 \\
\hline Denmark & 48 & 28 & 14 & 3 & 0 & 7 \\
\hline Estonia & 0 & 44 & 25 & 19 & 6 & 6 \\
\hline Finland & 32 & 11 & 5 & 52 & 0 & 0 \\
\hline France & 54 & 7 & 35 & 3 & 0 & 1 \\
\hline Germany & 70 & 19 & 8 & 1 & 0 & 2 \\
\hline Greece & 37 & 35 & 7 & 5 & 0 & 16 \\
\hline Ireland & 33 & 13 & 49 & 3 & 0 & 1 \\
\hline Luxembourg & 57 & 11 & 25 & 7 & 0 & 0 \\
\hline Malta & 44 & 25 & 16 & 0 & 3 & 13 \\
\hline Netherlands & 38 & 21 & 32 & 6 & 0 & 3 \\
\hline Romania & 28 & 20 & 43 & 3 & 1 & 4 \\
\hline Slovenia & 35 & 24 & 27 & 4 & 2 & 8 \\
\hline Sweden & 28 & 26 & 16 & 11 & 1 & 18 \\
\hline Turkey & 25 & 9 & 56 & 6 & 1 & 3 \\
\hline United kingdom & 26 & 9 & 57 & 3 & 0 & 6 \\
\hline Europe- 17 & 52 & 18 & 22 & 4 & 1 & 3 \\
\hline
\end{tabular}

The average revenue per practice in 2007 was considerably higher in the Netherlands ${ }^{45}$ than in Belgium. ${ }^{46}$ Practices with only 1 staff member earned 33,457 in Belgium and 84,497 in the Netherlands. Likewise differences exist in practices with more staff. In practices with 31 to 50 staff members for example, the average revenue was 1,750,000 in Belgium and 2,910,834 in the Netherlands. See Table 12.

Table 12

Average revenue per practice analysed by country and practice size Size of practice (number of architectural staff)

\begin{tabular}{lrrrrrrr} 
& 1 & 2 & 3 to 5 & 6 to 10 & 11 to 30 & 31 to 50 & $51+$ \\
\hline Austria & 67,216 & 198,915 & 271,281 & 457,591 & $1,530,625$ & $\mathrm{n} / \mathrm{a}$ & $\mathrm{n} / \mathrm{a}$ \\
Belgium & 33,457 & 88,979 & 147,571 & 171,167 & 334,375 & $1,750,000$ & $\mathrm{n} / \mathrm{a}$ \\
Denmark & 72,903 & 291,700 & $\mathrm{n} / \mathrm{a}$ & 566,330 & $\mathrm{n} / \mathrm{a}$ & $\mathrm{n} / \mathrm{a}$ & $\mathrm{n} / \mathrm{a}$ \\
Estonia & $\mathrm{n} / \mathrm{a}$ & $\mathrm{n} / \mathrm{a}$ & 231,665 & 322,500 & $\mathrm{n} / \mathrm{a}$ & $\mathrm{n} / \mathrm{a}$ & $\mathrm{n} / \mathrm{a}$
\end{tabular}

45 See also the report of the Dutch Central Agency of Statistics, Architecten-en ingenieursbureaus (Brancebeschrijving 2000-2006), 2 October 2008.

46 The Belgian Federal Public Service 'Economy, SMEs, Self-Employed and Energy' only has data regarding the gross average income of architects who work as employees. These data also include the income of engineers. The figures can therefore not be compared to those of Mirza \& Nacey, 2008. See also Alajääskö and Blackburn, 2004, who discussed the total turnover share of architectural and engineering activities products with regard to eight EU Member States. 
Chapter 2

\begin{tabular}{|c|c|c|c|c|c|c|c|}
\hline \multicolumn{8}{|c|}{ Size of practice (number of architectural staff) } \\
\hline & 1 & 2 & 3 to 5 & 6 to 10 & 11 to 30 & 31 to 50 & $51+$ \\
\hline Finland & 42,376 & 70,000 & 98,545 & 350,000 & 62,500 & $\mathrm{n} / \mathrm{a}$ & 600,000 \\
\hline France & 48,803 & 138,158 & 298,773 & 698,573 & $\mathrm{n} / \mathrm{a}$ & $\mathrm{n} / \mathrm{a}$ & $\mathrm{n} / \mathrm{a}$ \\
\hline Germany & 43,604 & 88,458 & 197,263 & 406,027 & $1,139,455$ & $1,745,167$ & $3,768,279$ \\
\hline Greece & 29,018 & 33,612 & 55,231 & 284,625 & 194,708 & $\mathrm{n} / \mathrm{a}$ & $1,328,750$ \\
\hline Ireland & 72,361 & 146,294 & 270,556 & 498,453 & $1,580,107$ & $4,650,000$ & $\mathrm{n} / \mathrm{a}$ \\
\hline Luxembourg & 61,335 & $\mathrm{n} / \mathrm{a}$ & 216,417 & 605,778 & $1,502,042$ & $\mathrm{n} / \mathrm{a}$ & $\mathrm{n} / \mathrm{a}$ \\
\hline Malta & 46,171 & 83,375 & 64,086 & 236,250 & 496,725 & $\mathrm{n} / \mathrm{a}$ & $\mathrm{n} / \mathrm{a}$ \\
\hline Netherlands & 84,497 & 103,714 & 292,003 & 325,909 & $1,401,228$ & $2,910,834$ & $\mathrm{n} / \mathrm{a}$ \\
\hline Romania & 39,555 & 39,680 & 72,235 & 129,915 & 273,301 & $\mathrm{n} / \mathrm{a}$ & $\mathrm{n} / \mathrm{a}$ \\
\hline Slovenia & 27,506 & 51,220 & 126,564 & 342,832 & 750,000 & 835,000 & \\
\hline Sweden & 54,762 & 257,250 & $\mathrm{n} / \mathrm{a}$ & 304,719 & 521,629 & $\mathrm{n} / \mathrm{a}$ & $1,542,654$ \\
\hline Turkey & 17,028 & 38,556 & 57,292 & 154,042 & 372,851 & $\mathrm{n} / \mathrm{a}$ & $1,261,888$ \\
\hline United kingdom & 52,205 & 130,164 & 212,467 & 893,258 & $\mathrm{n} / \mathrm{a}$ & $\mathrm{n} / \mathrm{a}$ & $\mathrm{n} / \mathrm{a}$ \\
\hline Europe- 17 & 59,389 & 117,827 & 201,693 & 498,563 & $1,282,563$ & $3,156,907$ & $4,563,556$ \\
\hline
\end{tabular}

Figures are averages (means). The minimum number of responses to give a reliable answer is 10 . But for smaller countries, Mirza \& Nacey have extended this to 5 and, in very exceptional cases, to 4 . Where there are fewer than four responses, or where the figure varies excessively from the mean, the researchers marked the data as $\mathrm{n} / \mathrm{a}$ Calculated as the sum of the average of each of four practice sizes. Where data for a practice size is $\mathrm{n} / \mathrm{a}$ the 'All' average for that size has been applied, but grossed up or down dependent upon the grossing factor calculated for available data for that country.

The most common method of calculating charges is as a percentage of the total contract value. A majority of jobs currently being undertaken by architects are being charged using this method. The number for Belgium is $57 \%$ and for the Netherlands $40 \%$. Next most popular (23\%) is a charge agreed after an estimate of the time required; while $16 \%$ base their charges on an hourly rate. $6 \%$ of jobs appear to be undertaken 'at risk', where there has been no agreement on charges. See Table 13.

Table 13

How charges are calculated (per cent current jobs)

\begin{tabular}{lcccc}
\hline & $\begin{array}{c}\text { Method of calculating charge } \\
\text { Per cent of } \\
\text { contract value }\end{array}$ & Lump sum & $\begin{array}{c}\text { Hourly } \\
\text { charge }\end{array}$ & $\begin{array}{c}\text { No charge agreed } \\
\text { (effectively at risk) }\end{array}$ \\
\hline Austria & 67 & 18 & 13 & 3 \\
Belgium & 57 & 21 & 19 & 2 \\
Denmark & 29 & 39 & 23 & 8 \\
Estonia & 47 & 41 & 9 & 3 \\
Finland & 5 & 43 & 48 & 3 \\
France & 68 & 26 & 6 & 1 \\
Germany & 61 & 18 & 18 & 4 \\
Greece & 39 & 41 & 12 & 8 \\
Ireland & 61 & 26 & 7 & 7 \\
Luxembourg & 72 & 13 & 13 & 2
\end{tabular}


The Architect

\begin{tabular}{lcccc}
\hline & $\begin{array}{c}\text { Method of calculating charge } \\
\text { Per cent of } \\
\text { contract value }\end{array}$ & Lump sum & $\begin{array}{c}\text { Hourly } \\
\text { charge }\end{array}$ & $\begin{array}{c}\text { No charge agreed } \\
\text { (effectively at risk) }\end{array}$ \\
\hline Malta & 58 & 17 & 13 & 11 \\
Netherlands & 40 & 38 & 17 & 4 \\
Romania & 64 & 23 & 8 & 5 \\
Slovenia & 60 & 39 & 8 & 7 \\
Sweden & 3 & 30 & 53 & 5 \\
Turkey & 45 & 42 & 18 & 20 \\
United kingdom & 35 & 23 & 16 & 3 \\
Europe- 17 & 56 & &
\end{tabular}

The Europe 17 average hourly charge-out rate for principals is 63 Euros per hour. This is the average rate which principals charge clients for an hour of their work, before tax. This is $21 \%$ more than the average rate at which architects are charged out by private practices (50 Euros per hour), technical staff is charged-out at an average of 40 Euros per hour. Average hourly charge-out rates vary considerably between the 17 surveyed countries. The researchers have attempted to adjust these data to take account of different price levels between the countries, using a Purchasing Power Parity (PPP) index. The researchers used an index sourced from Eurostat, whose Comparative Price Level Indices assess the price level of each country in comparison with all $27 \mathrm{EU}$ Member States. Each country's average hourly rate figure is divided by the country's index value to create the PPP adjusted figure. The PPP hourly charge-out rates are highest for principals in Ireland and the Netherlands. In the Netherlands, principals earn 116 Euros per hour, architects 92 Euros and technologists 68 Euros. In Belgium the earnings are considerably lower: principals earn 60 Euros per hour, architects 47 Euros and technologists 42 Euros. ${ }^{47}$ Lowest hourly rates are recorded in Romania and Turkey. The pattern is very similar for architects and for technical staff. See Table 14 and Chart 7.

Table 14

Average hourly charge-out rates adjusted to take account of Purchasing Power Parity

\begin{tabular}{|c|c|c|c|}
\hline & \multicolumn{3}{|c|}{$\begin{array}{l}\text { Average hourly charge-out rates adjusted to take account of purchasing power parities } \\
\text { (ppp), Euros }\end{array}$} \\
\hline & Principals & Architects & Technologists \\
\hline Austria & 79 & 69 & 54 \\
\hline Belgium & 60 & 47 & 42 \\
\hline Denmark & 73 & 65 & 54 \\
\hline Estonia & 74 & 46 & 32 \\
\hline Finland & 57 & 49 & 41 \\
\hline France & 74 & 69 & 46 \\
\hline Germany & 58 & 52 & 39 \\
\hline
\end{tabular}

47 The unadjusted average hourly charge-out rates also indicates a considerable difference between the rates in Belgium and the Netherlands: 120 Euros for principals, 95 Euros for architects and 70 Euros for technologists in the Netherlands; 64 Euros for principals, 50 Euros for architects and 45 Euros for technologists in Belgium. 
Average hourly charge-out rates adjusted to take account of purchasing power parities (ppp), Euros

\begin{tabular}{lccc} 
& Principals & Architects & Technologists \\
\hline Greece & 39 & 16 & 11 \\
Ireland & 116 & 80 & 60 \\
Luxembourg & 90 & 71 & 50 \\
Malta & 82 & 61 & 34 \\
Netherlands & 116 & 92 & 68 \\
Romania & 24 & 13 & 7 \\
Slovenia & 48 & 39 & 23 \\
Sweden & 73 & 64 & 55 \\
Turkey & 20 & 11 & 7 \\
United kingdom & 103 & 79 & 67 \\
\hline
\end{tabular}

Data is expressed in Euros, but each country's figure has been adjusted using an index of Purchasing Power Parity (PPP). This index takes account of price level differences across countries. An index sourced from Eurostat was used, whose Comparative Price Level Indices assess the price level of each country in comparison with all $27 \mathrm{EU}$ member countries. Thus EU $27=100$. Other indices are for example: Ireland 124, France 108, Germany 103 , Greece 89 , Turkey 71 , Romania 61 . Each country's average hourly rates figure is divided by the country's index value to create the PPP adjusted figure.

Chart 7

Average hourly charge-out rates for Principals, adjusted for Purchasing Power Parity

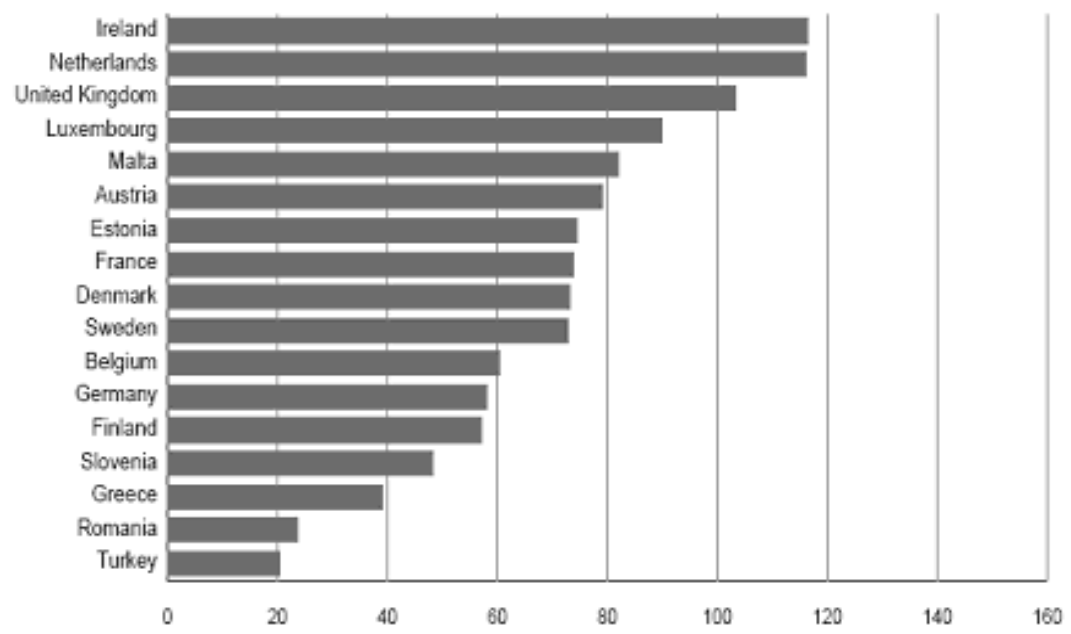

average rates, $€$ 's, adjusted for PPP

Architects in Europe earn an average of 36,686 Euros before tax. However, there is a substantial variation in this average across Europe. The researchers have attempted to adjust the average earnings to take account of differing price levels in the 17 surveyed countries, adjusting each country's average earnings figure by its purchasing power. These adjusted figures show average earnings are highest in the Netherlands (52,224 Euros adjusted for PPP; 54,000 Euros unadjusted) and Ireland, and lowest in Romania and Turkey (20,486 Euros adjusted for PPP; 14,648 Euros unadjusted). In Belgium the earnings are 28,222 Euros adjusted for PPP and 30,000 Euros unadjusted. 
In general, the highest earning group of architects is partners/directors. Their average earnings, at 44,847 Euros, are 17\% higher than those of the second highest earners, sole principals. Salaried architects in private practice earn an average of 34,047 Euros, some $24 \%$ below that of partners/directors. The average earnings of architects in lo$\mathrm{cal} /$ central government, at 25,124 Euros, are 26\% lower than those of salaried architects in private practice. Principals (sole principals and partners/directors) earn 30,000 Euros in Belgium ${ }^{48}$ and 72,500 in the Netherlands. Private practice salaried architects earn 24,000 Euros in Belgium and 42,000 in the Netherlands. It is obvious that there is a huge income difference between these two neighbouring countries. Table 15 deals with the average earning of full-time architects in general. These are ranged in Chart 8. Chart 9 gives an indication of the earning by field of employment.

Table 15

Average earnings analysed by country and field of employment (unadjusted)

\begin{tabular}{|c|c|c|c|c|c|c|c|c|c|c|}
\hline & 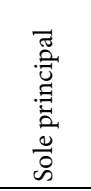 & 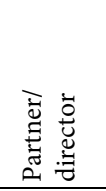 & 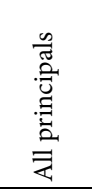 & 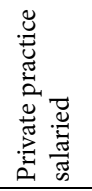 & 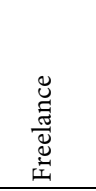 & 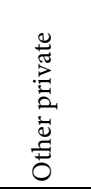 & 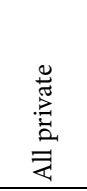 & 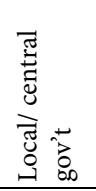 & 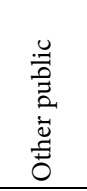 & 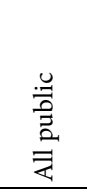 \\
\hline Austria & 50,000 & 40,000 & 48,000 & $\mathrm{n} / \mathrm{a}$ & $\mathrm{n} / \mathrm{a}$ & $\mathrm{n} / \mathrm{a}$ & 47,460 & $\mathrm{n} / \mathrm{a}$ & $\mathrm{n} / \mathrm{a}$ & $\mathrm{n} / \mathrm{a}$ \\
\hline Belgium & 30,600 & 24,000 & 30,000 & 24,000 & 30,000 & 31,000 & 30,000 & 28,500 & $\mathrm{n} / \mathrm{a}$ & 33,734 \\
\hline Denmark & 67,150 & 53,720 & 67,150 & 53,720 & $\mathrm{n} / \mathrm{a}$ & 46,736 & 53,720 & 53,720 & 30,218 & 53,720 \\
\hline Estonia & 41,280 & 25,800 & 27,735 & $\mathrm{n} / \mathrm{a}$ & $\mathrm{n} / \mathrm{a}$ & $\mathrm{n} / \mathrm{a}$ & 25,800 & $\mathrm{n} / \mathrm{a}$ & $\mathrm{n} / \mathrm{a}$ & $\mathrm{n} / \mathrm{a}$ \\
\hline Finland & 35,000 & 49,250 & 42,000 & 36,000 & $\mathrm{n} / \mathrm{a}$ & 36,500 & 39,800 & 45,000 & 42,500 & 45,000 \\
\hline France & 29,000 & 42,000 & 30,000 & 46,800 & 35,000 & 37,200 & 35,500 & $\mathrm{n} / \mathrm{a}$ & $\mathrm{n} / \mathrm{a}$ & 39,585 \\
\hline Germany & 40,000 & 46,300 & 40,000 & 36,000 & 35,000 & 48,000 & 40,000 & 45,000 & 50,500 & 47,000 \\
\hline Greece & 30,000 & 30,000 & 30,000 & 18,000 & 20,000 & 22,500 & 24,000 & 21,500 & 30,083 & 26,000 \\
\hline Ireland & 75,000 & 80,000 & 77,500 & 60,000 & $\mathrm{n} / \mathrm{a}$ & 72,500 & 65,000 & 70.000 & 60,000 & 66,000 \\
\hline Luxembourg & 57,000 & 45,000 & 50,000 & 90,000 & $\mathrm{n} / \mathrm{a}$ & 50,000 & 50,000 & $\mathrm{n} / \mathrm{a}$ & $\mathrm{n} / \mathrm{a}$ & $\mathrm{n} / \mathrm{a}$ \\
\hline Malta & 51,000 & 42,000 & 42,000 & 20,000 & 25,000 & $\mathrm{n} / \mathrm{a}$ & 25,250 & $\mathrm{n} / \mathrm{a}$ & $\mathrm{n} / \mathrm{a}$ & 25,000 \\
\hline Netherlands & 45,144 & 103,500 & 72,500 & 42,000 & $\mathrm{n} / \mathrm{a}$ & $\mathrm{n} / \mathrm{a}$ & 52,000 & $\mathrm{n} / \mathrm{a}$ & $\mathrm{n} / \mathrm{a}$ & $\mathrm{n} / \mathrm{a}$ \\
\hline Romania & 16,788 & 26,889 & 22,384 & 11.472 & 14,943 & 10,912 & 13,990 & 11,192 & 11,836 & 11,514 \\
\hline Slovenia & 33,000 & 26,000 & 30,000 & 16,500 & 12,000 & 15,600 & 24,000 & 17,000 & $\mathrm{n} / \mathrm{a}$ & 34,000 \\
\hline Sweden & 38,376 & 44,772 & 42,640 & 34,347 & 31,980 & 5,010 & 35,178 & 34,538 & 43,706 & 35,178 \\
\hline Turkey & 26,366 & 26,366 & 26,333 & 13,988 & 17,577 & 11,952 & 14,648 & 14,062 & 10,546 & 11,718 \\
\hline United kingdom & 50,992 & 58,373 & 56,360 & 46,966 & $\mathrm{n} / \mathrm{a}$ & 67,095 & 49,650 & $\mathrm{n} / \mathrm{a}$ & $\mathrm{n} / \mathrm{a}$ & $\mathrm{n} / \mathrm{a}$ \\
\hline Europe- $17^{\star}$ & 38,227 & 44,847 & 40,292 & 34,047 & 20,641 & 37,927 & 36,953 & 25,124 & 25,266 & 30,742 \\
\hline
\end{tabular}

* Europe -17 figure is a weighted average and takes account of the number of architects in each participating country. Earnings date converted from local currencies to Euro, exchange rate as at 01.09.2008. A table with average earnings, adjusted for Purchasing Power Parity, was not available.

48 In Belgium the average earnings of sole principals are higher than that of partners/directors. 
Chart 8

Average earnings, all full-time architects, adjusted for Purchasing Power Parity (PPP)

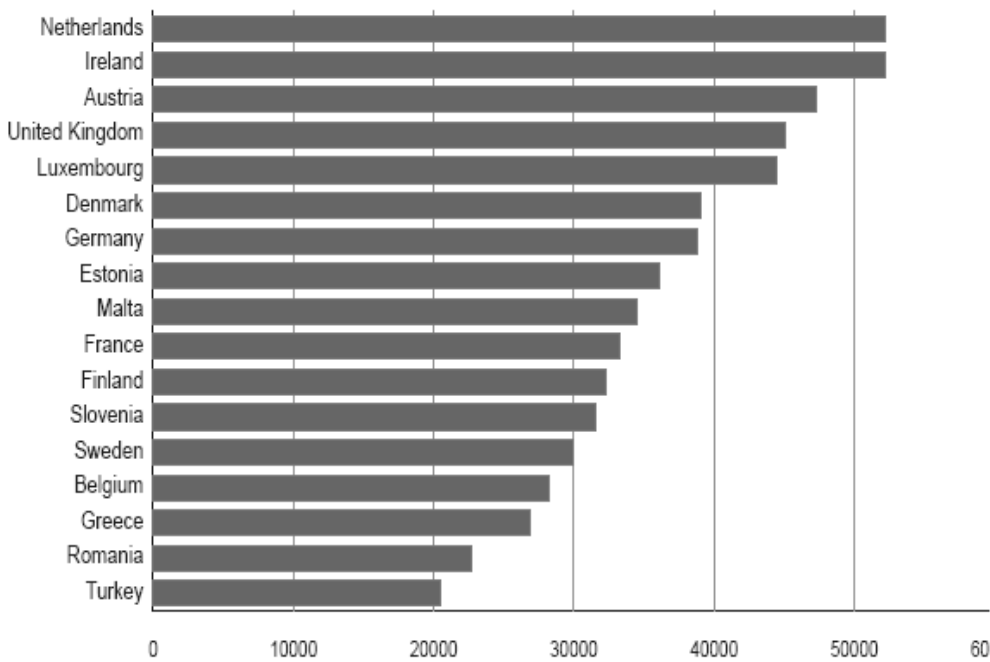

Chart 9

Earnings by field of employment (unadjusted)

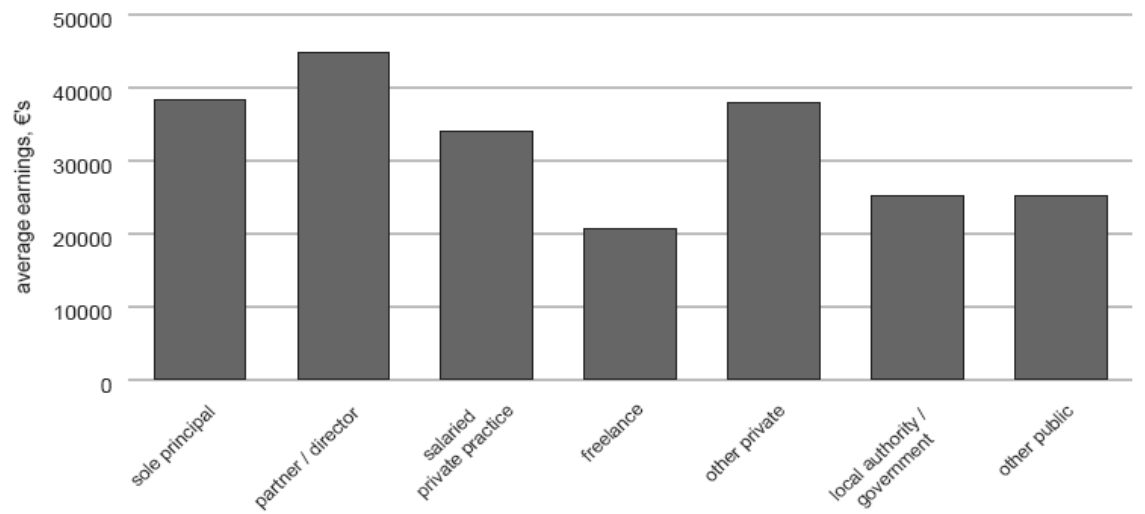

The Mirza \& Nacey research indicates that the highest number of hours worked is recorded by sole principals ( 51 hours per week) closely followed by partners/directors (50 hours per week). Their salaried colleagues in private practice work an average of 46 hours per week. Architects working in the public sector have a shorter working week than in the private sector, although average hours are still 42 (local authorities and central government) or 43 hours (other public). The longest working hours per week for partners/directors are recorded in Belgium (58 hours) and Malta (54 hours); the longest working hours for private practice salaried architects are in Belgium, Austria, France and Turkey (each over 48 hours). In Belgium, architects not working for the government, work more hours per week than their colleagues in the Netherlands (Belgium: sole principals 53.5 hours; parent/director 58.3 hours; private practice salaried 49.8 
hours; freelance architects 45.1 hours; other private: 48.8 hours; local/central government 43 hours; other public 45 hours - Netherlands: sole principals 48 hours; partner/directors 47.3 hours; private practice salaried 46.2 hours; freelance architects 42 hours; other private 47.3 hours; local/central government 50 hours; other public 51.7 hours). Furthermore, architects in all employment areas report that they work longer hours than their contracts demand. Table 16 gives an overview.

Table 16

Average number of hours worked per week, analysed by country and by field of employment

\begin{tabular}{|c|c|c|c|c|c|c|c|}
\hline & 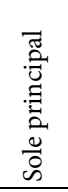 & 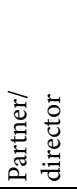 & 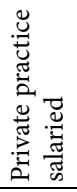 & 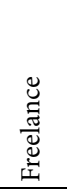 & 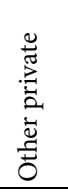 & 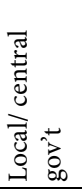 & 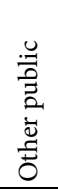 \\
\hline Austria & 54.0 & 51.3 & 48.8 & $\mathrm{n} / \mathrm{a}$ & $\mathrm{n} / \mathrm{a}$ & $\mathrm{n} / \mathrm{a}$ & $\mathrm{n} / \mathrm{a}$ \\
\hline Belgium & 53.5 & 58.3 & 49.8 & 45.1 & 48.8 & 43.0 & 45.0 \\
\hline Denmark & 44.3 & 47.0 & 39.5 & 40.0 & 40.1 & 40.1 & 40.7 \\
\hline Estonia & 56.0 & 45.3 & 43.8 & $\mathrm{n} / \mathrm{a}$ & 40.0 & $\mathrm{n} / \mathrm{a}$ & $\mathrm{n} / \mathrm{a}$ \\
\hline Finland & 44.9 & 43.3 & 37.9 & 38.8 & 39.1 & 39.0 & 40.5 \\
\hline France & 49.0 & 51.4 & 48.3 & 48.5 & 46.6 & 37.0 & 47.4 \\
\hline Germany & 51.5 & 51.8 & 46.1 & 46.9 & 47.1 & 43.0 & 44.6 \\
\hline Greece & 54.2 & 50.3 & 44.0 & 48.2 & 44.8 & 44.9 & 44.6 \\
\hline Ireland & 44.6 & 50.3 & 41.9 & 40.0 & 48.8 & 40.6 & 39.4 \\
\hline Luxembourg & 50.0 & 49.6 & 47.6 & 46.6 & 47.1 & 43.7 & 45.0 \\
\hline Malta & 57.1 & 54.1 & 45.8 & 48.8 & 50.0 & 46.9 & 48.8 \\
\hline Netherlands & 48.0 & 47.3 & 46.2 & 42.0 & 47.3 & 50.0 & 51.7 \\
\hline Romania & 51.5 & 50.5 & 45.6 & 50.8 & 46.2 & 45.8 & 48.3 \\
\hline Slovenia & 47.6 & 48.9 & 45.7 & 45.1 & 41.4 & 44.0 & 50.0 \\
\hline Sweden & 43.7 & 41.8 & 41.7 & 38.0 & 42.5 & 42.1 & 42.9 \\
\hline Turkey & 49.3 & 48.9 & 49.7 & 46.6 & 50.6 & 40.9 & 41.4 \\
\hline United kingdom & 47.5 & 45.3 & 42.3 & $\mathrm{n} / \mathrm{a}$ & 42.3 & 37.0 & 37.5 \\
\hline Europe- 17 & 51.0 & 50.1 & 46.0 & 47.0 & 46.6 & 42.2 & 43.3 \\
\hline
\end{tabular}

Approximately $6 \%$ of practice revenues are generated by work undertaken outside the country in which the architectural practices are based. This proportion is highest in Denmark (12\%), Turkey (9\%), Luxembourg (8\%), Romania and Malta (both 7\%). In Belgium, work undertaken outside the country amounts to $3.2 \%$ while in the Netherlands this number is 3.4\%. See Chart 10 and Table 17.

At first sight this might suggest that the profession is cautious in its approach to pan-European working.

However, this does not encompass that architects are not mobile. Since 1997, 2,536 decisions were taken regarding the recognition of architectural qualifications for the purpose of permanent establishment within the EU Member States, 
EEA countries and Switzerland. ${ }^{49}$ Most of these decisions were positive and the architectural profession was number 11 on the list of mobile professions.

The recognition of architectural qualifciations This will be further discussed in Chapter 3.

Table 17

Proportion of practice revenue derived from outside the country, analysed by country

\begin{tabular}{lc}
\hline & $\begin{array}{l}\text { Turnover derived from } \\
\text { outside the country (per } \\
\text { cent) }\end{array}$ \\
\hline Austria & 4.2 \\
Belgium & 3.2 \\
Denmark & 12.4 \\
Estonia & 4.2 \\
Finland & 3.9 \\
France & 3.9 \\
Germany & 3.4 \\
Greece & 1.5 \\
Ireland & 5.3 \\
Luxembourg & 7.6 \\
Malta & 7.3 \\
Netherlands & 3.4 \\
Romania & 7.4 \\
Slovenia & 5.3 \\
Sweden & 6.3 \\
Turkey & 9.2 \\
United kingdom & 5.8 \\
Europe- 17 & 6.0 \\
\hline
\end{tabular}

Chart 10

Source of revenue

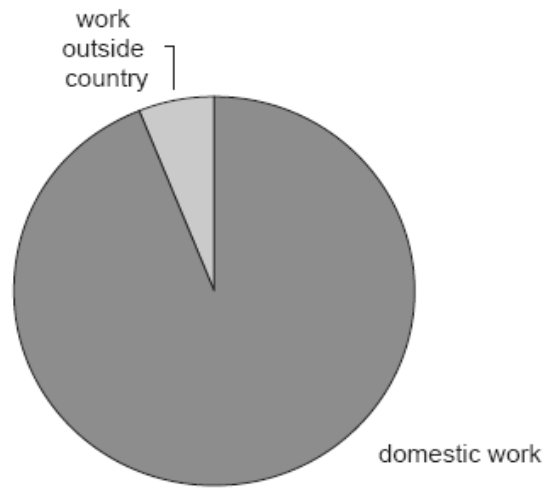

\section{Conclusion}

It can be concluded that the architectural profession is practised by a large number of professionals in Europe and that the value generated by the architectural market is considerable.

However, the profession has different particularities in every state. The architectural clientele differs as well as do the architectural business types and, perhaps most importantly, the architects' revenue. In the following part of this thesis dealing with the regulation of architects in the EU, Belgium and the Netherlands will be discussed in detail and it will be determined whether also the content of the architects' work differs in these Member States. In this way I will try to find an explanation for the abovementioned differences between these two states.

49 http://ec.europa.eu/internal_market/qualifications/regprof/index.cfm?fuseaction=stats.ranking\&services$=$ false 



\section{PART I}

\section{THE REGULATION OF ARCHITECTS IN THE EUROPEAN UNION}



Chapter 3

\section{PUBLIC REGULATION OF ARCHITECTS AT EUROPEAN UNION LEVEL}

\section{Introduction and structure}

Since architects provide a broad selection of services such as making designs, preparing and monitoring construction and land surveying, their work is of considerable importance and involves a high degree of responsibility, not only towards their clients, but also towards society as a whole. Buildings need to be safe and secure not only for their owners, but also for visitors, persons walking by, etc. The prevention of harm (negative external effects) is often invoked as one of the reasons why regulation is needed. ${ }^{1}$

The profession of architect ${ }^{2}$ is regulated in the vast majority of the EU Member States which means that the pursuit of the profession is subject, directly or indirectly, to laws, regulations or administrative provisions, and to the possession of evidence of education and training (or an attestation of competence). If and how these Member States regulate the profession falls within the competence of the Member States, either by the introduction of state regulation or by the creation of self-regulation by professional associations. A combination of both is also possible. However, even though States are not obliged to introduce regulation on title protection, professional protection or any other type of regulation, restrictions to the free movement of architects are not allowed unless they are justified and proportional. Since architects do not always intend to work in the state in which they obtained their qualifications and may wish to move to another state to practise their profession, while clients may want to engage an architect established in another country, a policy was created at the European Union level to ascertain the free movement of professionals and their clients within (and to) the Union. This freedom of movement forms part of a broader policy called European integration. In this chapter I will discuss the most important aspects of this process with regard to the architectural profession. In paragraph 3.2, the basic principles of free movement will be referred to while paragraph 3.3 discusses the recognition of professional qualifications

In Part III of this thesis (paragraph 11.3.6.), also other reasons will be given to explain the creation of regulation.

2 It should be repeated that this thesis only aims to discuss the regulation of architects in a narrow sense, and that it does not involve the regulation of town planners, garden and landscape architects or interior architects. 
in greater detail. In this regard it should be noted that the situation of third countrynationals possessing a diploma obtained in the EU as well as EU or third countrynationals holding evidence of qualifications obtained outside the EU, will be referred to as well. Paragraph 3.4 deals with the recent Directive on services in the internal market, and its implications on the free movement of architects. The different process of academic recognition as opposed to professional recognition will be explained in paragraph 3.5. Paragraph 3.6 briefly discusses some common restrictions which are often imposed upon liberal professions by professional associations or states in the field of EU competition law. Finally, paragraph 3.7 contains a conclusion. This thesis does not include a discussion of the possible advantages and disadvantages of the introduction of a binding European Code on contractual obligations and responsibilities of architects. In this regard I refer to the Draft Common Frame of Reference (DCFR) prepared by the Study Group on a European Civil Code and the Research Group on European Private Law. The PEL SC (Principles of European Law on Service Contracts), which is a research project initiated by the Study Group on a European Civil Code with the aim of drafting common European principles for the most important aspects of the law of obligations and for certain parts of the law of property in movables, should also be mentioned. The PEL SC contains a number of principles for different service contracts, including design contracts, and reflects the current approach to legal problems in the area of service contracts. However, since there is no legally enforceable European Civil Code, parties are allowed to deviate from these principles. For a discussion of the European harmonisation of construction law I refer the reader to Jansen's dissertation, Towards a European Building Contract Law ${ }^{3}$ and Kohl's article European Construction Law and the Draft Common Frame of Reference: Selected Topics.

\section{The legal foundations of the free movement of architects}

In this paragraph I will discuss if and under which conditions architects are allowed to move to an(other) EU State in order to practise the profession there. Paragraph 3.2.1 deals with EU nationals, while paragraph 3.2.2 discusses the situation of architects not holding the nationality of an EU Member State.

\subsection{Architects holding the nationality of an EU Member State}

As stated above, the architectural profession as such, as well as the educational programme which needs to be completed to become an architect, are regulated differently throughout the European Union. Member States often distrust foreign professionals and are not always eager to accept them with regard to working on their territory. Even today, professionals often face difficulties when moving to another country. By creating the European Economic Community (EEC) in $1957^{5}$, Member States had already de-

Jansen 1998

Kohl 2009.

The Treaty of Rome, establishing the European Economic Community (EEC), signed in Rome on 25 March 1957 and entered into force on 1 January 1958 
cided to make regulations on a 'European' scale to overcome such problems. Its purpose was to establish a customs union - a free trade zone with a common external tariff ${ }^{6}-$ based on the four freedoms: free movement of goods, persons, services and capital. The EEC reflected a conception of the individual, primarily as an economic actor, since it conferred rights by virtue of the individual's participation in the production process, and as an independent supranational economic organization. In this regard Article 2 EEC indicated that the Community had to establish a common market so that the development of economic activities would be promoted, including a high degree of competitiveness and convergence of economic performance and a better quality of life. After the European Union ${ }^{7}$ was created by the Treaty of Maastricht, the EEC was renamed and replaced by the European Community (EC). As held by Article 3(1) (c) EC, the EC aimed to create an internal market characterised by the abolition, as between Member States, of obstacles to the free movement of goods, persons, services and capital. In this area without frontiers (Article 14 EC) discrimination based on nationality would be prohibited (Article 12 EC). After the amendment of the EU and EC Treaty by the Lisbon Treaty $^{8}$, these principles can now be found in the amended Treaty on the European Union (TEU) and the Treaty on the Functioning of the European Union (TFEU). As held by Article 3(2) TEU, the Union shall offer its citizens an area of freedom, security and justice without internal frontiers, in which the free movement of persons is ensured, in conjunction with appropriate measures with respect to external border controls, asylum, immigration and the prevention and combating of crime. The Union shall establish an internal market (Article 3(3) TEU) in which the four freedoms are ensured (Article 26 TFEU) and any discrimination on grounds of nationality is forbidden (Article 18 TFEU).

The importance of these Articles, which contain general principles of EU law, is considerable. In 1962, the Court of Justice of the European Union (ECJ) held in Van Gend en Loos that, since the states have limited their sovereign rights in this area, Article 18 TFEU (article $12 \mathrm{EC})^{9}$ must be interpreted as producing direct effects and creating individual rights which national courts must protect. ${ }^{10}$ Furthermore, in Costa it was held

6 The same customs duties, quotas, preferences or other non-tariff barriers to trade apply to all goods entering the area, regardless of which country within the area they are entering. Economic efficiency and closer political and cultural ties between the member countries are the main purposes for the creation of a customs union.

7 The Treaty on the European Union which was signed in Maastricht on 7 February 1992 and which entered into force on 1 November 1993, renamed the 'European Economic Community' the 'European Community'.

8 Treaty of Lisbon amending the Treaty on European Union and the Treaty establishing the European Community, signed at Lisbon, 13 December 2007, entered into force 1 December 2009.

9 For the sake of clarity I will use the old numbering (before the entry into force of the Lisbon Treaty) between brackets after the new numbers, unless a certain article was introduced by the Lisbon Treaty and does not have a corresponding old number.

10 Case C-26/62 Van Gend en Loos. The ECJ held that the Community constitutes a new legal order of international law for the benefit of which the states have limited their sovereign rights, albeit within limited fields, and the subjects of which comprise not only Member States but also their nationals. Independently of the legislation of Member States, Community law therefore not only imposes obligations on individuals, but is also intended to confer rights upon them which become part of their legal heritage. According to the 
that Community law must be given primacy by national courts over any incompatible national law. ${ }^{11}$ It follows that individuals -and thus also architects- can invoke their nondiscrimination rights directly before their national courts.

Next to the general prohibition on discrimination mentioned in Article 18 TFEU, Title IV TFEU contains more detailed rules on the abolition of obstacles to the free movement of economically active persons and services in particular. Title IV (Free Movement of Persons, Services ${ }^{12}$ and Capital) of Part III (Union Policies and Internal Actions) of the TFEU contains the four fundamental freedoms which are recognised within the Union and consists of four chapters: Chapter 1 concerns the free movement of workers (Articles 45-48 TFEU) (Articles 39-42 EC), Chapter 2 the right of establishment (Articles 49-55 TFEU) (Articles 43-48 EC), Chapter 3 the freedom to provide services (Articles 56-62 TFEU) (Articles 49-55 EC) and Chapter 4 the free movement of capital and payments (Article 63-66 TFEU). As held by the Court of Justice of the European Union in Gebhard ${ }^{13}$, the situation of a Community ${ }^{14}$ national who moves to another Member State of the Community in order to pursue an economic activity there, is governed by the chapter of the Treaty on the free movement of workers, the chapter on the right of establishment or the chapter on the freedom to provide services, these being mutually exclusive.

Since architects may want to perform professional activities in another Member State as a worker or as a service provider, but may also move to another Member State to establish themselves there, this chapter will provide a detailed overview of the content and meaning of these freedoms and their implications for EU-architects. Paragraph 3.2.1.1 discusses the free movement of workers, paragraph 3.2.1.2 the freedom of establishment, and paragraph 3.2.1.3 the freedom to provide services. In 1992, free movement rights were extended to persons who are not economically active, and the concept of citizenship of the Union was introduced. This will be discussed in paragraph 3.2.1.4. It will become apparent that the rules concerning the freedom of movement constitute, each within its own area of application, leges speciales of the general prohibition of discrimination as provided for in Article $18 \mathrm{TFEU}$ (article $12 \mathrm{EC)} .{ }^{15}$

spirit, the general scheme and the wording of the Treaty, as held by the ECJ, individuals can thus directly rely on the prohibition of discrimination which is stipulated in Article 12 EC.

11 Case C-6/64 Flaminio Costa v. ENEL. In Costa, the ECJ continued its reasoning developed in Van Gend en Loos and held that the transfer by the states from their domestic legal system to the Community legal system of the rights and obligations arising under the Treaty, carries with it a permanent limitation of their sovereign rights, against which a subsequent unilateral act, incompatible with the concept of the Community, cannot prevail.

12 In case of the provision of services, emphasis is laid on the service in question, rather than on the person providing it.

13 Case C-55/94 Gebhard v. Consiglio dell'Ordine degli Avvocati e Procuratori di Milano [1995] ECR I-4165.

14 Even though the 'European Community' no longer exists as such, reference will still be made to the Community if case law or secondary legislation is discussed which dates from prior to the entry into force of the Lisbon Treaty.

15 Van Den Bossche 2004, p.804. 


\subsubsection{Free movement of workers (architect-employees)}

The principles, conditions and particularities concerning the exercise of the right to free movement by workers, is based upon a substantial legal framework which mainly consists of provisions enumerated in Chapter I of Title IV of Part III of the TFEU, secondary legislation and judgements of the Court of Justice of the European Union (ECJ). The relevant provisions and cases will be discussed in this paragraph.

As held by Article 45 TFEU (Article 39 EC), freedom of movement for workers shall be secured within the Union. Such freedom of movement entails the abolition of any discrimination based on nationality between workers of the Member States as regards employment, remuneration and other conditions of work and employment. It entails the right - subject to limitations justified on grounds of public policy, public security or public health - to accept offers of employment actually made; to move freely within the territory of Member States for this purpose; to stay in a Member State for the purpose of employment in accordance with the provisions governing the employment of nationals of that State as laid down by law, regulation or administrative action; to remain in the territory of a Member State after having been employed in that State subject to the conditions which shall be embodied by implementing regulations to be drawn up by the Commission. Article 45 TFEU is not applicable to employment in the public service.

The exact content and meaning of this Article has been explained and developed by the ECJ.

As stipulated in Hoekstra', the term 'worker' is a Community concept of which the Court claims ultimate authority in terms of defining its meaning and scope. It must be defined in accordance with objective criteria which distinguish an employment relationship by reference to the rights and duties of the persons concerned. The essential feature of an employment relationship is that, for a certain period of time, a person performs services for, and under the direction of, another person in return for which $s /$ he receives remuneration. ${ }^{17}$ These activities have to be effective and genuine, to the exclusion of all activities on such a small scale as to be regarded as purely marginal and ancillary. ${ }^{18}$ The principle of free movement of workers comprises thus the right of an employee to leave the territory of a Member State and to enter the territory of another Member State and to reside therein in order to take up work. As was ruled in Walrave ${ }^{19}$, Bosman $^{20}$ and

16 Case C-75/63 Hoekstra (née Unger) v. Bestuur der Bedrijfsvereniging voor Detailhandel en ambachten [1964] ECR 177.

17 Case C-66/85 Lawrie-Blum v. Land Baden-Württemberg [1986] ECR 2121, \$17. It should be noted that the activies may not be purely marginal and ancillary: Case C-337/97 C.P.M. Meeusen v. Hoofddirectie van de Informatie Beheer Groep [1999] ECR I-3289.

18 Case C-337/97 Meeusen v. Hoofddirectie van de Informatie Beheer Groep; Case C-357/89 Raulin v. Netherlands Ministry of Education and Science [1992] ECR I-1027. Also workseekers have a limited right to move freely within the territory of other Member States and to stay there for the purposes of seeking employment: See Case C-282/89 R. V. Immigration Appeal Tribunal ex parte Antonissen [1991] ECR I-00745; Case C-316/88 Centre Public d'Aide Sociale v Lebon [1987] ECR I-2811.

19 Case C-36/74 Walrave and Koch v. Association Union Cyclise Internationale [1974] ECR 1405. 
Angonese $^{21}$, Article 45 TFEU has vertical and horizontal direct effects. This indicates that it is not only binding on Member States but also applicable to private persons. The Article entails that direct or indirect discrimination ${ }^{22}$ on grounds of nationality is strictly forbidden, as well as national measures which are not directly or indirectly discriminatory on nationality grounds, but which do restrict the freedom of movement of EU workers..$^{23}$ It follows thus that even non-discriminatory restrictions can breach the Treaty if they constitute an excessive obstacle to the freedom of movement. Only if there is an objective justification for indirect discrimination or non-discriminatory restrictions (Article 45(3) TFEU, first sentence) or when the public service exception (Article 45(4) TFEU) applies, can exceptions to the core principle of free movement be tolerated.

Since architects can practise their profession as employees, Article 45 TFEU is of importance when discussing their free movement. The ECJ has not yet decided upon a case involving a violation of Article 45 TFEU with regard to the architectural profession in particular. However, since it is not excluded that an architect-employee can encounter limitations on his freedom of movement, the abovementioned principles as developed by the ECJ should not be ignored.

As stated by Article 46 TFEU (Article 40 EC), the Council shall issue Directives or make regulations setting out the measures required to bring about freedom of movement for workers as defined in Article 45 TFEU. This has resulted in the creation of secondary legislation which specifically deals with the free movement of workers in particular, but also of Directives which deal with the recognition of professional qualifications and are applicable to workers as well as to self-employed persons. As indicated above, the latter Directives will be discussed in paragraph 3.3. Finally Directive 2004/38/EC ${ }^{24}$, which

20 Case C-415/93 Union Royale Belge des Sociétés de Football Association and others v. Bosman [1995] ECR I-4921, paragraphs 82-84.

21 Case C-281/98 Roman Angonese v. Cassa di Riparmio di Bolzano SpA [2000] ECR I-4139.

22 Indirect discrimination occurs for example, where benefits are made conditional, in law or fact, on residency or place of origin requirements that can more easily be satisfied by nationals as opposed to nonnationals: Case C-355/98 Commission v. Belgium [2000] ECR I-1221. Furthermore, the imposition of a language requirement for certain posts can also be qualified as a form of indirect discrimination since it is likely that a far higher proportion of non-nationals than nationals will be affected by it. In certain circumstances, such a requirement can be justified as long as it is proportionate: Case C-379/87 Groener v. Minister for Education [1989] ECR 3967. In O'Flynn, the ECJ held that it is not necessary to prove that a national measure in practice affects a higher proportion of foreign workers, but merely that the measure is intrinsically liable' to affect migrant workers more than nationals: Case C-237/94 O'Flynn v. Adjudication Officer [1996] ECR I-2617.

23 It mostly concerns access to the employment market, e.g. if the transfer system developed by national and transnational football associations requires a football club, which seeks to engage a player whose contract with another club had come to an end, to pay a sum of money to the latter club. This rule can prevent players from securing employment with another club: See Case-415/93 Union Royal Belge des Sociétés de Football Association ASBL \& others v. Jean-Marc Bosman [1995] ECR I-4921. See also Case C-18/95 F.C. Terhoeve v. Inspecteur van de Belastingdienst Particulieren/Ondernemingen Buitenland [1999] ECR-I-345, paragraph 39; Case C-190/98 Volker Graf v. Filzmoser Mashinenbau GmbH [2000] ECR I-493.

24 Directive 2004/38/EC of the European Parliament and of the Council of 29 April 2004 on the Right of Citizens of the Union and their Family Members to Move and Reside Freely within the Territory of the Member States amending Regulation (EEC) No 1612/68 and repealing Directives 64/221/EEC, 68/360/EEC, 72/194/EEC, 73/148/EEC, 75/34/EEC, 75/35/EEC, 90/364/EEC, 90/365/EEC and 93/96/EEC, OJ L 158, 30 April 2004, pp. 77-123 
applies to all Union citizens (including workers) irrespective of their level of economic activity, also entered into force. This Directive will be discussed in paragraph 3.2.1.4.

As held by the preamble of Regulation 1612/68 of 15 October 1968 on the Freedom of Movement for Workers within the Community ${ }^{25}$, the objective of freedom of movement for workers entails the abolition of any discrimination based on nationality between workers of the Member States as regards employment, remuneration and other conditions of work and employment, as well as the right of such workers to move freely within the Community in order to pursue activities as employed persons, subject to any limitations justified on grounds of public policy, public security or public health. Due to this freedom, the worker is guaranteed the possibility of improving his/her living and working conditions and of promoting his social advancement, while s/he is helping to satisfy the requirements of the economies of the Member States. The most important provision of this regulation is Article 1 which states that any national of a Member State, shall, irrespective of his place of residence, have the right to take up an activity as an employed person, and to pursue such activity within the territory of another Member State in accordance with the provisions laid down by law, regulation or administrative action governing the employment of nationals of that State. S/he shall, in particular, have the right to take up available employment in the territory of another Member State with the same priority as nationals of that state. Furthermore, any national of a Member State and any employer pursuing an activity in the territory of a Member State may exchange their applications for, and offers of, employment, and may conclude and perform contracts of employment in accordance with the provisions in force laid down by law, regulations or administrative action, without any discrimination resulting therefrom (Article 2). As stated by Article 3(1), all national rules which limit application for, and offers of, employment, or the right of foreign nationals to take up and pursue employment or subject these to conditions not applicable in respect of their own nationals, will not apply. Of course this is also applicable to architects wishing to pursue their profession in another Member State. It follows that States that use these types of rule violate EU law. Examples of cases in which national restrictions were brought before the ECJ by an architect will be provided for in the following paragraphs, since the ECJ has not yet ruled upon such measures within the field of the free movement of workers.

Regulation 635/2006/EC of the European Commission of 25 April 2006 repealing Regulation 1251/70/EEC of 29 June 1970 on the Right of Workers to Remain in the Territory of a Member State after Having been Employed in that State, is another regulation which specifically deals with the free movement rights of workers. It repealed Regulation 1251/70/EEC ${ }^{26}$ since Article 17 of Directive 2004/38/EC already included its main elements and amended these by granting beneficiaries the right to remain a more privileged status, namely that of the right of permanent residence. I refer to paragraph

25 Council Regulation (EEC) 1612/68 of 15 October 1968 on the Freedom of Movement for Workers within the Community, OJ L 257, 19 October 1968, p. 2, amended by Council Regulation (EEC) No 312/76 of 9 February 1976, OJ L 039, 14 February1976, p. 2, Council Regulation (EEC) No 2434/92 of 27 July 1992, OJ L 245, 26.08.1992, p. 1 and Directive 2004/38/EC of the European Parliament and of the Council of 29 April 2004, OJ L 229, 29.06.2004, p. 35.

26 Regulation 1251/70 of the Commission of 29 June 1970 on the right of workers to remain in the territory of a Member State after having been employed in that State, OJ 1970, No. L142/24, p. 402. 
Public Regulation of Architects at European Union Level

3.2.1.4 of this thesis in which the right to remain of workers in the European Union will be compared to that of citizens who have not been economically active.

It follows that EU architects performing effective and genuine services for and under the direction of another person in return for remuneration, should be able to move freely within the Union. In principle, any discrimination as regards employment, remuneration and other conditions of work and employment is prohibited. This is, however, subject to limitations justified on grounds of public policy, public security or public health. These are all very broad and open concepts, upon which a myriad of possible limitations can be based. Some of these limitations are laid down in secondary legislation and specifically in the Directives on the mutual recognition of diplomas and professional qualifications which will be discussed in paragraph 3.3.

\subsubsection{Freedom of establishment (self employed architects)}

Article 49 TFEU (Article 43 EC) stipulates that restrictions on the freedom of establishment of nationals of a Member State in the territory of another Member State are prohibited. Freedom of establishment includes the right to take up and pursue activities as self-employed persons, and to set up and manage undertakings, in particular companies or firms, under the conditions laid down for its own nationals by the law of the country where such establishment is effected. Just like Article 45 TFEU on workers, Article 49 TFEU on the freedom of establishment requires equal treatment of persons working in another Member State of the European Union. The difference between both provisions lies in the fact that Article 49 TFEU applies to persons working in a self-employed capacity. ${ }^{27}$ In contrast to a provider of services who moves to another Member State to pursue his activity there on a self-employed and temporary basis, the concept of establishment allows a Union national to participate, on a stable and continuous basis, in the economic life of a Member State other than his state of origin. In this way he can contribute to the economic and social interpenetration within the Union in the sphere of activities as self-employed persons, while having an established professional base within the host Member State. ${ }^{28}$ Restrictions which are often imposed by Member States on persons who aim to establish themselves on their territory, relate to the entrance to a profession. In this way it occurs that requirements are demanded which cannot, or only with more difficulty, be obtained by foreigners, such as the possession of a certain 'national' diploma. Other restrictions relate, for example, to the actual pursuit of the profession, such as the imposition of higher social contributions payable by nationals of other EU states.

Even though the original EEC Treaty provided for a system of secondary legislation to be created in order to implement the freedom of establishment (as well as the freedom to provide services) so that the exact meaning and scope of these freedoms could be

27 Mayras AG in Case C-2/74 Jean Reyners v. Belgium State [1974] ECR 631 and Case C-107/94 Asscher v. Staatsecretaris van Financiën [1996] ECR I-3089.

28 Case C-55/94 Gebhard v. Consiglio dell'Ordine degli Avvocati e Procuratori di Milano; Case C-2/74 Reyners v. Belgium, paragraph 21. 
defined, during the transitional period only very few efforts were made. In the field of the architectural profession or any other liberal profession in particular, no activity had been undertaken at all. In 1974 however, the ECJ opened the way to the free movement of persons in two landmark cases which specifically dealt with the profession of lawyers: Reyners $^{29}$ in the field of freedom of establishment and Van Binsbergen ${ }^{30}$ with regard to the freedom to provide services. Since this section deals with the freedom of establishment, I will now discuss the former case as well as other landmark cases in this field. In this way the reader will be provided with an overview of the development of the principle of free movement by the ECJ. As held by the ECJ, the rule on equal treatment of all persons embraced in Article 49 TFEU, is one of the fundamental legal provisions in the Community. Since it lays down a precise result which has to be achieved, namely nondiscrimination on grounds of nationality, it can be directly invoked by nationals of all the other Member States, despite the Treaty requirement in Article 50 TFEU (Article 44 EC) that Directives should be adopted specifically with regard to the mutual recognition of diplomas. Even though the Council (at that time) failed to issue a Directive on the recognition of diplomas, non compliance was sanctioned by the Treaty itself, with direct effect. This would also be the case if an issued Directive would not meet the objectives of Article 49 TFEU. It follows that Article 49 TFEU precludes the competent national authorities from simply refusing, without further explanation, to allow nationals of another Member State to practise their trade or profession, on the grounds that their qualification is not equivalent to the corresponding national qualification. ${ }^{31}$ As held in Walrave and $\mathrm{Koch}^{32}$, this does not only apply to the action of public authorities, but extends likewise to rules of any other nature aimed at regulating, in a collective manner, gainful employment and the provision of services. It follows that Article 49 TFEU also has a certain horizontal direct effect. In this regard it should be noted however that it remains unclear as to whether the Treaty freedoms have full horizontal effect, in the sense of imposing legal obligations on all individuals and not only on powerful collective actors such as sporting organizations which are effectively self-regulating and possess powers akin to public law..$^{33}$ In Wouters $^{34}$-a case concerning a regulatory measure adopted by the Netherlands Bar Council on partnerships between barristers and accountants- the Court held that compliance with Articles 49 and 56 TFEU (Article 49 EC) is also required in the case of rules which are not public in nature, but which are designed to regulate, collectively, self-employment and the provision of services.

With regard to professional qualifications, it must be stated that, in the absence of harmonizing Directives, Member States are entitled to regulate the knowledge and qualifi-

29 Case C-2/74 Reyners v. Belgium.

30 Case C-33/74 Van Binsbergen v. Bestuur van de Bedrijfsverenging voor de Metaalnijverheid [1974] ECR 1299.

31 Case C-71/76 Thieffry v. Conseil de l'Ordre des Avocats à la Cour de Paris [1977] ECR 765; Case C-222/86 UNECTEF v. Heylens [1987] ECR 4097, paragraph 13.

32 Case C-36/74 Walrave and Koch [1974] ECR 1405.

33 Craig \& De Burca 2003, p. 771.

34 Case C-309/99 Wouters v. Algemene Raad van de Nederlandse Orde van Advocaten [2002] ECR I-577. 
cations necessary to pursue a particular occupation. ${ }^{35}$ It is quite logical that Member States will not allow everybody to practise as an architect on their territory since they want to ensure that architectural services are provided by professionals disposing of certain knowledge and competences, to safeguard the quality and safety of buildings to a certain extent. However, often Member States also act purely in a protectionist fashion to restrict competition and to privilege their own nationals with regard to the access to and the actual pursuit of work. The motives for regulations will be further analysed in Part III of this thesis. In any case, as mentioned above, the Union aims to establish an internal market (Article 3(3) TEU) (Article $2 \mathrm{EU}$ ) in which the freedom of movement is ensured (Article 26 TFEU) (Article 14 EC) and any discrimination on grounds of nationality is forbidden (Article 18 TFEU) (Article 12 EC). Since Member States can determine which qualifications are required to practise a profession, the procedure for the recognition of equivalence must enable the national authorities to assure themselves, on an objective basis, that the foreign diploma certifies that its holder has knowledge and qualifications which are, if not identical, at least equivalent to those certified by the national diploma. That assessment of the equivalence of the foreign diploma must be effected exclusively in terms of the level of knowledge and qualifications which its holder can be assumed to possess, having regard to the nature and duration of the studies and practical training which the diploma certifies that $s$ /he has carried out. Where employment is dependent on possession of a diploma, the ECJ ruled that it must be possible for a national of a Member State to obtain a judicial review of a decision on the part of the authorities of another Member State, and to ascertain the reasons for refusing to recognize the equivalence of a diploma. In Vlassopoulou ${ }^{36}$ the ECJ confirmed that a Member State which receives a request to admit a person to a profession to which access, under national law, depends upon the diplomas, certificates and other evidence of qualification which the person concerned has acquired in order to exercise the same profession in another Member State by making a comparison between the specialized knowledge and abilities certified by those diplomas and the knowledge and qualifications required by the national rules. ${ }^{37}$ Simple refusal without any inquiry is thus not allowed.

Just like Article 45 TFEU (article 39 EC), Article 49 TFEU (article 43 EC) does not only cover direct discriminatory restrictions. ${ }^{38}$ As held in $\mathrm{Kraus}^{39}$ and Gebhard ${ }^{40}$, all national

35 Case C-222/86 UNECTEF v. Heylens [1987] ECR 4097, paragraph 13.

36 Case C-340/89 Vlassopoulou v. Ministerium für Justiz, Bundes- und Europaangelegenheiten BadenWürttemberg [1991] ECR I-2357.

37 In this case the Advocate General held that, unlike Council Directive 89/48/EEC of 21 December 1988 on a general system for the recognition of higher-education diplomas award on completion of professional education and training of at least three years' duration, OJ 1989, No. L19/16, the Treaty did not of itself give EC nationals the right to establish themselves in any Member State, subject only to the possible requirement of completion of an adaptation period. Rather, Article $43 \mathrm{EC}$ simply required the state to take into account qualifications and training already received, and only if it were found that these were equivalent to the Member State's requirement, could an EC national rely upon them. This Directive was not applicable to Vlassopoulou's case since the time limit for its implementation had not yet expired.

38 It should be noted, however, that the exclusion of non-nationals from performing a certain profession is allowed if the function involves the exercise of official authority (Article 51 TFEU) (Article 45 EC). Special 
measures which are liable to hinder or make less attractive the exercise of any of the fundamental freedoms guaranteed by the Treaty are, in principle, forbidden. Only if the following four conditions are fulfilled may restrictions be justified: they must be applied in a non-discriminatory manner; they must be justified by imperative requirements in the general interest; they must be suitable for securing the attainment of the objective which they pursue; and they must not go beyond what is necessary in order to attain it. Gebhard extrapolated the rule of reason that was developed in the realm of the free movement of goods and services through the Cassis de Dijon ${ }^{41}$ and the Van Binsbergen cases, and which was later, through Kraus, also adopted for the freedom of establishment, to a rule of reason that is independent of the individual freedoms, stating that any restriction on any of the four freedoms should be objectively justified. ${ }^{42}$ However, in this regard, it should be noted that this system of objective justification only applies where the subject matter is not covered by secondary legislation or by the specific case law of the ECJ. The ECJ first developed specific rules for specific restrictions, with the result that different systems as laid down in case law apply for different restrictions. ${ }^{43}$ In this way, restrictions with regard to the recognition of diplomas could be solved under the Vlassopoulou doctrine. Where no secondary legislation applies, and where no specific system is laid down in case law, a national measure that is liable to hinder or make less attractive the exercise of one of the freedoms, may be objectively justified by applying the four-stage test that was laid down in Gebhard. It follows that not only direct and indirect discriminatory measures are forbidden (for example single-practice rules which are likely to have more adverse consequences for non-nationals who usually have a primary practice in another Member State ${ }^{44}$ ) but even national rules which constitute a sufficient hindrance to the freedom of establishment. ${ }^{45}$

The case law mentioned above does not concern architects in particular, but sets out general rules which can be applied to restrictions on the free movement of architects. The ECJ has, however, also made important rulings in relation to the free movement of architects in particular. In this chapter, I will discuss all the cases on the freedom of establishment of architects which have been decided upon by the ECJ. This paragraph only addresses the cases in which a violation of Article 49 TFEU was established as such - meaning without the involvement of a violation of a provision in an accompanying Directive. Both cases deal with restrictions regarding entry to the profession. Cases which specifically deal with the violation of secondary legislation on the recognition of architectural qualifications will be referred to in paragraph 3.3.

treatment of foreign nationals is also possible on grounds of public policy, public security or public health (Article 52 TFEU) (Article 46 (1) EC).

39 Case C-19/9 Kraus v. Land Baden-Württemberg [1993] ECR I-1663.

40 Case C-55/94 Gebhard v. Consiglio dell'Ordine degli Avvocati e Procuratori di Milano.

41 Case C-120/78 Rewe-Zentrale AG v. Bundesmonopolverwaltung für Branntwein [1979] ECR 649.

42 Claessens 2008, p. 23.

43 Ibid.

44 Case C-107/83 Ordre des Avocats v. Klopp [1984] ECR 2971.

45 It must be noted that, in most cases of direct discrimination, a justification can only be found in Article 52 TFEU (express derogations in Treaty), whereas in all other cases, wider public interest grounds (mandatory requirements) such as fiscal supervision, can be invoked. 
Patrick $^{46}$ concerned a dispute between the French Minister for Cultural Affairs and a British subject who possessed a certificate issued by the Architectural Association of the United Kingdom, which allowed him to practise the profession. In $1973 \mathrm{Mr}$. Patrick applied for authority to practise as an architect in France. Under the first subparagraph of Article 2(2) of the French law of 31 December 1940 establishing the Architects' Order and governing the title and profession of architect, nationals of foreign countries had to be authorized to practise the profession of architect in France, subject to the conditions of reciprocity laid down by diplomatic conventions and the production of a certificate equivalent to the certificate required for French architects. Under the third subparagraph of Article 2(2), foreigners not covered by provisions of a convention could, exceptionally, receive the said authorisation. According to a Ministerial Decree of 22 June 1964 which was introduced to implement this provision, holders of certificates issued by the aforesaid UK Architectural Association were considered to fulfil the conditions concerning equivalent qualifications as laid down in Article 2(2). Nevertheless, by a decision of 9 August 1973, the applicant was refused the authorization requested on the ground that, under the provisions of the law of 31 December 1940, such authorization was exceptional in the absence of a reciprocal convention between France and the applicant's country of origin, and that the EEC Treaty could not be a substitute for the convention, since Articles 52 to 58 EEC (Articles 49 to 54 TFEU) referred, for the attainment of this freedom, to Directives of the Council which had not yet been issued. The Administrative Tribunal of Paris, to which an application had been made for the annulment of this decision, asked the Court whether, given the state of Community law on 9 August 1973, a British subject was entitled to invoke in his favour, the benefit of the right of establishment to practise the profession of architect in a Member State of the Community.

The ECJ held that under the provisions of Article 52 EEC, freedom of establishment includes the right to take up activities as a self-employed person and to pursue them under the conditions laid down for its own nationals by the law of the country where such establishment is effected. In this regard the ECJ referred to its judgement in Reyners, in which it was held that the rule on equal treatment is, by its essence, capable of being directly invoked by nationals of all the other Member States. In the absence of transitional provisions concerning the right of establishment in the Treaty of Accession of 22 January 1972, by which the United Kingdom joined the EEC, the principle contained in Article $43 \mathrm{had}$, in the case of the new Member States and their nationals, been fully effective since the entry into force of the said Treaty on 1 January 1973. A Member State could not therefore, after 1 January 1973, make the exercise of the right to free establishment by a national of a new Member State subject to an exceptional authorization, in so far as s/he fulfils the conditions laid down by the legislation of the country of establishment for its own nationals. It followed that the old Member States ${ }^{47}$ were not allowed to invoke against the direct effect of the rule on equal treatment with nationals contained in Article 49 TFEU the fact that the Council had failed to issue Directives provided for by Articles 50 and 53 TFEU (Article 44 and 47 TFEU) on the mutual rec-

46 Case C-11/77 Patrick v. Ministre des Affaires Culturelles [1977] ECR 1199.

47 Belgium, the Netherlands, Luxemburg, France, Germany and Italy. 
ognition of diplomas, certificates and other evidence of formal qualifications. The applicability of the Treaty provisions had to be made easier by such Directives, but was not made dependent on the implementation of a programme of progressive measures so that Member States are not allowed to deny the practical benefits of that freedom to a person subject to Community law. It was thus concluded that, with effect from 1 January 1973, a national of a 'new' Member State who held a qualification recognized by the competent authorities of the Member State of establishment, as equivalent to the certificate issued and required in that State, enjoyed the right to be admitted to the profession of architect and to practise it under the same conditions as nationals of the Member State of establishment, without being required to satisfy any additional conditions. Requiring any kind of prior authorisation while the person involved fulfils the conditions laid down by the country of establishment for its own nationals, constitutes therefore a restriction on the effective exercise of the freedom of establishment, and is not allowed.

In Commission v Hellenic Republic ${ }^{48}$ Article 4(2) of the Greek Decree-Law No 2728 of 12 November 1953 and Article 2 of the Greek law No 1486 of 17 October 1984 were at issue. These provisions maintained that a person holding the required qualifications and the necessary authorization could not exercise the profession of architect, civil engineer, surveyor and lawyer, unless the individual concerned was an ordinary member of the professional body of architects, civil engineers, etc. Registration was thus a precondition for, and facilitated access to, the professions concerned, and their exercise in the Hellenic Republic. Consequently the conditions for registration with that body had to be identical for Greek nationals and nationals of the other Member States, in accordance with Articles 49 and 56 TFEU which prohibit, in their respective fields of application, any discrimination on the grounds of nationality. However, whereas Greek nationals were ordinary members of that body as of right, the Greek legislation did not provide for access by foreigners to that status. The national provisions in question did not expressly confer on the nationals of other Member States the right to register as ordinary members of the Technical Chamber. In this regard the Hellenic Republic maintained that the national provisions in question did permit the registration of foreigners as ordinary members of the Technical Chamber, and that that was the interpretation consistently adopted by that body. The ECJ, however, did not accept this argument. It held that the fact that the legislation was silent as regards the right of nationals of other Member States to register as ordinary members of the Technical Chamber, gave rise to an ambiguous state of affairs, and kept the persons concerned in a state of uncertainty as to the possibility of relying on the provisions of the Treaty which have direct effect. The retention of legislation with such a lacuna therefore amounted to a failure by the Hellenic Republic to comply with its obligations under the Treaty. The Court ruled furthermore that mere administrative practices which, by their nature, are alterable at will by the authorities and are not given the appropriate publicity, could not be regarded as constituting the proper fulfilment of obligations under the Treaty. ${ }^{49}$ By maintaining in force provisions which did not expressly uphold the right of nationals of the other

48 Case C-38/87 Commission of the European Communities v Hellenic Republic [1988] ECR 4415.

49 See in that regard also Case C-168/85 Commission v Italy [1986] ECR 2945. 
Member States to register as ordinary members of the Technical Chamber, where such registration is a precondition for, and facilitated access to, the professions concerned, and the exercise thereof in the Hellenic Republic, the Hellenic Republic had failed to fulfil its obligations under Articles 49 and 56 TFEU.

Since the Commission did not receive any notification of the measures which should have been taken by Greece to comply with this judgment, the Commission initiated the procedure provided for in Article 185 TFEU (Article 169 EC) and instituted another action before the ECJ against the Hellenic Republic, for failure to fulfil its obligations. In this subsequent case ${ }^{50}$, the ECJ held that even though Article 260 TFEU (Article 228 EC) does not specify the period within which a judgement must be complied with, the interest in the immediate and uniform application of Community law requires that the process of compliance with a judgment must be initiated immediately, and must be completed as soon as possible. Since Greece had not initiated such a process immediately after the judgement in case C-38/87, it had failed to fulfil its obligations under the Treaty.

It can be concluded that both the Commission and the ECJ are aware of the fact that compliance with the Court's judgements is of major importance, and that even every 'appearance' that foreigners are treated less favourably than nationals, constitutes a violation of the principle of freedom of movement. The Court's case law has therefore contributed significantly to the development of the internal market and to the mobility of professionals. Next to the far-reaching decisions of the Court, a general programme was adopted to eliminate restrictions to the freedom of establishment, by the adoption of numerous Directives laying down rules according to which professional qualifications obtained in one Member State would have to be recognized in other EU countries. ${ }^{51}$ These Directives were based on Article 50 TFEU (Article 44 EC) and Article 53(1) TFEU (Article 47(1) and (2) EC) and aimed, not only to eliminate overt discrimination, but also any form of disguised discrimination in respect of the taking up or pursuit of an activity as a self-employed person. Even though little effort was made initially, several successive recognition regimes were created in the course of time. In this regard, mention should be made of Directive 2004/38/EC on the right of citizens of the union and their family members to move and reside freely within the territory of the Member States which will be discussed in paragraph 3.2.1.4.; the Directives on the mutual recognition of diplomas and qualifications which can be found in paragraph 3.3. and Directive $2006 / 123 / \mathrm{EC}^{52}$ on services in the internal market which is not only applicable within the context of freedom of establishment, but also with regard to the free movement of workers and the freedom to provide services, and is therefore separately addressed in paragraph 3.4 .

50 Case C-328/90 Commission v. Hellenic Republic [1992] ECR I-00425.

51 General Programme for the abolition of restrictions on freedom of establishment adopted on 18 December 1961, 31961X1202, OJ 002 15.01.1962, p. 33.

52 Directive 2006/123/EC of the European Parliament and of the Council of 12 December 2006 on Services in the Internal Market, OJ L 376/36. 


\subsubsection{Freedom to provide services (self-employed architects)}

As stipulated in Article 56 TFEU (Article 49 EC), restrictions on freedom to provide services within the Union are prohibited in respect of nationals of Member States who are established in a State other than that of the person for whom the services are intended. Services are considered to be 'services' within the meaning of the Treaty where they are normally provided for remuneration, in so far as they are not governed by the provisions relating to freedom of movement for goods, capital and persons. They shall in particular include: activities of an industrial character; activities of a commercial character; activities of craftsmen; activities of the professions. Without prejudice to the provisions relating to the right of establishment, a person providing a service may, in order to do so, temporarily pursue his activity in the State where the service is provided, under the same conditions as are imposed by that State on its own nationals (Article 57 TFEU) (Article 50 EC). Just as is the case with regard to the free movement of workers and the freedom of establishment, the principle of freedom of services was interpreted and explained by the ECJ and regulated more extensively by secondary legislation.

After it was established in Reyners ${ }^{53}$ that Article 49 TFEU has direct effect, the ECJ concluded the same about Article 56 TFEU in Van Binsbergen ${ }^{54}$, since both Articles 49 and 56 TFEU impose a well-defined obligation. The freedom to provide services entails the carrying out of an economic activity ${ }^{55}$ for remuneration and during a temporary period, in a Member State in which either the provider or the recipient of the service is not established. In this regard, Article 56 TFEU forbids all discrimination -direct, indirect as well as non-discriminating impediments ${ }^{56}$ - against the provider by reason of his nationality, or the fact that he is established in a Member State other than that in which the service is to be provided. This is opposed to the freedom of establishment which is applicable to situations in which persons move to work in another EC Member State on a permanent basis. The freedom for the recipient to move is the necessary corollary of the provider's freedom. ${ }^{57}$ The limitation in time is determined by the regularity, periodicity or continuity of the service provision. As stated by Advocate General Mayras in Van Binsbergen, a fundamental aspect of the difference between, on the one hand, the mere occasional provision of services, even temporary activities and, on the other hand, establishment, is that the person providing services falls outside the competence and control of the national authorities of the country in which the services are provided.

As noted above, the Treaty's prohibition of discrimination on the grounds of nationality, extends likewise to rules of any other nature aimed at regulating, in a collective

53 Case C-2/74 Reyners v. Belgium.

54 Case C-33/74 Van Binsbergen v. Bestuur van de Bedrijfsvereniging voor de Metaalnijverheid. The case concerned a Dutch legal adviser who transferred his place of residence from the Netherlands to Belgium during the course of the proceedings. Under Dutch law however, only persons established in the Netherlands could act as legal advisers.

55 It is essential that the service has an economic nature: the remuneration must be a consideration for the service in question. Case C-263/86 Belgium v. Humbel [1988] ECR 5365.

56 Case C-427/85 Commission v. Germany (Lawyers' Services case) [1988] ECR 1123

57 Cases C-286/82 \& 26/83 Luisi and Carbone v. Ministero del Tesoro [1984] ECR 377. 
manner, gainful employment and the provision of services. ${ }^{58}$ In this way, nondiscriminatory measures issued by professional bodies fall under EU scrutiny. Ethical rules issued by self-regulatory professional bodies, which have been sanctioned by the public authorities, may even be considered national regulatory measures. ${ }^{59}$ This implies that these rules must be justified on grounds of public interest to be compatible with Articles 56 and 57 TFEU (Article 50 EC). ${ }^{60}$ Indeed, just as is the case for workers, or in case of establishment, restrictions on the freedom to provide and receive services must be adopted in pursuance of a legitimate public interest which is not incompatible with Community aims (Article 62 jo Article 52 TFEU) (Article 55 jo Article 46 EC) or in matters of public authority (Article 62 jo Article 51 TFEU) (Article 55 jo Article 45 EC). Furthermore, restrictions must be applied without discrimination and must be proportionate. Market access restrictions which apply to national service providers as well, can fall within the ambit of Article 56 TFEU, if these obligations are comparable to those imposed by the legislation of the home Member State (double burden for the foreign service provider). ${ }^{61}$ It follows that, if a ground of public interest is invoked by a State, it has to take account of the provisions to which a service provider is already subject in his Member State of establishment. ${ }^{22}$

With regard to cases relating to the free movement of architects in particular, it should be noted that almost all cases are based upon the non-recognition of professional qualifications, and mostly deal with provisions of secondary legislation. These are all discussed in paragraph 3.3. For now, reference is made again to case C-38/87 Commission v Hellenic Republic ${ }^{63}$, which has already been discussed in paragraph 3.2.1.2, since this case did not deal with professional qualifications.

As noted above, various approaches and regimes have been introduced to make job mobility for professionals a practical reality. Next to a general programme to eliminate restrictions to the freedom of establishment, a general programme for the abolition of restrictions to the freedom to provide services was created by the Council on 18 December $1961^{64}$ on the basis of Article 52 EC (Article 59 TFEU). In this regard, Directives were created in order to abolish restrictions on the freedom to provide services and to

58 The abolition, as between Member States, of obstacles to the freedom of movement for persons, would be compromised if the abolition of State barriers could be neutralized by obstacles resulting from the exercise of their legal autonomy by associations or organizations not governed by public law. It follows that Article 56 TFEU has a certain horizontal direct effect as well. See Case C-36/74 Walrave and Koch, paragraphs 17, 23-24; Case C-13/76 Donà [1976] ECR 1333, paragraphs 17-18; Case C-415/93 Bosman, paragraphs 83-84; Case C-281/98 Angonese, paragraph 32.

59 Case C-266-267/87 The Queen v. Association of Pharmaceutical Importers, ECR 1295.

60 Grounds of public interest can include professional rules relating to organizations, competence, professional ethics, supervision and responsibility: see the rule of reason doctrine as developed by the Court in Case C-8/74 Procureur du Roi v. Dassonville et al., [1986] ECR 3713 and C-120/78 Rewe-Zentral AG v. Bundesmonopolverwaltung für Branntwein, both cases concerning the free movement of goods.

61 Case C-369/96 \& C-376/96 Arblade [1999] ECR I-8453.

62 Case C-279/80 Webb [1981] ECR 3305, at 3325.

63 Case C-38/87 Commission of the European Communities v Hellenic Republic.

64 General Programme for the abolition of restrictions on freedom to provide services adopted on 18 December 1961, OJ L 0013 January 1994, p. 401. 
introduce into the law of the Member States, a set of provisions which would facilitate the effective exercise of this freedom. The secondary legislation which is relevant within the scope of the freedom to provide services is Directive 2004/38/EC which will be discussed in the next paragraph, since it deals with the movement rights of all EU citizens; the Directives on the recognition of professional qualifications; Directive 2006/123/EC which will be discussed in paragraph 3.4 and Directive 96/71/EC of the European Parliament and of the Council of 16 December 1996, concerning the posting of workers in the framework of the provision of services. The latter Directive is applicable to undertakings established in a Member State which, in the framework of the transnational provision of services, post workers to the territory of a Member State while having taken certain transnational measures (Article 1). The posting of workers refers to workers who wish to carry out their work for a limited period in the territory of a Member State other than the State in which they normally work. This Directive stipulates that Member States have to ensure that the undertakings guarantee workers posted to their territory, certain terms and conditions of employment. As held by the ECJ in Finalarte Sociedade Construçao Civil ${ }^{65}$, the potential overlaps between workers and temporary service providers can be found in the fact that workers employed by a business established in one Member State, who are temporarily sent to another Member State to provide services (posted workers), do not, in any way, seek access to the labour market in that second State since they normally return to their country of origin or residence after completion of the work. As will be discussed hereunder ${ }^{66}$, Article 17(2) of Directive 2006/123/EC stipulates that Article 16 does not apply to the posting of workers, as regulated by Directive 96/71/EC. This means the fact that the rules of the host Member State (i.e. the state where the employee is sent to work) will be applicable instead of the rules of the state of origin, which would be the normal case under Article 16 of the Services Directive. ${ }^{67}$

\subsubsection{Citizenship of the Union (architect-employees, self-employed architects)}

As noted above, the right of free movement of persons in the Community was introduced by the EEC Treaty, signed in Rome, in 1957. This freedom was not bound to any citizenship concept but was rather closely linked to the conduct of an economic activity. Consequentially, the right of residence was accorded to workers and their families, linked to the right to exercise a labour activity in another EEC Member State. With the entry into force of the Treaty of Maastricht (TEU 1992), provisions on European citizenship were included in the EC-Treaty (Article 17-22 and 255 EC) which can now be found in Articles 15 and 20-25 TFEU. The Preamble to the TEU 1992 states that the High Contracting Parties resolved to establish a citizenship common to nationals of

65 Case C-49/98 Finalarte Sociedade Construçao Civil v. Urlabus-und Lohnausgleichskasse der Bauwirtschaft [2001] ECR I-7831, paragraphs 22-23.

66 See Chapter 3.4.

67 In this regard it should be mentioned that Article 3 of Directive 2006/123/EC states that if the provisions of this Directive (e.g. Article 16) conflict with a provision of another Community act governing specific aspects of access to, or exercise of, a service activity in specific sectors of specific professions (Directive $96 / 71 / \mathrm{EC}$ ), the provision of the other Community act shall prevail, and shall apply to those specific sectors or professions. 
their countries. It has evolved as the process of European integration moved on to create an ever-closer Union among the peoples of Europe. As will be explained hereunder, through the introduction of a citizenship of the Union, the rights and interests of the nationals of the Member States would be strengthened and protected. Important in this regard is that, due to the introduction of EU-citizenship, one does no longer have to perform an economic activity to benefit from certain free movement rights. Since architects holding the nationality of a Member State are also considered to be Union citizens, their rights and freedoms as Unions citizens will also be discussed.

Article 2 TEU 1992 (Article 3 TEU) held that one of the objectives of the Union is to strengthen the protection of the rights and interests of the nationals of its Member States through the introduction of a citizenship of the Union. According to Article 20 TFEU (Article 17 EC), every person holding the nationality of a Member State is automatically a citizen of the Union. It follows that Member States therefore decide who is a Union citizen. ${ }^{68}$ Even though the concept of nationality is determined by national law and not autonomously, according to Community law ${ }^{69}$, Union citizenship exists alongside and complements national citizenship and provides additional rights to nationals of Member States of the Union. Union citizens enjoy the rights conferred by the Treaty and are subject to the duties imposed thereby. In this regard, Article 21 TFEU (Article $18 \mathrm{EC}$ ) indicates that every citizen of the Union has the right to move and reside freely within the territory of the Member States, subject to the limitations and conditions laid down in this Treaty, and by the measures adopted to give it effect. If action by the Union should prove necessary to attain this objective, and the Treaty has not provided the necessary powers, the European Parliament and the Council may adopt provisions with a view to facilitating the exercise of the above-mentioned rights. It follows that the citizens' rights which were introduced by the TEU 1992, make it possible for every citizen of the Union to move and reside freely within the EU. This freedom is however subject to the limitations and conditions laid down in the Treaty, and to the measures adopted to give it effect. This means that even though the right of free movement and the right of residence constitute the foundations of Union citizenship, these rights are not unlimited. The limitations are provided for in the Treaty (for example the exception to the right of free movement regarding public policy, public security and public health continue to apply ${ }^{70}$ ) as well as in Directives.

It should be noted that the introduction of Union Citizenship did not initially add substantially to Community law. Already existing rights were mainly reiterated or general-

68 See also Case C-192/99 R. v. Secretary of State for the Home Department ex parte Kaur [2001] ECR I-1237 and Case C-369/90 Micheletti and others v. Delegación del Gobierno en Cantabri [1992] ECR I-4239.

69 Final Act to the Maastricht Treaty, Pt. III $2^{\text {nd }}$ Declaration (on nationality of a Member State); see also Conclusions of the European Council in Edinburgh, Bull. EC 12/92, 26 et seq. It is for each Member State to lay down the conditions for the acquisition and loss of nationality.

70 Union Citizenship extends to all rights and duties of Union law and therefore includes fundamental freedoms resulting from constitutional traditions common to Member States (Article 6 EU) as well as to social rights which previously mainly existed only on the basis of secondary legislation. What is constitutive for a citizen's status are political rights, i.e. primarily the right to vote and stand for election (Article 22 TFEU) (Article 19 EC). 
ised. The Treaty provisions with regard to the free movement of workers, establishment and services were already interpreted by the ECJ as not as having a narrow economic purpose, but rather a wider social and economic purpose. However, with the contribution of the ECJ through the combined effects of Articles 20 and 18 TFEU (Articles 17 and $12 \mathrm{EC}$ ), the right to equal treatment was enhanced, and the general principle of equal treatment for lawful residents was established. In this regard the ECJ held, in Martinez Sala ${ }^{71}$, that the citizenship provisions provide substantive free movement rights in addition to those already granted by Community law, and that some kind of universal non-discrimination right (including access to all manner of welfare benefits) has taken roots in Community law as a consequence of the creation of the figure of the Union citizen..$^{72}$ Lawful and authorized residence in another Member State by a national of one of the other Member States was held to be sufficient to bring a person within the scope ratione personae of Community law. The economic status of the person involved was thus not at issue. On the basis of Articles 20 and 21 TFEU (Article 18 EC) protection against discrimination based on nationality was extended to every Union citizen. A citizen of the European Union, lawfully resident in the territory of a host member State, can rely on Article 18 TFEU in all situations which fall within the scope ratione materiae of Community law. ${ }^{73}$ As held in Grzelczyk, those situations include those involving the exercise of the fundamental freedoms guaranteed by the Treaty, and those involving the exercise of the right to move and reside freely in another Member State, as conferred in Article 20 TFEU. ${ }^{74}$ The Court indicated that Union Citizenship is destined to be the fundamental status of nationals of the Member States, enabling those who find themselves in the same situation to enjoy the same treatment in law, irrespective of their nationality, subject to such exceptions as are expressly provided for. Since the former connection with one of the free movement rights was abandoned, the scope of persons protected was extended. Through the ECJ's case law, for the first time a significant pronouncement on the meaning of European Citizenship was made: Union Citizens lawfully residing in a Member State other than their Member State of origin are entitled to equal treatment with respect to the full range of benefits which come within the material scope of EU law. The combined effects of Articles 20 and 18 TFEU enhanced the right to equal treatment to a general principle of equal treatment for all lawful residents. The same reasoning can be found in Bickel ${ }^{75}$. It follows that architects holding the nationality of, and lawfully residing in a Member State, who are moving to another Member State, and architects of that other Member State should be treated equally, on a professional

Case C-85/96 Martinez Sala v. Freistaat Bayern [1998] ECR I-2691.

2 Fries \& Shaw 1998, 533.

73 Primary and secondary law does not, by itself, enhance citizen status. This was only achieved by reference to Article 12 EC (Article 18 TFEU) by the ECJ. Article 12 EC provides the key granting of access to rights which state constitutions often reserve for their nationals. It has generally granted all Union citizens access to citizen's rights in terms of state constitutions: See Kadelbach 2003, pp. 39-40.

74 Case C-184/99 Rudy Grzelczyk v. Centre Public d'Aide Sociale d'Ottignies-Louvain-la-Neuve (CPAS) [2001] ECR I-6193.

75 Case C-274/96 Criminal Proceedings against H.O. Bickel and U. Franz [1998] ECR I-7637. The Court held that, if a European citizen was exercising his right to free movement as laid down in Article 18 EC, he would have a general right to non-discriminatory treatment in the sense of Article 12 EC. 
level, on the basis of their Union citizenship. ${ }^{76}$ In Baumbast ${ }^{77}$, the ECJ even conferred direct effect upon Article 21 TFEU, since the rights of free movement and residence are conferred directly on every citizen of the Union by a clear and precise provision of the Treaty. It follows that a citizen of the European Union who no longer enjoys a right of residence as a migrant worker in the host Member State can, as a citizen of the Union, enjoy there a right of residence by direct application of Article 21 TFEU. As held above, this right is not unconditional, since it is subject to the limitations and conditions laid down by the Treaty and by the measures adopted to give it effect. The competent authorities and, where necessary, the national courts, must ensure that these limitations and conditions are applied in compliance with the general principles of EU law and, in particular, the principle of proportionality.78 This means that national measures adopted on that subject must be necessary and appropriate to attain the objective pursued. ${ }^{79}$ In this way, Directive 90/364/EEC ${ }^{80}$, which has been repealed by Directive 2004/38/EC, holds that Member States can require that beneficiaries of the right of residence must not become an unreasonable burden on the public finances of the host Member State, and should be covered by sickness insurance. In the event of a lack of resources, a citizen of the Union does not derive from Article 21 TFEU the right to reside in the territory of a Member State of which he is not a national within the meaning of this Directive. Such a limitation is based on the idea that the exercise of the right of residence of citizens of the Union can be subordinated to the legitimate interests of the Member States. ${ }^{81}$ However, while the Member States may make residence of a citizen of the Union who is not economically active conditional on having sufficient resources, that does not mean that such a person cannot, during his lawful residence in the host Member State, benefit from the principle of equal treatment as laid down in Article 18 TFEU (Article 12 EC). In Trojani ${ }^{82}$, the applicant was lawfully resident in Belgium and should therefore have

76 In Wijsenbeek, the Court indicated that the mere presence of an EU citizen in any Member State other than his/her own, generates at least a basic obligation of equal treatment vis-à-vis the host State's own nationals. However, the presence of that citizen in his/her own Member State, does not generate any EU obligations at all: See Case C-387/97 Criminal Proceedings against Florus Ariel Wijsenbeek [1999] ECR I6207. See also Case C-224/98 Marie-Nathalie D'Hoop v. Office national de l'eploi [2002] ECR I-6191 in which was decided that inequality of treatment is contrary to the principles which underpin the status of citizen of the Union, that is, the guarantee of the same treatment in law in the exercise of the citizen's freedom to move.

77 Case C-413/99 Baumbast and R. v. Secretary of State for the Home Department [2002] ECR I-7091. Case C-224/98 Marie-Nathalie D'Hoop v. Office national de l'eploi [2002] ECR I-6191

78 Due to the fact that the application of the limitations and conditions acknowledged in Article 21 (1) TFEU in respect of the exercise of that right or residence is subject to judicial review, any limitations and conditions imposed on the right do not prevent the provisions of Article 21 (1) TFEU from conferring on individuals rights which are enforceable by them and which the national courts must protect.

79 See, to that effect, joined cases C-259/91, C-331/91 and C-332/91 Allué and Others [1993] ECR I-4309, paragraph 15 .

80 This Directive was at issue in Baumbast.

81 See also Case C-200/02 Kunqian Catherine Shu and Man Lavette Chen v. Secretary of State for the Home Department[2004] ECR I-09925.

82 Case C-456/02 Michel Trojani v. Centre public d'aide sociale de Bruxelles (CPAS) [2004] ECR I-7573. A lack of resources was precisely the reason why Mr. Trojani sought to receive a certain benefit in Belgium. This benefit was refused on the grounds that he did not have Belgian nationality, and could not benefit from regulation 1612/68/EEC since his activities were not seen as real and genuine . 
been treated equally, even with regard to social assistance benefits. In this regard it should be noted that migrant EU citizens have a legitimate expectation of a limited degree of financial solidarity in terms of their degree of integration into the host society. ${ }^{83}$ However the host Member State can decide that, due to this recourse to benefits, the applicant no longer fulfils the conditions related to the right of residence. In such situations, Member State may, within the limits imposed by Union law, take measures to remove such persons. ${ }^{84}$ It follows that, before Baumbast, it was widely assumed that non-economically active citizens had no rights of residence deriving directly from the TEC, only from Directives created under the Treaty. In Baumbast however, the ECJ held that Article 21 TFEU granted a generally applicable right to residence, which is limited by secondary legislation, but only where that secondary legislation is proportionate. Member States can thus only distinguish between nationals and Union citizens if the respective provisions satisfy the test or proportionality. It follows that Article $21 \mathrm{TFEU}$ does not create a generalized right to reside within the territory of another Member States for all times for all Union citizens.

The Citizens' Rights Directive - Directive 2004/38/EC - of the European Parliament and of the Council of 29 April 2004 on the Right of Citizens of the Union and their Family Members to Move and Reside Freely within the Territory of the Member States, amending Regulation (EEC) No 1612/68 and repealing Directives 64/221/EEC ${ }^{85}$, 68/360/EEC ${ }^{86}, 72 / 194 / \mathrm{EEC}^{87}, 73 / 148 / \mathrm{EEC}^{88}, 75 / 34 / \mathrm{EEC}^{89}, 75 / 35 / \mathrm{EEC}^{90}, 90 / 364 / \mathrm{EEC}^{91}$,

83 Case C-209/03 R (Dany Bidar) v. London Borough of Ealing and Secretary of State for Education and Skills [2005] ECR I-2119, paragraphs 56-59.

84 However, certain conditions need to be fulfilled before one can actually be removed. Recourse to the social assistance system by a citizen of the Union may not automatically entail such a measure. See, to that extent, Grzelczyk, paragraphs 42-43.

85 Council Directive 64/221/EEC of 25 February 1964 on the co-ordination of special measures concerning the movement and residence of foreign nationals which are justified on grounds of public policy, public security or public health, OJ Sp. Ed. 1964, No. 850/65, p. 117.

86 Council Directive 68/360/EEC of 15 October 1968 on the abolition of restrictions on movement and residence within the Community for workers of Member States and their families, OJ Sp. Ed. 1968, No L257/13, p. 485.

87 Council Directive 72/194/EEC of 18 May 1972 extending to workers exercising the right to remain in the territory of a Member State after having been employed in that State, the scope of the Directive of 25 February 1964 on the coordination of special measures concerning the movement and residence of foreign nationals which are justified on grounds of public policy, public security or public health, OJ L 121, 26 May 1972, p. 32.

88 Council Directive 73/148/EEC of 21 May 1973 on the abolition of restrictions on movement and residence within the Community for nationals of Member State with regard to establishment and the provision of services, OJ 1973, No. L172/14.

89 Council Directive 75/34/EEC of 17 December 1974 concerning the right of nationals of a Member State to remain in the territory of another Member State after having pursued therein an activity in a self-employed capacity, OJ 1975, No. L14/10.

90 Council Directive 75/35/EEC of 17 December 1974 extending the scope of Directive No 64/221/EEC on the coordination of special measures concerning the movement and residence of foreign nationals which are justified on grounds of public policy, public security or public health to include nationals of a Member State who exercise the right to remain in the territory of another Member State after having pursued therein an activity in a self-employed capacity, OJ L 14 of 20 January 1975.

91 Council Directive 90/364/EEC of 28 June 1990 on the right of residence, OJ 1990, No. L180/26. 
90/365/EEC ${ }^{92}$ and 93/96/EEC ${ }^{93}$ and amending Regulation 1612/68/EEC - entered into force on 30 April 2006. It amended regulation 1612/68/EEC on the freedom of movement for workers within the Community and repealed a number of Directives which mostly linked the freedom of movement to the pursuit of an economic activity. Some of these Directives were applicable to workers, students or other economically inactive persons, others to self-employed persons working in another Member State on a permanent or temporary basis. It was held that to remedy this sector-by-sector, piece-meal approach to the right of free movement and residence, and to facilitate the exercise of this right, there needed to be a single legislative act. However, from the early 1990s onwards, the link between the freedom of movement and the pursuit of an economic activity loosened pursuant to Directive 90/364/EEC and the Union Citizenship provisions in the TFEU. Due to these novelties, secondary EU legislation concerning free movement was restructured by Directive 2004/38/EC which consolidated, in a single text, the legislation on the free movement of citizens of the Union. As held by Article 2(1) and the preamble, Union citizenship should be the fundamental status of nationals of the Member States when they exercise their right of free movement and residence. It is important to note that the Directive also confers considerable rights upon the family members of moving EU citizens, since it was held that the freedom of movement of EU citizens would be limited if their family members, even if they are third-country nationals, could not join them. ${ }^{94}$ In this regard, Article 4(1) indicates that all Union citizens with a valid identity card or passport and their family members ${ }^{95}$ who are not nationals of a Member State and who hold a valid passport, shall have the right to leave the territory of a Member State to travel to another Member State. Accordingly, Article 5(1) holds that Member States shall grant Union citizens leave to enter their territory with a valid identity card or passport, and shall grant family members who are not nationals of a Member State leave to enter their territory with a valid passport. Both provisions apply without prejudice to the provisions on travel documents applicable to national border controls. It seems that, to enter the territory of a Member State, no economic activities are demanded, and the mere possession of Union citizenship is enough to benefit from these provisions. Union citizens and their family members in possession of a valid identity card or passport, who are not nationals of a Member State, and who accompany or join the Union citizen, even have a right of residence on the territory of another Member State for a period of up to three months without any conditions or any formalities (Article 6). However, they will only have this right as long as they do not become an unreasonable burden on the social assistance system of the host Member State (Article 14(1)). Nevertheless, to enjoy a right of residence on the territory of another Member State for a period of longer than three months, Union citizens have to be workers or self-employed persons in the host Member State or have to have sufficient resources for themselves and their family members not to become a burden on the social assistance system of the

92 Council Directive 90/365/EEC of 28 June 1990 on the right of residence for employees and self-employed persons who have ceased their occupational activity, OJ 1990, No. L180/28.

93 Council Directive 93/96/EEC 29 October 1993 on the right of residence for students, OJ 1993, No. L $317 / 59$.

94 There should therefore always be a Community dimension before the Directive applies.

95 Article 2(2) of the Directive gives an exhaustive list of who is qualified as a Citizen's family Member. 
host Member State during their period of residence, and have comprehensive sickness insurance cover in the host Member State (see Article 7(1) jo 14(2)). ${ }^{96}$ It is important to note that an expulsion measure may under no circumstances be adopted against Union citizens or their family members if the Union citizens are workers or self-employed persons, or if they entered the territory of the host Member State in order to seek employment (Article 14(4)). As held by Article 16(1), Union citizens who have resided legally for a continuous period of five years in the host Member State shall have the right of permanent residence there. In certain cases this right can already be enjoyed before completion of a continuous period of five years of residence (see Article 17). As held by Article 27(1), also within the application of Directive 2004/38/EC, Member States may restrict the freedom of movement and residence of Union citizens and their family members, irrespective of nationality, on grounds of public policy, public security or public health. ${ }^{97}$ It follows that Directive 2004/38/EC distinguishes between economically active and non-active persons, since only the former are allowed to stay for more than three months without having to prove that they have sufficient resources or a comprehensive sickness insurance cover in the host State.

Next to the right of residence, the Directive also regulates the right of Union Citizens to take up employment. As held by Article 24(1), subject to such specific provisions as are expressly provided for in the Treaty and in secondary law, all Union citizens residing on the basis of this Directive in the territory of the host Member State shall enjoy equal treatment with the nationals of that Member State within the scope of the Treaty. This right to equal treatment means, of course, the right to take up and fulfil work. ${ }^{98}$ These rights are described more specifically and in greater detail in Articles 45, 49 and 56 TFEU which have already been discussed. It follows that third-country architects

96 A right for residence for longer than three months is also conferred on union citizens who are enrolled at a private or public educational establishment, accredited or financed by the host Member State on the basis of its legislation or administrative practice, for the principal purpose of following a course of study, including vocational training and have comprehensive sickness insurance cover in the host Member State, and can assure the relevant national authority, by means of a declaration or by such equivalent means as they may choose, that they have sufficient resources for themselves and their family members not to become a burden on the social assistance system of the host Member State during their period of residence, as well as on family members accompanying or joining a Union citizen who satisfies the conditions referred to in Article 7 (see Article 7 (1) (c), 7 (1) (d) en 7 (2)). As already held above, Article 10 of Regulation 1612/68/EEC (repealed by Directive 2004/38/EC with effect from 30 April 2006 (see Article 38 (1)), gave the mover's family a right to install itself with him as well. However, this right was based on the mover's economic status as a worker, and not on his Union citizenship. As held above, this concept was only introduced in 1993 by the TEU.

97 These grounds shall not be invoked to serve economic ends. Measures taken on grounds of public policy or public security shall comply with the principle of proportionality, and shall be based exclusively on the personal conduct of the individual concerned. Previous criminal convictions shall not in themselves constitute grounds for taking such measures. The personal conduct of the individual concerned must represent a genuine, present and sufficiently serious threat affecting one of the fundamental interests of society. Justifications that are isolated from the particulars of the case or that rely on considerations of general prevention, shall not be accepted (Article 27 (2)). Before taking an expulsion decision on the grounds of public policy or public security however, the host Member State shall take account of several considerations enumerated in Article 28. This will not be further elaborated on within this thesis.

98 In Case C-131/85 Emir Gül v Regierungspräsident Düsseldorf [1986] ECR 1573, the ECJ already held in the light of Regulation 1612/68/EEC, that the third-country national spouse of a Union citizen must be subject to the same rules regarding access to, and pursuit of, an occupation as nationals of the host Member State. 
who are a family member of an EU citizen making use of free movement rights, can invoke Directive 2004/38/EC to join the citizen to another EU state, and take up employment there. Within the light of public policy and public safety, their qualifications will be checked if they want to design buildings. As indicated before, this recognition of qualifications will be discussed in paragraph 3.3.

Comparing the status of market and Union citizens, makes it clear that a person's personal status has become increasingly independent of the fundamental freedoms. As will be explained hereunder in more detail, the rights of economically active persons are broader than the rights of those who are not economically active. The recent developments in the ECJ's case law, and the content of Directive 2004/38/EC, seem to reflect a philosophy of compromise between what Union citizenship could or should yield, and what the political and financial sensibilities of Member States are prepared to tolerate. ${ }^{99}$ Since this thesis only concerns the regulation of economically active persons (architects), the emphasis of my research is on their status as workers or self-employed persons, and not on their Union citizenship status. The free movement rights of EU architects will therefore not be further discussed in the light of their EU citizenship. Since workers and self-employed persons are treated as 'a species of the genus citizen of the Union' ${ }^{100}$, I refer to the preceding paragraphs in this regard.

\subsection{Free movement of architects not holding the nationality of a Member State}

\subsubsection{Introduction}

Even though this research upon the situation of Belgian and Dutch architects, it would not be complete if the free movement rights of third-country architects (non-EU architects) would not be referred to. Indeed, European legislation has foreseen that also certain architects holding the nationality of a third country should be able, if certain requirements are fulfilled, to practise the profession of architect in the EU and thus also in Belgium and the Netherlands.

Even though the Treaty of Maastricht incorporated asylum and immigration policy into the EU framework in 1992, with the exception of visa policy, matters of immigration were not treated within the regular Community-pillar, but were dealt with under a third, intergovernmental pillar. ${ }^{101}$ However, with the entry into force of the Treaty of Amsterdam, the Community became responsible for the development of a common EU immigration policy and was competent to draft legislation regarding the position of third-country nationals. Legislation on the free movement of third-country nationals was based upon Article 63(3) (a) and 63(4) EC (Article 79(2) TFEU).

The legal migration of third-country nationals to the EU is regulated on the basis of five Directives which have already entered into force and one draft Directive: Directive

99 Dougan 2001, p. 93.

100 Cordinanzi, Lang \& Nascimbene 2008, p. 67.

101 Hailbronner 1999, p. 10. The pillar structure is abolished by the Treaty of Lisbon which means that almost all areas of Justice and Home Affairs will come under the Community method of decision-making: qualified majority voting in the Council and co-decision of the European Parliament. 
2003/86/EC on the right of family reunification ${ }^{102}$; Directive $2003 / 109 / \mathrm{EC}$ on the status of long-term residents ${ }^{103}$; Directive 2004/114/EC on the conditions of admission of students, pupils, unremunerated trainees and volunteers ${ }^{104}$; Directive 2005/71/EC on a specific procedure for admitting third-country national researchers ${ }^{105}$; Directive 2009/50/EC on the conditions of entry and residence of third-country nationals for the purposes of highly qualified employments ${ }^{106}$; draft Directive on a single permit and a common set of rights. As indicated above, these Directives are based upon Title V of the TFEU (Title IV EC) which was introduced into the EC-Treaty with the 1999 Treaty of Amsterdam, that established a legal basis for the creation of a common European immigration policy within an 'Area of Freedom, Security and Justice'. ${ }^{107}$ EU immigration law and policies have developed within the framework of multi-annual programmes, of which the first was adopted in Tampere in October 1999, the second one in The Hague in 2004 and, on 2 December 2009, the Swedish Presidency submitted to the General Affairs Council and the European Council the result of the discussions, especially in the Justice and Home Affairs Council, for approval in accordance with Article 68 TFEU (Article 61 EC) and publication in the Official Journal of the European Union. The Tampere European Council centred on the rights of legally residing third-country nationals, and stressed that these should enjoy "broadly the same rights and responsibilities as EU nationals" which are "rights and obligations comparable to those of EU citizens" ${ }^{108}$ The Hague programme reiterated that the integration of immigrants remained one of the policy priorities in the Area of Freedom, Security and Justice. ${ }^{109}$ Common Basic Principles were adopted by the Justice and Home Affairs Council on 19 November 2004, which established a direct link between immigration and the principles of nondiscrimination and equal treatment. As indicated in Article 79 TFEU (Article 63(3) and (4) EC), the Union shall develop a common immigration policy aimed at ensuring, at all stages, the efficient management of migration flows and the fair treatment of thirdcountry nationals residing legally in Member States. ${ }^{110}$ Since the legal status of third-

102 Council Directive 2003/86/EC of 22 September 2003 on the right to family reunification, OJ L 251, 3 October 2003, pp. 12-18.

103 Council Directive 2003/109/EC of 25 November 2003 concerning the status of third-country nationals who are long-term residents, OJ L 16, 23 January 2004, pp. 44-53.

104 Council Directive 2004/114/EC of 13 December 2004 on the conditions of admission of third-country nationals for the purposes of studies, pupil exchange, unremunerated training or voluntary service, OJ L 375 of 23 December 2004, pp. 12-18.

105 Council Directive 2005/71/EC of 12 October 2005 on a specific procedure for admitting third-country nationals for the purposes of scientific research, OJ L 289, 3 November 2005, pp. 15-22.

106 Council Directive 2009/50/EC of 25 May 2009 on the conditions of entry and residence of third-country nationals for the purpose of highly qualified employment, OJ L 155, 18 June 2009.

107 It should be noted that Denmark, the United Kingdom and Ireland are not bound by any measure in the area of migration law, as they have negotiated opt-outs from Title V TFEU.

108 The Commission held, however, that the scope of rights granted to third-country nationals may differ according to their length of stay. It should be noted, however, that the Tampere conclusions are merely political statements which are not legally binding as opposed to the Directives which do contain a binding set of rules which need to be implemented by the Member States. Furthermore, the Tampere conclusions are confined to third-country nationals who are already legally resident in an EU Member State.

109 Presidency Conclusions of the Brussels European Council, Annex I: The Hague Programme; Strengthening Freedom, Security and Justice in the European Union, 4 and 5 November 2004, 14292/04, points 1.5, 4.

110 The situation of asylum seekers or refugees or persons living illegally in the EU will not be discussed. 
country nationals should be approximated to that of Member State's nationals, there should be enhanced non-discrimination in economic, social and cultural life. ${ }^{111}$ With regard to long-term residents, the aim was to grant them a set of uniform rights "as near as possible to those enjoyed by EU citizens" which includes inter alia the right to reside, work, receive education and the non-discrimination principle. ${ }^{112}$ Two nondiscrimination Directives entered into force after the adoption of the Amsterdam Treaty: Directive 2000/43/EC implementing the principle of equal treatment between persons irrespective of racial or ethnic origin ${ }^{113}$ and Directive 2000/78/EC establishing a general framework for equal treatment in employment and occupation ${ }^{114}$. They are both based on Article 19 TFEU (Article 13 EC) and thus deal with discrimination based on sex, racial or ethnic origin, religion or belief, disability, age or sexual orientation. These Directives will not be discussed within this thesis which rather concerns itself with antidiscrimination law based on nationality. Since the regulation of the profession of architect is central, economically motivated objectives for anti-discrimination law rather than human rights concerns lie at the heart of this thesis.

However, next to these Directives it should not be forgotten that the free movement rights of certain third country nationals are also provided for by Directive 2004/38/EC which was discussed in the preceding paragraph. Furthermore, with regard to certain states, there are special rules under associations and partnership agreements.

In the following paragraph, an overview will be presented of those third-country nationals who enjoy free movement rights.

\subsubsection{Third-country national family members of EU citizens who made use of their free movement rights: Directive 2004/38/EC}

Directive 2004/38/EC confers extensive rights upon third-country family members of EU citizens who have made use of their free movement rights ${ }^{115}$. These family members are privileged in that their situation is governed by the law of the European Union rather than by national immigration laws. Within the scope of the Directive, family members are the spouse, the partner with whom the Union citizen has a registered partnership, the direct descendants of the Union citizen, his spouse or registered partner under the age of twenty one or the direct descendants who are dependant, as well as dependent direct relatives in the ascending line and those of the spouse or registered partner (Article 2(2) jo 3(1) of the Directive). The Directive must be applied with regard to these family members if they accompany or join the Union citizen. With regard to any other family members, irrespective of their nationality who, in the country from

${ }^{111}$ Presidency Conclusions of the Tampere European Council, 15-16 October 1999, Sn 200/99, Brussels, points 18-21.

112 Ibid.

${ }^{113}$ Council Directive 2000/43/EC of 29 June 2000 implementing the principle of equal treatment between persons irrespective of racial or ethnic origin, OJ L 180, 19 July 2000 pp. 22-26.

114 Council Directive 2000/78/EC of 27 November 2000 establishing a general framework for equal treatment in employment and occupation, OJ L 303, 02 December 2000 pp. 16-22.

115 See article 3 of the Directive. The situation of family members of EU nationals who did not make use of their free movement rights is regulated by the national law of the state of residence. In such cases, there is no issue of equal treatment. This will not be further discussed within this thesis. 
which they have come, are dependants or members of the household of the Union citizen having the primary right of residence, or where serious health grounds strictly require the personal care of the family member by the Union citizen, as well as with regard to the partner with whom the Union citizen has a durable relationship, duly attested, the host Member State shall facilitate entry and residence (Article 3(2)). As noted by Peers, the Court has not yet clarified the interpretation and extent of the facilitation obligation. ${ }^{116}$

Under Article 5 of Directive 2004/38/EC, Member States are required to grant these third-country national family members the right to enter with a valid passport. A visa can be requested in accordance with Regulation 539/2001/EC or, where appropriate, with national law. Since the UK and Ireland do not participate in the common visa policy, third-country family members must comply with the visa formalities according to national law. On the basis of Article 6(2), third-country national family members who are in the possession of a valid passport, accompanying or joining the Union citizen, have a right of residence for a period of up to three months without any other conditions or any formalities. This right lasts as long as they do not become an unreasonable burden on the state (Article 14(1)). As held by Article 7(2), third-country national family members accompanying or joining the Union citizen in the host Member State, shall enjoy the right of residence for more than three months if the Union citizen is a worker or self-employed person or has sufficient resources so that s/he and his/her family will not become a burden on the social assistance scheme of the host Member State, or is following a course of study and is covered by comprehensive sickness insurance. In this situation, these family members may apply for a residence card. Articles 12 and 13 deal with the retention of the right of residence by family members in the event of death or departure of the Union citizen and in case of divorce, annulment of marriage or termination of the registered partnership. As held by Article 16(2), third-country family members who have legally resided with the Union citizen in the host Member State for a continuous period of five years, have the right of permanent residence there. Article 17(3) jo Article 17(1) refer to certain situations in which the right of permanent residence can be enjoyed before completion of a continuous period of five years of residence. These will not be further discussed within this thesis. According to Article 18 of the Directive, third-country national family members who satisfy the five year requirement acquire the right of permanent residence and will be issued a permanent residence card (Article 20).

As held by article 23 of the Directive, irrespective of nationality, the family members of Union citizens who have the right of residence or the right of permanent residence in a Member State, shall be entitled to take up employment or self-employment there. In this regard I will discuss the recognition of the professional qualifications of thirdcountry nationals in more detail in paragraph 3.3.2. Finally, reference should be made to article 24 of the Directive which indicates that third-country nationals who have the right of residence or permanent residence, enjoy equal treatment with the nationals of the host Member State within the scope of the Treaty. Of course, in any case, the free-

116 Peers 2006, p. 199; Wiesbrock 2009, p. 85. 
dom of movement and residence of Union citizens and their family members can be restricted on ground of public policy, public security or public health (article 27).

\subsubsection{Family members of Union citizens who have not made use of their free movement rights}

If the Union citizen has not made use of his/her free movement rights, a purely internal situation in which national law prevails arises. It follows that the non-discrimination principle and the principle of equal treatment (on the basis of nationality) do not apply. The Court has underlined the national sovereignty of the Member States in such cases in Saunders ${ }^{17}$, Moser ${ }^{118}$, Kremzow ${ }^{119}$ and Uecker and Jacquet ${ }^{120}$. In these cases nationals of a Member State were treated less favourably than nationals of another Member State who came to live in that state and, in certain cases, even less favourably than resident thirdcountry nationals. ${ }^{121}$ Later, the Court accepted to apply the free movement principles if 'some kind of Community dimension' could be identified. In this regard, reference can be made to Singh ${ }^{122}$ in which the ECJ held that the temporary movement of a couple for employment in another Member State with the aim of avoiding an internal situation to be able to rely on Community law was not an abuse of rights. The Court has reiterated on numerous occasions that EU law applies to any EU national who works in a Member State other than that of his residence, irrespective of his place of residence and his nationality. ${ }^{123}$ Even persons who work in their home state but move for personal reasons to another state fall within the scope of the Treaty. ${ }^{124}$

\subsubsection{Association and Partnership agreements.}

The European Union has concluded Association Agreements with a number of countries on the basis of Article 217 TFEU (Article 310 EC). Such Agreements are concluded jointly by the European Community (since the entry into force of the Lisbon Treaty by the Union) and the Member States in areas where they both have competences. Due to these Agreements, third-country nationals of certain states enjoy special treatment with

117 Case C-175/75 R. v. Saunders [1979] ECR 1129, paragraph 1.

118 Case C-180/83 Moser [1984] ECR 2539.

119 Case C-299/95 Kremzow [1997] ECR I-2629.

120 Joined Cases C-64/96 and 65/96 Uecker and Jacquet [1977] ECR I-03171, paragraph 23.

121 In Cases C-35/82 and 36/82 Morson and Janjan v. Netherlands ECR 3723, two Dutch nationals working in the Netherlands had no right under Community Law to bring their parents, of Surinamese nationality, into the country to reside with them. Had they been nationals of any other Member State working in the Netherlands, they would have been covered by Article 10 of Regulation 1612/68/EEC. Since they were nationals working in their own Member State who had never exercised the right to freedom of movement within the Community, they had no rights under Community law. See Craig \& De Búrca 2003, p. 742.

122 Case C-370/90 The Queen v. Immigration Appeal Tribunal \& Surinder Singh, ex parte Secretary of State for Home Department [1992] ECR I-4265.

123 Case C-152/03 Ritter-Coulais [2006] ECR I-1711, paragraph 31; Case C-287/05 Hendrix [2007] ECR I6906; Case C-291/05 Eind [2007] ECR I-10719; Case C-60/00 Mary Carpenter v. Secretary of State for the Home Department [2002] ECR I-6279.

124 See Case C-527/06 Renneberg [2008] ECR I-7735 
regard to entry and/or residence rights, and the Community/Union system is, to a certain extent, applicable to them.

Commitments regarding freedom of movement fall, in any case, within the powers conferred on the Union by Article 217 TFEU. ${ }^{125}$

1. The European Economic Area

The Agreement on the European Economic Area (EEA) which was signed in Porto on 2 May $1992^{126}$ confers rights on nationals of the European Economic Area (European Union and Iceland, Liechtenstein and Norway). The Agreement allows them more specifically to participate in the Internal Market on the basis of their application of Internal Market relevant acquis. All new relevant EU legislation is dynamically incorporated into the Agreement, and thus applies throughout the EEA, ensuring the homogeneity of the internal market. The rules on entry and residence (Articles 28, 31 and 36 of the Agreement deal with the free movement of workers, the freedom of establishment and the freedom to provide services, respectively) contained in the Agreement are identical to those in the Treaty on the Functioning of the European Union and must be interpreted in accordance with the case law of the ECJ. Norway and Iceland are members of the Schengen Area since December 1996, with the result that all border controls between these states and the 24 other Schengen States are lifted.

\section{EC-Switzerland Agreement}

Switzerland concluded a bilateral Agreement on the Free Movement of Persons with the European Community on 21 June $1999 .{ }^{127}$ Swiss nationals and their family members are generally awarded the same free movement rights as EEA nationals and their family members. Article 1(a) and (d) indicates that the Agreement provides Swiss nationals with a right of entry, residence and stay, as well as access to work or self-employed activities. Article 2 contains the principle of equal treatment, and prohibits any discrimination on the grounds of nationality, of one of the contracting parties lawfully residing in another contracting party. Article 7 provides for the equal treatment with regard to access to, and the pursuit of, economic activities. The Contracting Parties have to take all necessary measures to apply rights and obligations equivalent to those contained in EC law in terms of relations between them (Article 16). Swiss nationals can rely on the acquis communautaire, and the case law of the ECJ has to be taken into account. As held by article 9 of Annex I, which deals with the free movement of persons, any employee who is a national of a Contracting Party may not be treated differently to nationals of the host state as regards conditions of employment and working conditions. The Agreement contains an annex specifically dealing with the mutual recognition of professional qualifications (Annex III). Since 12 December 2008, Switzerland has been part of the Schengen Area, and all land border controls between Switzerland and the 24 other Schengen countries are lifted.

125 Wiesbrock 2009, p. 100; Case C-12/86 Demirel [1987] ECR 3719.

126 OJ L 1, 3 January 1994. Case C-12/86 Demirel [1987] ECR 3719.

127 OJ L 114, p. 6. 
Public Regulation of Architects at European Union Level

\section{The EEC-Turkey Association Agreement}

The EEC-Turkey Association Agreement was signed on 12 September 1963. ${ }^{128}$ The Agreement includes a clause prohibiting discrimination with regard to Turkish employees in respect of remuneration and working conditions (Article 37). To progressively secure the free movement of workers between Turkey and the EU, the contracting parties have to be guided by Articles 48, 49 and 50 EEC (Articles 45, 49 and 56 TFEU). An Additional Protocol that was signed on 23 November $19700^{129}$ stipulates that the Association Council, which is composed of members from the governments of the Member States and the Turkish government as well as the Council and the Commission, has to lay down the rules necessary for securing, in progressive stages, the freedom of movement of workers (Article 36). In this regard, three Decisions have been taken. The most important one in terms of this thesis is Decision No. 1/80 which largely replaced the earlier Decision No. 2/76 130 and gives some specific rights to Turkish employees who are already legally employed in a Member State. After having been admitted to the employment market of a Member State on the basis of a domestic decision, a Turkish employee will gradually acquire the right to equal treatment and unrestricted access to the employment market of that Member State. ${ }^{131}$ In this regard the Court has held in Kurz $z^{132}$ that article 39 EC should be applied as far as possible to Turkish citizens under Decision No. 1/80. However, under this Decision Turkish workers only gradually acquire rights after having been granted access to the employment market of a certain Member State and after a period of legal employment. The rights laid down in Article 6(1) vary in accordance with the length of the period during which the Turkish employee has been legally employed in the Member State. After one year of legal employment in the Member State, a Turkish worker who is duly registered as belonging to the labour force of a Member State, acquires the right to a renewal of his/her permit to work for the same employer if a job is available. After three years of legal employment, and subject to the priority accorded to workers of EU Member States, a Turkish worker acquires the right to respond to another offer of employment with an employer of his choice, but only for the same occupation. After four years of legal employment, the worker obtains the right of free access to any paid employment of his choice in the Member State. However, it should not be forgotten that Member State are still sovereign when it comes to regulating the admission of Turkish workers on their territory, as well as the conditions of their first access to the employment market. ${ }^{133}$ Nevertheless, the rights held by Turkish workers on the basis of Article 6(1) of Decision No. 1/80 which has direct effect ${ }^{134}$, entail a right of residence. ${ }^{135}$ Family members (spouse and children) who have been authorized

\footnotetext{
OJ EC No. C 113/2 of 24 December 1973

OJ EC No. C 113/17, 24 December 1973.

130 Decision No. $3 / 80$ deals with social security rights and will not be discussed within this thesis.

31 Wiesbrock 2009, p. 103.

32 Case C-188/00 Kurz [2002] ECR I-10691, paragraph 30.

133 See for example Case C-340/97 Nazli [2000] ECR I-957, paragraph 29.

134 Case C-192/89 Sevince [1990] ECR I-3461, paragraphs 14 and 15.

135 Case C-36/96 Günaydin [1997] ECR I-5143, paragraph 26. It should be noted that in order to benefit from article 6 (1) of Decision No. 1/80, Turkish workers must have the status of 'worker', must have pursued legal employment and must be duly registered as belonging to the labour force of the Member State. As noted above, there are also requirements with regard to the duration of the employment.
} 
to join a Turkish worker who is duly registered as belonging to the labour force of a Member State, are also allowed to take up employment (Article 7 of Decision No. 1/80). After three years they receive an autonomous right to seek employment and an autonomous right of residence. Article 10, which also has direct effect, grants equal treatment and prohibits any Member State from discriminating against Turkish workers concerning remuneration and other working conditions, on the basis of their nationality. In this regard the EU Member States and Turkey are not allowed to introduce new restrictions on the conditions of access to employment applicable to workers and members of their family legally resident and employed in their respective territories (Article 13 Decision No. 1/80).

The Association Agreement also contains provisions on the abolishment of restrictions on the freedom of establishment (Article 13) and the free movement of services (Article 14). Although these provisions are not followed by a Decision, the provisions of the Treaty on the Functioning of the European Union and the case law of the ECJ have to be applied. Articles 13 and 14 of the Agreement jo article 41(1) of the Additional Protocol, aim to protect Turkish citizens from the introduction of more restrictive rules as those applicable at the date of entry into force of the Additional Protocol on the freedom of establishment and the freedom to provide services. It should be noted, however, that Article 41(1) does not provide Turkish nationals with a right of establishment or a right to provide services in the EU. Member States are only not allowed to introduce more stringent rules than those applicable at the time of entry into force of the protocol.

4. Partnership and Cooperation Agreements with Russia and other ex-Soviet states

The Partnership and Cooperation Agreement between the European Communities and Russia was signed on 24 June $1994 .{ }^{136}$ Russian nationals who are legally employed in the territory of a Member State have to be treated equally to nationals as regards working conditions, remuneration or dismissal, subject to the laws, conditions and procedures applicable in each Member State (Article 23). Member States are thus not allowed to discriminate Russian workers in these areas, but are still competent to regulate the entry and stay of these nationals, the working conditions as well as the establishment of natural persons, and the supply of services, unless this would jeopardize the purpose of the Agreement (Article 48). Russian nationals can rely on the Agreement before a national court. ${ }^{137}$ Similar Partnership and Cooperation Agreements have been concluded with Armenia $^{138}$, Azerbaijan ${ }^{139}$, Georgia ${ }^{140}$, Kazakhstan ${ }^{141}$, Kyrgyz Republic ${ }^{142}$, Moldova ${ }^{143}$, Ukraine $^{144}$ and Uzbekistan ${ }^{145}$.

136 OJ 1997 L 327, p. 1. It entered into force on 1 December 1997.

137 Case C-265/03 Simentukov [2005] ECR I-2579, paragraphs 23 and 29.

138 OJ L 239, 9 September 1999.

139 OJ L 246, 17 September 1999.

140 OJ L 4 August 1999.

141 OJ L 196, 28 July 1999.

142 OJ L 196, 28 July 1999.

143 OJ L 181, 24 June 1998.

144 OJ L 49, 19 February 1998

145 OJ L 229, 31 August 1999. 
Public Regulation of Architects at European Union Level

\section{The Euro-Mediterranean Association Agreement}

The European Union has concluded a bilateral Association Agreement with Egypt ${ }^{146}$, Israel $^{147}$, Jordan ${ }^{148}$, Lebanon ${ }^{149}$, Morocco $^{150}$, Tunisia ${ }^{151}$ and Algeria ${ }^{152}$. These Agreements saw the light in the framework of the Barcelona Process by which it was intended to establish political, economic and social cooperation between the European Union and certain countries of the Southern Mediterranean. Article 64 of all these Agreements prohibits any nationality discrimination of these Southern Mediterranean workers employed -even on a temporary basis- in the territory of a Member State in respect of working conditions, remuneration and dismissal (Article 64). This non-discrimination principle can be invoked directly by individuals before a national court. ${ }^{153}$ However, the renewal of residence permits is still governed by the national legislation of each Member State. ${ }^{154}$ Furthermore, these Agreements do not provide for any kind of freedom of movement of workers. Nevertheless, if a Euro-Mediterranean worker to which such an Agreement is applicable, is limited in his/her rights to remain when the Member State has granted him specific employment rights which go beyond his right of residence, the Member State is not allowed to deny his stay in the absence of a legitimate national interest such as public policy, public security or public health. ${ }^{155}$

\section{The ACP states and Latin American countries}

The European Union and 78 African, Caribbean and Pacific Countries (ACP) ${ }^{156}$ concluded a Partnership Agreement on 23 June 2000 - the Cotonou Agreement- for a period of twenty years. From 1975 until 2000 the ACP-EC relations were governed by the regularly adapted and updated Lomé Conventions (Lomé I - Lomé IV bis). However, important developments on the international stage, such as the joint fight against terrorism, and socio-economic and political changes in the ACP countries have highlighted the need for a re-thinking of ACP-EC cooperation. The Cotonou Agreement aims to establish better development, economic, trade and political cooperation. The special relationships with the ACP states have to be seen in the light of colonization. The main aim of the convention is to reduce poverty by the integration of these states into the world economy. Within the scope of this thesis, most important is Article 13 of the Agreement, which contains the prohibition for all contracting parties to discriminate, and an obligation to guarantee a fair treatment of third-country nationals on their territory. As held by Article 13(3), the treatment accorded by each Member State to workers of ACP countries legally employed in its territory, shall be free from any discrimination based on nationality, as regards working conditions, remuneration and dismissal, rela-

\footnotetext{
146 OJ L 304, 30 September 2004.

147 OJ L 147, 21 June 2000.

148 OJ L 129, 15 May 2002.

149 OJ L 143, 30 May 2006.

150 OJ L 138, 9 June 2000.

151 OJ L 97, 30 March 1998.

152 OJ L 265, 10 October 2005.

153 Case C-97/05 Gattoussi [2006] ECR I-11917, paragraph 28.

154 See Joint Declarataion annexed to the Final Act of the Agreements.

155 Case C-97/05 Gattoussi, paragraph 40.

156 The ACP Group of states counts 79 states. Only Cuba did not sign the Cotonou Agreement.
} 
tive to its own nationals. Furthermore, in this regard, each ACP State shall accord comparable non-discriminatory treatment to workers who are nationals of a Member State. As argued by Wiesbrock, this last paragraph is to be interpreted consistently with the Lomé Conventions and therefore carries direct effect and comprises at least the right to be treated equally in respect of public-sector employment contracts, rules of private associations on the nationality of persons who can play for a professional sports team, and rules about elections to chambers of workers. ${ }^{157}$ The Cotonou Agreement does not contain an initial right of entry to the territory of a Member State but means that the initial right of access to the EU is governed by the national law of the Member State concerned, unless one falls within the ambit of Directive 2004/38/EC or one of the Directives discussed in paragraph 3.2.2.5. As long as individuals are legally employed, their legal residence cannot be terminated unless there are public security, public policy or public health reasons. Only the Association Agreement with Chile ${ }^{158}$ contains specific rules on the admission of employees of service providers within the context of free trade in services (see Articles 95-115 and Annex VII to the Agreement). This will not be further discussed within this thesis. Numerous bilateral agreements between individual Member States and certain Latin American states exist, apart from the Cotonou Agreement.

7. Stabilization and Association Agreement with the Balkan states Croatia and Albania have both signed a Stabilization and Association Agreement with the EU on 29 October 2001 and 12 June 2006 respectively. Bosnia-Herzegovina, Serbia and Montenegro have also signed such agreements with the EU, but these are not yet ratified. These Agreements contain a non-discrimination clause with regard to working conditions. Just as is the case with the other Agreements discussed above (with the exception of the Association Agreement on the EEA and the Association Agreement with Switzerland), the conditions governing the right to entry still fall within the competence of the Member States.

\subsubsection{Non-privileged third-country nationals: Directives on legal migration of third- country nationals}

Third-country nationals legally residing in a Member State ${ }^{159}$ can also invoke one of the Directives on legal migration if they fulfil certain criteria. Directives 2003/86/EC, 2003/109/EC, 2004/114/EC and 2005/71/EC on legal migration contain a right for thirdcountry nationals to participate in the labour market of the host Member States after a certain period of time and/or under certain conditions. ${ }^{160}$ In paragraph 3.3.2 which deals with the recognition of professional qualifications in the light of the free movement of

157 Wiesbrock 2009, p. 110; Cases C-162/00 Pokrzeptowics-Meyers [2002] ECR I-1049; Case C-438/00 Seutscher Handballbund [2003] ECR I-4135.

158 OJ L 352, p.3.

159 As indicated before, Denmark, the United Kingdom and Ireland are not bound by any measure in the area of migration law, as they have negotiated opt-outs from Title V TFEU. Their situation is also governed by the national law of the state of residence and will not be further discussed within this thesis.

160 See Articles 11 and 14 Directive 2003/109/EC; Article 14 Directive 2003/86/EC; Article 18 Directive 2004/114/EC and Article 13 Directive 2005/71/EC. 
persons and services, I will discuss if and how these Directives provide for the recognition of professional qualifications obtained by third-country nationals to whom the Directives apply.

\section{Directive 2003/86/EC}

Directive 2003/86/EC, which was created under Article 63(3) (a) EC (Article 79 TFEU), provides for the right of third-country nationals who are legal residents of an EU Member State to be reunited with their family members. The sponsor who is a third-country national residing lawfully in a Member State and applying, or whose family members ${ }^{161}$ apply, for family reunification, has to hold a residence permit with a period of validity of at least one year and have reasonable prospects of obtaining the right of permanent residence (see Article 2(c) and 3(1) of the Directive). Family members should be granted a first residence permit of a duration of at least one year that is renewable. As held by Article 14(1) (b) of Directive 2003/86/EC, third country nationals eligible for family reunification will have, in principle, the same rights as the sponsor and have access to any employment and self-employed activity. ${ }^{162}$ This right however can be restricted for up to twelve months after entry on the basis of the labour market situation of the Member State concerned (Article 14(2)). After up to five years of residence, a sponsor' spouse and children who have reached majority, must be granted an autonomous residence permit (Article 15(1)-(3)).

\section{Directive 2003/109/EC}

In accordance with Article 4(1) of Directive 2003/109/EC, Member States are obliged to grant long-term resident status to those third-country nationals having resided in their territory legally and continuously for a period of five years. ${ }^{163}$ Such third-country nationals must demonstrate that they have stable and regular resources that are sufficient to provide for themselves and their family members without recourse to social assistance and comprehensive sickness insurance (Article 5(1) (a) and (b)). If these conditions are met, the applicant shall be granted permanent long-term residence status, and receive an EC residence permit with a validity of five years that is renewable (Articles 7(3), 8(1) and 8(2)). As held by Article 11(1) (a) long-term residents shall enjoy equal treatment with nationals as regards access to employment and self-employed activity, provided such activities do not entail even occasional involvement in the exercise of public authority, and as regards conditions of employment and working conditions, including conditions regarding dismissal and remuneration. Furthermore, Article 11(1) (c) indicates that equal treatment should also be granted regarding the recognition of professional diplomas, certificates and other qualifications, in accordance with the rele-

161 These are the sponsor's spouse and natural or adopted children of the sponsor and/or the spouse, who are unmarried and minors according to the age of majority set by the law of the Member State (Article 4 (1) paragraph 2 of the Directive). First-degree relatives in the direct ascending-line and adult unmarried children of the sponsor or the spouse, as well as unmarried partners, constitute voluntary categories of eligible family members (Articles 4 (2) and 4(3) of the Directive).

162 The requirements which need to be fulfilled for family reunification can be found in Articles 7 and 8 of Directive 2003/86/EC. These will not be discussed within this thesis.

163 Article 5 of Directive 2003/109/EC contains the conditions which need to be fulfilled. 
vant national procedures. Long term residents are allowed to reside in another Member State for more than three months if they are engaged in an employed or self-employed economic activity, pursue studies or vocational training or for other purposes. They may be accompanied by their family if the family was already constituted in the first Member State (Article 16). However, according to Article 14(3), Member States are allowed to examine their labour market and give preference to EU citizens. Furthermore they can deny long-term residents access to employment which is different from that for which the residence permit has been granted. Integration measures can be demanded unless the applicant has already complied with the integration conditions which were demanded in order to obtain long-term resident status in the first state. The attendance at language courses can always be demanded. (Article 15(3)).

\section{Directive 2004/114/EC and 2005/71/EC}

Directive 2004/114/EC and 2005/71/EC are two Directives that also concern the legal migration of specific categories of third-country nationals. The first Directive deals with the conditions on the admission of students, pupils, unremunerated trainees and volunteers. Since this thesis deals with the free movement of architects, being professionals who are 'fully fledged', Directive 2004/114/EC is not of importance within the scope of this thesis. Directive 2005/71/EC contains a specific procedure for admitting thirdcountry national researchers. Due to its limited importance for architects, this Directive will not be discussed either.

\section{Directive 2009/50/EC}

Due to the inability of the Council of Ministers to come to an agreement on the Commission's proposal on a Directive for economic migration in 2001 , there is currently no general instrument regulating the conditions for first entry and the residence of thirdcountry national labour migrants to the EU territory. However, in 2007 the Commission adopted another proposal for a Directive on the conditions for entry and residence of third-country nationals for highly qualified employment. Directive 2009/50/EC was adopted by the European Parliament on 25 May 2009 and has to be implemented in national law by 19 June 2011. As held by Article 2(1) (b), it applies to third-country nationals pursuing highly qualified employment, which is defined as genuine and effective work under the direction of someone else, for which a person is paid and for which adequate and specific competence, proven by the holding of higher professional qualifications, is required. Higher professional qualifications are defined as qualifications attested by evidence of higher educational qualifications or by at least five years of professional experience, when provided for by national law. Higher educational qualifications refer to the degree or diploma obtained after the completion of a post-secondary course of higher education of at least three years, which must be officially recognized in the state in which the educational institution concerned is situated. ${ }^{164}$ The possibility of replacing higher educational qualifications with relevant professional experience must be foreseen by national law, and only applies by derogation. The level of this professional experience must, in any case, be comparable to the higher educational qualifica-

164 See Article 2 (g) and 2 (h) of the Directive. 
tions and be relevant for the employment to be undertaken. Criteria for admission include a work contract or job offer for at least one year, compliance with the regulated professional rules or, for unregulated professions, the possession of relevant higher professional qualifications for the sector of occupation, valid travel documents and sickness insurance for the whole family (Article 5). Other requirements are related to the salary of the migrant worker which must be at least 1.5 times the average gross annual salary of the host State, and must comply with the applicable collective agreement or practices in the relevant occupation. ${ }^{165}$ It is important to note that the Directive does not create a right of admission as such, since Member States retain the competence to control how many and which type of qualified workers to admit to their labour markets, which means that they are allowed to apply quotas. ${ }^{166}$ Furthermore, Member States even retain the possibility not to grant any residence permits for employment in certain professions, economic sectors or regions. ${ }^{167}$ A Blue Card ${ }^{168}$ which entitles applicants to enter, re-enter and stay in the Member State issuing the permit and to enjoy the rights awarded to them by the Directive ${ }^{169}$, may be refused on the basis of their national labour market situation. Furthermore, as held by Article 8(2), preference may be given to Union citizens and resident third-country nationals. This is in line with Article 79(5) TFEU which holds that, with regard to economic migration, Member States have the right to determine the volume of admission of third-country nationals coming from third countries to their territory in order to seek work, whether employed or self-employed (Article 79(5) TFEU). Under the rules set by the Directive, especially Article 14, EU Blue Card holders will enjoy equal treatment with nationals of the member state issuing the Blue Card, as regards working conditions, including pay and dismissal, education, training and recognition of qualifications and several other rights. Member States are even free to adopt more favourable rules for different types of employment (Article 3(4)). The Card will initially be valid for a period of between one and four years, provided that the work contract has a duration of at least one year (Article 7(2)). Since the Directive does not provide for a possibility of renewing the permit, third-country nationals will not be able to acquire long-term resident status in the EU. However, as laid down by article 16, highly skilled workers are allowed to accumulate periods of residence in different Member States in order to achieve the five years of legal and continuous residence needed to obtain EU long-term residence status. During the first two years of employment, migrant workers are not allowed to change employment within the Member State without the written authorization by the Member State's authorities (Article 12(1) and (2) of the Directive). After two years, Member States are allowed, but are not obliged, to grant

165 Member States may also require that the applicant has an address in their territory and that the applicant does not constitute a risk to public security, public policy or public health. See Article $5(2)$ and $5(3)$ of the Directive.

166 See Article 6 and recital 8 of the preamble to the Directive.

167 See recital 8 of the preamble to the Directive.

168 See Article 7 (4) of the Directive. The Blue Card will facilitate access to the labour market for their holders and will entitle them to a series of socio-economic rights and favourable conditions for family reunification and movement across the EU. Since the Blue Card will, in principle, be valid for a period of between one and four years - at least if the work contract has a duration of one year - and is not renewable, thirdcountry nationals will be excluded from acquiring long-term resident status in the EU on this basis.

169 See Article 7 (1) jo 7 (4) of Directive 2009/50/EC. 
such individuals equal treatment with nationals as regards access to highly qualified employment, without having to meet the entry requirements in terms of salary and qualifications. After eighteen months of legal residence, Blue Card holders may also take up highly qualified employment in another Member State. ${ }^{170}$ An application for a second Blue Card has to be made however, and the same conditions for entry have to be fulfilled. The second Member State is also allowed to apply quotas, and can, while the application is still pending, impose restrictions upon the equal treatment of the applicant, except as regards the freedom of association and the recognition of diplomas. ${ }^{171}$ As indicated by Wiesbrock, this system leaves open the question of whether it is easier and more attractive for such migrant workers to apply for two separate Blue Cards, rather than to apply for two separate residence permits under national highly skilled migrant schemes. ${ }^{172}$ Family members of Blue Card holders will receive a residence permit with the same validity as that of the sponsor. It can thus be concluded that third-country architects not working in a self-employed capacity, who cannot invoke Directive 2004/38/EC as a family member of a moving EU citizen, can, after the implementation period has expired, invoke Directive 2009/50/EC if the conditions for entry and residence, as defined in the Directive, are respected. However, the Directive does not give them a right to admission so that Member States can still refuse them on the basis of their national labour market situation. It follows that the Directive provides for a certain degree of harmonization, but leaves much room for discretion to the Member States. Furthermore, since professionals will not be able to gain permanent residence, it is questionable whether the Directive is an active instrument for third-country professionals. Nevertheless, since it provides third-country nationals with a common set of rules, it should be considered as an important step towards a possible harmonisation of rules with regard to economic migration in the European Union.

\section{Draft Directive on a single permit and a common set of rights}

Finally, mention should be made of the Draft Directive on a single permit for thirdcountry nationals to reside and work in the territory of a Member State, and on a common set of rights for third country workers legally residing in a Member State, that was put forward by the Commission on 23 October 2007. ${ }^{173}$ The proposal applies to thirdcountry nationals seeking to reside and work in a Member State and to single permit holders who are defined as third-country nationals who have been issued a single permit, i.e. a valid residence permit issued by the authorities of a Member State, granting a right of residence for the purpose of employment. ${ }^{174}$ As held by Article 4, applicants will

170 Article 16 of the Directive allows highly skilled migrants to accumulate periods in two or three Member States in order to fulfil the five-year residence requirement to obtain long-term residence status. This is a derogation from Directive 2003/109/EC.

171 See Article 14 (4) of the Directive.

172 Wiesbrock 2009, p. 224.

173 COM (2007) 638 Final, 23 October 2007, CNS 2007/0229.

174 See Article 2 (b), 2 (c) and 3 (1) of the Draft Directive. However, in order to reach unanimity, the Presidency presented a revised draft which limited the scope of the proposal to single permit holders but opened up the possibility for Member States to maintain or adopt provisions granting equal treatment to other legally resident third-country nationals not holding a single permit. This means that the Draft does not include third-country nationals who were initially admitted to a Member State for other purposes such 
have to submit a single application in order to obtain the right to reside and to work in a Member State. However, the competence of the Member States with respect to the admission of third-country nationals to their labour markets will not be affected. The Directive aims to control the lawfulness of third-country nationals' residence and employment and to close the 'rights gap' between EU citizens and third-country nationals by granting a common set of equal treatment rights to single permit holders. ${ }^{175}$ As held by Article 11, third-country nationals obtain the right to enter and to stay in the Member State issuing the permit and to have free access to the entire territory of that Member State within the limits provided for by national legislation. Furthermore, they have the right to exercise the employment activity authorized under the single permit. A right of movement to other Member States is not included. As held by Article 12, equal treatment shall be enjoyed in respect of working conditions, education, recognition of qualifications, and some other rights. Equal treatment as regards the recognition of diplomas is only granted in accordance with national law. Recital 15 of the preamble even refers to Directive 2005/36/EC and holds that qualifications obtained by single permit holders in another Member State should be recognized in the same way as for Union citizens, which means that, in principle, access to the same profession ${ }^{176}$ shall be granted on equal footing as to nationals of the host Member State. If the Directive enters into force, it remains to be seen what the effects of this Directive will be on the migration of third-country architects.

In any case it should be concluded that the absence of a general policy for all types of workers demonstrates the lack of willingness of Member States to give up their sovereignty in immigration matters. However, the Directives prove that progress in this area has been made since they all contribute to the fair treatment of third-country nationals by restricting the discretionary powers of the Member State to a certain extent, and by providing minimum standards. It should be regretted that the Directives contains several possibilities to limit equal treatment rights on the basis of national law. With the entry into force of the Lisbon Treaty, it is expected that more legislation will be created granting third-country nationals stronger rights, since the Treaty provides for qualified majority voting in this area.

\section{Free movement of architects through the recognition of professional qualifications}

In the previous paragraphs, the free movement rights of economically and noneconomically active persons within and to the European Union have been described.

as students, family members, researchers and refugees, and who were subsequently granted access to the labour market. The Draft is also not applicable to family members of Union citizens exercising their free movement rights, third-country nationals and their family members who enjoy free movement rights equivalent to those of Union citizens on the basis of bilateral agreements, posted workers, seasonal workers, au pairs, self-employed persons, long term residents under Directive 2003/109/EC, and certain other categories of persons listed in Article 3 (1) of the Draft.

175 Recital 3 and 9 to the preamble of the Draft Directive.

176 As held by Article 4 (2) of Directive 2005/36/EC, a profession is considered to be the same as that for which the person is qualified in the home Member State if the activities are comparable. 
Since this thesis deals with the regulation of architects, I will focus only on the first category. As indicated above, each Member State is allowed to decide if and how it regulates a profession. It follows that the qualifications which are needed to practise the profession of architect -if any- are quite different and diverse in each Member State. Nevertheless, professionals, whether they are workers or self-employed persons, should be able to move freely within the EU, subject to the provisions laid down by law, regulation or administrative actions on grounds of public policy, public security or public health (Article 45(3), Article 49 jo 52 and Article 56 jo 62 TFEU) (Article 39(3), Article 43 jo 46 and Article 49 jo 55 EC). Furthermore on the basis of Article 79(2) TFEU (Article 63(3) and (4)), Directives have been created to ensure the efficient migration of third-country nationals to the Union, which generally entail equal treatment as regards access to employment and self-employed activity. Since it is of importance that buildings are safe, it is important that they are designed by competent persons in the possession of the relevant knowledge and abilities. It follows that Member States will demand a certain level of qualifications before an individual is allowed to work as an architect on their territory. To be able to determine whether someone disposes of the required qualifications, Directives have been created on the mutual recognition of diplomas, certificates and other evidence of formal qualifications on the basis of Articles 46, 50 and 53 jo 62 TFEU (Articles 40, 44 and 47 jo 55 EC). The Directives which are relevant for architects will be discussed in this paragraph. In this regard it should be noted however that since this thesis analyses the regulation of architects, it deals with professionals who are fully qualified to practise the architectural profession. It follows that the recognition of professional qualifications should be distinguished from academic recognition, which will be discussed in paragraph 3.5 and concerns the recognition of a foreign qualification for the purpose of further studies. Since the main objective of academic recognition is to establish whether or not the holder of the qualification is capable of continuing studies in a chosen direction and at a chosen level, academic recognition results in a precise, exhaustive comparison of the training followed by the prospective candidate in relation to that which is required in the host Member State. Professional recognition, on the other hand, concerns the knowledge and skills of a professional, and whether they are appropriate for the pursuit of a particular line of work. It follows that, in such cases, the fully qualified professional status of the candidate counts for recognition.

\subsection{Architects holding the nationality of an EU Member State}

As regards recognition for professional purposes, it is important to distinguish between regulated and non-regulated professions. If the profession one wishes to pursue is not regulated in the host state, one is subject to the rules of the labour market and the behaviour of that market, and not to any legal constraints with regard to the diploma. In such a case, the system of recognition provided for by the legal instruments (especially Directives) regarding the recognition of diplomas is not applicable. It follows that, in such cases, one does not have to apply for the recognition of qualifications, and one may pursue the profession in that country under the same conditions and with the same rights and obligations as that country's own nationals. A profession is said to be regu- 
lated on the other hand, when there is a statutory requirement to hold a diploma or other occupational qualification in order to pursue the profession in question. In that case, the lack of the necessary national diploma constitutes a legal obstacle to gaining access to the profession. If one seeks recognition of a certain diploma in order to pursue a regulated profession (whether on an employed or self-employed basis) in a Member State other than the one in which the qualifications were obtained, one is covered by Union law which the national authorities must apply. The right of establishment, the freedom to provide services and the free movement of workers are fundamental principles embedded in the TFEU. In order to enable these freedoms to be exercised, several Directives regarding the recognition of diplomas, applicable solely to the regulated professions, have been adopted at European level. These will be discussed later in this chapter.

In the ambit of professional recognition, two general programmes adopted on 18 December $1961^{177}$ made provision for Directives to abolish restrictions to the freedom of establishment and the provision of services for various activities. As held in paragraph 3.2., although the Council adopted a good number of these instruments, the work was far from complete in 1974 when the Court decided, in Reyners and Van Binsbergen, that despite omissions, under the terms of the Treaty, Articles 49 and 56 TFEU (Articles 43 and $49 \mathrm{EC}$ ) have direct effect from the end of the transitional period onwards, that is since 1 January 1970. It was held that for this reason, there was no need to continue creating rules relating to the abolishment of restrictions. Consequently, the pending Directives were withdrawn. The direct effect of these free movement rights was that EU nationals became entitled to be treated as nationals. Since discrimination on the basis of nationality is prohibited, the host Member State has to allow nationals of other Member States to establish themselves or to provide services on its territory under the same conditions as its own nationals. However, national conditions of access to, and exercise of, the activities continue to apply, which still leave barriers for non-nationals, since they can be obliged to engage in further studies to obtain the qualifications required. ${ }^{178}$ To diminish these obstacles, Community measures to facilitate free movement in the EU were still desired. These measures should secure mutual recognition of the national rules and possibly their harmonisation. Measures provided for by the Treaty (see Article 53(1) TFEU and Article 62 TFEU) (Article 47(1) and 55 EC) to facilitate freedom of establishment and provision of services include, firstly, the mutual recognition of the diplomas and other qualifications required in each country for access to the profession under consideration. Even though the mutual recognition of qualifications is also a matter of importance in the field of the free movement of workers, in the field of establishment and services, disputes over the non-recognition of qualifications occur most

177 General Programme for the abolition of restrictions on freedom of establishment, 31961X1202, OJ 2, 15.1.1962, pp. 36-45; General Programme for the abolition of restrictions on freedom to provide services, 31961X1201, OJ 2, 15.1.1962, pp. 32-35.

178 http://www.europarl.europa.eu/facts_2004/3_2_3_en.htm, last consulted 15 December 2009. Even though, through the cases of Reyners and Vanbinsbergen, the Court guaranteed the equal treatment of citizens across Member States, neither the mutual recognition of certificates of professional competence, nor the coordination of training requirements was guaranteed. 
frequently. Since national requirements concerning qualifications and diplomas can indeed constrain citizens of other Member States in practising their rights of establishment and offering their services as guaranteed in Articles 49 and 56 TFEU, the Council has, on the basis of Articles 53 and 62 TFEU, adopted Directives concerning the mutual recognition of diplomas in order to simplify the actual practice of the right of establishment and the unconstrained performance of services. ${ }^{179}$ Article 53(1) TFEU furthermore addresses the need to coordinate national rules on the taking-up and pursuit of a profession, involving a minimisation of harmonisation of the rules, especially on the training for the qualifications required. ${ }^{1{ }^{80}}$ However, since such harmonisation is a difficult process, the Treaty only insists on it as a precondition for mutual recognition in the case of the pharmaceutical profession (Article 53(2) TFEU). With regard to the architectural profession in particular, the major differences between national rules have prevented harmonization, so that only a Directive on the mutual recognition of architectural qualifications has been adopted. Since it only dealt with the architectural profession and since several other Directives were created with regard to other professions, this was referred to as the vertical approach. Later legislation on mutual recognition involved a more general approach which was valid for all regulated professions that had not previously been the subject of specific EC legislation. This was called the horizontal approach. The relevant Directives will now be discussed.

\subsubsection{Vertical approach towards the recognition of architectural qualifications}

Since no secondary legislation was created with regard to the architectural profession before the end of the transitional period, the ECJ decided that it should contribute to the development of the freedoms. The Van Binsbergen and Reyners cases are important examples of this policy. Later, between 1975 and 1985, the EC-institutions created a number of Directives to establish a minimum harmonization of education and mutual recognition of diplomas for the following regulated professions: doctors ${ }^{181}$, nurses $^{182}$, dentists ${ }^{183}$, veterinarians ${ }^{184}$, midwifes ${ }^{185}$ and pharmacists ${ }^{186}$. Until the mid-80s, a vertical

179 Schneider 1995, p.57.

180 The results of mutual recognition after harmonization have gone furthest in the health sector, since the professional requirements, and especially the training courses, do not vary much from one country to another making relatively easy to harmonize them. Most health professions benefit thus from full mutual recognition of national access diplomas in that the qualifications listed in Community Directives can be exercised in any Community country with regard to the establishment and freedom of services.

181 Council Directive 75/362/EEC of 16 June 1975 (recognition) and Council Directive 75/363/EEC of 16 June 1975 (minimum standards), [1975] OJ L 167.

182 Council Directive 77/452/EEC of 27 June 1977 (recognition) and Council Directive 77/453/EEC of 27 June 1977 (minimum standards), [1977] OJ L 176, 15 July 1977.

183 Council Directive 78/686/EEC of 25 July 1975 (recognition) and Council Directive 78/687/EEC of 25 July 1978 (minimum standards), [1978] OJ L 233, 24 August 1978.

184 Council Directive 78/1026/EEC of 18 December 1978 (recognition) and Council Directive 78/1027/EEC pf 18 December 1978 (minimum standards), [1978] OJ L 362, 23 December 1978.

185 Council Directive 80/154/EEC of 21 January 1980 (recognition) and Council Directive 80/155/EEC of 21 January 1980 (minimum standards), [1980] OJ L 33, 11 February 1980.

186 Council Directive 85/432/EEC of 16 September 1985 (minimum standards) and Council Directive 85/433/EEC of 16 September 1985 (recognition) [1985] OJ L 253, 24 September 1985. 
approach was thus used: access to each profession was regulated separately by means of sectoral Directives. ${ }^{187}$ Since the costs of exchanging information between identical systems are very low, it was seen as an efficient integration method: identical education would lead to identical diplomas. ${ }^{188}$ Directives were used to establish minimum standards and contained a list of all the diplomas which were recognized in Europe. This approach is called 'harmonization'. However by laying down minimum criteria for education, the essence of the vertical approach -the mutual recognition of the qualifications of individuals exercising a certain profession- was made 'harmless'. ${ }^{189}$ Indeed, a system based on harmonization does not seem to be build upon trust in each other's qualifications with an eye to recognition. For architects ${ }^{100}$ however, only a Directive regarding the mutual recognition of diplomas was issued. Minimum harmonisation of education was not provided for, due to the large differences in educational requirements and a lack of agreement. In this regard it should be noted that in 1959, the six national professional associations of architects had already organised themselves on a European level to advise the European Commission and the Council of Ministers about European measures which could affect them. In this way they aimed to promote the abolition of all restrictions concerning the mobility of architects. In 1961, the 'Working Group Architects', established by the European Commission and composed of independent experts of the six Member States of the European Community of that time, came together to make proposals for the European recognition of architects. ${ }^{191}$ In this way, a Directive for the harmonization of legal and administrative rules for architects was proposed, together with one for the mutual recognition of diplomas, certificates and other evidence of formal qualifications, and one for the co-ordinations of provisions relating to the freedom of establishment of architects. These would be the first Directives ever to encourage the free movement of professionals in the European Community and would be of huge importance as a precedent for numerous other professions. However, the different Member States did not come to a concordium. While some Member States (France, Italy and Belgium) held the opinion that the Directives should only apply to persons holding a university degree, others such as Germany and the Netherlands also wanted to approve non-university education in cases where practical experience complemented the theoretical knowledge up to university level. Another big obstacle for getting an agreement was the length of the education involved: while in France and Italy one had to follow theoretical courses for five years, the education at the German 'Ingenieurschulen' was comprised of three years of theoretical courses followed by three years of practical experience. This was unacceptable for the Italians and the French. The national association of architects in the Netherlands ${ }^{192}$-which was at that moment in time the only state within the European Community without public regulation of the profession of architect due to the vehement opposition of other actors in the building process- wanted to regulate the profession as strictly as possible. The fact that it was harder for Dutch archi-

187 A regulated profession is a profession to which access is regulated by law.

188 Dankelman 1999, p. 9.

189 Claessens 2008, p. 26.

190 Council Directive 85/384/EEC of 10 June 1985 (recognition), [1985] OJ L 223, 21 August 1985.

191 Dankelman 1999, p. 103; Kapteyn \& VerLoren van Themaat 1989, p. 437.

192 This is the BNA (Bond der Nederlandse Architecten). 
tects to find work in another state than vice versa stimulated the Dutch association to claim regulation and title protection. However, because of all the large national differences, no agreement was reached at the European level.

In the meantime, two Directives for the mutual recognition of doctors ${ }^{193}$ were adopted which contained minimum standards for the structure and content of their education and which served as an example for the desired architects' Directive. Meanwhile, the accession of some new Member States (Denmark, Ireland and the United Kingdom) in 1972 did not make things easier in the field of architecture due to the large differences between the countries: the United Kingdom and Ireland were unaware of the structure and educational culture of the architect profession in the continental form.

As held above, due to the two landmark decisions of the ECJ in the cases of Reyners ${ }^{194}$ and Van Binsbergen ${ }^{195}$ in 1974, in which Articles 49 and 56 TFEU were held to have direct effect, the Commission withdrew its proposals to issue Directives concerning the free movement of establishment and services of EC architects. However, the issue of the recognition of foreign diplomas still had to be dealt with. As the second ${ }^{196}$ and third ${ }^{197}$ enlargement of the European Community would soon take place, the Council wanted to place more emphasis on quality rather than on quantity requirements. Nevertheless, disagreements about the minimum duration of degree programmes continued to dominate the decision-making process. Those Member States requiring a lengthy education were afraid that reduced emphasis on the quantity aspect would lead to a quality deterioration leading to low European standards. ${ }^{198}$ Furthermore, for Germany, where the education at the Fachhochschulen was held to be equivalent to a university education, an acknowledgement of the universities and not of the Fachhochschulen (3 year education) on a European level was unacceptable. The Italians, on the other hand, did not want to back down due to the length of the Italian education process and its severe regulations. Another problem was that the engineers who had set up their own European interest organisation -le Comité Européen des Ingénieurs Conseils (CEDIC )- wanted to be included in the Architects' Directive because of their close cooperation. The Dutch BNA on the other hand, supported the European recognition of architects because this constituted the only way to have the profession regulated in the Netherlands after the withdrawal of the Dutch bill for the protection of the title of architect.

Finally, on 10 June 1985, Council Directive 85/384/EEC saw the light of day. ${ }^{199}$ This involved the mutual recognition of diplomas, certificates and other evidence of formal qualifications in architecture (hereafter: the Architects' Directive), including measures to facilitate the effective exercise of the right of establishment and freedom to provide

193 Directives 75/362/EEC and 75/363/EEC.

194 Case C-2/74 Reyners v. Belgium.

195 Case C-33/74 Van Binsbergen v. Bestuur van de Bedrijfsvereniging voor de Metaalnijverheid.

196 Greece became a new Member State in 1981.

197 Portugal and Spain joined the EC in 1986.

198 Dankelman 1999, p. 115.

199 The text of the Directive has been amended on several occasions, specifically due to the accession of new Member States. 
services. It was the result of lengthy, difficult negotiations which lasted almost eighteen years, and was based upon Articles 46, 53 and 62 TFEU (Articles 40, 47 and 55 EC). As noted above, unlike the Directives which recognized medical qualifications, the Architects' Directive was adopted without an accompanying Directive laying down minimum training requirements for architects (there was no coordination of national provisions relating to education and training) but merely provided for qualitative and quantitative criteria which were needed for a diploma to be recognized at the Community level. As concluded by the Commission, "The length of the negotiations which culminated in the adoption of Directive 85/384/EEC and its distinctive character in relation to the Directives recognizing the qualifications of certain medical professions reflect the fact that architecture is a complex, sensitive and problematic area. The main reason for these difficulties was the sometimes very pronounced differences between regulations in the field in the Member States. The enlargements of 1973 and 1981 meant that four additional legal structures had to be taken into account ${ }^{200}$, and this initially made the negotiations even more complex. Moreover, architecture was not regulated in some of the old Member States (Ireland, Denmark, Sweden and Finland, plus Norway in an EEA context). In other Member States (including the Netherlands, the United Kingdom and Germany) only the title of architect is protected. Lastly, in yet other Member States (including Spain, Belgium and France) the title of architect is protected and, in addition (with a few rare exceptions) architects enjoy a monopoly in pursuing their activity. What is more, architects' responsibilities and obligations vary greatly from one Member State to another. The difficulties caused by these sometimes very substantial differences in the way the profession is regulated and in the field of architecture itself explain why Directive 85/384/EEC does not contain a precise definition of architecture (see the seventh, ninth and tenth recitals and Article 1(2))"201. In this regard, Part II of this thesis discusses the differences between the regulations in Belgium and the Netherlands on a public law and private law level. Recognition of qualifications under the Architects' Directive applies only in so far as the holders of such qualifications are authorized to take up activities under the professional title of architect. ${ }^{202}$ It affirmed the fundamental principles of equivalence of diplomas if certain quantitative and qualitative requirements were fulfilled, and their mutual recognition by Member States. ${ }^{203}$ The principle that governed the implementation of Directive 85/384/EEC was the automatic recognition of diplomas in conjunction with the implication of the Court's ruling in the Vlas-

200 For many years the requirement of unanimity in the Council slowed the process. Now the co-decision procedure generally applies (Article 294 TFEU).

201 Report from the Commission Review, on the basis of experience, of Council Directive 85/384/EEC of 10 June 1985 pursuant to Article 30 thereof, p. 2.

202 Article 1 (2) Directive 85/384/EEC.

203 As held by Article 2, each Member State has to recognize the diplomas, certificates and other evidence of formal qualifications acquired as a result of education and training and awarded to nationals of Member States by other Member States, by giving such diplomas, certificates and other evidence of formal qualifications, as regards the right to take up activities referred to in Article 1 and pursue them under the professional title of architect pursuant to Article 23 (1), the same effect in its territory as those awarded by the Member State itself. The quantitative and qualitative requirements can be found in Articles 3 and 4 of the Directive. 
sopoulou case for various types of architectural training which are perfectly lawful, but which do not comply with the Directive.

Since the Architects' Directive was replaced by Directive 2005/36/EC of the European Parliament and of the Council of 7 September 2005 on the recognition of professional qualifications, the latter Directive will primarily be discussed within this thesis. ${ }^{204}$ However, numerous references will be made to Directive 85/384/EEC in order to compare the content of both Directives and to determine whether the new Directive contains some extra safeguards for architects enjoying their free movement rights. However, between 1985 and 2005, other initiatives have been taken as well on a horizontal level. These will be discussed initially in the following paragraph.

\subsubsection{Horizontal approach towards the recognition of professional qualifications}

Due to the limited scope of the vertical harmonisation method and the difficult and time-consuming negotiations, attempts were made to create an environment of mutual trust with regard to foreign diplomas so that there would be no need for harmonization. ${ }^{205}$ The sectoral approach was considered to be too rigid and tiresome, since every technical change in a Member State such as the introduction of a new education process or specialisation had to be processed into the recognition system which caused many difficulties such as a formal change in the text of the guidelines. The new system was based on the premise that the programmes of study and training through which people in the various Member States prepare themselves for a particular regulated profession are, in principle, of equal validity. Article 165(4) TFEU (Article 149(4) EC) which was introduced by the Maastricht Treaty, now even explicitly prohibits any harmonisation of the laws and regulations of the Member States. This new approach was strengthened by the abovementioned rulings of the ECJ in Reyners and Van Binsbergen. Recognition was not considered separately for each different profession, but for a group of professions for which the duration of education was the same. The regulations in the home country were applicable, even in cases of cross border trade, instead of the regulations in the receiving country. Mutual recognition without preceding harmonisation was the new technique to be used. ${ }^{206}$ This new line of reasoning, which actually, as early as 1974, was expressed by the Council in a non-binding resolution ${ }^{207}$, was reaffirmed by the European Council in 1984 in Fontainebleu, where it held that a new, more general approach towards the recognition of higher-education diplomas was necessary, and would certainly be necessary in the light of the admission of new Member States. This was concretized by the creation of the following Directives: Directive $89 / 48 / \mathrm{EEC}^{208}$ on a general system for the recognition of higher-education diplomas awarded on completion of profes-

204 See paragraph 3.3.1.2.

205 The principle of mutual trust was based on the Court's ruling in Case C- 120/78 Rewe-Zentral AG v. Bundesmonopolverwaltung für Branntwein (Cassis de Dijon); Schneider 1995.

206 See COM (85) 310, June 1985.

207 [1974] OJ C 98/1.

208 Council Directive 89/48/EEC of 21 December 1988 on a general system for the recognition of highereducation diplomas awarded on completion of professional education and training of at least three years' duration, OJ L 019, 24 January 1989, pp. 16-23. 
sional education and training of at least three years' duration; Directive 92/51/EEC ${ }^{209}$ on a second general system for the recognition of professional education and training to supplement Directive 89/48/EEC and Directive 99/42/EEC ${ }^{210}$, establishing a mechanism for the recognition of qualifications in respect of the professional activities covered by the Directives on liberalisation and transitional measures, and supplementing the general systems for the recognition of qualifications. These two Directives were both amended by Directive 2001/19/EC ${ }^{211}$ on the general system for the recognition of professional qualifications which also amended Directives 77/452/EEC, 77/453/EEC, 78/686/EEC, 78/687/EEC, 78/1026/EEC, 78/1027/EEC, 80/154/EEC, 80/155/EEC, 85/384/EEC, 85/432/EEC, 85/433/EEC and 93/16/EEC ${ }^{212}$ concerning the professions of nurse responsible for general care, dental practitioner, veterinary surgeon, midwife, architect, pharmacist and doctor. In 2005, Directives 89/48/EEC, 92/51/EEC, 1999/42/EC, 2001/19/EC, as well as all the sectoral Directives which have been referred to above, were replaced by Directive 2005/36/EC.

Directive 89/48/EEC established a common system for the recognition of diplomas and other higher education qualifications over three years in duration. The Directive concerned regulated professions and was complemented by Directive 92/51/EEC which dealt with diplomas obtained after a shorter education period and amended by general Directive 2001/19/EC. As indicated above, which professions are regulated varies from one country to another. Access to non-regulated professions is not governed by the Directives. Access to these professions is, and will remain, free. Directive 89/48/EEC was created on the basis of Articles 40, 47(1) and 55 EC (Articles 46, 53(1) and 62 TFEU) and differed from the previous sectoral Directives because it applied to all regulated professions for which university-level training of at least three years duration was required, and which were not covered by a specific Directive, such as the Architects' Directive. It foresaw that diplomas were to be mutually recognised and that recognition was based on the principle of mutual trust, without prior coordination of the preparatory educational and training courses for the various professions in question. As a basic principle, a host Member State could not refuse entry to a regulated profession to a national of a Member State who held the qualifications necessary for exercise of that profession in another Member State. This is due to the fact that the system was based on

209 Council Directive 92/51/EEC of 18 June 1992 on a second general system for the recognition of professional education and training to supplement Directive 89/48/EEC, OJ L 209, 24 July 1992, pp. 25-45.

210 Directive 1999/42/EC of the European Parliament and of the Council of 7 June 1999 establishing a mechanism for the recognition of qualifications in respect of the professional activities covered by the Directives on liberalisation and transitional measures and supplementing the general systems for the recognition of qualifications, OJ L 201, 31 July 1999, pp. 77-93.

211 Directive 2001/19/EC of the European Parliament and of the Council of 14 May 2001 amending Council Directives 89/48/EEC and 92/51/EEC on the general system for the recognition of professional qualifications and Council Directives 77/452/EEC, 77/453/EEC, 78/686/EEC, 78/687/EEC, 78/1026/EEC, 78/1027/EEC, 80/154/EEC, 80/155/EEC, 85/384/EEC, 85/432/EEC, 85/433/EEC and 93/16/EEC concerning the professions of nurse responsible for general care, dental practitioner, veterinary surgeon, midwife, architect, pharmacist and doctor, OJ L 206, 31 July 2001, pp. 1-51

212 Council Directive 93/16/EEC of 5 April 1993 to facilitate the free movement of doctors and the mutual recognition of their diplomas, certificates and other evidence of formal qualifications, OJ L 165 of 7 July 1993. 
the premise that the programmes of study and training through which people in the various Member States prepare themselves for a particular regulated profession are, in principle, of equal validity. As long as certain minimum conditions were met, completion of any of these programmes should provide access to the same regulated profession in any Member State. A person who, in one Member State, was sufficiently qualified to practise a particular profession could, in principle, also be allowed access to the same profession in another Member State, even if the study programmes in question differed to some extent in terms of duration and/or content. Member States should accept each other's qualifications without insisting that they represent exactly the same knowledge and skills in all respects. If recognition took place, this entailed that one could practise the profession, subject to the same laws, regulations, administrative provisions and codes of practice as nationals of the host Member State. It should be noted however, that the general system did not provide for an automatic guarantee to those holding certain qualifications obtained in a Member State. Compliance with the criteria set out in Directive $89 / 48 / \mathrm{EEC}^{213}$ guaranteed only a starting point for the person wishing to practise a trade or profession, and the qualification held by that person was subject to scrutiny and control by the authorities of the host Member State. Member States were therefore still able to supervise every step in the recognition process. However, even if one did not possess the appropriate national diploma, the authorities of the host Member State should authorize the pursuance of the profession on its territory if one held the required diploma in the member state of origin. If applicants had the qualifications required in their country of origin, the host Member State could not refuse access to the occupation in question. Nevertheless, a certain length of professional experience in the relevant profession could be demanded if their training had a shorter duration than the training in the host state. ${ }^{214}$ Furthermore, if there were major differences in education and training, or in the structure of a profession, the Directive provided for compensation mechanisms such as an adaptation period or an aptitude test. ${ }^{215}$ The application of a compensatory measure could only be imposed after an individual review of an applicant's knowledge and experience demonstrated that the candidate did not have the required knowledge and/or skills. It can be stated that Directive 89/48/EEC is a codification of the Vlassopoulou judgment of the ECJ. In this regard is should be noted that it was possible that a particular profession was of a higher education level in one state while it was outside the higher education system in another state. It followed that a profession which was covered by the first general Directive (Directive 89/48/EEC) in some countries was covered by the second Directive (Directive 92/51/EEC) in other countries. In such cases, the education and training could nevertheless lead to a comparable level of professional competence and prepare individuals for the equivalent responsibilities. If that was indeed the case, the competence should be approved by the host country. If not, the host Member State could demand that a compensation measure should be imposed after having proved that there was indeed a substantial difference. Furthermore, in case the

213 The person should have pursued the equivalent of a three-year higher-education course in the Community and should have completed the necessary professional training in order to be qualified to take up the 'regulated profession' in question. Likewise criteria were specified in the other general system Directives.

214 See Article 4 (1) (a) of Directive 89/48/EEC and Article 4 (1) (a) of Directive 92/51/EEC.

215 Bull. EC 6-1988, 11. The same principle was laid down in Directive 92/51/EEC. 
profession in question was only regulated in the country in which the person wanted to work, but not in the country where he or she received the training, the competent authority could require evidence that this person had at least two year of relevant professional experience within the last ten years, and possessed evidence of certain formal qualifications which prepared the holder for the pursuit of the profession. ${ }^{216}$ If the profession comprised specific regulated activities in the host state which did not form part of the profession as regulated in the Member State where the qualification was obtained, the host state was permitted to require the completion of an adaptation period or an

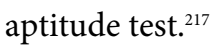

This general system permitted unrestricted professional movement for some 800 regulated professions in Europe, ranging from engineers to bakers, chiropodists, taxi drivers and geologists ${ }^{218}$, while each Member State remained competent for regulating the profession in question on its territory, and was thus free to determine the content and the level of training required for the professions concerned to operate on their territory. Nevertheless access to a regulated profession must be permitted to any European citizen who is fully qualified to practise the same profession in another Member State. In this regard it is important to note that recognition can only be granted to the 'end product', i.e. to fully qualified professionals who have already received certain professional training (if this was required to be able to practise the profession) in addition to their university diplomas. Just as with the vertical system of recognition, this horizontal system therefore applied to nationals who were fully qualified to pursue a given occupation in their own Member State and who wished to pursue the same occupation in the host Member State. As noted above, this profession had to be regulated in the host Member State and could not be covered by any other (vertical) recognition system. The horizontal system was, in principle, thus not applicable to architects who fell under the ambit of Directive 85/384/EEC. ${ }^{219}$ Garden and landscape architects, town planners and interior architects to whom Directive 85/384/EEC was not applicable, could invoke the provisions of the horizontal Directives to obtain recognition of their qualifications. In any case, under the general system, there was no list of diplomas which would automatically be recognised at European level, since a diploma was not recognized for its intrinsic value, but according to the profession to which it gave access. It follows that recognition depended on the profession to which the diploma gave access in the host Member State. Study programmes were therefore not harmonized in advance since the system was not designed for citizens wishing to study in another Member State, and seeking recognition of their diplomas for academic purposes. It follows that recognition still had to be formally requested from the competent authority in the host country. Even though the training and educational requirements were fulfilled, an individual had to specify clearly which occupation he wished to pursue in his application for professional recognition. The recognition granted constituted the right to pursue a specific regulated profession

216 See Article 3 of Directive 89/48/EEC and Article 3 of Directive 92/51/EEC.

217 See Article 4 (1) (b) of Directive 89/48/EEC and Article 4 (1) (b) of Directive 92/51/EEC.

218 ec.europa.eu/internal_market/smn/smn39/docs/specialfeature_en.pdf, last consulted, 31 December 2009.

219 It was held that it could give more protection for the observance of quality, health-care and security issues. 
under the same conditions as the holders of national diplomas, but did not encompass that the diploma was regarded as equivalent to a national diploma for other purposes. ${ }^{220}$

It can be concluded that under the horizontal recognition system, access to a regulated profession should be permitted to any European citizen who was fully qualified to practise the same profession in another Member State. Due to the lack of coordination of training requirements, automatic recognition could not take place which encompassed that if there were substantial differences between the training in the home and host Member State, an adaptation period or a test could be required. As will be discussed later in this thesis, the vertical system under Directive 85/384/EEC also entailed no harmonization of minimum training requirements. It did however foresee the automatic recognition of professional qualifications which is currently provided for by Chapter III of Title III of Directive 2005/36/EC. However, the numerous cases which were brought before the ECJ demonstrated that Member States often lost sight of the general rule of mutual recognition of diplomas and instead, turned their focus solely on adding supplemental requirements in order to recognise foreign qualifications. ${ }^{221}$ Since there will still be cases in which the education or training received does not fall within the scope of either the three general Directives or the earlier sectoral Directives, for example, if it concerns professions which are unregulated in the host Member State or in the case that a certain qualification is not included within the relevant sectoral Directive, the rulings in Heylens and Vlassopoulou on the direct effect of Article 49 TFEU in the context of mutual recognition have not lost their relevance. In such cases, the knowledge and qualifications already acquired or recognized in another Member State should always be taken into account.

Directives 89/48/EEC, 92/51/EEC, 1999/42/EC and 2001/19/EEC ${ }^{222}$ have now been replaced by Directive 2005/36/EC. Since they have never been applicable to fully fledged architects who fall under Directive 85/384/EEC, these Directives will not be further discussed. Most of these vertical Directives were also replaced by the new Directive 2005/36/EC. This Directive, also called 'the Professional Qualifications Directive', will now be discussed in detail since it is the only Directive which is nowadays applicable to the recognition of the architectural profession.

\subsubsection{Directive 2005/36/EC}

\section{Introduction}

Under the sectoral Directives, for all professions (with the exception of architects) automatic recognition was supported by the minimum co-ordination of training. With regard to this co-ordination, the necessary requirements were created by the Parliament and the Council acting in accordance with the co-decision procedure. In its explanatory

220 http://ec.europa.eu/education/policies/rec_qual/recognition/in_en.html, last consulted on 15 December 2009.

221 Schneider 1995. Recently the situation has considerably improved and it is held that, on average, $80 \%$ of demands for recognition result in a positive decision, with no need for compensatory measures. See ec.europa.eu/internal_market/smn/smn39/docs/specialfeature_en.pdf, last consulted on 15 December 2009.

222 This Directive incorporated the Vlassopoulou ruling in Directive 89/48/EEC. 
memorandum to Directive 2005/36/EC, the Commission held that since account should be taken of the increasing pace of development of society and technology in the application of procedures designed to maintain the relevance of the technical provisions underlying the general rules set out in EU law, technical updating of some requirements could be achieved more appropriately through the exercise of delegated powers. The sectoral Directives were considered to be unnecessarily inflexible and the technicalities specific to their application should appear in annexes and, when suitable, be subject to updating through the exercise of delegated powers. These are laid down in Chapter III of Title III of the new Directive. The general system applies to professions where there is no harmonisation of minimum training requirements, and which is also applicable to sectoral professions where the specialisation or the formal qualifications for architects are not listed in Annex V of Directive 2005/36/EC (Chapter I of Title III of the Directive). It is also applicable to professions which would normally benefit from automatic recognition, but where the migrant does not fulfil the requirements for automatic recognition. It applies to crafts professions whenever the conditions of professional experience are not met (Chapter II of Title III of the Directive). It was held that, due to the upcoming enlargement, recognition rules should be simplified by the abolition of the different Directives referred to above.

\section{Towards Directive $2005 / 36 / E C$}

In accordance with Articles 165 and 166 TFEU, Member States are responsible for the content of teaching and the organization of education systems and vocational training. It follows that national differences exist which produce barriers to the free movement of workers, the freedom of establishment and the freedom to provide services. In the light of the subsidiarity principle, common rules were necessary to ensure that qualifications obtained by nationals of a certain Member State would be recognized in other Member States. In this way, Directives were adopted in accordance with the proportionality principle, binding the Member States as to the result to be achieved, but leaving them the choice of the form and the most suitable methods of achieving that result. As noted above, for certain regulated professions, a vertical approach was adopted in the past with regard to the creation of legislation on the mutual recognition of professional qualifications. This enabled automatic recognition of qualifications without compensation arrangements since, for most professions ${ }^{223}$, training procedures were previously harmonised in the Member States. However, these Directives which were limited in number compared with the number of regulated professions, necessitated lengthy negotiations, were extremely complex and were incapable of being adapted to the growing number of professions. They were subsequently amended to bring their provisions into line with those of the new Directives based on the horizontal approach, before being absorbed into Directive 2005/36/EC.

The 1993 White Paper on 'Growth, Competitiveness and Employment' had already singled out the adaptation of education and vocational training systems as one of the measures necessary for developing the European economy, seeing it as a key element for

\footnotetext{
223 However, this was not the case for architects.
} 
the creation of a genuine European area and a market for qualifications and skills. The 1999 Bologna declaration and the Council of Ministers of Education in Prague of 18 and 19 May 2001 underlined the European commitment to introducing policies designed to facilitate access to education and continuous high quality training to improve the transparency of qualifications and diplomas in order to achieve sustainable professional mobility.

Following the European Council of Lisbon on 23 and 24 March 2000, which set a very ambitious goal for the development of the Union, with important economic, social and environmental implications, the Commission adopted a Communication on an Internal Market Strategy for Services ${ }^{224}$ which aimed in particular at making the free provision of services within the Community as simple as within an individual Member State. The overall objective for the advancement of the Union should be "to become the most competitive and dynamic knowledge based society in the world by the year 2010". In terms of this political and competition policy goal, all EU countries share an interest. By modernising the services sector where needed, they hoped to generate more growth and employment in the economy. ${ }^{225}$

After the Commission achieved a considerable consolidation of the 35 transitional Directives concerning crafts and trades professions through the third General System Directive (Directive 1999/42/EC - referred to above), the subsequent adoption of Directive 2001/19/EC 226 which was created in the light of the SLIM (Simpler Legislation for the Internal Market) strategy, further simplified the legal and procedural regime for professional recognition. However, even then there continued to exist some twelve main Directives covering seven professions (within which was included the Architects' Directive) plus three 'horizontal' Directives. As noted above, the piecemeal fashion in which the rules on professional recognition evolved, and the detailed variations in different parts of the legislation, provided the system with many difficulties and criticisms.

After the Communication from the Commission entitled New European Labour Markets, Open to All, with Access to All' ${ }^{227}$, the European Council of Stockholm on 23 and 24 March 2001 entrusted the Commission the task of presenting specific proposals for a more uniform, transparent and flexible regime for the recognition of qualifications. Furthermore, the Commission had to take action to ensure that citizens could get comprehensive information and advice, specific to their individual interest and rights. This had to be realized before the 2002 Spring European Council would begin.

In May 2001, at the time of the adoption of Directive 2001/19/EC on professional recognition, the European Parliament, the Council and the Commission agreed on the importance of consolidated versions, easily accessible to everyone, of the legal texts applicable in the field of the mutual recognition of professional qualifications. The Commission intended to integrate the sectoral Directives into a consolidated framework and further planned to examine the possibility of consolidating the Directives into the general system. The numerous Directives on professional recognition which existed

224 COM (2000) 888.

225 Comments and concluding remarks of former Commissioner Monti at the Conference on Professional Regulation, European Commission Centre Borschette, Brussels, 28 October 2003.

226 Directive 2001/19/EC [2001] OJ L 206/1.

227 COM (2001) 116. 
contained numerous parallel provisions and variations which made them very difficult to understand or to apply correctly. A single Directive would make the Community system easier to manage and would be clearer, quicker, friendlier and more transparent for users. Better regulations and clearer governance would help to prepare for enlargement.

Accordingly, in its 2002 Action Plan for Skills and Mobility ${ }^{228}$, the Commission, motivated by the Lisbon strategy to promote a more dynamic and competitive economy in Europe, held that Community Institutions and Member States should facilitate employment opportunities. The Communication on an Internal Market Strategy for Services which was adopted at the end of 2000, drew attention to the importance of services in the general economy, the new opportunities and practices developing out of new information and communications technologies, and the need to facilitate conditions of cross-frontier service provision Community-wide. To ensure that employment vacancies would be filled by qualified applicants and that there would be a regular supply of qualified service suppliers to meet market demand, Directive 2005/36/EC was proposed $^{229}$ by the Commission and submitted to the Parliament, pursuant to Article 294 TFEU (Article 251 EC) and Articles 46 and 53 TFEU (Articles 40 and 47 EC), in March 2002. In its explanatory memorandum, the Commission stipulated that the free movement of qualified professionals makes a particular contribution to the knowledge-based society and that it had particular importance in cases of specific shortages of qualified personnel. This proposal aimed to clarify and simplify the existing rules in order to facilitate the free movement of qualified persons between the Member States, particularly in view of an enlarged European Union..$^{230}$ The proposal took account of the viewpoints of a myriad of interested parties including professionals and professional associations, and maintained the safeguards which were offered by the various existing recognition systems while strengthening them with a number of new rules. In this way, a more flexible and automatic procedure was introduced, based on common platforms established by professional associations at the European level, stemming from increased cooperation between public and private sectors. Furthermore, the proposal involved a simplification of the management and an updating of the rules, particularly in view of technological progress. In addition, it provided for co-operation amongst national administrations and amongst national administrations and the Commission. Citizens could be informed and advised more easily in the event that they encountered difficulties with regard to the recognition of their professional qualifications. ${ }^{231}$

The Economic and Social Committee was consulted by the Council on the basis of Article 304 TFEU (Article 262 EC). The section for Employment, Social Affairs and Citizenship was responsible for preparing the Committee's work on the subject, expressed its opinion on 4 September 2002. Not long thereafter, on 18 and 19 September, the Economic and Social Committee, representing organized civil society, including the

228 COM (2002) 72.

229 COM (2002) 119 - 2002/0061 (COD), OJ C. 181 E, 30.7.2002, p. 183.

$230 \mathrm{http}: / /$ europa.eu.int/rapid/pressReleasesAction.do?reference=IP/02/393\&format=HTML\&aged=1\&language $=\mathrm{EN} \&$ guiLanguage $=\mathrm{en}$, last consulted 2 January 2008.

$231 \mathrm{http}: / /$ www.europarl.eu.int/oeil/resume.jsp?id=220062\&eventId=53758\&backToCaller=NO\&language=en, last consulted 23 December 2009. 
social partners and thereby also professionals and consumers, adopted its opinion during its $393^{\text {rd }}$ Plenary Session. The Commission's proposal was warmly welcomed since education and training, the development of the human resources and the development of the labour markets and their functioning, were considered to be the most important fields of action in order to achieve the Lisbon objective.

On 11 February 2004, the Commission welcomed the European Parliament's opinion at first reading. An amended proposal was published in April and in December of that same year, and the Commission supported the political agreement of the Council which retained the Commission's proposal as amended by the new proposal. ${ }^{232}$ On $28^{\text {th }}$ April 2005 the 'Recommendation for Second Reading on the Council's common position for adopting a Directive of the European Parliament and of the Council on the recognition of professional qualifications' was delivered after a number of informal contacts between the Council, the European Parliament and the Commission, in accordance with the provisions of Article 251(2) EC and the joint declaration on practical arrangements for the codecision procedure. It should be underlined that, throughout this whole process, the Commission did not advocate complete deregulation. Instead, careful re-regulation was called for.

On 11 May 2005, the European Parliament voted in favour of the new Directive. Not long after, on 17 May 2005, it was followed by the publication of the Outcome of the European Parliament's second reading, which took place in Strasbourg from 9 to 12 May. It contained some minor adjustments to the initial proposal, but had the same spirit.

On 7 September 2005, Directive 2005/36/EC was finally adopted. ${ }^{233}$ It entered into force on 20 October 2005. Member States had two years to implement the Directive into national law. This period ended on 20 October 2007.

\section{Content of Directive $2005 / 36 / E C$}

Directive 2005/36/EC replaced fifteen existing Directives in the field of the recognition of professional qualifications: Council Directive 89/48/EEC, 92/51/EEC, as well as Directive 1999/42/EEC of the European Parliament and of the Council on the general system for the recognition of professional qualifications, and Council Directives 77/452/EEC, 77/453/EEC, 78/686/EEC, 78/687/EEC, 78/1026/EEC, 78/1027/EEC, 80/154/EEC, 80/155/EEC, 85/384/EEC, 85/432/EEC, 85/433/EEC and 93/16/EEC concerning the professions of nurses responsible for general care, dental practitioners, veterinary surgeons, midwives, architects, pharmacists and doctors, by combining them in a single text. Therefore, the proposal constituted the first comprehensive modernization of the Community system since it was conceived forty years earlier. ${ }^{234}$

232 The importance of freeing up all markets and removing unnecessary regulation to promote greater competition was underlined by the Kok Report in November 2004: See: Facing the Challenge: The Lisbon Strategy for growth and employment, Report from the High Level Group chaired by Wim Kok, November 2004.

233 Directive 2005/36/EC of the European Parliament and of the Council of 7 September 2005 on the recognition of professional qualifications.

234 The provisions of the Directive do not apply to those regulated professions already covered by other instruments of Community law. The specific Directives on the provision of services and establishment of lawyers, Directives 77/249/EEC and 98/5/EC, are not covered by this exercise, since they concern the recognition, not of professional qualifications, but of the authorisation to practice. Recognition of lawyer's 
Since the objectives of this Directive, namely the rationalization, simplification and improvement of the rules for the recognition of professional qualifications, cannot be sufficiently achieved by the Member States and can therefore be better achieved at EU level, the Directive was adopted in accordance with the principle of subsidiarity as set out in Article 5(3) TEU (Article 5(2) EC). Nevertheless, in its first reading, the European Parliament stated that the system for the recognition of professional qualifications is not intended either to modify the professional rules, including ethical rules, that apply to anyone pursuing a profession in a Member State, or to interfere with the Member States' legitimate interests in preventing any of their citizens from evading the applicable national legal provisions relating to the professions. It follows that, in accordance with the principle of proportionality, as set out in Article 5(4) TEU, the Directive does not go beyond what is necessary in order to achieve those objectives (recital 40).

The legal bases of the Directive are Articles 46 TFEU (workers), 53 TFEU (establishment) and 62 TFEU (services). It is subdivided into six Titles, preceded by an extensive and important preamble. Title I lays down the General Provisions, including the relevant definitions and scope of the Directive. Title II lays down the provisions relating to the Free Provisions of Services, whilst Title III relates to Freedom of Establishment. Under this heading a "general system for the recognition of evidence of training", is established (Chapter I). This relates to all professions which are not covered by Chapters II and III of the Directive. Chapter II contains a system on automatic recognition of qualifications attested by professional experience in certain industrial, craft and commercial activities, while Chapter III contains a system of automatic recognition of qualifications for the professions of doctor, nurse, dentist, veterinary surgeon, midwife, pharmacist and architect. Hereunder the most relevant provisions will be discussed.

a. General provisions (Title I)

As held by Article 1, the Directive establishes rules according to which a Member State that makes access to or pursuit of a regulated profession in its territory contingent upon possession of specific professional qualifications -i.e. qualifications attested by evidence of formal qualifications, an attestation of competence- shall recognize professional qualifications obtained in one or more other Member States, and which allow the holder of the said qualification to pursue the same profession there for access to and pursuit of that profession. As noted before, a regulated profession is a professional activity or group of professional activities, access to which, the pursuit of which, or one of the modes of pursuit of which, is subject, directly or indirectly, by virtue of legislative, regulatory or administrative provisions to the possession of specific professional qualifications. In particular, the use of a professional title limited by legislative, regulatory or administrative provisions to holders of a given professional qualification shall constitute a mode of pursuit (Article 3(1)(a)). Although the Directive focuses on regulated professions, it will de facto encompass both regulated and non-regulated professions, and professions based on both shorter and longer periods of education, particularly because

qualifications was governed by Directive 89/48/EEC, and is thus covered by the new Directive 2005/36/EC (see recital 42). 
a lot of professions are regulated in some EU countries and not regulated in other Member States.

Article 2 of the Directive defines its scope. According to Article 2(1), the Directive shall apply to all nationals of a Member State wishing to pursue a regulated profession in a Member State, including those belonging to the liberal professions, other than that in which they obtained their professional qualifications, on either a self-employed or employed $^{235}$ basis. The liberal professions are, as a professional group, characterized by the requirement to have a particular professional qualification. As held by the Commission in its written observations in Urbing-Adam ${ }^{236}$, the liberal professions (mentioned in Annex $\mathrm{F}(2)$ of the Sixth Directive ${ }^{237}$ ) fulfil activities which, inter alia, are of a marked intellectual character, require a high-level qualification and are usually subject to clear and strict professional regulation. In the exercise of such an activity, the personal element is of special importance and such exercise always involves a large measure of independence in the accomplishment of the professional activities. As held by recital 43, liberal professions are those practised on the basis of relevant professional qualifications in a personal, responsible and professionally independent capacity by those providing intellectual and conceptual services in the interest of the client and the public. The exercise of the profession might be subject in the Member States, in conformity with the Treaty, to specific legal constraints, based on national legislation and on the statutory provisions laid down autonomously, within that framework, by the respective professional representative bodies, aimed at safeguarding and developing their professionalism and quality of service and the confidentiality of relations with the client. Even though liberal professions are occupations requiring special training in the liberal arts or sciences, such as lawyers, notaries, engineers, architects, doctors and accountants, it is not possible to establish an exhaustive list; different professions in different countries fall within this special category of service providers, ranging from journalists in Italy to oral hygienists in Finland. ${ }^{238}$ This does not stand in the way of architects practising their profession as an employee (worker). As stated before, the Directive is also based on Article 40 EC (Article 46 TFEU) dealing with the free movement of workers.

Since the recognition of a professional qualification enables beneficiaries to gain access in the host Member State to the regulated profession in which they are qualified, and to practise it under the same conditions as nationals of that state (Article 4(1)), this guarantee is without prejudice to compliance by the migrant professional with any nondiscriminatory conditions of pursuit which might be laid down by the host state, provided that these are objectively justified and proportionate (recital 3). It follows that a

235 See Article 29 of Directive 85/384/EEC.

236 Case C-267/99 Christiane Urbing-Adam c. Administration de l'enregistrement et des domaines [2001] ECR I-7467, paragraph 39

237 Council Directive 77/388/EC of 17 May 1977 on the harmonisation of the laws of the Member States relating to turnover taxes - Common system of value added tax: uniform basis of assessment, OJ $1977 \mathrm{~L}$ 145 , p. 1 .

238 Commission Services Working Document, Regulation in Liberal Professions and its Effects: Invitation to comment, Brussels, 27 March 2003, p. 3. 
migrant professional may have to comply with certain conditions in the host state which would not be imposed on him in his state of origin. However, the extra requirements to be fulfilled by these migrant professionals may not differ from the criteria to which the host country nationals are subjected. In any case, the profession which the applicant wishes to pursue in the host Member State for the purposes of this Directive, is the same as that for which he is qualified in his home Member State if the activities covered are comparable (Article 4(2)).

Since discrimination based on residence is not allowed, recital 12 makes sure that a citizen who wishes to use a professional qualification obtained in one Member State in order to pursue the profession in a Member State where he does not fulfil the requirements imposed at national level as a condition of pursuing the profession in question, will be able to do so only if recognition is not simply a means of evading more stringent national rules. In practice, such a person will have to prove that, in the State in which he obtained his professional qualification, he genuinely extended his own professional training. Prohibition of this practice, known as "zigzagging", is consistent with the Commission's interpretation of existing Directives. It follows that the Directive does not concern the recognition by Member States of recognition decisions adopted by other Member States pursuant to this Directive. In other words, if Member State X awarded professional qualification $\mathrm{Z}$ on its territory through the mere recognition and/or the acknowledgement of the qualifications awarded to applicants in member State Y (qualifications which the State Y does not consider to be sufficient to pursue the profession on its territory), the abovementioned applicant may not apply for recognition of his professional qualification $\mathrm{Z}$ in Member State $\mathrm{Y}$ if he cannot prove that he has really improved his training through the acquisition of further professional training and/or experience in Member State X. ${ }^{239}$ Consequently, individuals holding professional qualifications which have been recognized pursuant to this Directive may not use such recognition to obtain in their Member State of origin rights which are different from those conferred by the professional qualifications obtained in that Member State, unless they provide evidence that they have obtained additional professional qualifications in the host Member State (see also recital 12). Consequently, the Directive does not concern itself with recognition by Member States of recognition decisions adopted by other Member States.

It is important to note that where, for a given regulated profession, other specific arrangements directly related to the recognition of professional qualifications are established in a separate instrument of Community law, the corresponding provisions of this Directive shall not apply (Article 2(3)). If more specific legislation is applicable, the Professional Qualifications Directive should thus not be applied.

Finally, mention should be made of the fact that even though the Directive concerns the recognition by Member States of professional qualifications acquired in other Member

\footnotetext{
239 Explanation of the European Parliament in its recommendation for Second Reading on the Council common position for adopting a Directive of the European Parliament and of the Council on the recognition of professional qualifications ( 13781/2/2004 - C6-0008/2005 - 2002/0061(COD)).
} 
States, it does not create an obstacle to the possibility of Member States recognizing, in accordance with their rules, the professional qualifications acquired outside the territory of the European Union by third-country nationals (recital 10). Article 2(2) foresees that each Member State may permit Member State nationals in possession of evidence of professional qualifications not obtained in a Member State, to pursue a regulated profession on its territory, in accordance with its rules. Member States are thus not obliged to let such professionals carry out activities in their territory. In this regard, Article 6 of Directive 85/384/EEC ${ }^{240}$ stated that Member States shall examine diplomas, certificates and other evidence of formal qualifications in the field covered by this Directive that have been obtained by the holder outside the European Union in cases where those diplomas, certificates and other evidence of formal qualifications have been recognised in a Member State, as well as of training undergone and/or professional experience gained in a Member State. Council Recommendation 85/386/EEC of 10 June 1985 already urged the Member States to take into account the special position of nationals of Member States who have studied in a third country and who hold a diploma in architecture recognized under the legislation of a Member State. The Member State has to give its decision within three months of the date on which the applicant submits his application together with full supporting documentation. However, since this document was merely a recommendation, it was not legally binding.

Furthermore, recognition by one Member State on the basis of national regulations regarding educational qualifications acquired in a third country, does not entitle the holder of those qualifications to perform the professional activity in question in another Member State. Only if the holder has three years' professional experience in the profession concerned on the territory of the Member State which recognized his formal qualifications, do these qualifications have to be recognised by other Member States as well (Article 3(3)). This provision still deals with Union citizens however. With regard to the recognition of qualifications held by third country-nationals, Member States have (almost) full discretion. ${ }^{241}$

\section{b. Free provision of services (Title II)}

Title II of the Directive exclusively deals with the freedom to provide services. As held by Article 5(1), Member States are not allowed to restrict, for any reason relating to professional qualifications, the free provision of services in another Member State if the service provider is legally established in a Member State for the purpose of pursuing the same profession there, and where the service provider moves, if he has pursued that profession in the Member State of establishment for at least two years during the 10 years preceding the provision of services when the profession is not regulated in that Member State. The condition requiring two years' pursuit, shall thus not apply when

240 After amendment by Directive 2001/19/EC.

${ }^{241}$ Only in very specific circumstances can third country nationals rely on the Directive. For example, when married to a Union citizen, the equal treatment principle laid down in Article 24 of Directive 2004/38/EC is important. In the case of long term residence, these professionals can also rely on Directive 2003/109/EC while the rules laid down in GATS can also be beneficial for third country nationals. This will not be further discussed within this thesis. 
either the profession or the education and training leading to the profession is regulated. In the event that the profession is not regulated, and the migrant has not practised the profession for two years in his Member State of origin, Title II is not applicable. In that case, the Treaty on the Functioning of the European Union, as interpreted by the ECJ, will apply.

Moreover, the principle of free provision of services will only apply where the service provider moves to the territory of the host Member State to pursue a certain profession on a temporary and occasional basis. The temporary and occasional nature of the provision of services shall be assessed case by case, in particular in relation to its duration, its frequency, its regularity and its continuity. ${ }^{242}$ After movement, the service provider shall be subject to professional rules ${ }^{243}$ which are directly linked to his professional qualifications, as well as to disciplinary provisions which are applicable in the host Member State to professionals who pursue the same profession in that State (Article 5(3) and recital 8).

Even though the Directive makes the recognition of migrant professionals dependent on the possession of specific professional qualifications, the Member State shall exempt service providers established in another Member State from the requirements which it places on professionals established in its territory relating to authorisation by, registration with, or membership of, a professional organisation or body and registration with a public social security body for the purpose of settling accounts with an insurer relating to activities pursued for the benefit of insured persons (Article 6). ${ }^{244}$ Article 7(1) and (2) states which information the host Member State is allowed to require when the service provider moves for the first time from one Member State to another in order to provide services. It is normal that, in this respect, Member States are likely to seek evidence of professional qualifications before they allow a migrant to provide services on their territory. Member States can, for example, also require information about insurance coverage or other means of personal or collective protection with regard to professional liability (Article 7(1)). Declarations in this regard have to be renewed once a year if the service provider intends to provide temporary or occasional services. It should be noted that Article 7(1) contains an obligation to provide information, but not one to buy insurance. The purchase of insurance is dealt with by the Services Directive 2006/123/EC provided that the regulated profession under consideration falls under its scope. The relevant provisions of this Directive will be discussed in detail later. In case it is not applicable, the EC Treaty applies to matters which fall under its scope. In any case, if the documents mentioned in Directive 2005/36/EC are not produced, but .the applicant

242 These criteria are identified by the ECJ in earlier case law. See http://europa.eu/scadplus/leg/en/cha/c11065.htm, last consulted 2 January 2008. Recital 5 holds that in view of the different systems established for the crossborder provision of services on a temporary and occasional basis on the one hand, and for establishment on the other, the criteria for distinguishing between these two concepts in the event of the movement of the service provider to the territory of the host Member State should be clarified.

243 These can have a professional, statutory or administrative nature such as rules concerning the definition of the profession, the use of titles, and serious professional malpractice. These rules are directly and specifically linked to consumer protection and safety. See also recital 8.

244 See Article 22 of Directive 85/384/EEC. 
does not fail to fulfil any substantial condition (such as legal establishment, professional experience), a prohibition to practise for failing to respect formalities would go beyond what could be considered a proportionate sanction.

With regard to the first provision of services on the territory of another Member State, or in case of a material change in the situation substantiated by the documents, Member States may require that the declaration be accompanied by certain other documents, such as a proof of nationality of the service provider, evidence of professional qualifications, an attestation that he is legally established in the Member State for the purpose of pursuing the activities concerned, and that he is not prohibited from practising, even temporarily, at the moment of delivering the attestation. In the event that the profession is not regulated, proof can be demanded evidencing that the service provider has pursued the activity concerned for at least two years during the previous ten years (Article 7(2)). In any case the declarations which can be asked by the host State should not lead to a disproportionate burden on service providers, nor hinder or render less attractive the exercise of the freedom to provide services (recital 7).

In principle, the service shall be provided under the professional title of the Member State of establishment (Article 7(3)). However, by way of exception, the service of a regulated professional activity shall be provided under the professional title of the host Member State for cases referred to in Chapter III of Title III. As will be explained hereunder, in general, architects belong to this category. For professions that have public health or safety implications and which do not fall under the scope of Chapter III of Title III, the competent authorities ${ }^{245}$ may check the professional qualifications of the service provider prior to the first provision of services (Article 7(4)). If these qualifications are verified, the service shall be provided under the professional title of the host Member State.

As held by Article 8, the competent authorities of the host State may always ask the authorities of the Member State of origin to provide any information relevant to the legality of the service provider's establishment and his good conduct, as well as the absence of any disciplinary or criminal sanctions of a professional nature. Article 9 aims at providing the recipients of the services with additional information about the service provider when that service provider is not entitled to use the relevant professional title of the host Member State. It is therefore only applicable when the professional uses the professional title of the Member State of establishment and relates to matters concerning registration, authorization, professional title and insurance cover with regard to professional liability.

The aim of Articles 5 to 9 is to set out clear rules making temporary and occasional cross-border service provisions less onerous for the service provider than establishment in the host Member State, taking into account the existing case-law and the need to

245 As held by Article 3 (1) (d), the concept 'competent authority' refers to any authority or body empowered by a Member State specifically to issue or receive training diplomas and other documents or information, and to receive the applications, and take the decisions, referred to in this Directive. 
strike the appropriate balance between mobility and consumer protection..$^{246}$ The Directive nevertheless reserves for Member States certain supervisory rights (such as prior notifications, annual renewal of certain documents, delivery of documents supporting the initial declaration such as proof of nationality, legal establishment and qualifications, automatic temporary registration, pro forma admission to a professional association or body and respect of codes of conduct, prior checks in case of professions with public health or safety implications, ... ) over services undertaken on their territory, thus guaranteeing a balance between the free movement of services and the protection of the consumer. ${ }^{247}$ As underlined by the European Parliament, "masked establishment", which exists where provisions relating to the free provision of services allow a migrant to avoid the provisions relating to the right of establishment in the country where he practises, in fact by enabling him to benefit, without any reason, from more advantageous regulations than those laid down for national citizens, has to be avoided.

It can thus be concluded that the regime in place for the ensemble of regulated professions, frees service providers from being subject to a procedure for recognizing their qualifications.

Furthermore, as held by Claessens ${ }^{248}$, the rules laid down in Directive 2005/36/EC are clearly an improvement on the protection of those professionals who provide services without being fully qualified in Member States that allow such activities due to a lesser degree of regulation. Before the adoption of Directive 2005/36/EC the situation of these professionals was uncertain and only the 'capstone' rules could be applied to persons in this situation. This meant that any hindrance to the free movement of services was, in principle, prohibited, unless such a prohibition could be objectively justified. In the new atmosphere, the Directive expressly forbids the restriction of the free provision of services on the grounds of qualifications. The Directive offers no possibility for exemption. Whereas, under Article 49 EC and the Gebhard system, an objective justification for such a restriction was possible, at least in theory, no exemptions to the rule are allowed under the Directive, at least not with regard to restrictions on professional qualifications. Directive 2005/36/EC lays down a solid foundation for the possibility of providing services in those Member States where such activities belong to the profession of architect. With regard to other restrictions (i.e. restrictions other than those related to professional qualifications such as restrictions dealing with insurance policies or consumer protection), Directive 2005/36/EC is of no help since it only covers the first type of restriction. It follows that other restrictions on the provision of services by persons not holding the required qualifications must be addressed under the general system of Article 56 TFEU, and the objective justification test laid down in Gebhard. Directive 2006/123/EC, which will be discussed in detail in paragraph 3.4, also deals with such issues (see for example Articles 16 and 17 of this Directive).

\footnotetext{
${ }^{246}$ Report from the Presidency to the Permanent Representative Committee (Part 1)/Council (Competitiveness), Interinstitutional File: 2002/0061 (COD).

247 http://ec.europa.eu/internal_market/smn/smn39/docs/specialfeature_en.pdf, last consulted 23 December 2009.

248 Claessens 2008, pp. 127-128.
} 
c. Freedom of establishment (Title III)

With respect to establishment, the Directive comprises the three existing systems of recognition:

\section{$\rightarrow$ System of automatic recognition of qualifications for the professions of doctor, nurse, dentist, veterinary surgeon, midwife, pharmacist and architect (Chapter III)}

Chapter III contains the system of automatic recognition for a closed group of professions, including the architectural profession.

Section 1 contains some general provisions and the basic principle of automatic recognition in Article 21(1). This Article stipulates that each Member State shall automatically recognize evidence of formal qualifications such as that of a doctor giving access to the professional activities of a doctor with basic training and a specialized doctor, as a nurse responsible for general care, as a dental practitioner, as a specialized dental practitioner, as a veterinary surgeon, as a pharmacist and as an architect, as listed in annex V, points 5.1.1., 5.1.2., 5.2.2., 5.3.2., 5.3.3., 5.4.2., 5.6.2. and 5.7.1 respectively, which satisfies the minimum training conditions referred to in Articles 24, 25, 31, 34, 35, 38, 44 and 46 respectively, and shall, for the purposes of access to, and pursuit of, these professional activities, give such evidence the same effect on its territory as the evidence of formal qualifications which it itself issues. ${ }^{249}$

Such evidence of formal qualifications must be issued by the competent bodies in the Member States and accompanied, where appropriate, by the certificates listed in the annex $\mathrm{V}$.

Section 8 of Title III deals with the profession of architect in particular. As held by Article 48(1), the professional activities of an architect are the activities regularly carried out under the professional title of 'architect'. This Article defines the material scope of the Directive and can be compared to Article 1 of Directive 85/384/EEC. ${ }^{250}$ It follows that the architects in the possession of qualifications listed in annex $\mathrm{V}$ point 5.7.1 which satisfy the conditions enumerated in Article 46, should be recognized automatically in another EU Member State.

249 With regard to architects this provision can be compared to Article 2 of Directive 85/384/EEC.

${ }^{250}$ Article 1 of Directive 85/384/EEC referred to 'activities in the field of architecture which are usually pursued under the professional title of architect'. The concept of 'architecture' is opposed to the concept of 'architect' because, in a number of Member States, architects are not the only individuals authorized to work in this field. As held before, in most Member States, activities in the field of architecture are pursued, in law or in fact, by persons who hold the title of architect, whether alone or together with another title, without those persons having a monopoly in pursuing those activities, save where there are laws to the contrary. Nevertheless, the aforementioned activities, or some of them, may also be pursued by members of other professions, in particular by engineers who have received special training in construction engineering or building (see recital 28 of the preamble to Directive 2005/36/EC). Examples can be found in the list of diplomas mentioned in Article 11 which should be recognized by other Member States in accordance with Article 10. The fact that not only architects can work in the field combined with the market differences in regulations between Member States, explains the use of the term 'usually' in Article 1. The content of this Article is thus solely intended to indicate the scope of this Directive, without claiming to give a legal definition of activities in the field of architecture. 
As held by Article 21(3), the acquired rights referred to in Articles 23, and for architects more particularly laid down in Article 23(3), (4), (5) and 49, are not affected by this. According to these Articles, Member States are obliged to accept the evidence of formal qualifications as an architect listed in annex VI, awarded by the other Member States, and attesting a course of training which also began no later than the reference academic year referred to in that annex, even if they do not satisfy the minimum training requirements laid down in Article 46. ${ }^{251}$ The evidence of their formal qualifications shall, for the purposes of access to, and pursuit of, the professional activities of an architect, be given the same effect on the territory of the Member States as the evidence of formal qualifications as an architect which it itself issues. Under these circumstances, certificates issued by the competent authorities of the Federal Republic of Germany attesting that evidence of formal qualifications issued on or after 8 May 1945 by the competent authorities of the German Democratic Republic is equivalent to such evidence listed in that annex, shall be recognised. ${ }^{252}$ Moreover, certificates issued to nationals of Member States by the Member States which joined the Union as of 1 May 2004 and issued certificates from that moment onwards, and by Member States that became part of the Union as of 1 January 1995 and issued certificates afterwards, also have to be recognized by every Member State as long as they certify that the individual is allowed to use the professional title of architect, and that the individual has been effectively engaged in the activities in question for at least three consecutive years during the five years preceding the award of the certificate. For all other Member States, the reference date is 5 August 1987 (i.e. the date on which the Architects' Directive should have been implemented at the latest). This exception has been laid down in the Directive since Member States that joined the Union as of a certain date were not obliged prior to that date to issue qualifications satisfying all the requirements of the Directive, making it almost impossible for their nationals to move after membership. It follows that an Estonian architect who does not possess qualifications which meet the minimum requirements of the Directive, but is in the possession of a certificate indicating that he was authorised no later than 1 May 2004 to use the professional title in Estonia, and that he has worked there for at least three years during the five years preceding the award of the certificate, should also be recognized by the other Member States. Furthermore, if a certificate was issued to an Estonian national by the Soviet Union - thus before Estonia became independent - Article 23 indicates that such a certificate should be recognised by the EU Member States if Estonia has attested the same legal validity to it within its territory as the evidence of formal qualifications specified in annex VI. The Directive

251 See Article 10, 11 and 12 of Directive 85/384/EEC. In this regard reference should be made to Article 48 (2) of Directive 2005/36/EC as well, which holds that nationals of a Member State who are authorized to use the title of architect pursuant to a law which gives the competent authority of a Member State the power to award that title to Member States nationals who have especially distinguished themselves by the quality of their work in the field of architecture shall be deemed to satisfy the conditions required for the pursuit of the activities of an architect, under the professional title of 'architect' (Article 48 (2)). The architectural nature of the activities of the persons concerned shall be attested by a certificate awarded by their home Member State. See also Article 5 Directive 85/384/EEC.

252 See Article 14 of Directive 85/384/EEC. 
contains a likewise system for the Czech Republic, Slovakia, Latvia, Lithuania and Slovenia. $^{253}$

I will now turn to the requirements that need to be fulfilled so that the automatic recognition of qualifications can take place. As noted before, architects in the possession of qualifications listed in annex $\mathrm{V}$ point 5.7.1 which satisfy the conditions enumerated in Article 46, should be recognized automatically in another EU Member State. As indicated by Article 21(5), evidence of formal qualifications as an architect referred to in annex $\mathrm{V}$, point 5.7.1, which are subject to automatic recognition, proves the completion of a course of training which began not earlier than during the academic reference year referred to in that annex. This is generally the academic year after the Directive should have been implemented, but can also be a later year if certain qualifications were only granted at a later date, for example because a certain form of education did not yet exist in the particular Member State. As indicated above, evidence of earlier qualifications can fall under Article 49 dealing with acquired rights. ${ }^{254}$

According to Article 46, training as an architect shall comprise a total of at least four years of full-time study or six years of study, at least three years of which is on a fulltime basis, at a university or comparable teaching institution. The training must lead to successful completion of a university-level examination. ${ }^{255}$ That training, which must be of university level, and of which architecture is the principal component, must maintain a balance between theoretical and practical aspects of architectural training and must guarantee the acquisition of the knowledge and skills enumerated in Article 46(1) a-k.256

253 See Article 23(3), (4) and (5) of Directive 2005/36/EC.

254 It should be noted that Directive 85/384/EEC only contained a list of national qualifications which should be recognized on the basis of Article 10, which dealt with established rights. The Directive did not foresee a list of diplomas obtained by nationals after the notification of the Directive which should automatically be recognized. For the latter category the general system laid down in Articles 2, 3 and 4 of the Directive should be used. In Dreesen, the Court of Justice of the European Union has drawn a clear distinction between the 'established rights' arrangements (Chapter III of Directive 85/384/EEC) and the common arrangements (Chapter II of Directive 85/384/EEC) in respect of qualifications awarded after the aforementioned dates. As held by the Court, the open arrangements enshrined in Articles 7 to 9 of the Directive contrast with the closed, special and exceptional arrangements by virtue of established rights. The Articles setting out the latter arrangements must therefore be interpreted strictly and must rule out any broader interpretation or any interpretation by analogy. The arrangements in question are special and exceptional, and qualifications can be added to the list only in genuinely extraordinary circumstances, as when countries join the Union. The European Parliament commented however, that other arrangements should still be able to be reviewed as, in their present form they could, in the long-term in particular, give rise to clearly discriminatory situations. Otherwise, recourse to the procedure laid down in Article 7 would appear appropriate: See Report on the Commission's report 'Review on the basis of experience, of Council Directive 85/384/EEC of 10 June 1985 pursuant to Article 30 thereof', explanatory statement, paragraph 4.

255 See Article 4 Directive 85/384/EEC.

256 These requirements can equally be found in the UNESCO/UIA Charter for Architectural Education, which was created on the initiative of UNESCO and the International Union of Architects (UIA). The UIA was founded in Lausanne on $28^{\text {th }}$ June, 1948 , to unite the architects of the world without regard to nationality, race, religion, or architectural doctrine, and to federate their national organisations. From the 27 delegations present at the founding assembly, the UIA has grown to encompass the key professional organisations of architects in 124 countries and territories, and now represents, through these organisations, more than 1,300,000 architects worldwide. Over time, the UIA has become an accomplished non- 
Public Regulation of Architects at European Union Level

Article 46 gives thus a description of what is expected on a European level of persons holding formal qualifications in architecture and consequently contains very important and indispensable criteria.

These $\operatorname{are}^{257}$ :

(a) ability to create architectural designs that satisfy both aesthetic and technical requirements

(b) adequate knowledge of the history and theories of architecture and the related arts, technologies and human sciences

(c) knowledge of the fine arts as an influence on the quality of architectural design

(d) adequate knowledge of urban design, planning and the skills involved in the planning process

(e) understanding of the relationship between people and building, and between buildings and their environment, and of the need to relate buildings and the spaces between them to human needs and scale

(f) understanding of the profession of architecture and the role of the architect in society, in particular in preparing briefs that take account of social factors

(g) understanding of the methods of investigation and preparation of the brief for a design project

(h) understanding of the structural design, constructional and engineering problems associated with building design

(i) adequate knowledge of physical problems and technologies and of the function of buildings so as to provide them with internal conditions of comfort and protection against the climate

(j) the necessary design skills to meet building users' requirements within the constraints imposed by cost factors and building regulations

(k) adequate knowledge of the industries, organizations, regulations and procedures involved translating design concepts into building and integrating plans into overall planning.

Article 46 sets thus out the conditions which have to be met by courses leading to qualifications recognized by the Member States. These conditions are fairly general and merely set out the main qualitative principles which courses must meet in order to qualify for recognition under the Directive, such as an ability to create architectural designs that satisfy both aesthetic and technical requirements, a knowledge of the fine arts as an influence on the quality of architectural design and the necessary design skills to meet building users' requirements within the constraints imposed by cost factors and building regulations. With the exception of the professions of doctor and architect, the Directive provides a minimum programme of courses to follow, which leaves room for the Member States to draw up more detailed study programmes ${ }^{258}$. As stated above, it took

governmental organisation, an incomparable professional network of architects that exists in all continents. See http://www.uia-architectes.org/texte/england/Menu-1/0-pourquoi-new.htm, last consulted 11 October 2009.

257 See Article 3 Directive 85/384/EEC. As held by Article 46 (2) of Directive 2005/36/EC, the Commission may adapt the knowledge and skills listed in paragraph 1 to scientific and technical progress.

258 See in this regard recital 19. 
17 years before the Architects' Directive could enter into force while it only dealt with the mutual recognition of qualifications and did not contain harmonized study programmes. It is not difficult to imagine why this was not changed when Directive 2005/36/EC was set up. ${ }^{259}$ It follows that the present Directive does not contain stipulations about how the abovementioned skills should be developed, or about the mutual relationship between these skills. As held by Meijer and Visscher ${ }^{260}$ as regards Directive $85 / 384 /$ EEC which contains the same conditions, on the one hand, this gave Member States the freedom to determine the contents and (maximum) duration of their educational programmes. It was left to the discretion of individual Member States to select the educational institutions (and degree programmes) to be accredited based on these criteria. On the other hand, the Directive posed a risk: in practice, its requirements could come to be seen as mere formalities, and the monitoring of developments in the different Member States could become a very remote process. In this regard it should be noted that recital 27 stipulates that architectural design, the quality of buildings, their harmonious incorporation into their surroundings and respect for natural and urban landscapes and for the public and private heritage, is a matter of public interest. Mutual recognition of qualifications should therefore be based on qualitative and quantitative criteria which ensure that the holders of recognized qualifications are in a position to understand and translate the needs of individuals, social groups and authorities as regards spatial planning, the design, organisation and realisation of structures, conservation and the exploitation of architectural heritage, and protection of natural balances.

The Directive contains some derogations relating to architectural qualifications obtained in Germany. As held by Article 47(1), the training provided by the German Fachhochschulen over a period of three years which satisfies the requirements referred to in Article 46 and gives access to the activities referred to in Article 48 under the professional title of 'architect', will also be recognised as satisfying the requirements of Article 21 in so far as the training is followed by a four-year period of professional experience in Germany and is attested by a certificate issued by the professional association in whose roll the name of the architect wishing to benefit from the provisions of this Directive appears. ${ }^{261}$ Another exception to Article 21 can be found in Article 47(2) which relates to training as part of social betterment schemes or part-time university studies which satisfy the requirements referred to in Article 46 which is attested by an examination in architecture and passed by a person who has been working for seven years or more in the field of architecture under the supervision of an architect or architectural bureau. ${ }^{262}$ In this case, the examination must be of university level and be equivalent to the final

259 The lists of courses applicable to the other professions appear in Annex V (points 5.2.1, 5.3.1, 5.4.1, 5.5.1 and 5.6.1) and can be amended by a comitology procedure with a view to adapting them to scientific and technical progress (see Article 58 of the Directive). As held above, this is opposed to the general system in which there is no coordination of the minimum training requirements and thus also no automatic recognition.

260 Meijer \& Visscher 2006, p. 3

261 The professional association must first ascertain that the work performed by the architect concerned in the field of architecture represents convincing application of the full range of knowledge and skills listed in Article 46 (1). See Article 4 (1) (b) Directive 85/384/EEC.

262 See Article 4 (2) Directive 85/384/EEC 
examination referred to in Article 46(1), first subparagraph (Article 47(2)). Examples of qualifications that have been accepted under Article 47(2) are the Part II examination of the RIBA (Royal Institute of British Architects) in 1988 and the French DPLG (architecture diploma awarded by the Government) as part of the continuing vocational training and upward mobility programme (1994).

After the aspiring architects have fulfilled the relevant conditions, the competent authorities of the Member States will provide them with evidence of their qualifications, indicating one of the professional titles enumerated in Annex V point 5.7.1. This will enable them to practise the profession in any Member State.

It is important to note that Article 22(b) stipulates that continuing education and training in the Member States has to ensure that persons who have completed their studies are able to keep abreast of professional developments to the extent necessary to maintain safe and effective practice (see also recital 39). This Article does not, however, introduce any obligation for Member States to set up programmes of continuing education and training for architects, nor does it entitle Member States to require evidence of continuing professional development in terms of recognition. It follows that the absence of continuing education and training in the home Member State cannot be a reason to reject a request for recognition. Member States may only impose an obligation of continuing education and training on migrants already established on their territory to the extent that they do so, with regard to the profession concerned, for their own nationals.

\section{$\rightarrow$ General system for the recognition of professional qualifications (Chapter I)}

The general system for the recognition of evidence of training applies to all professions which are not covered by Chapters II and III of Title III ${ }^{263}$ and, in certain cases, in which the applicant's profession is covered by one of these chapters but the applicant does not satisfy, for specific and exceptional reasons, the conditions laid down in those chapters (Article 10 and recital 17). As indicated above and as will be discussed in detail hereunder, architects generally fall under Chapter III. However, the general system is still of importance. As indicated by Article 10(c) and (d), Chapter I is also applicable to architects who are migrants and who hold formal qualifications which are not listed in Annex $\mathrm{V}$, point $5.7^{264}$, and to architects holding evidence of formal qualifications as a specialist who must, for the purpose of the recognition of the speciality, follow the training leading to the possession of a title listed in annex $\mathrm{V}$ point 5.7.1 $1^{265}$ This is without prejudice to

263 The scope of the application of the new Directive is considerably broader than that of Directives 89/48/EEC and 92/51/EEC since every regulated profession which is not covered by part II or III is covered by Article 10. Problems with cases which fall in between these Directives will no longer occur. See for example Case C-102/02 Ingeborg Beutenmüller v. Land Baden-Württemberg, [2004] ECR I-5405.

264 Architects are in general covered by Chapter III of the Directive if they satisfy the requirements in annex V. In such cases their professional qualifications have to be recognized automatically.

265 The Economic and Social Committee has stated that the application of the general system on a subsidiary basis to members of professions that come under the sectoral system is incompatible with the harmonization of minimum training requirements. Moreover, there is no further point to the sectoral system if noncompliance with the minimum training requirements laid down therein, automatically trigger the application of the general system. Ultimately, this would create a two-tier profession of those whose training meets the minimum requirements of the sectoral Directive, and those whose training does not. It is, how- 
Articles 21(1) -principle of automatic recognition- and Article 23(3) dealing with architects who hold qualifications issued by the former Czechoslovakia, Soviet Union and Yugoslavia or who commenced their training in the Czech Republic, Slovakia, Estonia, Latvia, Lithuania or Slovenia before these states became independent.

In the general system of recognition, the various national education and training systems are grouped together in terms of a number of levels ${ }^{266}(5)$ without in any way affecting each Member State's educational structures (Article 11 and recital 13). ${ }^{267}$ When, in a host Member State, access to, or pursuit of a profession, is regulated, the competent authority in this Member State allows access to the profession in question, and pursuit thereof, under the same conditions as apply to its nationals, provided that the applicant holds an attestation of competence or evidence of formal qualifications required by another Member State (the home Member State) in order to gain access to, and pursue that profession, on its territory (Article 13(1)). The qualifications obtained in that Member State have to attest a level of professional qualifications at least equivalent to the level immediately below ${ }^{268}$ that required in the host Member State (Article 13(1)(b)), and have to be issued by a competent authority ${ }^{269}$ in a Member State. It follows therefore that not every professional may apply for diploma recognition under the general system, since the migrant holding a regulated profession only has the right to obtain recognition

ever, impossible for consumers to make that distinction and they themselves have no way of differentiating between qualified and less qualified providers. Since the profession of architect is covered in Chapter III of Title III of the Directive and the list in Annex 5 is quite extended, Article 10 will probably not be used very often in the case of architectural (related) occupations. See Opinion of the Economic and Social Committee on the 'Proposal for a Directive of the European Parliament and of the Council on the recognition of professional qualifications', OJ of the European Union, C 61/67, COM (2001) 119 final - 2002/0061 (COD), 2002/C 61/14, p. 9.

266 The first three which are described correspond to the three levels of qualifications covered by Directive 92/51/EEC. Directive 89/48/EEC has been split into the last two levels.

The diplomas awarded after the completion of a four-year post-secondary training course in a university or in an establishment of higher education are contained in both levels described under Article $11 \mathrm{~d}$ ) and under Article $11 \mathrm{e}$ ). This is the result of a difficult compromise and allows the Member States to consider that their corresponding training belongs either to one or the other of those levels. This could have resulted in excluding from the benefit of mutual recognition under the Directive, holders of qualifications under level 11 (c) when the host Member State would have chosen to classify the post-secondary training of 4 years required in its territory for the profession concerned under level 11 (e) (because of the gap of more than one level). In order to avoid this, and to keep the situation unchanged compared to the previous Directives 92/51/EEC and 89/48/EEC, a derogation was introduced in Article 13(3). According to this provision, the holder of qualifications under level 11 (c) has the right to have those qualifications recognised under the Directive if the host Member State requires post-secondary training of four years duration, regardless of whether this training is classified under level 11d) or 11e).

267 It is important to note that Article 12 (1) holds that if qualifications run parallel to standard qualifications (i.e. qualifications belonging to one of the five levels described in Article 11) and have an equivalent level and confer equivalent rights of access to, or pursuit of, a given profession, these qualifications have to be classified at the same level as the standard qualifications.

268 In general it must be said that the outlines of the system in Article 3 and 4 of Directive 89/48/EEC (and $92 / 51 / \mathrm{EEC}$ ) are still visible in the new system, but due to the creation of these levels, it can actually be more difficult to have one's professional qualification recognised.

269 As held by Article 3 (1) (d), a competent authority is any authority or body empowered by a Member State specifically to issue or receive training diplomas and other documents or information and to receive the applications, and to take the decisions referred to in the Directive. 
of his/her professional qualification if he is fully qualified in his home Member State for the same profession, and if the qualifications he holds are at least of the level immediately below that required in the host Member State. The rest cannot rely on the provisions of the Directive - although nothing precludes the application of the principles laid down in Gebhard and Vlassopoulou. This is without prejudice to the possibility for the host Member State to require a compensation measure under certain conditions described in Article 14. There is thus no obligation of recognition for the host Member State under the Directive if the migrant's qualifications are of a level lower than that immediately below the level required in the host Member State.

When, on the other hand, in the Member State of the applicant, access to a profession is not regulated (i.e. not subject to the possession of specific professional qualifications), the applicant should, in order to be able to gain access to, and pursuit of, the profession in the host Member State which does regulate that profession, provide proof of two years of professional experience on a full-time basis over the preceding ten years on top of the qualification (Article 13(2)). ${ }^{270}$ In this case as well, recognition is only granted if the applicant is in possession of formal qualifications, the level of which is at least equivalent to the level immediately prior that required in the host State. As held by Article 13(2), this two years of professional experience may, however, not be required if the evidence of formal qualifications which the applicant possesses actually certifies regulated education and training at the levels of qualifications described in Article 11, points (b), (c), (d) or (e).

It is important to note that if the professional can produce the requested attestations, integration is still by no means guaranteed. The only thing that is established at that point is the mere right to have one's qualification recognized. As indicated above, in the absence of harmonization of the minimum training conditions for access to the professions governed by the general system, it should be possible for the host Member State to impose a compensation measure in the form of an aptitude test or an adaptation period, even if the test under Article 13 would succeed (being at the same level of qualification or with a 1 level difference) (Article 14(1) and recital 15). This is the case if the training is one year shorter than that required by the host Member State, the training received is substantially different, and if the profession in the host Member State comprises one or more regulated professional activities which do not exist in the home Member State, while that difference consists of specific training which is required in the host Member State and covers substantially different matters from those covered by the applicant's qualifications. ${ }^{271}$ The migrant must be able to choose between these two options (Article 14(2)). ${ }^{272}$ Any derogation from that choice should, in each case, be justified by an imperative requirement in the general interest, or if the profession which the individual

270 Migrants are entitled to the same rights even when they have worked part time only. Even though this is not explicitly stated in the Directive, it refers to the pursuit of the profession 'on a full time basis'. The professional experience of the migrant having worked part-time has to be equivalent to the required duration on a full time basis.

271 In 2002 , more than $80 \%$ of the applications were accepted without compensatory measures.

272 Statistics observing similar conditions imposed by Directive 89/48/EEC showed that, in the past, migrants preferred adjustment training programmes to proof of competence. 
wishes to pursue requires a precise knowledge of national law (Article 14(3)). It follows that, as opposed to the provisions in the previous horizontal Directives, the possibility for a Member State to require professional experience rather than compensation measures in the event of substantial differences relating to the duration and not the content of training, is abolished. ${ }^{273}$ It is thus no longer possible for a Member State to ask for compensation in terms of a substantial period of professional experience. In any case, compensation measures should always be proportionate (Article 14(5)). The Vlassopoulou principle can be found in this Article. In particular, if the host Member State intends to require the applicant to complete an adaptation period or take an aptitude test, it must first ascertain whether the knowledge acquired by the applicant in the course of his professional experience in a Member State or a third country is of a nature to cover, in full or in part, the differences. If this is the case, compensation measures are not allowed. In the old horizontal system, differences in time could be compensated for by professional experience. Differences in content were compensated for by an adaptation period or an aptitude test. The content and scope of such compensation measures was determined after application of the Vlassopoulou test. ${ }^{274}$ Directive 2005/36/EC does no longer contain the possibility of making up for differences in time by the use of professional experience. In such cases an adaptation period or aptitude test can be required which will have to be proportional (Article 14(1)(a) and (5). With regard to differences in content, Article 14(5) specifically mentions that, to determine the scope and content of the compensation measures, the knowledge acquired by the applicant in the course of his professional experience has to be assessed. This means that, next to the proportionality principle, the Vlassopoulou test is used. ${ }^{275}$ Even though the qualifications are, with respect to the recognition effect, grouped into different levels, it should not be forgotten that the structure and level of the professional training, probationary or professional practice, is determined by the Member States (Article 3(e)). The grouping into different 'European levels' has thus no effect upon the national education and training structures, nor upon the competence of Member States in this field (recital 13). It follows that Member States retain the right to lay down the minimum level of qualification required to ensure the quality of the services provided on their territory. However, pursuant to Articles 18 TFEU and 45 and 49 TFEU (Articles 12 EC and 39 and 43 EC), they should not require a national of a Member State to obtain qualifications which they generally lay down only in terms of the diplomas awarded under their national educational system, where the person concerned has already obtained all or part of those qualifications in another Member State. Any host Member State in which a profession is regulated

273 See Article 4 (1)(a) Directive 89/48/EEC. In this sense, the Directive is thus stricter than the old system, since now a Member State may ask for more invasive compensatory measures such as an aptitude test or an adaptation period.

274 The ECJ's Vlassopoulou judgement was implemented in Directive 89/48/EEC after adaptation by Directive 2001/19/EC

275 As held by Claessens, the Vlassopoulou test was, for the first time, formulated as part of the principle of proportionality in Directive 2005/36/EC. Compensation for time differences must therefore be applied with the principle of proportionality in mind, yet without the specific reference to the Vlassopoulou principle. See Claessens, 2008, pp. 37-38. 
must take account of the qualifications obtained in another Member State and assess whether they correspond to those which it requires.

In any case, the general system for recognition does not prevent a Member State from making any person pursuing a profession on its territory subject to specific requirements due to the application of professional rules justified by the general public interest. Rules of this kind relate, for example, to the organisation of the profession, professional standards, including those concerning ethics, and supervision and liability.

Article 15 of the Directive contains a novelty: it makes provision for the waiving of compensation measures on the basis of common platforms. Common platforms are criteria of professional qualifications which are suitable for compensating for substantial differences which have been identified between the training requirements that exist in the various Member States for a given profession, and are laid down by a decision of the Committee on Recognition of Professional Qualifications ${ }^{276}$ pursuant to the comitology procedure $^{277}$ (recital 16). They affect potentially all professions whose minimum training conditions are not harmonised at Community level. These substantial differences shall be identified by comparison between the duration and contents of the training in at least two thirds of the Member States, including all Member States which regulate this profession. Common platforms may be submitted to the Commission by Member States or by professional associations or organisations which are representative at national and European levels. The implementation of this regime is thus based on a public/private partnership. If the Commission adopts such measures which are designed to amend non-essential elements of the Directive by supplementing it, and the applicant's professional qualifications satisfy the criteria established in these measures, the host Member State shall waive the application of compensation measures under Article 14 (Article 15(3)). In this way, a more or less automatic recognition of qualifications is promoted under the general system on the basis of so-called 'predefined compensation measures'. On the one hand, the free movement of professionals is facilitated by simplifying the case-by-case assessment of individual applications by the competent national authorities and, on the other hand, increased legal security is provided to migrants concerning the outcome of their applications. ${ }^{278}$ There is a thus movement from an individual case by case approach to a global solution open to all migrant professionals, while the Member States and the Community institutions will be able to benefit more from the work done by the professions in question with a view to promoting free movement. In any case, Member States continue to be competent with regard to deciding the professional qualifications required for the pursuit of professions in their territory, as well as the contents and the organisation of their systems of education and professional training. There is thus no question of harmonising national training conditions (Article 15(4)). This

276 This single Committee replaces the existing bodies, is composed of representatives from the Member States and presided over by a representative from the Commission.

277 See Article 5 of Decision 1999/468/EC, as well as Article 7, having due regard to Article 8.

278 A fully qualified professional who does not satisfy the criteria of the platform continues to benefit from the rules on recognition but could be required to comply with compensatory measures: See http://ec.europa.eu/internal_market/qualifications/docs/future/platforms_en.pdf, last consulted 31 December 2009. 
would, according to Article 165 TFEU (Article 149 EC), require the unanimous agreement of all Member States. Moreover, any request for recognition continues to be subject to examination by the competent national authorities, even if their scope will be 'framed' by the platform. ${ }^{279}$

Finally it should be repeated that since only architects falling within the scope of Article 10 (c) en (d) fall under the general system, the use of Chapter I of Title III is rather limited for the architectural profession. Therefore, this will not be further discussed.

\section{$\rightarrow$ System of automatic recognition of qualifications attested by professional experi- ence in certain industrial, craft and commercial activities (Chapter II)}

As noted by recital 18, there is a need to simplify the rules allowing access to a number of industrial, commercial and craft activities in Member States where those professions are regulated, in so far as those activities have been pursued for a reasonable and sufficiently recent period of time in another Member State. Article 16 of Directive 2005/36/EC therefore holds that if, in a Member State, access to, or pursuit of, one of the activities listed in Annex IV - referring to various sectors ranging from the textile industry through to the chemical industry, the petroleum industry, printing, manufacturing industry and construction industry in list I, the manufacture of transport equipment, activities allied to transport, postal services, telecommunication and photographic studios in list II and numerous sectors ranging from restaurants and hotels to personal, community and recreation services in list III - is contingent upon possession of general, commercial or professional knowledge and aptitudes, that Member State shall recognize previous pursuit of the activity in another Member State as sufficient proof of such knowledge and aptitudes (Article 16). For those activities, a system of automatic recognition based on professional experience is thus maintained. The elements taken into consideration are the duration and form of professional experience (in a self-employed or employed capacity) in the reference sector, as well as previous training which may reduce the amount of professional experience required. In such cases, the received previous training should be evidenced by a certificate recognized by the Member State or judged by a competent professional body to be fully valid (Articles $17-19$ ). Since architects do not fall under this category, this aspect will not be further discussed.

\section{d. Procedure and consequences of recognition}

Chapter IV of Title III of the Directive contains some common provisions on establishment. As held by Article 50(1), where the competent authorities of the host Member State decide on an application for authorisation to pursue the regulated profession in question by virtue of Title III, those authorities may demand several documents, under which a proof of nationality, a copy of the attestations of professional competence or of the evidence of formal qualifications, an attestation of possible professional experience

279 http://ec.europa.eu/internal_market/smn/smn39/docs/specialfeature_en.pdf, last consulted 31 December 2009 and http://ec.europa.eu/internal_market/qualifications/docs/future/platforms_en.pdf, last consulted 31 December 2009. 
and, if it also demands the same of its own nationals, proof of good character or repute ${ }^{280}$, proof of the absence of bankruptcy, proof of lack of serious professional misconduct, proof that the applicant is covered by a professional liability insurance, etc. ${ }^{281}$ Annex VII contains the complete list of documents which can be demanded. In the case of justified doubt, the host Member State is entitled to verify the authenticity and scope of the qualifications (Article 50(2) and (3)). ${ }^{282}$ As held by Article 51(1), the competent authority of the host Member State shall acknowledge receipt within one month and shall inform the applicant of any missing documentation. The procedure for examining an application for authorisation to practise a regulated profession must be completed as quickly as possible and must lead to a duly substantiated decision -this means that reasons need to be given for any rejection- by the competent authority in the host Member State, and in any case within three months of the date on which the applicant's complete file was submitted. ${ }^{283}$ The deadline may be extended by one month in cases falling under Chapters I and II (Article 51(2). The decision, or failure to reach a decision within the deadline, is subject to appeal under national law (Article 51(3)). ${ }^{284}$

With regard to the freedom of establishment, Article 52(1) is of major importance since it determines the consequence of recognition: if, in a host Member State, the use of a professional title relating to one of the activities of the profession in question is regulated, nationals of the other Member States who are authorised to practise a regulated profession on the basis of Title III, shall use the professional title of the host Member State, which corresponds to that profession in that Member State, and make use of any associated initials. ${ }^{285}$

Title IV contains rules which are relevant with regard to the free movement of establishment, as well as the free provision of services. As held by Article 53, persons benefiting from the recognition of professional qualifications should have knowledge of the language(s) necessary for practising the profession in the host Member State. Recognition of the professional qualifications can, however, not be denied or delayed until the migrant has acquired the necessary language skills. Article 54 deals with the use of academic titles as opposed to professional titles. It holds that host Member States have to ensure that persons are able to use academic titles conferred on them in their home Member State, and possibly an abbreviated form thereof, in the language of the home State. ${ }^{286}$ This is due to the fact that the recognition of professional qualifications does not necessarily imply practical equivalence in the education and training covered by such qualifications. The host Member State may require that title to be followed by the name and address of the establishment or examining board which awarded it. Where an academic title of the home Member State is liable to be confused in the host Member State with a title which, in the latter Member State, requires supplementary training not ac-

280 See Article 17 of Directive 85/384/EEC.

281 See Articles 24 and 25 of Directive 85/384/EEC.

282 See Article 27 of Directive 85/384/EEC.

283 See Article 20 of Directive 85/384/EEC.

284 See Article 6a of Directive 85/384/EEC.

285 See Article 23 of Directive 85/384/EEC.

286 See Article 16 of Directive 85/384/EEC. 
quired by the beneficiary, the host Member State may require the beneficiary to use the academic title of the home Member State in an appropriate form to be laid down by the host Member State. As indicated before, in paragraph 3.5. academic recognition will be discussed more extensively.

In order to facilitate the application of the provisions of the Directive, Article 56(1) provides for close collaboration between the competent authorities ${ }^{287}$ in the host and home Member States. The competent authorities shall exchange information regarding disciplinary action or criminal sanctions taken, or any other serious, specific circumstances which are likely to have consequences for the pursuit of activities under the Directive. To achieve this end, each Member State shall designate a coordinator who shall inform the other Member States and the Commission, of the initiatives taken. In most Member States, the competent authorities can, to some extent, delegate responsibility for management of the professions to independent bodies such as professional associations. In other words, management of the professions is encompassed within each Member State's internal affairs, and bodies other than government departments may consequently be made responsible for it.

Furthermore, as stipulated in Article 57 and recital 33, each Member State is obliged to designate a contact point to provide the citizens, and the contact points of the other Member States, with information concerning the recognition of professional qualifications, and to assist citizens in enforcing the rights which this Directive confers upon them, particularly through contact with the competent authorities who rule on requests for recognition. To this end, Article 58 sets up a single (comitology) committee which has to assist the Commission within the limits of the enforcement powers conferred on it by the Directive, and administer the Directive and its updating (see also recital 34). Contact points are thus set up to help professionals when they want to have their qualifications recognized. The recognition decision is taken by the competent authority.

The Directive entered into force on 20 October 2005 and should have been implemented by the Member States by 20 October 2007 at the latest. ${ }^{288}$ However, in September 2009, all Member States except Greece had transposed the Directive and 17 out of 27 Member States had fully implemented the Directive. ${ }^{289}$

\section{e. Conclusion}

Directive 2005/36/EC is intended to encourage the free movement of skilled labour throughout the European Union, while acknowledging that standards differ between the Member States. It aims to establish some equivalence between professionals trained in the Union so that such individuals should be able to move and practise in other Member

287 See Article 3 (1) (d) of Directive 2005/36/EC for the definition of 'competent authority'.

288 See Articles 63 and 64 of Directive 2005/36/EC.

289 Report of the European Parliament, Directorate-General for Internal Policies, Policy Department Economic and Scientific Policy A, Recognition of Professional Qualifications, September 2009, p. 6. See http://www.europarl.eu.int/oeil/resume.jsp?id=220062\&eventId=53758\&backToCaller=NO\&language$=$ en. As opposed to the Netherlands, Belgium has not fully implemented the Directive. However, as will be seen in Part II of this thesis, with regard to architects, the automatic system of recognition has been implemented. The reason for incomplete implementation is mainly due to the volume of the work, since some Member States have more regulated professions than others. 
States without unnecessary impediments. With regard to services, the Directive contains the general principle of the free provision of services under the original professional title, subject to certain conditions which aim to protect consumers. The Directive follows the principle of mutual recognition with host country control. ${ }^{290}$ Member States shall thus not restrict the free provision of services in another Member State for any reason relating to professional qualifications, where the potential service provider is allowed to exercise the same profession in his home Member State, or where the potential service provided has legally pursued the same activities for at least two years during the past ten years, in a situation in which the home Member State does not regulate the profession. It follows that the regime in place for the ensemble of regulated professions frees services providers from being subject to a procedure for recognizing their qualifications. This direct access is a great step forward. This is to be counterbalanced by an increase in the mandatory sharing of information between the authorities of the Member States, and with citizens.

With regard to establishment, the three regimes which were used before the entry into force of Directive 2005/36/EC are brought together in one legal instrument:

1. Automatic recognition of professional experience (Chapter II Directive 2005/36/EC - before Directive 1999/42/EC)

2. Automatic recognition of diplomas on the basis of minimum conditions of harmonised training (Chapter III Directive 2005/36/EC - before: vertical Directives). It should be noted that for architects, Directive 85/384/EEC contained no harmonized training requirements nor does the Annex to Directive 2005/36/EC contain such harmonization. However, for almost all other regulated professions, training requirements are harmonized.

3. Mutual recognition of training titles combined by the possible requirement for supplementary measures (Chapter I Directive 2005/36/EC - before Directives 89/48/EEC and 92/51/EEC). This recognition mechanism applies in a subsidiary way to regulated professions and specific situations not covered by other recognition rules.

The objective of the Directive was the creation of an efficient system for the recognition of qualifications in the field of the regulated profession, so that free movement will be enhanced and employment vacancies will be filled by a regular supply of qualified applicants. Since there is only one piece of legislation to refer to instead of the several sectoral and horizontal Directives, the system is simpler and more transparent. The body of the Directive contains the main rules on professional recognition, while the specific technicalities and details appear in the seven annexes. This envisages that the technical requirements should be easier and faster to update. Previously, national legislation had to be updated every time there was a change in the technical requirements to mirror a change at EU level. By referring to the annexes, national adjustments do not have to be made. The Directive brings greater liberalization in terms of the provision of services,

290 Compliance with the mutual recognition principle is extremely important, since the estimated cost of the non-application of the mutual recognition principle is around EUR 150 billion. 
more automatic recognition of qualifications, and increased flexibility in the procedures for updating the Directive. In this way it contributes greatly to mobility in terms of skills and brings us closer to the objective of a more competitive Europe as set out in the Lisbon agenda. The new legal framework constitutes a balanced opening of the market. The fact that a different number of professions are regulated in each Member State may hinder transparency however. Furthermore, the possibility of establishing more flexible recognition procedures through common platforms, raises concerns of professional associations that individuals with a shorter education can claim recognition more easily. In this regard, cooperation between the national administrators and national professional associations across the Union can contribute to enhanced free movement rights or at least better information systems for citizens.

However, for architects, not that much has changed. As held by Article 62 of Directive 2005/36/EC, references to Directive 85/384/EEC shall be understood as references to this Directive and acts adopted on the basis of these Directives shall not be affected by the repeal.

As will be seen hereunder, following the Bologna Declaration of June 1999, Schools of Architecture across the European Union have to notify the Commission of new diplomas in Architecture and existing diplomas in Architecture modified to relate to a two cycle Bachelor-Masters format or other formats, such as a $3+2$ model. After 20 October 2007 , diplomas will only be evaluated in the context of Directive 2005/36/EC. Both Directive 85/384/EC and Directive 2005/36/EC require an education of at least four years the practice for most third level institutes in Europe is, however, a five year study programme. Furthermore, Article 46 of Directive 2005/36/EC which forms the basis for the study curriculum leading to a qualification in architecture, corresponds to Article 3 of Directive 85/384/EEC. ${ }^{291}$ A difference between the Directives is that the old Architect's Directive did not make such a strong formal distinction between the freedom of establishment and the freedom to provide services as Directive 2005/36/EC does. Furthermore, as opposed to the former Directive, Directive 2005/36/EC contains an express provision on permanent education and retraining in Article 22(b). In case the Directive is not applicable, for example because the profession is unregulated in the host Member State ${ }^{292}$, the professional can still find protection in the Treaty Articles and the Vlassopoulou and Gebhard rulings of the ECJ. ${ }^{293}$ Directive 2005/36/EC can be qualified as a

291 Advisory Committee on Education and Training in the Field of Architecture, Draft recommendation concerning a Guideline Document relating to establishing an opinion regarding Diplomas in Architecture and their compliance with the Architects' Directive 85/384/EEC, adopted by the Committee at its meeting of 7 April 2006, MARTK/D/4984/12006-EN.

292 See for example Case C-164/94 Aranitis v. Land Berlin [1996] ECR I-135; Case C-234/97 Fernandez de Bobadilla v. Museo Nacional del Prado, Comité de Empresa del Museo Nacional del Prado, Ministerio Fiscal [1999] ECR I-4773; Case C-313/01 Christine Morgenbesser v. Consiglio dell'Ordine degli avvocati di Genova [2003] ECR I-13467. In the latter case the ECJ held that in such a case the Vlassopoulou ruling has to be applied since Directive 2005/36/EC does not apply to professionals who are not 'produit fini'); Case C-285/01 Isabel Burbaud v. Ministère de l'Emploi et de la Solidarité [2003] ECR I-08219 (entry exams).

293 As held above, the ECJ developed a considerable amount of case law and contributed to the development of the recognition of diplomas by holding, in Thieffry and Heylens, that discriminatory barrier have to be removed. Such barriers are only allowed if there is an objective justification (see Klopp, Kraus, Säger (Case 
lex specialis compared to the system of relying directly on Articles 49 and 56 TFEU (Articles 43 and 49 EC) combined with the discussed judgements. It should be noted, however, that with regard to the creation of aptitude tests in case of differences between the qualifications required in the home and the host Member State, cooperation between the bodies and the universities is a challenge, as the universities do not have an incentive to make these. ${ }^{294}$

In sum, it can be said that Directive 2005/36/EC tries to strike a balance between the free movement of skilled professionals and consumer protection (see also recital 44). It relies significantly on the exchange of information between national authorities, particularly regarding the disciplinary, administrative or penal sanctions that would affect migrant professionals, or with regard to the authenticity of their diplomas. It is a more flexible system than that existed in the past, but problems with the recognition of qualifications have not disappeared. As held by the Parliament, this may be due to the fact that the education systems in the different Member States differ, especially when it comes to specialisation, which means that automatic recognition is not easily applied. Furthermore, since automatic recognition is a procedure regulated in a particularly detailed manner, it can be difficult for the competent authorities and for individuals to obtain all the necessary documentation. ${ }^{295}$

C-76/90, Manfred Säger v. Dennemeyer \& Co. Ltd. [1991] ECR I-4421), Vlassopoulou., Gebhard,...). In this regard the ECJ held in Säger that national legislation which makes the provision of certain services within the national territory by an undertaking established in another Member State subject to the issue of an administrative licence for which the possession of certain professional qualifications is required, constitutes a restriction on the freedom to provide services within the meaning of Article 56 TFEU. Even though specific requirements can be imposed in the light of the particular characteristics of certain provisions of services, the freedom to provide services may be limited only by rules which are justified by imperative reasons relating to the public interest, and which apply to all persons or undertakings pursuing an activity in the State of destination, insofar as that interest is not protected by the rules to which the person providing the services is subject in the Member State in which he is established. Furthermore, those requirements must be objectively necessary in order to ensure compliance with professional rules and must guarantee the protection of the recipient of services, while they must not exceed what is necessary to attain those objectives. See also Cases C-154/89 Commission v France [1991] ECR I-659, C-180/89 Commission v Italy [1991] ECR I-709 and C-198/89 Commission v Hellenic Republic [1991] ECR I-727. Although the situations covered in cases like Vlassopoulou and Gebhard are nowadays covered by secondary legislation, the principles laid down in these cases are still of the utmost importance in connection with situations that are not covered by secondary legislation.

294 Report of the European Parliament, Directorate-General for Internal Policies, Policy Department Economic and Scientific Policy A, Recognition of Professional Qualifications, September 2009, p. 30; Cases C154/89 Commission v France [1991] ECR I-659, C-180/89 Commission v Italy [1991] ECR I-709 and C198/89 Commission v Greece [1991] ECR I-727.

295 Report of the European Parliament, Directorate-General for Internal Policies, Policy Department Economic and Scientific Policy A, Recognition of Professional Qualifications, September 2009, p. 55. 


\subsection{Architects not holding the nationality of an EU Member State}

\subsubsection{Introduction}

In paragraph 3.2.2 the free movement rights of third-country nationals were discussed. Since Directive 2005/36/EC is not applicable to third-country nationals wishing to pursue a regulated profession in another Member State, and does thus provide for recognition of their professional qualifications, one has to verify whether the Directives and Agreements discussed in paragraph 3.2.2 contain some clauses related to professional recognition.

\subsubsection{Third-country national family members of EU citizens who made use of their free movement rights: Directive 2004/38/EC}

Even though Directive 2005/36/EC is not applicable to third-country nationals wishing to pursue a regulated profession in a Member State (Article 2(1)), the same principles should be applied to third-country family members of Union citizens on the basis of Article 24 of Directive 2004/38/EC. As held by the ECJ in Gül with regard to the then applicable Directive $75 / 363 / \mathrm{EEC}^{296}$, a third-country national spouse of a worker must be able to rely on the right to equal treatment in respect of the recognition of professional qualifications and diplomas under the same conditions as nationals of the host Member State. ${ }^{297}$ As held by Wiesbrock, the same conclusion can be drawn in respect of Directive 2005/36/EC. ${ }^{298}$ Thus, in the case of a third-country national who has acquired a professional qualification in a Member State, he should, in principle, obtain access to the same profession as exercised in that country under the same conditions as nationals of the host Member State. It follows that, since it is possible that a specific architectural qualification of a third country national is listed in Annex V.7, if the qualifications were obtained within the EU, automatic recognition should take place in accordance with Chapter III of Title III of the Directive. If this is not the case, recognition can possibly be granted in accordance with the general system which entails that the level of professional qualifications should be at least equivalent to the level immediately below that which is required in the host Member state. The completion of an adaptation period, or the taking of an aptitude test, may be required in accordance with Article 14 of Directive 2005/36/EC.

It is, however, more likely that a third-country national spouse is in the possession of a third-country qualification. If this is the case, in the light of Article 24 of Directive 2004/38/EC which imposes equal treatment, reference should be made to Article 3(3) of Directive 2005/36/EC which indicates that the evidence of formal qualifications issued by a third country shall be regarded as evidence of formal qualifications if the holder has three years' professional experience in the profession concerned on the territory of the

296 Council Directive 75/363/EEC of 16 June 1975 concerning the coordination of provisions laid down by law, regulation or administrative action in respect of activities of doctors , OJ L 167, 30 June 1975, pp. 1416.

297 See paragraph 29 of the judgement.

298 Wiesbrock 2009, p.89. 
Member State which recognised the evidence of formal qualifications. In all other cases, the third-country national has to rely on the case law of the ECJ in Vlassopoulou, TawilAlbertini ${ }^{29}$ and Hocsman. ${ }^{300}$ As indicated above, in the first case, the ECJ held that, when assessing third-country qualifications, Member States are obliged to examine whether the work experience gained in another Member State corresponds to the experience required under national law. In Tawil-Albertini however, the Court held that the recognition by a Member State of qualifications obtained in third-countries is not binding upon other Member States. In Hocsman it was held that all the diplomas, certificates and other evidence of formal qualifications of the person concerned, together with all relevant experience, must be taken into account by comparing the specialized knowledge, abilities and experience certified with the knowledge and qualifications required by national law, even if they are obtained outside the European Union. It follows that, even though decisions of one Member State may not be binding upon another Member State, a third-country national family member with a third-country diploma should receive a comprehensive assessment of his or her diploma and the professional experienced gained in another Member State or a third country.

\subsubsection{Family members of Union citizens who have not made use of their free movement rights}

As indicated in paragraph 3.2.2.3, if the Union citizen has not made use of his free movement right, one deals with a purely internal situation in which national law prevails. It follows that the non-discrimination principle, the principle of equal treatment (on the basis of nationality) and thus also the obligation to recognize professional qualifications, do not apply.

\subsubsection{Association and Partnership agreements.}

1. The European Economic Area

As indicated in paragraph 3.2.2.4, the Agreement on the European Economic Area $(E E A)^{301}$ allows nationals of Iceland, Liechtenstein and Norway to participate in the Internal Market on the basis of their application of Internal Market relevant acquis. All new relevant EU legislation is dynamically incorporated into the Agreement, and thus applies throughout the EEA, ensuring the homogeneity of the internal market. The rules on entry and residence contained in the Agreement are identical to those in the Treaty on the Functioning of the European Union, and must be interpreted in accordance with the case law of the ECJ. An amendment to Annex 7 of the EEA Agreement had to be made in order to permit a simultaneous application of the Directive in the EU and in the EEA States. ${ }^{302}$ This was done by means of a decision from the EEA Joint Committee that

299 Case C-154/93 Tawil-Albertini [1994] ECR I-451.

300 In Case C-238/98 Hugo Fernando Hocsman v. Ministre de l'Emploi et de la Solidarité [2000] ECR I-6623 and Case C-319/92 Salomone Haim v. Kassenzahnärztliche Vereinigung Nordrhein [1994] ECR I-425 the Vlassopoulou principle was extended to third-country qualifications.

301 OJ L 1, 3 January 1994.

302 http://ec.europa.eu/internal_market/qualifications/docs/future/faq_en.pdf, last visited 23 December 2009. 
is responsible for the day-to-day management of the EEA Agreement, and is composed of ambassadors of the EEA-EFTA States, representatives from the European Commission, and EU Member States. This decision was taken on 26 October 2007. With regard to architects, the list of certificates which have to be given the same effect on the Member States' territories due to Article 49(2) of the Directive which deals with acquired rights specific to architects, is supplemented by certificates issued to nationals of Member States by Iceland and Norway from 1 January 1994 onwards and 1 May 1995 for Liechtenstein. These states and the diplomas to be recognized are also added to Annex VI.6 of the Directive. Furthermore, in accordance with the Decision of the EEA Joint Committee, Annex V.7 which contains a list with diplomas that have to be recognized automatically, is supplemented by diplomas issued by Iceland, Norway and Liechtenstein together with the respective reference academic year. Directive 2005/36/EC applies to both EU nationals and nationals from Iceland, Liechtenstein and Norway since 1 July 2009.

\section{EEC-Switzerland Agreement}

As indicated in paragraph 3.2.2.4, in 1999, the European Community and its Member States, on the one hand, and Switzerland, on the other, concluded a bilateral agreement on the free movement of persons which entered into force on 1 June 2002. A protocol, which entered into force on 1 April 2006, was concluded to extend the agreement to the ten new Member States while a second protocol of 27 May 2008 makes the Agreement applicable to Bulgaria and Romania. ${ }^{303}$ Article 9 and Annex III of the agreement dealt with the recognition of professional qualifications. Article 18 of the agreement provides that amendments to Annex III must be adopted by decision of the Joint Committee. The Annex adds a number of Swiss diplomas that have to be recognized throughout the Union, and indicates that Switzerland has to recognize the EU diplomas as well. However, the above procedure has to be completed before Swiss nationals can be covered by Directive 2005/36/EC. Until then, the 'old' Directives continue to apply. They will apply even when repealed by the new Directive at the end of the transposition period.

\section{The EEC-Turkey Association Agreement}

Neither the EEC-Turkey Association Agreement, nor Decision No. 1/80 contains a specific clause on the recognition of professional qualifications. However, numerous studies have been conducted to compare the qualifications associated with the professions covered by the automatic system of Directive 2005/36/EC with Turkish qualifications. ${ }^{304}$ As held in paragraph 3.2.2.4, Decision No. 1/80 does not constrain the competence of Member States to regulate the admission of Turkish workers to their territory or their competence to lay down the conditions of their first access to the employment market.

${ }^{303}$ OJ L 89, 28 March 2006.

${ }^{304} \mathrm{See}$ for example, http://www.tobb.org.tr/abm/haberler/09ilerleme/Tarama\%20Raporu.pdf; http://www.abgs.gov.tr/tarama/tarama_files/03/SC03DET_mutual_recognition.pdf, both visited last on 23 December 2009. 
Public Regulation of Architects at European Union Level

4. Partnership and Cooperation Agreements with Russia and other ex-Soviet states

The Partnership and Cooperation Agreements do not contain special rules relating to the recognition of professional qualifications. Even though the individuals covered by the Agreements should be treated equally in general, Member States retain their competence to apply their laws and regulations regarding entry and stay, work, labour conditions and establishment of natural persons and supply of services, except where such legislation is applied in a way that nullifies or impairs the benefits arising out of the Agreement.

5. The Euro-Mediterranean Association Agreements

These Agreements do not contain specific rules relating to the recognition of professional qualifications.

6. The ACP states Latin American countries

As indicated in paragraph 3.2.2.4, the Cotonou Agreement does not contain an initial right of entry to the territory of a Member State, but only contains a general nondiscrimination clause and the guarantee of fair treatment of third-country nationals on the territory of Member States. There is no specific clause dealing with the recognition of professional qualifications.

7. Stabilization and Association Agreement with the Balkan states Again, the conditions governing the right to entry fall entirely within the competence of the Member States. There is only a general non-discrimination principle in respect of working conditions, but there are no specific rules dealing with the recognition of professional qualifications.

\subsubsection{Non-privileged third-country nationals: Directives on legal migration of third- country nationals}

1. Directive $2003 / 86 / E C$

As held by Directive 14(1)(b) of Directive 2003/86/EC, third country nationals eligible for family reunification will have, in principle, the same rights as the sponsor - i.e. a third country national residing lawfully in a Member State and applying, or whose family members apply, for family reunification to be joined with him/her - to any employment and self-employed activity. ${ }^{305}$ Since the Directive's principle aim is to deal with family reunification, it does not contain a specific clause dealing with the recognition of professional qualifications.

\section{Directive 2003/109/EC}

Article 11(1)(a) of Directive 2003/109/EC indicates that long-term residents shall enjoy equal treatment with nationals as regards access to employment and self-employed activity, provided that such activities do not entail even occasional involvement in the exercise of public authority, and conditions of employment and working conditions,

305 The requirements which need to be fulfilled for family reunification can be found in Articles 7 and 8 of Directive 2003/86/EC. These will not be discussed within this thesis. 
including conditions regarding dismissal and remuneration. Furthermore, as held by Article 11(1)(c), equal treatment should also be granted regarding the recognition of professional diplomas, certificates and other qualifications, 'in accordance with the relevant national procedures'. With regard to the recognition procedure, I refer to the analysis in this paragraph with regard to third-country family members of EU citizens (Directive 2004/38/EC).

\section{Directive 2004/114/EC and 2005/71/EC}

Since these Directives are not important within the scope of this thesis for the reasons set out in paragraph 3.2.2.5, I will not discuss them any further.

\section{Directive 2009/50/EC}

Directive 2009/50/EC which applies to third-country nationals pursuing highly qualified employment for which higher professional qualifications are required and which should attest to the completion of a post-secondary course of higher education of at least three years duration ${ }^{306}$, reference should be made to recital 19 of the preamble which indicates that professional qualifications acquired by a third-country national in another Member State should be recognised in the same way as those of Union citizens. Qualifications acquired in a third country should be taken into account in conformity with Directive 2005/36/EC. As held by Article 14(1)(d), EU Blue Card holders shall enjoy equal treatment with nationals of the Member State issuing the Blue Card, as regards recognition of diplomas, certificates and other professional qualifications in accordance with the relevant national procedures. Individuals who belong to a regulated profession must fulfil the relevant professional rules on the same footing as are applicable to EU citizens under national law. ${ }^{307}$ With regard to unregulated professions, practitioners have to provide proof of possessing the required higher professional qualifications in the occupation or sector concerned. ${ }^{308}$ The Directive must be implemented by 19 June 2011 at the latest. Again with regard to the recognition procedure, reference is made again to my analysis in this paragraph regarding the qualifications of third-country family members of EU citizens.

\section{Draft Directive on a single permit and a common set of rights}

The Draft Directive for a single permit and a common set of rights refers in recital 15 of the preamble also to Directive 2005/36/EC. The procedure has been described above. It should be noted however that since Article 12 of the Directive does not specifically mention Directive 2005/36/EC, and since most third-country national workers are likely to have qualifications obtained in a third country and reside in their Member State of admission and are therefore dependent upon the national legislation of that Member State with regard to the recognition of their qualifications, it is unlikely that Directive 2005/36/EC will be taken into account. Equal treatment in respect of qualifications is not even awarded to long-term residents and highly qualified professionals.

${ }^{306}$ As indicated before, the possibility of replacing higher educational qualifications with relevant professional experience must be foreseen by national law, and only applies by derogation.

307 See Article 5 (1) (b) of Directive 2009/50/EC.

308 See Article 5 (1) (c) of Directive 2009/50/EC. 
Public Regulation of Architects at European Union Level

\subsection{Case law on the recognition of architectural qualifications}

In paragraph 3.2, case law has been discussed which specifically dealt with the free movement of architects. These cases were based on the provisions in the Treaty. In this paragraph I will now focus on the cases which have been decided upon by the ECJ regarding the recognition of architectural professional qualifications as provided for in the Directives which have previously been discussed. It should be noted that all the cases are still based on the Treaty and the provisions of Directive 85/384/EEC.

Egle ${ }^{309}$ concerned a German national residing in Belgium who applied to have his name entered on the register of the Architects' Association of the Province of Limburg in Belgium. Mr. Egle held a diploma awarded by the Department of Architecture of the German Constance Fachhochschule on 25 July 1981 following completion of four years of study, including two practical semesters, in accordance with the Fachhochschulgesetz of the Land Baden-Wuerttemberg. Mr. Egle's application was rejected by the Council of the Architects' Association of the Province of Limburg. The Council held that Chapter II, and more specifically Article 4(1)(a) of Directive 85/384/EEC - which holds that each Member State shall recognize the diplomas, certificates and other evidence of formal qualifications acquired as a result of education and training of which the total length of education and training consists of a minimum of either four years of full-time studies at a university or comparable educational establishment, or at least six years of study at a university or comparable educational establishment of which at least three must be full time, and which is awarded to nationals of Member States by other Member States- only intended to include four years of full time theoretical studies. After appeal and appeal in cassation, the Belgian Supreme Court raised a preliminary question before the ECJ and asked whether education and training which lasts for four years, and which includes integrated practical semesters supervised by the college, can be regarded as four years of full-time study.

The ECJ first observed that even though Article 4(1)(a) of the Directive requires that the length of education and training consists of at least four years of full-time studies, the second subparagraph of Article 4(1) provides that training given over three years in 'Fachhochschulen' in the Federal Republic in Germany satisfies the requirements of the Directive as to the length of training, provided that such training is supplemented by a four-year period of professional experience in the Federal Republic of Germany. ${ }^{310}$ The Court continued and held that, with regard to the concept of 'studies', within the meaning of Article 4(1)(a) of the Directive, it should be pointed out that, according to Article 3 , the courses of architectural studies are to be balanced between the theoretical and the practical aspects of training. Consequently, the concept of 'studies' could be applied to practical training which the student must undergo in order to obtain the architectural diploma.

The Court further held that it was, in that respect, apparent from the documents before it, that the practical semesters organized by the Fachhochschulen formed an inte-

309 Case C-310/90 Nationale Raad van de Orde van Architecten v Ulrich Egle [1992] ECR I-177.

310 See Articles 21, 46 and 47 of Directive 2005/36/EC. 
gral part of the studies. The content of those semesters was precisely regulated by the Fachhochschulen, and their completion by the student resulted in an assessment by a member of the teaching staff. Moreover, the practical semesters were integrated into the courses of architectural studies in such a way that they were always placed between semesters of theoretical training, so that the studies could never finish with a practical semester. For these reasons it was held that this kind of practical training constituted an integral part of the architectural studies for the purposes of Article 4(1)(a) of the Directive.

The Court went even further and stipulated that with regard to the requirement laid down in Article 4(1)(a), stating that the studies must be full-time, it had to be pointed out that this refers to the time which the student must devote to his training in order to obtain the diploma in architecture. Such is the case when the practical semesters are organized and supervised by the university, and demands that the student makes himself available full-time in the same manner as is required during the semesters of theoretical training.

As remarked by the Court in its judgement, this interpretation was confirmed by a joint declaration of the Commission and the Council, contained in the minutes of the session at which the Directive was adopted, which states that "periods of practical training incorporated into the course culminating in an examination do not affect the full-time nature of such training"' That same interpretation is further confirmed by the fact that the second subparagraph of Article 4(1) of the Directive lays down a different rule with regard to architectural training given over three years in the Fachhochschulen. Those years are recognized, provided that they are supplemented by a four-year period of professional experience. The Court held that that requirement of professional experience in the case of training given over three years would be meaningless if training consisting of four years of study also fell within the scope of that rule. As remarked before, Mr. Egle completed a study comprising four years of education. If the Community legislature had wished to bring within that rule all courses of architectural training provided in the Fachhochschulen in the Federal Republic of Germany, it would not have distinguished between those lasting three years and those lasting four years.

It was thus concluded that Article 4(1)(a) of Directive 85/384/EEC is to be interpreted as meaning that education and training which last for four years, and which includes practical semesters organized and supervised by the Fachhochschulen, must be regarded as four years of full-time study.

In Bauer $^{311}$ the same question was posed, but this time in the light of Chapter III of Directive 85/384/EEC (Articles 10 and 11) which introduced transitional rules for Community nationals who commenced their studies during the third academic year at the latest, following notification of the Directive (August 1985). The Court referred to its interpretation and judgement in Egle, and stated that the third subparagraph of Article 11(a) must be interpreted in such a way that education and training which lasts for four years, and which includes two practical semesters supervised by the Fachhochschule of Stuttgart, must be regarded as four years of study.

311 Case C-166/91 Bauer v. Conseil National de l'Ordre des Architectes [1992] ECR I-02797. 
Dreesen (I) ${ }^{312}$ concerned a Belgian national residing in Belgium, who studied to obtain an engineer's diploma in building construction ('Ingenieur-Urkunde, Fachrichtung Hochbau') at the Aachen State Civil Engineering College. He received his diploma on 16 February 1966 and was then entitled to describe himself as 'Ingenieur (grad.)'.

From 1 August 1966 until 1991, that is for 25 years, Mr Dreessen worked in Belgium as a salaried architect in various firms of architects. After the bankruptcy of his last employer, he applied, on 12 December 1991, to the 'Ordre des Architectes de la Province de Liège' (Architects' Association of the Province of Liège) for his name to be entered on the register of that association, so that he could practise as a self-employed architect. The Council of the Architects' Association of the Province of Liège rejected his application on the ground that his diploma was 'not equivalent to a diploma awarded by a department of architecture within the meaning of the Directive'. Mr. Dreesen appealed against that decision. The Council of Appeal stayed the proceedings and requested the ECJ for a preliminary ruling on the interpretation of the expression 'Architektur/Hochbau' in Article 11 of Directive 85/384/EEC, and for a ruling on whether a diploma awarded in 1966 by the 'Allgemeiner Hochbau' (general construction) department of the Staatliche Ingenieurschule für Bauwesen Aachen must be treated as equivalent to a diploma awarded by the 'Architektur' department for the purposes of Article 11 of the Directive.

As held above, under Article 10 of the Directive, each Member State has to recognize the diplomas, certificates and other evidence of formal qualifications set out in Article 11, where such nationals already possessed these qualifications at the time of notification of the Directive or where their studies leading to such diplomas, certificates and other evidence of formal qualifications commenced during the third academic year at the latest following such notification. This is the case even if those qualifications do not fulfil the minimum requirements laid down in Chapter II. Member States have to give these qualifications as regards the taking up and pursuit of the activities referred to in Article 1, the same effect within their territory as the diplomas, certificates and other evidence of formal qualifications which they award in architecture. Under the fourth indent of Article 11(a) of the Directive, the diplomas, certificates and other evidence of formal qualifications referred to in Article 10, include, in Germany, the diplomas ('Pruefungszeugnisse') awarded before 1 January 1973 by the departments of architecture of Ingenieurschulen, accompanied by a certificate from the competent authorities to the effect that the person concerned has passed a test of his formal qualifications in accordance with Article 13. The question of interpretation raised by the fourth indent of Article 11(a) was thus whether that provision is capable of covering the engineer's diploma in Allgemeiner Hochbau awarded to Mr Dreessen on 16 February 1966.

To answer the questions, the ECJ referred to the distinction made in Directive 85/384/EEC between the definitive arrangements (Chapter II) relating to the professional title of architect and the transitional arrangements (Chapter III) for ensuring recognition of rights acquired in the field of architecture. The transitional system which was applicable to this case was characterized by an exhaustive list of the diplomas, cer-

312 Case C-447/93 Dreesen v Conseil national de l' Ordre des Architectes [1994] ECR I-4087. 
tificates and other evidence of formal qualifications of each Member State which are eligible for recognition. With respect to colleges of engineering in Germany, recognition was limited to the diplomas awarded by departments of architecture. Mr Dreessen's diploma was not awarded by such a department. Consequently, having regard to the wording of the fourth indent of Article 11(a) of the Directive, his diploma could not be recognized at Community level. According to the Court, the fact that the former colleges of engineering (Ingenieurschulen), which did not have departments of architecture, were incorporated as from 1971 into Fachhochschulen whose diplomas form part of the system of recognition introduced by the Directive, did not militate against that conclusion. Advocate General M. Darmon held in that regard that if this designation was incorrect or incomplete, it was up to the Member State in question -that is the Federal Republic of Germany- to seek and obtain an amendment to the Directive in order to correct that error or omission. It followed that a diploma awarded in 1966 by the Allgemeiner Hochbau department of the Staatliche Ingenieurschule für Bauwesen, Aachen, could not be equated with the diplomas referred to in the fourth indent of Article 11(a) of the Directive.

Dreesen (II) ${ }^{313}$ was the continuation of the Dreesen (I)-case. After the ECJ's negative ruling, Mr. Dreesen made a fresh application to the Provincial Council for his name to be entered on the register, claiming, primarily, that his diploma did not appear in the list in Article 11(a) of the Directive owing to an error on the part of the German authorities. He held that the Provincial Council should have carried out a comparative examination of the education and training received, in accordance with the Court's judgment in Vlassopoulou. The Provincial Council rejected his fresh application on the ground that it was not required to take into consideration Mr Dreessen's knowledge and qualifications, or to evaluate them. Since he had already made an application which had been rejected, his second application was held inadmissible as being res judicata. The Appeals Committee reversed that decision on 16 June 1999, finding that Mr Dreessen had shown that he possessed the qualifications and knowledge required under Belgian legislation, and ordered that his name be entered in the register of the Provincial Association. The National Council brought an appeal on points of law, claiming that where a Directive has been adopted on the basis of Article 47(1) EC (Article 53 TFEU) to determine the conditions for mutual recognition of the diplomas required for admission to a profession, the competent authorities of a Member State to which an application has been made for authorisation to practise that profession must restrict themselves to ascertaining whether or not the conditions laid down by the Directive have been met. The National Council held that where those conditions are not met, the competent authorities cannot go on to carry out a comparison between the qualifications and the knowledge of the applicant, and those required under the national provisions governing access to the profession -as the Appeals Committee had decided on the basis of Article 43 EC (Article 49 TFEU). Finally, the Belgian Supreme Court decided to refer a preliminary question to the ECJ. It asked whether Articles 10 (Article 4 TEU) and 43 EC meant that the competent authority of a Member State was required to take into consideration the diploma

313 Case C-31/00 Conseil National de l'Ordre des Architectes v. Dreesen [2002] ECRI-663. 
relied upon by the applicant, and to make a comparison between, on the one hand, the specialised knowledge and abilities and the qualifications evidenced by that diploma and, on the other hand, those required under the national rules, even where there exists, with regard to the profession in question, a Directive adopted by the Council on the basis of Article 47(1) and (2) EC (Article 53(1) and (2) TFEU), and that Directive provides, so far as it concerns courses of study taken up or pursued during a transitional period, an exhaustive list of the diplomas or certificates, awarded in the various Member States, which are to enable the profession concerned to be practised in the other Member States, where the applicant falls within the scope of that transitional scheme, and where the diploma on which he relies is not included in that exhaustive list.

The ECJ held that, by reason of the express terms of the question which gave rise to the judgment in Dreessen (I), which were solely concerned with the interpretation of Article 11 of the Directive, the Court gave no ruling on the possibility of Mr Dreessen's qualifications being recognised on the basis of the Court's interpretation of Article 43 EC in Vlassopoulou. In the case under consideration, by contrast, the question referred for a preliminary ruling specifically concerned that question. Therefore, the purpose of the present reference for a preliminary ruling was not to ascertain whether, in the case in the main proceedings, the national authorities were required to recognise Mr Dreessen's diploma as being equivalent to the qualifications in architecture referred to in Directive 85/384/EEC, but to ascertain whether those authorities must examine whether Mr Dreessen's professional qualifications and experience corresponded in full or in part to the requirements and conditions for access to the profession of architect in Belgium and, depending on the outcome of that examination, accord him the right to practise that profession there. The ECJ referred to its former rulings in Vlassopoulou, Haim ${ }^{314}$ and Hocsman ${ }^{315}$ and held that the authorities of a Member State to which an application has been made by a Community national for authorisation to practise a profession, access to which depends, under national legislation, on the possession of a diploma or professional qualification or on periods of practical experience, are required to take into consideration all of the diplomas, certificates and other evidence of formal qualifications of the person concerned and his relevant experience, by comparing the specialised knowledge and abilities so certified and that experience with the knowledge and qualifications required by the national legislation. The Court confirmed that those judgments are merely the expression of a principle inherent in the fundamental freedoms of the Treaty, and that the legal effect of that principle cannot be reduced as a result of the adoption of Directives on mutual recognition of diplomas. ${ }^{316}$

In Commission v. Greece ${ }^{317}$, the Commission brought a case before the ECJ since it held that by adopting and retaining in force the provisions of Article 3(1)(c) and (2) of Presidential Decree No 107/1993 (Decree No 107/1993) of 22 March 1993, and by accepting that the Greek Technical Board with which a person must be registered in order to be

314 Case C-319/92 Haim [1994] paragraphs 27-28.

315 Case C-238/98 Hocsman [2000] paragraphs 23.

316 See Hocsman, paragraphs 24-31.

317 Case C-471/02 Commission of the European Communities v. Hellenic Republic [2004] ECR I-7973. 
able to pursue the profession of architect in Greece, systematically refused to register Community nationals holding diplomas which had not been awarded in Greece and which ought to be recognised under Council Directive 85/384/EEC, the Hellenic Republic had failed to fulfil its obligations under that Directive.

In Greece, Decree No 107/1993 was adopted in order to implement, among others, the Directive. Article 3(1)(c) of Decree No 107/1993 laid down, among the conditions for obtaining authorisation from the Technical Board to pursue the profession of architect, the obligation to produce the certificate issued by the competent authorities of the person's Member State of origin, or of the State from which he comes, attesting that the diplomas or other evidence of formal qualifications submitted corresponded to those provided for by that decree. However, Article 27 of Directive 85/384/EEC provided that such a certificate could only be required in exceptional circumstances, where legitimate doubt existed. It follows that the obligation laid down in Article 3(1)(c) of Decree No $107 / 1993$ required the persons concerned to adduce additional proof not provided for in Directive 85/384/EEC. The Court held that such obligation had a deterrent effect which went against the facilitation of the effective exercise of the right of establishment, which the Directive and Article 43 EC (Article 49 TFEU) sought to achieve and to maintain.

Another complaint was associated with the fact that the Technical Board did not examine applications within the time-limits laid down in the Directive. In this regard, Article 20 of the Directive required that the procedure for authorising the person concerned to take up one of the activities in the field of architecture is to be completed as soon as possible, and not later than three months after presentation of all the documents relating to the person concerned. The only exceptions to that requirement were the institution of an appeal or where it was necessary to carry out a re-examination of the file if the host Member State had detailed knowledge of a serious matter which had occurred prior to the establishment of the person concerned in that State, or if it knew that the declaration referred to in Article 17(3) of the Directive contained incorrect information (see Articles 17(4) and 18(2) Directive 85/384/EEC).

None of the above derogations were pleaded by the Greek Government. Nevertheless, a quick and effective registration procedure is one of the objectives envisaged by the Directive. Accordingly, as held by the ECJ, the need to register the persons concerned as soon as possible applied to the whole of the procedure for the processing of applications and also for required the persons concerned to be called upon to complete their application by submitting any missing documentary evidence as soon as possible. That obligation was also among those flowing from Article $43 \mathrm{EC}$, which seeks to eliminate restrictions on the freedom of establishment. It followed that the Hellenic Republic had violated its obligations under Directive 85/384/EEC.

In Commission v. Spain ${ }^{318}$, the Commission started proceedings against Spain since Article 10(2) of the Spanish Royal Decree 1081/1989 of 28 August 1989 held that where work consists in drawing up construction projects or optionally assuming control over works, holders of qualifications in architecture awarded by another Member State which have been recognized in Spain pursuant to the provisions of the Decree, were not al-

318 Case C-421/98 Commission v. Spain [2000] ECR I-10375. 
lowed to pursue in Spain activities other than those which they were authorised to pursue in their country of origin on the basis of the qualifications awarded by the latter. This would only be different if they would collaborate with another member of the profession who is authorised to pursue those activities and who holds a qualification which is likewise recognised under Spanish law.

The Spanish Government submitted that it was for the national legislation of the host Member State to define the scope of activities of the profession of architect, and to determine the applicable legal regime. It held that Articles 2 and 10 of the Directive did not require more than that the host Member State should recognise diplomas awarded by other Member States and to give them the same effect within its territory as the diplomas which are awarded by itself. Since the definition of the profession of architect differs from Member State to Member State, the host Member State would enjoy wide powers to regulate the conditions under which the title of architect could be used.

The Commission, on the other hand, held that although the statutory definition of the field of architecture and the legal arrangements governing the profession of architect are matters for the national legislation of the host Member State, the scope of the activities of architects holding a qualification obtained in Spain is no wider than that of architects from other Member States. In the event that the scope was wider however, a migrant architect could, in the host Member State, have a wider scope in terms of professional activity than that for which he was originally trained. That possibility had been anticipated by the Directive which held in Article 1(2) that activities in the field of architecture shall be those activities usually pursued under the professional title of architect. ${ }^{319}$ It followed that the Community legislature accepted that the recognition of qualifications required by Articles 2 and 10 of the Directive may have the consequence that members of the profession will be authorised to exercise, under the professional title of architect, certain activities which their qualifications do not entitle them to pursue in their country of origin.

The Spanish Government referred to Article 1(2), and contended that the Directive indeed covered the activities usually pursued under the professional title of architect. In this regard, Spanish legislation recognised the diplomas, certificates and other formal qualifications that open the way to activities within the architectural sector that are usually pursued under the professional title of architect. However, the activities covered by Article 10(2) of the Royal Decree did not form part of these usual activities. According to the Spanish Government, activities consisting of drawing up construction projects or optionally assuming technical control over works, are matters which come, in various Member States, within the competence of civil engineers. Article 10(2) of the Royal Decree was designed precisely to remedy the fact that certain qualifications mentioned in the Directive do not confer on those holding them full competence within the technical field relating to the stability of buildings. The provision therefore required only that,

319 As held in the preamble, the mutual recognition of diplomas, certificates and other evidence of formal qualifications presupposes that such diplomas, certificates and other evidence of formal qualifications authorize the taking up and pursuit of certain activities in the Member State of issue. Therefore, the recognition of certain certificates under this Directive should continue to apply only insofar as the holders of such certificates will be authorized, in accordance with legal provisions still to be adopted in the Member State of issue, to take up activities under the professional title of architect. 
in the case where the formal qualification awarded in the Member State of origin does not confer full competence on the migrant architect, the latter must work in conjunction with another member of the profession who is appropriately authorised, and whose qualification is recognised by Spanish legislation. This other member of the profession did not necessarily need to be a Spanish national or to have obtained his qualification in Spain. According to the Spanish Government, there were thus significant differences in terms of the scope of the activities covered by the qualification giving access to the profession of architect and in regard to the training, tasks and liability of architects. In the absence of harmonisation of the rules relating to training and areas of competence of architects in the different Member States, the Spanish Government held that Article 46 $\mathrm{EC}^{320}$ allows the Member States to put in place mechanisms to ensure that those benefiting from the Directive may assume responsibility for the security of architectural projects. That is the situation, in particular, where a case involves members of the profession who, in their Member State of origin, are required to work in conjunction with another member of the profession in order to be able to guarantee that the project will meet the requirements of public security specific to that State. According to the Government, Article 10(2) of the Royal Decree complied with the principle of proportionality and was designed to protect public security, which is guaranteed by the requirement of collaboration with a member of the profession who is authorised to make structural calculations.

Nevertheless, the Commission held that in any event, in order to guarantee adequate protection for the recipient of the services supplied by an architect, the Community legislature provided in Article $16(2)^{321}$ of the Directive, a specific measure designed to inform consumers of the conditions of training and the origin of the qualification of migrant architects. Within the existing legal framework, Member States had thus at their disposal, safeguard measures designed to ensure that the Directive is effective and to remedy situations which do not satisfy the conditions of the Directive. Any additional measure taken by the host Member State, such as an obligation to work in conjunction with a member of the profession who is authorised, in that State, to perform the activities in respect of which the migrant architect has not received training, was thus prohibited. Furthermore, since it had not been established that there was a substantial difference regarding the training and the scope of the activities of architects from other Member States compared with holders of Spanish qualifications, it was not even necessary to consider whether Article 46 would be applicable to the present case. In addition, the Commission submitted that Article 10(2) did not comply with the principle of proportionality.

320 Article 46 (1) EC states: ' The provisions of this Chapter and measures taken in pursuance thereof shall not prejudice the applicability of provisions laid down by law, regulation or administrative action providing for special treatment for foreign nationals on grounds of public policy, public security or public health ...'

321 As held above, Article 16 (2) provides that if the academic title used in the Member State of origin, or in the Member State from which a foreign national comes, can be confused in the host Member State with a title requiring, in that State, additional education or training which the person concerned has not undergone, the host Member State may require such a person to use the title employed in the Member State of origin or the Member State from which he comes in a suitable form to be specified by the host Member State. 
The ECJ held that under Article 10(2) of the Royal Decree, the range of activities open to persons holding qualifications in architecture awarded by a Member State other than the Kingdom of Spain, is not the same as is open to persons holding qualifications obtained in Spain. However, Directive 85/384/EEC is designed to ensure mutual recognition of diplomas by giving the qualifications acquired in another Member State the same effect as they have in the host Member State as regards access to the activities usually pursued under the professional title of architect (Article 2 Directive). Furthermore, as noted above, Article 10 of the Directive which refers to acquired rights, extends mutual recognition to certain other qualifications which do not meet the requirements set out in Chapter II of the Directive, including those specified in Articles 3 and 4. It follows from Articles 2 and 10 of the Directive that, when an activity is usually pursued by architects holding a qualification awarded by the host Member State, a migrant architect holding a formal qualification coming within the scope of the Directive must also be able to pursue such an activity, even if his qualifications are not necessarily substantively equivalent in terms of the training received. The Court stipulated that, while it is true that it is for the national legislation of the host Member State to define the field of activities covered by the profession of architect, once an activity is considered by a Member State as coming within that field, the requirement of mutual recognition means that migrant architects must also be able to pursue that activity. As regards the Spanish Government's argument that the Directive, in accordance with Article 1(2) thereof, covers only activities usually pursued under the professional title of architect, and that the activities covered by Article 10(2) of the Royal Decree do not form part of those usual activities, the Court ruled that it was not disputed that those activities are usually pursued by architects holding a qualification awarded by the Kingdom of Spain. It follows that such activities therefore do come within the scope of the Directive. Furthermore, the preamble to the Directive makes it clear that Article 1(2) is not intended to provide a legal definition of activities falling within the architectural sector. Furthermore, with regard to the application of Article 46 EC (Article 52 TFEU) to the present situation, the ECJ held that it should be borne in mind that this provision is not designed to reserve certain matters to the exclusive jurisdiction of Member States, but permits national laws to derogate from the principle of free movement to the extent to which such derogation is and continues to be justified for the attainment of the objectives referred to in that Article (public health, public policy, public security) ${ }^{322}$ However, where Community Directives provide for harmonisation of the measures necessary to ensure the protection of a specific objective, recourse to Article $46 \mathrm{EC}$ is no longer justified, and the appropriate checks must be carried out and the measures of protection adopted within the framework outlined by the harmonising Directive. ${ }^{323}$ Directive 85/384/EEC provides for measures to be taken where there is no substantive equivalence between, on the one hand, the training received in the Member State of origin or from which the person concerned comes and, on the other, that provided in the host Member State. In this

322 This was already decided in Case C-5/77 Tedeschi v. Denkavit [1977] ECR 1555, paragraph 34.

323 Case C- 251/78 DenkavitFuttermittel v Minister für Ernährung, Landwirtschaft und Forsten des Landes Nordrhein-Westfalen [1979] ECR 3369, paragraph 14; Case C-190/87 Oberkreisdirektor des Kreises Borken and Another v Moormann [1988] ECR 4689, paragraph 10, and Case C-112/97 Commission v Italy [1999] ECR I-1821, paragraph 54. 
regard, Article 16(2) of the Directive even provides that if the academic title used in the Member State of origin, or in the Member State from which a foreign national comes, can be confused in the host Member State with a title requiring, in that State, additional education or training which the person concerned has not undergone, the host Member State may require such a person to use the title employed in the Member State of origin or the Member State from which he comes in a suitable form to be specified by the host Member State. It followed that, by providing, in Article 10(2) of the Royal Decree, that persons holding qualifications in architecture awarded by another Member State and recognised under the Directive, may not pursue in Spain activities other than those which they are authorised to pursue in their country of origin on the basis of the qualifications awarded by the latter, unless they collaborate with another member of the profession who is authorised to pursue those activities and who holds a qualification which is likewise recognised under Spanish law, the Kingdom of Spain had failed to fulfil its obligations under Articles 2 and 10 of that Directive. It follows that once an activity is regarded by a Member State as coming within the field of activities covered by the profession of architect, the requirement of mutual recognition means that migrant architects must also be able to pursue that activity.

In Commission v. Italy ${ }^{324}$ the Commission initiated proceedings against the Italian Republic for failing to adopt all the measures necessary to implement Articles 4(1) second subparagraph, 4(2), 7, 11 and 14 of Directive 85/384/EEC. This case dealt with the lack of implementation measures or the incorrect transposition of the Directive into domestic law, and the violation of Articles 43 and 49 EC. In this way Italy failed to implement Article 4(1) second subparagraph on the automatic recognition of the training given in the German Fachhochschulen, Article 4(2) on social betterment schemes, Article 14 on the recognition of qualifications issued by the German competent authorities attesting the equivalence of qualifications awarded from 8 May 1945 with the formal qualifications listed in Article 11 and Article 11 with regard to the recognition of the university diploma in civil engineering awarded by the Faculty of Engineering of the University of Oporto. In this regard the ECJ referred to the general principle that a Member State cannot rely on the direct effect of a Directive in order to absolve itself from taking, in due time, implementing measures sufficient to meet the purpose of that Directive. ${ }^{325}$ Since Member States always have to fulfil their supranational Community obligations, the Commission's complaint with regard to the abovementioned Articles was held to be well founded.

The Commission also made a complaint for the incomplete implementation of Article 7 of the Directive. According to this Article, each Member State has to communicate as soon as possible, simultaneously to the other Member States and to the Commission, the list of diplomas, certificates and other evidence of formal qualifications as well as any amendments which are awarded within its territory and which meet the criteria laid down in Articles 3 and 4. As held by Article 7(2) of the Directive, for infor-

324 Case C-298/99 Commission v. Italy [2002] ECR I-03129.

325 Case C-102/79 Commission v. Belgium [1980] ECR 1473, paragraph 12 and Case C-96/95 Commission v. Germany [1997] ECR I-1653, paragraph 37. 
mation purposes, the lists and the updating thereof will be published by the Commission in the Official Journal of the European Communities.

According to the Italian Government, it was not necessary to list expressly the qualifications which must be accorded automatic recognition under national law since to have an overview, it was sufficient to consult the Commission communications.

The ECJ held that Article 7 of the Architects' Directive does indeed not expressly require Member States to set out, in a national list, the qualifications to be accorded automatic recognition included in the lists published by the Commission pursuant to Article 7(2). However, the transposition of a Directive into national law must effectively guarantee the full application of the Directive in a sufficiently clear and precise manner so that, where the Directive is intended to create rights for individuals, the persons concerned can ascertain the full extent of their rights and, where appropriate, rely on them before the national courts. ${ }^{326}$ The Italian legislation did not contain provisions adequately stating which qualifications would be recognised by the Italian authorities. More specifically, annex A to Decree No 129/92 concerned only the recognition on a transitional basis of the qualifications mentioned in Article 11 of Directive 85/384/EEC. Article 2 of the decree provided merely that recognition was to be accorded to the qualifications fulfilling the requirements of Article 3 of the Directive, Article 5(1)(a) authorised the person concerned to establish himself when he is in the possession of a recognised qualification, and Article 9(1)(a) contained a similar provision on the exercise of freedom to provide services. Since it is essential that nationals of Member States are able to identify the qualifications which must be accorded automatic recognition by the host Member State in order to guarantee effective mutual recognition of qualifications in architecture, since this was not the case in Italy, the Italian Republic had failed to adopt the measures necessary to implement Article 7 of the Directive.

In the same case, problems were also encountered with regard to Article 4(2)(a) of the Italian Decree No 129/92 which provided that architects wishing to obtain recognition in Italy of a qualification awarded to them in another Member State are required to submit their original diploma or a certified copy. As held by the Court, this obligation constituted an impediment to the freedom of establishment, and to the freedom to provide services enshrined in Article 43 and 49 EC, in that it gives rise to additional obstacles for all architects applying for recognition of their qualifications, having regard to the risk of the original diploma being lost or of possible delay on the part of the Member State of origin in awarding that diploma, and the additional steps and costs resulting from the procedures for certifying true copies of original diplomas. Furthermore, the requirement specifying that the only acceptable evidence is the original of the diploma or a certified copy, is clearly disproportionate to the objective pursued -the practise of the profession only by those who have acquired certain qualifications attested by a recognised diploma (public interest) - in that it precludes any other form of evidence which might establish with the same degree of certainty the existence of the diploma in question, such as a certified statement or recognition of the applicant's diploma by the authorities or professional organisations of the Member State of origin. It followed that

326 Case C-365/93 Commission v Greece [1995] ECR I-499, paragraph 9; and Case C-96/95 Commission v Germany, paragraph 35 
Article 4(2)(a) of Decree No 129/92 was incompatible with Articles 43 and 49 EC. The same was true for Article 4(2)(c) of Decree No 129/92 and Article 4(1)(c) of Decree No $776 / 94$ which provided that the application for recognition of a qualification must be accompanied by a certificate of nationality. Article 4(3) of Decree No 129/92 and Article 10 of Decree No 776/94 stated that all documents which have not been drawn up in Italian must be accompanied by a translation into Italian. Those translations had to be certified as true to the original by the Italian diplomatic or consular authorities located in the Member State in which the documents were drawn up, or by an approved translator. Just like the requirement in Article 4(2)(a) of the Decree which was discussed above, the Court held that the requirements incorporated in Article 4(2)(c) of the Decree could not be regarded as necessary or justified by overriding reasons in the public interest. They were therefore incompatible with Article 43 EC.

With regard to Article 11(1)(c) and (d) of Decree No 129/92, the Court identified another violation of the Directive. According to Article 12 of the Directive, an exception to the minimum training requirements defined in Articles 3 and 4 is made with regard to architects to whom another Member State had issued a certificate stating that, at the time when Directive 85/384/EEC was implemented, they were entitled to bear that title in that other Member State, even though such persons did not fulfil the minimum requirements. The deadline for the validity of the certificates which could be issued in the context of Article 12 of the Directive corresponds to that for the obligation to implement the Directive, namely 5 August 1987. Article 11(1)(c) and (d) of Decree No 129/92 on the other hand, accorded the title of architect to persons who, before the decree entered into force, that is to say before 19 February 1992, were authorised to bear that title in another Member State. The extension of the deadline in Italy to February 1992 was said to be the result of the belated implementation of the Directive. Its intention was to give the persons concerned a transitional period corresponding to that which would have been prescribed if the Directive had been implemented on the due date. ${ }^{327}$ In this regard, the ECJ made it clear however that a Member State which had been late in implementing Directive 85/384/EEC may not extend the transitional period provided for in Article 12 of the Directive.

Furthermore, Article 9(1) of the Italian decree also violated EC law. This Article prohibited architects established in other Member States, and who wished to provide services in Italy, from having there a permanent infrastructure. In this respect, the Court referred to its previous rulings in Gebhard ${ }^{328}$ and Commission v. Italy ${ }^{329}$. It stipulated that the fact that the provision of services is temporary does not mean that the service provider may not equip himself with some form of infrastructure in the host Member State (including an office, chambers or consulting rooms) in so far as such infrastructure is

327 As held before, Article 12 of Directive 85/384/EEC relates to certificates issued to nationals of Member States by Member States in which there are regulations at the time of notification of this Directive governing the taking up and pursuit of the activities referred to in Article 1 under the professional title of architect, stating that the holder received authorization to bear the professional title of architect before the implementation of this Directive and had effectively exercised the activities in question under such regulations for at least three consecutive years during the five years preceding the issue of the certificate.

328 Case C-55/94 Gebhard paragraph 27.

329 Case C-145/99 Commission v Italy [2002] ECR I-2235, paragraphs 22 and 23. 
necessary for the purposes of performing the services in question. Consequently, Article 9 of the Decree was held to be incompatible with Article 49 EC.

Finally, Article 9(3) of Decree No 129/92 provided that even in respect of the provision of services, architects had to be enrolled on the registers held by the provincial councils and the national council of the professional body for architects. That registration was at the expense of the professional body for architects. Enrolment on the register of one provincial body did not authorise the provision of services in another province. Services could only be provided after the council had authorised registration. As stated above, Article 22(1) of Directive 85/384/EEC indicated in this respect that Member States shall, in the case of provision of services, exempt nationals of other Member States from registration with a professional organization or body. Member States may however, so as to permit the implementation of the provisions relating to professional conduct in force in their territory, require automatic temporary registration or pro forma registration with a professional organization or body or in a register, provided that this registration does not delay or in any way complicate the provision of services or impose any additional costs on the person providing the services. However, the registration required under the Italian legislation delayed the provision of services, since enrolment on the register occurred only within 30 days of submission of the application, while the first services could only be provided after effective registration. Furthermore, enrolment on the register of each provincial body in whose district a service was to be provided further complicated that provision of services. Article 9(3) of the Italian Decree thus violated Article 22 of Directive 85/384/EEC.

In Commission v. Hellenic Republic ${ }^{330}$, the ECJ held that by failing to adopt and communicate to the Commission, within the prescribed periods, the laws, regulations and administrative measures necessary to comply with Directive 85/384/EEC, the Hellenic Republic had failed to fulfil its obligations under the EEC Treaty. As stated before, the Court keeps, together with the European Commission, an eye on whether or not the EU Member States take the necessary measures to implement Directive 85/384/EEC. This should be an incentive for Member States to adopt implementing measures on time, and in a correct way, to prevent violation of EC law. The same was held in Commission $v$. Italy ${ }^{331}$.

The most recent example in which a failure by a Member State to fulfil its obligations under Directive 85/384/EEC was attacked was in Commission v. Portugal. ${ }^{332}$ In this case the Court held that by requiring holders of profession qualifications in architecture conferred by other Member States to sit an entrance exam for the Portuguese Institute of Architects whenever they were not enrolled in the institute of architects in another Member State, the Republic of Portugal has failed to fulfil its obligations under Articles 2 and 10 of Directive 85/384/EEC.

330 Case C-309/90 Commission v Hellenic Republic [1991] ECR I-5311. The exact facts of the case have not been published, but they are not that important because it is obvious that there was a violation of EC law due to a lack of communication.

331 Case C-296/90 Commission v Italy [1991] ECR I-03847.

${ }^{7332}$ Case C-43/06 Commission of the European Communties v. Republic of Portugal [2007] ECR I-73. 
It can be concluded that states and professional associations are quite inventive when it comes to thinking about reasons for restricting the entry of new professionals into their territory. However Directive 85/384/EEC and Directive 2005/36/EC are quite clear and precise and the above-mentioned case law demonstrates that the Court is quite active in safeguarding the free movement rights of EU architects. It is clear that application of the Directive does not always result in automatic recognition of the applicant's qualifications. It is thus possible that, even though a person holds a diploma in a field in which a Directive on mutual recognition of diplomas has been adopted, he cannot avail himself of the mechanism for automatic recognition laid down by such a Directive, for example because his diploma was awarded in a third country or because, for other reasons, the conditions for the applications of that mechanism are not met. Since the object of such Directives is to facilitate the mutual recognition of qualifications by laying down rules and common criteria which result, as far as possible, in automatic recognition, it is not the purpose for those Directives to make recognition of such qualifications more difficult in situations falling outside their scope, nor may they have such an effect. It follows therefore that Member States must comply with their obligations as regards mutual recognition of professional qualifications arising from the Court's interpretation of Articles 49 and $53 \mathrm{TFEU}^{333}$, in examining any application for authorisation to practise a profession, access to which depends, under national legislation, on the possession of a diploma or professional qualification or on periods of practical experience, where the diploma held by the Community national is not the subject of automatic recognition under a Directive on the mutual recognition of diplomas, even if such a Directive has been adopted in the professional field in question. As held by the Court in Dreessen (II), those authorities are thus required to take into consideration all of the diplomas, certificates and other evidence of formal qualifications of the person concerned as well as his relevant experience, by comparing the specialised knowledge and abilities so certified and that experience, with the knowledge and qualifications required by the national legislation. As held above, the fact that a person concerned cannot avail himself of the mechanism for automatic recognition laid down by the Directive on the mutual recognition of diplomas, does not necessarily entail that his qualifications will not be recognized at all.

Due to the clear system of Directive 2005/36/EC and the Court's case law, I expect that, in the future, most cases which will have to be decided upon will deal with the rights of third-country nationals who aim to practise their profession in the European Union. With the entry into force of the Lisbon Treaty on 1 December 2009, the ECJ is also competent to give preliminary rulings the Area of Freedom, Security and Justice. ${ }^{334}$ The recognition of the qualifications of third-country nationals will now be discussed.

333 See, in particular, Vlassopoulou, Haim and Hocsman.

334 As regards visas, asylum, immigration and other policies related to free movement of persons (in particular, judicial cooperation in civil matters, recognition and enforcement of judgments), any national court or tribunal -no longer just the higher courts- will be able to request preliminary rulings, and the Court will have jurisdiction to rule on measures taken on grounds of public policy in connection with cross-border controls. Consequently, the Court of Justice will have general jurisdiction in this area from the date of entry into force of the Treaty of Lisbon. 
Public Regulation of Architects at European Union Level

\section{Directive $2006 / 123 / \mathrm{EC}$ on services in the internal market ${ }^{335}$}

\subsection{Towards Directive 2006/123/EC}

As noted above, one of the Union's aims is establishing or ensuring the functioning of the internal market (Article 26 TFEU). In the decade after the completion of the first Single Market programme in 1993, the removal of barriers created at least 2.5 million extra jobs and an increase in wealth of nearly 900 billion Euros. ${ }^{336}$ Competition increased as companies found new markets in other Member States. As will be explained in Part III of this thesis, this generally entails that the price of numerous products decreases while the number of products available to consumers is augmented. Most of these benefits occurred in the market for goods however. With regard to services, the Single Market had not yet worked as well as it should have. A report from the Commission on 'The State of the Internal Market for Services' demonstrated that, a decade after the envisaged completion of the internal market, there were still a large number of barriers preventing or slowing down the development of services between Member States, in particular those provided by small and medium sized enterprises. ${ }^{337}$ There were still numerous barriers hindering service providers from establishing themselves in other Member States or from trading across borders, so that there was still a huge gap between the vision of an integrated European Union economy and the reality as experienced by European citizens and providers. These barriers were mostly administrative in nature and were based on the lack of mutual trust between Member States, fed by the legal uncertainty that is associated with cross-border activities. Since services accounted for between 60 and $70 \%$ of economic activity in the EU 25 $5^{338}$, Europe had a serious problem. Of course all these violations could be addressed by means of infringement proceedings launched by the Commission on a case-by-case basis. ${ }^{339}$ However, due to the range and scale of the problems identified, infringement proceedings alone could not cure the encroachments, certainly not in a systematic way. The numerous country-specific regulations led to barriers to free movement which could only be removed solely by relying on direct application of Articles 49 and 56 TFEU (Articles 43 and 49 EC). ${ }^{340}$ Especially following the 2004 enlargement, it became extremely complicated and costly for national and Community institutions to address these barriers on a case-by-case basis through infringement procedures against the Member States concerned. Moreover, the

335 Directive 2006/123/EC of the European Parliament and of the Council of 12 December 2006 on services in the internal market. The Directives is also called the 'Services Directive' or the 'Bolkestein Directive' as a reference to the Commissioner who proposed this Directive to extend the market even more.

336 See http://ec.europa.eu/internal_market/services/docs/services-dir/explanatory/completing_UE_SM_for_services_en.pdf, last consulted 17 December 2009.

337 A characteristic of country-specific regulations is that they cause additional fixed costs that are often independent of firm size. This implies that, in relative terms, the strongest effect of policy heterogeneity falls upon small-and medium-size service firms. See Kox, Lejour \& Montizaan 2004, p. 9.

338 Services account for $+/-70 \%$ of the gross domestic product (GDP) and employment in the majority of Member States. See http://ec.europa.eu/internal_market/top_layer/index_19_en.htm, last consulted 17 December 2009.

339 De Witte 2007, p. 5-6.

340 See recital 1 of the preamble to Directive 2006/123/EC. 
lifting of many barriers requires prior coordination of national legal schemes, including the setting up of administrative cooperation.

Since services constitute the engine of economic growth and since the fragmentation of national regulations has a negative impact on the entire economy and prevents consumers from gaining access to a greater variety of competitively priced services, the European Commission proposed a Directive on services in the internal market in March $2004 .{ }^{341}$ In this way the Directive aimed to provide a legal framework that would eliminate the obstacles to the freedom of establishment for service providers and the free movement of services between the Member States, so that the EU would become the most competitive and dynamic knowledge based society in the world by the year 2010 and would achieve the goal set by the European Council in Lisbon on 23 and 24 March 2000. It has been argued that the Commission realized at the time that the double-track approach to the establishment and functioning of the internal market for services (on the one hand, the most 'obstructed' and economically important sectors had been the subject of sector-specific internal market legislation as part of the 1992 programme and, on the other hand, the Court of Justice of the European Union had put in place a 'catchall' legal regime ${ }^{342}$ which allowed the Commission -in its other capacity as guardian of the Treaty- and interested firms or individuals to tackle national impediments to the services market that had been left in place by the EU legislative programme) was not sufficient for the establishment of a true single market of services. ${ }^{343}$ During its plenary session in Strasbourg on 15 November 2006, the European Parliament reached an agreement on the proposal.

To overcome these difficulties, Directive 2006/123/EC (the Services Directive) was created. This establishes a general legal framework that benefits a wide variety of services while taking into account the distinctive features of each type of activity or profession and its system of regulation. Since legal obstacles are often common to a large number of different activities, the Commission opted for a horizontal approach. In the Explanatory Memorandum to the Proposal of the Directive it was held that the adjustment of legislation by all the Member States according to common principles and a common timetable would make it possible to benefit on a European scale from the resulting economic growth, to avoid distortions of competition between Member States that make their adjustments at different rates, and to encourage improved mobilisation around this objective, also in terms of the allocations of national and Union administrative resources.

${ }^{341}$ Proposal for a Directive of the European Parliament and of the Council on services in the internal market, COM 20042 Final - 2004/0001 COD.

${ }^{342}$ The ECJ stated in 1991 that the Treaty requires the abolition of any restriction, even if it applies without distinction to national providers of services and to those of other member States, when such a restriction is liable to prohibit or otherwise impede the activities of a provider of services established in another Member State. See Case 76/90 Säger v. Dennemeyer, paragraph 12. This extension of the scope of the Treaty prohibition was compensated by the fact that national restrictions, if indistinctly applied, may be kept in place if they are necessary to achieve one of a long list of mandatory requirements: See Gebhard.

${ }_{343}$ De Witte 2007, p. 11. 
Public Regulation of Architects at European Union Level

\subsection{Content of Directive 2006/123/EC}

\subsubsection{General provisions}

The Services Directive, which is based on Articles 53(1) jo 62 TFEU (Articles 47(1) jo 55 EC) builds on, and complements, the Union acquis, especially with regard to the rules concerning the freedom of establishment and the freedom to provide services. ${ }^{344}$ Its provisions are, to a large extent, based on the rulings of the ECJ, so that its content is not a novelty but a clarification of the Court's case law. It does not result in a detailed and systematic harmonisation, but is limited to the essential rules concerning the freedom of establishment and services. Harmonisation is only opted for in terms of matters with regard to which other solutions are deemed to be ineffective, such as administrative cooperation or reliance on the adoption of codes of conduct by the interested parties at Community level.

It is important to note that the Directive has a residual character: it only applies if no other, more specific Directive, regulation or other EC act, applies. As held by recital 31, the Directive is consistent with, and does not affect, Directive 2005/36/EC. It deals with questions other than those relating to professional qualifications, such as professional liability insurance, commercial communications, multidisciplinary activities and administrative simplification. ${ }^{345}$ Both Directives are thus complementary instruments. With regard to temporary cross-border service provision, a derogation from the provision on the freedom to provide services in this Directive ensures that Title II on the free provision of services of Directive 2005/36/EC is not affected. Therefore, none of the measures applicable under that Directive in the Member State where the service is provided is affected by the provision on the freedom to provide services. This is confirmed in Article 3(1)(d) which holds that, if the provisions of this Directive conflict with a provision of another Community act governing specific aspects of access to, or exercise of, a service activity in specific sectors or for specific professions such as the Professional Qualifications Directive, the provisions of the other Community act shall prevail, and shall apply to those specific sectors or professions. It should be noted that this concerns only the specific conflicting provisions and not the remaining provisions of the Service Directive which will still apply. Important within the scope of this thesis is that recital 33 specifically indicates that the Services Directive includes the services provided by architects.

It should be noted that even though Directive 2006/123/EC is often referred to as the 'Services' Directive, the concept of 'service provider' should not be limited solely to cross-border service provision within the framework of the free movement of services (Article 56 TFEU), but should also cover cases in which an operator establishes itself in a Member State in order to develop its service activities there (Article 49 TFEU). ${ }^{346}$ In

\footnotetext{
344 See recital 30 of the preamble to Directive 2006/123/EC.

345 An example of administrative simplification is the use of electronic procedures.

346 See recital 77 of the preamble to Directive 2006/123/EC.
} 
this way Article 1(1) holds that the Directive establishes general provisions facilitating the exercise of the freedom of establishment for service providers, and the free movement of services, while maintaining a high quality of services. The Directive shall apply to services supplied by providers established in a Member State (Article 2(1)). It follows that the following types of service provision are thus included: services provided by someone who establishes in another Member State; services provided by someone who temporarily moves to the country where the customer is located; services provided by someone at a distance from his country of establishment, for example over the internet, by phone, or through direct marketing; services provided by someone in his home Member State to a customer who has travelled from another Member State. ${ }^{347}$

\subsubsection{Administrative simplification}

Chapter II of the Directive contains rules on administrative simplification. As held by Article 5(1), Member States have to examine the procedures and formalities applicable to access to a service activity and to the exercise thereof, and simplify them in the event that the procedures and formalities are not sufficiently simple. In this way Member States have to accept any document from another Member State which proves the possession of a certificate, attestation, or any other document proving that a requirement ${ }^{348}$ has been satisfied, and may not require a document from another Member State to be produced in its original form save in the cases provided for in other Community instruments, or where such a requirement is justified by an overriding reason relating to the public interest, including public order and security (Article 5(3)). However, this is not the case with regard to the documents referred to in Article 7(2)-documents which may be demanded before the first provision of services- and Article 50 of Directive 2005/36/EC -documents which can be required in the event of establishment in another state to pursue a profession (see Article 5(4)). It follows that these documents may be demanded in their original form or as a certified copy.

A very important provision is Article 6(1) which indicates that Member States have to ensure that it is possible for providers to complete procedures and formalities for access to the exercise of services activities through points of single contact. These points have an important role to play in providing assistance to providers, either as the authorities directly competent to issue the documents necessary to access a service activity, or as

347 Examples are hotel services, services provided in theme parks or other tourist attractions, and health services.

348 The Services Directive applies to those requirements which affect the access to, or the exercise of, a service activity. As held by Article 4(7), the concept of requirement covers any obligation, prohibition, condition or limit provided for in the laws, regulations or administrative provisions of the Member States, or in consequence of case-law, administrative practice, the rules of professional bodies, or the collective rules of professional associations or other professional organisations, adopted in the exercise of their legal autonomy. The Services Directive does not apply to those requirements which do not specifically regulate or specifically affect the service activity, but have to be respected by providers in the course of carrying out their economic activity in the same way as by individuals in their private capacity. This means that, for example, rules concerning the development or use of land, town and country planning as well as building standards will generally not be affected by the Services Directive (recital 9). 
intermediaries between the provider and the authorities which are directly competent. In this way, service providers do not need to contact several competent authorities or bodies $^{349}$ to collect all relevant information, and to complete all necessary steps relating to their service activities. It follows that administrative procedures are further simplified in this way (recital 48). It should be noted however, that the detailed tasks of the points of single contact differ from the tasks of the contact points mentioned in Article 57 of Directive 2005/36/EC, insofar as the latter handle only the information requirements ${ }^{350}$ for the recognition of professional qualifications. Whereas only one single contact point is to be set up in each Member State which will make available information concerning recognition of professional qualifications and assistance to citizens wishing to have their professional qualifications recognised in another Member State, the points of single contact will make it possible for citizens and businesses to actually complete all procedures and formalities relating to access to, and exercise of, service activities, including those related to the recognition of professional qualifications. It follows that the role of the points of single contact is to inform providers of services (from other EU Member States and from its own State) complete and comprehensive information about all relevant procedures and formalities needed for access to his service activity ${ }^{351}$; coordinate requests from providers with the relevant competent authorities, and receive certain obligatory information from the provider such as applications for authorisation that is needed to exercise his service activity. In this regard it should be emphasized that the points of single contact do not monopolise access to the competent authorities. Service providers are free to communicate directly with these authorities. The competence of the points of single contact includes the means by which service providers can complete all pertinent procedures and formalities, although the Commission has clarified that

349 As held by Article 4(9) Directive 2006/123/EC, competent authorities are any body or authority which has a supervisory or regulatory role in a Member State in relation to service activities, including, in particular, administrative authorities, including courts acting as such, professional bodies, and those professional associations or other professional organisations which, in the exercise of their legal autonomy, regulate in a collective manner access to service activities or the exercise thereof. Hence it may be concluded that the term 'competent authority' is not applied in the same sense as in Article 56 of Directive 2005/36/EC which defines competent authorities in Article 3(d) as any authority or body empowered by a Member State to issue or receive training diplomas and other documents or information and to receive the applications, and take the decisions referred to in this Directive. The real differences between the two types of competent authorities will only become clear after the implementation of the two Directives in the Member States and it seems that some governments may decide that both roles should be taken up by the same body or authority as there is a certain logic in such an approach: See Architects' Council of Europe, Directive 2006/123/EC on Services in the Internal Market (SIM), Guide for the Member Organisations of the ACE on Transposition and Implementation of the SIM Directive, Draft version 6.1, 12 September 2007.

350 These information requirements include the relevant laws, codes of conduct and social legislation. The Contact Points are supposed to form a network structure at European level as the Directive only requires that one Contact Point be defined by each Member State.

351 As held by Article 7 (1), Member States shall ensure that certain necessary information is available to the providers and recipients through points of single contact (PSC). If concrete questions arise, the PSC must act as a portal to the relevant competent authority that can provide more detailed information and advice on the general interpretation and application of the relevant requirements. This information must be delivered in plain and intelligible language, easily accessible to service providers and recipients, available by electronic means (Article 7 (1) and (3)), up-to date (Article 7(3)) and delivered as quickly as possible (Article 7 (4)). The PSC do not give legal advice in individual cases, but general information on the way in which requirements are usually interpreted (Article 7(6)). 
Member States may decide that they only play a coordinating role so that final decisions remain with the existing competent authorities. ${ }^{352}$ To speed up the process, Member States have to ensure that all procedures and formalities relating to access to a service activity and to the exercise thereof, may be easily completed through the relevant point of single contact and with the relevant competent authorities, at a distance, and by electronic means (Article 8). It follows that Directive 2006/123/EC contains some new rules which encourage and even oblige Member States to actively cooperate with each other when dealing with cross border service provisions. The Directive aims to ensure that this cooperation works effectively and rapidly.

\subsubsection{Measures relating to the freedom of establishment for service providers}

Chapter III of the Directive only applies to cases of establishment and not to crossborder service provision. The freedom to provide services is specifically dealt with in Chapter IV. Chapter III covers both the situation where a service provider seeks to establish in another Member State and the situation where he wants to establish in his own State. In short, Member States have to examine whether existing authorisation and licensing schemes can be replaced by simpler measures such as notifications (Article 9). Authorisation schemes which are maintained must respect principles such as nondiscrimination, objectivity and transparency. Any measures that are discriminatory to the provider, and that are not objectively justifiable by an over-riding reason relating to the public interest, are therefore not allowed. In addition, authorisation procedures will have to be streamlined, criteria for obtaining an authorisation will have to be known in advance, and deadlines for replies will have to be made public and respected. The procedures will thus be screened and, where unjustified, removed.

Article 14 contains a list of requirements which are prohibited and which can thus not be maintained by Member States. Examples are requirements that are discriminatory or in other ways particularly restrictive ${ }^{353}$, prohibitions on having an establishment in more than one Member State, a case-by-case application of an economic test making the granting of authorisation subject to proof of an economic or market need ${ }^{354}$, an obligation to provide or participate in a financial guarantee or to take out insurance from a provider or body established in their territory, an obligation to be pre-registered, for a given period, in the registers held in their territory, or to have previously exercised the activity for a given period in their territory. Article 15 on the other hand, contains examples of severe obstacles to the freedom of establishment which are subject to evaluation since they can often be replaced by less restrictive means, but might nevertheless be justified. There is no outright prohibition, but Member States are required to review their legislation and rules provided for by professional associations and to evaluate these on the basis of the criteria of non-discrimination, necessity and proportionality as set out in Article 15(3). Member States have to examine whether their legal systems impose

352 See recital 48 of the preamble and Article 6 (2) of the Directive.

353 In many cases the ECJ has already found them to be incompatible with Article $43 \mathrm{EC}$, such as nationality requirements or requirements relating to the place of residence of providers.

354 This prohibition shall not concern planning requirements which do not pursue economic aims, but serve overriding reasons relating to the public interest. 
certain requirements on service providers, including quantitative or territorial restrictions, in particular in the form of limits fixed according to population or of a minimum geographical distance between providers, obligations to operate through specific legal forms ${ }^{355}$, requirements relating to shareholding in a company ${ }^{356}$, requirements relating to reserved functions, and compliance with fixed minimum and/or maximum tariffs (cost information systems) $)^{357} .{ }^{358}$ It is noted that such requirements are permissible, provided they are non-discriminatory, necessary and proportional.

It can be concluded that obstacles to the freedom of establishment will be eliminated through:

- administrative simplification measures in Member States which make it easier for a service provider in one Member State to become established in another Member State

- $\quad$ certain principles which authorization schemes must respect: they cannot discriminate against a service provider on grounds of nationality; the authorisation schemes must be objectively justified (they must be in the public interest) and the objective cannot be attained by means of a less restricted measures (Article 9);

- $\quad$ the prohibition of particularly restrictive legal requirements (Article 14);

- the obligation to assess further certain other legal requirements (Article 15). ${ }^{359}$

\subsubsection{Measures relating to the free provision of services}

With regard to the freedom to provide services, Article 16(1) indicates that Member States shall respect the right of providers to provide services in a Member State other than that in which they are established. As noted above, the freedom to provide services is characterized by the absence of a stable and continuous participation in the economic life of the host Member State. The Member State in which the service is provided shall ensure free access to and free exercise of a service activity within its territory. ${ }^{360}$ It cannot

355 As held by recital 38, the concept of 'legal person' leaves operators, according to the Treaty provisions on establishment, free to choose the legal form which they deem suitable for carrying out their activity.

356 In a case concerning the establishment of opticians, the ECJ found that imposing a given level of participation of opticians in the share capital was not proportionate for attainment of the objective of protecting public health: See Case C-140/03 Commission v Hellenic Republic [2005] ECR I-3177. In this case, less restrictive measures were deemed to be possible e.g. by requiring the physical presence of qualified, salaried or associated professionals in each shop, by applying rules concerning civil liability for the action of others or national rules requiring professional liability insurance.

357 Such tariffs are often not necessary since rules relating to qualifications, professional ethics, organisation, supervision and liability may suffice in themselves to attain the objectives of the protection of consumers. See Joined Cases C-94/04 and C-202/04 Federico Cipolla v. Rosaria Fazari, née Portolese and Stefano Macrino and Claudia Capodarte v. Roberto Meloni [2006] ECR I-1 1421.

358 See Article 15 (2) of the Directive.

359 See http://www.entemp.ie/trade/marketaccess/singlemarket/servicesDirective.htm, last consulted 19 December 2009.

360 See Article 16 (1) of the Directive. Article 16 (1) used to state initially (first reading): 'Member States shall ensure that providers are subject only to the national provisions of their Member State of origin which fall within the coordinated field.' This was referred to as the 'country of origin' principle. Member States were not allowed to restrict the freedom to provide services in the case of a provider established in another Member State, so the country of destination had no right to impose new regulations (Articles 17,18 and 19 
make access to, or exercise of, a service activity on its territory subject to requirements which do not respect the principles of non-discrimination, necessity and proportionality. It follows that this general rule is a codification of the objective justification test laid down in Gebhard. In this regard, host Member States are not allowed to demand that services providers have an establishment in their territory, in order to obtain an authorisation from the competent authorities, including entry in a register or registration with a professional body or association in their territory (except where provided for in this Directive or other instruments of Community law) or to impose other obligations which hinder service provision. ${ }^{361}$ Only requirements which are justified for reasons of public policy, public security, public health or the protection of the environment, and which are in accordance with Article 16(1), can be accepted (Article 16(3)). Member States should therefore refrain from applying their own requirements to services providers established in other Member States. However, they are allowed to maintain their requirements with regard to their national operators.

contained some derogations). Only the country of origin could supervise the provider and the services performed by him. The basic principle was thus that when the requirements of the country of establishment were fulfilled, one would automatically be considered to fulfil the requirements of the other EU-countries too. However, this led to a great deal of criticism since the states which imposed the lowest level of regulation could set the norm. One feared that this could lead to a 'race to the bottom' and it did not take long before the Bolkestein Directive was called the 'Frankenstein' Directive. Furthermore, as held by De Witte, 'The country of origin principle represented a substantive shift compared to the ECJ's case law, and compared to the Commission's own approach in drafting internal market legislation. The case law of the ECJ does not challenge, as a matter of principle, the application of the host country's laws and regulations. The principle of mutual recognition, as adopted by the Court, simply meant that the host state must take into account the laws and regulations to which the service provider is subject in its home state, so as not to create unjustified double burdens. This is not the same thins as imposing, as a matter of principle, the application of the laws of the country of origin.' See De Witte 2007, p. 8.

The final version of the Directive does not include the 'country of origin' principle as such but, instead, reminds Member States of the principle of free movement, while accepting inroads when free movement collides with other public interests. However, before making such inroads, authorities have to verify and recognize any protection already provided in the country of origin - under the mutual recognition principle, they need to take into account what takes places in other countries before proceeding. It was said that, because of this, the Directive on Services has become less liberal and that the 'free game of the social forces' is bound by more rules: See Kranenburg, 'Minder Liberaal', NRC Handelsblad, 15 November 2006. As held by De Witte, the price for the removal was the enactment of a highly complex and very confusing Article 16, which, taken as a whole, is reminiscent of the existing case-law of the ECJ on restrictions of services, but with some major differences which are not well explained in the rambling preamble of the Directive. Article 16(3) which specifies the acceptable justifications for host country requirements does not name the mandatory requirements which the ECJ has recognized: See De Witte, p. 10. The country of origin principle in the Commission's original proposal would have allowed service providers to jump over such restrictions when operating temporarily in another country. It was rejected for several reasons including concerns about possible abuses and monitoring problems. Under the Directive that is now adopted, the barriers that may remain after the screening process and the application of the freedom to provide services clause will still need to be challenged using the existing infringement procedures. Because the legal process is slow, the Directive should be bolstered by quicker and cheaper remedies in order to get the greatest benefit from the reform. See: 'Economic survey of the European Union 2007: Ever closer union? Moving forward in the single market',

http://www.oecd.org/document/30/0,3343,en_2649_34111_38979998_1_1_1_1,00.html, last consulted 18 August 2009.

361 See for more examples Article 16 (2) of the Directive. 
Very important within the scope of this thesis is that Article 17 provides that Article 16 shall not apply to matters covered by Title II of Directive 2005/36/EC. It follows that Article 16 will only apply to those matters not linked to professional qualifications such as commercial communications, multidisciplinary partnerships, tariffs, advertising, etc. This means that Title II of Directive 2005/36/EC fully applies, encompassing that the host Member State can, for example, require on an annual basis a prior declaration, including the details of any insurance cover or other means of personal or collective protection regarding professional liability, and the provider will be subject to professional rules of a professional, statutory or administrative nature, which are directly linked to professional qualifications. Article 17 also excludes from the application of Article 16, requirements reserving an activity to members of a certain regulated profession. It follows that if a Member State reserves the design of buildings to architects, the provisions on the freedom to provide services in Article 16 will not apply. Thus, a person who is allowed to design building projects in his Member State of establishment, but is not qualified as an architect, will not be able to rely on Article 16 to provide architectural services in another Member State where such services are reserved to architects. While this provides comfort to the profession, it must be recalled that the derogation does not apply to matters such as commercial communications, multidisciplinary practices, tariffs, etc., for which the provisions of Article 16 apply. ${ }^{362}$ In these cases the measures applicable in the host Member State will not be affected. In exceptional circumstances Member States may also take measures relating to the safety of services (Article 18).

Section 2 of Chapter IV deals with the rights of service recipients. As held by Article 19, Member States may not impose on a recipient, requirements which restrict the use of services supplied by a provider established in another Member State. In this way the general conditions of access to a service are not allowed to contain discriminatory provisions (Article 20). Member States have to ensure that recipients can obtain, in their Member State of residence, information relating to the requirements applicable in other Member States in terms of the access to, and exercise of, service activities, and in particular, those relating to consumer protection, information on the means of redress available in the case of a dispute between the provider and the recipient, and the contact details of associations or organisations, including the centres of the European Consumer Centres Network, from which providers or recipients may obtain practical assistance (Article 21).

In order to eliminate obstacles to the free movement of services, Directive 2006/123/EC provides for the free movement of services which means that Member States have to respect the right of service providers to provide services in a Member State other than that in which they are established, as well as the right of recipients to avail themselves of

362 Matters covered by the provisions of Directive 2004/38/EC that lay down administrative formalities of the competent authorities of the Member State where the service is provided with which the beneficiary must comply as well as matters covered by Directive 96/71/EC (posting of workers)are likewise excluded. With regard to posted workers, the rules of the host Member State (where the employee is sent to work) are applicable. 
services from other Member States which will bring about increased competition in different sectors of the economy to the benefit of consumers. ${ }^{363}$

\subsubsection{Quality of services}

In Chapter V, the Directive sets out a range of provisions that Member States can implement in order to encourage service providers to improve the quality of their services. A high quality of service is aimed for by encouraging, among other things, selfregulation through the elaboration of European Codes of Conduct. However, only a few provisions of Chapter $\mathrm{V}$ are obligatory in nature, such as the requirement to make certain information available to recipients, information on the professional body with which the provider is registered in case of regulated professions, the professional title, the Member State in which the title has been granted, the price of the services, the insurance details, etc. ${ }^{364}$ In this regard, Member States have to ensure that providers supply the following information at the recipient's request: the price of the service (where the price is not pre-determined by the provider) or the method for calculating the price or a sufficiently detailed estimate (if an exact price cannot be given), a reference to the professional rules applicable in the Member State of establishment, and how to access them $^{365}$, and information on multidisciplinary activities and partnerships which are directly linked to the service in question, and on the measures taken to avoid conflicts of interest. The provider also has to specify how to access detailed information on the characteristics of, and conditions for, the use of non-judicial means of dispute settlement (Article 22(3)). Member States may ensure that any operator providing services involving a direct and particular health, safety or financial risk for the recipient or a third person, subscribes to appropriate professional liability insurance ${ }^{366}$, or to another form of guarantee which is equivalent or comparable. ${ }^{367}$ This means that such an operator must have adequate insurance cover for services provided in one or more Member States other than his Member State of establishment. However, since the insurance or guarantee should be appropriate to the nature and extent of the risk, it should be necessary for the provider to have cross-border cover only if he actually provides services in other Member States. As held by Article 23(2), when a provider establishes himself in their territory, Member States may not require professional liability insurance or a guarantee from the provider when he is already covered by a guarantee which is equivalent, or essentially comparable as regards its purpose, and the cover it provides in terms of the insured risk, the insured sum or a ceiling for the guarantee and possible exclusions from the cover, in another Member State in which the provider is already established. Where equivalence is only partial, Member States may require a supplementary guaran-

363 See http://www.entemp.ie/trade/marketaccess/singlemarket/servicesDirective.htm, last consulted 19 December 2009.

364 See Article 22 (1) of the Directive.

365 This requirement holds with regard to regulated professions.

366 As held by Article 23(5), professional liability insurance refers to insurance taken out by a provider in respect of potential liabilities to recipients and, where applicable, third parties arising out of the provision of the service.

367 See recital 98 to the preamble of the Directive and Article 23 (1). 
tee to cover those aspects not already covered. Since providers and insurance companies should maintain the necessary flexibility to negotiate insurance policies precisely targeted to the nature and extent of the risk, Member States should not lay down more detailed rules concerning the insurance cover and fix, for example, minimum thresholds for the insured sum or limits on exclusions from the insurance cover. Furthermore, as indicated by recital 99, it is not necessary for an obligation of appropriate insurance to be laid down by law. It should be sufficient if an insurance obligation is part of the ethical rules laid down by professional bodies. There should be no obligation for insurance companies to provide insurance cover.

Article 24 deals with commercial communications ${ }^{368}$. Member States have to remove all total prohibitions on commercial communications. This is specifically with regard to bans which forbid one or more forms of communication, such as a ban on all advertising in one or more given media (recital 100). Furthermore, Member States have to ensure that commercial communications by the regulated professions comply with professional rules which relate in particular to the independence, dignity and integrity of the profession, as well as to professional secrecy in a manner consistent with the specific nature of each profession and in conformity with EU law. ${ }^{369}$ In any case, professional rules on commercial communications shall be non-discriminatory, justified by an overriding reason relating to the public interest and be proportionate. As regards the content and methods of commercial communication, it is deemed to be necessary to encourage professionals to draw up, in accordance with EU law, codes of conduct at EU level. ${ }^{370}$

Article 25 contains measures on multi-disciplinary partnerships. Member States have to ensure that providers are not made subject to requirements which oblige them to exercise a given specific activity exclusively, or which restrict the exercise jointly or in partnership, of different activities. As will be explained in more detail hereunder, it is in the interest of recipients, in particular consumers, to ensure that it is possible for providers to offer multidisciplinary services. Nevertheless, recital 101 indicates that, with regard to the regulated professions, an exception might be justified in order to guarantee compliance with the rules governing professional ethics and conduct which vary according to the specific nature of each profession, and can be necessary in order to ensure their independence and impartiality (recital 101). In this regard the Directive indicates that the prevention of conflicts of interest and the independence and impartiality required for certain services activities, should be protected next to the removal of restrictions on the free movement of the provider. It follows that Member States which allow multidisciplinary activities must ensure that conflicts of interest are prevented, that the independence and impartiality required for certain activities is ensured, and that the rules governing professional ethics and conduct for different activities are compatible with

368 The notion of commercial communication covers any form of communication aimed at promoting services or the image of a service provider (Article 4 (12)). It thus covers advertising as well as other forms of commercial communication, such as business cards mentioning the title and speciality of the service provider.

369 European Commission, Handbook on the Implementation of the Services Directive, 2007, p. 49.

370 See Article 37 of the Directive. 
one another. With regard to the architectural profession, this is of growing importance, since the design and creation of buildings becomes every day more complex due to the introduction of new and different techniques.

To obtain a high level of quality, Article 26 indicates that Member States have to resort to the certification or assessment of services by independent or accredited bodies that will verify whether a provider has performed the services required properly and in accordance with specific standards. Another possibility in terms of ensuring quality is the drawing up by Member States of their own quality charter, or participation in quality charters or labels, drawn up by professional bodies at community level. The development of voluntary European standards should be encouraged ${ }^{371}$ Furthermore, Member States have to take the general measures necessary to ensure that providers who are subject to a code of conduct or are members of a trade association or professional body, which provides for recourse to a non-judicial means of settling disputes, should inform the recipient thereof. ${ }^{372}$ In the majority of the Member States, such procedures are already in place for the resolution of disputes between architects and their clients. In this way the number of cases that end up in front of the courts can be reduced.

\subsubsection{Administrative cooperation}

Chapter VI obliges Member States to give each other mutual assistance, and to put in place measures for effective cooperation to ensure the supervision of providers and their services (Article 28). The chapter aims to enhance trust and confidence between the Member States by improving the efficiency of supervision. The Member State of establishment has to supply information on providers established in its territory when requested to do so by another state and has to undertake inspections, checks and investigations if requested (Article 29). Articles 30 and 31 provide for a division of tasks between the Member States involved, and indicate which Member State's requirements apply. Each Member State is, in principle, responsible for the supervision and enforcement of its own requirements. Other Member States have to cooperate in the effective supervision. Article 31(1) foresees supervision with respect to national requirements which may be imposed pursuant to Articles 16 or 17, by the Member State where the service is provided, in the event of the temporary movement of the provider, while Article 30(1) deals with supervision by the Member State of establishment in the event of the temporary movement of a provider to another Member State. The latter occurs if the Member State where the service is provided is not allowed to apply its own requirements to service providers because they cannot be categorized under Articles 16 or 17 of the Directive. ${ }^{373}$ At the request of a competent authority of a Member State, Member States have to supply information on disciplinary or administrative actions or criminal sanc-

371 The Architects' Council of Europe, which is the representative organisation of the architectural profession in the European Union, has already done substantial work in this area. It adopted a Code of Conduct in November 2005 and a Guide to Quality Management which makes it easier to apply certification or assessment methods.

372 See Article 27 of Directive 2006/123/EC.

373 See Articles 30 (1) and 31 (2)) of the Directive. 
tions, and decisions concerning insolvency or bankruptcy involving fraud, taken by their own competent authorities in respect of the provider, which are directly relevant to the provider's competence or professional liability (Article 33(1)). Furthermore, with regard to the exchange of information, the Directive prescribes the establishment of an electronic system (Article 34(1)).

It can be concluded that the Directive contains several measures aimed at increasing administrative cooperation between Member States. Whether the Member States will better assist each other has to be seen, since Member States were only required to implement the Directive by 28 December 2009. ${ }^{374}$

\subsubsection{Convergence programme}

Due to the increase in cross-border activities, and the development of a genuine internal market for services, a greater convergence of professional rules at the European level is desirable. In this regard, Article 37(1) indicates that Member States have to take accompanying measures to encourage the drawing up, at Community level, particularly by professional bodies, organisations and associations, of codes of conduct aimed at facilitating the provision of services, or the establishment of a provider in another Member State, in conformity with Community law. By the creation of common minimum rules of conduct, such European codes have to ensure, in particular, independence, impartiality and professional secrecy and to establish rules on commercial communications and, where appropriate, insurance requirements, so that the free movement of service providers is facilitated and the trust and confidence of recipients is enhanced. In this spirit, the Internal Market and Services Directorate-General conducted a public on-line consultation from 30 May to 15 August $2007^{375}$, inviting professional organizations to provide it with information on their codes of conduct and to give their views on the best possible way of establishing codes of conduct at the European level. A significant number of replies were received: 172 professional organizations representing more than 25 different service sectors and 25 Member States, with the majority coming from the regulated professions. $75 \%$ of the professional organizations responded that they had a code of conduct. As indicated above, Directive 2006/123/EC encourages the drawing-up of such codes at European level, since the existence of codes of conduct at national level only brings about a purely national perception of the quality of services. This might result in market fragmentation, while European codes of conduct can help to promote a high quality of services and to establish a relationship of confidence between consumers and professionals. The Directive is based on the premise that European codes of conduct give consumers more freedom of choice with regard to the service provider, since they have the knowledge that the service providers are subject to a common European code of conduct. Such codes may also help to bring out the specific nature of the services of certain sectors, especially regulated professions, by guaranteeing that they can exer-

${ }^{374}$ See Article 44 (1) of the Directive.

375 European Commission, Enhancing the quality of services in the Internal Market: The role of European codes of conduct, 2007. See http://www.fenca.org/uploads/Surveys/codeconduct_en.pdf, last consulted 23 December 2009. 
cise their profession independently, and by protecting the impartiality of the rules of professional conduct.

In general, professional organisations have always played a major role with regard to the regulated professions by helping to provide a framework for the pursuit of the activities of their members. Compulsory registration or membership of the representative professional organization is a specific mode of regulation of these professions, which leads to the fact that these professions are generally characterized by high levels of self-regulation. According to the above-mentioned consultation, most professional organizations seem to be governed by private law. Furthermore, many professions (including the architectural profession) have not only representative professional organizations at local and/or national level, but also at international and European levels. With regard to architects, reference should be made to the Architects' Council of Europe ${ }^{376}$, which is the only representative organization of architects at EU level. It is based in Brussels and monitors relevant policy and legislative developments in the EU. In this way it aims to influence those areas of EU policy that have an impact on architectural practice, and on policies affecting the overall quality and sustainability of the built environment. The Architects' Council of Europe advises the Commission about issues which it considers to be important, indicates problems which architects often encounter, and gives opinions about legislative proposals, such as the proposal leading to Directive 2005/36/EC and Directive 2006/123/EC and the Lisbon Recognition Convention. In this way the Architects' Council of Europe contributes significantly to the promotion of the architectural profession and the protection of European architects. Professionals can choose to join a national professional organisation but are not members as such of the European organization which consists of national representatives of professional organisations of different Member States, and is organized in accordance with the principle of self-regulation. ${ }^{377}$ Although membership of professional associations is often compulsory at national level, this does not exist as such at the European level. The organizations at European level are all governed by private law, and many of them, including the Architects' Council of Europe, have already adopted European codes of conduct. ${ }^{378}$ The current European codes have only declaratory value however, and can only be binding with regard to their members. This is the logical consequence of their status as private organizations. In any case, the codes of conduct must comply with EU law and, in particular, with internal market and competition law $^{379}$. Ideally it should be possible for the European code of conduct to be transposed by the national organisations into their

376 The Architects' Council of Europe was founded in Treviso (Italy) on the 11th May 1990 by the merger of the former Liaison Committee of the Architects of the United Europe and the former Council of European Architects.

377 Members are the regulatory and professional representative bodies of all European Union Member States, Accession States, Switzerland and Norway. Through them, the Architects' Council of Europe represents the interests of over 480,000 architects in Europe. See http://www.ace-cae.org/, last consulted 19 December 2009.

378 The deontological code of the ACE of 19 November 2005 is not legally binding.

379 The Commission held, for example, with regard to the Belgian architects' fee system, that agreements are 'particularly serious' considering that, through its very nature, the object of an agreement fixing the price of goods or services is to restrict competition on the market. See decision of 24 June 2004. 
national codes, in order to guarantee its effectiveness. ${ }^{380}$ However, as stipulated in recital 14 of the Directive, the European Codes do not replace the national codes, but only complement them..$^{381}$

\subsubsection{Conclusion}

While Directive 2005/36/EC focuses on the recognition of professional qualifications with regard to market access to regulated professions, Directive 2006/123/EC concentrates on matters relating to the quality of services. The Directive focuses on the prohibition of national measures restricting either establishment or free movement of services and relies almost exclusively on negative as opposed to positive integration. The core provision of Directive 2006/123/EC is Article 16(1), which provides that Member States have to respect the right of providers to provide services in a Member State other than that in which they are established. Since Member States are still allowed to impose certain requirements if justified for public interest reasons (Article 16(3), and in certain specific cases (Article 17 and 18), the Directive strike a certain balance between guaranteeing the rights of service providers to free access and free exercise of a service activity, whilst allowing Member States the right to invoke their most essential requirements in certain clearly-defined circumstances. According to former Commissioner McCreevy, this will definitively improve legal certainty for service providers and consumers. ${ }^{382}$ Since the Directive makes it easier for service providers to establish themselves anywhere in the EU, saving time and money, it provides a welcome boost to cross-border service provision. The Directive is underpinned by obligations on Member States to cooperate with and assist each other, to ensure that businesses are properly and efficiently supervised across the EU while avoiding the duplication of controls. To achieve its aims, Member States have to simplify the procedures and formalities which are applicable to the access to certain activities and the exercise of these. Discriminatory measures and other requirements have to be eliminated from national legislation, and Member States

380 Member States or national professional organisations can always stipulate more detailed rules in order to provide greater protection.

381 On an international level, reference should be made to the International Union of Architects which was founded in Lausanne in 1948, to unite the architects of the world without regard to nationality, race, religion, or architectural doctrine, and to federate their national organisations. The Union, which is an intergovernmental organization, means the key professional organizations of architects in 124 countries and territories and represents, through these organisations, more than 1,300,000 architects worldwide. In 1999 the Union established an accord on Recommended International Standards of Professionalism in Architectural Practice, which is an advisory document that contains standards and practices that should best serve community interests, define what is considered best practice for the profession, and express the standards to which the profession aspires. It is an advisory document containing principles of professionalism and professional standards in the interest of public health, safety, welfare, and culture, and supports the position that interrecognition of standards of professionalism and competence is in the public interest as well as in the interest of maintaining the credibility of the profession. The global principles and standards of the UIA are aimed at the thorough education and practical training of architects so that they are able to fulfil their fundamental professional requirements. See http://www.uia-architectes.org/texte/england/Menu-1/0-pourquoi-new.html, last consulted 19 December 2009.

382 Statement of McCreevy on the vote of the European Parliament on the Services Directive, 15 November 2006. See http://europa.eu/rapid/pressReleasesAction.do?reference=SPEECH/06/687, last consulted 19 Decemer 2009. 
have to accept any document, including copies, from another Member State which proves that a certain requirement has been fulfilled. In general this would include that, if a Member State invokes that only registered professionals are allowed to perform a profession, proof of an individual's registration should be sufficient without having to deliver proof of the specific qualifications as well. However, Article 5(3) does not apply to the documents enumerated in Article 7(2) and 50 of Directive 2005/36/EC which refers to Annex VII (Article 5(4)). It follows that attestations of professional competence or evidence of formal qualifications and attestations of professional experience can therefore still be asked for, while the host State is allowed to invite the applicant to provide information concerning his training to the extent necessary in order to determine the existence of potential differences (Annex VII point $1 \mathrm{~b}$ ). Market entry regulations regarding the protection of the architectural title generally demand such qualifications.

The Directive also takes into account the rights of the recipients of services: they must be able to use services from other Member States without being hindered by restrictive measures or discriminating behaviour on the part of their own government. Member States shall ensure that they can obtain information relating to access to services, means of redress, etc. To establish mutual trust, Member States shall ensure that information on providers and their services will be made available, and that there will be stronger mutual assistance between national authorities to promote the effective supervision of services. It follows that service providers can be confident that they are dealing with fair and transparent authorisation regimes and that there are swift and simple procedures. They will be able to obtain information and complete administrative formalities through points of single contact in any Member State and, in addition, in electronic form. This will simplify, accelerate and reduce the cost associated with the setting up of a new business, and will obviate the need to deal with different levels of authority.

The Directive sets out what kind of restrictions the Member State where the services are provided (the host States) may still impose (Articles 16 and 17) and what manner of supervision can be exercised, either by the State of establishment (Article 30), or by the host State (Article 31). Member States are thus not prevented from supervising companies and workers operating on their territory. The Member State where the service is provided can enforce working conditions, including minimum wages which means that companies posting workers to another Member State will not benefit from bringing in 'cheap' workers from other Member States. 'Social dumping' will therefore be avoided. However, as held by Heremans, the list of limitations and exceptions to its scope as well as the weakening of the country of origin principle to a 'freedom to provide services' principle, can be expected to have heavily reduced the integrative potential of this instrument. ${ }^{383}$

The Directive also provides for harmonization in certain areas of legislation such as professional insurance, dispute settlements, quality of services, etc. In sum, it wants to cut the administrative burden and strengthen the position of service providers by removing discriminating measures and regulations that hinder cross-border service activi-

\footnotetext{
383 Heremans 2010, p. 198.
} 
ties. By creating mutual trust between Member States, it aims to facilitate and to increase cross border provision, and the receipt of services, so that the cross-border competition in service markets increases, consequently bringing down prices and improving quality of choice for consumers. ${ }^{384}$ In order to have a smooth and workable system, the Directive provides for single points of contacts which can be seen as single desks at which service providers can complete all the administrative procedures relevant to their activities, preferably by electronic means. According to Commissioner Charlie McCreevy, the Services Directive provides a real added value to the Internal Market, cutting red tape, removing barriers, and improving legal certainty for businesses and consumers. It will remain to be seen how far the Directive will fulfil its promises, and effectively boost economic growth. ${ }^{385}$ The Services Directive entered into force on 28 December 2006. According to Article 44(1), Member States shall bring into force the laws, regulations and administrative provisions necessary to comply with this Directive before 28 December 2009.

\section{Academic recognition}

In paragraph 3.3, the meaning of academic recognition as opposed to professional recognition was explained. Academic recognition refers to recognition decisions that allow a person to pursue or continue a course of study, or confers the right to use a national academic title or degree from the host country on the basis of a title or degree acquired in the country of origin. Since it covers a totally different aspect of law and has nothing to do with the recognition of professional qualifications, it will not be discussed extensively within this thesis. However, it cannot be ignored either, since it has an influence upon the free movement of architects in the European Union.

As stated before, individual Member States are responsible for the efficient functioning and quality of their education system. According to Article 165 TFEU (Article 149 EC), the Union shall contribute to the development of quality education by encouraging cooperation between Member States and, if necessary, by supporting and supplementing their action, while fully respecting the responsibility of the Member States for the content of teaching and the organisation of education systems and their cultural and linguistic diversity. Union action shall be aimed at developing the European dimension in education, particularly through the teaching and dissemination of the languages of the Member States; encouraging mobility of students and teachers, by encouraging inter alia, the academic recognition of diplomas and periods of study, promoting cooperation between educational establishments, and developing exchanges of information and experience on issues common to the education systems of the Member States. In this

384 See for more information http://www.entemp.ie/trade/marketaccess/singlemarket/servicesDirective.htm, last consulted 19 December 2009.

385 It is expected that the overall economic growth potential of EU countries shall improve along three main channels: the service sector will be better capable of exploiting scale economies through production in other EU markets; the competitive selection process will become stronger and will cause under-performing firms to exit sooner; and the influx of more productive foreign subsidiaries raises the overall productivity of domestic service industries. 
regard the Union and the Member States shall foster cooperation with third countries, and the competent international organisations in the field of education and sport and, in particular, the Council of Europe. However, in order to contribute to the achievement of these objectives, the European Parliament and the Council shall adopt incentive measures, excluding any harmonisation of the laws and regulations of the Member States. It follows that there are no Union provisions imposing the mutual recognition of diplomas except for certain regulated occupations that are discussed under the heading of professional recognition. Nevertheless, the European Commission has encouraged mutual recognition for academic purposes between the various education systems in Europe through such Community programmes as Erasmus. A tangible result of the effort to promote understanding of the academic recognition of qualifications, under the Erasmus programme, is the network of national information centres for the recognition of diplomas (NARIC). ${ }^{386}$ Universities, which are autonomous institutions, are entirely responsible for the content of their curricula, and for awarding diplomas and certificates to students. The diplomas and certificates are recognized by the authorities of the Member State concerned.

However, over time, the ECJ has developed case law which does not necessarily respect this strict division of power and is applicable to those who are in the process of becoming fully-fledged professionals.

Examples of cases are Morgenbesser ${ }^{387}$, Commission v. Austria ${ }^{388}$ and Commission v. Belgium $^{389}$. In the first case, the question was asked whether EC law precluded a Member State from refusing a person from registering in a register of trainee lawyers based on the mere fact that the person's law degree was not conferred by a university of the host state. The ECJ held that trainees cannot be assimilated with 'true' lawyers since an additional step was still needed in order to qualify as a lawyer. Trainees could not be regarded as a separate profession and Directive 89/48/EEC could not be invoked to claim free movement rights. Nevertheless the ECJ held that candidates who had already finished their theoretical studies but were in the course of a traineeship which needs to be finished before they can pursue a regulated profession, and consequently are not fully fledged professionals yet, should obtain an individual review of the qualifications and knowledge they already possessed. It followed that the national authority was not al-

386 http://ec.europa.eu/education/policies/rec_qual/recognition/in_en.html, last consulted 23 December 2009.

387 Case C-313/01Christine Morgenbesser v. Consiglio dell'Ordine degli avvocati di Genova. As held above, in Morgenbesser, the ECJ has extrapolated its ruling on Vlassopoulou so that it also applies to candidates from a regulated profession who cannot yet be considered as a produit fini, i.e. that they are fully qualified in a regulated profession in another Member State. It follows that the candidate is entitled to a fair assessment of his or her qualifications, taking into account all the relevant knowledge and experience obtained by that candidate (also by means of courses and other practical experience). After such a comparison has been conducted, the national authority will then make a decision on what the candidate still has to do in order to obtain recognition.

388 Case C-147/03 Commission v. Austria [2005] ECR I-5969.

389 Case C-65/03 Commission v. Belgium [2003] ECR I-6427. The case is similar to Case C-147/03. The Court held that, by failing to take the measures necessary to ensure that holders of secondary education diplomas obtained in other Member States can gain access to higher education organised by Belgium's French Community under the same conditions as holders of the certificat d'enseignement secondaire supérieur (CESS), the Kingdom of Belgium had failed to fulfil its obligations. 
lowed to refuse the registration of Ms. Morgenbesser on the sole ground that she did not have a diploma conferred, ratified or recognized by a university of the host Member State. With this judgement, the ECJ indicated that the Vlassopoulou principle has to be applied in cases where the migrant is not yet fully qualified, so also in cases when a purely academic qualification is at stake. This can bring about the situation that, in the future, anyone can rely on this judgement at any stage of qualification for a certain regulated profession, and can rely on Vlassopoulou.

Very recently, the ECJ reiterated in Pesla ${ }^{390}$, which dealt with the same issue, its ruling in Morgenbesser and stated that the knowledge attested by the diploma granted in another Member State and the qualifications and/or work experience obtained in other Member States, together with the experience obtained in the Member State in which the candidate seeks enrolment, must be examined. However, the mere fact that legal studies relating to the law of one Member State may be regarded as comparable, from the point of view of both the level of training received, and the time and effort invested to that end, to studies seeking to provide the knowledge attested by the qualification required in another Member State, cannot of itself lead to an obligation to give priority, not to the knowledge required by the national provisions of the Member State in which the candidate seeks to benefit from the professional training required in order to enter the legal professions, but to knowledge which relates essentially to the law of another Member State, as attested by the qualifications obtained in that latter State. The ECJ indicated that Article $39 \mathrm{EC}$ is to be interpreted as meaning that the knowledge to be taken as a reference point for the purpose of assessing the equivalence of training following an application for direct admission to a legal traineeship for the legal professions, without taking the exams he would otherwise have to sit, is that attested by the qualification required in the Member State in which the candidate seeks to be admitted to serve such a legal traineeship. ${ }^{391}$

The cases Commission v. Austria and Commission v. Belgium deal with the right of holders of secondary education diplomas obtained in other Member States to gain access to higher education. ${ }^{392}$ The ECJ decided that recognition of academic diplomas forms a part of access to higher education, which is subject to EU law. In sum, candidates may never be automatically denied on the basis that they do not have the correct qualifications. Member States are limited when it comes to the recognition of academic degrees, since they have to show, in each individual case, that their rules are necessary and proportionate to attain the aim pursued. It follows that the assumption that the Union has no competence to legislate in the area of education, will increasingly be under pressure. ${ }^{393}$ If education is seen as a basis, the legislative competence to act will be contained in Article 114 TFEU (Article 95 EC) which indicates that the European Parliament and the Council shall adopt the measures for the approximation of the provisions

390 Case C-345/08 Krzysztof Peśla v. Justizministerium Mecklenburg-Vorpommern, judgement of 10 December 2009.

391 See also Case C-119/09 Robert Koller v. Rechtsanwaltsprüfungskommission beim Oberlandesgericht Graz, which is still pending.

392 See also Case C-73/08 Nicolas Bressol and others and Céline Chaverot and others v. Gouvernement de la Communauté fançaise [2010], to be published.

393 See also Garben 2008. 
laid down by law, regulation or administrative action in Member States which have, as their objective, the establishment and functioning of the internal market. ${ }^{394}$ Since, as held above, the failure to recognize a diploma obtained in another EU Member State for academic purposes might constitute an infringement of one of the fundamental freedoms, and since academic recognition is a pre-condition for student mobility, which is an explicit EU competence, it can be noted that the EU does have competence in the area of education. This is strengthened by the fact that the Union has created Directives 2004/114/EC and 2005/71/EC regarding the admission of students and researchers holding the nationality of third-countries.

The Member States have decided to standardize rules in this area in a process that takes place outside the realm of the EU, the so-called Bologna Process. The Bologna Declaration is a key document which marks a turning point in the development of European higher education. It was signed by 29 countries in 1999, and is currently ratified by 48 signatories. The Bologna Declaration is not just a political statement, but a binding commitment to an action programme at intergovernmental level. Each Member has freely taken up the obligation to reform its own higher education system or systems, in order to create overall convergence at the European level. By the creation of a European space for higher education, the employability and mobility of citizens will be enhanced, and the international competitiveness of European higher education should increase. The Bologna process aims at creating convergence, and is not a path towards the standardisation or uniformisation of European higher education. It reflects a search for a common European answer to common European problems. The process originates from the recognition that, in spite of their valuable differences, European higher education systems are facing common internal and external challenges related to the growth and diversification of higher education, the employability of graduates, the shortage of skills in key areas, the expansion of private and transnational education, etc. The Declaration recognises the value of coordinated reforms, compatible systems and common action. It contains a set of specified objectives: the adoption of a common framework of easily understandable and comparable degrees ${ }^{395}$; the introduction of a system of two main cycles (undergraduate/graduate) in all countries, with first degrees no shorter than three years and relevant to the labour market; a credit system (such as the European Credit Transfer System) also covering lifelong learning activities; a European dimension in quality assurance, with comparable criteria and methods; the elimination of remaining obstacles to the free mobility of students (as well as trainees and graduates) and teachers, as well as that of researchers and higher education administrators. The signatory countries are committed to attain the Declaration's objectives by means of inter-

\footnotetext{
394 With regard to 'real' students who are still studying, Directive 93/96/EEC was created after the ECJ ruled upon their rights in Case C-152/83 Sandro Forcheri and his wife Marisa Forcheri, née Marino v. Belgian State and asbl Institut Supérieur de Sciences Humaines Appliquées - Ecole Ouvrière Supérieure [1983] ECR 02323; Case C-293/83 Françoise Gravier v. City of Liège [1985] ECR 00593 and Case C-375/89 V.J.M. Raulin v. Minister van Onderwijs en Wetenschappen. This Directive has now been replaced by Directive 2004/38/EC. In Case C-109/04 Karl Robert Kraneman v. Land Nordrhein-Westfalen, [2005] ECR I-02421 the ECJ held that trainee lawyer can also benefit from the free movement of workers.

395 This should also be achieved by the International Diploma Supplement.
} 
governmental cooperation in collaboration with higher education institutions and associations. ${ }^{396}$

The Bologna Process aims to facilitate the recognition of qualifications by the issuing of a Diploma Supplement which indicates the higher education system in which the diploma was earned, and the overarching qualifications framework. Furthermore, networks have been set up to facilitate mobility. In this way the academic recognition of foreign qualifications is carried out by ENIC/NARIC centres and Higher Education Institutions (HEI's). ${ }^{397}$ It should be noted however that the Bologna Process has no legally binding effect. Nevertheless, a part of the Process concentrates on diploma recognition which is covered by the Lisbon Recognition Convention (LRC) -a Treaty conceived in the framework of the Council of Europe, which does have binding effect. ${ }^{398}$ The LRC, was elaborated by the Council of Europe and UNESCO in 1997.399 The core of the convention is to give every applicant appropriate access to an assessment of his/her foreign academic qualifications, and that such foreign qualifications have to be recognised unless substantial differences can be demonstrated to exist in regard to the length of study, curriculum content, etc. The Convention therefore adopts the idea of acceptance, and aims for fair and transparent recognition procedures. Each party must provide appropriate information on their education system, qualifications and institutions. In the event of refusal, the burden of proof lies upon the host country.

The Bologna Process entails that everybody is entitled to an assessment of an application for recognition of qualifications, solely on the basis of the knowledge and skills achieved, and that Member States may not discriminate against an individual in this respect on any ground such as the applicant's gender, race, colour, disability, language, religion, political or other opinion, national, ethnic or social origin, association with a national minority, property, birth or other status, or on the grounds of any other circumstance not related to the merits of the qualification for which recognition is sought. (Article

396 The importance of tackling professional recognition is also visible in the tendency to integrate recognition into trade agreements, by considering education and, therefore, qualifications as services. Such initiatives are being undertaken in the framework of the General Agreements on Trade and Services (GATS), and also of regional agreements (NAFTA for North America). This will not be further discussed within this thesis.

397 In 1984, the National Academic Recognition Information Centres (NARICs) were established on the initiative of the European Commission. In 1994 the Council of Europe and CEPES, the higher education department of UNESCO, formed the European Network of Information Centres on Recognition and Mobility (ENIC). Both networks identify recognition problems or issues and, if possible, try to solve them. With regard to professional recognition, competent authorities are very often not linked to NARIC/ENIC but to professional associations.

398 The Lisbon Convention dates, however, from before the Bologna Process, and is independent from it in terms of legal structure.

399 The Lisbon Recognition Convention has to be ratified by all countries participating in the Bologna Process. Greece and Italy have not yet ratified the Convention. However, at the European Council meeting in Feira in March 2000, contrary to the agreement reached in Bologna, the Member States could not come to an agreement for the 'Establishment of a European Area of Education'. The Member States considered their sovereignty in general educations matters too important, while the European Council announced in March 2000 the Lisbon Strategy proclaiming the European knowledge-based society. 
III.1(2) LRC). Signatories therefore commit themselves to recognising higher education diplomas from other Member States (Article VI.1 Lisbon Treaty). This recognition may only be withheld if there are substantial differences between the qualifications with regard to which recognition is sought and the qualification obtained. It is the national recognition authority that decides whether substantial differences exist, and it remains to be seen how strict these authorities will be, since this will determine whether or not the Lisbon Convention will be a success or a waste of effort. It should be noted that the Bologna Process does not guarantee the free movement of students. At this moment it only provides for the same terminology in the signatory states, but contains no coordination of the content of studies and thus no coordination of access for students. The content of the curriculum is still in the hands of the universities, academies and schools. ${ }^{400}$ Students must thus rely on the acquis communautaire and the rights of free movement conferred on them within the framework of the EU. However, the application of the Morgenbesser ruling does not formally lead to academic recognition. The ECJ does not deliver a certificate of recognition, but only states that, in a certain cases, the refusal of recognition goes against EC law. As noted by Claessens ${ }^{401}$, this seems to have particular effect on the prospective professional however, since it leads, or must lead, to a decision of a national authority, stating what the candidate must do in order to achieve access to the profession, or to one of its preparatory stages. The LRC, on the other hand, states that recognition can be withheld in cases where substantial differences exist which suggests that a negative answer without clarification on what needs to be done in order to obtain the recognition sought (as is the case with the application of the Vlassopoulou formula), can follow (Article IV(1) LRC).

The processes of academic recognition and de jure professional recognition are separate, in that while a decision on academic recognition is made under the Intergovernmental Lisbon Convention, using procedures which have been developed to satisfy that Convention, the decision on de jure professional recognition is made on criteria specified at EU level, and is made by a separate authority legally recognized for that purpose. Thus, academic recognition may determine that a foreign academic award satisfies all the criteria necessary for the level of qualification claimed for it while, at the same time, the professional recognition process may decide that the particular body of knowledge which has been thereby acquired by the holder is not sufficient for de jure professional

400 Orbasli and Worthington (1995) have conducted research on architectural education in the European Union. They compared higher professional training courses in architecture and town planning in different educational institutions in the Netherlands, Belgium, the United Kingdom, France, Germany and Spain. Also ENHSA (European Network of Heads of School of Architecture) has made reports on the shaping of the curriculum in the European Higher Architectural Education Area, the curricula, and emerging challenges for the content of architectural studies. See http://www.enhsa.net. The EAAE (European Association of Architectural Education) is an international non-profit association which is also committed to the exchange of ideas and people within the field of architectural education and research. See for more information about architectural education http://www.eaae.be/eaae2/info.php? mainType=about\&help=about, last consulted 17 December 2009.

401 Claessens 2008, p. 299. 
recognition. ${ }^{402}$ Although some signatory countries specifically underlined that the Lisbon Convention should be seen purely in terms of the framework of academic recognition, it is also very useful with regard to professional recognition. As noted before, professional recognition relates to the methodologies and procedures for evaluating credentials for work purposes, and is quite an intricate matter. The system of professional qualifications reflects both the national system of education and the organization of professions, industries and professionals themselves. Professional requirements can be set under national law, or by professional organizations. Academic recognition and professional recognition have therefore different objectives, and may require different approaches and instruments. ${ }^{403}$ However, they do share a methodology for evaluating the educational component of the credential or qualification. ${ }^{404}$ Of course, what is decisive in the end is the objective of the evaluation: further study or work. In the latter case, the employer might have specific questions for the credential evaluator. ${ }^{405}$ It is yet to be seen whether the case law of the ECJ will be of direct influence on the development of the European Area of Higher Education as provided for in the Bologna Process.

\section{Competition law}

\subsection{Introduction}

Next to the fact that regulations can limit the free movement of professionals, they can also restrict free competition in the European Union. With the adoption of the Single European Act in 1986, which promoted an increased degree of European economic integration through both free movement and competition, competition policy has a crucial role to play in EU law. ${ }^{406}$ As indicated in the previous paragraphs, the nondiscrimination principle as contained in Articles 18, 21, 45, 49 and 56 TFEU (Article 12, $18,39,43$ and 49 EC) and the application of these Articles by the ECJ, have removed numerous limitations in the area of the free movement of professionals. Since the 1990s

${ }^{402}$ Glanville 2004, p. 2. The holder of a Master's degree in International Law in London will be well qualified to undertake Doctoral studies in International law in Belgium, and might even become a professor in International Law in the Law Faculty of a Belgian university, but it is very unlikely that he or she would be considered equally qualified to set up an attorney's office in Belgium, interpreting Belgian domestic law. In other words, the Master's degree could be granted full academic recognition as a degree in Law, but would not receive the de jure professional recognition which would allow the holder to practise domestic Belgian law. They are separate recognition decisions and, in consequence, may conflict with one another.

${ }^{403}$ In some countries such as Germany and the Netherlands, most academic qualifications also serve as professional qualifications without additional requirements. In other countries such as the UK, professional qualifications are usually acquired upon completion of specific professional training that takes place outside and after university.

${ }^{404}$ Divis 2004, p. 1. The question of professional practical training was not raised in Bologna and the system of lifelong learning has hardly developed.

405 The international Diploma Supplement is another instrument which is mainly developed in the field of academic recognition, but is also very useful for professional recognition. It was developed in 1999 by a joint working group of the European Commission, the Council of Europe and UNESCO, and explains the qualifications and the courses involved in terms that are both understandable and useful for both academic admissions officers and employers or their Human Resource Development departments.

${ }^{406}$ Jones \& Sufrin 2004, p. 36. 
-after the formal establishment of the internal market in 1992- the Commission and the Court have made decisions in respect of professional regulation and competition law. ${ }^{407}$ As suggested by Wendt, the establishment of the internal market can therefore be understood as a catalyst, not only for an intensified application of the free movement guarantees, but also for an emerging application of competition law to the regulated professions. ${ }^{408}$ While the free movement provisions in the Treaty only cover cases in which a transboundary element is present, this is not a necessary requirement for the competition rules to be applicable. It follows that even if no borders are crossed, and professionals rules are imposed within one Member State only, EU competition law can be applicable. This is, however, only the case if the rules have an impact on the EU market and affect trade between Member States. ${ }^{409}$ Since EU competition policy is also important for practising architects, I will now discuss the key features of this policy. The reader should note, however, that I do no aim to present a complete analysis of the influence and effects of competition law on the architectural profession, since this does not fall within the scope of this thesis, and is already covered by the book written by Wendt, The Tension Between Rules Regulating the (Liberal) Professions and EC Competition Law - Reason and Passion in Discussing Professional Regulation. A discussion of competition law is of particular importance in the light of the economic analysis of the regulation of architects presented in Part III of this thesis. As will be explained in Part III, the public interest approach towards regulation is based on the perceived shortcomings of the market system, such as a lack of competition, which leads to less social welfare and therefore justifies the creation of regulation.

\subsection{The affectation of trade by undertakings}

As held by Article 3(3) EU (article 2 EC), the Union has to work for the sustainable development of Europe, based on balanced economic growth and price stability and a highly competitive social market economy aiming at full employment and social progress, and a high level of protection and improvement of the quality of the environment. Article 119 TFEU (Article 4 EC) indicates that, to achieve this aim, the Member States and the Union have to adopt an economic policy which is based on the close coordination of Member States' economic policies, on the internal market, and on the definition of common objectives, and should be conducted in accordance with the principle of an open market economy with free competition. This implies that there should be equal chances for all the market participants, without certain persons or undertakings having an advantage over their competitors, nor abusing their economic power. ${ }^{410}$

407 See for example Commission Decision CNSD, 1993; Case C-35/96 Commission v. Italian Republic (CNSD II) [1998] ECR I-3851.

408 Wendt 2009, p. 29.

409 See Articles 101 and 102 TFEU.

${ }^{410}$ Case C-18/88 Régie des télégraphes et des téléphones v. GB-Inno-BM SA [1991] ECR I-5941, paragraph 25. 
Article 101(1) TFEU (Article 81(1) EC) contains the general rule that the restriction of competition is not allowed in the EU. All agreements between undertakings, decisions by associations of undertakings and concerted practices which may affect trade between Member States, and which have, as their object or effect, the prevention, restriction or distortion of competition within the common market, shall be prohibited as incompatible with the common market. Such agreements or decisions will automatically be void (Article 101(2) TFEU) (Article 81(2) EC). Only if such an agreement, decision or practice contributes to improving the production or distribution of goods or to promoting technical or economic progress, while allowing consumers a fair share of the resulting benefit, may it be allowed. This is only the case if it does not impose on the undertakings, restrictions which are not indispensable to the attainment of these objectives, or which afford such undertakings the possibility of eliminating competition in respect of a substantial part of the products in question (Article 101(3) TFEU) (Article 81(3) EC). ${ }^{411}$

As the Court has observed in Portelange $e^{412}$, Article 101 TFEU is arranged in the form of a rule imposing a prohibition (paragraph 1) with a statement of its effects (paragraph 2 ), mitigated by the exercise of a power to grant exceptions to that rule (paragraph 3 ). The prohibition of the distortion of competition implies that there should be a workable degree of competition within the market which is necessary to ensure the observance of the basic requirements and the attainment of the objectives of the Treaty, in particular the creation of a single market achieving conditions similar to those of a domestic market. In this regard, the nature and intensiveness of competition may vary to an extent dictated by the products or services in question, and the economic structure of the relevant market sectors. ${ }^{413}$ Since collusive behaviour is in principle held to be incompatible with the common market, it can be said that there is a link between competition policy and the goal of market integration. Hence, competition policy is often seen to complement the free movement provisions by eliminating private market-dividing practices which endanger the market integration objective pursued by removing public obstacles to trade. ${ }^{414}$

It follows that Article $101 \mathrm{TFEU}$ is as such thus not applicable to state legislation. However, as will be demonstrated, professions are often defined by self-regulation which may fall within the scope of EU competition law. I will now discuss the different requirements of Article 101 TFEU in more detail. Article 102 TFEU (Article 82 EC), which has not yet been sufficiently considered by the EU institutions, will not be discussed within the scope of this thesis. However, as demonstrated by Wendt, where ap-

411 Under the competition law rules, the private actor can defend the economic rationality of his prima facie anti-competitive action.

As held by Heremans, the lack of economic grounds of justification seems to deprive private actors of an important legitimate route of defence within the free movement analysis. The deferent attitude which the Court generally displays when scrutinizing the justifications invoked by Member States does not seem appropriate in respect of self-interested private action. Rather than adapting the free movement acquis to a different type of addressees, it makes sense to subject their actions solely to the traditional competition law analysis. See Heremans 2010, p. 122.

412 Case C-10/69 Portelange v. Smith Corona Marchant International [1969] ECR 309.

413 Case C- 26/76 Metro SB-Großmärkte GmbH \& Co. KG v. Commission of the European Communities [1977], ECR 1905.

414 Heremans 2010, p. 235. 
plied by practitioners of free professions, professional regulations can lead to both instrumental use of market power and market structure abuses. ${ }^{415}$ With regard to the latter, it might be argued that the rules created by undertakings and their application by the profession can constitute the abuse of a dominant position. It will generally not be necessary to prove whether a particular professional self-regulation has the purpose of strengthening the collective dominant position of the profession's members, as long as it has the natural and foreseeable effect to alter the structure of the professional service market. This means that the professional association has to demonstrate that it has not made an instrumental use of the statutory monopoly of the collectivity to provide certain professional services so that claimants do not need to demonstrate the extent to which such self-regulation has the effect of limiting the competitive process in professional markets.

\subsubsection{Undertakings vs. states}

Article 101(1) TFEU prohibits certain agreements between 'undertakings'. The Court has defined an undertaking as any autonomous legal entity, constituted by a single organization of personal, tangible and intangible elements, engaged in an economic activity, regardless of its legal status (e.g. public or private) and the way in which it is financed. ${ }^{416}$ The activity should thus, by its nature, its aims and the rules to which it is subject, belong to the sphere of economic activity ${ }^{417}$ and cannot be connected with the exercise of the powers of a public authority ${ }^{418}$. The concept of 'economic activity' as found in the Court's definition of an undertaking, represents, according to settled caselaw, any activity consisting of offering goods and services in a given market for remuneration. ${ }^{419}$ However, even though the profession is regulated by the government, this will not remove it from competition rules unless the government regulation does not leave the undertakings any scope for competition. Architectural associations thus also fall within the ambit of the concept 'undertaking', since architects provide their services for remuneration in markets. ${ }^{420}$

415 Wendt 2009, pp. 251-312.

416 Case C-67/96 Albany International BV v. Stichting Bedrijfspensioenfonds Textielindustrie [1999] ECR I5751; Case C-19/61 Mannesmann AG v High Authority of the European Coal and Steel Community [1962], 675; Case C-41/90 Höfner and Elser c. Macrotron [1991] ECR I-1979, paragraph 21; Case C-244/94 Fédération française des sociétés d'assurances and Others [1995] ECR I-4013, paragraph 14; Case C-55/96 Job Centre (II) [1997] ECR I-7119, paragraph 21. The concept of 'undertaking' thus covers any type of company, individuals, public bodies and some systems of social insurance but not bodies vested with public authority in their exercise of that authority.

417 Joined Cases C-159/91 and C-160/91 Poucet and Pistre [1993] ECR I-637, paragraphs 18 and 19.

418 Case C-364/92 Sat Fluggesellschaft [1994] ECR I-43, paragraph 30; Case C-343/95 Diego Cali \& Figli [1997] ECR I-1547, paragraphs 22-23. The exercise by a professional association of regulatory authority delgated to it by the State, does not qualify as the exercise of public authority. See Case C-309/99 Wouters, Savelbergh, Price Waterhouse Belastingsadviseurs NV and Algemene Raad van de Nederlandse Orde van Advocaten [2002] ECR I-1577, paragraphs 57-58.

419 Case C-118/85 Commission v. Italy [1987] ECR 2599, paragraph 7; Case C-35/96 Commission v. Italy (CNSD II), paragraph 36

420 As held in Becu members of the liberal professions, insofar as they are not employees, are engaged in an economic activity because they provide services against remuneration on markets: Case C-22/98 Becu [1999] ECR I-4449. See, for example, also Article 1 of the Belgian Competition Law Act of 15 September 
As will be demonstrated hereunder, the application of the competition rules to the liberal professions mostly arises as a result of restrictive regulations created by professional associations in their own interest. However, these associations often pretend that the regulations to be adopted are being used to support the public interest. Although Article 101 TFEU is, in itself, concerned solely with the conduct of undertakings, and not with laws or regulations emanating from Member States, that Article -read in conjunction with Article 4(3) EU (Article 10 EC)- nonetheless requires the Member States not to introduce or maintain in force measures, even of a legislative or regulatory nature, which may render ineffective the competition rules applicable to undertakings. ${ }^{421}$ As held by Article 4(3) EU, Member States must take all appropriate measures to ensure the fulfilment of the obligations arising out of the Treaty, or resulting from action taken by the Union's institutions. They shall facilitate the achievement of the Union's task and shall abstain from any measure which could jeopardize the attainment of the objectives of the Treaty. Since the single market system which the Treaty seeks to create, excludes any national system of regulation hindering, directly or indirectly, actually or potentially, trade within the Union ${ }^{422}$, the Court has ruled on several occasions that Articles 3(3) EU jo 4(3) EU jo 101 TFEU are infringed where a Member State requires or favours the adoption of agreements, decisions or concerted practices contrary to Article 101 TFEU, or reinforces ${ }^{423}$ their effects, or where it divests its own rules of the character of legislation by delegating to private economic operators, responsibility for taking decisions affecting the economic sphere. ${ }^{424}$ In this regard it should be noted that Article 3(3) EU (Article 2 EC) only provides that the activities of the Union shall include a system ensuring that competition in the internal market is not distorted, without providing for the abolition of all anti-competitive state measures, even if they jeopardize the single market system, while Article 4(3) TFEU only indicates that Member States have to respect the obligations of the Treaty. There is therefore no negative integration provision in the treaties explicitly prohibiting such measures. Nevertheless, Articles 3(3) EU jo 4(3) EU jo 101 TFEU are the basis for the state liability doctrine which means that Member States are, in principle, not allowed to enact measures enabling private undertakings to escape from the constraints imposed by Article 101 TFEU by invoking the public interest. However, if a state does require the adoption of a certain agreement which, in principle, would fall within the ambit of competition policy, it can place private undertakings outside the reach of Article 101 TFEU if these undertakings are not associated in the legislative or regulatory process. Nevertheless, in the event that state authorities assume full responsibility (no delegations, no agreement of an undertaking),

2006, B.S. 29 September 2006 and the ruling of the Belgian Supreme Court of 7 May 1999, J.L.M.B. 2000, p. 224. See also Thirion, 2000, p. 293.

421 This was first decided in Gb-Inno-BM, paragraph 31. See also: Case C-267/86 Van Eycke [1988] ECR 4769, paragraph 16; Case C-185/91 Reiff [1993] ECR I-5801, paragraph 14; Case C-153/93 Delta Schiffahrts- und Speditionsgesellschaft [1994] ECR I-2517, paragraph 14; Case C-96/94 Centro Servizi Spediporto [1995] ECR I-2883, paragraph 20; Case C-35/96 Commission v. Italian Republic [1998] ECR I-3851, paragraph 53.

422 Case C-13/77 Gb-Inno-BM, paragraph 31.

${ }^{423}$ A state reinforces the effects of a pre-existing agreement only if it incorporates either wholly or in part the terms of these agreements: See Case C-13/77 GB-INNO-BM, paragraph 18.

424 Van Eycke, paragraph 16; Reiff, paragraph 17-19, 24; Joined Cases C-140/94 to C-142/94 DIP and Others [1995] ZCR I-3257, paragraphs 18-19. 
any abusive company behaviour remains unlawful even if it was encouraged by such a state measure. It follows that even where the State requires the undertakings to engage in anti-competitive conduct, if the undertakings remain at least partially capable of autonomously restricting competition -for example because it enjoys a margin of discretion in the implementation of the national legislation- both the undertakings and the State can be held liable. ${ }^{425}$ State legislation which requires economic actors to engage in anti-competitive conduct may itself infringe Articles 3(3) EU jo 4(3) EU jo 101 TFEU or 102 TFEU. Furthermore, Article 106(1) TFEU explicitly holds that a Member State shall neither enact nor maintain in force, any measure contrary to the rules contained in the Treaty, in particular to those provided for in Article 18 TFEU (Article 12 EC) and 101 to 109 TFEU in the case of public undertaking, and undertakings to which Member States grant special or exclusive rights.

When comparing the prohibition for states to limit free movement in the Union and the competition provisions in the Treaty, it should be noted that the Court appears to rely essentially on the complementarity between market integration and undistorted competition objectives, as it sees the Treaty's provisions pertaining to competition as levers for market integration. ${ }^{426}$ As indicated in paragraph 3.2., the provisions on free movement explicitly prohibit (negative integration) Member States from impeding the free flow of goods, persons, services or capital. Anti-competitive state measures consequently constitute unlawful obstacles to market integration. As suggested by Gyselen, given the prominent reference to the single market system in its judgement, and the Treaty provisions explicitly prohibiting state measures which interfere with market integration, either directly (free movement provisions) or indirectly (competition), the Court seems to have had a constitutional lacuna in mind in GB-INNO-BM. It must have taken the view that state measures which interfere with the system of undistorted competition can be just as harmful for the single market system, so that there has to be a basis in the Treaty for challenging these measures. The ECJ found this basis in Article 3(1)(g) EC jo Article 10(2) EC (Article 3(3) jo 4(3) EU) which serves as an implied constitutional limitation on anti-competitive state measures. As maintained by Gilliams, since public authorities may have a variety of public interest reasons for introducing regulation that have a restrictive effect on competition, and since Article 3(3) EU does not call for such regulation to be prohibited, it seems difficult to argue that state measures that are compatible with the four freedoms are prohibited by Article 4(3) EU, solely

425 In this regard the European Court of First Instance held in Spedizionieri Doganali (Case T-513/93 Consiglio Nazionale degli Spedizionieri Doganali v. Commission of the European Communities, [2000] ECR II01807) that an association can be considered liable despite the legislative framework where the law provides for the Association to set, for example, a fee scale. This is because the association used its margin of discretion in the application of the law in such a way that a restriction of competition could result from its own conduct. To the extent to which such an organization has room for manoeuvre in performing the obligations imposed on it by the national legislation, within which it could and ought to have acted in such a way as not to restrict the existing level of competition, the restrictive effects on competition resulting from a tariff set by it may originate in its conduct. Depending on the legislative framework in which the professional association operates, if an anti-competitive practice can be identified, either the Member State or the Association or both can, in some circumstances, be found responsible for it.

426 See GB-Inno-BM SA; Gyselen 2004, p. 359. 
on account of their restrictive impact on competition. ${ }^{427}$ To turn all anti-competitive state measures into potentially unlawful acts -on the sole basis of these provisions and in the absence of an express Treaty provision specifically prohibiting such measureswould ignore the fact that all other state measures impeding market integration are only unlawful under Article 3(2) EU jo 4(3) EU an express Treaty provision which specifically prohibits such measures (such as the free movement provisions). ${ }^{428}$

It can therefore be concluded that the competition rules apply if professional regulations restrict competition appreciably. However, such regulations will escape the competition rules if they pursue a clearly articulated public interest purpose. It is possible that a delegation of rule-making power by public authorities to professional associations constitutes an infringement by the delegating Member State of Article 4(3) EU. However, that does not exclude action from being taken on the basis of Article 101 or 102 TFEU against the beneficiary of the delegation (for example the professional association) as well, unless certain behaviour is imposed upon the association. ${ }^{429}$ Restrictive measures that are attributable to the public authorities, or which implement clearly articulated public interest considerations, will escape the applicability of Articles 101 and 102 TFEU, and will -except in quite rare circumstances- not be prohibited by Article 4(3) EU. It follows that Article 4(3) EU does not preclude restrictive arrangements that are not already caught by Article 101 and 102 TFEU, except if the public measures simply reproduce a prohibited agreement, unnecessarily cover a prohibited agreement with the cloak of public authority, or entirely delegate to a private body the power to set binding parameters for competition in the market. ${ }^{430}$

\subsubsection{Agreements - Decisions - Concerted practices}

As held by the Court of First Instance in Hercules ${ }^{431}$, for there to be an 'agreement' within the meaning of Article 101 TFEU, it is sufficient that the undertakings in question have expressed their joint intention to conduct themselves in the market in a specific way. In this regard, Article 101 TFEU makes no distinction as to whether the parties are at the same level in the economy (so-called horizontal agreements) or at different levels (so-called vertical agreements). ${ }^{432}$ It follows that even if there is no abuse of a

427 Gilliams 2004, p. 306.

428 Gyselen 2004, p. 383.

${ }^{429}$ Gilliams 2004, p. 315 for an overview of the different possibilities for division of public/private responsibility.

430 See especially Case C-35/96 Commission v. Italian Republic (CNSD).

431 Case T-7/89 SA Hercules Chemicals NV v. Commission of the European Communities [1991] ECR II1711

432 Article 101 (1) TFEU does not only comprise any possible competition between the parties to the agreement, but also any possible competition between one of them and third parties. This must be all the more the case since the parties to such an agreement (e.g. the producers) could attempt, by preventing or limiting the competition of third parties (e.g. the distributors) in the product, to set up or preserve to their gain an unjustified advantage detrimental to the consumer or the user, contrary to the general objectives of Article 101 TFEU. See Case C-32/65 Italian Republic v. Council of the European Economic Community and Commission of the European Economic Community ("Challenge to Regulation 19/65") [1966] ECR 389, pp. 407-408. 
dominant position, an agreement between businesses operating at different levels may affect trade between Member States and, at the same time, have as its object or effect, the prevention, restriction or distortion of competition, and thus fall under the prohibition of Article 101 TFEU. It follows that such agreements cannot be legally binding. In assessing an agreement under Article 101 TFEU, account should be taken of the actual conditions under which it functions, in particular the economic context in which the undertakings operate, the products or services covered by the agreement, and the actual structure of the market concerned. ${ }^{433}$ In this regard it should be noted that agreements containing obvious restrictions of competition such as price-fixing, market-sharing or the control of outlets ${ }^{434}$ may be weighed against their claimed pro-competitive effects only in the context of Article 101(3) TFEU ${ }^{435}$, with a view to granting an exemption from the prohibition in Article 101(1) TFEU. ${ }^{436}$

A 'decision' by associations of undertakings, on the other hand, in particular refers to an association's recommendations to its members, which can lead to an assimilation among the members of competitive parameters such as price, capacities and commercials relations with third parties (as in a collective boycott).

A 'concerted practice' can be defined as any direct or indirect contact between such operators, the object or effect whereof is either to influence the conduct on the market of an actual or potential competitor, or to disclose to such a competitor the course of conduct which they themselves have decided to adopt, or contemplate adopting on the market, where the object or effect of such contact is to create conditions of competition which do not correspond to the normal conditions of the market in question, regard being had to the nature of the products or services offered, the size and number of the undertakings and the volume of the said market. ${ }^{437}$ In order to prove that there has been

433 Joined Cases T-374/94, T-375/94, T-384/94 and T-388/94 European Night Services and Others v. Commission of the European Communities [1998] ECR II-3141, paragraph 136; Case C-399/93 Oude Luttikhuis and Others v. Coberco [1995] ECR I-4515 paragraph 10; Case T-77/94 VGB and Others v. Commission [1997] ECR II-759 paragraph 140; Case C-234/89 Delimites [1991] ECR I-935 paragraph 31; Case C-250/92 Gottrup-Klim v Dansk LandbrugsGrovvareselskab AmbA [1994] ECR I-5641 paragraph 31. In Société Technique Minière the ECJ held in this regard that, in order to decide whether an agreement containing a clause 'granting an exclusive right of sale' is to considered as prohibited by reason of its object or of its effect, it is appropriate to take into account in particular the nature and quantity, limited or otherwise, of the products covered by the agreement, the position and importance of the grantor, and the concessionaire in the market for the products concerned, the isolated nature of the disputed agreement or, alternatively, its position in a series of agreements, the severity of the clauses intended to protect the exclusive dealership or, alternatively, the opportunities allowed for other commercial competitors in the same products by way of parallel re-exportation and importation: See Case C-56/65 Société Technique Minière (L.T.M.) v. Maschinenbau Ulm Gmbh (M.B.U.) [1966] ECR 235, p. 250.

434 These are specifically referred to in Article 101 (1) TFEU.

435 The Commission's Guidelines on the application of Article 81(3) EC which were issued in connection with the entry into force of Regulation 1/2003/EC of 16 December 2002 on the implementation of the rules on competition laid down in Article 81 and 82 of the Treaty, state that, in order to benefit from an exemption under Article 81(3) EC, the restrictive arrangement must produce efficiency gains: it must contribute to improving the production or distribution of goods or to promoting technical or economic progress. A claim on which restrictions are based on fair competition is not valid. The protection of fair competition is a task for the legislator, and not for undertakings.

436 Case T-148/89 Tréfilunion v Commission [1995] ECR II-1063, paragraph 109.

437 Case T-25/95 Cimeteries CBR SA et al. V. Commission of the European Communites [2000] ECR II-491; Case C-49/92 Commission of the European Communities v Anic Partecipazioni SpA [1999] ECRI-04125, 
a concerted practice, it is not therefore necessary to show that the competitor in question has formally undertaken, in respect of one or several others, to adopt a particular course of conduct, or that the competitors have colluded over their future conduct on the market. ${ }^{438}$ It is sufficient that, by its statement of intention, the competitor should have eliminated or, at the very least, substantially reduced uncertainty as to the conduct expected of the others on the market. ${ }^{439}$

In any case, agreements, decisions and concerted practices have to be capable of constituting a threat, direct or indirect, actual or potential, to freedom of trade between member States in a manner which might harm the attainment of the objectives of a single market between states. Even if an agreement encourages an increase, even a large one, in the volume of trade between states, this is not sufficient to exclude the possibility that the agreement may affect such trade as in the manner described above. ${ }^{440}$

\subsubsection{Affectation of trade}

The requirement that Articles 101 TFEU is applicable in the case of affectation of trade between Member States, indicates the boundary between the areas respectively covered by EU law and the law of the Member States. EU law covers any agreement or any practice which is capable of constituting a threat to freedom of trade between Member States in a manner which might harm the attainment on the objectives of a single market between the Member States, in particular by sealing off national markets or by affecting the structure of competition within the common market. ${ }^{441}$ If an agreement, decision or practice is capable of affecting trade between Member States, it must have an influence, direct or indirect, actual or potential, on the pattern of trade between Member States, so that the attainment of a single market between Member States may be hindered. Moreover, that influence (effect) must not be insignificant. ${ }^{442}$ In the case of services, it may consist, as the ECJ has held, in the activities in question being conducted in such a way that their effect is to partition the common market, and thereby restrict freedom to provide services, which constitutes one of the objectives of the Treaty. ${ }^{43}$ However, since the overall majority of competition restrictions in the professional services area have their origin and effect in a single Member State and markets for professional services have largely remained local, ${ }^{44}$ administrative enforcement falls mainly to national competition authorities, and private enforcement of these rules can be achieved in the na-

paragraph 117; Case C-199/92 Hüls v. Commission of the European Communities [1999] ECR I-4287, paragraph 160; Case C- 114/73 Suiker Unie and Others v Commission of the European Communties [1975] ECR paragraph 174; Case C-172/80 Züchner [1981] ECR 2021 paragraph 14; and Case C-7/95 John Deere v Commission of the European Communities [1998] ECR I-3111, paragraph 87.

438 Opinion of Advocate General Darmon in Joined Cases C-89, 104, 114, 116, 117 and 125 to $129 / 85$ A. Ahlström Osakeyhtiö and others $v$ Commission of the European Communities [1988]ECR 5193.

439 Case T-4/89 BASF v. Commission of the European Communities [1991] ECR II-1523, paragraph 242; Hercules, paragraph 140.

440 Joined Cases C-56/64 and C-58/64 Établissements Consten S.A.R.L. and Grundig-Verkaufs-Gmbh v. Commission of the European Economic Community [1966] ECR 299, p.341.

441 Case C-22/78 Hugin v. Commission [1979] ECR 1869, paragraph 17.

442 Case C-306/96 Javico [1998] ECR I-1983, paragraph 16.

443 Case C-30/87 Bodson [1988] ECR 2479, paragraph 24.

444 Ehlerman, 1993, p. 143. 
tional courts. ${ }^{445}$ As indicated in Chapter II of this thesis, according to the Mirza \& Nacey research, in Europe only $6 \%$ of architectural practice revenue is generated by work undertaken outside the home country. It should be repeated however that this is just estimation based on the result of questionnaires. However, it should be noted that architects from Member State A who establish themselves in Member State B can be considered as architects of Member State B who in turn can perform services in Member State C. Due to globalization and the knowledge-based economy more and more services will be performed internationally. Since national regulations restricting competition generally also apply to foreign service providers and generally cover the whole territory of the Member State, they generally have at least a potential appreciable effect on trade between Member States. The ECJ has consistently held that a restriction of competition which extends to the whole territory of a Member State affects interstate trade within the meaning of Article 101(1) TFEU because it has, by its very nature, the effect of reinforcing the compartmentalisation of markets on a national basis, thereby holding up the economic interpenetration which the Treaty is designed to bring about. ${ }^{446}$ In this way, trade between Member States may be affected by a measure which prevents an undertaking from establishing itself in another Member State with a view to providing services there. ${ }^{447}$ It follows that intra-state restrictions of competition can affect interstate trade even if they do not hinder such trade, i.e. even if they do not foreclose interstate competition, so that Article 101 TFEU is applicable to them. ${ }^{448}$ It is thus for national courts to determine, having regard to the economic characteristics of the relevant market, whether there is a sufficient degree of probability that a certain rule will actually prevent operators established in Member States other than the Member State in question, either from providing their services in that Member State, or from establishing themselves there.

\subsection{Common examples of restrictions to trade}

As noted above, in March 2000 the Lisbon European Council adopted an economic reform programme to make the EU the most competitive and dynamic knowledgebased economy in the world by 2010. In improving the competitiveness of the EU economy, professional services were held to play an important role. A large-scale research

445 In Fiammiferi, the Court held that where undertakings engage in conduct contrary to Article 81(1) and where that conduct is required or facilitated by State measures, a national competition authority has a duty to disapply those state measures and to give effect to Articles 81 and 82. Private enforcement in national courts does not only cover Articles 81 and 82 as they apply to undertakings and associations of undertakings, but is also possible against Member States under Articles 86(1) in conjunction with Articles 82/81 or against them under Articles 3(1)(g), 10(2) in conjunction with Articles 81/82. See Case C-198/01 Consorzio Industrie Fiammiferi (CIF) [2003] ECR I-08055.

446 Case C-35/96 Commission v. Italy [1998] ECR I-3851, paragraph 48; Case C-35/99 Arduino [2002] ECR I1529, paragraph 33; Wouters paragraph 95.

447 See, to that effect, Case C-161/84 Pronuptia [1986] ECR 353, paragraph 26.

448 Gyselen 2004, p. 386. Gyselen refers to the Commission's Guidelines on the 'affect on trade' concept in which the Commission holds that cartels covering a single Member State are capable of reinforcing the compartmentalisation of markets because their participants normally need to take action to exclude competitors from other Member States. This applies mutatis mutandis to anti-competitive state measures. 
project on competition in professional services was conducted on behalf of the European Commission. ${ }^{449}$ In this way the Commission aimed to determine whether the current regulations related to professional services serves the interests of consumers, and is thus the most efficient and least restrictive in terms of competition, or whether better regulations, more closely adapted to the modern world, could help spur economic growth, and deliver better services and value for consumers. ${ }^{450}$ The Commission based this research on an independent study which was carried out by the Institute for Advanced Studies in Vienna, which contained a schematic overview of regulations in the then 15 EU member States with regard to six professions, including architects. For each of these professions an overview was presented of all the rules restricting entry to the profession and the rules restricting market conduct. In this way regulations concerning price fixing, recommended prices, advertising regulations, entry requirements and reserved rights and regulations governing business structure and multi-disciplinary practices as categories of regulation which are possible to restrict competition, were identified. ${ }^{451}$

449 Paterson, Fink \& Ogus 2003. See for more information: http://ec.europa.eu/competition/sectors/professional_services/studies/studies.html, last consulted 1 December 2009.

450 See http://ec.europa.eu/comm/competition/sectors/professional_services/overview_en.html, last consulted 1 December 2009.

451 In its report, the Commission also mentioned the reactions of the respondents to the findings of the IHS. With regard to architects, the majority of respondents supported appropriate entry regulation to ensure that architects are competent to carry out their functions and to respect safety standards. However, the Commission argued that few respondents commented in detail on the extent to which licensed or certified architects should hold exclusive or reserved rights. Likewise, very few discussed the regulatory framework in countries such as Denmark, Ireland and the Netherlands, where unqualified practitioners are permitted to offer a range of architectural services. The Architects' Council of Europe, for example, commented that control mechanisms are essential because the quality of architectural services is only discernible after the construction process.

With regard to price fixing, the majority of the respondents argued in favour of price regulation and recommended prices for architectural services. Most suggested that these regulations are necessary to ensure quality. Unrestricted price competition would force prices to levels at which it would be impossible to respect quality and safety standards. According to the Architects' Council of Europe, for example, reasonable fixed prices are necessary to ensure that professionals compete on quality rather than on price. Without fixed prices, service providers would be tempted to offer the lowest price in order to obtain contracts, leading to a reduction in the quality of construction. The Architects' Order of Belgium argued that fixed prices are necessary to allow architects to make a reasonable profit and to exercise their functions honourably and with dignity. They suggested that price competition would force architects to use inferior materials that would reduce the strength and security of buildings. In the Commission's view, however, none of the respondents explained why price regulation, as opposed to other mechanisms such as planning permission procedures, construction standards and monitoring, should offer an effective means of quality control. No reason was given to indicate why price regulation should be expected, in itself, to improve or safeguard construction standards, nor was any explanation given as to why architects subject to price regulation would not have strong motivations to reduce quality in order to maximise profits.

No evidence was provided to suggest that standards are higher in the minority of Member States that have minimum or fixed fees. A large majority of respondents were also in favour of recommended prices for architectural services. However, few commented in detail on the justification for this type of regulation. As held by the Commission, few of the respondents commented on the concern that recommended prices might facilitate collusion. Likewise, they did not explain why consumers should need recommended prices for architects' services, despite the fact that they do not rely on recommended prices when purchasing other complex products. In this regard, the Bundesarbeitskammer, an Austrian consumer organisation, even suggested that the Austrian professions sometimes lead consumers to believe that recommended 
In the present chapter I will discuss in more detail these examples of restrictions which are generally imposed by professional associations, and which are likely to fall within the ambit of Article 101(1) TFEU. In this way it will become apparent that architects may also experience other restrictions than those directly interfering with their free movement rights in the practice of their profession. These restrictions are often not linked at all to their nationality as is required for restrictions considered within the framework of the free movement provisions of the Treaty on the Functioning of the European Union. In this regard it should also be noted that Articles 101(1) and 101(2) TFEU have vertical and horizontal direct effect since they are clear, precise and unconditional and do not require any further implementation by the Member States. ${ }^{452}$ In Part III of this thesis these restrictions will be discussed from a law and economics point of view. It will become clear that the ECJ also bases its decisions on economic principles. As stated before, the Court does not only investigate whether the undertakings are liable under Article 101 TFEU, but also whether the state authorities can be held responsible under Article 101 TFEU jo 4(3) EU.

\subsubsection{Market entry restrictions}

In its case law on the freedom of establishment, and the free movement of services, the ECJ has made clear on numerous occasions that the prohibition of discrimination on grounds of nationality also has to be respected by the self-regulatory professional associations. ${ }^{453}$ The same goes for all indirect or non-discriminatory rules such as establishment $^{454}$ or diploma requirements which foreigners find more difficult to obey. In

prices are fixed prices in order to avoid giving discounts. They added that Austrian architects face few incentives to reduced prices and costs.

With regard to advertising, the majority were of the opinion that architects should be free to engage in truthful advertising.

Finally, as far as business structure and inter-professional cooperation are concerned, the majority believed that there is a need for regulation to ensure transparency of ownership of architectural services companies, and to preserve architects' independence from other groups. In this way, the Architects' Council of Europe argued that, given the complex nature and potential impact of architectural services, it is important for clients to be aware of the ultimate ownership of architectural services companies. The Council also suggested that architects' independence should not be compromised as a result of co-operation with other groups. However, the Commission considered that the respondents did not comment on the potential economic advantages of cooperation between architects and other groups such as engineers and builders. Nor did they comment on service provision in the majority of EU Member States where there are no significant regulations restricting architects' participation in multi-disciplinary practices.

452 Case C-127/79 BRT and SABAM [1974] ECR 51 paragraph 16 and Case C-282/95 P Guérin Automobiles v. Commission [1997] ECR I-1503 paragraph 39.

453 See for example, Case C-246/80 Broekmeulen v. Huisarts Registratie Commissie [1981] ECR 2311 in which it was decided that a national of a Member State who has obtained a diploma of medical doctor in another Member State and who may practise general medicine in that other Member State, is entitled to establish himself in his own country even if the Bar makes entry into the profession subject to additional requirements. See also Thieffry in which the ECJ held that the Bar cannot refuse permission to register for practical training to a national of one Member State who has obtained a diploma of doctor in his country of origin and which has been recognized as an equivalent qualification by the competent authority under the legislation of the country of establishment.

454 The ECJ has ruled that non-discriminatory deontological rules prohibiting the keeping of more than one office, or the entering into partnership at more than one Bar, are incompatible with the freedom of estab- 
Gebhard, the Court even held that non-discriminatory rules restricting the right to bear a professional title and compulsory membership of public professional bodies must be justified by imperative requirements in the general interest. With regard to the entry on the register of a professional organisation, it has been argued that professional examinations to enter the register of a professional organization should not be carried out by the Order itself, since the Order has an economic interest in limiting the number of successful applicants. ${ }^{455}$ Membership can be denied by reason of subjective decisions (for example good conduct-requirements) which can harm competition. ${ }^{456}$ This issue was addressed by the ECJ in Mauri ${ }^{457}$ with regard to the State examination for access to the Italian bar. A question was raised about the composition of the examination committee which consisted of five members appointed by the Minister for Justice, namely two judges, a professor of law and two advocates, the latter being nominated by the lawyer's professional association on a joint proposal by the bar councils of the district concerned. The applicant was worried that the presence of the advocates was disadvantageous to him since they might want to restrict the access of new competitors to the profession by failing applicants.

With regard to the freedom of establishment, the ECJ considered that although an examination for access to the profession of advocate may indeed constitute an obstacle, this was not the case for the rule relating to the composition of the examination committee. Even assuming that the participation of advocates in the State examination committee may in itself constitute a restriction on the freedom of establishment, that participation may be justified in the public interest, namely the need to assess as well as possible the aptitude and ability of persons called to practise as advocates, and is suitable for securing the attainment of that objective. Since advocates have professional experience, they are particularly qualified to assess candidates in the light of the specific requirements of their profession.

With regard to the application of the competition law provisions, the ECJ held that including advocates as members of an examination committee may be treated as undertakings in the sense of Article 10 TFEU. Even though Articles 4(3) EU jo Article 101 TFEU requires Member States not to introduce or maintain in force measures which may render ineffective the competition rules applicable to undertakings the state, in the case in hand, still occupied a significant position on the committee itself due to the presence of two judges who, even if they are not hierarchically subordinate to the Minister for Justice, must nonetheless be regarded as an emanation of the state. Since the Minister for Justice can supervise each stage of the proceedings, and can even intervene during the proceedings in that he also appoints the members of the committee and chooses the examination subjects, the state had not given up its powers. Furthermore, a negative decision could be subject for proceedings before the administrative courts. The ECJ

lishment. See Case C-96/85 Commission v. France [1986] ECR 1475 and Klopp. Even if such restrictions would be acceptable for reasons of public interest, they will probably not satisfy the proportionality test.

455 OECD Competition Policy and the Professions. Paris: OECD, 1985, p. 35.

456 In this regard, Van den Bergh has held that an economic analysis of the proportionality requirement may be useful. Van den Bergh 1999, p. 99.

457 Case C-250/03 Ministero della Giustizia and Commissione per gli esami di avvocato presso la Corte d'appello di Milano [2005] ECR I-01267. 
therefore concluded that Article 101 TFEU did not preclude the rule at issue. This line of reasoning has often been repeated by the ECJ.

\subsubsection{Market conduct restrictions}

\section{Price regulations}

a. $\quad$ Fixed prices

In most EU Member States, the fees charged for professional services are negotiated freely between practitioners and their clients. However it occurs that fixed maximum and minimum prices are applied. In this regard reference should be made to Article 101 TFEU which explicitly prohibits agreements between undertakings, decisions by associations of undertakings and concerted practices which directly or indirectly fix purchase or selling prices, or any other trading conditions which may affect trade between Member States and have, as their object or effect, the prevention, restriction or distortion of competition within the internal market. Such agreements will be void ab initio. Since the absence of fixed prices in the architectural profession is common, it can be concluded that fixed prices are not essential regulatory instruments, and that other less restrictive means can be used to maintain high standards. However the Commission and the ECJ have decided upon numerous cases involving price fixing, some with regard to the architectural profession.

$B N I C^{458}$ concerned an agreement signed by the representatives of dealers and winegrowers fixing a minimum price for wines for distillation and the manufacture of cognac throughout the whole of France. They agreed that any contract concluded in breach of this agreement would be void, and this agreement was made generally binding by an order issued by the Minister for Agriculture. An action was brought against Mr. Clair who bought cognac from various wine-growers at prices lower that those laid down by the Order. The Court held that the agreement fell under Article 101 TFEU since it was negotiated and concluded by persons who were, although appointed by the public authorities, generally proposed for appointment by the trade organizations directly concerned. For this reason they should be regarded as representing those organizations in the negotiation and conclusion of the agreement. The Court considered that an agreement fixing a minimum price for a product, even if it is submitted to the public authorities for the purpose of obtaining approval for that minimum price, so that it becomes binding on all traders in the market in question, is intended to distort competition, and is therefore contrary to EU competition law. Since minimum prices prevent operators from competing by setting prices below the minima laid down, they constitute a significant restriction of competition. Therefore, they deny consumers the opportunity to acquire the goods or services concerned at the best price. Furthermore, minimum

${ }^{458}$ Case C-123/83 Bureau National Interprofessional du Cognac v Guy Clair [1985] ECR I-391, paragraph 22. 
prices artificially reinforce the barriers to entry for operators wishing to enter the market since they deprive the latter of a fast and effective means of penetrating the market. ${ }^{459}$

In $C N S D^{460}$, the public authorities required the Italian National Council of Customs Agents (CNSD) -a private undertaking- to conclude price-fixing arrangements (minimum and maximum tariffs) for the services of customs agents. CNSD, a body governed by public law, was thus responsible for setting the tariff for the services provided by customs agents. This tariff was approved by a decree of the Italian Minister for Finance. The Court held that even though customs agents can be qualified as liberal professionals, they do fall under the concept of an undertaking, since this covers any entity engaged in an economic activity, regardless of its legal status and the way in which it is financed. An activity consisting of offering goods and services in a given markets is thus an economic activity. As indicated above, the public law status of a national body such as the CNSD does not preclude the application of competition rules, since the legal framework within which agreements are made, and such decisions are taken, and the classifications given to that framework by the various national legal systems, are irrelevant for the application of Article 101 TFEU. In this regard it should be noted that the members of the CNSD were the representatives of professional customs agents and nothing in the national legislation prevented the CNSD from acting in the exclusive interests of the profession. Since the tariff created by CNSD was made mandatory by a national decree, Italy did not only require the conclusion of an agreement contrary to Article 101 TFEU, but also assisted in ensuring compliance with it. The ECJ confirmed thus that by adopting and maintaining this Decree in force, which in granting the relative decision-making power required the CNSD to adopt a decision consisting of setting a compulsory tariff, Italy had failed its obligations under the Treaty and was liable under Article 3(3) EU jo 4(3) EU jo 101 TFEU.

As held before, the ECJ has also dealt with price fixing in the architectural profession. Giuseppe Conte v. Stefania Rossitic1 dealt with Italian legislation providing for minimum tariffs in respect of the services provided by engineers and architects. Initially those tariffs were fixed directly by the legislator. Article 2 of the fee scale annexed to Law No 143/49 of 2 March 1949462, approving the professional scale of fees for engineers and architects, provided for four types of fees which were fixed: (a) by percentage, that is on the basis of the value of the work to be done; (b) by unit, that is on the basis of the unit of measurement; (c) by time, that is on the basis of the time spent; and (d) by discretion, meaning that they are left entirely to the professional. With regard to the latter possibility, Article 5 of the fee scale annexed to Law No 143/49, which was of particular importance in the main proceedings, listed the services for which fees could be set at the dis-

459 See, to this effect, Commission Decision 95/188/EC of 30 January 1995 relating to a proceeding under Article 81 of the EC Treaty (IV/33.686 - Colegio Oficial de AGhentes de la Propriedad Industrial (COAPI) (OJ 1995 L 122, p. 37, paragraph 38 of the account of the facts).

460 Case C-35/96 Commission v. Italy, paragraphs 2-9, 41, 59, 55, 57 and 59.

461 Case C-221/99 Giuseppe Conte v. Stefania Rossi [2001] ECR I-09359.

462 Gazetta Ufficieal della Repubblica Italiana no 90 of 19 April 1949, p. 3. 
cretion of the professional. Subsequently, Law No 143 of 4 March $1958^{463}$ provided that the scales of fees and emoluments for engineers and architects, and the criteria for the reimbursement of expenses, were to be laid down by decree of the Minister for Justice, by agreement with the Minister for Public Works, on a proposal from the National Councils of the Associations of Engineers and Architects. However, the law held that the fee scales laid down according to this new procedure were not applicable to the services referred to in Article 5 of the scale annexed to Law No 143/49. Architects thus still enjoy discretion in setting their fees in respect of those services.

In case of professional disputes such as disputes on architectural fees, the Association Council, which is composed of members elected by registered architects, has to give its opinion. ${ }^{464}$ Hereafter, an architect can lodge an ex parte application to obtain an enforceable court order against his debtor in the event that his fees are not paid. The architect has to add his fee invoice to his application which must be endorsed by the opinion of the competent professional association unless the fee is fixed on the basis of mandatory tariffs. In accordance with the Italian Code of Civil Procedure, the Court is bound to follow the opinion of the professional association as regards the sums claimed - the correction of clerical errors aside - unless the court dismisses the application on the grounds that it is insufficiently substantiated. However, in the event that the defendant does not agree, he may apply within the time limit to have the order set aside and an ordinary civil procedure inter partes has to be followed. In this regard it should be noted that the opinion of the architectural association only binds the court seized of the dispute at the first ex parte stage of the procedure. If the debtor initiates an inter partes procedure to have the order set aside, the opinion of the association is thus no longer binding on the court.

Since the national court still has the final say in an independent way, the ECJ held that the opinion of the architectural association which is related to individual services provided by a specific practitioner, cannot constitute a decision by an association of undertakings which may, in itself, restrict or distort competition within the meaning of Article 101 TFEU. It follows that Article 4(3) EU jo 101 TFEU does not preclude national legislation which, in the context of a summary procedure for the recovery of debts relating to the fees of an architect, requires the court seized of the dispute to follow the opinion of that association in relation to the settlement of those fees, insofar as that opinion ceases to be binding, where the debtor initiates proceedings inter partes. Since the services in respect of which the procedure for the recovery of debts was implemented were not subject to an obligatory tariff, while each practitioner had freedom to set its relevant fee, the ECJ held that the Italian legislation did not promote the creation of anti-competitive agreements. Articles 4(3) EU and 101 TFEU therefore did not preclude national legislation which provides that the members of a profession may set, at their discretion, the fees for certain services which they perform.

Arduino was about a public authority requiring a private undertaking, the Italian Council of the Bar (CNF), to conclude price-fixing arrangements for the services provided by

463 Gazetta Ufficieal della Repubblica Italiana no 65 of 15 March 1958, p. 1101.

464 See Article 5 of Law No 1395 of 24 June 1923, GURI No 157 of 5 July 1923, p. 5193. 
its members, and reinforce the effect thereof. The Italian law spelled out which criteria the Council of the Bar needed to take into account, and the Minister had to approve these tariffs. CNF was only responsible for producing a draft tariff which, as such, was not compulsory, and did not have to take into account public-interest criteria. Even though the Minister could only reject or endorse the CNF's proposal, and even though there was little doubt that his decree was merely a rubber stamp, by refusing to approve the draft tariff with the consequence that the old tariff remained applicable, the Minister could prompt the CNF to amend its draft along the lines he indicated, so that the state still had the final say, as opposed to the situation in CNSD where the public authorities did not assume full responsibility for the restriction of competition, since they wholly relinquished, to private economic operators, the powers of the public authorities as regards the setting of tariffs. Since in Arduino the Italian State had not waived its power to make decisions of last resort, or to review implementation of the tariff, it had not delegated its responsibility for taking decisions affecting the economic sphere. In other words, the Italian State had not divested its own rules of the character of legislation by delegating to private economic operators responsibility for taking decisions affecting the economic sphere. The state also did not require or encourage the adoption of decisions contrary to competition law. Accordingly, the Court decided that, since the final responsibility was assumed by the public authority (a genuine state measure), Article 101 TFEU was not applicable, and that the state measure was lawful. ${ }^{465}$ In the case of such genuine state measures, the presence of public interest grounds is a given which means that neither the Commission nor the Court should inquire these grounds when assessing such measures under EU competition law. ${ }^{466}$

465 See also Fiammiferi, paragraphs 70-79. In this case a production quota system pursuant to which the match manufacturers belonging to the German consortium of domestic match manufacturers (CIF) were entitled to production volumes which corresponded to their existing market share. The national legislation did not preclude the match manufacturers from engaging in autonomous conduct provided for a quota system. However since the quota system did not impose any calculation criteria, the members of the quota allocation committee were acting exclusively in their own interests while the public authorities had no effective means of controlling the decisions of the committee and had no say at all in the committee which was composed solely of CIF members. The Italian public authorities therefore did not assume full responsibility for the restriction of competition. They only rubber-stamped the decisions made by the committee. The Court held that national legislation precluding undertakings from engaging in autonomous conduct, does not shield these undertakings forever against the constraints of Article 81 and 82 EC, and held that any provision of national law which contravenes Community legislation should be disapplied, not only by the national courts, but also by the National Competition Authority. Undertakings may even face penalties for conduct subsequent to the decision to disapply the national legislation, once the decision has become definitive in their regard, while a Member State that requires the adoption of anti-competitive agreements infringes Article 10 and 81 EC. As held by First 2004, p. 262, Fiammiferi looks first at the extent to which anticompetitive conduct is compelled by the state. Compulsion is important, not only because it removes discretion from a party with respect to its conduct, making liability for that conduct unfair, but also because compulsion demonstrates clearly a state policy to displace competition with regulation. Fiammiferi looks at whether discretionary conduct can be blamed on the party, or is attributable to the state. The consequence of the judgment is that when a decision by a national competition authority to disapply national legislation has become definitive, the State compulsion defence is no longer available. For the period prior to the decision to disapply the legislation, the State compulsion defence is valid, and the undertakings enjoy immunity from fines and also immunity from damage claims.

466 It can be questioned why the Court, in its Arduino judgement, did not indicate that Italy's regulation of lawyers' fees would have to be disapplied in the future as well. According to the ECJ, in Arduino the price 
Cupola ${ }^{467}$ concerned an Italian Royal Decree stating that the criteria for determining fees and emoluments payable to lawyers in respect of civil and criminal proceedings and out-of-court work are to be set every two years by the National Lawyers' Council (CNF). When this Council has decided on lawyers' fees, the scale must be approved by the Minister of Justice for it to be binding. According to the scale, the fees have to be based on the monetary value of disputes, the level of the court seized, and the duration of the proceedings. In the case under consideration, parties had, however, made a flat-rate agreement about the remuneration of the lawyer which was not based on the scale. The Court held that the draft scale of fees which was created by the CNF did not encompass that the Italian State had waived its power to make decisions of last resort, or to review the implementation of that scale. This was confirmed by the fact that Italian legislation foresees that courts may depart from the maximum and minimum limits, and by the fact that the Minister has the power to have the draft amended by the CNF. The Court thus held that Articles 4(3) EU and 101 and 102 TFEU do not preclude a Member State from adopting a legislative measure which approves, on the basis of a draft produced by a professional body of lawyers such as the CNF, a scale fixing a minimum fee for members of the legal profession, from which there can generally be no derogation. However, the Court indicated that the prohibition of derogation, by agreement, from the minimum fees set by a scale such as that lay down by the Italian legislation, was liable to render access to the Italian legal services market more difficult for lawyers established in a Member State other than the Italian Republic. Indeed, it deprived such lawyers of the possibility, by requesting fees lower than those set by the scale, of competing more effectively with lawyers established on a stable basis in the Member State concerned, and who therefore have greater opportunities for winning clients than lawyers established abroad. Since it was likely to restrict the exercise of their activities providing services in that Member State, the prohibition amounted to a restriction within the meaning of Article 56 TFEU. The Court also stipulated that the prohibition limited the choice of service recipients in Italy, because they could not resort to the services of lawyers established in other Member States who would offer their services in Italy at a lower rate than the minimum fees set by the scale. Nevertheless, the protection of consumers and the

fixing was the result of the state's action, rather than the action of the bar Association. This was due to the fact that public Ministries reviewed and approved the fee schedule. In Fiammiferi, quota allocations and transfers were approved by public ministries as well, but it was held that public authorities did not have an effective means of controlling decisions taken by the quota-allocation committee, of which four of the five members were from the industry, with the result that the decisions could be made exclusively in the private interest. This, however, was also the case for the bar association's fee schedule in Arduino, but this was not taken into account by the ECJ. It is obvious that the last word has not been said yet. As held by First 2004, the more recent Fiammiferi case indicates that the Court may now be more inclined to place anticompetitive conduct within the control of competition law, even though that conduct is subject to some degree of state control but there is no real framework (yet): See First 2004, p. 11. In any case, it seems that the ECJ is wiling to accept public interest justifications for professional regulation without either a close evaluation of the anticompetitive effects of such regulation, or an effort to assess how strong those justifications are in relation to the anticompetitive effects. Without further development, the result may be to allow the liberal professions great latitude to engage in self-regulation that furthers the private economic interests of the profession itself.

467 Joined Cases C-94/04 and C-202/04 Federico Cipolla v. Rosaria Fazari, née Portolese and Stefano Macrino and Claudia Capodarte v. Roberto Meloni [2006] ECR I-1 1421. 
safeguarding of the proper administration of justice are objectives to be included among those which may be regarded as overriding requirements relating to the public interest, capable of justifying a restriction on freedom to provide services ${ }^{468}$ on condition that the national measure at issue in the main proceedings is suitable for securing the attainment of the objective pursued, and does not go beyond what is necessary in order to attain that objective (see Article 56 job 52 TFEU). The ECJ held that it is a matter for the national court to decide whether, in the case at issue, the restriction on freedom to provide services introduced by that national legislation fulfils those conditions. When deciding, the national courts has to take into account whether there is a correlation between the level of fees and the quality of the services provided by lawyers and whether, in particular, the setting of such minimum fees constitutes an appropriate measure for attaining the objectives pursued, namely the protection of consumers and the proper administration of justice. Although it is true that a scale imposing minimum fees cannot prevent members of the profession from offering mediocre quality services, it is conceivable that such a scale does serve to prevent lawyers, in a context such as that of the Italian market which is characterised by an extremely large number of lawyers who are enrolled and practising, from being encouraged to compete against each other by possibly offering services at a discount, with the risk of deterioration in the quality of the services provided. This has to be seen in the light of the problem of information asymmetry ${ }^{469}$ in the field of lawyers' services, which is an economic argument. In this regard, the ECJ held that the national court will also have to determine whether professional rules in respect of lawyers, in particular rules relating to organisations, qualifications, professional ethics, supervision and liability, suffice in themselves to attain the objectives of the protection of consumers and the proper administration of justice. It was thus concluded that, in principle, legislation containing an absolute prohibition of derogation, by agreement, from the minimum fees set by a scale of lawyer's fees such as that at issue for services which are court services reserved to lawyers, constitutes a restriction on freedom to provide services laid down in Article 56 TFEU. However, it is for the national court to determine whether such legislation, in the light of the detailed rules for its application, actually serves the objectives of protection of consumers and the proper administration of justice which might justify it, and whether the restrictions it imposes do not appear disproportionate in the light of those objectives.

\section{b. Recommended prices}

Even the circulation of recommended tariffs by a trade organization is liable to prompt the relevant undertakings to align their tariffs, irrespective of their costs. Such a method dissuades undertakings whose cost prices are lower, from lowering their prices, and thus creates an artificial advantage for undertakings which have the least control over their

468 See, to that effect, Case C-3/95 Reisebüro Broede [1996] ECR I-6511, paragraph 31 and Case C-124/97 Läärä and Others [1999] ECR I-6067, paragraph 33.

469 This entails that professionals have more or better information at their disposal than their clients with regard to the particular services. The economic effects of such information asymmetry will be described in detail in Part III of this thesis. 
production costs. ${ }^{470}$ Since Article 101(1) TFEU also applies to associations of undertakings insofar as their own activities or those of the undertakings affiliated to them are calculated to produce the results which it aims to suppress, ${ }^{471}$ even a recommendation without binding effect cannot escape its application where compliance with the recommendation by the undertakings to which it is addressed has an appreciable influence on competition in the market in question. ${ }^{472}$ In the case of advisory prices, profession members are, in theory, still free to set their prices, although the chance of collective pricing behaviour is rather high. ${ }^{43}$ Recommended prices can mislead consumers as to what is a reasonable price for the service they are receiving, and as to whether or not this recommended price is negotiable. As indicated by the Commission Staff Working Document of September 2005, the key justifications given for maintaining recommended fee scales centre on the need to provide a guide to consumers on likely costs and protect against what is termed 'unfair' competition between practitioners. However, recommended fees and reference scales can still act to facilitate price co-ordination. There are other less distorting ways to provide consumers with a 'guide' to prices. For instance, active monitoring by consumer associations on pricing and the collection and publication of survey based historical price data by independent organisations. Ways can also be developed to provide customers with costs of the professional service ex ante, at the moment of giving the mandate. ${ }^{47}$ Indeed, the fixing of prices, even those which merely constitute a target, affects competition, since such target prices enable all the participants in a cartel to predict, with a reasonable degree of certainty, what the pricing policy pursued by their competitors will be. Even if such an agreement only extends over the territory of one Member State, it has, by its very nature, the effect of reinforcing the compartmentalization of markets on a national basis, thereby holding up the economic interpenetration which the Treaty is designed to bring about, and protecting domestic production. ${ }^{475}$

While in the late 1990s recommended prices were abolished for architects in France ${ }^{476}$ and while in the United Kingdom, the Office of Fair Trading came to the conclusion that the Royal Institute of British Architects' (RIBA) indicative fee guidance could facilitate collusion ${ }^{47}$, in 2003 the European Commission sent the Belgian Architects' Association a warning that its recommended minimum fee scale could constitute a violation of

470 Commission Decision 96/438/EC of 5 June 1996 relating to a proceeding pursuant to Article 81 of the EC Treaty (IV/34.983 - Fenex), OJ L 181, 20 July 1996, pp. 28-36.

471 Case C-71/74, Frubo v. Commission, [1975] ECR 563; Cases 209 to 215 and 218/78 Van Landewyck and Others v. Commission [1980] ECR 3125.

472 Case C-96/82 NV IAZ International Belgium and others v Commission of the European Communities [1983] ECR 3369.

473 Philipsen 2003, p. 36. See also Commission Decision of 30 June 1993 relating to a proceeding pursuant to Article 85 of the EEC Treaty (IV/33.407 - CNSD), OJ L 203 , 13 August 1993, pp. 0027 - 0033

$474 \operatorname{COM}(2005) 405$ final p.21.

475 Case C-8/72 Vereeniging van Cementhandelaren v. Commission of the European Communities [1972] ECR 977.

476 The French Conseil de la Concurrence also prohibited the French Architects' Association from further elaborating and distributing fee scales: See Decision no. 97D45 of 10 June 1997 and Communication from the Commission - Report on Competition in Professional Services $/{ }^{\star}$ COM/2004/0083 final ${ }^{\star} /$

477 However, the Office of Fair Trading adopted the RIBA's new fee guidance based on historical information and the collation of price trends that do not provide a lead on the current year's prices. 
EU competition rules. ${ }^{478}$ This fee scale found in 1967 its origin in Article 12 of the Association's Code of Ethics, which new version was given binding force by Royal Decree in 1985. ${ }^{479}$ This Article held that depending on the form in which he exercises his profession, an architect shall be remunerated by fees or a salary that enable him to earn his living and carry on his profession with honour and dignity. They must enable him to cover his expenses, and in particular his professional liability insurance. The National Council shall set the minimum fee scales by means of standards made binding in accordance with Article 3. Anyone infringing these provisions shall be liable to the disciplinary penalties provided for in Article 21 of the Act of 26 June 1963. The National Council shall also propose reference scales for salaries. In this regard the report to the King explaining the Association's need to have the 1985 Code approved, stated that in order to take account of the evolving nature of the profession, the Code of Ethics may subsequently be clarified by means of rules made compulsory by Royal Decree discussed in Cabinet. This will be the case, in particular, for the provision setting a minimum fee scale. Furthermore, Article 3 of the Code held more particularly that the Code may be clarified by means of binding rules approved by Royal Decree discussed in Cabinet, on a proposal from the National Council of Association, or by means of recommendations issued by the National Council of the Association. Based on these provisions, the disputed fee scale for architects was created in 1967 and the document was called 'Ethical Standard No 2'.

Article 1 of Ethical Standard No 2 immediately exposed the aim of the fee scale: the determination of minimum remuneration for self-employed architects. ${ }^{480}$ Fees were to be calculated as fixed percentages of the expenditure on the building work. ${ }^{481}$ Following this, the National Council drew up and published a standard architect-client contract ${ }^{482}$ which stipulated, in Article 10, the express agreement of the parties that the fees are to be fixed and paid in accordance with Ethical Standard No 2, a copy of which would be attached. A Royal Decree making the text of Ethical Standard No 2 binding, was never adopted, since the then Minister for Small and Medium-sized Enterprises, the Profes-

478 The Commission held also, on other occasions, that Article 81 EC fully applies if a Member State gives authority to a professional association to fix prices, thereby violating Article 3 (g), 10 and 81 EC. See for example Consiglio nazionale degli spedizionieri doganali: Decision of 30 June1993. [1993] OJ L 203; Colegio Oficial de Aghentes de la Propriedad Industrial: Decision of 30 January 1995 [1995] OJ L 122. When professional associations promulgate fee schedules on the basis of such authority, they will not be immune from antitrust scrutinisation. In both decisions, price fixing was held to be illegal.

479 Article 39 of the Architects' Order Act empowers the Crown, at the National Council's request, to give binding force to the Code of Ethics by means of a Royal Decree discussed in Cabinet. This happened on 5 July 1967 while the new Code of Ethics was given force by Royal Decree in 1985.

480 The reference is to Articles 7 and 10 of the 1967 Code of Ethics, defining independent and salaried architects.

481 When the Commission asked the Association's provincial councils to produce copies of the 20 most recent contracts in which fees were lower than those determined by the scale, the provincial councils in Namur and Hainaut - the only councils who replied that they were in possession of copies of contracts - each sent 20 contracts. Although the Commission had asked them to produce contracts in which fees were lower than those determined by the scale, most of the contracts in fact stipulated fees equivalent to those determined by the scale. In all, over three quarters (32 out of 40) of the recent contracts examined referred explicitly to the scale. While it is true that this was only a limited sample, there is nothing to indicate that the situation might be different in the other regions.

482 This was approved at its meeting of 27 September 1968. 
sions and the Self-employed did not find this advisable. This was clearly against the Association's intention.

After becoming aware of the fee scale's difficult and disputed status, in 2002 the Belgian Architectural Association published a statement indicating that since both the Belgian Competition Council and the Court of Justice of the European Union seem to be taking a particular interest in the compatibility with the competition rules of fee scales drawn up by regulated professions, the fee scale should be understood as a guideline. Furthermore, in 2003, the steering committee of the National Council decided to delete all reference to the fee scale with immediate effect, and to rescinded the second paragraph of Article 30 of the Code of Ethics which held that the architect must abstain from participating in any public or private invitation to tender aimed at encouraging architects to compete on the of their services. ${ }^{483}$

This however did not stop the Commission from finding that the fee scale had violated EC competition law. It considered that Ethical Standard No 2 was a decision by an association of undertakings which might affect trade between Member States, and which had, as its object, the prevention, restriction or distortion of competition within the common market. ${ }^{484}$

Firstly, the Commission held that the Architects' Association was an association of undertakings within the meaning of Article 101(1) TFEU. Even though it has public-law status, and even though ten of twenty of the members of the national Council are appointed by the Government, the Association did not perform a special duty to protect the general interest in accordance with criteria laid down by law. On the contrary, the Association was able to act in the exclusive interest of the profession, and the minimum fee scale constituted the expression of the intention of the members of the profession, and was clearly intended to govern the behaviour of the members of the Association. ${ }^{485}$

483 On 4 May 2000, the Association's Dutch-speaking Appeal Board delivered two decisions finding that this second paragraph of Article 30 of the Code of Ethics was null and void under Article 2 of the Belgian Act of 5 August 1991, consolidated by the Royal Decree of 1 July 1999, concerning the protection of economic competition. In these two decisions, the Appeal Board explicitly acknowledged that the provision appreciably restricted competition between architects. The Association denied any link between the scale and the second paragraph of Article 30 of the Code of Ethics; but the fact that it did not inform all its members of the finding by the Dutch-speaking Appeal Board, is a further indication that is was pursuing a policy of avoiding all forms of price competition.

${ }^{484}$ Commission Decision of 24 June 2004

485 At the time Ethical Standard No 2 was created (1967), there was no legislation giving the Association the task of formulating the rules and practices determining the method by which architects' fees were to be calculated as fixed percentages of the expenditure on the building work. ${ }^{485}$ Furthermore, Article 12 of the Code of Ethics of 1985 which stated that minimum fee scales had to be created did not appear in the 1967 Code. Despite the absence of a Royal Decree which would make the text of Ethical Standard No 2 binding, the Association published the standard, circulated it, and updated it in 1978 and 2002. In this regard it should be noted that there was no evidence that the standard was simply a codification of existing rules and practices. Although the preamble stated that the standard set out the existing rules and practices, in reality it contained statements that had an intentionally rule-making tone, such as: 'The Code of Ethics stipulates that all architects are obliged to set their fees at a level determined at the very least by the relevant rules and practices accepted by the authorities of the Association'; 'It is the responsibility of the authorities of the Association to state the rules and practices determining the method for calculating architects' fees' and 'Rates lower than those set out below will not enable the architect to perform all the duties incumbent upon him conscientiously and responsibly. If he failed to apply them, he would run the risk of 
Unlike the scale set in the Arduino ${ }^{486}$ case, Ethical Standard No 2 was more than a mere preparatory act. The scale created an artificial link between the total cost of building work and the architect's fees. In this regard the Commission held that, while it is true that the cost of the work is a determining factor in the insurance premium to be paid by the architect, there is no other direct link between the cost of the work and the architect's costs, or any necessary link with the value added by his services. According to the Commission, fees charged for professional services should reflect the architect's skills, efficiency and costs, and perhaps his fame or notoriety, and should not be dependent solely on the value of the works or the price asked by the entrepreneur. The architect should be able to determine his fee independently of competitors, and in agreement with the client only. Important in this regard is that Article 12 stipulated that an architect may incur disciplinary penalties if he infringed the 1985 Code of Ethics. The Commission therefore concluded that Ethical Standard No 2 was a decision of a prescriptive character, and not a descriptive codification, and could not be considered to be a State measure or simply as an act preparatory to a State measure. As indicated by the Commission, even though referred to as a 'guideline', an act described as a recommendation may be contrary to Article 101 TFEU, whatever its legal status, if it aims to coordinate the conduct of the members of an association in accordance with the terms of the recommendation. ${ }^{487}$ Since all participants can predict, with a reasonable degree of certainty, what the pricing policy pursued by their competitors will be, especially if the provisions on target prices are backed up by the possibility of inspections and penalties, professional organisation are liable to prompt the relevant undertakings to align their tariffs, irrespective of their costs. ${ }^{488}$ This dissuades undertakings whose costs are relatively low from lowering their prices and thus creates an artificial advantage for undertakings which have the least control over their production costs ${ }^{489}$ and can mislead consumers as

neglecting his client's interests ... He would thereby be undermining the honour and dignity of the profession of which the Association is guardian.' In any event, it was unlikely that a straightforward codification of existing practices would produce so detailed a scale.

486 As held above, in the Arduino case, the professional association's part in the fixing of scales was limited to producing a draft that the responsible Minister was free to modify. Without the Minister's approval, the draft tariff did not come into force, and the earlier tariff remained applicable. Without approval, therefore, the draft could not affect the market. The Court concluded that there had not been any contestable delegation of authority to the operators.

${ }^{487}$ See Court of Justice in Case 45/85 Verband der Sachversicherer [1987] ECR 405, paragraph 32; see also Joined Cases 209 to 215 and Van Landewyck, paragraph 86. The question whether a decision has the objective of restricting competition depends therefore on a number of factors. Its objective may be deduced from the terms of the decision, its aims, the legal and economic context, and the conduct of the parties. See IAZ International paragraphs 22-25. See also Court of Justice in Joined Cases 29 and 30/83 Compagnie Royale Asturienne des Mines and Rheinzink [1984] ECR 1679, paragraph 26 and the Commission Guidelines on the application of Article 81(3) of the Treaty, OJ C 101, 27. April 2004, p. 97, paragraphs 21 and 22.

488 See Vereeniging van Cementhandelaren, paragraph 21. As held by the ECJ in Belasco, even though fixed prices might not have been observed in practice, the decision to fix them has the objecive of restricting competition. See Case 246/86 Belasco [1989] ECR 2117.

489 Such a risk is not, however, inherent in the circulation of information that would help the undertakings to calculate their own cost price structures so as to enable them to establish their selling prices independently. See Commission Decision 96/438/EC in Case IV/34.983 - Fenex, OJ L 181, 20 July 1996, p. 28, paragraphs $60-65$. 
to what is a reasonable price for the service they are receiving, and as to whether this recommended price is negotiable. ${ }^{490}$ The establishment of a (recommended) minimum fee scale can therefore not be considered as necessary in order to ensure the proper practice of the architect's profession. Whilst recommended prices do not automatically and always restrict competition, information on prices can be provided in other ways, such as the publication of information collected by independent parties (such as consumer organisations) concerning prices generally applied, or information based on a survey. These methods can constitute a more reliable yardstick for consumers and may lead to fewer distortions in terms of competition. The minimum fee scale drawn up and circulated by the Association between 12 July 1967 and 21 November 2003 therefore violated Article 101(1) TFEU.

\section{c. Conclusion}

Professions do not hesitate to use price fixing. They claim that minimum and even maximum or recommended prices are adopted to safeguard high quality services. If professionals are not able to compete on prices, their argument runs that they will concentrate on providing high quality services rather than reducing quality to offer their services at lower cost. However, fixed fees do not generally trigger innovation and prevent that tariffs are adapted to various levels in quality. Due to the fact that consumers are generally not able to assess the exact quality level of the services rendered (they did e.g. not receive the same education as architects), there is a risk that low level services are provided in case a maximum price has been determined. It follows that competition on quality is in principle hardly triggered in professional services. Minimum prices on the other hand prevent professionals from competing by setting prices below the minimum laid down. It follows that compulsory tariffs have as their object the restriction of competition and deny consumers the opportunity to acquire the services at the best price. Furthermore, fixed prices can also prevent new operators to enter the market since they are restricted to sell their services at a lower (or higher) price. Even recommended prices may be violating free competition if they aim to coordinate the conduct of the members of a professional association. It follows that regulations are not only able to limit the free movement of professionals, but can restrict free competition as well. If professional associations have created certain rules that hinder competition, national courts should disapply these rules unless they can be justified in accordance with Article 101(3) TFEU and are proportional.

\section{Advertising restrictions}

Advertising is a very important means of creating genuine outlets for all goods and services throughout the Union, and is used to promote the quality and price of a product. In this way it also increases competition. The ECJ has also delivered judgement in cases where Article 101(1) TFEU was said to be infringed due to advertising restrictions.

490 As held above, shortly after the scale was drawn up, the Association drafted a standard contract in which the only option for determining fees was a reference to the scale; this too attests to its intention to restrict competition on prices between its members by drawing up a minimum fee scale. It circulated this standard contract for eighteen years. 
In Institute of Professional Representatives before the European Patent Office ${ }^{491}$ (EPI), the Institute established a Code of Professional Conduct for its members. This Code stated, in Article 2(b)(1), that comparison of the professional services of one member with those of another is forbidden. The Court referred to Council Directive 84/450/EEC ${ }^{492}$ as amended by Directive 97/55/EC ${ }^{493}$ which provides in Article 3(a) that comparative advertising $^{494}$ is to be permitted on condition, inter alia, that it is not misleading. ${ }^{495}$ The Court thus concluded that when it is fair and in accordance with the appropriate rules, comparative advertising makes it possible in particular to provide more information to users and thus help them choose a professional representative in the Community as a whole, whom they may then approach. Even though Article 7(5) of this Directive states that Member States are authorised to maintain or introduce provisions prohibiting comparative advertising of professional services in compliance with the provisions of the Treaty, a simple prohibition of comparative advertising restricts the ability of more efficient professional representatives to develop their services, with the consequence, inter alia, that the clientele of each professional representative is crystallised within a national market. Fair and appropriate comparative advertising therefore has favourable effects on competition, while the prohibition of any form of that method of advertising entails a restriction on competition. The Court concluded therefore that where it is not shown that the absolute prohibition of comparative advertising is objectively necessary in order to preserve the dignity and rules of conduct of the profession concerned, the rule at issue violates Article 101(1) TFEU. This was in line with the opinion of the Commission which stipulated that the prohibition of comparative advertising restricts the ability of more efficient representatives to develop their services, to the detriment of

491 Case T-144/99 Institute of Professional Representatives before the European Patent Office [2001] ECR II1087.

${ }^{492}$ Council Directive 84/450/EEC of 10 September 1984 relating to the approximation of the laws, regulations and administrative provisions of the Member States concerning misleading advertising, OJ L 250, 19 September 1984, pp. 17-20.

493 Directive 97/55/EC of the European Parliament and of the Council of 6 October 1997 amending Directive 84/450/EEC concerning misleading advertising so as to include comparative advertising, OJ No L 290, 23 October 1997, p. 18. Directive 84/450/EEC is now repealed by Directive 2006/114/EC of the European Parliament and the Council of 12 December 2006 concerning misleading and comparative advertising (codified version) [2006] O.J. L149/22.

${ }^{494}$ Comparative advertising is defined as 'any advertising which explicitly or by implication identifies a competitor or goods or services offered by a competitor' (Article 2 (c) Directive 2006/114/EC).

495 Articleof the Directive 2006/114/EC indicates in what circumstances comparative advertising is permitted. This is the case when it is not misleading, compares goods or services meeting the same needs or intended for the same purpose, is objective, does not discredit or denigrate trade marks, does not take unfair advantage of the reputation of a trade mark, does not present goods or services as imitations of goods or services bearing a protected trade mark, and does not create confusion among traders. In order to make sure that consumers can and must make the best possible use of the internal market, the basic provisions governing the form and content of comparative advertising should be uniform. However, as held by by Article 8 (4): 'Nothing shall prevent Member States from maintaining or introducing bans or limitations on the use of comparisons in the advertising of professional services, for regulating the exercise of a professional activity under the law of the Member States for regulating the exercise of a professional activity'. It follows that national differences can become common in this regard. If the conditions of the use of comparative advertising in the Member States are harmonized, this will help demonstrate objectively the merits of the various comparable products, the more so as advertising reaches beyond the frontiers and is received on the territory of other Member States. 
less efficient representatives. Moreover, such prohibitions are not necessary to ensure professional responsibility, independence or secrecy, or to prevent false or deceptive statements or conflicts of interest, or to ensure that members of a professional association comply with the rules of professional conduct, which would not, in themselves, restrict competition. ${ }^{496}$ The members of a profession should have the freedom to actively seek out clients without thereby directly jeopardising the quality of the personal relationship between service providers and their clients. Providing information on the services on offer, where it is accurate and precise, and comparative advertising, where it compares representative and verifiable aspects and is not misleading, are means of increasing user information to the benefit of the users, and are important elements of the competitive process. They allow users to distinguish between the alternatives which exist at the time of obtaining a service, and to make a rational choice of service provider, whether it is within their national frontiers or elsewhere in the Community. They also make it easier for new operators to establish themselves in the market and stimulate innovation in the means of providing services. ${ }^{497}$

It follows that a general prohibition of comparative advertising is not allowed. ${ }^{498}$ However, under limited circumstances, professional associations can forbid this kind of publicity when it is deemed necessary to safeguard the dignity and the deontology of the free profession. ${ }^{499}$ Since the architectural profession functions effectively without the need for any significant sector-specific advertising restrictions in a large number of Member States, sector specific advertising restrictions in these professions may not be essential for protecting consumers from misleading claims. ${ }^{500}$

496 Arguments that such restrictions are necessary in order to ensure the profession's reputation do not justify obstructing access to clear and accurate information with regard to the services in question, how much they cost and the conditions on which they are supplied, so as to enable the client to choose freely which supplier of services to engage. Furthermore, advertising covers not only accurate information for the user but also a promotion of the services on offer, including comparison with a competitor or with the services of competitors.

497 Commission Decision of 7 April 1999, IV/36.147 EPI code of conduct, paragraphs 40-43.

498 In this regard it should be noted that consumer protection is one of the goals of the Union (see Article 3 EU and 169 TFEU. The right to information is held to be one of the most important rights of consumers: see paragraph 3 (d) of the Annex to Council Resolution of 14 April 1975 on a preliminary programme of the European Economic Community for a consumer protection and information policy (OJ C 92, 25.04.1975, p. 1) in which the right of information is held to be one of the basic rights of consumers. This right is confirmed in paragraph 40 of the Council Resolution of 19 May 1981 on a second programme of the European Economic Community for a consumer protection and information policy (OJ C 133, 03.06.1984, p. 1) which deals specifically with consumer information.

499 See for example Article $6 \$ 4$ of the Belgian "Wet betreffende de misleidende en vergelijkende reclame, de onrechtmatige bedingen en de op afstand gesloten overeenkomsten inzake de vrije beroepen."

500 See Communication from the Commission - Report on Competition in Professional Services $/{ }^{*} \mathrm{COM} / 2004 / 0083$ final $^{*} /$. In the 1990 s, restrictive advertising rules were removed from the architectural profession in Denmark. 
With regard to misleading advertising ${ }^{501}$ reference should also be made to Council Directive 84/450/EEC (now replaced by Directive 2006/114/EC) which indicates that this may cause a consumer to take decisions prejudicial to him when acquiring goods or other property or when using services. The Directive holds that Member States have to ensure that adequate and effective means exist for the control of misleading advertising, so that legal or administrative action can be taken. ${ }^{502}$ Finally, reference should also be made to the Services Directive which has already been discussed. Article 24 of Directive 2006/123/EC holds that Member States have to remove all total prohibitions on commercial communications by regulated professions. They have to ensure that commercial communications by such professions comply with professional rules, in conformity with Community law, which relate, in particular, to the independence, dignity and integrity of the profession, as well as to professional secrecy, in a manner consistent with the specific nature of each profession. Professional rules on commercial communications shall be non-discriminatory, justified by an overriding reason relating to the public interest and be proportionate.

\section{Structural restrictions}

Wouters was decided on the same day as Arduino, which was discussed before. In this case, two Dutch lawyers, Mr. Wouters and Mr. Savelbergh separately applied to the National Dutch Bar Association (NOVA) for authorisation to enter into a partnership with Dutch accountancy practices. NOVA refused since its 1993 Regulation on Joint Professional Activity concerning partnerships with other professions, banned multidisciplinary partnerships (MDPs) between attorneys and accountants. ${ }^{503}$ NOVA held this to

501 In the preamble, misleading information is qualified as the making of a representation in any form in connection with a trade, business, craft or profession in order to promote the supply of goods or services, including immovable property, rights and obligations which, in any way, including its presentation, deceives or is likely to deceive the persons to whom it is addressed or whom it reaches and which, by reason of its deceptive nature, is likely to affect their economic behaviour or which, for those reasons, injures or is likely to injure a competitor.

502 Directive 2006/114/EC does not exclude a voluntary control by self-regulatory bodies (Article 6). Since Article 8 (1)holds that the Directive shall not preclude Member States from retaining or adopting provisions to ensure a more extensive protection with regard to misleading advertising for consumers, persons carrying on a trade, business, craft or profession, and the general public, Member States' provisions on misleading advertising diverges significantly. As held above, since these disparities cause uncertainty and create many barriers causing additional costs, Directive 2005/29/EC deals with unfair commerical practices, as created. According to Article 5, unfair commercial practices shall be prohibited. A commercial practice shall be unfair if: (a) it is contrary to the requirements of professional diligence, and (b) it materially distorts or is likely to materially distort the economic behaviour with regard to the product of the average consumer whom it reaches, or to whom it is addressed, or of the average member of the group when a commercial practice is directed to a particular group of consumers. Commercial practices shall be in particular unfair if they (a) are misleading as set out in Articles 6 and 7, or (b) are aggressive as set out in Articles 8 and 9. Section 1 of Chapter II contains more detailed rules on misleading commercial practices. Section 2 deals with aggressive commercial practices.

503 In this regard it should be noted that structural restrictions are liable to limit, not only the internal competition i.e. the competition between practitioners within the same professional group, but also the external competition with other -but comparable- professions by means of a broad definition of professional monopoly 
be necessary in order to protect the confidential lawyer/client relationship. ${ }^{504}$ When adopting deontological rules, NOVA did not have to take into account specified publicinterest criteria, but had to adopt regulations to ensure the proper practice of the profession. In this regard the ECJ held that NOVA, which consisted exclusively of members of the Bar elected solely by members of the profession, did not fulfil a social function, nor exercised the powers of a public authority (the Dutch public authorities had not defined the essential principles of what constitutes the 'proper practice of the profession') but was acting purely as a regulatory body. For these reasons it had to be regarded as an association of undertakings composed only of bar members (and not of government representatives) and thus falling within the scope of Article 101(1) TFEU. ${ }^{505}$ In the first place, the ECJ found that the areas of expertise of NOVA members and of accountants could be complementary. Since legal services frequently require financial advice, a MDP between NOVA members and accountants would make it possible to offer a wide range of services. This would bring about a 'one-stop shop' advantage, while the resulting economies of scale might have a positive effect on the cost of services. ${ }^{506}$ The Dutch ban on MDPS was thus liable to limit production and technical development within the meaning of Article 101(1)(b) TFEU. As held by the Court, unreserved and unlimited authorization of multi-disciplinary partnerships between different professions can lead to an overall decrease in the degree of competition prevailing in the market, as a result of the substantial reduction in the number of undertakings present in that market. Nevertheless, insofar as the preservation of a sufficient degree of competition in the market for legal services can be guaranteed by less extreme measures than national rules which prohibit absolutely any form of multi-disciplinary partnership, whatever the respective sizes of the firms of lawyers and accountants concerned, those rules restrict competition. According to the ECJ, competition in legal services can, in principle, be guaranteed by less restrictive measures than a complete ban on accountant/lawyer MDPs. Therefore the regulation could have an adverse effect on competition, and was likely to affect trade between Member States since it also applied to foreign lawyers and accountancy firms seeking to form partnerships with practitioners in the EU. However, the ECJ held that account should also be taken of the decision's objectives (overall context), which are here connected with the need to make rules relating to organisations, qualifications, professional ethics, supervision and liability, in order to ensure that the ultimate con-

504 According to Siragusa, this refers to the existence of a margin of discretion on the part of bar associations in deciding what they deem appropriate and necessary to protect the proper practice of the profession in their respective Member States, in light of their respective national legal context and of the prevailing perceptions of the profession in their respective Member State: See Siragusa 2004, p. 585. As stated above, professional associations are normally better placed to fully evaluate whether a restrictive professional regulation is necessary to protect the core values of the profession. As stated by Gilliams 2004, p. 316, paragraph 97 of the judgment should not be seen as a 'rule of reason'. A 'rule of reason' approach may be compared to the application of Article 81(3) EC, since Article 81(3) EC concerns the balancing of the restrictive effects of an arrangement against efficiency benefits that may be expected to result from the arrangement. This does not happen in Wouters. It only created a limited 'subject matter'.

505 If the State wants professional association regulation to be State measures, then it must define the publicinterest criteria and the essential principles with which the association's rules must comply, and it must retain its power to adopt decisions in the last resort.

506 Wouters, paragraph 87. 
sumers of legal services and the sound administration of justice are provided with the necessary guarantees in relation to integrity and experience, and that it has then to be considered whether the consequential effects restrictive of competition are inherent in the pursuit of those objectives. In the Netherlands, the lawyers' duty to act on behalf of their clients in complete independence and in their clients' sole interest, their duty to avoid all conflicts of interest, and their duty to observe strict professional secrecy, were not imposed on accountants. Since the Dutch rules on professional conduct require the members of NOVA to remain independent, while accountants are not subject to such requirements, the Court ruled in paragraph 109 that NOVA was entitled to consider that the objectives pursued by the 1993 Regulation could not be attained by less restrictive means that a ban on MDPs. ${ }^{507}$ The NOVA could thus have reasonably considered that the regulation, despite the effects restrictive of competition that are inherent in it, was necessary for the proper practice of the legal profession as organized in a Member State. ${ }^{508}$ Since Article 101(1) TFEU was not infringed, the state liability issue was not relevant. ${ }^{509}$ It should be noted that the Court also made reference to the provisions on free movement. The abolition as between Member States of obstacles to the freedom of movement for persons would be compromised if the abolition of state barriers could be neutralised by obstacles resulting from the exercise of their legal autonomy by associations or organisations not governed by public law. ${ }^{510}$ The Court held that the provisions concerning the right of establishment and/or freedom to provide services are applicable to a prohibition of MDPs between members of the bar and accountants, such as that laid down in the 1993 Regulation, and that that regulation constitutes a restriction on one or both of those freedoms. ${ }^{511}$ However, due to the reasoning laid down in paragraph 97 , that restriction would be justified.

507 Wouters did not escape the application of the competition rules due to its author or due to any action undertaken by the public authorities, but due to the subject matter of the regulation and the goals pursued by it. In Klopp, the Court already held in paragraph 17 that although Member States may regulate the exercise of the legal profession in their own territory, they could not require a lawyer to have only one place of establishment within the EEC.

508 It should be repeated that, in defining the criteria for the application of Article 101 (1) TFEU to a specific case, account should be taken of the economic context in which the undertakings operate, the products or services covered by the agreements, the structure of the market concerned, and the actual conditions in which it functions. See Oude Luttikhuis, paragraph 10. It should be noted that with regard to the freedom to provide services, the Court recognized already in 1974 in Van Binsbergen that the specific nature of certain services can create a need for professional regulatin that might supersede the free movement objective: 'Taking into account the particular nature of the services to be provided, specific requirements imposed on the person providing the service cannot be considered incompatible with the treaty where they have as their purpose the application of professional rules justified by the general good-in particular rules relating to organization, qualifications, professional ethics, supervision and liability-....'. See paragraph 16.

509 See also Gilliams 2004, p. 313.

510 See Walrave and Koch, paragraphs 17, 23 and 24; Case C-13/76 Dona [1976] ECR 1333, paragraphs 17 and 18; Bosman, paragraphs 83-84; Angonese paragraph 32. As has been indicated above, in its case law on the free movement of persons and services, the ECJ moved beyond the application of an extensive state concept and explicitly recognized the applicability of those provisions to certain private measures. In Walrave the Court held that not ony merely action of public authorities but also rules of any other nature aimed at collectively regulating gainful employment and services can infringe Article 56 TFEU. See paragraph 3.2.1.

511 Wouters, paragraph 120-123; Van den Bossche 2004, p. 831. 
With this judgement, the Court seems to refer, on the one hand, to one of the advantages of self-regulation: the specific knowledge of professional bodies (private interest). On the other hand, by relying on the Bar's judgement, the ECJ explicitly acknowledged that competition is not the only goal, and its judgement introduces elements other than pure competition concerns that should be taken into account when assessing whether an agreement falls under Article 101 TFEU prohibition (principles of independence, confidentiality and loyalty towards consumers) which can be qualified as public interest concerns. ${ }^{512}$ However, since NOVA did not have to take public interests into account, the reason given by the ECJ can only, with doubt, be qualified as a public interest exception. It should be noted that Article 101(1) TFEU does not specifically foresee that public interest exceptions and the exceptions enumerated in Article 101(3) TFEU are limited..$^{513}$ In this regard, reference should be made to the Commission's Guidelines on the application of Article 101(3) TFEU which were issued in connection with the entry into force of Regulation 1/2003/EC which provides for the full application of the EU rules by the Commission, but also by the competent national instances (competition authorities and courts). According to these guidelines, in order to benefit from an exemption under Article 101(3) TFEU, the restrictive arrangement must produce efficiency gains: it must contribute to improving the production or distribution of goods or to promoting technical or economic progress. ${ }^{514}$ Restrictions which are based on fair competition are thus neither valid under Article 101(3) TFEU since broad public interest concerns are not covered nor under Article 101(1) TFEU, since this Article does not foresee in a rule of reason. Furthermore, despite the fact that the regulation restricted competition, the Court held that it did not go beyond what is necessary in order to ensure the proper practice of the legal profession, and was not caught by Article 101(1) TFEU. The Court

512 Forrester 2004, p. 282.

513 In Wouters the ECJ did not engage in the balancing of pro-competitive and anti-competitive effects, and therefore did not indicate that a balancing between competition rules and other values should be resorted to. Instead, the ECJ looked at loyalty, independence and other values which are not linked to competition. It follows that the non-economic norm (in Wouters, the protection of the legal profession's independence) was not brought into the substance of Article 101 TFEU (in its first or in its third paragraphs), thus blurring its purity, but was taken into account at a preceding stage, leading to an exception from the ambit of Article 101 TFEU as a whole, subject to a control of proportionality.

514 Before Regulation 1/2003/EC entered into force, agreements which were liable to restrict and affect trade between Member States had to be notified to the Commission in order to qualify for an exemption under Article 101(3) TFEU. The Commission had an exclusive power to authorize such agreements if the conditions of Article 101(3) TFEU were met. Since the entry into force of Regulation 1/2003/EC, the application of Article 101 TFEU is in the hands of the national authorities and national courts. If agreements fall under the conditions of Article 101(3) TFEU, a prior decision is no longer needed. According to Komninos 2004, when the Commission still had a central role in EC competition law, it hesitated with regard to the introduction of a more economic approach or of a fully fledged rule of reason in Article 101 (1) TFEU (as opposed to Article 101(3) TFEU) since the rule of reason would have led to an indirect transfer of competencies from the Commission to national competition authorities and courts, while the Commission aimed for a uniform approach with regard to these matters. The fear was also that this might lead to a renationalisation of competition enforcement in Europe, since agreements benefiting from rules of reason would be granted a negative clearance under Article 101 (1) TFEU rather than an exemption under Article 101(3) TFEU, thus inviting the application of stricter national competition law. It followed that a rule of reason was not introduced in Article 101 (1) TFEU. With regard to Article 101 (1) TFEU, the burden of proof lays on the Commission, national authorities or third parties, while this lies on the undertakings with regard to Article 101(3) TFEU. See Komninos 2004, pp. 452, 460-461. 
did not explain why the ban could not be narrower. In any case, the Court provides little by way of limiting principles for when a public interest justification will take place outside the scope of Article 101 TFEU, either with regard to the types of professions involved or the types of professional restraints. ${ }^{515}$ It will therefore be for the court hearing the case (and not the professions themselves) to decide whether or not the rule of professional conduct at issue is in the public interest. ${ }^{516}$ However, I agree with Gilliams, the lawyer who represented Mr. Wouters before the ECJ, that in a democratic system it should be for the public authorities to define what constitutes the public interest. It would be more in line with competition law, if the ECJ would make a genuine economic analysis instead of an analysis of factors which are, in principle, not related to competition law. If state measures restrict competition to an appreciable extent, and produce an appreciable effect upon interstate trade, these anti-competitive state measures can be saved only by the grounds of efficiency gains as mentioned in Article 101(3) TFEU. There is, in principle, no room for non-economic, public interest justifications like those mentioned in Article 36 TFEU or the mandatory requirements of Cassis de Dijon. If an analysis of non-economic factors is deemed to be necessary, it is up to the legislators to decide. This would, in any case, be more democratic.

When comparing Wouters with Arduino, it can be stated that the price fixing in Arduino was not subject to public interest criteria, nor was it done by an independent group. In that case the Italian Minister of Justice was required to approve the regulation before it could enter into force, whereas the Dutch regulation in Wouters entered into force unless annulled by government decree. Nevertheless, the Court did not focus on this difference in Wouters. This is odd, since Ministers of Justice in Italy are generally inclined to approve bar association fee fixing, while bar regulation in the Netherlands can be closely reviewed and sometimes annulled. Taking Wouters together with Arduino thus yields an unsatisfying articulation of the principles for deciding when regulations of professional associations will be attributable to the association rather than being viewed as a state measure under Article 4(3) EU jo 101(1) TFEU. As held by First, the factual distinction between the two cases indicates that it might take very little to turn such rules into government action. ${ }^{517}$ Although Wouters drew attention to the composition of the bar association and the lack of articulated public interest criteria to guide its decision, Arduino held these were not critical. Considering that the two cases were decided on the same day, it is difficult to conclude that more is required than simply an affirmative government review prior to implementation.

515 First 2004, p. 245.

516 It could be questioned whether the courts are best placed to answer such a question. However the courts will only have to decide in cases in which the public interest goals have not been sufficiently determined by the public authorities, but even then decisions will only be made on a case by case basis which can lead to discrepancies. In the event that these goals are defined already, the courts do not have to undertake this task. In any case, the public interest concept is not privatised to the benefit of the professions. The ECJ did not say that legislation to permit MDPs is unlawful. It only said that the Dutch rule prohibiting MDPs was not unlawful. It can thus be acceptable for some Member States to authorise MDPs between lawyers and accountants, while others might not. See Forrester 2004, p. 283.

517 First 2004, p. 247. 


\subsection{Conclusion}

Next to the fact that regulations can limit the free movement of professionals, they can also restrict free competition within the European Union. While the free movement provisions in the Treaty only cover cases in which a transboundary element is present, this is not a necessary requirement for the competition rules to be applicable. It follows that, even if no borders are crossed and professional rules are imposed within one Member State only, EU competition law can be applicable. This is, however, only the case if the rules have an impact on the EU market and affect trade between Member States. ${ }^{518}$

EU competition rules of the Treaty are applicable to regulations created by undertakings unless they can be attributed to the State, which is the case if the state implements or complies with sufficiently clearly articulated public policy goals, while the public authorities have maintained power to adopt decisions in the last resort. In this regard, rubberstamp approvals and practices whereby the authorities of a Member State can only reject or endorse the proposals of professional bodies without having the possibility to alter their content or substitute their own decisions for these proposals, are unlawful state measures since, in those cases, the public authorities do not assume full responsibility for the restriction of competition. As held by Gilliams, this does not mean, however, that a state measure adopted pursuant to lobbying is immune from challenge under Article 4(3) EU or under the Treaty provisions relating to the free movement of goods and persons, and the freedom to provide services. It does mean, however, that the Treaty's competition rules cannot be applied to that regulation or, stated differently, that the professional association, for purposes of the regulation at issue, is not to be considered as an association of undertakings. ${ }^{519}$ After Wouters it seems that restrictions of undertakings which cannot be attributed to public authorities and which relate to matters for which the public authorities have not set a sufficiently clearly articulated public policy, may nevertheless escape the application of the competition rules if these rules pursue the public interest. It remains to be seen how this principle will develop in the future. National competition authorities and courts are obliged to set aside national rules where these influence the market conduct of economic entities.

\section{Conclusion}

In the European Union, numerous efforts have been made to ensure that architects can freely move without being denied access to another Member States, especially on the grounds of the possession of different qualifications. The general non-discrimination principle contained in Article $18 \mathrm{TFEU}$ and the free movement rights of workers and self-employed professionals have provided European architects with a legal framework to move within Europe without having to face direct or indirect restrictions based upon

518 See Articles 101 and 102 TFEU.

519 Gilliams 2004, pp. 306-307.

519 See Wouters and Fiammiferi. If the state measure is invalidated or disapplied on the basis of Article 4 EU, the 'state compulsion' defence ceases to apply as from the time that the relevant state measure is declared contrary to Article 4 EU. 
their nationality. A lot of problems have been solved over time which can specifically be attributed to the case law produced by the Court of Justice of the European Union which has held that the free movement Articles in the Treaty have direct effect. In this way, many problems have been solved, but case law demonstrates that Member States are often still reluctant to accept foreign diplomas. This is due to the fact that each Member State is allowed to decide if and how it regulates a profession, so that the qualifications which are needed to practise the profession of architect -if any- are quite different and diverse in each Member State. It follows that generally Member States will demand a certain level of qualification before an individual is allowed to work as an architect on their territory. In this regard, Directives have been created on the mutual recognition of diplomas, certificates and other evidence of formal qualification on the basis of Articles 46, 47 and 56 jo 62 TFEU. These Directives are only applicable with regard to regulated professions which state that there is a statutory requirement to hold a diploma or other occupational qualification in order to pursue the profession in question. For architects, Council Directive 85/384/EEC regulates the mutual recognition of architectural qualifications. A Directive dealing with minimum harmonisation of education has not been provided for, due to the large differences in educational requirements and a lack of agreement between the Member States. However, due to the limited scope of the vertical harmonisation method, and the difficult and time-consuming negotiations, an attempt has been made to create an environment of mutual trust in terms of foreign diplomas so that there would be no need for harmonization. Horizontal Directives were created based on the premise that the programmes of study and training through which people in the various Member States prepare themselves for a particular regulated profession are, in principle, of equal validity. However, for the professions which were already covered by the sectoral Directives, the system did not change, and the sectoral Directives remained in force. This changed however in 2005 with the entry into force of Directive 2005/36/EC which was inspired by the Lisbon strategy to promote a more dynamic and competitive economy in Europe. This Directive replaced fifteen existing horizontal and vertical Directives in the field of the recognition of professional qualifications, by combining them in a single text. The Directive is thus only applicable to regulated professions. For architects, Chapter III of Title III provided for a system of automatic recognition if one's qualifications were enumerated in the annex to the Directive. If this was not the case, Chapter I would be applicable, which grouped the various national education and training systems according to a number of levels. Qualifications which attest a level of professional qualifications at least equivalent to the level immediately below that required in the host Member State will have to be recognized. This is without prejudice to the possibility for the host Member State to require compensation measures (an aptitude test or an adaptation period at the choice of the professional concerned) if there are substantial differences between the qualifications obtained and demanded. In such a case, Member States must always ascertain whether the knowledge acquired by the applicant in the course of his professional experience in a Member State or a third country, is of a nature to cover, in full or in part, the differences, and any consequent compensation measure has to be proportional. Professionals who cannot invoke the Directive can still try to rely on the principles provided for by the ECJ in Gebhard and Vlassopoulou. In this way Member States are obliged to examine 
whether the work experience gained in another (Member) State corresponds to the experience required under national law. As held by Article 2(2) of Directive 2005/36/EC, each Member State may permit Member State nationals in possession of evidence of professional qualifications not obtained in a Member State, to pursue a regulated profession on its territory in accordance with its rules. Member States are therefore not obliged to let such professionals carry out activities in their territory. Article 3(3) of Directive 2005/36/EC on the other hand, deals with nationals of third counties, and indicates that the evidence of formal qualifications issued by a third country shall be regarded as evidence of formal qualifications if the holder has three years' professional experience in the profession concerned on the territory of the Member State which recognised that evidence of formal qualifications. In all other cases, the third-country national has to rely on the case law of the ECJ in Tawil-Albertini and Hocsman which extended the Vlassopoulou principle to qualifications obtained outside the European Union. With the entry into force of the Treaty of Amsterdam, the Community became responsible for the development of a common EU immigration policy and was competent to draft legislation regarding the position of third-country nationals. Legislation on the free movement of third-country nationals was based upon Articles 63(3)(a) and 63(4) EC (Article 79(2) TFEU). Legal migration of third-country nationals to the EU is regulated on the basis of five Directives which have already entered into force and one draft Directive: Directive 2003/86/EC on the right of family reunification; Directive 2003/109/EC on the status of long-term residents; Directive 2004/114/EC on the conditions of admission of students, pupils, unremunerated trainees and volunteers; Directive 2005/71/EC on a specific procedure for admitting third-country national researchers; Directive 2009/50/EC on the conditions of entry and residence of third-country nationals for the purposes of highly qualified employments; draft Directive on a single permit and a common set of rights.

Directive 2004/38/EC confers extensive rights upon third-country family members of EU citizens who made use of their right of free movement. All these Directives contain a right for third-country nationals to participate in the labour market of the host Member States after a certain period of time, and/or under certain conditions.

In accordance with Article 4(1) of Directive 2003/109/EC, Member States are obliged to grant long-term resident status to those third-country nationals who have resided in their territory legally and continuously for a period of five years. ${ }^{520}$ As held by Article 11(1)(a), long-term residents shall enjoy equal treatment with nationals as regards access to employment and self-employed activity, provided such activities do not entail even occasional involvement in the exercise of public authority, and conditions of employment and working conditions, including conditions regarding dismissal and remuneration. Furthermore, Article 11(1)(c) indicates that equal treatment should also be granted regarding the recognition of professional diplomas, certificates and other qualifications, in accordance with the relevant national procedures.

Furthermore, according to Directive 2003/86/EC, third country nationals eligible for family reunification will have, in principle, the same rights as the sponsor -i.e. a third country national residing lawfully in a Member State and applying, or whose family

520 Article 5 of Directive 2003/109/EC contains the conditions which need to be fulfilled. 
members apply, for family reunification to be joined with him/her- to any employment and self-employed activity. ${ }^{521}$

Positive as this may be, due to the inability of the Council of Ministers to come to an agreement on the Commission's proposal on a Directive for economic migration in 2001, there is currently no general instrument regulating the conditions for first entry and residence of third-country national labour migrants to the EU territory.

However, in 2007, the Commission adopted another proposal for a Directive on the conditions for entry and residence of third-country nationals for highly qualified employment. Directive 2009/50/EC, which has to be implemented in national law by 19 June 2011, applies to third-country nationals pursuing highly qualified employment, which is defined as genuine and effective work under the direction of someone else for which a person is paid and for which adequate and specific competence, proven by higher professional qualifications, is required. The Directive does not create a right of admission as such, since Member States retain the competence to control how many and which type of qualified workers to admit to their labour markets, which indicates that they are allowed to apply quotas. ${ }^{522}$ Under the rules set by the Directive, especially Article 14, EU Blue Card holders will enjoy equal treatment with nationals of the member state issuing the Blue Card as regards working conditions, including pay and dismissal, education, training, the recognition of qualifications, and several other rights. Member States are even free to adopt more favourable rules for any purpose of employment (Article 3(4)). After eighteen months of legal residence, Blue Card holders may also take up highly qualified employment in another Member State. ${ }^{523}$ A new application for a second Blue Card has to be made however, and the same conditions for entry have to be fulfilled. However, the Directive does not give them a right to admission so that Member States can still refuse them on the basis of their national labour market situation.

Finally, the Draft Directive on a single permit for third-country nationals to reside and work in the territory of a Member State, and on a common set of rights for third country workers legally residing in a Member State, that was put forward by the Commission on 23 October 2007, applies to third-country nationals seeking to reside and work in a Member State and single permit holders who are defined as third-country nationals who have been issued a single permit, i.e. a valid residence permit issued by the authorities of a Member State granting a right of residence for the purpose of employment. Applicants will have to submit a single application for obtaining the right to reside and to work in a Member State. However, the competence of the Member States with respect to the admission of third-country nationals to their labour markets will not be affected. Third-country nationals obtain the right to enter and to stay in the Member State issuing the permit, and have free access to the entire territory of that Member State within the limits provided for by national legislation. Furthermore, they have the right to exercise the employment activity authorized under the single permit. A right of

521 The requirements which need to be fulfilled for family reunification can be found in Articles 7 and 8 of Directive 2003/86/EC. These will not be discussed within this thesis.

522 See Article 6 and recital 8 of the preamble to the Directive.

523 Article 16 of the Directive allows highly skilled migrants to accumulate periods in two or three Member States in order to fulfil the five-year residence requirement to obtain long-term residence status. This is a derogation from Directive 2003/109/EC. 
movement to other Member States is not included. Moreover, equal treatment shall be enjoyed in respect of working conditions, education, recognition of qualifications, and some other rights. Equal treatment as regards the recognition of diplomas is only granted in accordance with national law. Recital 15 of the preamble even refers to Directive 2005/36/EC, and holds that qualifications obtained by single permit holders in another Member State should be recognized in the same way as for Union citizens, which means that, in principle, access to the same profession shall be granted on an equal footing with nationals of the host Member State. However, since Article 12 of the Directive does not specifically mention Directive 2005/36/EC, and since most third-country national workers are likely to have qualifications obtained in a third country and reside in their Member State of admission and are therefore dependent upon the national legislation of that Member State with regard to the recognition of their qualifications, it remains to been seen whether Directive 2005/36/EC will be taken into account. What the effects of this Directive will be on the migration of third-country architects once it enters into force, has to be awaited. Since the ECJ is only competent to rule upon these matters since the entry into force of the Lisbon Treaty, we will have to wait to see how these Directives will be applied by the Member States, and how they will be interpreted by the ECJ. In any case, it should be concluded that the absence of a general policy for all types of workers demonstrates the unwillingness of Member States to give up their sovereignty with regard to immigration matters. However, the Directives prove that progress in this area is being made since they all contribute to the fair treatment of thirdcountry nationals by restricting the discretionary powers of the Member State to a certain extent, and by providing minimum standards.

While Directive 2005/36/EC focuses on the recognition of professional qualifications with regard to market access to regulated professions, Directive 2006/123/EC concentrates on matters relating to the quality of services. The main focus of the Directive is on the prohibition of national measures restricting either establishment or free movement of services and relies thus on negative integration as opposed to positive integration. The core provision of Directive 2006/123/EC is Article 16(1) which provides that Member States have to respect the right of providers to provide services in a Member State other than that in which they are established. Since Member States are still allowed to impose certain requirements if justified in terms of the public interest (Article 16(3) and in certain specific case (Article 17 and 18), the Directive strikes a certain balance between guaranteeing the rights of service providers to free access and free exercise of a service activity, whilst allowing Member States the right to invoke their most essential requirements in certain clearly-defined circumstances. As held by former Commissioner McCreevy, this will definitively improve legal certainty for service providers and consumers. Since the Directive makes it easier to establish anywhere in the EU, saving time and money, it provides a welcome boost to cross-border service provision. The Directive is underpinned by obligations on Member States to co-operate among, and assist each other, to ensure that businesses are properly and efficiently supervised across the EU while avoiding the duplication of controls. To achieve its aims, Member States have to simplify the procedures and formalities which are applicable to the access to certain activities and the exercise of these. However, attestations of professional competence, or 
evidence of formal qualifications and attestations of professional experience, can still be demanded, since the Directive holds that it does not affect the provisions of Directive 2005/36/EC. The Directive sets out what kind of restrictions the Member State where the services are provided (i.e. the host States) may still impose (Articles 16 and 17), and what manner of supervision can be exercised, either by the state of establishment (Article 30) or by the host State (Article 31). Member States are therefore not prevented from supervising companies and workers operating on their territory. The Member State where the service is provided can enforce working conditions, including minimum wages which means that companies posting workers to another Member State do not benefit by bringing in 'cheap' workers from their Member States. Social dumping will therefore be avoided. However, the list of limitations and exceptions to its scope as well as the weakening of the country of origin principle to a 'freedom to provide services' principle, can be expected to have heavily reduced the integrative potential of this instrument.

The Directive also provides for harmonization in certain areas of legislation such as professional insurance, dispute settlement, quality of services, etc. In order to have a smooth and workable system, the Directive provides for single points of contacts which can be seen as single desks at which service providers can complete all the administrative procedures relevant to their activities, preferably by electronic means. As both Directive 2005/36/EC and Directive 2006/123/EC are cross-sectoral Directives dealing with the free movement of individuals and services respectively, a certain amount of cooperation between the national contact points (Directive 2005/36/EC) and the points of single contact (Directive 2006/123/EC) is desirable. However, it seems that national contact points and points of single contact do not (yet) have not yet established regular relationships due to budget restraints and the fact that they are located in different ministries which traditionally do not work together. ${ }^{524}$

Next to the fact that regulations can limit the free movement of professionals, they can also restrict free competition within the European Union. While the free movement provisions in the Treaty only cover cases in which a transboundary element is present, this is not a necessary requirement for the competition rules to be applicable. It follows that even if no borders are crossed, and professionals rules are imposed within one Member State only, EU competition law can be applicable. This is, however, only the case if the rules have an impact on the EU market and affect trade between Member States. EU competition rules of the Treaty are applicable to regulations created by undertakings unless they can be attributed to the State, which is the case if the state implements or complies with sufficiently clearly articulated public policy goals, while the public authorities have maintained power to adopt decisions as a last resort. In this regard, rubberstamp approvals and practices whereby the authorities of a Member State can only reject or endorse the proposals of professional bodies, without having the possibility to alter their content or substitute their own decisions for these proposals are unlawful state measures since, in such cases, the public authorities do not assume full

524 Report of the European Parliament, Directorate-General for Internal Policies, Policy Department Economic and Scientific Policy A, Recognition of Professional Qualifications, September 2009, p. 49. 
responsibility for the restriction of competition. After Wouters, it seems that the restriction of undertakings which cannot be attributed to public authorities and which relate to matters for which the public authorities have not set a sufficiently clearly articulated public policy, may nevertheless escape the application of the competition rules if these rules are in the public interest. It remains to be seen how this principle will develop in the future. Regulations or agreements which may hinder competition are often linked to market entry, but also to market conduct such as price fixing, advertising restrictions and restrictions on business structure. As held by Article 15(1) of Directive 2006/123/EC, Member States have to examine whether, under their legal system, certain requirements are imposed and to ensure that these requirements are compatible with the non-discrimination, the necessity and the proportionality principles. Such requirements relate, for example, to quantitative or territorial restrictions, in particular in the form of limits fixed according to population or of a minimum geographical distance between providers, and fixed minimum and/or maximum tariffs with which the provider must comply (Article 15(2) of the Directive). In any case, national competition authorities and courts are obliged to set aside national rules where these influence the market conduct of economic entities.

Finally, it should be noted however, that the recognition of professional qualifications is a different process from that of academic recognition. Academic recognition still falls within the Member States' sovereign powers. However, over time, the ECJ has developed case law which does not necessarily respect this strict division of power, and is applicable to those who are in the process of becoming a fully-fledged professional. The Member States have decided to standardize rules in this area, in a process that takes place outside the realm of the EU, the so-called Bologna Process, which is a binding commitment to an action programme at intergovernmental level that is not legally binding. The Process aims to create convergence, and is not a path towards the standardisation of European higher education. The Lisbon Recognition Convention, which is a Treaty conceived in the framework of the Council of Europe, does have binding effect, and aims to give every applicant appropriate access to an assessment of his/her foreign academic qualifications, and holds that such foreign qualifications have to be recognised unless substantial differences can be demonstrated in regard to the length of study, curriculum content, etc. The Convention therefore adopts the idea of acceptance, and aims for fair and transparent recognition procedures. The Lisbon Recognition Convention aims to create convergence in Europe, and indicates that Member States may not discriminate against an individual for not possessing a national diploma. Since it does not foresee the harmonisation of architectural studies, and since recognition may be withheld in the event of substantial differences, it remains to be seen whether this Convention will genuinely contribute to free movement. 



\section{PART II}

\section{THE REGULATION OF ARCHITECTS ON A NATIONAL LEVEL}



Chapter 4

\section{THE REGULATION OF ARCHITECTS IN THE LOW COUNTRIES}

\section{Introduction}

In this Part, the regulation of architects in Belgium and the Netherlands will be discussed. In the first instance one might think that it is odd that two countries which are so closely related, and which even used to form one single state, have been chosen for a comparative research. True as this might be, the reader will soon discover that the regulation of architects in these neighbouring states is anything but comparable, and sometimes even contradictory, making this research all the more interesting.

As noted in Part I of this thesis, the European Union has created a Directive on the mutual recognition of diplomas, certificates and other evidence of formal qualification in architecture, including measures to facilitate the effective exercise of the right of establishment and freedom to provide services (Directive 85/384/EEC) which is now replaced by Directive 2005/36/EC on the recognition of professional qualifications. However, due to the large difference in educational requirements and the lack of agreement among the Member States, no legislation was created at EU level to coordinate national provisions in respect of the activities of architects. It follows that there is no harmonisation of minimum standards to be observed regarding training courses, while the member states have freedom of organisation as regards teaching, due to Article 165 TFEU. Next to the organisation of the educational process, the regulation of the profession also falls within the competence of the Member States. This means that the states do not have to introduce or maintain professional or title protection, or any other type of regulation. They only have to guarantee that no unjustified restrictions are imposed with regard to the recognition of qualifications which are obtained in another Member States, and the free movement of architects.

It follows that architects need to be well informed in case they are involved in a crossborder project, and also their clients need to be aware of the legal consequences of the engagement of a designer from their own or from another country from within or even without the EU. 
In the following paragraph, I will offer a brief overview of the history of The Low Countries. Subpart A) discusses the public law regulation of architects in Belgium in Chapter 5 and Chapter 6 and deals with the private law regulations. Subpart B) discusses, in Chapters 7 and 8 , the public and private law in the Netherlands, while subpart C) presents a comparative overview of all regulations in each state. Subsequently, subpart D) offers a brief overview of the regulations in several other EU Member States.

\section{The Low Countries: a brief historical overview}

The Low Countries are the historical lands situated around the low-lying delta of the Rhine, Meuse, Scheldt and Ijssel rivers, including the modern countries of Belgium and the Netherlands. Since the $15^{\text {th }}$ Century they formed a unit after the marriage of Duchess Maria of Burgundy and Maximilian of Austria, the Emperor of the Holy Roman Empire, and were governed by the Habsburg regime. Maximilian was succeeded by his grandson, Charles V, who donated the Low Countries to his son, Philip II of Spain. During the reign of the latter, internal unrest arose. This was due to the fact that Philip, who was a catholic, aimed to exterminate Protestantism by sending an army under the leadership of the Duke of Alva. The southern catholic part of the country supported Philip, while the northern part aimed to establish an independent republic. As a result, the Eighty Years War started in 1568. The northern part signed the Union of Utrecht in 1579 which was a written declaration promulgated by several regions in which they agreed to expel the Spanish ruler. In 1581, the States-General formally pronounced that they would not obey Philip II anymore (Act of Verlathinge) and the independent Republic of the Seven United Provinces was established. This was composed of the northern regions of Friesland, Gelderland, Groningen, Holland, Overrijssel, Utrecht and Zeeland.

Even though the northern provinces were occupied with the task of preparing for and making war, the most important activity of the state as a whole was to stimulate trade and to find measures to defend itself against the danger posed by flooding. ${ }^{1}$ As stated above, several big rivers tended to flood in the Low Countries, while the north and the west is bordered by the North Sea and often suffers from flooding. For this purpose, architects and engineers were needed and played an important role in society. The Republic of the Seven United Provinces grew so strong on a military, economic and political level, that it became an international superpower. There were numerous guilds that had a monopoly position to regulate all sorts of aspects of the profession life of architects. Even though a formal education system did not exist, the guilds organised the transfer of knowledge and skills of those participating in the building process by letting students imitate their masters. During the second half of the $17^{\text {th }}$ Century however, the Republic's position became weakened due to bad economic policy and numerous wars. In 1795, French troops invaded the republic and established a new one: the Batavian Republic ${ }^{2}$. The guilds were worried that new and unknown techniques would be intro-

\footnotetext{
Dankelman 1999, p.85.

The Batavian Republic was proclaimed on 19 January 1795 and ended on 5 June 1806 with the accession of Louis Bonaparte to the throne of the Kingdom of Holland.
} 
duced, and tried to maintain their own position by preventing renovations and technical modernizations. Due to their misuse of power, and the fact that the working class was fed up with the bad working conditions, they revolted against the social power of the guilds. Consequently, the guilds were abolished altogether in 1798. As a consequence, the position of the independent architect did not exist following the abolition of the guilds which meant that the functions of architect and builder were merged into one. However, at the beginning of the 19th Century, the architectural profession revived once more. During the period of French domination, an organised education system for architects was set up, and in Delft, the very first academy for architecture was established. Nevertheless, due to the vehement opposition of other actors who were involved in the building process, the architects did not manage to separate themselves as a professional group. It followed that no efforts were made to create public legislation to regulate the profession.

In 1816, the northern and southern parts of the Low Countries gained their independence from France and were united after the Congress of Vienna. The United Kingdom of the Netherlands was created which was composed of modern Belgium and the Netherlands. The Kingdom was able to repulse new French attacks on its territory. However there was no strong internal cohesion due to differences in history, language, culture, mentality and religion. The United Kingdom lasted until 1830, the year in which the southern provinces revolted to form the separate state of Belgium. 

A. THE REGULATION OF ARCHITECTS IN BELGIUM 



\section{Chapter 5}

\section{PUBLIC LAW IN BELGIUM}

\section{The situation before the Architects Act of 1939}

As noted in Chapter 4, after the abolishment of the guilds by the French rulers at the end of the $18^{\text {th }}$ Century, the combination of the professions of architect and entrepreneur within one person was very common. The profession of architect was thus exercised by persons who also practised the profession of entrepreneur. This combination also existed before the creation of the guilds. Especially in the $15^{\text {th }}$ Century, when business flourished, architects did not only design and plan, but also furnished all the necessary means such as materials and even workers. In the Renaissance, when there was a tendency to long for antiquity, an aim was made to rule out all commercial activities and a proper education system for architects was created with the help of the elite. ${ }^{1}$ In this way, Colbert created the 'Académie Royale d'Architecture' in 1671 in Paris. However, the merging of the professions could not be ruled out since even the new educated architects were still fulfilling the task of entrepreneur. After the French Revolution, in the name of liberty and equality, it was normal that anyone could work as both an architect and an entrepreneur, regardless of that person's particular qualifications. The Napoleonic $\mathrm{Code}^{2}$, which was introduced in many countries occupied by the French during the Napoleonic Wars, including Belgium and the Netherlands, is a child of the French Revolution. This is strongly reflected by its content: the titles of architect and entrepreneur were used as synonyms. The Napoleonic Code therefore did not protect the architectural profession.

It was only in the second half of the $19^{\text {th }}$ Century that, under pressure from architects who had graduated from the schools of architecture ${ }^{3}$ and who had formed professional

Rigaux 1975, p. 21

Code Napoleon, promulgated on 21 March 1804. On 3 September 1807 the Act received the official name Code Napoleon. The Dutch text was established by Acts of 30 December 1961and 30 April 1962, Official Gazette 18 May 1962.

3 In the $19^{\text {th }}$ Century, architectural education was provided in academies and drawing-schools. The establishment of such institutions in Antwerp, Bergen, Bruges, Brussels, Ghent, Leuven, Liège, Mechelen and Tienen were a real preparation for the profession. Initially, these academies provided a traditional 'Beaux- 
associations, that organisations of architects aimed to give back the profession its specificity, together with its liberal, intellectual and artistic character. ${ }^{4}$ The associations advocated a law which would make a distinction between the intellectual and artistic work (design) on the one hand, and executive work on the other. In this way the first Belgian association of professional architects was founded in 1848 in the form of 'The Royal Association of Antwerp's Building Masters'. In the course of time more professional societies were created. Without there being a legal framework, membership of a professional society reflected a sign of quality to the outside world. ${ }^{5}$ In 1895 , the conference of French architects held at Bordeaux, adopted, for the first time, a formal report on the tasks of architects which were clearly separated from those of entrepreneurs. This report was presented by Guadet, the General Inspector of Public Buildings, in the name of the Central Society of Architects ${ }^{6}$. Later the Royal Federation of Belgian Architectural Societies also promulgated a comparable deontological code for its members. ${ }^{7}$ Furthermore, in 1905, the various Belgian architectural associations united and formed 'The Royal Federation of Belgian Architectural Associations', which represented the architects on a national level, with the aim of promoting architecture and the profession of architect, of protecting the profession and the professional, social and cultural interests of its members on a national and international level, and of coordinating the actions ${ }^{8}$ of its members. ${ }^{9}$ The members' main concern was to stay independent, and to have the opportunity to practise their profession without the commercial preoccupations the building contractors have to deal with. Consequently, specific case law saw the light of day. By interpreting the contracts in the light of the will of the parties (Article 1156 CC), and by supplementing it with clauses commonly used in the field, judges could no longer confuse the two professions which increasingly marked their differences. ${ }^{10}$ In this way, the separate tasks of the professionals, and the different contractual responsibilities, were judicially recognised. Due to the efforts of the Royal Federation of Belgian Architectural Associations, the foundations of the Architects Act of $1939^{11}$ (AA) - which constituted the first legal recognition of the profession of architect - and the Architects' Order Act

arts' education. Later, a more technical approach was taken, and in 1835 a special school for civil construction was created in Ghent. In 1862, a special section was created for engineer-architects. See http://www.fab-arch.be/architectuur/historische_context.php, last consulted 16 October 2009. At the beginning of the $20^{\text {th }}$ Century the profession of architect only had an artistic or moral value.

Rigaux 1975, p. 22.

5 Most of these associations were recognized however by the Act of 31 March 1898 dealing with professional associations.

6 This report is still called the 'Code Guadet'. See: Liet-Veaux 1963, n² 20

Delvaux 1968, t. I, n² 221.

8 For example, actions against disloyal competition by officials of the provinces; actions against simple drawers who were asked to make studies for the restoration of historical buildings; actions regarding the fixing of prices; actions with regard to the nomination of architects as experts in court cases; actions regarding intellectual property; etc. See http//www.fab-arch.be/architectuur/historische_geboorte.php , last consulted 16 October 2009. Before the creation of the Royal Federation of Belgian Architectural Societies, the prohibition of publicity and the fixing of prices was already rooted in the professional codes of most associations.

9 See http//www.fab-arch.be/architectuur/historische_geboorte.php, last consulted 16 October 2009.

10 Rigaux 1975, p. 222.

11 Wet op de bescherming van de titel en van het beroep van de architect, 20 February 1939, Official Gazette 25 maart 1939 . 
of $1963^{12}$ (AO) were laid down, for the 1939 Act made the existing deontology created by the Royal Federation legally binding. It follows that the 1939 Act codified a distinction which already existed fifty years earlier in the form of a deontological rule, inspired by the natural principle of independence, by creating, in Article 6, an incompatibility between the two professions. Finally the Architects Activities which were deemed to have only a civil and not a commercial character, were formally distinguished from the tasks carried out by entrepreneurs through a protected title..$^{13}$

However, even nowadays, after the introduction of the Architects Act, the Belgian Civil Code (CC), which is a direct translation/copy of the French Napoleonic Code, is not very clear on this matter. As held above, before 1939 the legislators did not acknowledge the specificities of the tasks carried out by architects, and saw the tasks which are nowadays separately carried out by architects and entrepreneurs, as the practice of one profession. In this regard it should be noted that even today, the professions of architect and entrepreneur are used as synonyms in the Belgian Civil Code. ${ }^{14}$ This can, for example, be seen in Article 1792 CC, which states that both will be held liable for defaults in the building for a period of ten years after completion of the work:

"When a building, erected against a fixed price, perishes in whole or in part due to a default in the building itself or the unsuitability of the soil, the architect and the entrepreneur are liable for a ten year period."

as well as in Article 1793 CC which holds:

"Whenever an architect or entrepreneur erects a building against a fixed price, and in accordance with a plan which was agreed on between him and the building master, he cannot ask for an increase in salary..."

12 Wet tot Instelling van een Orde van Architecten, 26 June 1963, Official Gazette 5 July 1963.

13 Delvaux 1968, t.I, n² 213, $4^{\circ}$; Liège 2 April 1959, Jur. de Liège, 1958-1959, p. 23. Reference should be made to Article 1 of the Belgian Commercial Code which states that merchants are those who engage in commerce and who make it their profession. Article 2 describes which acts qualify as commercial acts. As opposed to commercial obligations, the professional obligations of the architect have a civil character. The obligations of the building master have mostly a civil character, unless he contracted within the framework of his business or industry. This is particularly so when the building is constructed to be sold, or when the building is used for business. The nature of the relationship has consequences for the competence of the court. As held by Article 573, $1^{\circ}$ of the Judicial Code, the tribunal of commerce is competent for disputes among merchants. It follows that contestations between a non-merchant and a merchant fall under the competence of the civil court. Accordingly, the civil court is competent for all the contestations regarding the interpretation or the execution of the contract of architecture. However, if the other party holds the opinion that the dispute is about a commercial debt, the architect has the possibility to raise the issue before the tribunal of commerce (Article 573, $2^{\circ}$ Judicial Code). If the architect performs commercial activities in spite of the prohibitions named in Article 6 AA and Article 10 Deontological Code, the tribunal of commerce is competent to examine his case.

14 Minvielle $1921, \mathrm{n}^{\circ} 66$. 
Before 1939, these Articles were created at a time in which construction activities were regulated by freely negotiable contracts ${ }^{15}$. Even though they mention each profession separately, they were indicating that architects and entrepreneurs are both sufficiently able and qualified to erect a building. ${ }^{16}$ Since its content has never been amended, they should now be interpreted in the light of Article 6 of the Architects' Act.

Due to the work of the professional societies which did their utmost to stress the differences between the profession of architect and that of entrepreneur, the architects' goals were attained by the three main innovations that the 1939 Act established: ${ }^{17}$

- the creation of a monopoly to exercise the profession of architect (Article 1)

- an enumeration of projects for which the involvement of an architect is obligatory (Article 4)

- a fundamental guarantee that architects work independently (Article 6), i.e. the incompatibility of the profession of architect and entrepreneur.

It follows that nowadays the profession of architect is a regulated profession in Belgium. The content and peculiarities of the profession will be discussed in the following paragraphs.

\section{The Architects' Act (AA)}

The Architects' Act aims to guarantee the safety of inhabitants and the health and beauty of buildings, to preserve Belgium's artistic patrimony, and to protect the capital invested in the building by the building master. ${ }^{18}$ To preserve these interests, the legislator has granted architects ${ }^{19}$ a monopoly to design buildings which they have to use in accordance with the public interest. Important in this regard is that the Architects' Act is of 'public order' which means that contractual clauses which are in violation of the Act's provisions have to be declared void and without effect. ${ }^{20}$ The court has to pronounce the nullity ex officio. ${ }^{21}$

15 Article 1792 Code Napoleon was in its turn inspired by the Lex Omnes promulgated by Emperor Theodosianus I in 382 B.C. .: Van den Berg, 1998, part B, stipulation 1.

16 A person could thus perform architectural as well as entrepreneurial tasks without having to demonstrate any qualification. See Rigaux 1975, pp. 21 and 33; Soinne, La responsabilité des architecte et entrepreneur après la réception des travaux, t. I, p. 37.

17 Rigaux 1975, p. 37.

18 Explanatory Memorandum, Gedr. St., Kamer, 1936-37, nr. 236.

19 The Architects' Act only concerns the profession of architect stricto sensu. This means that it does not regulate the profession of interior architect, town planner or garden and landscape architect. The Association of Belgian Interior Architects introduced a request to obtain title protection on 26 January 2007. So far (21 October 2009), there has been no Royal Decree to ratify this request.

20 Ann. Parl., Chambre, Session 1936-1937, pp. 1775, 1777 ; Ghent 1 April 1966, R.W., 1965-1966, col. 1855

21 Court of First Instance Liège 27 September 1968, R.J.I., 1971, 35. 
Articles 1, 7, 8 and 12 of the original version of the Architects' Act ${ }^{22}$, or Articles 1, 7, 8 and 2 of the new version ${ }^{23}$, state who is allowed to use the title and/or to practise the profession of architect.

Before the 2006 Act concerning the Practice of the Profession of Architect within the Framework of a Legal Person entered into force, Article $1 \$ 1$ AA stipulated:

"No one is allowed to use the professional title of architect OR to practise the profession without being in the possession of a diploma which indicates the successful completion of the exams which are mandatory to obtain the diploma."

It seems that the term 'architect' can be defined in two ways: a) by reference to the diploma which permits the use of the title; b) by the legal conditions which have to be fulfilled in order to lawfully exercise the profession and to exclusively undertake architectural tasks.

The new version of Article $1 \$ 1$ AA states:

"No one is allowed to use the professional title of architect without being in the possession of a diploma which demonstrates the successful completion of the exams which are required to obtain the diploma."

It is immediately noticeable that Article $1 \$ 1$ AA no longer prohibits the practice of the profession of architect without being in the possession of the required diploma. It therefore seems possible to practise the profession without having a particular diploma. As noted above, this amendment appeared as a result of the 2006 Act concerning the Practice of the Profession of Architect within the Framework of a Legal Person. This Act, as well as its implications, will be discussed in detail hereunder.

First the implications of the architectural title and the practice of the profession will be discussed in the light of the architects' monopoly.

\subsection{The architects' monopoly}

1. Design and supervision

Article 4(1) AA holds that the involvement of an architect is mandatory for the design of the plans and the supervision of the execution of the building works for which a preliminary building permit is required by law, decree or regulation. This provision gives an 'absolute' monopoly position to architects. This means that no one has the right, not even for his or her personal use, to fulfil the tasks which only an architect is allowed to

22 By this is meant the Act as it entered into force in 1939.

23 The Act was amended after the adoption of the 2006 Act concerning the Practice of the Profession of Architect within the Framework of a Legal Person: Wet betreffende de uitoefening van het beroep van architect in het kader van een rechtspersoon, 15 February 2006, Official Gazette 25 April 2006. 
carry out. ${ }^{24}$ The Constitutional Court held that Article 4 AA and Article 1792 CC do not violate the equality and non-discrimination principle laid down in Articles 10 and 11 of the Belgian Constitution insofar as the architects' liability which stems from these clauses is carried by the natural person using the architectural title. ${ }^{25}$ Persons using the title are thus liable for their professional actions. According to the 1936/1937 bill, the protection of the architect's function was, in the first place, necessary to protect the public interest. The safety of the building and of the people occupying it, the aesthetics of the building, hygiene, the conservation of the countries' artistic possession, the contribution to the artistic possession of the county, and the financial means that were vested in the project by architects were also taken into account. ${ }^{26}$

It is important to note that the architects' monopoly does not cover all the activities which are associated with the regular tasks of an architect. As held above, it is limited to the design of plans and the supervision of the execution of works which require a building permit. ${ }^{27}$ It is thus limited to important projects for which the intervention of an architect constitutes a guarantee for public and private interests. It follows that the architectural title does not have any legal effect on the right to fulfil all the other tasks which are generally carried out by an architect but which do not fall under the monopoly such as town planning activities, estimations, expertise, etc. Furthermore, constructions which do not require the involvement of a professional architect can be designed by anyone..$^{28}$ The Royal Decree of 16 December $1971^{29}$ regarding the determination of

24 Court of First Instance Bruges 24 February 1966; T. Aann. 1966, 161; Res Jur. Imm. 1966, 161.

25 Constitutional Court 10 October 2001, A.A. 2001, afl. 4, 1663; A.J.T. 2001-02, 781; Official Gazette 1 December 2001; Cah. dr. immo 2002, afl. 1, 10; JLMB 2001, afl. 42, 1816 annotated by B. Louveaux, Juristenkrant 2001 afl. 36, 4; R.J.I. 2001, 106; Burssens 2001, no. 106.

26 Explanatory Memorandum to the Bill on the Tiel and Profession of Architects, no. 236.

27 See the law of 29 March 1962 on the Organisation of Spatial Planning and Town Planning, Official Gazette 12 April 1962. The building permit should be distinguished from all other accessory authorizations which are necessary for a particular building, for example those regarding conformity: Flamme and Lepaffe 1966, $n^{\circ} 327$. Article 20 of the Deontological Code holds that the architectural contract has to enumerate precisely whether the architect is charged with one of the following tasks: designing the provisional plan (investigation of the location and the rules of town-building, investigation of the soil, sketch, description and estimate, model, advice on building-materials, installations etc., quality and design); assistance in making up all the official documents (dossier to get the building permit, administrative and non-administrative rights, building contract); drawing up the final plan; drawing up the specification plans; making the specification (descriptive, quantitative and budgetary); drawing up the work plan; elaborating a budgetary estimation; activities concerning the tender; management (assisting the principal, leading and controlling the construction site, controlling and correcting the plans and documents drawn up by third parties, coordinating construction activities); administration of the project; completion and delivery; examining the accounts (terms of payment, approval of accounts and final accounts).

28 Furthermore, drawing plans without the intention of a concrete execution do not fall under the privilege of the architect. Anyone is allowed to make plans which are general, abstract and not related to a precise situation. Only architects, members of the Order, are allowed to draw plans regarding the construction of a particular project on a particular place which needs an administrative authorisation for building to take place. See Rigaux, 1975 p. 73.

29 Royal Decree on the determination of works and actions which are exempt from either the involvement of an architect, or the acquisition of a building permit or the corresponding advice of the authorized official, Official Gazette 19 January 1972. In the light of Article $6 \$ 1, I, 1^{\circ}$ of the Special Law regarding the Reformation of the Institutions of 8 August 1980 which makes matters relating to spatial planning and urbanism 
works and actions which are exempt from either the involvement of an architect, or the acquisition of a building permit or the corresponding advice of an authorized official, enumerates in detail for which projects the involvement of an architect is not compulsory. Examples are, dependent on the Region, actions which do not involve construction problems, or the stability of the building; certain tasks related to the outside of a building; small constructions like carports, greenhouses, annexes to a house, lanterns, etc.

Article 4(3) AA makes it possible for the King to distinguish the obligation to involve an architect from the obligation to be in the possession of a building permit. ${ }^{30}$ The former is especially concerned with the quality improvement of buildings, the latter with urbanism and spatial planning. In this regard it should be mentioned that, in 1939, a building permit was required in exceptional cases, while nowadays it is exceptional if a building permit is not required. ${ }^{31}$

Article 4(2) AA states that exemptions to the monopoly as described in Article 4(1) AA can be granted by the Provincial Governor after the College of Alderman of the municipality where the project is to be constructed made a proposal to this end. ${ }^{32}$ This 'proposal' is not merely an advice. If the College arrives at a negative decision, the governor cannot decide differently. ${ }^{33}$

\section{Penalties}

Violations to the architects' monopoly are penalized by Article 53 of the Architect's Order Act which imposes a criminal sentence upon persons who design plans without being registered on a tableau of the Order, or included in a list of trainees, and are not

fall under the responsibility of the Regions, after several amendments this decision was finally annulled and substituted for the Flemish Region by the Decision of 29 May 2009, Official Gazette 25 August 2009; for the Walloon Region by Chapter 4 of the Walloon law book on spatial planning, urbanism and patrimony of 14 May 1984 Official Gazette 25 May 1984; and for the Brussels Capital Region by the Decision of the Brussels Capital Region of 29 June 1992 Official Gazette 1 July 1992, after several amendments was finally annulled and substituted by the Decision of 13 November 2008, Official Gazette 12 December 2008.

30 Delvaux, t. I, 1968, n 241, quoting Debecker, La protection du titre et de la profession d'architecte, 1941.

31 Examples include, dependent on the region, certain types of small buildings; the renewal of certain foundations, and silos.

32 Due to this Article it is possible for the governor to allow a civil engineer to construct his own house without the involvement of an architect: See Council of State, 20 June 1985, R. W., 1985-86, 880; Arr. R. v. St. 1985; Council of State 28 April 1981, Pas. 1984, IV, 43; Arr. R. v. St. 1981, 582; R.A.C.E.1981. However the governor is not allowed to ask the engineer to fulfil the same requirements as the architect, such as the registration with the Order, traineeship, etc: Council of State 1 June 1979, A.P.M. 1979, 3; Arr. R. v. St. 1979, 648; R.J.I. 1980, 11; T.B.P. 1980, 69. Contrary to Article 4(3), this exemption is not limited to projects of limited importance: Council of State 24 January 1955, R.J.I., 263; Council of State 9 June 1970 , L'Entreprise et le Droit, 1972, 257, annotation De Caluwé. Nevertheless, exceptional circumstances are required: see judgement. However, if the engineer works as an official of the city, he is compelled to involve an architect since Article $5 \mathrm{AA}$ is applicable (this will be further discussed hereunder).

33 Council of State 8 December 1967, Arr. R. v. St. 1967; T.B.P. 1969, 125; R.A.C.E. 1967; Pas. 1968, IV, 70; R.J.D.A. 1968, 202; R.J.I. 1969, 123; R.J.I. 1971, 39; Rev. dr. commun 1968, 16. 1970, L'Entreprise et le Droit, 1972, 257, annotation De Caluwé. 
Public Law in Belgium

otherwise authorised to act as an architect. ${ }^{34}$ It follows therefore that each plan has to be signed by a registered architect. ${ }^{35}$ The signature on the plan signifies that it was designed 'by or under the supervision' of the architect, for example by persons working according to his instructions and who are controlled by him. ${ }^{36}$ If a plan is designed by someone who is not an architect and who does not work under the supervision of an architect, while an architect puts his signature on the plan after getting some remuneration, the real designer of the plan does not only violate Article 53 AA, but he also violates, together with the architect, Article 196 of the Criminal Code which imposes a prison sentence of five to ten years on persons committing forgery. ${ }^{37}$ Moreover, the architect is likely to suffer a (severe) deontological sanction as well ${ }^{38}$, such as the striking out of his name from the register due to manifest 'dishonourable' behaviour. ${ }^{39}$ In accordance with Article $2 \mathrm{AO}$, the Order has to report every violation of the laws and regulations protecting the title and the profession of architect to the judicial authorities.

The two traditional tasks of architects have inspired the definition of architect in the works of the Liaison Committee of Architects of the Common Market and are reproduced in the preamble to the Act of 26 June 1963 on the institution of the Architects' Order. ${ }^{40}$ In case a certain construction requires a building permit and falls within the ambit of Article 4(1) AA, a registered architect should be involved who satisfies all the conditions of the Architects' Act or who fulfils the requirements of Article $8 \$ 2(1)$ or (2) of the Architects' Order Act. These requirements will now be discussed in paragraphs 5.2.2 and 5.2.3

\subsection{The right to use the title}

\section{Introduction}

Article $1 \$ 2$ AA states that Belgians and nationals of EC/EEA Member States can use the title of architect in Belgium if they are in the possession of a diploma, certificate or other title as described in the annex $1 \mathrm{~b}$ to the Act. This annex is adopted in accordance with Council Directive 85/384/EEC ${ }^{41}$ and amended in accordance with the provisions of Directive 2005/36/EC and Directive 2006/100/EC. The Act of 21 November 2008 amended the Architects' Act and the Architects' Order Act and implemented the 2005 and 2006 Directive with regard to the architectural profession. ${ }^{42}$ Since Directive 2005/36/EC should have been implemented in national legislation by 20 October 2007,

34 On numerous occasions this has been confirmed by the Supreme Court and the Council of State: see for example, Supreme Court, 4 May 1970, Pas., 1970, I, 753; Council of State 21 February 1962, Arr. Et Avis Cons. Etat, 1962, 150.

35 Supreme Court, 4 May 1970, Pas., 1970, I, 753.

36 Ghent 23 February 1973, L'Entreprise et le droit, 1974, 153.

37 Article 196 Criminal Code. See Ghent, 17 April 1967, R.W., 1966-1967, col. 2056.

38 Council of Appeal Ghent, 8 February 1966, R.J.I., 1968, p. 43; Council of Appeal Liege, 7 March 1973, not published.

39 See Conseil Ordre Brabant Francophone, 8 February 1972.

40 See also Doc. Parl., Senate, Session 1961-62, Session of 3 July 1962, nº 299, p. 2.

41 The annex was adopted by Royal Decree of 6 July 1990, Official Gazette 28 July 1990

42 Official Gazette 11 February 2009. 
Belgium clearly failed to implement the Directive on time. By a ruling of 9 July 2009, the Belgian State was condemned by the Court of Justice of the European Union for this failure. ${ }^{43}$ Even before Belgium amended the Architects' Act for it to be in line with European Union law, architects could already rely on the Directive due to its vertical direct effect after the deadline for transposition had passed. It follows that, after 20 October 2007, qualifications obtained by EU/EEA nationals that are listed in Annex V or VI of the Directive can no longer be scrutinized, since persons holding such qualifications automatically obtain the title of architect without any further procedural matters. The same goes for qualifications listed in Annex VII to the EEA Agreement.

Since the use of the title is connected to the possession of a diploma or attestation, only natural persons can use the title of architect in Belgium. Obviously, legal persons are not able to obtain a diploma or pass an exam.

\section{Requirements}

a. Belgian qualifications

Just as in the Netherlands, where a division is made between a theoretically-based university education and a more practical education at a Dutch academy, the architectural education in Belgium is organised at two levels which both offer a five-year course: the architectural specialisation in civil engineering education which leads to the title of 'civil engineer-architect' (university) and the education at an academy (non-university) which leads to the diploma of 'architect'. Since the importance and seriousness of the architects' function was increasingly better understood, the Act of 18 February 1977 on the reorganisation of the architectural education ${ }^{44}$ was introduced. This Act foresees that all architectural education (thus also those at the academies) has to be of university level. ${ }^{45}$ Nevertheless, the institutional distinction is still made.

The following institutions award the diploma of 'architect' in Belgium:

In the Flemish Community

- 'Artesis Hogeschool, Departement Ontwerpwetenschappen, Afdeling Architectuurwetenschappen, Henry van de Velde', Antwerp.

- 'Hogeschool voor Kunsten en Architectuur', which was created in 2008 and is composed of several pre-existing academies. These are, with regard to architecture, the Saint-Lucas institutes of Brussels (Dutch speaking) and Ghent.

- 'Provinciale Hogeschool Limburg', Hasselt.

In the Walloon Community

- 'Institut Supérieur d'Architecture de la Communauté Française La Cambre, Brussels (Henri van de Velde)

43 Case C-469/08 Commission of the European Communities v. Kingdom of Belgium, ECR OJ C 6, 10.01.2009, ECR 2009.

44 Official Gazette 12.03.1977

45 See also: Council of State 24 May 1988, A.P.M. 1988, 86; Arr. R. v. St. 1988; T.B.P. 1989, 259. 
Public Law in Belgium

- 'Institut Supérieur d'Architecture Saint Luc', Brussels (French speaking), Tournai and Liege

- 'Institut Supérieur d'Architecture Lambert Lombard', Liège

- 'Institut Supérieur d'Architecture', Mons

- 'Institut Victor Horta', Brussels

The last three institutions form 'L'Institut Supérieur d'Architecture Intercommunal' (I.S.A.I).

- As stated above, there are educational programmes at Belgian universities leading to the title of 'civil engineer-architect'. These programmes involve, in addition to architectural education, courses on the composition of the soil, land building materials, construction technologies, the physical aspects of buildings, town planning, the environment, etc. They can be followed at the following institutions:

In the Flemish Community

- 'Katholieke Universiteit Leuven, Faculteit Ingenieurswetenschappen, Afdeling Architectuur'

- 'Vrije Universiteit Brussel, Faculteit Ingenieurswetenschappen, Afdeling Architectuur'

- 'Universiteit Gent, Faculteit Ingenieurswetenschappen, Afdeling Architectuur'

In the Walloon Community

- 'Université de Liège, Faculté des Sciences Appliquées, Etude Ingénieur-Civil Architecte'

- 'Université de Mons, Faculté Polytechnique, Etude Ingénieur-Civil Architecte'

- 'Université Catholique de Louvain', Faculté d'architecture, d'ingénierie architecturale, d'urbanisme et d'aménagement du territoire.

In the light of the Bologna process, the Decree of the Flemish Community on the Restructuring of Higher Education in Flanders was created on 4 April 2003. To make it easier for students to navigate through different programmes of study and to follow extra courses, the degrees of 'Bachelor' and 'Master' were introduced. In addition, academies were required to associate themselves with a university in order to lift the education system of the academies to a higher level. It follows that academies are only allowed to offer academic courses if they cooperate with a university ${ }^{46}$. In this way the 'Artesis Hogeschool Antwerpen' associated with the 'Universiteit Antwerpen' in 2003, and their cooperation was called 'Associatie Universiteit \& Hogescholen Antwerpen'. The 'Hogeschool voor Kunst en Architectuur' was created in 2008 and abolished the 'Hogeschool voor Wetenschap en Kunst' which consisted of establishments in Brussels (Saint-Lucas) and Ghent (Saint-Lucas). These establishments form part of the new Academy which is associated with the 'Katholieke Universiteit Leuven'. Likewise, the 'Provinciale Hogeschool Hasselt' cooperates with the 'Universiteit Hasselt' to form the

46 See chapter VI of the Decree. 
'Associatie Universiteit-Hogescholen Limburg'. The Decree entered into force on 1 January 2003.

In the Walloon Community, the Decree on the Organisation of the Transfer of Higher Architectural Education to the University was promulgated on 30 April 2009. It also aims to create an architectural education of university level by the integration of the academies and universities. A pluralistic and emancipating education system will have to strengthen and deepen the knowledge of the professionals involved, and allow them to respond to the increasing complexity of the architectural tasks. It indicates that: the 'Institut Supérieur d'Architecture Saint-Luc de Bruxelles' will be integrated into the 'Université Catholique de Louvain' ${ }^{47}$ (Chapter II); the 'Institut Supérieur d'Architecture Saint-Luc Tournai' will also be integrated into this university (Chapter III); the 'Institut Supérieur d'Architecture Victor Horta' will be integrated into the 'Université Libre de Bruxelles' (Chapter IV); the 'Institut Supérieur d'Architecture de la Communatuté Française La Cambre' will be integrated into the 'Université Libre de Bruxelles' (Chapter V); the 'Institut Supérieur d'Architecture Lambert Lombard' will be integrated into the 'Université de Liège' (Chapter VI); the 'Institut Supérieur d'Architecture Saint-Luc de Liège' will be integrated into the 'Université de Liège' (chapter VII); the 'Institut Supérieur d'Architecture Intercommununale d'Enseignment Supérieur d'Architecture' in Mons will be integrated into the 'Université de Mons' (Chapter IX). The Decree will enter into force on 1 January 2010.

The Architects' Act has not yet taken these recent changes into account. Furthermore, the qualifications which are mentioned in annex 2a to the Architects' Act which have been obtained not later than during the academic year 1987/1988, also allows the use of the title. Since this is not applicable to those who currently want to obtain qualifications, this will not be discussed further.

- Furthermore, as stated in annex 2a to the Architects' Act, persons holding a university diploma of civil engineer together with a certificate of traineeship delivered by the Architects' Order, can also use the title of 'architect' in Belgium in the event that these qualifications are not obtained later than during the academic year 1987/1988. Since there is no express clause in the Directive dealing with this type of qualification, professionals falling within this category have to apply the general system dealt with by Directive 2005/36/EC to obtain recognition of their qualifications at EU level.

- Lastly, persons having obtained a diploma in architecture awarded by the Central Examination Commission or by an examination commission instituted by the State for the granting of the architects' title, can also benefit from the use of the title (Article 1

47 Due to the 2009 Decree the 'Faculté d'architecture, d'ingénierie architectural, d'urbanisme et d'aménagement du territoire' was created. Prior to that, the education was provided at the 'Ecole Polytechnique de Louvain, Département Architecture, urbanisme, génie civil et environnemental, Etude Architecte et Ingénieur Civil-Architecte'. 
\$2(1) jo annex 2a). Such an examination cannot have been completed later than the academic year 1987/1988.

As stipulated in Article 7 AA, professionals who do not possess the required diploma but who can be distinguished due to their experience, can be allowed to use the title if they pass a test organised by the Central Examination Commission. This will be further discussed under $d$. Also, for these architects, the general system of Directive 2005/36/EC has to be used.

\section{b. EC/EEA qualifications}

As stated above, Article $1 \$ 2$ AA states that Belgians and nationals of EU/EEA States can use the title of architect in Belgium if they are in the possession of a diploma, certificate or other title as described in annex 1b. This annex contains a list of the EU diplomas of the twelve States which formed the EU before 1995, and which are automatically recognized in Belgium. This was added to the Architects' Act by Royal Decree of 6 July $1990^{48}$ which was created to fulfil Article 1 of the Act of 4 July $1989^{49}$ which implemented Directive $85 / 384 /$ EEC and which states that the King (i.e. the government) has to amend, abolish or supplement the Architects Act for it to be in line with the Directive. The Annex was further updated by implementation of the provisions of Directive 2005/36/EC as amended by Directive 2006/100/EC, and is fully in line with Annex V.7.1. of Directive 2005/36/EC. As noted in Part I of this thesis, this annex contains a list of 14 Member States: this is the (old) EU 15 except for Luxemburg in which there is no institution where architecture is educated. In accordance with Article 21 of the Directive, the qualifications enumerated therein have to be recognised automatically since these are deemed to comply with the conditions which must be fulfilled by the training to become an architect, and which are mentioned in Article 46 Directive 2005/36/EC.

Article $1 \$ 2 / 1$ AA which was added to the Architects' Act by the Act of 21 November 2008, holds that the Belgian State recognises the evidence of formal qualifications as an architect that is awarded by other Member States, and attests to a course of training which began no later than the reference academic year in annex $2 a$, even if they do not satisfy the minimum requirement mentioned in annex 1a. Article $1 \$ 2 / 1 \mathrm{AA}$ is the implementation of Article 49(1) of Directive 2005/36/EC, while annex 2a is a copy of Annex VI. Annex 1a is the implementation of Article 46 of Directive 2005/36/EC, and gives an overview of the general requirements that the architectural training must have. The Belgian State gives the same legal effects to these titles with regard to the entry and exercise of the professional practice of architect on its territory as to the academic titles delivered by itself. ${ }^{50}$ It follows that the implementation, although too late, is in line with

48 Official Gazette 28 July 1990. This Royal Decree was amended by Royal Decree of 3 October 1990, Official Gazette 9 October 1990, which was on its turn annulled by decision nr. 37.308 of the Council of State of 25 June 1991, A.P.M. 1991, 95, Official Gazette 21 August 1991, 18.051 and eventually amended by Royal Decree of 29 March 1995, Official Gazette 26 July 1995.

49 Official Gazette 13 September 1989.

50 The Article adds that the declarations issued by the competent authorities of the Federal Republic of Germany which serve as proof of the respective equality of the educational titles issued by the competent authorities of the German Democratic Republic after 8 May 1945 to the titles mentioned in annex 2a, will be recognised under these conditions. This is in line with Article 49 (1) Directive 2005/36/EC 
European legislation, except for the fact that Annex 1a does not contain a derogation for the training provided by the German 'Fachhochschulen' as meant in Article 47(1) Directive 2005/36/EC, nor for training as part of social betterment schemes or part-time university studies as mentioned in Article 47(2). However annex $2 \mathrm{a}$ also foresees that the training provided by the German 'Fachhochschulen' will be accepted if this training was followed by a four-year period of professional experience in Germany. This is in line with Article 47(1) of the Directive.

Furthermore, the new Article $1 \$ 2 / 2$, also incorporated by the Act of 21 November 2008, holds that, notwithstanding Article $1 \$ 2 / 1 \mathrm{AA}$, the declarations issued to the nationals of Member States by Member States which have regulations for the access and practice of the profession of architect at the following dates will be recognised:

$1^{\circ} 1$ January 1995 for Austria, Finland and Sweden

$2^{\circ} 1$ May 2004 for the Czech Republic, Estonia, Cyprus, Lithuania, Hungary, Malta, Poland, Slovenia and Slovakia

$3^{\circ} 1$ January 2007 for Bulgaria and Romania

$4^{\circ} 5$ August 1987 for the other Member States ${ }^{51}$

The declaration has to confirm that its possessor has obtained the permission to use the title of architect on this date at the latest, and that he has practised the profession for three consecutive years during the five years which preceded their issue.

This Article correctly implements Article 49(2) of Directive 2005/36/EC as amended by Directive 2006/100/EC, and is thus in line with European law.

As held by Article $1 \S 3$ AA, Belgians, as well as nationals of other EU or EEA Member States who satisfy the requirements as described in the annex, can use the title (and abbreviation) they obtained in their state of origin in the original language as well.

Article $1 \$ 5$ AA stipulates that, in certain cases, Articles 13-17 of the Act of 12 February 2008 instituting a new General Framework for the recognition of EC-qualifications ${ }^{52}$ are applicable. These Articles implement the General System of Recognition under Directive 2005/36/EC regarding the freedom of establishment. ${ }^{53}$ The General System is applicable when:

$1^{\circ}$ the applicant does not satisfy the requirements for effective and lawful professional practice as intended in paragraphs $2 / 1$ and 2/2; (implementation of Article 10(b) Directive 2005/36/EC)

$2^{\circ}$ the applicant holds evidence of formal qualifications which are not mentioned in annex 1b; (implementation of Article 10(c) Directive 2005/36/EC)

51 This is the date at which Directive 85/384/EEC should have been implemented in the (old) EU-15. Belgium only transposed the Directive by Royal Decree of 6 July 1990 and 12 September 1990.

52 Official Gazette 9 April 2008.

53 Article 13 of the Act is the implementation of Article 11 of the Directive; Article 14 of the Act is the implementation of Article 12 of the Directive; Article 15 of the Act is the implementation of Article 13 of the Directive; Article 16 of the Act is the implementation of Article 14 of the Directive; Article 17 of the Act is the implementation of Article 15 of the Directive. 
$3^{\circ}$ the applicant holds evidence of formal qualifications as a specialist which follows the training leading to the possession of formal qualifications mentioned in annex $1 \mathrm{~b}$, and solely for the purpose of the recognition of the relevant speciality, notwithstanding the requirement mentioned in annex $2 \mathrm{~b}$ for qualifications delivered by the former Czechoslovakia, Czech Republic, Slovakia, the former Soviet-Union, Estonia, Latvia, Lithuania, the former Yugoslavia and Slovenia ${ }^{54}$ (implementation of Article 10(d) Directive 2005/36/EC)

Articles 13-17 of the Act of 12 February 2008 implement Articles 11-15 of Directive 2005/36/EC correctly.

c. Non EC/EEA qualifications

As held above, Articles 13-17 of the Act of 12 February 2008 implement the General System of Recognition. Article $1 \$ 5,4^{\circ}$ AA holds that the General System is also applicable when the applicant satisfies the requirement of Article $2 \$ 3$ of the Act of 12 February 2008, instituting a new General Framework for the Recognition of EC-professional qualification, which equalises formal qualifications issued by a third state if the holder has three years of professional experience on the territory of the Member State which has recognised the formal qualifications and, in the event that the Member State confirms this professional experience (Article 3(3) jo 2(2) Directive 2005/36/EC). In this regard it should be noted that, contrary to the EC/EEA diplomas enumerated in the abovementioned annexes to the Architects' Act which automatically permit the use of the title, the Belgian competent authorities will 'examine' the diplomas, certificates and other titles which fall under the ambit of Directive 2005/36/EC but which are obtained outside the European Union, if they were recognized by another Member State. In these cases, the training/experience obtained in another Member State will also be evaluated (Article $1 \S 4 \mathrm{AA}$ ). In this regard it should be repeated that the Directive is not applicable to third-country nationals.

d. Earned rights and examinations

As held by Article 7 AA, Belgian nationals born before 1907 can continue using the title of architect even if they do not possess the required diploma. This is possible if they are known for practising the profession or if they were actively involved in designing plans for another architect for more than ten years. However, this latter group of professionals has to pass an exam organised by the Central Examination Commission. The same goes for Belgians born between 1907 and 1917. If they have not disposed of the required diploma, they can continue to use their title as long as they can prove to a commission that they have sufficient practical experience. If they do have a certain diploma or certificate of studies in building arts, they can be exempt from this proof as long as they can provide a certificate of competence. Since only a very small category of professionals falls under this provision, it will not be further discussed in this thesis. In any case, these professionals can, in my opinion, not use the automatic recognition system as provided for in Chapter III of Title III of the Directive. Article 48 of the Directive only refers to persons who are authorised to use the title pursuant to a national law which gives the

54 See Article 23(3), (4) and (5) Directive 2005/36/EC. 
competent authority of a Member State the power to award that title to Member States' nationals who are especially distinguished by the quality of their work in the field of architecture. I do not believe that Article 7 AA, or any other Article, refers to such persons.

Also persons having obtained a diploma in architecture awarded by the Central Examination Commission or by an examination commission instituted by the State for the granting of the architects' title, can benefit from the title use. As stipulated in Article 7 AA, professionals who do not possess the required diploma, but who can be distinguished due to their experience, can be allowed to use the title if they pass a test organised by the Central Examination Commission. Also, for these architects, the general system of Directive 2005/36/EC has to be used.

\section{Penalties}

Those who can use the title, are allowed to make their activities known to the public in a discrete manner (publicity) and are even obliged to mention their name on a plate at the building site during the construction works (Article 13 Deontological Code).

Article 10(1) AA stipulates that the unauthorised use of the professional title of architect can lead to fines of between 200.00 and 1,000.00 Euros. When one does not ask for the cooperation of an architect even though this is required by law (i.e. when a building permit is required), a fine of 200.00 to 1000.00 Euros can be imposed upon the building master. Persons or institutions awarding diplomas while not being authorized to distribute documents which grant the title of architect, risk getting a fine of 200.00 to 1,000.00 Euros and/or a prison sentence of 8 days to 3 months (Article 11). Due to the revaluation of money these amounts have to be multiplied by $5.5 .^{55}$ Furthermore, fake diplomas will be destroyed. In the event that a legal (non-natural) person practises the profession, the legal person will be held responsible for the payment of the fines and the restoration measures to which the organs or directors are condemned (Article 12 AA jo Article 53 AO). This will be further discussed hereunder. The penalties discussed in this section should be distinguished from those discussed in paragraph 5.2.1 above. This section deals with the unauthorised use of the title. The other types of penalty do not condemn the unauthorised user of the title, but condemn the practise of the profession in itself in the event that one is not authorised thereto. It is clear that the Architects' Act really aims to protect the title of architect. Every abuse or misuse of the title is sanctioned by criminal law, and can lead to a criminal punishment. However, the right to use the title does not in itself allow one to practise the profession. The reason is that, according to Article $5 \mathrm{AO}$, one has to be registered in order to practise.

This will be discussed in paragraph 5.2.3.

4. Academic titles

As held by Article $1 \$ 6 \mathrm{AA}$, architects whose professional qualifications are recognised have the right to use their academic titles which are conferred on them in their Member State of origin, and possibly an abbreviated form thereof in the language of the Member

55 See Article 1 of the Law of 5 March 1952 on the 'opdécimes op de strafrechtelijke geldboeten'. 
State of origin. It should be noted that this provision has to be separated from the other Articles which were discussed above and which all deal with the use of professional titles. Article $1 \$ 6$ AA is an implementation of Article 54 of Directive 2005/36/EC.

\subsection{The right to practise the profession}

There is no legal document which explicitly defines what the 'practise' of the profession of architect exactly means. This is due to the fact that, in 1939, architects were deemed to know everything concerning real estate. Nowadays the object of the monopoly is defined and strictly interpreted ${ }^{56}$. However, clients are becoming increasingly demanding: they expect their architect to be a good negotiator, that their financial interests are being taken care of, that the works are coordinated when other building actors such as promoters or safety coordinators are involved, etc.

As laid down by Article $5 \mathrm{AO}$ :

"No one is allowed to practise the profession of architect in whatever capacity in Belgium, without being registered on one of the Order's tableaux $x^{57}$ or on the list of trainees, or without fulfilling the requirements of Article 8 \$2(1) or (2) AO."

Furthermore, Article $4 \mathrm{AO}$ states:

"No one will be registered on a tableau or on the list of trainees without fulfilling the requirements of the Act of 20 February 1939 on the protection of the title and the profession of architect."

It follows that, to be registered, one has to meet the requirements of the Architects' Act. The Order will not register a new member if it is aware of the fact that the applicant does not live up to all the conditions stipulated in the Architects' Act, such as the prohibition with regard to being an entrepreneur or a public official ${ }^{58}$. By being registered, one automatically fulfils all the conditions imposed by the Architects' Act.

Article $8 \$ 1 \mathrm{AO}$ holds that, just as with regard to Belgian nationals, nationals of other EEC or EEA States, as well as other foreigners authorised to practise the profession of architect in Belgium according to Article $8 \mathrm{AA}$, who want to practise the profession of architect and establish themselves temporarily or permanently in Belgium, have to apply for registration on a tableau or list of trainees of the Order at the competent council. The same goes for the legal persons mentioned in Article $2 \$ 2$ AA. One can only be registered on the tableau after having completed a traineeship of two years at the office

56 Council of State 18 January 1966, Arr. et Avis Cons. Etat, 39; Supreme Court 17 February 1969, Pas., 1969, I, 536 ; J.T., 1969, p. 480; Council of State, 25 January 1962, Arr. R.v.St. 1962; R.A.A.C.E. 1962; La Construction 1962, 48; Pas. 1963, IV, 4; R.J.D.A. 1962, 155; R.J.I. 1962, 172; Supreme Court 18 December 1967, Pas., 1968, I, 516.

57 Tableaux are lists (per province) on which the Order's members are registered after the fulfilment of the traineeship.

58 See Articles 5 and 6 Architects Act. 
of an architect who has already been registered on the tableau for at least ten years (Article $50 \mathrm{AO})$. A trainee will therefore always be registered on the list of trainees.

To practise the profession, it is thus necessary to:

- be registered (and thus be a member of the Architects' Order) and to fulfil all the requirements of the Architects' Act OR

- fulfil the requirements of Article $8 \$ 2(1)$ or (2) AO.

There are different categories of persons who can practise the profession of architect. These will now be discussed. However, first some general remarks have to be made with regard to the practise of the profession. These apply to all the categories under discussion:

Firstly, as held by Article 6 AA, the practice of the profession of architect is incompatible with the practice of the profession of entrepreneur. This Article, which lays down the independence of architects and which is of public order ${ }^{59}$, should be seen in the light of the architects' monopoly in Belgium. Since Article 4 AA requires the involvement of an architect for the design of plans and the supervision of building works for which a building permit is required, the entrepreneur and architect cannot be the same person due to their opposing interests ${ }^{60}$ : the person who constructs a house cannot be the same as the one who controls the constructor. ${ }^{61}$ The advantage architects gain by their monopoly is thus compensated for by the prohibition to be a building contractor. In this way, every association of an architect and a building contractor and any subordination is directly contrary to Article 6 AA. ${ }^{62}$ It is argued that economic dependence stands in the way of an honourable exercise of the profession since it prevents the architect from freely appreciating the collective interest and the interests of his clients. Any (appearance of) collusion between the architect and the entrepreneur -for example when the entrepreneur collects the honorarium of the architect ${ }^{63}$, when the building contract stipulates that the entrepreneur has the right to choose the architect himself ${ }^{64}$ or when the entrepreneur agrees to give advantages (such as commissions) to the architect ${ }^{65}$ - is held to be immoral and, more importantly, illegal. Since the Architects' Act does not only protect the architect but also his (inexperienced) clients, the architect cannot limit his advice to the technical, functional and legal aspects of the building process. The financial aspects are also covered by his examination. Professionals such as the entrepreneur, who only have commercial interests, are deemed to be not suitable for this task. It follows that a maximal independence and objectivity is guaranteed so that the building master can be

59 Every contract which is at odds with it, is void and of absolute nullity: Flamme \& Lepaffe 1966, $\mathrm{n}^{\circ} 373$ bis.

60 Vergauwe, Le droit de l'architecture, De Boeck-Wesmael, Brussels, 1991, pp. 44-45.

61 Doc. Parl., Sénat, 1937-1938, n 25, p. 2.

62 Supreme Court 26 January 1978, Arr.Cass. 1978, 780; R.W. 1978-79, 665 ; T. Aann. 1979, 416, annotated by Flamme; Pas. 1978, I, 759; Brussels 31 October 1961, Pas., 1962, II, 267.

63 Court of First Instance Brussels 6 April 1964, Pas., III, 25.

64 Supreme Court 24 September 1976, Arr.Cass. 1977, 98; R.W. 1976-77, 2269; Pas. 1977, I, 101 ; J.T. 1977, 471 ; Rev. not. b. 1977, 602; Brussels 11 December 1984, Ann dr. Lg 1986, 128, annotated by Y. Hannequart.

65 Brussels 25 March 1970, Pas., 1970, II, 155, J.C.B., 1973, I, 161. 
sure that the architect will make the best choices concerning the necessary building techniques and materials. ${ }^{66}$ The liberal character of the architectural profession refers therefore to the absence of any subordination in the relationship with the building master. ${ }^{67}$ Furthermore, it involves the pursuit of social interests such as the safety of buildings, a better use of the environment, a better quality of equipment, good comfort and hygiene - and not of personal ones. However, this does not mean that the profession cannot be lucrative. Of course every professional has to earn money. Nevertheless the architect, under the supervision of the Order, has to refrain from actions which are at odds with his conscience.

The present architects' Deontological Code ${ }^{68}$ confirms, in Article 10, $1^{\circ}$ and 11 , the incompatibility of the two professions. Some exceptions can be found in Article 10, $2^{\circ}$ $4^{\circ}{ }^{69}$ It can be said that the Architects' Act and the Deontological Code do not only regulate market entry but also -to some extent- market conduct in the form of business structure restrictions.

Secondly, professionals authorised to use the title of architect, but who are not registered by the Order, are not allowed to be in charge of building projects or to design plans for buildings which require a building permit. These architects are not subject to the incompatibility rules (these concern the practice of the profession) and do not have to comply with any rules of the Order. The architects' deontology does not concern them. Professionals who carry the diploma of architect can thus establish themselves as an entrepreneur and use the title of architect, as long as they do not carry out, when using this title, tasks which fall within the architect's monopoly. In this way, clients can be sure that when they need an architect for a project which requires a building permit, they are assisted by a person who has the required technical competence, and belongs to a professional Order with a rigorous deontology. ${ }^{70}$

Thirdly, the profession of architect cannot be practised by architects who are not covered by professional liability insurance (see Article $2 \$ 4$ and 9 AA). This will be discussed in detail in subsection 4 .

Finally the Act of 21 November 2008 added that those whose professional qualifications are recognised need to have appropriate language skills to be able to practise the profession in Belgium (Article $2 \$ 5 \mathrm{AA}$ ). This is an implementation of Article 53 of Directive 2005/36/EC.

66 The independence of the architect has always been acknowledged by the Council of State (see for example Council of State, $3^{\mathrm{e}}$ Ch., 22 January 1974, $\mathrm{n}^{\circ}$ 16204) as well as by other tribunals (see for example Brussels 13 May 1970, J.T., 1670, 547; Brussels 3 February 1972, J.C.B., 1972, I, 416.

67 Liège 3 January 1964, R.J.I., 1964, 193.

68 Deontological Code of 16 December 1983 created by the National Council of the Architects' Order, ratified by Royal Decree of 18 April 1985, Official Gazette 8 May 1985.

69 The Order of Architects can determine other incompatibilities than the one described in Article 6 AA, as long as they find their origin in the protection of the independence and the dignity of the architect: See Council of State 18 January 1974, T. Aann. 1974, 30, annotated by Flamme; T.B.P. 1975, 102; Pas. 1976, IV, 19.

$70 \quad$ Rigaux 1975, pp. 29-30. 
Chapter 5

\section{Natural persons}

a. EC/EEA nationals

Article $2 \$ 1$ (the old Article 12) AA indicates who is allowed to practise the profession of architect. It concerns:

$1^{\circ}$ persons who are authorized to use the title of architect according to Article 1

$2^{\circ}$ engineers who were certified according to the Acts on Academic Degrees

$3^{\circ}$ engineers who obtained their diploma at a Belgian university or an assimilated institution

$4^{\circ}$ military officers belonging to the Royal Engineers or the Artillery who attended an application school

The categories of professionals that are authorised to use the architectural title were discussed in paragraph 5.2.2. Of course, they are also allowed to practise the profession.

Article $2 \$ 1$ AA therefore extends the monopoly to engineers and certain military officers holding a Belgian diploma. ${ }^{71}$ Just like all other applicants, they have to fulfil a traineeship of two years before they can be registered on the tableau (Article $50 \mathrm{AO}$ )..$^{72} \mathrm{It}$ should be noted that, in 1939, the legislator only meant to extend the monopoly to civil engineers. The holders of these diplomas were deemed competent to deal with technical and scientific questions concerning the building art. ${ }^{73}$ The Supreme Court decided, however, that the Architects' Act does not give a precise description of the required engineering 'branch' nor of the required knowledge or level of experience, so that the fact of being an engineer in whatever branch suffices to allow that individual to practise as an architect. ${ }^{74}$ However, only professionals holding an engineering diploma which is enumerated in annex $2 \mathrm{a}$ can also use the architectural title.

It is important to note that Article 2 does not explicitly or implicitly allow the combination of the profession of architect and engineer. ${ }^{75}$ It only holds that the holder of an engineering diploma is allowed to practise the profession of architect. ${ }^{76}$ Nevertheless, this does not mean that it is impossible to practise the function of architect and engineer at the same time. However, the Council of the Order has the right to refuse an architect

71 Supreme Court 22 September 2005, Juristenkrant, 2005, ed. 118, 11: an engineer holding the diploma of civil electric engineer can practise the profession of architect.

72 Supreme Court 21 April 1969, Arr. Cass. 1969, 779; J.T. 1969, 565; Pas. 1969, I, 730 ; R.J.I. 1970, 7.

73 Council of State 26 June 1986, R.A.C.E., 1986.

74 Supreme Court 22 September 2005, Juristenkrant 2005, ed. 118, 11; Pas. 2005, ed. 9-10, 1712. The Court held that Article 1 of the Act on the Academic degrees of 21 May 1929 (Official Gazette 25 May 1929) and Article 1 of the Regent's Decision of 31 December 1949 (Official Gazette 1 March 1950) enumerate engineering education in other branches which also give rise to academic degrees.

75 Supreme Court 23 March 1973, Arr.Cass. 1973, 736 - 738; Pas. 1973, I, 700.

76 Council of State 9 February 1971, R.J.I. 1973, 165; Supreme Court 9 February 1971, Arr.Cass. 1971, 555; R.W. 1971-72; Pas. 1971, I, 527; R.J.I. 1973. 
the authorisation to practise both professions at the same time, if he does not dispose of the time required to fulfil his functions with due care. ${ }^{77}$

Article $8 \$ 2(2)$ AO concerns EC or EEA nationals who normally practise their profession in their home member state. If they want to perform a temporary service in Belgium and head in this regard for the first time to Belgium, they are obliged to notify the Architects' Order by making a written declaration which contains information on their insurance coverage or comparable individual or collective forms of professional liability protection. The requirement that information on insurance coverage has to be given was added by the Act of 21 November 2008 which implements Article 7(1) of Directive 2005/36/EC. The Architects' Order will register them in the 'Services Register'. The following documents have to be added to the declaration:

$1^{\circ}$ an attestation which indicates that the professional practises legally in his member state of establishment;

$2^{\circ}$ an attestation which indicates that the professional is in the possession of one of the diplomas, certificates or other titles which are enumerated in the annex to the Architects Act;

$3^{\circ}$ in case neither the profession nor the education which gives access to the profession is regulated in the Member State of establishment, an attestation which stipulates that the service provider has practised the profession for at least two years during the ten years which preceded the service provision ${ }^{78}$

$4^{\circ}$ an attestation of professional indemnity insurance, which covers the ten year liability risk. This attestation can be issued by an insurance company of another Member State if it indicates that the insurer respects the legal and administrative conditions concerning the character and extent of the coverage which are in force in Belgium

$5^{\circ}$ an attestation of nationality of the service provider ${ }^{79}$

These requirements can also be found in Title II of Directive 2005/36/EC on the free provision of services. Article 15 of the Act of 21 November 2008 indicates that Title II of the Act of 12 February 2008 instituting a new General Framework for the Recognition of EC professional qualifications is applicable on service providers who come to Belgium to practise the regulated profession of architect in a temporary and incidental manner. Title II of the latter Act implements Title II of Directive 2005/36/EC. ${ }^{80}$ Within the framework of this Act, the Architects' Order is the competent authority. ${ }^{81}$

Supreme Court 23 June 1970, Arr.Cass. 1970, 1000; R.W. 1970-71, 603; Pas. 1970, I, 942

78 Before implementation of Directive 2005/36/EC by the Act of 21 November 2008, it was only foreseen that an attestation which stipulates that the professional has at least two years of professional experience was needed for every professional.

79 This requirement was introduced by the Act of 21 November 2008 implementing Directive 2005/36/EC for the architectural profession.

80 Article5 (1) of the Directive is implemented by Article 7 of the Act; Article 5 (2) and (3) of the Directive is implemented by Article 6 and 7 (2) of the Act; Article 6 of the Directive is implemented by Article 8 of the Act; Article 7 of the Directive is implemented by Article 9 of the Act; Article 8 of the Directive is implemented by Article 10 of the Act; Article 9 of the Directive is implemented by Article 11 of the Act.

81 See also De Graeve 2009, vol. 2, p. 181. 
Professionals falling within the ambit of Article $8 \$ 2(2)$ AO, even if not registered, have to obey the deontological rules which apply in Belgium (Article 8 \$2(5) AO). It follows that the registration, as meant in Article $5 \mathrm{AO}$ jo Article $8 \$ 2(2) \mathrm{AO}$, is not just a formality. The Order has to verify the title of the candidate carefully, and has to make sure that there is no incompatibility or any deontological requirement standing in the way. ${ }^{82}$

\section{b. Non EC-EEA nationals}

As held by Article 8(1) AA, professionals who are not an EU or EEA national can practise the profession in Belgium and can enjoy the benefits of the Architects' Act, as long as their state of origin has created reciprocal benefits. As stated in Part I of this thesis, Directive 2005/36/EC is not applicable to third country nationals. An administrative authorisation is not necessary. However, a mere reciprocity 'by fact' does not suffice. ${ }^{83}$

Furthermore is it possible that foreigners can obtain permission to practise as an architect in Belgium by Royal Decree (when there is no reciprocity) (Article 8(2) AA). An application has to be sent to the Ministry of Public Education and the permission can be limited in time. The preparatory works indicate that this possibility has to be limited to exceptional circumstances, for example when the involvement of a foreign specialist is really necessary. ${ }^{84}$ As long as the exceptional character of the authorization is mentioned, the permission as such can be described in a general way, and does not have to be limited to a particular project or be restricted in time..$^{85}$ A Royal Decree which grants a definite permission for all projects is therefore illegal. ${ }^{86}$

Professionals falling within the scope of Article 8(1) AA or 8(2) AA have to register to practise just like EC/EEA nationals. However, in the case non EC or EEA nationals who only want to practise the profession occasionally in Belgium, and to provide a service, they have to get permission of the Order's Council which is territorially competent (Article $8 \$ 2(1) \mathrm{AO}) .^{87}$ In such case they do not have to register.

Just like professionals falling within the ambit of Article $8 \$ 2(2)$ AO, those to whom Article $8 \$ 2(1)$ AO applies have to obey the deontological rules which apply in Belgium, even if they are not registered (Article $8 \$ 2(5) \mathrm{AO}$ ). The authorisation as described in Article $8 \$ 2(1)$ AO is thus also not just a pure formality. The Order has to verify the title of the candidate carefully and has to make sure that there is no incompatibility or any deontological requirement standing in the way.

82 Rigaux 1975, p. 85

83 In the Netherlands the profession of architect is not regulated as in Belgium. A Belgian professional can practise there without any authorisation. This possibility, based on mere fact, is not sufficient: see Council of State 22 December 1961, R.J.D.A., 1962, p. 184.

84 De Becker 1941, p. 135 ; Delvaux 1968, t. I, nº 243.

85 Council of State 4 August 1970, Arr. et Avis Cons. Etat, 1970, 758; Supreme Court 15 February 1971, R.J.I., 1972, 141.

86 Council of State 10 December 1952, Arr. R. v. St. 1952; R.A.C.E. 1952; Pas. 1954, IV, 41; R.J.I. 1953, 159.

87 The place of performance of the architectural services indicates which council is territorially competent. 
It should be noted that, with regard to the use of the title, Article $1 \$ 4 \mathrm{AA}$ indicates that the Belgian competent authorities have to examine the qualifications which fall under the ambit of Directive 2005/36/EC but which have been obtained outside the European Union, if they were recognized by another Member State. With regard to the practise of the profession by non EC-EEA nationals which is of relevance within this paragraph, Article 8(1) AA indicates that reciprocal benefits should be granted, or that a Royal Decree should allow this practice (Article 8(2) AA). These requirements render the free movement of third-country nationals who are in possession of the necessary qualifications useless if there is no reciprocity. This is not in line with the provisions of Directive 2004/38/EC or with the principles laid down in the Directives on legal migration as discussed in paragraphs 3.2.2 and 3.3.2 of this thesis and do not require any reciprocity. Indeed, third-country nationals to whom one (or more) of these Directives is applicable, should be treated equally with EU nationals. It follows that, if an EU national in the possession of a third-country diploma is allowed to practise the profession of architect due to the application of Article 3(3) jo 2(2) of Directive 2005/36/EC, a third-country national who falls within the scope of Directive 2004/38/EC or one of the other Directives dealing with the integration of third-country nationals in the EU (or one of the Association Agreements) should be treated equally if these Directives provide for equal treatment with regard to access to the profession. This is also confirmed by the Court of Justice of the European Union in Gül.

2. Natural persons practising the profession within the framework of a company or association As held above, when the Architects Act was created, only natural persons could practise the profession. ${ }^{88}$ This did not change after the new Deontological Code of $1985^{89}$ permitted the practice of the profession within the framework of a professional civil ${ }^{90}$ company or association. ${ }^{91}$ Often several architects set up a company of means, which meant that

88 This followed from the then present text of Articles 1 (1), 2, 7, 8 and 12 AA and Articles 4, 5 and 8 AOA. See also Ghent 18 June 2004, T.B.O. 2004, 238.

89 Article 5(3) Deontological Code. This Royal Decree of 18 April 1985 by which the Deontological Code created by the National Council of the Archtitects' Order was given legal force, annulled the former Royal Decree of 5 July 1967, Official Gazette 19 August 1967, which ratified the preceding and first Deontological Code. The former Code was replaced due to the judgement of the Supreme Court of 23 June 1970. The Court held that the Royal Decree of 5 July 1967 was illegal since it was approved without a second investigation by the Council of Ministers. Furthermore the Council of State of 18 January 1974 annulled Articles 13.2 and 14.1 of the 1967 Deontological Code since these Articles prohibited the registration of engineers with an assimilated diploma who were in the possession of a labour contract and worked with a person practising a profession which was considered to be incompatible with the profession of architect. Therefore, the Order asked for the approval of a new Code which would stipulate that architects could practise their profession in the form of a professional civil company. Furthermore, the new Code states that - with the exception of incompatibilities - paid participation of architects in industrialized constructions and their cooperation with building contractors should be authorized by the Order. The relationship of architect and technical advisor is also clarified by the Code, and the calculation of the honorarium of the architect is based on the work done. To safeguard the dignity of the members of the Order, the insurance for professional liability, including the ten year liability, became compulsory. See Council of State 18 January 1974, T. Aann. 1974, 30, annotated by Flamme; T.B.P. 1975, 102; Pas. 1976, IV, 19.

90 Commercial companies are not allowed.

91 The National Council of the Order informally already allowed architects to be part of a professional association or company with legal personality since 2 February 1979. They could also unite with persons prac- 
they shared the means necessary for the practice of the profession. The revenues of the individual architects were not brought into the company. This form of cooperation, which is still used today, is convenient for the purchase of professional rooms and office equipment and for the joint use of personnel. In these cases, the company or the association is not registered as an architect on the list/tableau of the Order. Instead, it is the natural persons forming part of the association. ${ }^{92}$ This means that even if the legal person concluded the architectural contract, the architect-natural person who executed the contract for the account of the legal person, can also be held personally liable for the defaults in the execution. His personal wealth is therefore also at stake. ${ }^{93}$ Consequently, in the event that a building is affected by a certain fault, the architect-natural person will be held responsible for the professional failure.

On 28 November 1997, the National Council of the Order approved a Recommendation ${ }^{94}$ concerning this possibility.

Article 4 of the Recommendation stipulates that architects can opt for a company or association with or without legal personality. It is important that the objective of the company should be the practice of the profession of architect, and all the related and compatible disciplines (Article 5.2). Multi-disciplinary companies/ unions are therefore allowed. Furthermore, only civil companies are allowed which means that commercial companies are excluded. ${ }^{95}$ The Order considers the architectural profession, not as a commercial profession, but as a moral and honourable one which should be practised in accordance with the public interest. As held by Article 5.4.2., the partners/associates have to be actively involved and have to contribute to the company's objective. Even legal persons can be members or shareholders as long as they do not possess the majority of the shares. Furthermore, all shares have to be 'nominal' (Article 5.5.). While most members have to be physical persons, most board members have to be architects (Article 5.6.1). Moreover, decisions relating to the practice of the profession can only be taken by architects (Article 5.6.2.2). These measures aim to avoid situations in which non-architects will control the architectural profession.

It is forbidden for the statutes of the company or union to violate the Deontological Code. The architect can only work within a company or union after the competent Provincial Council has stated that the statutes are in conformity with the Deontological Code (Article 7.1).

tising a related and compatible profession. De Caluwé 1989, pp. 1-28. The contract or statutes of the company cannot violate the deontological rules. This will be looked after by the competent Provincial Council of the Order in advance.

92 The statutes of the company or association are not allowed to violate the Deontological Code. Furthermore, the architect can only work in a company or association after the competent Provincial Council has stated that the statutes are in conformity with the Deontological Code.

93 Brussels 17 March 2004, R.R.D. 2004, ed. 113, 333.

94 The Order's Recommendations are pronounced on the basis of Article 3 of the Deontological Code which foresees that the Deontological rules can be worked out by binding norms, approved by Royal Decree at the suggestion of the National Order, or by recommendations of the National Order.

95 The civil company can however have a form as provided for in the Act on Commercial Companies. 
As held by Article 6.1.5, the statutes (in the case of a company, with or without legal personality) or the association contract has to state that every architect-partner or architect-associate has to insure his civil and professional liability. The architects' insurance obligation will be further discussed hereunder. However, the Article does not impose an insurance obligation on the company/association itself.

Since the Recommendation is not ratified by Royal Decree, it has no coercive force. Therefore it contains merely guidelines for architects wishing to work within the framework of a company. Due to the Act of 15 February $2006^{96}$ on the practice of the profession of architect by a legal person, this recommendation will probably be revoked or drastically changed. ${ }^{97}$ At the moment of writing, this has not happened. As will be explained hereunder, the 2006 Act foresees in the possibility of legal persons practising as an architect. Nevertheless, architects will still have the possibility to practise their profession within the framework of a legal person as meant in the Deontological Code of 1983 and the 1997 Recommendation. The 1997 Recommendation will continue to be applicable for every company of association of architects which does not meet the requirements of the Act.

\section{Legal persons}

a. Situation before the Laruelle Act

The 2006 Act concerning the practice of the profession of architect within the framework of a legal person ${ }^{98}$ (hereafter called: Laruelle Act (LA)) extends the categories of persons who are allowed to practise the profession of architect. For the very first time, a free profession can be practised by a legal person in Belgium.

Previously, only natural persons could practise as an architect since the practice of the profession was linked to the possession of the required diploma ${ }^{99}$ (old Article $1 \$ 1 \mathrm{AA}$ ). Belgium was the only state of the EU (when it was comprised of 15 member states ${ }^{100}$ ) with the exception of Italy ${ }^{101}$, which did not allow a legal person to practise the profession of architect. When creating the Act in 1939, the legislator held that certain professional competences could only be given to natural persons.

As noted above, this situation did not change after the Deontological Code of 1983 permitted the profession to be practised within the framework of a professional civil company or union, since it was not the company or the union but still the natural person who was registered as an architect on the list/tableau of the Order. Consequently, the

96 Wet betreffende de uitoefening van het beroep van architect in het kader van een rechtspersoon, Offical Gazette 25 April 2006. This Act is also called 'Wat Laruelle'. It was named after the Minister of Independent Professions.

97 Burssens 2007, p. 21.

98 Act of 15 February 2006 on the Practice of the Architectural Profession within the Framework of a Legal Person, Official Gazette 25 April 2006.

99 Ghent 18 June 2004, T.B.O. 2004, 238; Rigaux 1993, p. 185.

100 Additional research should be done on the situation in the new Member States.

101 In Italy, however, the ten year responsibility only rests on the entrepreneurs and not on the architects. 
natural person was held liable, and all his wealth was at stake when facing professional faults. Nevertheless, since building projects mostly have a substantial dimension, it is an illusion to think that the architect's personal wealth could cover the damage. On the other hand, all the other building partners, such as the promoters, the entrepreneurs and the engineers have the possibility to 'hide' behind a legal person, and can safeguard their personal wealth by the formation of a professional company with legal personality. In this way only the capital of the company would be at risk whenever a professional fault occurred, while the professional's personal wealth was exempt from any claim. The Constitutional Court held that this distinction was compatible with Articles 10 (equality) and 11 (prohibition of discrimination) of the Constitution. It stated that the difference in treatment with regard to the professional liability could objectively and reasonably be justified due to the legal monopoly which was given to the architect by the Architects Act and his compulsory intervention. ${ }^{102}$ Nevertheless, a study of the Research Centre for Insurances CEA Belgium demonstrated that this situation was disadvantageous for Belgian architects when compared to architects of the other (old) 14 EU Member States: ${ }^{103}$ it often happened that in case of an in solidum conviction, the architect was the only party the creditor turned to get damage compensation, since he was the only building partner that was deontologically obliged to obtain professional liability insurance.

The Laruelle Act brought about two important changes in the Belgian regulation of architects: the practise of the profession of architect by legal persons, and a legal obligation for architects to buy professional liability insurance. The first novelty will now be discussed.

b. The Laruelle Act

Since the entry into force of the 2006 Act concerning the Practice of the Profession of Architect within the Framework of a Legal Person (the Laruelle Act), it is possible for a legal person with legal personality ${ }^{104}$ which fulfils the requirements as mentioned in Article $3 \S 2$ LA (i.e. Article $2 \$ 2$ AA) to practise the profession of architect. It follows that associations which do not have legal personality cannot practise the profession.

As held above, due to the Laruelle Act, Article 1 of the Architects' Act has been amended. While this Article used to state that no one was allowed to use the title or to practise the profession without being in the possession of the required diploma, the diploma requirement is now limited to the use of the title. The reason is that legal persons are not able to obtain a diploma while the new Act makes it possible for them to practise the profession.

102 Constitutional Court 10 October 2001, Official Gazette December 2001, 41279; J.L.M.B. 2001, 1816, annotated by B. Louveaux; Uytterhoeven 2004, pp. 193-197.

${ }^{103}$ Bill on the Practice of the Profession within the Framework of a Legal Person, explanatory memorandum, Gedr. St. Chamber 2004-2005, nr. 1920/2, p. 4.

104 A company only gets legal personality after its deed of erection has been deposed at the clerk's office of the court of commerce where the company has its legal seat ( see Article $2 \$ 4$ (1 jo) AA and Article 68 Company Code). 
The title of the Laruelle Act is somewhat misleading. This is due to the fact that the possibility for legal persons to practise the profession themselves is much more farreaching than the practice of the profession 'within the framework of a legal person ${ }^{105}$ ' as indicated in the title. This latter possibility has already been discussed under 2 .

The concept of legal personality means that the company has to be seen as an independent legal entity, not depending on its partners with its own wealth, distinct from that of the individual partners. This means that the creditors of the company can only claim compensation from the company's wealth and that the architect-natural person's wealth cannot be claimed against in terms of damage compensation.

Since the entry into force of the Laruelle Act, Article 1 of the Architects Act is only concerned with the architects' title and no longer with the practice of the profession, since it states that no one is allowed to use the title of architect without being in possession of the necessary diploma. It follows that the possession of a diploma is not always a necessary condition for practising the profession.

Since the architectural contract is concluded with the architect-legal person, the natural persons who are an organ or mandatory of the legal person can, in principle ${ }^{106}$, not be held liable by the legal person's co-contractor, since there is no contractual or legal relationship between the building master and the architect-natural person. Furthermore, the building master can, in principle ${ }^{107}$, neither institute an extra-contractual claim against the architect-natural person, unless his fault is a shortcoming to the general standard of care (and not the failure of a contractual obligation) and the damage caused due to the extra-contractual fault is different from the damage which results from the failure of the contractual obligation. ${ }^{108}$ It follows that, due to this new possibility, the architects-natural persons can protect their personal wealth from claims based on their professional liability.

105 As held above, this latter possibility was already created by the 1985 Deontological Code.

106 In case of certain 'imperfect' legal persons, the partners are personally and even jointly and severally liable for the company's obligations (see Article 201 and further of the Company Act). Since the entry into force of the Laruelle Act, the partners can only be held personally liable if the company itself is convicted. The 'imperfect' legal persons under Belgian law will not be further discussed within this thesis.

107 It is therefore not wise to choose a company with unlimited and joint and several liability. The extra-contractual liability of the legal person for faults of his organs or mandatories, excludes the personal liability of the natural person (Article 1384 CC). See also Supreme Court, 11 April 1989, Arr.Cass. 1988-89, 318. However if an architect-natural person commits a tort in his capacity of board member, he can be held personally liable, even if the legal person can be held liable as well, based on Article 1384 CC. The legal person can be held criminally liable if there is a connection between the crime and the legal person's aim, its interests or if the crime is committed for its account (Article 5 (1) Criminal Code). See also Supreme Court 9 Novmeber 2004, NJW 2005, 796, annotated by E. Brems. If the legal person is held liable due to a fault committed by a natural person solely, only the one who committed the most serious fault will be convicted. (Article 5 (2) Criminal Code). In such a situation, the judge will take into account the degree of autonomy of the natural person involved: See Constitutional Court 10 July 2002, R. W. 2002-03, 857). Only if the natural person committed the crime intentionally, can he be convicted together with the legal person (Article 5 (2) Criminal Code in fine). Examples are working without insurance, not respecting town planning regulations, etc.

108 Supreme Court, 7 November 1997, Arr.Cass 1997, 457. 
Before the Laruelle Act entered into force, the Order could, on the basis of its deontological competence, create all the rules on how to practise the profession when a legal person was involved. The Laruelle Act now determines the main rules itself. Nevertheless, the National Council of the Order was given the task of executing the new Act, and was asked to give concrete indications on how legal persons could practise the profession. Therefore, on 27 April 2007, the National Council created a Recommendation concerning the practise of the profession within the framework of a company or association Recommendation on the practise of the architectural profession by legal persons. For the same reasons as those stated above with regard to the title of the Act, the title of this Recommendation is also confusing. This Recommendation is applicable to all architects-legal persons and their architects-partners who practise the profession. The 1997 Recommendation will only be applicable to architectural associations (without legal personality) and architectural companies which do not fulfil the requirements of the Architects' Act. ${ }^{109}$ The 2007 Recommendation is based on Article 3(2) of the Deontological Code and contains some closer rules with regard to the legal person's practice. It has not been ratified by a Royal Decree. Its most important provisions will be referred to in the following section.

A legal person can only practise the profession if the following conditions are fulfilled (Article $3 \$ 2 \mathrm{LA}$ - Article $2 \$ 2 \mathrm{AA}$ ):

" ${ }^{\circ}$ All the business managers, directors, members of the board -more generally all independent mandatories, practising in name and for the account of the legal person-are natural persons authorized to practise as architect according to Article 2(1) and registered on one of the tableaux of the Order of Architects."

With this stipulation, the legislator aimed to make sure that everyone with a right of say in the company has the required diploma and is registered. In this way the company will not be controlled by non-architects. ${ }^{110}$ This Article is repeated in Article 10.1 of the 2007 Recommendation on the Practise of the Profession of Architect within the Framework of a Legal Person, which was created to make application of the Laruelle Act and its encompassing Royal Decree easier. The management functions can therefore not be fulfilled by legal persons. Also foreign architects who practise the profession in Belgium, and move their seat temporarily or permanently to Belgium, and who are registered in accordance with Article $8 \$ 1 \mathrm{AO}$ can thus have such a position. The question has been asked whether this provision violates Article $49 \mathrm{EC}$ on the free provision of services, since EU and EEA professionals who do not move their seat to Belgium and are thus not registered on a tableau of the Order, but only on the register of service providers (Article $8 \$ 2(2) \mathrm{AO}$ ), cannot have a management function within a (temporary) Belgian company which they have erected with other Belgian architects. ${ }^{111}$ In order to be in line with the EC-Treaty and the case law of the Court of Justice of the European Union, this Arti-

109 Uytterhoeven 2008, p. 16.

110 Lamon 2006, pp. 1-3.

111 Uytterhoeven 2008, p. 22. 
Public Law in Belgium

cle should therefore be amended. Of course, for non EU/EEA nationals who fall under Article $8 \$ 2(1) \mathrm{AO}$, this causes a problem as well.

" 2 ' The objective and activity of the legal person have to be limited to the provision of services belonging to the practise of the profession of architect and cannot be irreconcilable with this."

Since the objective and activity of the legal person has to be limited to the provision of architectural services ${ }^{112}$, the architectural company will have a civil character since the services which are offered also have a civil nature. ${ }^{113}$ The description of the company's aim is more limited than the description of Article 5(2) of the 1997 Recommendation. Previously, the aims of the company were, next to the practise of the architectural profession, the practise of all disciplines which were related and not incompatible with the profession. When reading the Act strictly, one has to conclude that, at present, multiprofessional companies cannot practise the profession of architect. Even though an architectural company has partners who are compatible professionals, these partners cannot practise their profession in the name and for the account of the architectural company. The reason for this is that the company can only practise the profession of architect and no related profession. Nevertheless, as held by Burssens, one can deduce from the Preparatory Works that the legislator intended that multi-professional companies could also practise the profession. ${ }^{114}$ Therefore he concludes that the Provincial Councils have to decide on a case by case basis whether the activities of the professional legal person can be qualified as architectural ones. ${ }^{115}$

$3^{\circ}$ "When the legal person is formed as a public limited company or a limited partnership on shares, the shares have to be nominal."

This requirement aims to make the division of shares transparent, and intends to prevent non-architects from controlling a legal person.

$4^{\circ}$ "At least $60 \%$ "116 of the shares as well as $60 \%$ of the voting rights have to be in the possession, directly or indirectly, of natural persons authorized to practise the profession of ar-

112 Architectural services are not limited to those services which fall under the architects' monopoly. The term refers to all act which are 'usually' performed by architects. See Supreme Court 25 June 1973, J.T. 1974, 247. The fact that non-architects can be a partner, indicates that a broad interpretation is given to the concept of 'architectural services'

113 Article 3 (2) Company Act.

114 Burssens 2007, pp. 13-15. The fact that only 60\% of the shares have to be owned by architects is explained by the possibility to take into account the present reality, for example the existence of multi-professional companies. Furthermore, if the aim and activity of the company has to be limited to architectural activities, the inclusion of the phrase that the objective of the company cannot be incompatible with the architectural profession, would have been useless.

115 Interior advice or stability studies are carried out by interior architects or engineers, but can also be done by architects. Multi-professional companies of architects and engineers or interior architects should thus be possible according to Burssens.

116 Originally the Act demanded that $67 \%$ (the bill foresaw $80 \%$ ) of the shares and the voting rights had to be in the possession, directly or indirectly, of natural persons authorized to practise the profession of architect and registered on one of the Order's tables. Even before the Act entered into force, the percentage had al- 
chitect according to Article $2 \$ 1$ and registered on one of the tableaux of the Order of Architects; all the other shares can only be in the possession of natural persons or legal persons who practise a reconcilable professions and have reported themselves to the Council of the Order of Architects."

The National Council's Recommendation of 27 April 2007 contains some more detailed provisions on the division of the shares. As held by Article 8. 2 of this Recommendation, the phrase 'directly or indirectly' refers to the fact that the said $60 \%$ of the shares can also be owned by another legal person-architect. As opposed to the stipulation in the 1997 Recommendation (Article 5.4.2), the partners do not have to cooperate through the practice of their profession in order to accomplish the aims of the company. They only cannot practise an incompatible profession ${ }^{117}$. However, as held by Article 8.1.1 in fine of the 2007 Recommendation, architects-public officials cannot own shares or vote except if their public task is educating. This provision directly follows from Article 5 AA which forbids functionaries and officials of the State, the provinces, the municipalities and public institutions, to operate as architect outside their function. Next to the profession of entrepreneur (Article $6 \mathrm{AA}$ ), this is therefore another example of professions that are incompatible with the profession $\mathrm{f}$ architect. The reason for this is that there is a risk that architect-officials can obtain the required building permission more easily or obtain an unfair advantage. Due to this incompatibility, the public interest ${ }^{118}$ as well as the particular interests of the profession are protected. ${ }^{119}$ An exception is made for architects who work in the above-mentioned capacity to teach architecture (Article 5(2) AA) ${ }^{120}$ or for architect-officials who design plans and supervise the execution of the building works concerning their own house. ${ }^{121}$

$5^{\circ}$ "The legal person is not allowed to own shares in other companies/legal persons than those of an exclusive professional character. The social object and the activities of those companies cannot be irreconcilable with the function of architect."

It is therefore possible for an architectural company to own shares in another architectural company, a multi-professional company or an engineering company.

ready been amended by Articles 169 and 170 of the Act of 20 July 2006 containing diverse provisions (Official Gazette 28 July 2006).

117 As held by Article 1.6 of the 2007 Recommendation, an incompatible profession refers to every professional activity which is neither legally nor deontologically linked to that of an architect.

118 Supreme Court 25 April 1960, R.J.I., p. 311; Pas.1960, I, 988.

119 The prohibition concerns also the functionaries and officials working part-time and not performing any 'architectural' acts during their official working time: See Supreme Court 10 April 2006, T.B.O. 2007, ed. 2, 113, annotated by W. Mertens, R.A.B.G., 2006, ed. 11, 795, annotated by B. Maes.

120 Supreme Court, 28 February 1984, AR 4256, nr. 76, unpublished.

121 Article 5 AA has to be interpreted independently from Article 4: See Council of State 23 June 1970, Arr. Et Avis Cons. Etat, 1970, 645. Article 4 AA holds that the cooperation of an architect is only required for the drawing up of the plans, and the supervision of the execution of the building project. Article 5 AA however underlines the incompatibility for every activity which is related to the profession of architect with a public function. In most cases, the violation consists of a functionary asking an independent architect to sign his plans, or to cover for him in another way when necessary. By his signature his colleague violates the provisions as well. Both are guilty of forgery: Supreme Court 25 April 1960, Pas. I, 988; Ghent 5 February 1966, R.W., 965-66, col. 1952. Furthermore, the functionary is liable to be sanctioned for violation of Article 53 AO. 
$6^{\circ}$ "The legal person is registered on one of the tableaux of the Order or Architects." The legal person has to be Member of the Order (Article 9(1) in fine AO).

As already held under $1^{\circ}$, only legal persons with a permanent or temporary seat in Belgium can be registered (Article $8 \mathrm{AO}$ ). Architects who are empowered by Article 8 $\$ 2(1)$ (non EC/EEA temporary service providers which generally practise abroad) and 8 $\$ 2(2) \mathrm{AO}$ (EC/EEA nationals who generally practise in their home state and temporarily provide a service in Belgium) to practise the profession, are not registered on one of the Order's tableaux. This can constitute a problem since Article $2 \$ 26^{\circ}$ AA states that only legal persons who are members of the Order can practise the profession. ${ }^{122}$ However, Article $38,7^{\circ} \mathrm{AO}$ states that it is the task of the National Council of the Order to register the nationals and legal persons of EC/EEA Member States in the Register of Service Provisions. The Explanatory Memorandum indicates that it was the meaning of the legislator to register EC/EEA legal persons in the Register of Service Provisions which indicates implicitly that these legal persons can then practise the profession of architect in Belgium. If this would be otherwise, Articles 38, $7^{\circ}$ and $8 \$ 2(2) \mathrm{AO}$ would be meaningless, and even in violation with Article 49 EC. Furthermore these stipulations would then violate the equality principle as well, since natural persons can practise the profession without being an Order's member, as long as they are subscribed in the Register of Service Provisions. Consequently, Article $8 \$ 2(2)$ AO has to be amended so that legal persons are mentioned as well. ${ }^{123}$ Of course, for non EC/EEA falling under the ambit of Article $8 \$ 2(1) \mathrm{AO}$, this causes a problem as well.

It is important to note that the legal person has to be registered on one of the tableaux of the Architects' Order (Article $3 \$ 26^{\circ}$ LA - i.e. Article $2 \$ 2,6^{\circ}$ AA) and is thus be a member of the Order. This means that that legal person has to respect the Order's deontology, and that disciplinary sanctions can be imposed upon that legal person (Article 21 AO). However, the legal person cannot be elected as member of a Council and cannot vote for other candidates. Furthermore, the independent architects who intervene in their capacity of business manager, director or member of the board in the name of, and for the account of, the legal person, have also to be personally registered.

As held by Article 6.1 of the 2007 Recommendation, the legal person's name has to contain the words 'architect' and 'civil company' and has to refer to the 'form/type' the civil company has.

If the legal person stops fulfilling the requirements of practising the profession of architect due to the decease of a natural person as meant in $1^{\circ}$ or $4^{\circ}$, it has a period of 6 months to live up to the abovementioned stipulations once more. During that period the legal person can still practise the profession of architect (Article $2 \$ 2 \mathrm{AA}$ in fine). This transitional period is, however, not applicable in the case of suspension, cancellation or discharge of a business manager, director or board member. In such a case, an

${ }_{122}$ Kohl 2006, p. 35.

${ }^{123}$ Uytterhoeven 2008, p. 32. 
immediate replacement has to be found so that the interests of its clients are not endangered (Article 11.1 Recommendation 27 April 2007).

According to Article $3 \$ 3$ LA (i.e. Article $2 \$ 3$ AA), a trainee can only form a legal person or be a partner, business manager, director or board member, when he practises the profession together with his patron or with a registered architect. This is exactly the opposite of what the 1997 Recommendation on the practise of the profession within the framework of a legal person provided for. In 1997 the Order feared the imbalance between the power of the patron and that of his trainee, so that it was forbidden for him to be part of a company or association to which his patron also belonged (Article 5.4.2). With this provision, the legislator wanted to make sure that a high level of quality was provided for clients.

A legal person can only practise the profession of architect if the requirements discussed in this paragraph are fulfilled. Furthermore the statutes of the legal person have to be approved by the Architects' Order (Article 12.2. Recommendation of 27 April 2007) and deposited at the Court of Commerce of the place of subscription of the legal person. ${ }^{124}$ They have to indicate that the legal person and its partners will not violate the Deontological rules. In this way all partners, even those who are not architects, have to obey the deontological rules. Furthermore, the legal person has to be registered with the Order and needs to be covered by professional liability insurance. This latter obligation will now be discussed.

\section{Professional liability insurance}

As held above, architects are not allowed to register unless they are covered by professional liability insurance. The insurance obligation, which is laid down in the Architects Act, is applicable to natural as well as to legal persons practising the profession. However, this obligation did not always exist as such. I will now discuss the content and development of the insurance obligation of architects.

a. Deontological insurance obligation

As held by Article 15 of the 1983 Deontological Code:

"The Architect, whether he works alone or in a company or union, is obliged to insure his civil professional liability, including his ten year responsibility.

This insurance can be a part of an obliged global insurance of all building partners.

It will have effect during ten years after the reception of the building works as long as those works have taken an end at the moment of the insured's decease."

This Deontological obligation was created to protect the architect against insolvency, and was inspired by the values related to the honour and dignity of the profession. Since the Deontological Code did not provide for details on the insurance obligations and the extent of the coverage, the National Council of the Order made a Recommendation with regard to insurance obligations on 26 March. The Recommendation's aim was to make

124 This is required by Article 2 (4) of the Company Act. 
it easier for architects to obey their deontological obligations by laying down minimum standards which have to be fulfilled by every insurance contract (Article 1). Hereunder the most important provisions of the 1993 Recommendation will be discussed.

Article 3 of the Recommendation states:

"The insurance has to cover all the architect's liabilities, notably

3.1. his contractual liability before the reception of the works, under reservation of what will be précised hereunder

3.2. his ten year liability, which starts to run from the moment of reception

The policy can indicate that the provisional reception is the starting point of the ten year period.

3.3. his 'quasi-delictual' responsibility towards third parties and towards the building master which is not limited in time"

The provisions of Articles 3.1 and 3.2 concern the architects' contractual liability, while Article 3.3 deals with the non-contractual professional liability. These concepts will be further explained hereunder.

The only type of insurance contract which lives up to the requirements of the Deontological Code, is the 'professional liability insurance contract'. Only this type of contract covers all architectural activities (Article 2). The architects' professional liability can be covered in the form of a 'career' policy or a 'single building/single project' policy. As the name implies, the latter policy only covers the activities on one building project. The career policy, on the other hand, is the most beneficial insurance contract for the architect as well as for the insurer. All damage is covered as long as the insurance policy is active and not suspended. This type of insurance contract is tacitly renewed every year, while the premium is adapted yearly in accordance with damage cases and administrative costs.

Article 5 of the Recommendation holds:

"5.1. With regard to the application in time of the insurance contract, it is necessary that all the damage cases which occur during the contract are covered.

The damage cases are covered even if the causal facts occurred before the conclusion of the contract, with the exception of the facts known by the architect before the conclusion of the contract. ('anterior risk' principle)

Damage cases which occur during the contract but for which a claim is only instituted after the contract has expired, are also included.

5.2. Damage cases which occur after the contract has expired, but which find their origin in a causal fact which occurred during the contract, also have to be insured ('posterior risk' principle).”

Damage caused by the architect's deceit or severe fault, the non-execution of the contract, the infringement of the stipulations on time, type and technical parts of the construction, as well as by some other damage causing facts, is not covered (Article 8 Recommendation). 
Article 9 states that the architect has the possibility to determine the upper limit of his insurance in accordance with the financial extent of his designs, as a function of the risks he incurs, and the amount of exemption he deems bearable. It further states that it is desirable that the upper limit of the insurance is fixed at least 10 million Belgian Francs (247,893.52 Euros) per damage case, and 20 million Belgian Francs (495,787.05 Euros) for material damages and 50 million Belgian Francs (1,239,467.62 Euros) per year per damage case for physical damage. Experience has shown however, that a cover of +/- 250,000 to 350,000 Euros is often not enough due to the high extent and costs of building works. ${ }^{125}$ In such cases it would be wise for the architect to buy a higher coverage in order to protect his personal wealth.

Due to the fact that the architect's personal wealth would generally not be able to cover substantial damage claims, the building master's guarantee was situated in the insurance contract. ${ }^{126}$

It followed that, in order to protect consumers, judges mostly held that the deontological insurance obligation had the value of a legal obligation. ${ }^{127}$ Furthermore, the Order made observance mandatory for its members.

In this regard, the provisions of the State Insurance Act (SIA $)^{128}$ should be referred to since it is applicable to every insurance contract which covers the insured for compensation claims due to damage causing events as described in the contract, and which protects the insured's wealth within the limits of the coverage against all debts which arise from an established liability (Article 77).

Article 78 SIA, which contains another sort of posterior risk principle, stipulates:

" $\$ 1$. The insurance covers damages which occurred during the contract and is extended to claims which are instituted after its expiration.

$\$ 2 \ldots$. Parties can agree that the insurance only covers claims which are instituted in written during the duration of the contract for damage which occurred during that same period.

In this case claims to obtain compensation which are instituted in written against the insured of the insurer within 36 months after the end of the contract, will also be taken into account if they are related to

- damage which occurred during the contract and which is not covered by another insurer after the expiration of the contract (the damage is thus caused during the contract, but the client only complains after the contract has ended)

125 Daelman 2007, p. 38

126 If the solvency of the architect was the decisive factor with regard to the signing of an architectural contract, every building master would have to worry in advance about the personal assets of the architect, rather than about his professional qualities. Is also seems difficult to combine the protection of the interests of the client with the protection of .the architect's own wealth. See Louveaux 2001, p. 26.

127 Daelman 2007, p. 33.

128 Wet op de Landsverzekering 25 June 1992, Official Gazette 20 August 1992. 
Public Law in Belgium

- acts or facts which occur during the contract and are reported to the insurer which can give rise to damage (the causal fact occurred during the contract and the damage occurred within 36 months after the contract (if there is no damage one cannot institute a claim)"

It follows that, if the insurance contract only covers damage which occurred during the contract, and for which a claim is instituted during the contract, the architect will be covered for 36 months ( 3 years) after the end of the contract if the requirements of Article $78 \$ 2$ SIA are fulfilled. Unless the architect pays a 'posterior risk premium', he will therefore only be covered for the three years after the end of the contract, which normally falls together with three years after the end of his activities. Consequently, all the building works which are less than 7 years of age face a non-insured risk period if the architect does not take additional measures. ${ }^{129}$ As an architect approaches the end of his career, it is therefore best to cover this risk period by paying an extra 'posterior risk' premium. Since the Laruelle Act and its encompassing Royal Decree contains detailed provisions on specific architectural insurance, the State Insurance Act will not be further discussed.

Article 15 of the Recommendation contains some practical provisions and stipulates how the Order can control its members' observance of the (deontological) insurance obligation. The architect has to inform his Order immediately in the event of suspension or withdrawal of his insurance contract. However, as held by Daelman, the deontological obligations are not controlled very punctually by the Architects' Order. ${ }^{130}$

Due to the fact that the situation of Belgian architects was not very beneficial -as noted above, their personal wealth was always at stake while they were 'deontologically' obliged to buy an insurance policy- the 2006 Laruelle Act aimed to create a more balanced liability regime which also offered more guarantees for the building masters. ${ }^{131}$ This Act will now be discussed in detail.

b. Insurance obligation laid down by the Laruelle Act

Due to the creation of the possibility that legal persons can perform architectural services, for the very first time architects are able to pass their professional responsibility to a legal person. This means that the architects-natural persons' personal wealth is no longer completely and automatically at stake whenever they commit a professional error. ${ }^{132}$ For architects, this might be a relief. Article $2 \$ 4$ AA - Article $3 \$ 4$ LA should protect their clients. It stipulates:

129 Daelman 2007, p. 36

130 Daelman 2007, p. 38

131 Bill on the Practice of the Profession of Architect within the Framework of a Legal Person, Explanatory Memorandum, Gedr. St. Chamber 2004-2005, nr. 1920/1, pp. 4-5.

132 It is still possible however that the architect-natural person can be held liable (together with the legal person on the basis of Article 1382 CC) in terms of his directors' liability. The architect-natural person can also incur criminal liability (Article 5 Penal Code). 
"No one is allowed to practise the profession of architect without being covered by an insurance as provided by Article 9 AA."

Furthermore, Article 9(1) AA (Article 4 LA) states:

"Every natural and legal person authorised to practise the profession of architect and whose liability, including the ten year liability, can be linked to his professional acts or the acts of his employees, has to be covered by an insurance. This insurance can be included in a global insurance of all building partners."

As opposed to the 1985 deontological insurance obligation which was created to protect the architect against insolvency, and which was inspired by the values related to the honour and dignity of the profession, the legal insurance obligation was created in the first place to protect clients/consumers. By demanding that the legal person has to be insured, the legislator made sure that the new possibility (the practice of the profession by a legal person) does not affect consumers' protection negatively. Consequentially, more and more recourse is taken to insurance companies. Since judges take this development into consideration, case law shows that they tend to be more lenient towards claims instituted by consumers, causing a broader interpretation of the concepts of 'fault', 'causality' and 'damage'. In this way, an increased liability system is created which is not beneficial for the architect. ${ }^{133}$ However, as held by the recent Recommendation on the Obliged Insurance of 24 April 2009, the legal insurance obligation does not nullify the deontological insurance obligation. The Recommendation gives some clearer rules on the insurance obligations in accordance with Article $3,2^{\circ}$ of the Deontological Code.

The architect-natural person and the architect-legal person both have to be registered on a list/tableau of the Order. However, it is not necessary for them to be separately insured, since the legal person's insurance will cover all architects and functionaries which work in its name and for its account (Article 4 LA). A separate insurance is however required if they continue to undertake certain projects personally.

The business managers, directors, members of the board - more generally all independent mandatories who act in the name of, and for the account of the legal person, are jointly and severally liable for the payment of the insurance premiums (Article 4(3) LA - Article 9(3) AA). Since they also have to be registered, they have to abide by the professional ethics. Furthermore, if the legal person is not covered by insurance, the mandatories are jointly and severally liable towards third parties for the damage arising out of the ten year responsibility (Article 9(4) AA - Article 4(4) LA). The joint and several liability are thus not applicable to defects which fall under the regular liability regimes for small hidden defects after the acceptance of the work, or to defects which fall under the regular contractual liability regime before acceptance or the extra-contractual liabil-

133 Fontaine 1996, p. 292. This tendency already started since the Deontological insurance obligation was introduced. Since the entry into force of the Laruelle Act, insurance premiums have increased. See htpp://www.protect.be/_CLIENTS/Protect/Documenten/2007-2-27-(121511)_De\%20Tijd.pdf, last consulted 27 December 2009. 
ity regime. ${ }^{134}$ Furthermore, as held by Article 6 LA (Article 11(4) AA), those who practise the profession without being insured are liable for a fine of 200.00 to $1,000.00 \mathrm{Eu}$ $\operatorname{ros}^{135}$. Natural persons can also be liable for a prison sentence. Of course, disciplinary sanctions can also be imposed.

It is important to note that the insurance obligation does not only cover acts which belong to the architects' monopoly, but also ones which are generally made by architects without being reserved to them, such as town planning activities, estimates, expertise, etc. As held by Ramboer, other persons who fulfil such activities are not obliged to buy insurance. ${ }^{136}$

A contract with an architect who is not lawfully insured is void, since this contract is concluded with a person who is not allowed to practise the profession.

As held by Article 4 LA, the architects' insurance can be part of the global insurance of all the building partners. It is thus possible that other partners are also insured for their professional liability. Nevertheless, with the exception of the safety coordinator, the architect is the only building partner who is legally obliged to buy professional liability insurance. ${ }^{137}$ On 12 July $2007^{138}$ the Belgian Constitutional Court held that, due to this fact, the chance that damage compensation will de facto be claimed from the architect in the event of a conviction in solidum is much higher than that of the other building partners. The Court held that there is no objective and reasonable justification for this difference in treatment. However, the Court held that the discrimination is not a consequence of the insurance obligation of architects as foreseen by the law, but is due to the fact that there is no comparable insurance obligation for the other building partners even the building master is not obliged to buy insurance. According to the Constitutional Court, only the legislator can solve this problem. Until now the legislator has not acted upon the Council of State's suggestion. However, the benefits of a global mandatory insurance are proven by the situation in France. In this state, all building partners ${ }^{139}$ -even promoters- are lawfully obliged to buy insurance to cover a ten year period which starts to run after receipt of the finished work. This mandatory insurance regime is laid down in Article 4 of the Spinetta Act of 4 January 1978. ${ }^{140}$ The Spinetta Act aimed for a

134 Burssens 2007, p. 27. This will be explained in more detail hereunder.

135 Augmented with 'updecimes'.

136 Ramboer 2008, p. 109. Other persons who fulfil such activities are not obliged to buy insurance.

137 According to figures of Joint Stock Company Protect, experts and market leaders in the insurance of professional liability of designers in Belgium, only 0.02 per cent of entrepreneurs are covered by ten year professional liability insurance. Information Session Protect.

138 Constitutional Court 12 July 2007, A.GrwH 2007, afl. 3, 1163.

139 Sub-contractors as well as fabricators and suppliers of building materials which can bring about a joint liability are excluded. Their liability is not limited to ten years after receipt of the finished work.

140 The benefits which are brought about for the victims are not created by the Spinetta Act but by case law. Likewise, Article 1792 of the French Civil Code was adapted after an abundance of case law held that every building partner is liable by law for building damage and now stipulates: "Tout constructeur (The concept of 'constructeur' is interpreted as 'someone who executes a part of the building work' and can thus be translated as 'particpant of a building work'. Even fabricants, sellers or promoters fall under this concept) d'un ouvrage est responsable de plein droit, envers le maître ou l'acquéreur de l'ouvrage, des dommages, mê- 
better protection of consumers. The Act makes sure that the building master -who has to buy an insurance to cover any damage- is compensated quickly ${ }^{141}$ and in full ${ }^{142}$. Consequently, the Act's first objective is fulfilled. Due to the absence of any exemptions, the building master will turn immediately to the insurance company without any hesitation. This has caused the number of reported cases of damage to increase as well as pushing up the expenses of the insurance companies which, in turn, brings about an increase in the premiums which have to be paid. Nevertheless, the division of risk is spread in a much better way than was the case before the ten year insurance obligation was introduced. Due to the insurance obligations of all building partners, architects are less exposed to the risk that they will be convicted in solidum. As held by Maurin, a previous Secretary General of the 'Association Française des Assureurs Construction', the architects' share has decreased from 16 to $4 \% \cdot{ }^{143}$ The Spinetta Act has led to better protection for the consumer and a better division of liabilities.

As noted above, in Belgium, only the architect and the safety coordinator ${ }^{144}$ are obliged to buy insurance. They can insure their liability either for their whole career, per building, or within the framework of a more or less extensive global insurance. As already indicated, the insurance has to cover the individual's contractual liability (until the moment of provisional delivery), his ten year liability which starts to run at the moment of provisional delivery as well as his extra-contractual liability (see Article 77 State Insurance Act). The career policy is still the most beneficial type of contract for the insured and the insurer. The yearly premium which has to be paid covers any damage cases which occur during that same year. Therefore, it is less expensive than the French system. However, due to the Laruelle Act, the insurance contract will automatically have to cover the ten year responsibility of the legal person, even in cases of liquidation or bank-

me résultant d'un vice du sol, qui compromettent la solidité de l'ouvrage ou qui, l'affectant dans l'un de ses éléments constitutifs ou l'un de ses éléments d'équipement, le rendent impropre à sa destination."

The constructors' liability by law is presumed (the building partners are thus in the possibility to demonstrate that their responsibility is not involved). The building partners therefore carry the burden of proof. The presumed liability of these building partners ends ten years after delivery in the event of damage to the firmness of (a part of) the building work, or when the building is rendered unoccupiable in terms of its use. The building parts which do not fall under the ten year liability principle have to be guaranteed for two years, while the entrepreneur has to guarantee a perfect finalisation within one year (he has to repair all the defects which were reported by the building master at the moment of reception). See Maurin 2002, pp. 1-65.

141 The building master buys the insurance. His insurer will pay the damage compensation immediately if there are concerns, even before the liability of the involved building partners are determined. Afterwards the building master's insurer will deal with the insurer of the responsible party.

142 Supreme Court, 12 May 1993, civ I, Bull civ I, $\mathrm{n}^{\circ} 25$. The insurer has to compensate for the material damage in full.

143 Maurin 2002, p. 30.

144 Royal Decree 25 January 2001 on the temporary and mobile building sites. The safety coordinator has to ensure that the necessary health and safety measures are taken and that they are observed. As held by Article 16 (1) the building master or the director of the project (i.e. mostly the architect) which makes the design, has to appoint a safety and health coordinator during the execution phase of the building work if it is planned that several entrepreneurs will work on the building site. The safety coordinator, as well as the architect, is also obliged to buy insurance. 
Public Law in Belgium

ruptcy, and of natural persons in case of death. This will necessarily raise the premium. ${ }^{145}$

The creation of an insurance obligation for all building partners at the same time is difficult for the Government, since this involves the authority of several Ministers. Due to the express wish to compensate victims at all costs, those who are most solvent will be held responsible very easily, in solidum convictions are very common in Belgium. To compensate victims in any situation, a liability regime without fault has more or less originated in fact. ${ }^{146}$ By safeguarding consumers from instituting several claims against possible insolvent debtors, the in solidum conviction which was originally created as an exception in case one was unable to distinguish the responsibilities of different building partners, has become current practice. In this way, all convicted partners have to repair the damage in full, but it is mostly the architect who is turned to since he is insured anyway. For architects the problem is not solved however by transforming the deontological insurance obligation into a legal obligation. In both instances there is still the risk that the architect will be the one paying due to an in solidum conviction in the event that the entrepreneur is insolvent or not insured. A solution could be to introduce a legal insurance obligation for all parties, including the building master, such as is laid down by the Spinetta Act in France. Another solution is to oblige the building master to contract only with registered entrepreneurs. In this way a first step might be taken in terms of quality improvement. It is also possible to contractually agree that the architect will not be held liable in solidum. ${ }^{147}$

To conclude, it has to be mentioned that the Laruelle Act has no influence on contracts which were concluded under the old regime. This means that an architect who signed a contract in name, and for the account of his company, is still personally (or together with the company) liable, even if the company is afterwards registered on one of the Order's tableaux. ${ }^{148}$ However, if the building master has agreed in writing, the rights and obligations which arise out of a contract concluded by an architect-natural person, can be transferred to an architect-legal person (Article 16(5) LA). In these cases the architect will no longer be personally liable. The architects-natural persons and the architects working within the framework of a legal person can thus exclude their personal liability. However, in this regard, it is important that the insurer of the architect-legal person admits the anteriority rule, since this is not obligatory.

The Laruelle Act does not regulate the insurance obligations in detail. Therefore, Article 4(2) LA, states that the King will decide upon:

- the minimum level of coverage

- the amount of possible exemptions

- the duration in time of the coverage

145 AR-CO News, Insurer in the building industry, Number 7, Special Edition, p. 3.

146 Rigaux 1993, p. 338.

147 In solidum convictions do not have a public order character. See http://www.interfidesko.be/archit.htm, last consulted 21 October 2009

148 Burssens 2007, p.28. 
- the risks which have to be covered

These elements, which were previously covered by the Order's 1997 Recommendation, are at present thus decided upon by the King. The provisions of the Royal Decree with regard to obligatory insurance as provided for in the Act of 20 February 1939 on the Protection of the Title and the Profession of Architect ${ }^{149}$ (Royal Decree Laruelle), will now be discussed in more detail.

c. The Royal Decree Laruelle

As held by Article 16(1) LA, the Laruelle Act would enter into force on a date to be determined by the King and at the latest on the first day of the sixth month after the Act would be published in the Belgian Official Gazette. Furthermore, according to Article 16(2) LA, the Act could not enter into force before the entry into force of a Royal Decree on the rules and conditions of the obligatory liability insurance. This Royal Decree of 25 April 2007 is known as the Royal Decree Laruelle (RDL) and laid down the minimum insurance conditions. ${ }^{150}$ After the Laruelle Act was enacted, it therefore took more than a year before the Royal Decree was created. This was due to the fact that several parties were involved in the process, each with opposing interests. As suggested by Uytterhoeven $^{151}$, firstly the consumers looked for high and extensive minimum guarantees. Secondly, the architects did not want the content of their deontological obligation to change. Thirdly, the insurance sector, which falls under the competence of the Ministry of the Economy, held that certain damages could not be insured. Fourthly, it was thought that a control mechanism had to be set up which needed the involvement of the Cabinet of Administrative Simplification, and that the Commission of Insurance had to give its advice as well.

After a compromise had been reached, the King decided that the date of entry into force of the Act and the Royal Decree would be 1 July 2007 (Article 8 RDL).

\section{Article 1 RDL states:}

"Every insurance agreement which is endorsed by the Act of 20 February 1939 on the Protection of the Title and the Profession of Architect has to contain coverage which is at least in accordance with the minimum requirements as determined by this Decision."

All insurance policies have therefore to fulfil the requirements of the Royal Decree Laruelle. The insurance companies are not allowed to offer other contracts.

Furthermore, Article 2 RDL holds:

"The insurance covers the civil liability which results from the activities of the architect as long as these activities are related to work and performances executed in Belgium."

149 Official Gazette 2 June 2007.

150 Royal Decree of 25 April 2007 on the Compulsory Insurance as provided for in the Act of 20 February 1939 on the Protection of the Title and the Profession of Architect, Official Gazette 23 May 2007.

151 Uytterhoeven 2008, p. 108. 
The contractual liability, including the ten year liability, as well as the extra-contractual liability have thus to be insured. This was already provided for by the Order's $1993 \mathrm{Rec}-$ ommendation and is reaffirmed in the Recommendation of 24 April 2009. Foreign architects who provide services in Belgium, also fall under this obligation. Since Belgian architects active abroad are not included, they have to buy extra insurance.

Article 3 RDL stipulates which persons have to be covered by the insurance contract:

"Every natural or legal person authorised to practise the profession of architect and mentioned in the insurance contract as well as his appointees are covered. Mandatories, trainees and other co-workers of the architect which are authorised to practise the profession, as long as they work for the account of the architect, are considered to be appointees of the legal person. Furthermore, the directors, board members and all the other organs of the legal person which administer and control it are covered whenever they work for the account of the legal person within the framework of the architect's profession."

As already held above, in the event that several architects work together in a company with or without having created a legal person which allows them to limit their personal liability - it is desirable that a policy is concluded by the company for the account of the natural architects in which they are included as insured persons. In this way, discussions between insurance companies are avoided. ${ }^{152}$

Article 4 RDL states:

"The coverage of the civil liability insurance cannot be lower then

$€ 1,500,000$ for damage resulting out of physical harm

$€ 50,000$ for the total of material and immaterial damage

$€ 10,000$ for objects which are entrusted to the insured ...

per damage case ..."

If these amounts are compared with the amounts indicated in the 1993 Recommendation, it is immediately notable that the upper limit of the insurance has been augmented. As already indicated, the 1993 amounts were often not sufficient since damage cases in the building sector always lead to very high compensation claims. This means that the premiums which have to be paid by the architect have also increased. Furthermore, as provided for by the Article, the coverage will be given 'per damage case' and not per year or per project as was the case before. Since more damage cases can arise per project bringing about a larger coverage- this will also result in higher premiums. ${ }^{153}$

In contrast to Article 8 of the 1993 Recommendation, the Royal Decree Laruelle only excludes two events from insurance coverage: damages resulting from radioactivity and

152 Ramboer 2008, p. 111.

153 Daelman 2007, p. 49. See also htpp://www.protect.be/_CLIENTS/Protect/Documenten/2007-2-27(121511)_De\%20Tijd.pdf, last consulted 23 December 2009. 
physical damage caused by illegal products (Article 5 RDL). Damage caused by deceit or a severe fault, etc. is, in principle, thereby covered, which ameliorates the architect's situation. Article 8 of the State Insurance Act holds that the insurer can only exclude coverage in such cases if the severe fault is explicitly described in the policy (for example supervising a building work which has no building permit, being drunk during the execution of the profession, ...). This will again have consequences with regard to the premium to be paid.

As stipulated in Article 6 RDL:

"The insurance coverage applies to claims which are instituted in written against the insured or the insurer during the duration of the insurance contract and which are based on a liability which is covered in the contract and which concerns damage which arose during the duration of the contract.

The coverage is extended to claims which are instituted within ten years after the end of the registration on the tableau of the Order of architects)"

From now on, the coverage is thus extended to claims which are instituted within ten years after the end of registration. This is rather odd, since the architects' liability has no connection with his registration. Furthermore, the moment that registration ends is often unknown, since one can stop it for personal reasons, or one can get a disciplinary sanction which ends registration.

This Article is of great importance. As opposed to Article $78 \$ 2$ State Insurance Act which was discussed above, and which foresees an extended coverage lasting 36 months after the end of the insurance coverage, there is now an obligatory insurance period (posterior principle) of ten years which starts to run the moment the architect's registration has ended. Previously, a ten year insurance coverage was not obligatory and was only present if one paid an additional premium. Due to the Laruelle Act, the insurance company is now obliged to guarantee ten year coverage. This will increase the premium. Article $7 \$ 2 \mathrm{RDL}$ states that the architectural contract has to mention the name of the insurance company of the architect and his policy number. Every year the insurance companies have to provide a list to the Council of the Order which contains all its architect- clients. The insurance contract cannot be withdrawn by the insurance companies or the architect without informing the Order (Article $7 \$ 1$ RDL). Furthermore, every three months, the insurance companies have to communicate to the Order which insurance contracts have ended or have been withdrawn or suspended. The control on the insurance coverage is therefore carried out by the Councils of the Order, as well as by the insurance companies. In this way, the legislator aims to have a full and better supervision possibility regarding the insurance obligation. However, since this brings about a considerable administrative burden, the premiums will be increased..$^{154}$

Finally, Article 8 RDL holds:

"This Royal Decree as well as the Act of 15 February 2006 on the practice of the profession of architect within the framework of a legal person enter into force on 1 July

${ }^{154}$ Daelman 2007, p. 52. 
2007, with the exception of Articles 11 and $14^{155}$ of the Act.

The stipulations in the Act and the Decision are applicable to all architectural contracts which are concluded after their entry into force.

They are also applicable to the existing insurance contracts which cover the architectural contract which are concluded after the entry into force of the Act and the Decision.

Notwithstanding the application of the stipulations in this Decision, the insurance companies have to adapt their contracts and other insurance documents to the stipulations in this Decision at the latest on the date of adaptation, renewal, extension or remodelling of the running contracts."

The 'new type' of architectural contract which will be signed by an architect-natural person who acts for the architect-legal person in accordance with the Laruelle Act, could therefore only be concluded from 1 July 2007 onwards. The reason is that a legal person can only practise as architect from that date. The new Act is thus not applicable to architectural contracts which were concluded prior to 1 July 2007. In such cases, the architect-natural person is therefore still personally liable for the damage which is a consequence of acts which happened before or even after this date. The same goes for contracts which were concluded with a company before 1 July 2007, which currently practises the profession of architect itself.

\section{The Architects' Order and the Architects' Order Act}

\subsection{Introduction}

In paragraph 5.2, the content of the Architects Act was discussed in detail. As was noted above, the Architects' Order Act is the second Act which regulates the profession. Since the provisions of both acts are often connected, some provisions of the Architects' Order Act have already been discussed in the light of the foregoing. Hereunder, the tasks of the Order, its history and institution will be discussed in more detail.

After the Second World War, the legislator aimed to improve the quality of the buildings on its territory. The importance of spatial and town planning as a means of realizing this aim was fully understood as well as the fact that private persons/institutions were needed to achieve it. To be sure that architects worked well, certain quality standards and a supervision system had to be imposed.

Since the Architects' Act only protects the title and profession of architect, rules were therefore necessary to regulate the organization and the structure of the profession, and to establish a professional code. A continuous supervision of architects was necessary to check whether or not they were acting in accordance with their legal duties. Therefore, in 1963, the Architects' Order Act was created, together with the Architect's

155 These Articles deal with the composition of the National Council of the Architects' Order, the members contribution and the budget. 
Order, an institution with genuine regulatory and disciplinary powers charged with the architects' supervision. ${ }^{156}$ From then on, it would be illegal to practise the profession without being a member of this Order.

Due to the creation of the Order, the professional associations can now concentrate more on the advancement of collegiality among architects, the permanent education of their members, and the improvement of the quality of architecture and the art of building. The Order, on the other hand, has autonomous powers and has to apply the legal requirements concerning admission to the profession and when determining the professional duties and disciplinary sanctions. ${ }^{157}$ It also has to watch over compliance with the protective title legislation, and has the right to report every violation to the Public Prosecutor. The Order can present itself as a civil party in any proceedings.

\subsection{Tasks of the Order}

The Order is a public law institution ${ }^{158}$ which exercises a disciplinary function in the interest of the profession in order to safeguard its collective honour. ${ }^{159}$ It is a registration organisation, yet not a professional association. By the creation of the Order, the public interest character of the profession, which cannot be accomplished if the Order would not obligatory unite all its members, was recognized by law. ${ }^{160}$

Since the Order possesses legal personality (Article 1 AO), it can possess property, conclude contracts, be represented in court, etc. Nevertheless, as held by Article $48 \mathrm{AO}$, it cannot possess immovables other than those necessary for its proper functioning and the performance of its tasks, nor accept gifts without the King's permission.

156 The tasks of the Architects' Order cannot be compared to those carried out by the Royal Federation of Belgian Architects, discussed in paragraph 10.1. The Order, instituted by public law, takes into account public interests. Membership of the Order is obligatory, and a contribution has to be paid by each architect. Membership of professional associations, such as the Royal Federation, is optional. See X., Info Jonge Architecten, Architectenunie, October 1997, p. 31. After the regionalisation of Belgium, the Royal Federation created two wings: the Dutch 'Bond van Vlaamse Architecten' (BVA) and the Walloon 'Sociétés des Architectes Francophones' (SAF). These societies are also referred to as private professional societies. Next to these associations there are several others, e.g. the Professional Union of Architects (UPA-BUA); the National Architectural Association (NAV) and several regional organisations. The main functions of the BVA are: defending the professional, social and cultural interests of its members; improving collegiality among its members; representation of its members towards third parties; giving information about the different tasks of architects to persons who want to promote architecture; giving technical advice; supplying artistic training; etc. The BVA does not impose disciplinary sanctions on its members. This is a task of the Order.

157 Mast et all. 1999, nr. 104. As held by Article 1 of the Act on the Professional Associations of 31 March 1898, Official Gazette 8 April 1898, professional associations have legal personality within the legal limits and conditions. Article 2 indicates that a professional association is only created to study, protect and develop the professional interests of its members.

158 It is established by public law.

159 Wigny 1952, t. I, n 247.

160 Conclusion of the Public Prosecutor Ganshof Van Der Meersch in Supreme Court 3 May 1974, J.T., 1974, 568-569. 
Article $2 \mathrm{AO}$ enumerates the tasks of the Architects' Order. These are:

- the creation of deontological rules and the supervision of their observance.

- the supervision of the honour, discretion and dignity of its members when exercising (or regarding the exercise) of the profession.

- informing the judicial authorities of every violation of a law or regulation which intends to - protect the title and the profession of architect.

Since the Order's competence is limited to the deontological field, it is not obliged to assure the application of the law. However, it is possible that an illegal act affects the honour and dignity of the profession or that it is against the disciplinary rules.

As has already been discussed in detail before, one needs to be registered or satisfy the requirements of Article $8 \$ 2(1)$ and (2) AO, to be allowed to practise the profession. Registration will only take place if the professional fulfils the conditions of the Architects' Act. In this regard it is important to note that the Belgian Supreme Court held that the obligation to register with the Order does not violate the constitutional principle of freedom of association, which is also guaranteed by Article $11 \$ 1$ of the European Convention of Human Rights. The Court held that since members freely choose to register themselves, they have to obey the Order's rules. ${ }^{161}$

Furthermore, to be registered on the tableau, new architects have to conclude a traineeship of two-years with a professional who has already been registered on the tableau for at least ten years (Article $50 \mathrm{AO}$ ). ${ }^{162}$ The traineeship will take two years, starts after the trainee contract has been signed ${ }^{163}$, and ends upon delivery of the traineeship certificate. ${ }^{164}$ As noted above, trainees are members of the Order and are registered on a list.

The purpose of the traineeship is to give practical guidelines to persons who have received a relatively theoretical education. As held by Article 20 of the Traineeship Regulation created by the Order's National Council on 5 February 1965, every Council of the Order has to supervise the traineeship. This task is delegated to a Traineeship Commission which is composed of members of the Council. Article 39 of the 1963 Act holds that the King (i.e. the government) can give legal force to the deontological rules and regulations concerning the traineeship by means of a decision discussed in the council of Ministers at the request of the National Council of Architects. The Royal Decree on the Approval of the Traineeship Regulation was proclaimed on 13 May $1965 .{ }^{165}$ The disciplinary rules are therefore also applicable to trainees.

161 Supreme Court 3 May 1974 and conclusion of the Public Prosecutor Ganshof Van Der Meersch, J.T., 1974, p. 564 and p. 568.

162 Article 52 AO contains some exceptions to the traineeship requirement.

163 Section 8, 13-14 Traineeship Regulation

164 Section 23 Traineeship Regulation

165 Royal Decree of 13 May 1965 rendering the regulations on the traineeship compulsory, Official Gazette 26 June 1965. 
The Order's Councils can permit that the traineeship be fulfilled abroad in the office of someone who is an architect and who can offer the same guarantees as those which are set for the Order's members in Belgium (Article 50(3) AO). ${ }^{166}$ As stated previously, the relationship between a patron and his trainee has to be laid down in a traineeship contract which has to be in accordance with the model drawn up by the competent Council of the Order, and has to be approved by the Minister of the Independent Professions (Article 13 Traineeship Regulation). The Councils of the Order can prolong the duration of the traineeship (Article $51 \mathrm{AO}$ ) or give an exemption for it to EU/EEA members, when the applicant has fulfilled certain tasks abroad which are equivalent to the tasks s/he has to fulfil during the traineeship. The same goes for architects who are not EU/EEA members but who have practised the profession abroad for more than two years (Article $52 \mathrm{AO}$ ).

The trainee has the obligation to execute the tasks which are entrusted upon him (for a minimum of 120 hours/week), to respect the professional secrecy and to collaborate and respect his patron and the other members of his bureau (Articles 18-19 Traineeship Regulation). His patron is responsible for him with regard to third parties in terms of the work he imposes upon him. This is not the case however for the activities the trainee fulfils on his own account, and over which the patron has no permanent control (Article 17 Traineeship Regulation).

At the end of the traineeship and after the Commission has given a positive advice, the Order's Council will deliver a certificate to the professional which makes is possible to register on the tableau (Article 23 Traineeship Regulation).

\subsection{Institutional organization of the Order}

The Architects' Order has three specialized types of organs: the (Provincial) Councils, the Councils of Appeal and the National Council. Its structure is based on that of the Order of Medicines ${ }^{167}$, the Order of Pharmacists ${ }^{168}$, and the Order of Veterinaries ${ }^{169} .{ }^{170}$

The organs do not posses legal personality. The Council and the Council of Appeal have disciplinary powers while the National Council makes regulations and protects the interests entrusted to the Order. Therefore, it is said that the first two organs have a certain 'judicial' character while the national council has an 'administrative' function and exercises public authority. This is confirmed by the fact that an appeal can be lodged against a decision of the National Council before the Administrative Section of the Council of State (Article $40 \mathrm{AO}$ ).

\footnotetext{
166 The Councils decide sovereign whether this condition is fulfilled: See Council of Appeal, Liege, 8 February 1972, unpublished.

167 Instituted by the law of 25.07.1938

168 Instituted by the law of 15.04 .1949

169 Instituted by the law of 19.12 .1950

170 See also Doc. Parl., Senat 1961-1962, Nº 299, pp. 2-5.
} 
The Provincial Councils are the local organs of the Order charged with the discipline in their resort. ${ }^{171}$ Their competence is limited to the persons registered on the tableau or on the list of trainees, as well as over the Belgian or foreign architects established in another state who are authorized to practise the profession in its resort. The criteria of subscription and authorization are local, but the jurisdiction of the Councils extends to every activity wherever its members' practise. ${ }^{172}$ Registration has to be asked to the Council of the Order of the resort where most of the professional activities take place. According to Article 7 there are two Councils for the province of Brabant, a French speaking one and a Dutch speaking one. The language of the municipality in which most of the activities are performed decides which one of the Councils is competent. The architects established in the Brussels-Capital Region are allowed to choose. As described above, in the situations as described in Article 8(2) AO, the main place of establishment is not the only determining factor. Trainees are subscribed on the list held by the Council to which their patron belongs. After being registered, the architect gets a professional card so that he can prove his registration in all cases, especially when he hands over his application to obtain building permission (Article $41 \mathrm{AO}$ ).

The Provincial Councils of the Order decide about the admission of trainees on the list and of architects on the register (Article $17 \mathrm{AO}$ ). When doing this, they always have to verify first whether the professional satisfies the criteria of the Architects' Act. No one is therefore registered ex officio on the tableau or on the list. Every candidate has to hand over his diploma and a certificate of nationality. If one has a foreign (non EC/EEA) nationality, the Council will check whether there is a Treaty containing a reciprocal agreement or whether there is a Royal Decree allowing the admission. Furthermore the

171 As held by Rigaux, one can ask whether the professional organization and the disciplinary powers of the professional authorities do not violate Article 144 of the Constitution. This provision holds that contestations about civil rights belong to the exclusive competence of the 'judicial' authorities. It is thus forbidden to create extraordinary commissions or tribunals for these matters. In principle, disciplinary sanctions are not considered to violate a civil right (See Supreme Court 2 June 1983, Arr.Cass. 1982-83, 1217; Bull. 1983, 1005; J.T. 1984, 298; Pas. 1983, I, 1105; R.W. 1983-84, 2047). Also Article 6 (1) ECHR does not require that disciplinary sanctions such as the suspension or the deletion of the list have to be imposed by the judicial authorities (See Supreme Court 2 November 1989, Arr.Cass. 1989-90, 298; Bull. 1990, 262; Pas. 1990, I, 262; R.W. 1989-90, 924; Supreme Court 14 January 1983, Arr.Cass. 1982-83, 657; Bull. 1983, 579; Pas. 1983, I, 579; R.W. 1982-83, 2544). The Councils of the Order and the Councils of Appeal have a judicial function in a private order. Nevertheless, they do not have public authority. Since they obtain their power by law, neither an administrative court, such as the Council of Competition, nor another court can interfere in the execution of the disciplinary procedures. Furthermore, Article $40 \$ 1$ (1) of the 2006 Law on the Protection of Economic Competition (Act of 10 June 2006 on the Protection of Economic Competition, Official Gazette 29 June 2006), which states that the President of the Council of Competition can take provisional measures to suspend practices which restrict competition, does not allow the President to enter into the sphere of competence of another institution (See, for example, Brussels 14 November 1996, J.L.M.B. 1997, 9; Jb. Hand.Med. 1996, 816; T. App. 1997, ed. 4, 30; T.B.H. 1997, 66). His competence is restricted to those measures which are strictly necessary to achieve the goal of the Competition Law, and does not extend to prohibit every act of a judicial or administrative authority which is liable to harm competition (Supreme Court 27 November 1997, Arr.Cass. 1997, 1233; Bull. 1997, 1292; Pas. 1997, I, 1292). In sum, architects have to respect not only their own deontological rules but also the legal and constitutional principles of their national legal system (Supreme Court 13 December 1973, J.T. 1974, 60). Disciplinary prosecutions do not fall under the ambit of Article 144 of the Constitution, which reserves the competence over disputes exclusively to the judicial order.

172 Rigaux 1975, p. 142. 
Council will verify whether there is any incompatibility as per Article 6 AA and, when the registration on the tableau is asked for the first time, whether all the conditions concerning the traineeship are fulfilled. A negative decision requires a two-third majority of the votes in the Council. However, when a candidate fulfils all the criteria to become a member of the Order, the Council is not allowed to limit the effect of his registration in any way. As soon as a member no longer fulfils the conditions, it is his obligation to inform the Council and ask for the striking out of his name. If he fails to do this, the Council has to pursue the striking out following the procedure described in Article 21 AO.

Since Article 19 AO states that the Councils are in charge of the supervision of the disciplinary rules, members have to practise the profession with honour, integrity and discretion. ${ }^{173}$ The Council thus supervises the honour, discretion and dignity of the Members of the Order. It reports every violation and misuse of the title to the judicial authorities. Furthermore, as held by Article $20 \mathrm{AO}$, the Councils rule in disciplinary proceedings against its members. As already noted above, trainees and professionals fulfilling the requirements of Articles $8 \$ 2(1)$ and (2) AO can also receive a sanction. The Councils can also determine the size of the honoraria at the joint request of the parties, or give advice to the tribunals and courts on these matters (Article $18 \mathrm{AO}$ ). If a party does not agree with the decision of the Council, it can start a procedure before the competent civil law court.

Before a complaint is brought before a Council, the Council's office investigates it. If necessary, it refers the complaint to the Council. Following Article 24 AO, a disciplinary sanction cannot be imposed without the person concerned being invited by registered post to present himself at the meeting of the Council by which his case is examined. This letter has to be sent at least thirty days prior to the meeting. The professionals have the opportunity to be represented by a lawyer. ${ }^{174}$

Article $21 \mathrm{AO}$ enumerates the disciplinary sanctions which can be imposed upon a professional failing to fulfil his obligations: warning; disapproval; reprimand; suspension; deletion from the list.

Disciplinary sanctions can only be imposed for faults which are related to the exercise of the profession. Since the suspension and deletion from the list are heavy punishments, a two-third majority is needed to impose them (Article $21 \mathrm{AO}){ }^{175}$ The other sanctions require a simple majority. During the suspension, which cannot last longer than two years, the architect is not allowed to exercise the profession. However, suspension does not involve the striking out of one's name on the tableau. The deletion from the list, on the other hand, is permanent.

173 Rigaux 1975, p. 154.

174 Supreme Court 12 June 1987, Arr.Cass. 1986-87, 1258; Bull. 1133; Pas. 1987, I, 1133; T.R.V. 1988, 57, annotated by $S$. Raes.

175 Supreme Court 1 February 1996, Arr.Cass. 1996, 145; Bull. 1996, 164; Pas. 1996, I, 164; R.W. 1996- 97, 330. 
With regard to architects established abroad, and who are authorised to work occasionally in Belgium, the only severe sanction is the withdrawal of permission (Article $21 \$ 3$ $\mathrm{AO})$. The suspension or deletion from the list is therefore not possible for this category. Appeal can be lodged with the Council of Appeal within thirty days.

The first three sanctions will be wiped out after five years if the professional does not receive another sanction during this period (Article $42 \$ 1 \mathrm{AO}$ ). For the other two sanctions, an application for rehabilitation has to be handed in by the Council of Appeal (Article $42 \$ 2 \mathrm{AO}$ ). When wiping off is applied, or the rehabilitation is granted, the consequences of the sanction are suspended (Article $42 \$ 3 \mathrm{AO}$ ). The procedure which has to be followed before the Council of Appeal is described in Article 24 -26(3), 46 AO.

There are two Councils of Appeal: one which uses the French language and is seated in Liege, and one which uses Dutch and is seated in Gent. The Council of Appeal decides with regard to an appeal which is instituted against a decision of the Council, following Article 17 AO (registration, authorisation to practise based on Article $8 \$ 1$ and $8 \$ 2(1)$ $\mathrm{AO}, 20 \mathrm{AO}$ (disciplinary sanctions) and $61 \mathrm{AO}$ (seniority) (Article 31(1) AO). It rules in first and last instance over matters described in Article $44 \mathrm{AO}$ (revocation of Council members' mandate when criminally sanctioned) and Article $45 \mathrm{AO}$ (sanction of Council or Council of Appeal members' when not present at two successive meetings), as well as over the applications for rehabilitation as described in Article $42 \$ 2 \mathrm{AO}$ (Article 31(5) AO). Following Article 26 of the Royal Decree of 31 August 1963, the Council of Appeal is also competent in the last resort, in matters relating to the election of members of the Councils. As held by Article 33 AO, cassation (Supreme Court) is possible within a month of the notification of the decision.

Article 37 states that the National Council legally represents the Order, and is entitled to stipulate or conclude contracts in its name. It therefore represents the material as well as the moral interests of the Order. According to Article 38 AO, the tasks of the National Council are as follows: creating disciplinary rules (such as forms and modalities of practising the profession, insurance, confidentiality, relations with the principal), making regulations with regard to traineeship, supervising the observance of the disciplinary rules (which is delegated to the provincial boards) and traineeship regulations which are rendered obligatory by Royal Decree, making suggestions to the public authorities on legal or administrative measures dealing with the profession and giving advice about the practise of it, making regulations of internal order of the Councils and their bureaus, supervising the activities of the Councils and collecting their decisions, registering the nationals and legal persons of an EU or EEA Member State in the register of service provisions, taking the necessary measures for the accomplishment of the Order's aims (i.e. giving non-obligatory directions to the Order's Councils concerning deontological mattes and matters relating to the surveillance of the traineeship) and the publication of the tableau of architects and the list of trainees on its internet site. ${ }^{176}$ After the imple-

176 Doc. Parl., Senat, Session 1960-1961, exposition of motifs, n² 299, p.30. 
mentation of Directive 2005/36/EC by the Act of 21 November 2008, it was added that the National Council has to cooperate closely and exchange information with the competent authorities from the Member State of origin or the host Member State in accordance with the provisions of Title V of the Act of 12 February 2008, instituting a new General Framework for the Recognition of EC professional qualifications. The National Council has therefore a general competence over all the members of the Order and over all the persons authorised to exercise the profession of architect in Belgium. However, it is not competent to verify the observance of the deontological rules or to impose disciplinary sanctions.

The National Council is composed of twenty members in active service. Article $34 \mathrm{AO}$ describes the exact composition. The Dutch and French speaking sections can deliberate either separately or jointly (Article $35 \mathrm{AO}$ ).

\section{Conclusion}

The Architects' Act lays down in detail who is allowed to use the title of architect in Belgium. In general it can be said that Belgian and other EC/EEA nationals need to be in possession of a certain diploma obtained in Belgium, which requires five years of study. It is also possible to obtain formal qualifications elsewhere in the EU/EEA. If these qualifications are listed in annex $1 \mathrm{~b}$ or $2 \mathrm{a}$ to the annex which implements annex $\mathrm{V}$ and VI of Directive 2005/36/EC, recognition should be granted automatically. If this is not the case, an aptitude test or adaptation period can be completed in accordance with the Act of 12 February 2008, instituting a new General Framework for the recognition of EC-qualifications, which implements the general system mentioned in Chapter I of Title III of the Directive. Professionals who obtained their qualifications outside the EU can invoke Article $1 \$ 4 \mathrm{AA}$.

Architects in Belgium have a monopoly with regard to designing houses and supervising building works for (almost) all constructions which require a building permit. Not only the title but also the profession is protected. To be able to practise the profession, architects have to register with the Architects' Order. To be registered on the tableau, a two year period in which professional experience is obtained, has to be completed. The Architects' Order issues the licence to practice, manages the architectural register, determines the duties and rights of architects, and is responsible for (the formulation and execution of) disciplinary rules. Only persons who are allowed to use the title can practise the profession, as well as third country nationals in cases of reciprocal allowance by their state, or in the event that they obtain permission by Royal Decree. This is not in violation of the Directive, since the latter only applies to EC/EEA nationals.

EC/EEA service providers will be registered in the Services Register in conformity with Article $8 \$ 2$ (1) AO. This Article implements Title II of Directive 2005/36/EC. Third country nationals will have to obtain the permission of the Council of the Order located in the area in which the service will be provided.

Due to the Laruelle Act of 2006, legal persons are also allowed to undertake architectural tasks. They are, however, not allowed to use the title. It is argued that a com- 
pany can, in principle, overcome the problems faced by natural persons, such as illness or death. From 1 July 2007 onwards, architects can secure their personal wealth by the creation of a legal person which is registered as architect. Since all architects, including legal persons, are obliged to buy insurance, the building master has more certain that he will receive damage compensation (there is almost always coverage up to 500,000 Euros). Other positive aspects of the Laruelle Act are held to be: ${ }^{177}$ more continuity due to the fact that legal persons can practise the profession; no personal liability; more coverage; coverage per damage fact and not per 'project' or 'per year'; ten years posterior coverage included instead of 36 months; fewer exclusions; application of the anteriority principle in the event that the architect contracts with another insurer, and adjusted control of the insurance obligation which makes the supervision by the Order's Council easier. ${ }^{178}$

Nevertheless the Laruelle Act contains some negative aspects such as more administration since the 'natural persons coverage' can be changed into 'legal persons coverage'; higher premiums ${ }^{179}$; the architect-natural person who is not involved in a legal person will also have to meet the higher price of his insurance; a risk that good professionals will pay the price for the faults of bad professionals; discrimination in terms of the other building partners continues to exist; there is a risk that the architects' insurance obligation will negatively affect the quality of the entrepreneur's work.

Overall, it can be said that Belgium has implemented Directive 2005/36/EC well, although too late. However, neither the Architects' Act, the Architects' Order Act or the Deontological Code contain any provision on permanent education as intended in Article 22 (b) of the Directive. At this moment (26 October 2009) Directive 2006/123/EC has not yet been (fully) implemented in Belgium. A bill ${ }^{180}$ on the amendment of the Act of 16 January 2003 establishing a Central Enterprise Databank and modernising the Commerce Register and creating Recognised Enterprise Counter and Diverse Regulations on the tasks of the single contact point ${ }^{181}$ has been proclaimed at federal level in order to bring the Act in line with the Directive regarding the single point of contact requirement. The bill aimed to implement Articles 6, 7 (partially) and 8 (partially) of the Directive by adding to the tasks of the Enterprise Counter the task of being a single point of contact. Other initiatives have also been taken, mostly to incorporate existing acts which deal with administrative simplification into one document, but at this mo-

177 Daelman 2007, p. 66.

178 The insurers take part in the supervision (Article $7 \$ 1 \mathrm{RDL}$ ) so that the architects' administrative obligations become lighter. Most of these points were also referred to by Prof. Dr. R De Wit, Vrije Universiteit Brussels, during his lecture on the 'Architectural Company' at 11 January 2007 at the Vrije Universiteit Brussels.

179 Daelman 2007, p.69. See also htpp://www.protect.be/_CLIENTS/Protect/Documenten/2007-2-27(121511)_De\%20Tijd.pdf and http://www.nav.be/site2/interview-detail.php?id=13, both last consulted 23 December 2009. See for more information also Part III of this thesis.

180 Bill of 20 October, Parl. Doc. 2212/001

181 Official Gazette 5 February 2003. 
ment in time, no binding documents have yet been ratified. ${ }^{182}$ At the regional level, several initiatives have also been taken with regard to the single point of contact. ${ }^{183}$

This chapter has aimed to describe who can use the title of architect and practise the profession. Chapter 6 will indicate what the profession of architect really means, and which tasks architects need to fulfil.

182 Telephone conversation with Mr. Jean-Marie Van De Sande, Adviser to the Directorate General on Economic Potential, Division Services Federal Public Service Economy, Small and Medium Sized Companies, Medium Classes and Energy, 23 October 2009.

183 On 16 and 23 October 2009 the Flemish Government formally approved initiatives in this regard. On 11 December 2009 the Flemish Government decided to partially transpose Articles 6 and 8 of the Directive. This Decision entered into force on 28 December 2009. 


\section{Chapter 6}

\section{CONTRACT LAW IN BELGIUM}

\section{Introduction}

In the preceding chapters, emphasis has been put on the conditions which have to be fulfilled in order for one to enter the profession of architect and to practise the profession in Belgium.

The architects' tasks and prerogatives were only briefly discussed by referring to Article 4 of the Architects' Act which holds that the involvement of an architect is mandatory for the design of plans and for the supervision of building works for which a building permit is required.

In this chapter more emphasis will be placed on the content of the architectural tasks and the relationship of the architect with the building master, as well as with other building partners, especially with the entrepreneur. Even though the professions of architect and entrepreneur are incompatible in Belgium (Article $6 \mathrm{AA}$ ) these professionals are dependent on each other in the sense that the entrepreneur is not allowed to construct a house which requires a building permit without the involvement of an architect. The architect, on the other hand, will not be able to supervise the building works if the entrepreneur does not give him the opportunity to inspect them. Due to the fact that their activities are so closely related, one can therefore not just say that the task of the entrepreneur begins where that of the architect ends. This will be further explained hereunder.

In this thesis the tasks of the entrepreneur will not be described in detail since my aim is to discuss the architectural profession. Nevertheless to understand the scope of the architectural tasks, the main characteristics of the contractual relationship between the architect and the entrepreneur have to be discussed, as well as a consideration of certain specific tasks of some of the other building partners and of the building master himself. By discussing and delimiting some important duties of the parties involved, I aim to give the reader an idea of what the architectural profession exactly means. In this regard the 
1975 book of Rigaux, 'L'Architecte, Le Droit de la Profession't and his updated version of 1993 'Le Droit de l'Architecte, Evolution des 20 dernières années' was of considerable importance since these are -to my knowledge- the only books which extensively deal with the profession of architect in Belgium in all its facets. This is in contrast to the myriad books on 'construction law' generally dealing with the process of the execution of a building construction by the entrepreneur.

As pointed out in Chapter 1, this thesis aims to analyse and compare the public and private regulation of architects on a multi-national level, and to scrutinize the difficulties architects encounter if they want to move within the European Union. It does not therefore aim to offer an extensive overview of Dutch and Belgian construction law. The preceding chapter on public law dealt with the requirements that architects have to fulfil to be able to enter and practise the profession. Therefore it mainly deals with problems architects may encounter before they actually start to fulfil a concrete design or supervision task. The present chapter on private law, on the other hand, refers to the situation of the architect after access to the profession has been obtained, and discusses his tasks and prerogatives during and after the start of a building work. The exact ambit of the architectural tasks is generally laid down in a contract. That is why I have also chosen to discuss the position of the architect from a contract law perspective. In this regard the contractual liabilities of architects will also be discussed in relation to the tasks of the building master and other building partners. Of course it is possible that the architect is also liable in tort with regard to third parties (such as the entrepreneur, neighbours, persons renting a house, etc.). In this regard it should be noted that the extracontractual responsibility will only be withheld if no contractual obligations are violated. ${ }^{3}$ Since the responsibilities and tasks of architects are determined by a contract, and since my analysis of case law on the liabilities of architects has demonstrated that the overall majority of cases holding architects liable are based on their contractual liability, I will not discuss the liability in tort of architects or their criminal liability.

\section{The legal position of the architect}

\subsection{Liberal profession}

Architects practise a liberal profession..$^{4}$ As held by Article $2,1^{\circ}$ of the Act of 2 August 2002 on Misleading and Comparative Advertising, Illegal Conditions and Distance Contracts concerning the Free Professions", "Every independent professional activity which comprises the provision of services or the delivery of goods and which does not qualify as an act of commerce or trade as meant in the Act of 18 March 1965 on the trade

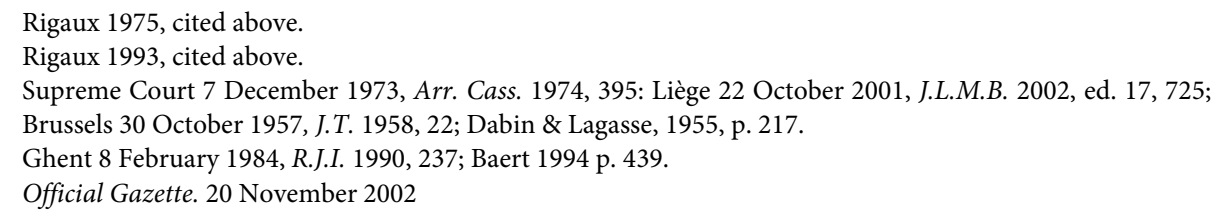


register and is not meant in the Act of 14 July 1991 on the Trade Practices and the Information and Protection of the Consumer, with the exception of rural activities and cattlebreeding can be qualified as a free profession'. It follows that a liberal professional is independent and does not engage in commerce or trade. This means that he is deemed not to work in his own interests, but in the interest of his client, as well as in the general interest. The services which are provided consist in general of intellectual performances for which they personally carry responsibility. Therefore free professionals should, in principle, have followed a certain educational path and should have obtained certain qualifications. It can be added that they are answerable to a disciplinary code which aims to guarantee and ameliorate their professionalism, the quality of their work and the trust of clients.

\subsection{The legal classification of the architectural contract}

Book III of the Belgian Civil Code determines, in eleven Titles, how 'ownership' can be obtained, each title explaining one way in which one can become an owner. In this way, Title VIII deals with 'rent'. It may come as a surprise that 'rent' is seen as a way to become an owner. Within the scope of this thesis this will not be discussed in detail. Furthermore, it may even come as a bigger surprise that Title VIII of the Belgian Civil Code holds that the relationship between the architect and his client should be qualified as a type of 'rent'. According to Belgian legislation, not only goods but also work can be 'rented'. This is explicitly stated in Article 1708 CC.

Chapter I of Title VIII contains some general provisions on rent, Chapter II contains provisions on the rent of goods, Chapter III on the rent of work and services and Chapter IV on the rent of cattle. Since architects are human beings who, or whose performances, cannot be seen as goods or cattle, Chapter III has to be consulted to determine the legal classification of the architectural contract.

Article 1710 CC of the Civil Code specifically deals with the rent of work. It states that a contract for the rent of work is a contract by which one party engages itself to do something for another party in return for the payment of an agreed price. Then, Article 1711 CC holds that the classification 'rent of work' can be divided into the rent of labour and the rent of services. Even though the Civil Code is not very clear and precise on this matter, the concepts are more accurately described in legal doctrine. Rigaux holds that the distinction between rent of labour and rent of services is situated in the fact that the rent of services requires a relationship of subordination between the contracting parties, which means that one is 'at another one's service'. ' Rent of labour, on the other hand, refers to a contract by which a person engages himself to execute independently a material, intellectual or mixed work for the account of another person against remuneration. ${ }^{8}$

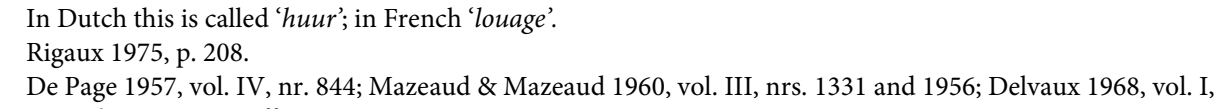


Furthermore, Article 1779 CC states that there are three types of 'rent of work and rent of services' ${ }^{\text {'9 }}$ the rent of employees who work for an employer ${ }^{10}$ (discussed in Section I of Chapter III), the rent of transporters ${ }^{11}$ (discussed in Section II) and the rent of entrepreneurs $^{12}$ (discussed in Section III). It appears that the Civil Code uses the concepts of rent of work and rent of services as synonyms in this provision, while they seem to be treated as different concepts in Articles 1710 and 1711 CC. The confusing use of these terms, and the blurry design of the Civil Code, have often been criticized, since very different situations seem to be equalized ${ }^{13}$. Indeed, within a working relationship, two situations can appear: one can work for another and be completely at the other's disposal (location operarum) or one can merely execute a particular task for the other (location operis faciendi). This distinction has not been made accurately in the Civil Code. The first situation belongs to Section I and refers to the classic employer-employee relationship, while the second situation refers to Section II or III in which there is no such relationship. The difference between the location operarum and location operis faciendi is thus situated in the presence or absence of subordination.

Since the rent of services requires a relationship of subordination, one can say that Section I belongs to this category. Sections II and III can then be qualified as rent of labour in the absence of subordination.

\subsection{The status of the architect}

The Deontological Code of the Architects' Order ${ }^{14}$ holds that an architect can work:

- $\quad$ as a self-employed professional

- $\quad$ as an employee who signs an employment contract and works in whole or in part for a natural or legal person

- $\quad$ as an official of a public administration

When these options are translated in the terms of the Civil Code, one can say that in his relationship with the client-building master, the architect can execute a contract of rent of labour, a contract of rent of services or when he is an official of a public administration, by executing his function. ${ }^{15}$ These options will be discussed hereunder. It should be remembered however, that even though the capacity in which the architect works brings about consequences as to the nature of the legal actions which are performed by the architect, the applicable social security and fiscal regime and the extension of the contractual responsibilities ${ }^{16}$, it should be noted that the architect always has to fulfil his obligations with intellectual independence and obey the deontological and legal rules.

\footnotetext{
In Dutch: 'Huur van werk en van diensten'.

In Dutch: 'Huur van dienstboden en werlieden'.

In Dutch: 'Ondernemers van vervoer te land en te water'.

In Dutch: 'Bestekken en aannemingen'.

See for example Steyaert, De Ganck \&De Schrijver 1990, pp. 8-10.

See Articles 5-8 Deontological Code.

Rigaux 1975, p. 204

Rigaux 1975, p. 203.
} 


\subsubsection{The contract of the self-employed architect: rent of labour}

The legal independence of the architect in his relationship with the building master characterises the self-employed architect as a contract of rent of labour ${ }^{17}$ : the 'entrepreneur' ${ }^{18}$ is contractually obliged to realize a certain work (locatio operis faciendi) but is free in the organization of his work and in the choice of means to realize it. ${ }^{19}$ As held above, next to the rent of transporters, the rent of entrepreneurship is a type of rent of work in which there is no employer-employee relationship. The rent of entrepreneurship is a contract by which one party, the entrepreneur, engages himself with regard to another party, his client, to realize a certain work against a certain price. ${ }^{20}$ The difference between a contract of entrepreneurship and an employment or 'labour' contract ${ }^{21}$ finds its origin in the fact that the object of the latter agreement is the execution of labour, and not the result of the labour itself. ${ }^{22}$ When the agreement only aims for a certain result, there will be no subordination. ${ }^{23}$ The absence of subordination within the relationship 'client-entrepreneur' characterises the entrepreneurial contract and distinguishes it from an employment contract, the locatio operarum. ${ }^{24}$

It is important to note that, in this context, the concept of 'entrepreneur' does not only refer to building contractors. The concept of entrepreneurship refers to everyone who performs a certain work/service (except the transportation of goods/persons) against a certain price for another one without there being a relationship of subordination. The Belgian legislator only aimed to include material work within the concept of entrepreneurship. Articles 1711(6) and 1787-1971 CC refer to raw materials which are delivered by the entrepreneur or his client, and which are used to create a certain material work. According to the legislator, the artistic and intellectual work of architects is thus not included. This type of work is, however, also a type of 'rent of work'. Since architects mostly work with great intellectual freedom, their contracts cannot be classified under Section I of Chapter III -the rent of employees who work for an employer- nor do they belong to the category of rent of transporters as discussed in Section II. If Section III the rent of entrepreneurs- was also not applicable to architectural contracts, their working situation would not be regulated at all, since the Civil Code does not contain any other provisions on the provision of this kind of service. Therefore it was concluded that these contracts were an unregulated species of 'rent of labour' contract. Nevertheless,

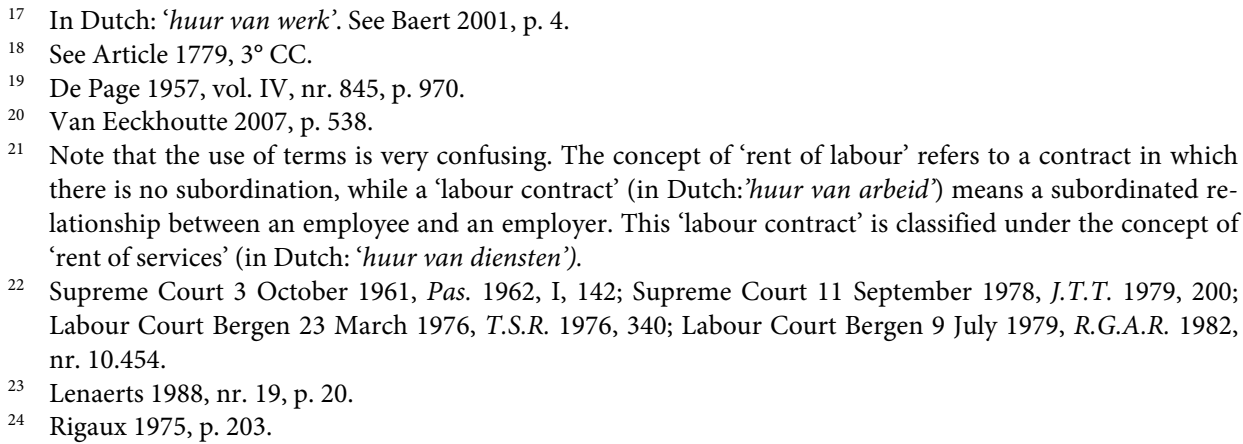
there is no subordination, while a 'labour contract' (in Dutch:'huur van arbeid') means a subordinated relationship between an employee and an employer. This 'labour contract' is classified under the concept of 'rent of services' (in Dutch: 'huur van diensten').

22 Supreme Court 3 October 1961, Pas. 1962, I, 142; Supreme Court 11 September 1978, J.T.T. 1979, 200; Labour Court Bergen 23 March 1976, T.S.R. 1976, 340; Labour Court Bergen 9 July 1979, R.G.A.R. 1982, nr. 10.454 .

23 Lenaerts 1988, nr. 19, p. 20

24 Rigaux 1975, p. 203. 
Belgian legal doctrine and case law also includes intellectual work within the concept of entrepreneurship. ${ }^{25}$ One then speaks about entrepreneurship lato sensu. ${ }^{26}$ In this way, the architectural contract which is concluded between an independent architect and his building master is thus also a species of the 'entrepreneurial contract'. ${ }^{27}$ Therefore these provisions are also applicable to the work of architects.

It follows that a shoemaker is an entrepreneur if he repairs his client's shoes, but also that architects are their client's entrepreneurs when designing a plan or supervising building work. The architectural contract is thus a type of 'entrepreneurial contract'. ${ }^{28}$

Finally it should be noted that the relationship between the building master and his architect is, in principle, thus not qualified as a 'mandate'29 as meant in Article 1984 CC. ${ }^{30}$ The architect who is bound by a contract of rent of labour, performs intellectual or manual acts in his own name in return for remuneration. He represents the building master technically, not legally, as is the case when the architect holds a mandate. ${ }^{31}$ This means that when supervising the execution of building work, the architect does not represent the building master. However, he works in his own name for the account of the building master. Since an entrepreneur works for his own account and at his own risk, while a mandatory works for the risk and the account of his principal, the architect is, in principle, not allowed to conclude contracts between the building master and the entrepreneur in the building master's name..$^{32}$ Nevertheless, the contract of the independent architect does not exclusively have to be a contract of rent of labour. ${ }^{33} \mathrm{~A}$ mandate can be added for a specific task, and does not change anything in terms of the professional obligations of the architect. It does, however, add certain private law effects, since the architect represents his client with regard to certain acts which are necessary in the construction process. Since the architect legally substitutes his client due to the mandate, his responsibility is increased.

In any case it should be noted that even though the architect has an extensive technical autonomy, he cannot disrespect the wishes of the building master. Nevertheless, the rent of work tolerates that directives are given and that a certain control is exercised. ${ }^{34}$

Flamme \& Lepaffe 1966, nr. 3

6 De Page 1957, vol. IV, nr. 856.

27 Ghent 16 November 1990, T.G.R. 1991, 8; Brussels, 13 March 1978, T. Aann., 1979, 264; Brussels 26 November 1965, Pas. 1996, II, 291.

28 Nackaerts 2005, p. 108

29 In Dutch: 'lastgeving' or 'volmacht'. If architects exceed their competence, they are strictly liable towards the entrepreneur if the latter suffers damages because of this action.

30 Tilleman 1997, p. 26-28, nr. 32.

31 Bricmont 1971, nr. 2.

32 It is possible, however, that the architect performs a small amount of legal acts for the benefit and in the name of the building master. In these cases the scope of his mandate has to be interpreted restrictively.

33 Bricmont 1971, nr. 3 ; Brussels 15 November 1973, R.J.I., 1966, nº 4268.

34 Rigaux 1975, p. 310. 
Chapter 6

\subsubsection{The contract of the employed architect: rent of services ${ }^{35}$}

As held by the Supreme Court, the exercise of a liberal profession is compatible with the status of employee. ${ }^{36}$ This is also confirmed by Article 7 of the Deontological Code. As stated earlier, a contract of rent of services means a relationship of subordination, for example a contract of employment. ${ }^{37}$ In this case the architect is thus not an 'entrepreneur' and his relationship with his employer - who does not have to be a member of the Order and is not obliged to respect the deontological rules - is characterized by the fact that the architect does not dispose of legal independence. His intellectual independence cannot be touched upon. In the event that the level of subordination is so high that it affects the personal and technical autonomy of the employed architect, the architect is not allowed to fulfil the tasks which fall within his legal monopoly. ${ }^{38}$

As held by Article 7 of the Deontological Code, the architect-employee has to have the opportunity to take up his responsibility due to the specificity of his profession. He has to make sure that the relations between his employer and the latter's co-contractor do not violate the acts and regulations concerning the architectural profession. If this were to be the case, he has to inform his employer.

Lastly, it should be remembered that it is forbidden for an architect to be employed by a building contractor (hereinafter: entrepreneur) or by a promoter, due to the possible conflicts of interests (Article 6 AA). Promoters can, however, conclude contracts with architects but these will only be valid as long as the architects are self-employed. Since this type of architectural contract is not common within traditional construction law, it will not be further discussed.

\subsubsection{The architect - public official}

The architect working for the public authorities does not dispose of an employment contract. He is thus not an employee as outlined in Article 1779, $1^{\circ} \mathrm{CC}$ (rent of services), but is unilaterally appointed by the administration to fulfil a certain task and is subordinated to it. ${ }^{39}$ Since Article 5 AA prohibits the officials of the State, provinces, municipalities and public institutions from operating as architect outside their function, these architects have a limited competence. This incompatibility finds its origin in the possibility that architect-officials can obtain the required building permissions more easily, or obtain unfair advantages. As suggested before, an exception is made for architects who work in the above-mentioned capacity to teach architecture (Article 5(2)

35 The 'rent of services' - in Dutch: 'huur van diensten' - does not refer to the provision of services in general but to the fact that 'one works at someone's service'.

36 Supreme Court 27 March 1968, R.C.J.B., 1970, p.78.

37 Supreme Court, 12 November 1964, Pas., 1965, I, 254 ; Supreme Court 17 November 1960, Pas. 1962, I, 334 ; Supreme Court 11 January 1962, Pas. 1962, I, 571; T.S.R. 1962, 366

38 Rigaux 1975, p.216.

39 The statute of the federal officials is regulated by the Royal Decree of 3 October 1937. 
$\mathrm{AA})^{40}$ or for architect-officials who design plans and supervise the execution of the building works concerning their own house. ${ }^{41}$

Since the great majority of architects working in a traditional construction process are self-employed, while the type of architect under consideration has limited competences, the status of the architect-public official will not be discussed further.

\section{Parties to the architectural contract}

The architectural contract is mostly concluded between the architect and a nonprofessional building master. As indicated above, in Belgium the architectural contract which is concluded between a self-employed architect and his building master is seen as a species of the entrepreneurial contract. The 'architect-entrepreneur' is 'hired' by the building master to fulfil a certain task against a certain price (Article 1711(6) and 1787 CC). As noted before, he is, in accordance with Article 4 AA, normally engaged to draw up the plans and to supervise the execution of the building works by the entrepreneur, and is thus an actor in the construction process.

It follows that the legal principles of construction law $^{42}$ are described by referring to the different functions of the participants. In this way one can say that the four main functions of the construction process are incumbent on the person ordering the construction, the person designing the construction, the person erecting the construction, and the person supervising the erection of the construction.

Another way of considering the construction process as the source of construction law, is by looking at the successive phases of the process instead of at the functions of the actors. According to Janssen, this method can be more advantageous since, to an increasing extent, functions of the construction process are often co-joined and performed by a single participant. ${ }^{43}$ This has resulted in the development of new, alternative construction processes in addition to the traditional construction process in which the 'design' of the building work and the actual 'execution' of the building work are performed by different participants. Nevertheless, the traditional construction process is still considered to be the basic form, in which the initiator (i.e. the building master) or the de-

40 Supreme Court, 28 February 1984, AR 4256, nr 76, unpublished.

41 Article 5 AA has to be interpreted independently from Article 4: See Council of State 23 June 1970, Arr. Et Avis Cons. Etat, 1970, 645. Article 4 AA holds that the cooperation of an architect is only required for the drawing of the plans and the supervision of the execution of the building project. Article 5 AA however, underlines the incompatibility for every activity which is related to the profession of architect with a public function. In most cases, the violation consists of a functionary asking an independent architect to sign his plans or to cover for him in another way when necessary. By his signature his colleague violates the provisions as well. Both are guilty of forgery: Supreme Court 25 April 1960, Pas., I, 988; Ghent, 5 February 1966, R.W., 965-66, col. 1952. Furthermore, the functionary is liable to be sanctioned for violation of Article 53 AO.

42 Construction law regulates the rights and obligations of persons and legal entities who perform functions of the construction process as well as the mutual legal relationships between those participants. Of course the architect is an actor in the construction process.

43 Jansen 1998, pp. 10-12. 
sign/managing intermediary (i.e. mostly an architect; however in some states the involvement of an architect is not required) on his behalf, is deemed to have a very large influence on the builder's performance of the contract. At the other end of the scale, an alternative construction process is to be found which recognises only a minimum amount of influence exercised on the process as a whole by, or on behalf of, the initiator. Between both ends of this scale, various examples of alternative construction processes are to be found, depending on the amount of influence of the initiator. In an alternative construction process, for example, a process in which a building promoter is involved, the building master normally does not conclude separate contracts with his architect and entrepreneur, but concludes one agreement with a building promoter. These promotor agreements are thus concluded between a professional promoter and his client, and foresee, in principle, that the promoter will take care of the construction process from the beginning to the end. He will lead the technical and legal organisation of the project and will offer a global service package. In this way his clients do not have to contract with the architect and the entrepreneur separately.4 ${ }^{44}$ It appears that 'building masters' ${ }^{\prime 45}$ who were abolished by the Architects' Act in 1939 have been revived again. Even though it is still forbidden to combine the profession of architect and entrepreneur, the promoter hires both types of professionals, but is the sole contracting party of the final consumer.

The aim of the promoter is to have a construction erected which he subsequently will sell to his client. An important advantage of an alternative construction process lies in the period of time which is required to complete a building. This means, however, that the architect is not particularly occupied with the interests of the initiator but only with the interests of the promoter who actually functions as the architect's building master. ${ }^{46}$ Since the initiator only has to sign the promoter contract, these projects are often called 'key-on-the-door projects'. It follows, therefore, that the promoter can conclude a contract in which he engages himself to deliver services which belong to the monopoly of the architect. ${ }^{47}$ Nevertheless, as suggested above, the architect engaged by the promotor is never allowed to lose his independence. Whatever his status is, Article

44 Bergen 25 June 1991, J.L.M.B. 1992, 758, annotated by B. Louveaux; Antwerp 7 November 1977, Limb. Rechtsl. 1979, 73

45 In this sentence, building master refers to 'bouwmeester' which was a title given to professionals who practised the profession of architect and entrepreneur at the same time. See paragraph 10.1.

46 Liège 26 March 1997, T. Aann. 1998, 263.

47 Since the initiator, whose choices are limited, contracted with a promoter, the latter can be held contractually liable towards the initiator for faults made by the architects or entrepreneurs chosen by him: The promotor has an obligation of result: Ghent 1 March 1984, R.J.I. 1984, 331 and Bergen, 26 March 1999, Cah. dr. immo 2000, ed. 2, 19, annotated by J. Henrotte. The promoter can thus be held liable for faults in the conception and the execution: See Antwerp 14 November 2002, R.W. 2005-2006, ed. 17, 667; T. Aann. 2003, ed. 2, 114. However, if the damage results from a fault of one of the constructors, the promoter can institute an action in recourse: Ghent 1 March 1984, R.J.I. 1984, 331 and Bergen, 26 March 1999, Cah. dr. immo 2000, ed. 2, 19, annotated by J. Henrotte. Brussels 15 February 1996, J.L.M.B. 1996, 1482. The ten year liability principle, which will be discussed later, is also applicable to the seller and the building promoter. However the architect and/or the entrepreneur can also be held liable e.g. based on their ten-year responsibility principle, or in tort, while it is also possible that the promoter and the architect/entrepreneur are condemned in solidum. The liability of the promotor will not be further discussed in this thesis since it aims to discuss the regulations relating to architects. 
4(2) of the Deontological Code states that the architect always has to stay independent so that he can practise his profession in accordance with his task of public order and incur liability for his own acts. ${ }^{48}$

Due to the lack of control by the client in such cases, the Belgian legislators developed the House-building Act $^{49}$ which aims to protect consumers who have concluded a contract with a building promoter for the purchase of a construction which still has to be built, or which is being built. The Act contains certain requirements which have to be fulfilled and which cannot be deviated from in order to prevent the promoters' misuse due to the clients' lack of speciality, knowledge and wealth caused the fact that there was no coercive legislation on the content and modalities of the contracts, which were mostly written in the promoters' favour..$^{50}$ By requiring a predetermined price, a double delivery $^{51}$, a limited payment in advance of a maximum of $5 \%$ of the total cost-price of the construction, a guaranteed security on the part of the promoter, supervision by a notary, mandatory stipulations in the contract, ten year liability period with regard to the promoter, etc., the House-building Act aims to protect the consumer and increase legal certainty for all parties.

This thesis aims to discuss the regulation of architects and the architects' tasks within the traditional construction process. ${ }^{52}$ Therefore the House-building Act will not be further discussed. The reason is that, even though promoter agreements and key-onthe-door projects are becoming increasingly popular, the traditional construction process still predominates in the private building market. ${ }^{53}$ The use of alternative construction processes cannot be considered as widespread in this market. Furthermore the alternative construction principles are mostly based, or dependent on, the traditional ones or are heavily influenced by them. Therefore they can, in any case, not be considered independently from the traditional principles. ${ }^{54}$ It follows that every time legal aspects of alternative construction processes are analysed, the frame of reference should be the traditional construction process itself. For these reasons this thesis only discusses the most important aspects of the traditional construction process.

48 Supreme Court 1 December 1994, Arr.Cass. 1994, 1038; Bull. 1994, 1031; J.L.M.B. 1995, 1078, annotated by F. Moises; J.T. 1995, 316; Pas. 1994, I, 1031; R.W. 1994-1995, 1377.

It should be noted that the architect is not allowed to contract with the promoter's client as well. If he does so, his independence with regard to the promoter - being the architects' original building master - is jeopardized: President of the Council of Competition 31 October 1995, A.J.T. 1995-1996, annotated by J. Billiet; J.L.M.B. 1996,263, annotated by J. Vergauwe; J.T. 1996, 346; Brussels 26 September 1979, J.T. 1980, 26. If the building master holds the opinion that there is a lack of independence, he has to prove this in concreto: Ghent 9 June 2006, N.J.W. 2007, ed. 156, 134, annotated by K. Vanhove.

49 Act of 9 July 1971, B.S. 11 September 1971. This Act is also called the 'Breyne Act' after the former Minister of Household and Housing.

50 Meulemans 2005, p. 67

51 This will be explained in paragraph 12.5.3.2.

52 Public procurement is thus also excluded.

53 Janssen 1998, p. 106

54 Jansen 1998, p. 108. 
Chapter 6

\section{Content of the architectural contract}

Since the 'rent of work' which includes the 'rent of entrepreneurs' is a type of contract, the general principles of contract law are applicable to the bilateral architectural contract which entails reciprocal obligations..$^{55}$ This means that the contract has to be concluded by two or more consenting parties, that the parties have to be legally capable to bind themselves, that the agreement comes into existence without a substantial default of intention (error, deceit ( $\mathrm{dol}$ ) or violence), that the object has to be determined, and that the obligations have to have a legal cause (see Article 1108 CC).

Since this thesis deals with the regulation of architects and their specific contractual obligations and liabilities, I will not explain these general principles of contract law in great detail.

With regard to the fact that both parties have to consent, the architect who holds the opinion that it is impossible or unsafe to build according to the wishes of the building master, has to refuse his cooperation, or adapt the instructions given to him before he enters into the contract. He has to stay independent throughout the whole construction process in order to fulfil his legal tasks.

In this regard it can be noted that Belgian legislation does not require that the architectural contract should be laid down in writing. The existence of the contract can be proven according to the regular rules of general contract law (Article 1315-1369 CC). The plan and the building permit application, both signed by the client, constitute sufficient proof. ${ }^{56} \mathrm{~A}$ written contract is only necessary in the event that the building master wants the architect to undertake additional work and if a vast price has been agreed with regard to the erection of a building on the land of the building master in accordance with the architects' plan (Article 1793 CC) ${ }^{57}$. Furthermore, all agreements to which the House-building Act is applicable, have also to be laid down in writing (Article 7 Housebuilding Act). Notwithstanding all these provisions, architects have a deontological obligation to conclude a contract in writing with their building master (Article 20 Deontological Code).

Of course it is strictly forbidden for the architect to intentionally mislead his contracting party in order to obtain an agreement or to use violence for this aim. Since there is an information asymmetry between both parties, the architect has the obligation to inform his inexperienced client. If he fails to do this, he can be held liable. ${ }^{58}$

The object of the architectural contract is to determine a programme and a budget. ${ }^{59}$ This programme is, as held above, of public interest. It follows therefore that there has

5 Rigaux 1975, p. 226

56 Antwerp 4 December 2002, N. .J.W. 2003, ed. 43, 1000, annotated by W. Goossens.

57 It is possible to contractually agree that a written agreement is not necessary. However, this is not easy to prove in the event of a dispute. Laurent, pp. 79-88.

58 Court of First Instance Brussels 21 January 1958, R.J.I., 275.

59 Antwerp 10 November 1999, A.J.T. 1999-00, 969; Ghent 9 November 1993, A.J.T. 1994-95, 67, annotated by B. De Temmerman; Pas. 1993, II, 18; R.W. 1993-94, 1235. 
to be an agreement on the work which has to be carried out by the architect within a certain period of time, as well as on the fact that a price has to be paid by the building master for the work which has been executed. Furthermore, parties have to agree on all other essential and substantial special conditions. ${ }^{60}$ To make sure that both parties have the same object in mind, the programme should be refined by the fixing of a budget. This budget approximates the expenses that the building master has to bear and should be determined before the contract is concluded. Nevertheless, the exact sum does not have to be determined in advance (Article 1710, 1711(6) and 1787 CC). In this way, one also tries to ensure that the financial resources of the building master are sufficient for the execution of the programme. ${ }^{61}$

The legal cause is the underlying reason which causes parties to agree to, and conclude, the contract. As held by Article 1131 CC, an agreement without a cause or with a false or illicit (unlawful) cause, has no consequences and is void. This is the case when the cause is prohibited by law, is contrary to good morals (for example collusion between the architect and the entrepreneur (Article $6 \mathrm{AA})$ ) or is in violation of public order.

The content of the architectural contract is not limited to the provisions in the contract itself. Moreover, the contractual freedom and the autonomy of the parties involved is not even unlimited. Articles 1792 and 2270 concerning the ten year liability principle of the architect and the entrepreneur have coercive force as well as does Article 1793 CC on the proof of additional work in the event that a certain price has been agreed on. ${ }^{62}$ These Articles which were already referred to in paragraph 5.1, will be discussed in more detail in paragraph 6.5.3.2. Furthermore, as held by Article 1135 CC, contracts do not only oblige the parties to honour what is specifically agreed to, but also encompass all the consequences which result from equity, usage and the law, according to the nature of the contract. The Civil Code's provisions on entrepreneurship do not contain an enumeration of the entrepreneur's (and thus the architect's) tasks, nor those of the building master. Only by studying the general rules on entrepreneurship stated in Article 1787 CC and further, can some important characteristics of the architectural contract and the obligations of the contracting parties be derived, taking into account the specific demands of the profession. As will be seen, only Articles 1792 and 2270 CC specifically deal with building works, while the other Articles are applicable to entrepreneurship in general.

Lastly it should be noted that the Civil Code does not contain a definition of entrepreneurship. Nevertheless, Article 1787 CC gives an indication. It states that if one hires someone to execute a certain work, one can agree that that person will only offer his labour or services, or that he will also deliver the materials. Entrepreneurship concerns thus the creation/execution of a certain 'work' and not the purchase/sale ${ }^{63}$ of it, even if

Brussels 24 January 1972, T. Aann. 1980, 187, annotated by De Nève.

61 Rigaux 1975, p. 243.

62 Baert 2001, p.32.

63 The transfer of ownership takes place at the moment of delivery and by 'natrekking' in the case of immovables. 
the entrepreneur delivers the material himself. ${ }^{64}$ The result is that the entrepreneur's labour is his main obligation, even if he has to deliver the materials. As held above, Belgian case law and doctrine consider the architect as a type of entrepreneur. Article 1787 $\mathrm{CC}$ indicates thus that the entrepreneur has to execute and deliver a certain work to his client.

\subsection{Obligations of the architect}

The obligations of an architect with a full mission can be summarised as follows: the design of a plan, the delivery of the plan to the building master, and the supervision of the execution of the building works within the agreed period. The intervention of the architect in general consists of four phases:

- Provision of assistance and advice to the client

The architect has to inform his clients about the desired methods/materials to be used, about the possible risks of the construction, etc. He also has to inform his client about the applicable legal rules, such as building prescriptions, and advise the building master about the choice of entrepreneur, check the latter's registration ${ }^{65}$, and study the different offers made.

\section{- Determination of the programme and the budget}

The determination of the programme and the budget takes place after the architect has obtained information about his client's desires. As noted above, this is the object of the entrepreneurial contract. The architect has to stay within the limits of the budget (Article 16 Deontological Code) and also has to check the costs of the entrepreneur. ${ }^{66}$ In this regard it should be noted that Article 1793 CC indicates that neither the architect nor the entrepreneur can demand a higher fee unless the building master has given his permission for the higher fee in writing. It follows that the architect has to warn his client if the agreed budget will be exceeded, and has to verify whether his client agrees with this. ${ }^{67}$ This determination takes place before the architect starts the actual work for which the legislator had given him a monopoly. These tasks are described hereunder. With regard to the setting of the price, reference should be made again to paragraph 3.6.3.2 of this book where it was held that the European Commission held that the recommended fee scale that was created by the Belgian Architects' Order in 1967 and which got binding force by Royal Decree in 1985, violated EC competition law. ${ }^{68}$ Recommended minimum tariffs are generally created to coordinate the conduct of architects so that architects whose costs are lower are dissuaded from lowering their prices. Consequently, the recommended fee scale was revoked by the Order.

64 De Page, 1957, nr. 870; Duranton 1844, XVII, nr. 250; Duvergier 1837, nr. 335

65 Supreme Court 9 June 1997, Arr.Cass. 1997, 625 ; Bull. 1997, 649 ; Fiskoloog 1998, ed. 646, 1 : J.L.M.B. 1997, 1276.

66 Court of First Instance Brussels 1 September 1998, T.B.B.R. 2000, 56.

67 Liège 15 May 2008, R.G.A.R. 2008, afl. 10, nr. 14448; T. Aann. 2990, afl. 1, 70; Liège 6 May 1992, J.T. 1992, 797; J.L.M.B. 1992, 1268, annotated by B. Louveaux.

68 See also paragraph 11.3.6.4. 


\section{- Design of the plan}

As stated before, the architect has been given a prerogative by the Architects' Act to design plans for constructions which require a building permit. He therefore has to assist the building master with obtaining a building permit by designing a plan which fulfils all the legal requirements.

Such a plan, of course, has to be without technical faults (stability, safety, durability), in conformity with the legal regulations ${ }^{69}$, etc. To be able to do this, the architect has to make a study of the soil, the foundations and all factors which are important when it comes to designing a proper plan. If he is not able to do this, he has to engage an expert with sufficient skills. Since architects can hire engineers to perform certain specific technical design services for which architects are not sufficiently educated, it can be argued that the monopoly of the position is less strict. ${ }^{70}$ However, architects have to hire professionally skilled specialists.

The architect does not have to guarantee that a building permit will be granted (obligation of means); however, his design has to comply with the applicable legislation (obligation of result).

\section{- Supervision of the execution of the building works}

As held by Article 4 AA, the cooperation of an architect is required for the drawing up of the plans and the supervision of the execution of the building project. A full supervision means the verification of whether the project is built in conformity with the plans, according to the state of the art, with the appropriate safety requirements, with the building regulations, etc. However, since the architect's tasks have a strictly intellectual character, he does not have to guarantee a good execution of the building contract by the entrepreneur in terms of the building master. He does not have any construction obligation and cannot even fulfil any construction tasks due to the incompatibility stipulated in Article 6 AA.

With regard to his supervisory tasks, the architect is not obliged to be present at the building site at all times. ${ }^{71}$ The number of verifications depends on the danger and risks associated with the building works, their importance, the nature of his obligations, and the competence of the entrepreneur, etc..$^{72}$ However, at crucial moments, when important steps are taken, the architect has to be present. ${ }^{73}$ The daily 'supervision' rests on the entrepreneur. ${ }^{74}$ In this regard it should be noted that there is no contractual relationship

69 See Article 17 Deontological Code; Ghent 9 December 1994, R. W. 1995-1996, 90.

70 Supreme Court 3 March 1978, Arr.Cass. 1978, 780; R.W. 1978-79, 711; T. Aann. 1981, 262, annotated by Krings; J.T. 1979, 28, annotated by Krings; Pas. 1978, I, 759; , R.C.J.B. 1982, 176, annotated by M. Alexandre; R.J.I. 1979, 7 .

71 Brussels 18 October 2002, R.J.I. 2003, 195; Antwerp 14 October 2003, N.J.W. 2003, 1266, annotated by W. Goossens.

72 Brussels 23 January 1975, T. Aann. 1975, 146; Herbots 1980, p. 231.

73 Antwerp 14 October 2003, N.J.W. 2003, ed. 50, 1266, annotated by W. Goossens; R.W. 2005-06, ed. 22, 863; TBO 2005, ed. 2, 110, annotated by M. Debaene and A. Van Grunderbeek; Ghent 18 April 1997, A.J.T. 1999-00, 41, Brussels 23 January 1975, T. Aann. 1975, 151, Dendermonde 21 June 2001, T. Aann. 2002, ed. 2, 159.

74 Brussels 18 October 2002, R.J.I. 2003, ed. 3, 195: Brussels 30 September 1999, T. Aann. 2000, 146; Brussels 3 February 1988, R.J.I. 1988, 275. 
between the architect and the entrepreneur which means that the architect does not have any legal authority over the entrepreneur, only a technical one. It follows that the entrepreneur is free to neglect the instructions of the architect and to decide that the work has to be executed in a way of his own choosing. ${ }^{75}$

However, if the entrepreneur does not take into account the advice given by the architect, the architect would be wise to write down his advice and inform the building master about it, so that the latter is aware of the possibility of putting the entrepreneur in default. If the architect does not warn his client, he risks being held liable for improper supervision of the building work. The architect will not be held liable, however, if he can prove that, although he supervised the works frequently, he could not prevent the damage or that he took every necessary measure to prevent it. Architects are always allowed to engage experts to assist them during the verification of the building works.

It follows that the theory that the architect has -due to his supervising task- the obligation to make sure that the building is constructed in conformity with the project and without any defaults, is incorrect. ${ }^{76}$ His only occupation is to make sure that the entrepreneur comprehends the technical documents (directions a priori) and to control the execution (verifications a posteriori). ${ }^{77}$ Articles 28-30 of the Deontological Code also mention these tasks. It should be noted that the architects' supervision task is, in principle, an obligation of means, not an obligation of result. However, often the result is the only way to determine whether the supervision of the architect was sufficient. Therefore, the architectural obligation is often treated by courts as an obligation of result. It has become clear that the execution of the contract of the architect and that of the entrepreneur run parallel, and that the architect is the supervisor of the building works but is not the entrepreneur's superior.

\subsection{Obligations of the building master}

The main tasks of the building master are the following ${ }^{78}$ :

- Give the architect and the entrepreneur the opportunity to execute their work.

This means that he has to give them access to the terrain and, in the event that this is agreed on, to put the necessary materials at the entrepreneur's disposal and make sure that all necessary permits and authorisations, such as the building permits, are available. If the building materials are not handed over to the entrepreneur, the architect is also hindered in his supervisory function. Furthermore, next to this duty to cooperate, the building master also has a duty to abstain from interfering in the architects' and entrepreneurs' work. Since the architect does not only have to take into account the interests

75 The sub-contractors of the entrepreneur are also independent of the entrepreneur and are not subjected to his orders.

76 Soinne 1969, p. 572.

77 De Caluwé, annotation under Supreme Court of the Netherlands, 4 December 1970, L'entreprise et le droit, 1972, p. 41; Flamme \& Lepaffe 1966, nr. 398.

78 Pothier 1766, nr. 404 and 410; Kluyskens 1952, IV, nr. 353. 
of his client, but also those of society as a whole, he cannot reject his responsibility if the building master interferes with his work. The architect can therefore not invoke an order of his client to decline his responsibility towards third parties. ${ }^{79}$ However, the architect is not liable if the building master is a specialist in his field. ${ }^{80}$ In such a case, the latter has to bear the consequences of his own actions. It follows that a building masterengineer who overrides the architect's conception of the foundations with his own views, is personally responsible for his decision. ${ }^{81}$ Every time the building master interferes with the architect's prerogatives, he violates the contract. The building master is not allowed to contract with an entrepreneur without informing and consulting his architect. He also has to withhold from giving instructions to the entrepreneur without the architect's consent, from approving the works, accepting their delivery and from paying the entrepreneur's bills, without the architect's approval. ${ }^{82}$

However, it is important for the architect, as well as for the entrepreneur, to refuse performing more services, and to ask for the judicial resolution of the contract every time the building master does not take into account his advice. ${ }^{83}$ In such a situation, the professional should ask to be relieved from liability. ${ }^{84}$

\section{- Provide all necessary information}

The building master has to provide the architect and the entrepreneur with all relevant information in order to fulfil his task properly. He has to inform the architect, as well as the entrepreneur, if he is aware that special precautions have to be taken.

\section{- Pay the price}

The execution of the work and the delivery within the time limits constitute the basis for the duty to pay, not the approval. It follows that if the building master refuses to approve the works without any justification, the entrepreneur still has the right to be paid. If the building only contains small defects, full payment cannot be refused, but a partial retention is justified.

As held in the preceding paragraph, it should be noted that in the event that a fixed price has been agreed on, as meant in Article 1793 CC, this price cannot be augmented, not even in the event of a rise in building material costs, an increase in wages or adaptations to the plan, unless written permission is granted for these adaptations and the augmentation of the price has been agreed upon. Article 1793 CC is, however, only applicable in the event that the building master is the owner of the territory on which the construction is being undertaken.

It aims to protect the building master-owner since he may have invested a lot of his wealth and deserves protection. Building masters who do not own the territory do not need this protection since they have a sales contract and will feel less 'obliged' to pay an

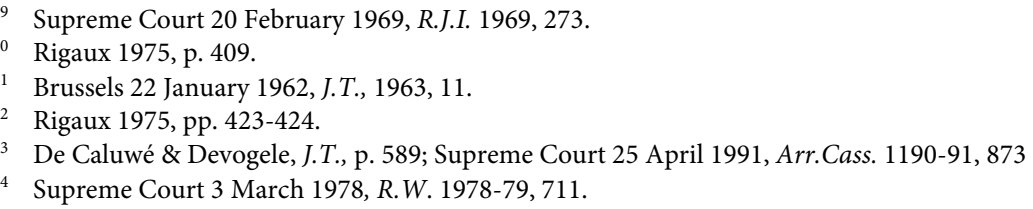


additional sum. In the event that more money is asked, they will refrain from buying and will not lose their prior investment. However in the event that the architect/entrepreneur has to fulfil more work than was initially presumed, for example due to an adaptation of the plan and extra calculations due to unforeseeable difficulties with the territory such as subsidence, additional payment can be asked since in such a case, one presumes that the architect/entrepreneur could and should not have been aware of the said difficulty.

The price does not have to be determined in advance. In principle, parties can agree to determine the price after the work has been executed. In the event that the contract does contain a provision on remuneration, the architect still has the right to be paid. In such a case, the budgetary limits of the client have to be taken into account. Even though the architect is not obliged however to ask for payment for his services,$^{85}$ the Councils of the Order can decide that when an architect asks such a low fee that it causes him to have an abnormally high number of clients, the honour and dignity of the profession are harmed. ${ }^{86}$ In general however, the honorarium of the architect is laid down in the contract and is usually proportional to the costs of the building work. With regard to the amount of the architects' honoraria, it should be noted that the National Council of the Belgian Order of Architects has created a scale of minimum honoraria in 1967: Deontological Norm Nr. $2 .{ }^{87}$ In 2002, the Order qualified this scale as a guide, with an indicative value. The scale contains a table in which the architects' honoraria are determined and are based on a certain percentage of the value of the works. However, this Norm has not been ratified by Royal Decree. It is therefore not opposable by the building master when not expressly included in the contract. In such a case, the honorarium of the architect will be determined by taking into account the work done, the difficulty and scope of it, and the level of responsibility of the architect. ${ }^{88}$ The Norm is thus not binding for judges. ${ }^{89}$ However, even though it has a mere advisory function, it was almost always used by architects as it was the only way to determine their salary.

As already indicated in Part I of this thesis, in 2004 the Court of Brussels decided that Deontological Norm Nr. 2 is void due to the content of European competition law as embraced in Article 81(2) EC. ${ }^{90}$ The reason was that the European Commission had

85 Ghent 9 December 1913, Pas. 1914, II, 47

86 Supreme Court 23 February 1978 , Arr.Cass. 1978, 743; Pas. 1978, I, 723; Council of Architects Namen, 26 June 1976, J.L. 1972-73, 15; R.J.I. 1972, 205.

87 See Chapter 3.6.3.2 and Chapter .

88 Liège 23 January 1995, J.T. 1995, 385; Pas. 1994, II, 3; R.R.D. 1995, 40.

89 Brussels 14 June 1971, J.C.B., 1971, I, 568; J.C.B., 1971, I, 568.

In the case of disagreement, parties can also turn to the provincial orders. However, its decision is only of moral value. If the parties still disagree, they can go to court. The judge, not bound by the decision of the Order (see Council of State 27 April 1994, Arr. R.v.St. 1994; R.A.C.E. 1994) will then determine the honorarium ex aequo et bono by considering the extent of the mission, the rendered services and the assumed responsibility: see e.g. Brussels 14 June 1971, B.R.H. 1971, 568; J.C.B., 1971, I, 568.

90 Brussels 28 September 2004, Jb.Hand.Med. 2004, 925. Eight years previously, this same Court held however that the president cannot prohibit the Councils from applying Article 12 of the Deontology Code, concretised in the Deontological Norm Nr. 2 concerning the scale of the architect's honoraria: See Brussels, 14 November 1996, J.L.M.B. 1997, 9 ; Jaarboek Handelspraktijken \& Mededinging 1996, 816; T. App. 1997, ed. 4, 30; T.B.H. 1997, 66. This was due to the fact that Article $40 \$ 1$ (1) of the 2006 Law on the Pro- 
qualified this Norm as a decision prohibited by Article 81(1) EC. This meant that national competition law is no longer allowed to lead to another conclusion and that the Deontological Norm Nr. 2 can no longer be expressly relied upon to determine the amount of the honoraria. ${ }^{91}$

Every time he has made progress, the architect can ask to be paid.

He can only interrupt his work after having duly warned his client that this will happen in the event that his honorarium will not be paid (exceptio non adimpleti contractus). However, when suspending his contractual obligations, he has to make a report of the situation, mention probable risks and remind his client of the legal obligation to involve an(other) architect to control the work in question..$^{92}$

Finally, mention should also be made of Article 1798 CC which holds that bricklayers, carpenters, workmen, craftsmen and sub-entrepreneurs who are involved in the erection of a building or another work which is constructed by an entrepreneur, have a direct claim against the building master which cannot be higher than the amount the building master owes to the entrepreneur at the moment that the claim is instituted. In this case, the sub-entrepreneur is considered to be an entrepreneur, and the entrepreneur to be a building master in terms of the sub-entrepreneur's own sub-entrepreneurs. The purpose of Article $1798 \mathrm{CC}$ is to give the unpaid sub-entrepreneur and his own subcontractors more security in the event that the main entrepreneur does not pay or goes bankrupt. By treating the entrepreneur as a building master, he is encouraged not to contract with impecunious sub-entrepreneurs. In such a case, he would risk having to pay the sub-sub-entrepreneur ${ }^{93}$. Article 1798 CC thus aims to protect these subcontractors. However, the Article is also beneficial for the building master, since workers who know they can turn to him are more encouraged to continue working in the event that the entrepreneur does not pay. As noted above, the sub-entrepreneurs and workers can only ask for payment of the amount which the entrepreneur still owes them. Furthermore their claim is limited to the amount the building master is still due to the entrepreneur. ${ }^{94}$ In this regard it should be noted that the workers of the entrepreneur have to be paid by the entrepreneur in accordance with the provisions of the con-

tection of Economic Competition (Act of 10 June 2006 on the Protection of Economic Competition, Official Gazette. 29 June 2006) which states that the President of the Council of Competition can take provisional measures to suspend practices which restrict competition, does not allow the President to enter into the sphere of competence of another institution (i.e. the Order's Councils).

91 In 1995 the President of the Belgian Competition Council came already to the same conclusion since he held that architects can be qualified as undertakings as meant in Article 2, $1^{\circ}$ of the 2006 Law on the Protection of Economic Competition and that a collective fixation of honoraria restricts the freedom of economic undertakers and thus violates Article 3 of this law: See President Council of Competition, 31 October 1995, A.J.T. 1995-96, annotated by J. Billiet; J.L.M.B. 1996, 263; J.T. 1996, 346.

92 Rigaux 1975, p. 482.

93 The text of the Article makes clear that it cannot be applied by sub-sub-sub-entrepreneurs and only by workers of the main entrepreneur. Nevertheless, the workers of the sub-entrepreneur are protected due to the fact that the sub-entrepreneur can institute claim against the main entrepreneur which includes their wages.

94 Dirix 1984, nr. 145; Supreme Court 21 December 2001, Pas. 2001, I, 22007; T.B.H. 2002, 443, annotated by W. Derijcke. 
tract. The building master, on the other hand, only has to pay for good work. He never has to pay more to the workers than he has to pay to the entrepreneur in the light of the quality of the work performed by the latter (and his workers).

\section{- Approve and accept the works}

If the works are performed in a good and professional manner, they should be approved and accepted by the building master. The building master is obliged to approve the work as soon as possible after the entrepreneur has put the construction at the building master's disposal, assuming that the work has been executed properly. If the building master does not accept the works without any reasonable justification, he has to incur the risk of the perishing of the building by a fortuitous event, or in case of force majeure (Article 1788 and 1790 CC) and the entrepreneur can demand the dissolution of the contract and claim damage compensation (Article 1184 CC). It should be noted that even though the building master has to approve the work, he is not obliged to really inspect it. However, if he approves it without inspection, he cannot complain about defects which might have been noticed in the event of an inspection. ${ }^{95}$ With regard to constructions which require the involvement of an architect, the building master is, in principle, obliged to get assistance from his architect with regard to the approval (Article 4 AA). Nevertheless, it is the building master who actually has to approve the work, not his architect (Article 1119 CC). ${ }^{96}$ If the House-building Act is not applicable, the approval can be done tacitly. If the construction was put at the building master's disposal, and if he did not complain within a reasonable time, it is presumed that he has tacitly approved the building work. The use of a building work for a certain time without any reservations is thus seen as approval, and obliges the building master to pay. ${ }^{97}$ The payment of the price without any reservation is mostly held to indicate approval. The entrepreneur has to prove that approval has taken place. ${ }^{98}$ After approval, the entrepreneur delivers the work and the building master has to pay for it. With the approval, the building master releases the architect/entrepreneur from their liability risk (except in case of hidden faults, deceit and a case of defects which are so serious that (part of) the building can perish). This will be explained in more detail in paragraph 6.5. The building master cannot refuse approval in the event of small defects. In such a case, he is allowed, however, to postpone payment of a part of the price. If there is no justification for delaying payment, the architect/entrepreneur can put the building master in default and demand acceptance (and go to court for this) ${ }^{99}$, demand payment of the price as well as of possible additional costs, resolve the contract and demand damage compensation, etc. (see Articles 1137, 1146 and 1184 CC).

95 Asser-Thunissen 1994, nr. 562

96 Only in the event of a 'mandate' can the architect approve the work himself.

97 Supreme Court 24 October 1963, Pas. 1964, I, 197.; Brussels 4 May 1995, A.J.T. 1995-96, 101

98 Supreme Court 8 January 1976, R.J.I. 1976, 115

99 Court of First Instance Dendermonde 26 April 1968, T. Aann. 1972, 12, annotated by R. Moors. 
Contract Law in Belgium

\section{Liabilities and risks of the architect and the entrepreneur}

\subsection{Introduction}

As noted above, this thesis aims to discuss the regulations pertaining to the architectural profession. In this regard not only are the requirements that the architect has to fulfil on a public level (diploma, registration, etc.) important, but also the architects' contractual and other tasks which in general are defined by private law. In the preceding paragraph the tasks of the architect were briefly described. However, due to the lack of any clear provisions on the extent and true scope of the architects' responsibilities, one is forced to study legal literature and case law. It then becomes noticeable that the ambit of the architects' responsibilities can only be determined by looking at the tasks and responsibilities of the building master and the entrepreneur. This becomes clear since Article 4 AA states that the architect has to supervise building works, which means that he has to supervise the work executed by the entrepreneur. Furthermore, in the event that other building partners are involved, their actions should also be taken into account. It is obvious that the responsibilities of the building partners are often interrelated, so it is not always easy to determine where the responsibility of one party ends, and where the responsibility of another begins. This is even more so due to the fact that the Civil Code only contains a few provisions on this matter. It follows that, in order to get a better understanding of the extent of the architect's responsibilities, it is useful to discuss the most important liability principles by discussing the respective Articles of the civil code, together with the leading viewpoints of the Belgian courts and legal doctrine. It should be noted that the question as to whether or not the architect is liable $e^{100}$, always depends on the circumstances of the case under consideration. As noted above, only the position of the self-employed architect will be discussed. ${ }^{101}$ In the following I do not try to provide the reader with an exhaustive set of rules to determine who is liable. Instead, my aim is to discuss the main rules which are applied by judges to determine whether or not the architect has violated his contractual obligations. Again it should be repeated that this will only be discussed with regard to the traditional construction process.

\subsection{Proof of liability}

The architect has to work as a professional with a reasonable amount of care and attention. Therefore he only commits a fault if he does not fulfil his obligation of due dili-

100 It should be noted that the liabilities which will be discussed within this thesis only concern contractual liabilities. Liabilities in tort and penal liabilities will therefore not be referred to.

101 The architect-official working for the state and the architect-employee who has an employment contract, do not work for their own account, and do not carry the risks of a self-employed architect. This means that they are not personally contractually liable with regard to the clients of their employer, which entails that Articles 1792 and 2270 CC are not applicable to them. Their liability with regard to their employer depends on their contract or statute. However, they are personally liable for torts towards third parties (Article 1382-1383 CC), within the limits of Article 18 of the Labour Agreements Act. This has nothing to do with the ten year liability principle: See X. 'Responsabilité des organes et des préposés des pouvoirspublics', Tijdschrift voor Sociaal Recht 1988, 249. 
gence. His creditor has to prove that he was negligent, imprudent or incompetent. However, it is very difficult for a consumer to collect 'proof of negligence, or the mistakes of a professional ex post. Furthermore, as will be explained in paragraph 6.5.3.2, the mere existence of a certain fault is often seen as proof of the architect's imprudence. It is possible that the contract foresees a certain obligation of result, especially with regard to the entrepreneur. ${ }^{102}$ If the contract foresees a certain result, and sometimes also if it is considered to be 'normal' that a building has a certain quality, for example that it is waterproof, it is argued that the professionals have an obligation of result, and the building indeed has to be waterproof, at least if the professionals want to escape liability. ${ }^{103}$ This also is the case with regard to the stability and insulation of the works, since this is considered to be a basic element of the design which can never be neglected. It follows that, if one claims that the architect made a contractual fault, one has to demonstrate, in principle, in addition to the existence of damage, that a certain fact is 'abnormal', that there is a causal link between this fact and the architect's behaviour, or that the architect can be held accountable for the 'abnormality' and that a pre-existing contractual obligation is violated. ${ }^{104}$ Even though the building master does not have to prove the fault of the architect as such, account should be taken of the fact that it is too easy -and not allowed- to suggest that a fault was made just because there is a defect in the construction. If this was possible, we would deal with obligations of result, which is, as stated above, not the case in principle. When the documents of conception are complete and sufficient, when the architect gives the necessary directions, and when the reports of his visits demonstrate a genuine and profound control, the entrepreneur, and not the architect will, in principle, be held liable for faults in the execution. ${ }^{105}$

Most of the actions of the building master against the architect tend to be concerned with the incompatibility of the building with certain aspects the building master considers to be essential, such as the comfort or stability (firmness) of the building. Since the architect is substantially responsible for the design and the supervision of the building works, he will be held liable in the event that the building work does not live up to its requirement due to a fault in the design or defective supervision. The task of the architect is, however, not the delivery of the building (this is the task of the entrepreneur) but the provision of an intellectual effort which is so concrete and precise that another person can materialize it (plan) and will materialize it (supervision) accurately.

As indicated in paragraph 6.4.1, architects have an obligation of means (negligence) to design with due care. If they do not see themselves as being competent with regard to a certain specific commission, they are allowed to engage an expert. ${ }^{106}$ However, architects are liable if the engaged expert lacks sufficient skill. As indicated before, the architect will easily be held liable if the design does not guarantee the stability of the building, nor good insulation and water tightness, which tends towards an obligation of result. Fur-

102 Simont \& Degrave 1970, p .166; Supreme Court 30 March 1967, Pas., 1967, I, 895.

103 See Rigaux 1993, p. 316 and 403; Van Gulijk 2009, p. 49 and p. 69.

104 Supreme Court 15 December 1995, J.L.M.B. 1986, 780.

105 Rigaux 1993, p. 383.

106 Baert 2001, nrs. 1199-1200. 
thermore, in the event that the architect exceeds the limits of his competence, he will also be strictly liable. ${ }^{107}$ Since the architect is a professional who certainly has to be aware of all building regulations ${ }^{108}$, he will be held liable if his design is not in accordance with the applicable legislation. This is an obligation of result. This does not mean however, that the architect also has to guarantee that a building permit is issued. Since the decision to refrain from granting a permit can also be based on a particular policy of the granting authority or for any other reason which are maybe not even known to the architect, he only has to make sure that his design is in conformity will the publicly known rules. Furthermore, if the building was erected on soil which is unfit to carry the construction, the architect is responsible, since he has a duty to inspect the territory and to determine what type of construction is desirable. The architect has an obligation of means, but is easily held liable if the stability or the final purpose of the building is hampered by a faulty examination of the land which seems very likely because severe damage will almost always occur when this obligation has not been duly performed. ${ }^{109}$ The architect also has an obligation to advise the building master on the selection of building materials. This is also sometimes considered to be an obligation of means ${ }^{110}$ which can also lean towards an obligation of result if the perishing or the solidity of the building is at stake. This means that, in general, the architect will not be liable if a normally informed professional would not have noticed the fault either. ${ }^{11}$ The architect is free to hire an expert to assist him, and will only be liable if he should have been aware that the expert was not well qualified for this task. If the budget is exceeded without the permission of the building master, the architect will also be held liable. However, since architects cannot be expected to predict every situation which can have an influence on the price, this is deemed to be an obligation of means. This means that certain margins can be allowed. Finally, as held in paragraph 6.4.1, the architect has an obligation of means with regard to his supervisory function. He does not have to be present at the building site at all times. Since the architect has to assist the building master at the moment of reception, he is also liable in the event that he could/should have noticed certain defects but did not mention them. With regard to this supervision obligation, the architect is thus liable if the building is constructed in the wrong way or with the wrong materials, a fault which he could and should have noticed. However, it should be noted that the existence of a construction fault does not automatically lead to a presumption of fault on the part of the architect. ${ }^{12}$ In general it can be said that if the architect has fulfilled his obligations with due care, and has supervised the building works accurately, he can be absolved of all liability. Since the organisation of the execution is the task of the entrepreneur sensu stricto (i.e. the building contractor) ${ }^{113}$, the architect has to reveal every

107 Van Gulijk 2009, p. 97.

108 Article 17 Deontological Code.

109 Van Gulijk 2009, p. 49 and p. 69. However it should be noted that Article 1792 CC which deals with the total or partial of the building only contains an obligation of means. See paragraph 12.5.3.2 of this thesis.

110 Deketelaere, Schoups \& Verbeke 2004, no. Xi.16; Laurent 1887, pp. 42-44.

111 Bergen 8 October 1990, J.T. 1991, 585; RGAR 1993, nr. 12.171

112 Brussels 25 June 1986, R.J.I. 1988, 5.

113 This also means that he has to make sure that the building site is not dangerous for other workers or third parties. 
fault in the execution of the work and demand their reparation. In this way the architect has to order the entrepreneur to start over and rebuild the construction or to use other materials. However, since the entrepreneur is not subordinated to the architect due to the absence of a contractual relationship, the architect cannot command him, and has to turn to the building master in the event that the entrepreneur does not listen to his advice. In this way the building master can remind him of his contractual obligations. On the other hand, if the entrepreneur discovers a fault of conception made by the architect, he has to notify him and refuse to execute the work until the fault has been corrected. ${ }^{114}$ As noted by Flamme, there is thus a reciprocal control of these building actors. ${ }^{115}$ This is logical, since both contracts are dependent on each other while the architect and the entrepreneur are third parties in their underlying relationship. The non-performance by the architect of his supervisory obligation does not constitute a force majeure situation for the entrepreneur. ${ }^{116}$ Even if the building master does not engage an architect to supervise the building works when this is required, the entrepreneur is liable for his own shortcomings. Even without supervision, he is obliged to follow the design or the building specifications and to work with due care so that his work is free of faults. ${ }^{1{ }^{17}}$ Nevertheless, due to the building master's obligation to engage an architect, in such cases the responsibility for damages is often shared between the entrepreneur and the building master. ${ }^{118}$

It is always important to determine the nature of the fault and the one responsible for it. Since the Civil Code does not determine anything about the respective liabilities of the architect and the entrepreneur, these liabilities are often determined by the degree of the entrepreneur's specialization and the delimitation of the tasks. ${ }^{119}$ Specialists are more readily considered to have an obligation of result. However, as noted before, in the event that the architects engage experts, they are liable if the hired specialist lacks sufficient skills. When damage arises due to the different faults of different parties which have concurred in such an indivisible way that it is impossible to determine which fault caused the damage - this means that without the fault of A the fault of B would not have been enough to cause damage - the building master can hold both professionals responsible for the same damage. ${ }^{120}$ As held above, the architect will be held mainly liable due to insufficient supervision or due to faults in his design. The entrepreneur, on the other

114 Flamme, 1975, p. 7; Court of First Instance Arlon 28 November 1972, J.L., 1972-1973, 213; Bergen 3 June 2002, R.G.A.R. 2003, nr.13765.

115 Flamme 1975, p. 7 ; Arlon, 28 November 1972, J.L., 1972-1973, p. 4.

116 Antwerp 9 October 1990, T. Aann. 1997, 164, annotated by J. Embrechts.

117 Court of Commerce Brussels, 27 November 1970, B.R.H. 1971, 203; Supreme Court, 20 May 1965, Pas., I, 1010; Brussels 13 May 1972 and Supreme Court 27 September 1972, unpublished.

118 Account will be taken of the degree of competence of the entrepreneur: the more specialized and better equipped he is, the more he will be deemed responsible for the damages. On the other hand, if the building master turns to an entrepreneur who is not very competent to execute the building work, the building master's responsibility will be considerably higher: See Delvaux 1968 n $^{\circ} 240$; Brussels 2 December 1959, R.J.I., 1959, 379. Full responsibility on the part of the building master is rather rare: Brussels 20 June 1960, J.T., 188. When the execution of the project is not supervised, the entrepreneur has the right to ask the building master for the dissolution of the contract and for damages.

119 Supreme Court 9 April 1970, Arr.Cass. 1970, 725

120 Brussels 19 April 1971, R.J.I., 1971, 113. 
hand, will be held liable in the event of damage caused by defective execution such as a deviation from the plan, as well as damage caused by the use of defective building materials or by violation of building regulations. Furthermore, in the event of insufficient guarding of the building site, or a delay in the works, the entrepreneur can be held liable, as well as if he failed to notice defects in the architect's plan ${ }^{121}$. If both the architect and the entrepreneur have violated their contractual obligations, they will be responsible in solidum ${ }^{122}$ and have to meet the costs of repairing the total damage. ${ }^{123}$ This means that if one party compensates the victim, it can start a proceeding in recourse against the other to get partial compensation. ${ }^{124}$ In this regard, it should be remembered that the responsibilities of the architect and the entrepreneur are distinct, since they arise from different contractual and incompatible obligations. ${ }^{125}$ The same applies when more architects are involved (for example one for the conception and one for the supervision of the execution) and a fault in the conception appears. Both architects can then be held liable, since it is possible that the architect responsible for the execution should have noticed the fault and should have corrected it. Nevertheless, the responsibility of the first architect is considered to have decreased due to the fact that he was not able to correct some aspects of his plans during the execution.

Lastly, it should be mentioned that it is possible to insert an exoneration clause in the contract. Since these clauses are an exception to the general rule that one is liable for one's own faults, they have to be interpreted restrictively. ${ }^{126}$ Of course exoneration clauses may not violate the law, undo the contract of its objective or are applied in cases of deceit or malicious intent. Moreover, the architect always has to keep a minimal amount of responsibility; he cannot reject every intervention whatsoever. Clauses which limit the liability period or the amount of compensation that has to be paid, or clauses which exclude compensation for consequential damage, are thus valid. However, Belgian case law is divided about the scope and validity of certain types of exoneration clauses. In its decision of 22 February 1963, the Court of Appeal of Brussels was already opposed to these clauses in the event that the stability of the building works was at stake,

121 See for example Brussels 28 June 1978, R.J.I. 1979, 139.

122 The responsibility in solidum has to be distinguished from the legal figure of 'passive solidarity' among parties as meant in Article 1202 CC. Since the professions of architect and entrepreneur are incompatible, and since the object of their contract is complementary yet distinct, they can not have solidary obligations. See: Brussels 22 May 1902, Jur.Comm.Brux. 1906, 392; Delvaux 1968, nr. 448. In such a case, a fault of both the architect and the entrepreneur is necessary for the damage to arise. They are both bound to compensate the whole damage, even though their separate faults did not cause the total damage: Supreme Court 2 February 1979, R.W. 1979-80, 51. The building master can turn to both professionals, but if he gets paid by one of them, he cannot turn to the other to get futher payment. It is possible however for parties to agree that the professional will only carry the consequences of his own faults: See Ar-co number 6 / 1sem 2006.

123 Supreme Court 2 February 1979, Arr.Cass. 1978-79, 626; T. Aann. 1981, 212, annotated by K. Ver Berne; Pas. 1979, I, 629; Brussels 12 October 2001, A.J.T. 2001-02, 740, annotated by G. Ballon; J.L.M.B. 2002 , ed. 17, 718; Antwerp 16 March 1994, Limb. Rechtsl. 1994, 21. Supreme Court 21 June 1984, T. Aann. 1997, 323; Brussels 19 April 1971, R.J.I., 1971, 113; Arlon, 28 November 1972, J.L., 1972-1973, nº 27, p. 213.

124 Brussels 20 January 1956, R.J.I. 1957, 3496.

125 Pourvoyeur 2000, p. 100.

126 Court of First Instance Leuven 21 February 1968, R.W., 1971-1972, col. 276. 
causing a threat to public safety. ${ }^{127}$ Furthermore, in Belgium, standard conditions which regulate the legal relationship between the architect and the building master and which possibly limits the architects' liability, are not commonly used, and will therefore not be discussed. ${ }^{128}$ In any case, exoneration clauses can never be invoked with regard to third parties. The limitation of the liability period will be discussed in detail in paragraph 6.5.3.2.

On the other hand, the architect and/or entrepreneur are allowed to take up all responsibility, except in the case of malicious intent or deceit on the part of the building master. ${ }^{129}$ It should be kept in mind that clauses to augment the responsibility of the entrepreneur do not lessen the architect's responsibility. ${ }^{130}$

\subsection{Liability before and after reception of the building works}

As noted above, in the traditional building process, a building master hires an architect and an entrepreneur to have a building constructed according to his wishes. After the architect and entrepreneur have executed their tasks, the building master should regain possession over his territory in order to inspect whether the building fulfils his desires. It follows that, after the architect and entrepreneur have completed their tasks, the build-

127 Brussels 22 February 1963, Pas. 1963, II, 274. The Court held that the ten year liability principle as stated in Article 1792 CC is of public order.

128 The Royal Decree of 26 September 1996, Official Gazette 18 October 1996 lays down exist standard conditions for public contracts (contracts from the government or local administrations). See also http://www.pinakes.be/static/pinakes_checklistoverheidsopdrachten.aspx, last consulted 15 November 2009. These regulate the relationship of the building master and the entrepreneur. Furthermore, the Flemish Building Confederation, an organisation representing around 9,000 building companies has created general conditions for private building works. These are not commonly used and are only applicable if parties agree so. Only Article 7.2 briefly refers to the tasks of the architect: the architect, as the designer of the building, has a full commission and thus has to supervise the building works as well. If the building master relieves him of certain tasks, he has to inform the entrepreneur immediately. The Article also states that the honorarium of the architect is never included in the amount of the offer of the entrepreneur and that the architect is never the mandatary of the building master, unless otherwise agreed. It is important to note that Article 35.1 indicates that the liabilities of the architect and the entrepreneur towards the building master are regulated by Articles 1789-1799 and 2270 CC. This means that, in general, the architect is the adviser of the building master and is only liable for faults in his design. The standard conditions indicate, however, that in the event that both professionals are liable, the building master can demand compensation from both, but only for the amount of the damage caused by them respectively. The building master cannot hold them liable in solidum. It follows that arbitration is also not commonly used in Belgium with regard to building disputes. Most arbitration decisions are taken by 'Cepina', the general Belgian Centre for Arbitration and Mediation. See http://www.cepani.be/NL/, last consulted 15 November 2009). However, parties are always allowed to bring their case before another institute. There are also arbitration institutes which specialise in the building industry. However, these have almost no activities and the same applies to the Reconciliation Commission for the Building Industry which was set up in 2001 by the Flemish Confederation for the Building Industry, the Royal Federation of Belgian Architectural Associations, the consumer organisation 'Testaankoop', and the Building Union Federation, an association which provides assistance to, and represents, entrepreneurs. See further: Verbist 2003, pp. 76-87.

129 Supreme Court 29 September 1972, Arr.Cass. 1973, 121.

130 Supreme Court 21 September 1979, Arr.Cass. 1979-80, 84. 
ing master is in principle invited by the entrepreneur to approve and accept the construction, so that the building work can be delivered to him. ${ }^{131}$

To be able to receive the work, it has to be put at the disposal of the building master. He has to be invited, sometimes obliged, to verify it (traditio). Mostly, the architect takes the initiative to organise the traditio. ${ }^{132}$ The traditio contains the proof of the completion of the building work, and is not regulated by law unless the House Building Act applies, or with regard to commissions emanating from the government or local public authori$\operatorname{ties}^{133}$. If the construction was built on the building master's territory, the entrepreneur will leave it, put it at the disposal of the building master, and hand over the keys. ${ }^{134}$ This is the first phase of the reception. If the traditio is accepted by the building master, the entrepreneur can ask to be paid. As noted above, the traditio brings about the transfer of risk (Article 1788 and 1790 CC and Article 5 House-building Act). ${ }^{135}$ It should be noted that, since the traditio (provisional reception) does not contain a final approval of the work by the building master, it does not necessarily entail the end of the entrepreneur's responsibility for certain apparent or hidden faults. ${ }^{136}$ This will be further discussed hereunder. Next, the work has to be accepted, which means that the building master has to express his approval of the executed work. This unilateral legal action is the second phase of the reception. Only the approval brings about further legal consequences between the parties. ${ }^{137}$ It can be done expressly or tacitly ${ }^{138}$, for example by the occupation of the work without making any reservations or complaining about any defect. ${ }^{139}$

However, the building master is not obliged to accept the work if the building does not contain the agreed specifications, or is not fit for its intended use. Since the task of the architect is to supervise the building works, the architect will normally assist his building master with inspecting and approving the building works. If the building master decides that the building work has been executed properly, he will approve the work and allow the entrepreneur to deliver it. By receiving the building work, the building master acknowledges, after verification, the good and entire execution of the obligations of the locator operis (architect and entrepreneur) and accepts the work done by them. ${ }^{140}$ After reception of the building works by the building master, the entrepreneur does not have to guard the construction anymore. ${ }^{141}$ The reception of the building work constructed by the entrepreneur under the direction of the architect, has the same effect on both profes-

131 As held by Article $1791 \mathrm{CC}$ the approval can also take place in parts in case the creation of the work is divided into different parts as well.

132 Ramboer, Evens \& Van Daele 2002, p. 13.

133 Royal Decree of 26 September 1996, Official Gazette 18 October 1996.

134 Asser-Thunissen 1994, nr. 561.

135 Ghent 16 January 1886, Pas. 1886, II, 108

136 Supreme Court 16 October 1969, R.C.J.B., 1971, 390, annotated by Glansdorff.

137 Supreme Court 24 September 1981, R.W, 1982-83, 1062.

138 Supreme Court 24 October 1963, Pas. 1964, I, 197.

139 Bricmont, 1971, nr. 70 ; Anwerp 24 May 1983, R.W. 1985-86, 2718; Ghent 20 September 1996, A.J.T. 19971998, 280, annotated by P. De Smedt.

140 Rigaux 1975, p. 492.

141 Court of Commerce Brussels 23 November 1982, T.B.H. 1983, 594. 
sionals: a transfer of risk. ${ }^{142}$ Articles 1788 (delivery) and 1790 (reception) CC are very important in this regard, and lay down this transfer of risk from the locator operis to the building master.

The moment of delivery is therefore very important, since a distinction is made between the moment before and after the delivery of the building works when determining the liabilities of the respective parties. This will be further discussed in paragraphs 6.5.3.1 and 6.5.3.2.

\subsubsection{Liability before the reception of the building works}

As held by Article 1788 CC, if the 'workman' uses his own materials and the construction perishes for whatever reason before it is delivered, he carries the risk unless the building master is in default with regard to accepting the work: res perit domino-res perit debitori (Article $1788 \mathrm{CC}$ ). This is even so in the case of force majeure or coincidence (risk for his own materials and no payment since the building work was not delivered) and is logical since the building master does not receive what he has contracted for. In such a case the 'workman' cannot ask to be paid. Since the present-day architect will normally not his use own materials, this Article is, in principle, only applicable to the entrepreneur. Whether the building master has to be put in default first depends on the contractual clauses. If he was at fault in accepting the works, he has to compensate the entrepreneur for his materials and his work.

Articles 1789 and $1790 \mathrm{CC}$ on the other hand are applicable to the situation in which the entrepreneur does not use his own materials to erect the construction. It is applicable in the event that the building was constructed on the building master's territory with the latter's own materials.

If the entrepreneur was only hired to execute the work and the building work perishes before it is received due to force majeure or coincidence, the building master has to bear the risk of the loss of his materials: res perit domino. In all other cases, the architect/entrepreneur bears the risk in the event that the building work perishes. In this way, the legislator of 1804 aimed to give consumers more protection. It follows that the entrepreneur is liable for the building master's damages if the building perishes due to his fault, whether or not this happened before or after delivery (Article 1789 CC). Since the professional is contractually obliged to deliver the building work in accordance with the wishes of the building master, he has to prove that there was a situation of force majeure or coincidence, which prevented him from performing his obligations correctly. The building master does only have to demonstrate the damage and the causal link between the damage and the involvement of the professional. He does not have to prove the professional's fault.

Whether or not the entrepreneur committed a fault before the work was received, while the building master was not in default in terms of approving the work (i.e. if the entre-

142 Liet-Veaux 1963, nr. 265. 
preneur committed a fault or if the building due to force majeure or coincidence), the entrepreneur cannot ask for payment (at the moment of delivery the contractually agreed performances cannot be established), unless the perishing was caused by a default in the building master's materials (Article 1790 CC). In such a case, the payment he already received has to be returned. It follows that if the architect/entrepreneur has not committed any fault, and the building work perishes anyway before the works are received due to the fact that the building master's materials were defective, the architect/entrepreneur is still entitled to get payment for his work. Even though this is not provided for in the Civil Code, it is held that if the defect in the materials could have been noticed by the architect/entrepreneur who failed to inform the building master, no payment can be claimed, and the professional is responsible for the damage. ${ }^{143}$ In this regard it should be noted that if the materials provided by the building master perish, the contract will normally end, since it has no object anymore. If the materials do not perish but only the work executed does, whether or not this is imputable to the entrepreneur, the entrepreneur has to repair it and start over without being entitled to obtain compensation for this, unless the perishing was caused by a default in the building master's materials. ${ }^{144}$

It should be noted however, that none of the Articles mentioned in this paragraph have coercive force. It follows that parties can therefore always depart from their content by contract. ${ }^{145}$ They are also applicable in the relation between the entrepreneur and the sub-entrepreneur.

\subsubsection{Liability after reception of the building work}

The Civil Code only refers to one moment of delivery being the final reception of the building work. However, it is possible that, if the building does not contain any major faults, the building master can formulate his reservations, and provisionally accept the work while granting the entrepreneur some additional time to repair any defects. If reparation is impossible, or has not taken place within the additional time period, the building master can hold the architect, the entrepreneur, or both, liable. In situations in which specialists were involved, these can be held liable as well. Inspired by the provisions of the House-building Act, parties often contractually foresee a provisional and a definitive reception. The definitive reception generally takes place one year after the provisional reception. The building master is then granted a period of one year to discover visible defects which are not serious since, after the moment of definitive reception, these defects become his risk.

1. In principle: no liability of the architect/entrepreneur after reception

If the building master refuses to accept the work without any justification, he commits a contractual fault for which the architect/entrepreneur can seek damages. The building

143 Court of Commerce Ghent, 26 October 1923, J.C.Fl. 1925, 72, annotated by E. Vrebos.

144 Diephuis 1889, p. 370.

145 Delvaux 1968, nr. 28; Supreme Court 29 September 1972, Arr.Cass. 1973, 121. 
master is not allowed to refuse reception in the event of a minor defect. He then has to make a reservation in the report of provisional reception. If he does not do this, the professional can summons him to obtain payment.

Even though the architect normally assists the building master with the approval of the building work, the building master decides. If the architect did not warn of any defects in the work or in the materials which he could/should have discovered, he will be held liable, even though the building master has approved the work. ${ }^{146}$ Furthermore, it should be noted that before the entrepreneur leaves the site, the architect has to make a verification report to safeguard his own interests and the interests of the building master. In this way he can prove the effectiveness of his controls and make sure that the building master cannot change his former decisions. The verification report is added to the reception report. By the reception report the building master declares that he is aware of the content of the verification report and has received the work. It proves that the architect has informed his client about all the important facts at the moment of approval.

The entrepreneur is therefore obliged to deliver the building works, while the building master is obliged to approve/disapprove them.

With regard to building works, however, it is common that parties agree that a provisional reception will take place followed by a maintenance period (mostly of one year ${ }^{147}$ ) to compensate for any difficulties which surround the verification by an inexperienced building master. The contracting parties can therefore agree to prolong the verification period so that the building master can test the conformity and sustainability of the building. In this way, the reception can be divided into a provisional reception and a definitive reception, separated by a prolonged verification or probationary period. ${ }^{148}$ During this period the building master takes possession of the building and acknowledges the completion of the work. He will use the period to find out whether there are any faults and to criticize any non-conformity. ${ }^{149} \mathrm{He}$ is thus in the position to verify whether or not the building fulfils all the necessary requirements over a certain period. However, the professionals will no longer be liable for any visible defects. ${ }^{150}$ From the moment of provisional reception, the building master has to bear the risk of loss by force majeure or coincidence.

If the parties agree to split the reception into two phases, they can decide which effects the provisional reception will bring about. ${ }^{151}$ They can, for example, decide that the provisional reception will be the starting point of the ten year liability regime. ${ }^{152}$

146 Bergen 30 October 1991, R.R.D. 1992, 52

147 Ramboer, Evens \& Van Daele 2002, p. 14

148 For building projects to which the House-building Act is applicable, a two-staged reception is even obligatory. As held by Article 9, the definitive reception can only take place at least one year after the provisional reception.

149 Brussels 27 February 1967, unpublished.

150 Ramboer, Evens \& Van Daele 2002, p. 16.

151 Supreme Court 6 November 1959, unpublished. It is the architect who has to make sure that, if wanted, the possibility of reception in two stages is laid down in the contract.

152 This is not required however: Liège 28 June 2002, R.R.D. 2002, ed. 105, 458; T.Aann. 2003, ed. 8; Ghent 24 April 1997, A.J.T. 1998-99, 894; Brussels 25 October 1994, R.J.I. 1995, 91. 
After the maintenance period has ended, the final delivery/final reception takes place. As held by the preparatory works ${ }^{153}$, the Code Civil contains the principle that the reception ends, in principle, the contractual responsibility of the locator operis. This is opposed to the thirty year prescription stipulated in Article 2262 CC. The legislator had to reconcile two conflicting social interests: that of the building master who needs the full possibility to control the quality of his building, and that of the architect and the entrepreneur who need legal security so that they cannot be held responsible forever. Therefore the locatores operis -the entrepreneur as well as the architect ${ }^{154}$ - will only be liable until the moment of reception by the building master, except for the situations as described in Articles 1792 and 2270 C.C. which contain the ten-year responsibility of the architect and entrepreneur with regard to immovables, in case of deceit and in case of hidden defects.

It follows that if the building master approves the work, all visible defects are cov$\operatorname{ered}^{155}$ and the architect is no longer liable for the execution faults of the entrepreneur about which he has warned his building master. However, when the verification has been executed in a negligent way, the architect can be held responsible. ${ }^{156}$ Nevertheless, since the architect does not have an obligation of result, his behaviour should be compared to that of a professional being normally prudent and attentive. As noted above, if the architect, contractually responsible for faults committed during the reception, is found liable, it is possible that he can institute a tort law recourse against the entrepreneur if the latter made a fault which a 'reasonable' entrepreneur would not have committed.

As noted above, both the architect and the entrepreneur are no longer liable for their work except for hidden defects and in a case of deceit. This means that the entrepreneur is still liable for hidden defects even if they are not hidden intentionally. They also continue to be liable over a ten year period for visible defects which put the stability of the building in danger (Articles 1792 and 2270 CC).$^{157}$ Visible defects ${ }^{158}$ which do not endanger the stability (firmness) of the building are thus at the building master's risk. This will be further discussed hereunder. It should be noted however that the act of reception does not release the architect or the entrepreneur from their liability towards third parties. ${ }^{159}$

It should also be noted however that one is not obliged to foresee in a double delivery. Only in case that the House-building Act is applicable, or if the contract foresees it, a double delivery and a double reception are mandatory.

153 Fenet 1827, XIV, pp. 261-262.

154 Brussels 6 October 1973, J.T., 1974, 43; De Page 1957, IV, nr. 882-883.

155 Brussels 8 February 1990, R.J.I. 1990, 179.

156 Delvaux 1968, I, nr. 470.

157 Supreme Court 18 November 1983, R.W. 1984-85, 47.

158 Supreme Court 18 May 1961, R.W. 1961-62, 1961.

159 Ibid. 


\section{Exception 1: Hidden defects}

Even though the Civil Code does not contain any provision dealing with hidden defects in building works, very soon after its introduction in 1804, judges held that the entrepreneur should be liable for hidden defects -i.e. defects which are not visible to the lay$\operatorname{man}^{160}$ - even if these defects do not endanger the stability of the building as intended in Article 1792 CC, since the building master would not have approved such defects if he was aware of them at the time of approval. ${ }^{161}$ This has often been confirmed by the Supreme Court. ${ }^{162}$ It follows that the architect and entrepreneur are contractually liable for hidden defects which render the building unfit for its intended use, or which diminish the opportunity to use it in such a way that the building master would not have accepted the work, or only against a lower price, if he had known of these defects. ${ }^{163}$ As noted above, the professionals have, in principle, only an obligation of means. However, the liability for hidden defects as well as the ten year liability period which will be discussed next, are based on a guarantee-obligation which is enclosed in the contract every time the building master has no security about the definitive quality of his building. In such cases, the building master only has to prove the existence of the damage, the existence of the defect and the accountability of the defect, to the professional. The guarantor on the other hand, has to prove that the defect was visible, that he is not responsible for the damage (for example in case of the wrong use of the building) or that there is a situation of force majeure or coincidence. ${ }^{164}$

In the event that the building is affected with a hidden defect and does not contain the promised positive qualities or the qualities which can normally be expected at the moment of delivery, while these defects could and should not be noticed by the building master, the professional cannot hold that the building master approved the works to escape his liability. Moreover, the building master does not even have to prove the professional's 'fault' but only the existence of the physical defect and the professional's accountability. He can hold the architect, the entrepreneur, or both, liable (in solidum). ${ }^{165}$ Of course, the architect/entrepreneur or both will try to prove that the building is not defective to escape liability. ${ }^{166}$ Their defence that no fault has been committed will not

${ }^{160}$ If the defect is hidden for the building master but could have been discovered by the architect, the judge will decide whether it will be qualified as a defect or not. See Supreme Court 31 May 1978, T. Aann. 1983, 30 .

161 See e.g. Ghent 12 August 1864, B.J. 1965, 919.

162 See e.g. Supreme Court 25 October 1985, T. Aann. 1986, 204, annotated by J. Embrechts; Supreme Court 18 May 1987, R.W. 1988-89, 1124; Supreme Court 8 April 1988, Arr.Cass. 1987-88, 1000; Supreme Court 15 September 1994, Arr.Cass. 1995, 29.

163 See Kluyskens 1952, IV, nr. 352; Supreme Court 18 November 1983, R.W. 1984-85, 47; Arr.Cass. 1983-84, 323; Pas. 1984, U, 303; J.T. 1984-549; Supreme Court 25 October 1985, T. Aann. 1986, 240, annotated by J. Embrechts; Arr.Cass. 1985-86, 270; R.W. 1988-89, 670, annotated by C. Van Schoubroeck; as. 1986, I, 226; J.T. 1986, 438 .

164 Supreme Court 6 October 1961, R.W. 1961-62, 783.

165 The sub-entrepreneur also has to guarantee his liability for hidden defects towards the entrepreneur, even if the works executed by him are approved by the building master and the entrepreneur. In the event of disagreement, the building master will turn to the entrepreneur while the entrepreneur will turn to the sub- entrepreneur: Supreme Court 25 October 1985, Arr.Cass. 1985-86, 270.

166 Supreme Court 15 December 1995, Arr.Cass. 1195, 1135. 
benefit them since the mere existence of a defect proves that they did not create a proper and safe building. Nevertheless, both the architect and the entrepreneur can contest their responsibility by proving their 'invincible ignorance' ${ }^{167}$, force majeure or coincidence.

The hidden defect can be a defect in the design, the materials ${ }^{168}$, the manner of execution or in the information, precaution or repair duty. Not only the entrepreneur, but also the architect who had to notice the defect, can be held liable since the building is less fit for its intended use, or less durable, causing the building master to suffer damage. ${ }^{169}$ Therefore, the building master can demand compensation or reparation or institute a proceeding against the architect/entrepreneur based on the contractual shortcoming (Article 1146 CC).

It is important to note that the guarantee for hidden defects is limited to defects which do not endanger the building's stability. The reason is that defects which do endanger the building's stability fall under the scope of the ten year liability period described in Articles 1792 and 2270 CC. ${ }^{170}$ Nevertheless, as noted above, the hidden defect has to be sufficiently serious so that it diminishes the building work's quality, or makes the construction unfit for its intended use so that the building master would be allowed to refuse approval and reception. Furthermore, the fact that the building master did not notice a certain irregularity does not make this defect a hidden one. The building master is presumed to have examined the building with due care. Even though he is not obliged to inspect it, he cannot be rewarded for his lack of involvement. If he is not competent to verify the building himself, he has to get assistance (for example through the use of an expert). ${ }^{171}$

The period in which the architect and/or the entrepreneur can be held liable for hidden defects is not defined. In any case, it is held that the building master should have a reasonable amount of time to complain about defects which become visible after the work has been received. ${ }^{172}$

This period is as long as is reasonably necessary to ensure that the building has been properly executed. The liability period is thus limited in time, and is determined by practice and reasonableness. Its length depends on the seriousness of the defect and the circumstances of the case, such as the building master's experience and the promises of the architect or the entrepreneur. The judge will decide on a case by case basis. ${ }^{173}$ It is

167 Supreme Court, 6 October 1961, R.C.J.B, 1963, p. 5, annotated by Lagasse.

168 In such a case, the building master can also turn to the supplier (Article 1615 CC): Ghent 26 January 1995, A.J.T. 1995-96, 49

169 Supreme Court 15 September 1994, R.A.C. 1995, 29; Supreme Court 15 September 1994, R.W. 1995-96, 454.

170 Supreme Court 18 November 1983, R.W. 1984-85, 47.

171 Flamme \& Lepaffe 1966, nr. 503.

172 Supreme Court, 15 September 1994, R.W. 1995-96, 454.

173 Supreme Court 8 April 1988, Arr.Cass. 1987-88, 1000; Supreme Court 15 September 1994, Arr.Cass. 1995 29. Often a period of 1 or 2 months is applied. Supreme Court 8 April 1988, Arr.Cass. 1987-88, 1000; Supreme Court 15 September 1994, Arr.Cass. 1995, 29. If it seems that the building master has accepted the 
held that this period can, in no event, be longer than ten years. ${ }^{174}$ The period starts to run at the moment of approval, or at the moment at which the building master was put in default to verify and approve the building works. Sometimes it is also held that the period only starts at the moment of discovery of the defect. In any case, a possible claim has to be instituted within this period. ${ }^{175}$

It should be noted, however, that since this liability is not one of public order, parties can contractually agree that the architect/entrepreneur will not, or only for a certain time, be liable for hidden defects. ${ }^{176}$ Such contractual clauses will have to be interpreted critically and can never indicate that professionals do not have to work in accordance with good practice. The more specialised the professional, the less he can invoke such a clause.

In any case it should be noted that, also with regard to hidden defects, architects are only liable if the client demonstrates that the architect was negligent. If he has taken all required precautionary measures or in a case of force majeure, he cannot be held liable for the damages.

3. Exception 2: Perishing of the building due to serious defects

Articles 1792 and 2270 CC foresee a special contractual liability regime which renders architects and entrepreneurs liable during a period of ten years after the acceptance of the work, for certain serious defects caused by them, whether or not these defects were visible at the moment of reception. ${ }^{177}$ This is due to the fact that it is possible for the building master to know the existence of the defect, while he may not realize the consequences of it.

As held by Article 1792 CC:

"When a building, constructed at a fixed price, perishes totally or partially due to a defect in the construction, even due to the unsuitability of the land, the architect and the entrepreneur are liable for this during ten years."

Article 2270 CC, situated under the chapter dealing with 'prescription', holds:

"After the expiration of ten years, the architects and the entrepreneurs are dismissed from their liability with regard to big projects which are executed or leaded by them."

These Articles were created to protect the building master and for reasons of public safety. Since the ten year liability period is of public order, and since the Articles have

defects, for example because he did not act for a very long time after he noticed them, his claim can be declared unreceptive.

174 Herbots, Pauwels \& Degrootte 1989, p. 647; Liège, 23 April 1998, TOGOR 1999, 106, annotated by J. Geradin.

175 Brussels 22 September 1994, J.L.M.B. 1996, 1476, annotated by J. Henrotte; Court of First Instance Brussels 18 April 1989, J.T. 1989, 733

176 Supreme Court 15 September 1994, Arr.Cass. 1994, 748

177 The building promotor is also liability during ten years after reception (see Article 6 House-building Act). 
coercive force, no agreements can be made regarding the liability period. ${ }^{178}$ The liability of the architect/entrepreneur can therefore not be contractually exonerated or reduced. This prohibition should be read in the light of Article 4 AA which provides the architect with a monopoly in the public interest. It is always possible to prolong this period.

Even though the Belgian jurisprudence and doctrine hold that both provisions have the same scope and meaning, Rigaux holds that their difference is rather evident ${ }^{179}$ :

- Only Article 1792 CC mentions the condition of a construction 'at a fixed price'

- Article 1792 CC holds the locator operis in any case responsible for damage caused by the (partial) perishing of the building due to a defect in the construction, and even due to the unsuitability of the soil, while Article 2270 CC does not seem to depart from the general principle of private law which holds that not only the damage, but also the fault, the accountability for it by the debtor, and the causal link between the fault and the damage, have to be proven.

For this reason Rigaux holds that Article 2270 CC contains the general rule, while Article 1792 CC will only be applied under certain conditions.

It follows that when applying Article $2270 \mathrm{CC}$, the building master has to prove the fault, the accountability for the fault to the architect/entrepreneur, the damage, and the causal link between the fault and the damage, while Article 1792 CC only requires the proof of the fact that the building has perished due to a defect in the construction, or the unsuitability of the soil. In that case, the liability of the professional is presumed. It then incurs on the constructor to prove that the damage arose due to a foreign cause, or due to invincible ignorance of the fault. ${ }^{180}$ It is thus argued that Article 2270 CC merely intends to indicate the length of the prescription period for claims instituted against the architect and/or the entrepreneur, while Article 1792 CC indicates who is responsible in the event that a construction perishes. Article 1792 therefore protects the building master since even though the work was approved by him, he still gets a period of ten years to turn to the architect/entrepreneur in the event that a defect has arisen, causing (part of) the building to perish. Article $2270 \mathrm{CC}$, on the other hand, protects the professionals. After the ten year liability period - the time needed to prove the solidity of the constructions ${ }^{181}$ - the architect and the entrepreneur are freed from all contractual responsibility. ${ }^{182}$

However, together with Laurent ${ }^{183}$, I hold the opinion that Article 1792 CC does not aim to establish who is responsible for what. He submits that since every architect has to act as a good and careful pater familias as a general rule, so that Article 1792 CC does not include anything new regarding the architect's responsibilities. It only indicates that, for

178 Supreme Court 9 September 1965, J.T., 1965, 577 with regard to entrepreneurs; Supreme Court 17 October 1968, Pas., 1969, I, 181

179 Rigaux 1975, p. 545.

180 Dekkers 1954, II, nr. 1124 and 1128

181 Zachariae 1907, p.24.

182 Preparatory Works, Records of the Council of State

183 Laurent 1887, volume XXVI, pp. 32-33, 49. 
this type of damage (total or partial perishing of the building), architects are liable for ten years. It follows that Article 1792 CC only deals with the duration of responsibility. Article 2270 CC complements Article 1792 CC by extending it to actions other than building works. It includes all 'big works' and reparations as well. According to Laurent, the objective of the two Articles is thus the same: the determination of the duration of liability. There is no presumption of fault in either Article: the building master still has to prove the architect's fault. ${ }^{184}$ It follows that the architect will, in principle, only be held liable for ten years if he has committed a fault. If the building perishes due to a defect in the building or the soil, the architect will be liable, since he should have known of such a defect. ${ }^{185} \mathrm{He}$ has to investigate the soil and warn the building master in the event of a defect, and dissuade him from building. Article 2270 CC is applicable to all big projects and whether or not a fixed price was agreed on. It can therefore be concluded that with regard to the architect, Article 2270 CC only complements Article 1792 CC.

In general, the ten year liability period starts to run at the moment of definitive reception. ${ }^{186}$ However, parties can agree otherwise, for example from the provisional reception onwards ${ }^{187}$ However, if such a provision is written down in the entrepreneurial contract, it will not benefit the architect. ${ }^{188}$ In any case, the liability period described in Articles 1792 and 2270 CC has the same starting point. It should be noted however, that in the event that the provisional reception counts as the starting point of the ten year liability period, this does not mean that the building master refrains from the normal consequences arising out of the provisional reception which does not contain the approval of the work. ${ }^{189}$ Nevertheless, if parties agree that the provisional reception also counts as approval, visible defects which do not endanger the stability of the building are the risk of the building master. The architect/entrepreneur has to prove that the delay has elapsed. If there is no formal act of approval, factual actions such as the occupation of the building can also count as an act of reception.

A ten year period is deemed necessary during which all defects should be noticed. In the event that defects are only apparent later, it is held that these are caused by old age and reparations.

Hereunder both Articles will be discussed in detail.

a. Article 1792 CC:

Articles 1792 and 2270 CC used to refer to the ten year liability risk of the 'architecte', referring to the professional who combined the functions of designer and executor of a building work. This liability risk found its origin in the coûtume de Paris in which brickmen, carpenters and rooflayers were, as early as the end of the $17^{\text {th }}$ Century, held

184 Laurent 1887, p. 68. See also Court of First Instance Liège 25 June 1996, T.Aann. 1997, 222.

185 Laurent 1887, p. 35.

186 De Page 1957, IV, nr. 996; Supreme Court 16 October 1969, R.W. 1969-70, 1053

187 Supreme Court 4 March 1977, Arr.Cass. 1977, 730.

188 Brussels 25 October 1994, R.J.I. 1995, 91.

189 Supreme Court 21 June 1984, T. Aann. 1997, 323. 
liable for a ten year period. The legislator of 1804 referred to the 'architecte' (Article 1792 and 2270 CC) and to 'big works' (Article 2270 CC). Since the 'architecte' was responsible for the design and the execution of the construction, the Commission of the Year VIII aimed to express that he who is deemed competent to erect stable buildings should be responsible for their stability. As stated before, Article $1792 \mathrm{CC}$ held that if the building perishes due to the unfitness of the soil or a defect in the construction, the 'architecte' is liable. This was so, even if the 'architecte' advised the building master not to build on that particular piece of land, but the building was constructed anyway and even if the building only perished partially. As held in the meeting of the Council of State of 5 January 1804, the 'architecte' should not yield to the arguments of the building master, and has to understand that his work is of public nature: not only the safety of the building master has to be insured, but also that of the general public. ${ }^{190}$ Of course the same is true for present-day architects and entrepreneurs.

Eventually, in February 1804, the word 'entrepreneur' was added to the word 'architecte' in Articles 1792 and 2270 CC at the request of the Legislative Section of the Tribunate. The reason was that, in certain provinces of France, the word 'architecte' was not used, while both terms were seen as synonyms anyway. ${ }^{191}$ As noted before, due to the Architects' Act of 1939, architects can no longer fulfil entrepreneurial tasks. However, since the present-day architect fulfils certain functions of the former 'architecte', Article 1792 is still applicable to him, even though he does not engage in a traditional entrepreneurial contract.

Even though some case law indicates that Article 1792 CC contains an obligation of result which means that the architect's fault is presumed ${ }^{192}$, it is generally accepted that the architect's fault and the causal link still have to be proven. ${ }^{193}$ As noted before, this is also the view of Laurent. According to the Supreme Court, the building master has to prove that the building has perished due to a defect in the building. The architect can only absolve himself if he can prove that he could, and should not have been, aware of the defect. ${ }^{194}$. It is often said that this leans towards a presumption of fault on the part of the architect or the entrepreneur. ${ }^{195}$ As noted above, since the entry into force of the Architects' Act in 1939, it is no longer permitted to combine the profession of architect and entrepreneur in one person. Nevertheless, they are still liable over a ten year period in the event that a building perishes.

190 Locré 1803, VII, p. 174, nr. 18.

191 Baert 2001, p. 465; Locré 1803, VII, p. 189, nr. 41 en VIII, p. 340, nr. 8

192 Brussels 10 June 1960, R.J.I., 1960, 67. The Belgian ten year liability period for defects which can cause the of the building on the other hand, stemmed from a guarantee-obligation which meant that the building master only has to prove the existence of the damage, the existence of the defect, and the architect's accountability for the defect. In such cases, the exact fault of the architect does not have to be proven.

193 Court of Commerce Antwerp22 March 1985, La Construction, 11 April 1986, 7, annotated by Ph. Flamme; Liège 29 October 1985 R.R.D. 1985, 339; Bergen 8 October 1990, J.T. 1990, 584; Baert 1994, pp. 801-802.

194 Supreme Court 6 October 1961, R.C.J.B, 1963, p. 5, annotated by Lagasse. Supreme Court 6 October 1961, R.W. 1961-62, 783; Jur. Comm. Brux. 1963, 186; Pas. 1962, I, 152; R.C.J.B. 1963, 5 annotated by Lagasse; R.G.A.R. 1962, nr. 6905; R.G.A.R. 1962, nr. 6927; R.J.I. 1962, 383 and 1964, 331.

195 Burssens 2001, p. 728. 
To be complete, it should be added that Article 1799 CC, which states that bricklayers, carpenters and rooflayers who fulfil works against a fixed price, have to obey the rules laid down in Section III of Chapter III of Title VIII of the Civil Code. It is an addition to the Bill of the Commission at the request of the Court of Appeal of Lyon to oppose that these artisans would no longer be liable after approval (Fenet IV, 212). They are therefore also liable during a ten year period for the works executed by them.

Fixed price

The 'architecte' often agreed to fulfil a certain task against a fixed price. This meant that contracts were, in general, concluded by forfait which meant that unitary prices were agreed for different parts of the building work. The legislator of 1804 was very critical with regard to the building industry. Since there were no guilds anymore, there was no education and no supervision of the handicrafts. It followed that the skills of the professionals were not very high. To get a commission, the professionals often offered a very low price. However, after the work was granted, they often persuaded the unsuspecting building master to adapt or enlarge the building so that they were able to raise the price. The restoration of the handicrafts has taken more than a century, and was due to the revival of the professional associations and the introduction of vocational education. ${ }^{196}$ The legislator held that the building industry had to be restored by free competition and fixed prices (Article $1793 \mathrm{CC}^{197}$ ) but also by a limited liability period of ten years for large projects.

As noted above, Article 1792 CC is only applicable in the event that a fixed price has been agreed upon. The building master deserves special protection since the 'architecte' was in the position to work as cheaply as possible, which often led to a low quality results.

Defect in the building or unsuitability of the soil

As noted above, Article 1792 CC deals with the situation in which there is a defect in the building, or that the land on which it is built is unsuitable. The Article is therefore not applicable to situations of force majeure (for example an unforeseeable natural disaster) since they do not constitute a defect in the building or the unsuitability of the soil. The unsuitability of the soil can also be qualified as a 'defect in the building' since the soil is held to be a part of the construction. The quality of the soil determines, for example, the applicable foundation system. It follows that the architect is liable in the event that the land is deemed to be unfit to build on since he has to take the quality of the soil into account. The entrepreneur, on the other hand, is not liable if he executed the work in accordance with the architect's plans/instructions, except if he had noticed faults in the

196 Fontein 1988, p. 19.

197 Article 1793 CC states that if an architect or entrepreneur has agreed to erect a building against a fixed price in accordance with a plan which was agreed to by the building master, an increased price cannot be asked, not even if the wages or the prices of building materials have risen, or the plan has been adapted, unless the building master has given his written permission for these adaptations and has agreed on their price. 
plan, or if he could have seen that the soil was unsuitable for the execution of the building work. ${ }^{198}$

The entrepreneur can also be held liable in a situation in which he should have noticed the unfitness of the soil. ${ }^{199}$ Only in the event of invincible ignorance, coincidence or force majeure, can the professional escape liability (for example in case of a sudden subsidence). The architect has fulfilled his contractual obligations if he has taken the necessary precautions.

As noted above, the architect is obliged to inform the building master about all the means which are necessary to secure the solidity of the building. ${ }^{200} \mathrm{He}$ has to make sure that the building is erected in accordance with the design, the building specifications, the building permission and the rules of good professionalism. If he notices any faults, he has to warn the building master and ask the entrepreneur to repair these.

Total or partial perishing of the building

Architects and entrepreneurs are not only liable for hidden defects after the work has been accepted, but also for visible defects which are liable to make the building perish, whether or not the work has been accepted. ${ }^{201}$ It follows therefore that the architect and entrepreneur are, in principle, not liable for visible defects if the building work has been approved. This is different however if such defects affect the stability of the building. The liability for these kinds of visible defects is based on the fact they can affect public safety. ${ }^{202}$ A building perishes if it can no longer be used for its intended purpose, or misses certain required qualities. However, it is not necessary for it to have collapsed.

The building master does not only have to prove any damage, but also the defects in the building or the unsuitability of the soil and the causal link. ${ }^{203}$ If he has proven that the perishing of the building was caused by a defect in the building, or by the unsuitability of the soil, the architect and entrepreneur are deemed to be responsible, based on the principle of peritia artis, by the mere existence of the fault, at least if the defect is accountable (for example no force majeure or coincidence) to him..$^{204}$ As noted above, there is discussion on whether or not Article 1792 CC contains an obligation of result (guarantee-obligation). The mere defect in the building, together with the damage and the accountability of the professional, are often held to be enough to hold the architect responsible. ${ }^{205}$ The architect/entrepreneur is therefore not liable if the defect is not accountable to him, and in case of force majeure or coincidence, or if the building master caused the damage himself. Even if he can be held accountable, he can be freed from

198 Supreme Court 19 November 1970, T. Aann. 1971, 43, annotated by M.A. Flamme. The entrepreneur does not have to verify the architect's plan. This is not his task.

199 Liège 22 February 1988, J.L.M.B. 1988, 1284, annotated by R. De Briey.

200 Supreme Court 3 March 1978, R.W. 1978-79, 711.

201 Supreme Court, 11 April 1986, Arr.Cass. 1985-86, 1088; Supreme Court 18 November 1983, Arr.Cass. 1983-54, 323).

202 Baert 2001, p. 450.

203 Supreme Court 15 December 1995, Arr.Cass. 1995, 1135.

204 De Page 1957, IV, nr. 897.

205 Supreme Court 28 September 1995, R.W. 1995-96, 932. 
liability in the event of 'invincible ignorance'. ${ }^{206}$ However, as held above, Article 1792 CC does not contain a presumption of fault.

It should be noted that for reasons of public safety, the ten year liability principle is also applicable in the relationship between the entrepreneur and the sub-entrepreneur. The entrepreneur can institute an action against his sub-contractor in the event that the defect was caused by the latter. This is due to the fact that the sub-entrepreneur is liable to the entrepreneur for his work. ${ }^{207}$ In the event that the entrepreneur and the architect could not have noticed a defect due to the sub-entrepreneur's specialization, the latter will be held liable for the whole damage. In such a case, the action of the entrepreneur does not concern the building master, who is only contractually related to the entrepreneur.

\section{b. Article 2270 CC}

Article 2270 CC refers to 'big projects'. Unlike Article 1792 CC, it is not only applicable to 'buildings', but also to other large and important projects, such as monuments, canals and pools. . To verify under what circumstances a project is considered to be 'big', one has to determine whether the stability and safety of the construction is affected by the project, or whether it is an essential part of the construction and affects its intended purpose. ${ }^{208}$ Decorating works are therefore not included. Furthermore, Article 2270 CC is not only applicable in a situation in which a fixed price has been agreed upon, and only deals with serious faults which are defined as 'faults that can endanger the stability or the solidity of the building or can render it unsuitable for its purpose'. As noted above, the architect has to assist the building master with the supervision of the building work. If he does not fulfil his task with due care, he has to indemnify the building master for the damage the latter has suffered. ${ }^{209}$ It follows that the ten year liability period of the architect and the entrepreneur softens the inconveniences which may arise for the building master after the definitive reception. ${ }^{210} \mathrm{His}$ action has to be instituted within the same time limit.

\section{Exception 3: Deceit}

The majority of case law states that, in the event of deceit, the architect/entrepreneur can be held contractually liable for a twenty year period (Article 2262bis CC), notwithstanding the ten year liability period described in Articles 1792 and 2270 CC. It is held that in such cases, the professional should not benefit from the liability limitation in these Articles. Of course, the precise consequences of deceit will be determined on a case by case basis.

\footnotetext{
206 Supreme Court 6 October 1961, R.C.J.B, 1963, p. 5, annotated by Lagasse; Supreme Court 6 October 1961, R.W. 1961-62, 783; Jur. Comm. Brux. 1963, 186; Pas. 1962, I, 152; R.C.J.B. 1963, 5 annotated by Lagasse; R.G.A.R. 1962, nr. 6905; R.G.A.R. 1962, nr. 6927; R.J.I. 1962, 383 and 1964, 331.

207 Supreme Court 11 April 1986, Arr.Cass. 1985-86, 1088.

208 Court of Commerce Brussels 24 September 1972, J.C.B., 1973, 263.

209 De Page 1957, nr. 894. This is also the case if the Housing Building Act is applicable.

210 Rigaux 1975, p. 572.
} 


\subsection{The liability of the architect for subordinates and sub-entrepreneurs}

Article 1797 CC holds that the entrepreneur and the architect $^{211}$ are responsible for the acts of the persons he 'uses' to fulfil a certain mission. This means that the architect and entrepreneur are liable to the building master for damage caused by persons whom they employ, as well as for sub-entrepreneurs. The architect/entrepreneur is therefore contractually responsible for the good and proper fulfilment of the tasks executed by these persons. The building master, on the other hand, has nothing to do with sub-contractors or subordinates and will directly turn to the architect/entrepreneur. According to Article $1165 \mathrm{BW}$, obligations only have consequences between the contracting parties and cannot cause harm to third parties.

Lastly, it should be noted that the entrepreneur is not liable for damage caused by his sub-contractors to third parties, since he is not in charge of them. ${ }^{212} \mathrm{He}$ is, however, liable in tort for his employees (Article 1384, $3^{\circ} \mathrm{CC}$ ). This will be further discussed hereunder.

\section{Liabilities of the specialists involved}

Due to the multiplicity and the complicity of the techniques used in the building process, an architect cannot be specialized in every aspect of the building process. Therefore, it is possible that the contract foresees that the architect cannot be held liable for damage caused by certain actions, and that a specialist will be engaged. Specialists can be hired by the building master, the architect or the entrepreneur. However, since the building master is often inexperienced, and does not know whether it is better to engage a specialist or not, the architect is obliged to inform the building master whenever he deems the presence of a specialist necessary for the proper fulfilment of the project. According to the nature and the complexity of the project, a certain specialist can then be consulted, especially when the architect's experience and education are not sufficient to guarantee safety. If the specialist concludes a contract with the architect himself, the latter is contractually responsible for his actions.

The architect can be held liable if his choice of specialist was not a good one. ${ }^{213}$ In this way, often an engineer ${ }^{214}$ will be consulted to deal with certain specific technical problems. As described above, the architect designs the plan, controls the execution of it, and gives advice to his clients with whom he normally has close contact. This is necessary, since he tries to reconcile the thoughts of his clients with his own ideas. The engineer, on the other hand, works with techniques to ensure the stability and durability

211 The case law made clear that the Article was also applicable to architects.

212 Liège 20 June 1996, J.L.M.B. 1997, 382; Antwerp 13 May 1997, T. Aann. 1998, 366; Brussels 20 January 1989, R.G.A.R. 1991, nr. 11.764.

213 Supreme Court 3 March 1978, Arr. Cass. 1978, 790; R.W. 1978-79, 711; T. Aann. 1981, 262, concl. Krings; J.T. 1979, 28, concl. Krings; Pas. 1978, I, 759; R.C.J.B. 1982, 176, annotated by M. Alexandre; R.J.I. $1979,7$.

214 In 1947 the engineers, moved by the same motivations as the architects at the beginning of the 20th Century, grouped themselves into professional associations. In 1947 the Royal Federation of Belgian Associations of Engineers adopted a regulation for Civil Engineers. 
of the construction and mostly only takes into account the technical aspects of the building.

The architect also has to control and coordinate the specialists and verify their competence. ${ }^{215} \mathrm{He}$ has to make sure that the required technical studies are carried out and applied. ${ }^{216}$ In principle, he is not liable for the faults committed by the specialist. ${ }^{217}$ However, if he fails to notice a fault of a specialist which he could, and should have, noticed, based on his knowledge and capability, he will be held liable anyway. ${ }^{218}$ It is held that architects are still held liable too often for the faults of experts due to their supervision obligation, while these experts do not notice these faults themselves. ${ }^{219}$ In such a case, the degree of technicality of the studies has to be compared to an architect's normal competence.

It should be noted, however, that the ten year liability period described in Articles 1792 and $2270 \mathrm{CC}$ is, according to the Civil Code, only applicable to the architect and the entrepreneur and not to the specialists involved. The weight on the shoulders of the architect is thus quite high. This is even more so since he is responsible for all the tasks which are not delegated to specialists: he disposes of a full and residual responsibility. ${ }^{220}$ Where the responsibility of the specialist ends according to the object of his mission, the responsibility of the architect reappears. ${ }^{221}$ However, case law made Article $2270 \mathrm{CC}$ and 1792 CC also applicable to engineers, technicians, technical consulting firms and building promoters ${ }^{222}$ since they also often intervene in the building process..$^{223}$

\section{Conclusion}

In Belgium, design contracts are qualified as 'entrepreneurial contracts' which is a specification of the more general 'rent of labour'. As held by Article 1779 CC, the rent of work and services covers work provided by entrepreneurs performing in accordance with building specifications. The architect has to advise his client, design a plan, determine the programme and the budget, and supervise the building works.

The existence of a monopoly for the architect to design and supervise building works for which a building permit is required, brings about a liability regime in which the architect is easily held liable for defects in the building. For the architect to be liable, a fault in the performance of his contractual activities, damage, and a causal link, must be proven. In this regard, architects are also liable if they engaged an expert who lacks sufficient

215 Brussels 10 April 1997, T. aann. 1997, 343; Brussels 22 May 1981, R.J.I. 1981, 269; Brussels 13 May 1966, R.J.I., 341; Liège 25 May 1955, J.T. 1955, 680.

216 Council of State 13 October 1987, Arr.R v.St. 1987.

217 Brussels 25 November 1976, T. Aann. 1981, 261.

218 Supreme Court 1 April 1982, R.W. 1984-1985, 603; Arr.Cass. 1981-82, 963; Pas. 1982, I, 909; Bull. 1982, 909; Credoc 1983, ed. April, 7; J.T. 1983, 309.

219 Ramboer, Evens \& Van Daele 2002, p. 52.

220 Rigaux 1975, p. 331.

221 Rigaux 1975, pp. 394-396.

222 See also House-building Act.

223 Brussels 22 January 1962, J.T., 1963, 11; Brussels 22 February 1963, J.T., 315. 
skills. The liability regime is next to the general provisions in the Civil Code specifically laid down in Articles 1787-1799 CC. In principle, the architect is not liable after the building works have been accepted (received) by the building master. After reception, the architect is still liable, but only for (small) hidden defects. The same is true for serious defects, which cause the building to perish totally or partially (Article 1792 jo 2270 CC). These Articles are of public order, since they are said to protect public safety and cannot be contractually deviated from. It follows that the architectural liability cannot be limited. This gives protection to the building master. It follows that standard terms are not commonly used in Belgium, and disputes are almost always settled by judicial courts. For certain defects, such as problems with stability, insulation or water tightness, judges are sometimes more lenient towards the building master, and hold that the architect has an obligation of result. However, the myriad of case law and the legal literature indicate that Article 1792 CC does not contain a presumption of fault.

In Belgium, the architect is often held liable in solidum with the entrepreneur. If the entrepreneur has made a fault in the construction, the architect is often held liable as well, due to defective supervision. Since the architect is the only building partner who is obliged to buy professional liability insurance, including decennial liability, he mostly suffers from huge liability claims. To cover their own losses, as well as losses of other building partners, clients often take out a Construction All Risks Insurance, which covers damage during the realisation of the building work.

It can be concluded that the weight on the shoulders of architects is very heavy. This has been mitigated by the Laruelle Act which allowed legal persons (as opposed to natural persons only) to practise the profession of architect. This means that the creditors of the company can only claim compensation from the company's assets, and that the architect-natural person's wealth cannot be claimed from in terms of damage compensation. 
B. THE REGULATION OF ARCHITECTS IN THE NETHERLANDS 



\section{Chapter 7}

\section{PUBLIC LAW IN THE NETHERLANDS}

\section{History of the Architects' Title Act}

Just as in Belgium, historically, the art of developing and designing buildings was often combined with the handicraft of carpenter, bricklayer or - more often - stonemason. However, in the course of the $18^{\text {th }}$ Century, the phenomenon of master buildings dealing exclusively with development and design appeared in Holland for the first time. ${ }^{1}$ After the French Revolution, this evolution continued and intensified.

In 1842, the 'Society for the Advancement of Architecture' was created. Membership was not open only to architects, but also to other building actors. The desire of most architects to exercise their profession independently from commercial relations with the building industry, and to unite on the basis of social standing and occupation, led to the creation of the 'Association of Dutch Architects' in 1908. Members were subjected to a code of conduct, which excluded the combination of the professions of architect and contractor. ${ }^{2}$

After the 'Society for the Advancement of Architecture' modified its structure in 1915 in such a way that only private and official architects could become members, the members of the 'Association' joined the 'Society' in 1919 and, in so doing, gave birth to the 'Royal Society for the Advancement of Architecture, Institute of Dutch Architects' which received royal patronage in 1957. This society was also called the 'Association of Dutch Architects' (Bond der Nederlandse Architecten - BNA). ${ }^{3}$ Until now, the BNA is still the only general professional association of Dutch architects. Its main aim is to protect the profession and its title. The BNA advocated legislation to realize this protection as early as 1940 . However, due to the chaotic wartime situation, the matter remained undiscussed.

In 1948, the BNA set up a private register for architects. It held that registration signals a certain professional quality and competence. Through membership, architects

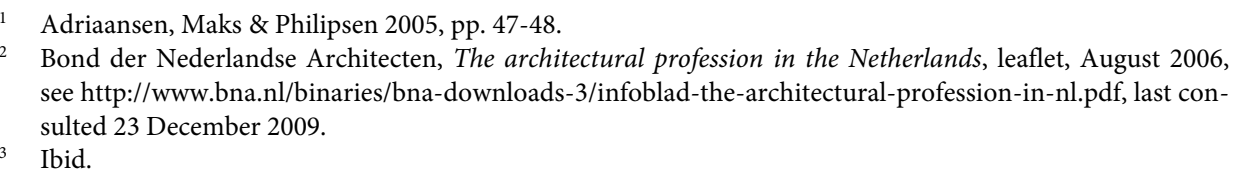


could thus distinguish themselves from the other, 'unqualified' professionals. In this way, the status of registered architects grew stronger.

After the Second World War, on 27 January 1949 the Dutch government introduced a legislative proposal before the Second Chamber of Parliament to give the register a public character. The enactment supplied a protection of both the title and the profession. 'The title and the profession of architect were reserved to officially registered persons, who had to comply with specific requirements of professional ability (education and experience) before being registered and who moreover exercised the profession independently, i.e. not in employment, but also not in combination with a company (contractor's firm, brokerage, supplier of building materials). This requirement was directly associated with the reliability of the architect (the competent and professional confidant). In this way, the architects in employment and those combining the profession with a company were implicitly put aside as unreliable. ${ }^{3}$ Of course, vehement opposition on the part of architects-employees and architects-entrepreneurs to the proposal occurred $^{5}$. Furthermore clients did not want to be obliged to engage an architect. It followed that the government finally revoked the proposal in 1960, since it feared that other professions would be disadvantaged by the protection enjoyed by the independent architects. Furthermore, since the state itself was, to a large extent involved in the building process through the creation of all sorts of building regulations, the protection of architects was not considered to be really necessary. Besides, the private initiatives of the BNA made public regulations less urgent. ${ }^{6}$

In 1957, the BNA made a new proposal which was reduced to the protection of the title - at least on paper. Apart from the requirements regarding the necessary education, requirements were set out with regard to the practical experience and to the way of exercising the profession which had to be fulfilled in order to be registered as an architect: although being in employment was authorised, commercial interest in the execution of constructions, in deliveries for constructions, or in the trade of real estate, was prohibited. A certain professional protection was therefore still included, since those combining the profession of architect with one of these activities could -according to the bill- continue to work but they were not entitled to call themselves architect. Of course this prejudiced the competitive position of that category of architects. ${ }^{7}$ Nevertheless, the government still held the opinion that the proposal was too heavy-handed.

It was only at the end of the 1960s that the need for legislation on the use of the title of architect was generally accepted. Dutch architects needed an official 'name' for their profession in order to get easy access to the profession in other EC Member States. On 30 March 1971, the Kleijn-Commission was instituted by the Minister of Public Accommodation and Spatial Planning, engineer W.F. Schut. The Commission was chaired

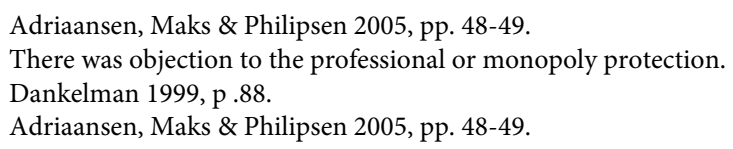


by Prof. A. Kleijn and had to draft legislation in order to protect the title of architect. On 27 April 1972, the Kleijn-Commission held that title protection was desirable.

However, after the proposal was made, the Cabinet decided in 1974 that legislation was only necessary if it was indispensable on the EEC-level - in the EEC the Directive on the free movement of architects was under construction - and if garden and landscape architects were included as well. Eventually, in 1975, it was formally stated that legislation was necessary to protect the titles of architect, town planner, garden and landscape architect and interior architect.

An interdepartmental consultation group was set up to prepare the bill based on the Kleijn draft. In 1977 the Council of State gave advice and on 12 May 1980 the bill was presented to the Second Chamber. Due to Cabinet changes and formations, the procedure came to a deadlock after the Second Chamber had made its final report in 1982. The first Lubbers-cabinet wanted to deregulate. The deregulating commission instituted by the Lubbers-cabinet -the Geelhoed-commission- was of the opinion that there were not enough public inducements to create regulations with regard to all categories of architects. Therefore, in March 1984, it advised the Cabinet to revoke the bill. However, it added that if the EEC-Directive on the free movement of architects came into existence, a justified need could arise to harmonise with the legislation of other EEC-states in which the legal protection of architects did already exist.

Even though there were numerous opponents holding that registration was only a question of status, a breakthrough arose thanks to the progress of the European Community in its work concerning the European recognition of architects. After the Architects' Directive saw the light on 10 June 1985, and due to the professional associations insisting on the continuation of the parliamentary treatment of the bill, the Cabinet decided in December to continue with the bill's treatment and to use it as framework for the implementation of the Directive. Regarding the professions of town planner, garden and landscape architect and interior architect, the proposed national legislation was maintained as well, due to its connection and the social equality between the four disciplines. Finally, on 9 September 1986, the Second Chamber voted in favour of the bill, followed by the First Chamber on 7 July 1987.

On 1 October 1988, the legislation entered into force and the architects obtained the protection of their title through public legislation: see Article 23(1) jo Article 2 of the Architects' title $\mathrm{Act}^{8}$ (ATA). ${ }^{9}$ It followed that the private BNA register disappeared as the architects' register' in 1988. Article 23 however entered into force five years after the other provisions of the Act. A five year period was deemed necessary to give nonregistered professionals the opportunity to successfully complete the Examination, as described in Article 25, or to fulfil one of the other educational requirements which make registration -and the use of the title- possible. This will be further discussed in paragraph 6.2.2.1.

Official Gazette 1988, p. 439.

Adriaansen, Maks \& Philipsen 2005, pp. 47-50 and Groeneveld 2007, pp. 11-26. 
Public Law in the Netherlands

\section{The Architects' Title Act}

The explanatory memorandum to the Act of 7 July 1987 containing Regulations on the Protection of the Titles of Architect, Town Planner, Garden and Landscape Architect and Interior Architect ${ }^{10}$ (Architects' Title Act - ATA) indicates that it aims to improve the living quality and the professional skills of architects". It was held that "Although the Directive does not pronounce itself on the desirability to protect the title of architect and does not contain an obligation to make any regulations in this regard, it is necessary -not only to prevent unclearness and misunderstandings but also to have uniform regulationsto give those who fulfil the European requirements to use the title to the exclusion of all others." Since these professionals are considered to have a high level of responsibility, legislation was needed to bring to an end, the existing situation in which anyone could make use of these titles. By the creation of legislation which protects the title, one could distinguish certain professionals from others and guarantee that some of them have the skills which are required to practise these professions. In this way consumers are -at least to some extent- protected against male-fida professionals, and the spatial quality of the environment can also be better protected. Another aim of the ATA is therefore to ensure consumer protection, and to ensure competent professional practice. Finally the ATA also carries out the EU Architects Directive. The Act entered into force on 1 October 1988, with the exception of Article 23, which entered into force 5 years later. ${ }^{12}$

I will now discuss what the Architects' Title Act exactly entails. In this regard it should be noted that in the following I will only discuss the situation of architects stricto sensu. I will therefore not deal with the situation of town planners, garden and landscape architects and interior architects. Directive 85/384/EEC was not applicable to these latter categories, while they fall under the general system of Directive 2005/36/EC (Chapter I of Title III). As held above, they are not included in the Belgian Architects' Act or in the Belgian Architects' Order Act.

\subsection{No monopoly - no protection of the profession}

In the Netherlands there is no public legislation which gives architects a monopoly to provide certain services. The Act of 7 July 1987 only regulates the use of the title of architect. However, it does not create a monopoly or give the profession as such an official status. The architects' profession is therefore not protected. This means that anyone can perform architectural services and that the building master is not obliged to get assis-

10 Wet van 7 juli 1987 houdende regelen omtrent de bescherming van de titels architect, stedebouwkundige, tuin- en landschapsarchitect en interieurarchitect, Official Gazette 1987, 347

11 Explanatory Memorandum to the Architects' Title Act, Parliamentary Documents Lower House 1979/80.16.191, no. 3 .

12 Article 42 ATA states that a Royal Decree will determine when the Architects' Title Act will enter into force with the exception of Article 23 which will enter into force five years later. The Royal Decree of 20 September 1988, Official Gazette 1988, 439, stipulates that the Architects' Title Act entered into force on 1 October 1988. 
tance from an architect or any other expert. ${ }^{13} \mathrm{An}$ explanation can be found in the fact that architects mostly practise their profession as part of a team of engineers, constructors and financial experts on the one hand, while on the other hand the practice of the profession in the building process is well regulated through public regulations such as the Housing Act ${ }^{14}$, the Building Decree ${ }^{15}$, the Spatial Planning Act $^{16}$, the Monuments and Historic Buildings $\mathrm{Act}^{17}{ }^{18}$ These instruments contain strong regulations on construction requirements, quality demands and safety demands. The Building Decree contains details requirements which buildings need to satisfy. Furthermore, designs will be examined by welfare commissions (welstandscommissies) which are composed of architects, town planners and regular citizens and advise the municipality. They approve building applications and decide whether the proposed construction is of sufficient quality and whether it fits in with the surroundings. This system of public building and housing inspection seems to control the public order aspect, instead of protecting the function of the profession of architect. ${ }^{19}$ As a result, anyone may perform the function of an architect, provided that the design complies with the requirements of the Building Decree, regardless of whether or not this person carries the title of architect. ${ }^{20}$

\subsection{Title protection: natural persons and legal persons}

As indicated before, until 1988 there was no public legislation which distinguished the professional group of architects from other professions in the building industry. By virtue of the Architects' Title Act, only architects, whether Dutch or foreign, registered in the legal register, may call themselves 'architect'. It follows that the use of the title of 'architect', abbreviations of it (for example 'Arch'), or words relating to the profession (such as architectural office), is forbidden when one is not registered in accordance with the Architects' Title Act. ${ }^{21}$ The requirements for registration will now be discussed.

Council of Arbitrationfor the Building Industry 8 April 2002, nr. 21.877, unpublished.

Act of 28 September 1992, amending the Housing Act of 1901, Stb. 1991, 439 (Woningwet).

Building Decree of 7 August 2001, Stb. 2001, 410 (Bouwbesluit).

16 Spatial Planning Act of 20 October 2006 containing new rules on spatial planning, Stb. 2006, 566 (Wet op de Ruimtelijke Ordening).

17 Monuments and Historic Buildings Act of 23 December 1988, Stb. 1988, 638 (Monumentenwet).

18 The precise content of these acts will not be discussed in this thesis. See Priemus et al 2001, p. 24; Van Gulijk 2009, p. 76.

19 Van Gulijk 2009, p. 34.

20 Article 40 of the Housing Act as well as the Building Decree foresee that if a building permit is required for a building, preventive inspection by the government is allowed. Even if a building permit is not necessary, the initiator of the work has to comply with the Building Decree as well, and may be liable if inspection after realisation of the building shows that the quality requirements of the Building Decree have not been (duly) met.

21 Since Article 23 is the core of the Architects' Title Act because it determines who has the right to use the title of architect, and what can be done against persons who use it illegally, it has given rise to numerous court proceedings. See for example Nijmegen 13 September 1996, nr. 4432/95/21; Harderwijk 18 September 1996, nr. 603/96. 
As held by Article 23(1), the title of architect or an abbreviation of it, either without a more detailed description, either in a compound of words in which the title or an abbreviation of it are mentioned, can only be used by those registered under this title.

As held by Article 24(1) ATA, without prejudice to Article 23(1), professionals that fulfil the requirements mentioned in Article 9(1) i, j, k, l, m or n, are allowed to use their legal title or the abbreviation of their title which is used in another involved state in the official language(s) of that state. ${ }^{22}$ EU or EEA states, as well as Switzerland, are considered to be involved states (Article 1 ATA). The Bureau ${ }^{23}$ can decide that in such cases, the name and place of establishment of the institute or the Examination Commission which granted the title, has to be mentioned (Article 24(2) ATA).

Article 23 entered into force five years after the other provisions of the Act. A five year period was deemed necessary to give non-registered professionals the opportunity to successfully complete the Examination described in Article 25, or to fulfil one of the other educational requirements which make registration -and the use of the title- possible. It follows that from 1 October 1993 onwards, one is not allowed to use the title without being registered.

With regard to legal persons, it should be noted that the Articles of the Architects' Title Act which are currently in force, only foresee the registration of natural persons which suggests that, in principle, only natural persons can make use of the title of architect. It follows that a legal person has to refrain from using the title, with or without a more detailed description, in abbreviated form or in a compound word. This is due to the fact that it would be too easy for natural persons who are not allowed to use the title, to escape the prohibition of Article 23(2) ATA by practising the profession in the form of a legal person. As held by the District Court of Wageningen, if the name of a legal person contains the word 'architect', a wrongful impression that those who work for the legal person will fulfil the requirements of the Architects' Title Act. ${ }^{24}$ It is thus forbidden to let consumers believe that the director, as well as other persons who work for the legal person, are architects. ${ }^{25}$ However, it has been held that it would go too far if legal persons were forbidden to use a name which contains the word architect in all circumstances.

22 Before the ATA was amended due to the implementation of Directive 2005/36/EC, Article 24 (1) referred to other indents of Article 9. It was then amended due to the implementation of Article 7 (2) of Directive 89/48/EEC of 21 December 1988 on a general system for the recognition of higher-education diplomas awarded on completion of professional education and training of at least three years' duration, by the general Act of 15 December 1993 on the regulations concerning a general system of recognition of higher education diplomas obtained in the Member States of the European Community which involves a professional education of at least three years, which entered into force on 19 January 1994. This Act has been annulled and replaced since 21 December 2007 by the Act of 6 December 2007 holding general regulations on the recognition of EC-professional qualifications, Official Gazette 2007, 530 (General Act EC-professional qualifications). Note that the 'letters' indicated in Articles 9 and 24 ATA will be changed by the entry into force of the 2010 amendment.

23 The tasks of the Bureau and its aims will be explained hereunder in paragraph 10.2.1.1.

24 District Court Wageningen 21 January 1998, nr. 79784 CV 1272/1996.

25 Zutphen 10 July 1997, nr. 9303 HA ZA 97-214. 
According to the explanatory memorandum of the Architects' Title Act, a legal person can be allowed to use the title if the purpose of the act, i.e. consumer protection, is respected. It is thus possible for a legal person to use the name of a registered architect, if that architect is the director of the legal person which performs architectural activities. ${ }^{26}$ Since the title protection serves two goals, namely the quality of living and the protection of consumers, it is important that all architectural activities are performed by or under the leadership of a natural person-architect. ${ }^{27}$ It is not required however that all board members, or a certain number of them, be in possession of the professional title. ${ }^{28}$ In this regard the court of Zutphen held that a legal person is allowed to use the title if the natural person who is a director of the legal person is registered as an architect, and if the majority of natural persons working for the legal person are also registered. ${ }^{29}$ The fact that a legal person employs architects is not sufficient, since these architects are subordinated to the partners, and have no genuine influence..$^{30}$ Even if registered architects are leading the legal person de facto, a wrong impression is given to the public when the person leading the legal person de iure is not in the possession of the title, while his personal name is indicated in the name of the legal person..$^{31}$ Cooperation with another architect, whether this is a registered natural person or a registered legal person, does not exempt one from having to be registered oneself..$^{32}$ Architects have the responsibility to prevent, at all costs, their name being used illegally on sign boards ${ }^{33}$ It follows that even though the Architects' Title Act does not contain any provision on the use of the architectural title by legal persons, case law has filled this void, even before the amendment to the Architects' Title Act of 4 March $2010^{34}$ was proclaimed. Due to the 2010 amendment, the new Article 23a ATA specifically codifies the decisions of the court of Zuthpen and the court of appeal of Amsterdam mentioned above. The 2010 Act has not yet entered into force ${ }^{35}$

\footnotetext{
District Court Utrecht 13 May 1998, nr. 94 416-CV-97-116.

Eindhoven 5 June 2003, case nr. 259612, 3603/02; Court of Appeal 's-Gravenhage 18 July 2003, 02/325.

Supreme Court 15 December 2000, NJ 2001, 57; RvdW 2001, 8.

Zutphen 10 July 1997, nr. 9303 HA ZA 97-214.

Breda 28 October 1998, nr. 100 924/CV/98-1834.

Court of Appeal Amsterdam 8 January 2004, 1529/02.

Alkmaar (Den Helder) 8 July 2004, 153390.

Almelo 12 June 2002, nr. 46570 HA ZA 773-2001.

34 Act of 4 March 2010 amending the Architects' Title Act (professional experience, life-long learning for town planners, garden and landscape architects en interior architects, amdements related to the Framework Act on Independent Agencies and some other amendments), Official Gazette 2010, 130. In this book, reference will be made to the Architects' Title Act as it is currently applicable. Mention will be made of the most important amendments imposed by the 2010 Act.

35 Article VIII of the Act of 4 March 2010 indicates that it will enter into force on a date that will be deter-
} mined by Royal Decree. The Act will probably enter into force in several stages. 
Public Law in the Netherlands

\subsubsection{Registration by the Foundation Bureau Architect's Register}

\section{Introduction}

As provided for in Article 3(1) ATA, the Minister of Public Housing, Spatial Planning and Environmental Management -the VROM Minister- created the 'Foundation Bureau Architects Register' -hereafter: the Bureau. ${ }^{36}$

The initial provisions of the bill foresaw a separate legal person, the 'Bureau Architects' Register', which could act independently regarding all aspects for which the law did not require a direct responsibility from one or more Ministers. The Director and the staff of this bureau were government officials. To have some democratic control on the management of the register and the administration of the Bureau, the bill stated that the director of the Bureau would be appointed and could be removed by the VROM Minister, and had to obey the instructions of the Minister and justify his acts in writing every year. Furthermore the Minister could make rules with regard to the financial management of the Bureau. To give the professionals and their clients more direct control, the bill foresaw the creation of a Council of Supervision. The majority of the members of the Council of Supervision were persons practising or having practised one of the professions at issue. The Council of Supervision could ask the Director for advice and, more importantly, could object to his decisions. Furthermore, the Director was obliged to listen to the Council on the tariffs, and had to give an annual justification of the Bureau's acts to the Minister.

Due to the Second Chamber approved amendment of 9 September $1986^{37}$, the ' $\mathrm{Bu}$ reau Architects' Register' was changed into the 'Foundation Bureau Architects' Register' which was created by the VROM Minister. The staff no longer had to be composed of government officials. The Bureau as it currently stills exists, is an independent agency of private law. The overall aim of privatisation played an important part in this. ${ }^{38}$ Independent agencies have a public or administrative function. They practise on a national level, and are not directly subordinated to a Minister. The ministerial responsibility is limited to what is determined in the act of establishment. In general, the Minister is responsible for the creation of the agency's policy and will control the execution of it. The Bureau has legal personality and a legal task and does not receive financial support from the government. The General Administrative Act ${ }^{39}$ is applicable to its actions. As held by Article 4(1) ATA, the VROM Minister appoints and removes the Chairman and the members of the board, after consulting the Ministers of Agriculture, Nature and Food Quality and Education, Culture and Science. The appointment or dismissal of the board's Director needs the permission of the VROM Minister (Article 5 ATA). The 'democratic control' which is required, since registration is obligatory to use the title, is nowadays fulfilled by the board of the Foundation which replaced the Council of Supervision. The majority of the board's members are persons practising or having practised one of the relative professions (Article 4(2) ATA). It can advise the Director of the Bu-

\footnotetext{
As indicated above, this Article will be deleted after the entry into force of the 2010 amendment. Amendment De Beer, Kamerstukken II 1985/89, 16 191, nr. 14; handelingen II 1985/86, p. 5736. Groeneveld 2007, p. 36.

Act of 4 June 1992, containing general rules of administrative law (Algemene wet bestuursrecht).
} 
reau and is able to turn to the VROM Minister to object to the Director's decisions. Furthermore, as held by Article 8(1) ATA, the VROM Minister still has to approve the reports and balance-sheets on a yearly basis. It follows that even though the Foundation Bureau Architect's Register is an independent agency, the VROM Minister has the final responsibility of control. The Bureau is thus an independent executive institution, and not a professional organisation.

However due to the Act of March 2010, which has not yet entered into force, the Foundation Bureau Architects' Register will be replaced by the Bureau Architects' Register which will be an independent agency of public law (see new Article 2a ATA). The Framework Act on Indepedent Agencies, which harmonizes the position and direction of independent agencies, will be applicable. This entails that the VROM Minister will get more possibilities to control the Bureau. Not only will the Minister be responsible for approving the budget, he will also have the possibility to create policy rules concerning the tasks carried out by the Bureau, to annul its decisions and to intervene in the event the Bureau neglects its tasks. ${ }^{40}$

\section{Tasks}

Article 2(1) ATA states that there is an architects' register, which will be called 'the register' further on in this Act. On request, persons fulfilling the requirements which are laid down by, or pursuant to, this law will be inscribed in this register in their quality of architect, town planner, garden and landscape architect or interior architect (Article 2(2)).

The most important task of the Bureau is to administer the register (Article 3(1) and (2) ATA). The VROM Minister and the Minister of Agriculture, Nature and Food Quality, as well as the Minister of Education, Culture and Sciences, can give directions on the institution of the register (Article 2(3)). It follows that the Bureau does not have discretionary freedom to decide who will be registered.

After the amendment of the Architects' Title Act by the Act of 12 June 2008, which implements Directive 2005/36/EC, Article 3(3) ATA, now foresees that the Bureau is the competent authority as meant in the Directive. With regard to the former Directive 85/384/EEC, the Ministerial Regulation of 10 March 1989 on the appointment of the competent authority for the issuing of diplomas, certificates etc. in the area of architecture, has already appointed the Bureau as such. In this capacity it closely cooperates with the competent authorities of other involved states, and provides to, or requests from those authorities, information on disciplinary measures, penal sanctions or other serious matters if these are deemed necessary to judge the legality of the entry to the profession

${ }^{40}$ The board of the Bureau will have three members at most. The Minister of VROM appoints the chairman; one member is appointed by the Minister at the recommendation of the collected professional organisations, and one member may be appointed from the circle of those included in the Architects Register who are not a member of a professional organisation. The board draws up governance rules. In those rules the participation of professional organisations and those who are registered but are not a member of a professional organisation must be given form and attention has to be devoted to the way in which the individual identity of the various disciplines is guaranteed in the preparatory trajct of the various rules to be determined by the board. See Article 5 of the 2010 Act. 
of a person who is registered in accordance with Article 13, or who has based an application on this Article. Article 13 ATA stipulates that anyone who wants to be registered has to fill in a form and make a request to the Bureau (Article 13). If one fulfils the legal requirements, registration cannot be refused. Registration of persons not fulfilling the requirements has to be refused. These requirements will be discussed hereunder. In its capacity of competent authority, the Bureau also checks whether the information given by other competent authorities is correct, and indicates possible remarks and consequences. Most importantly, the Bureau receives the necessary documentation or information which is necessary to register as an architect, and hands over declarations to architects about the period in which they were working, in the event that these are requested. The Bureau also provides information on Directive 2005/36/EC, and provides in this regard, assistance to persons with regard to the practise of the profession (Article 3(3) ATA).

Another important task of the Bureau is to provide the assistance as meant in Chapter VI of this law (Article 3(2) ATA). This means that the Bureau has to give persons who fulfil the requirements of Article 9(1) g, (see Article 25) and those who fulfil the requirements of Article 9(1) c, while being registered but not fulfilling Article 4(2) of the Architects' Directive, the opportunity to take part in Examinations (Article 25). This will be further discussed hereunder.

The Bureau does therefore have a registration function. It informs every requesting person in writing on whether a certain person is inscribed in the register, and which title he possesses, upon payment of the fee as described in Article 7 ATA (Article 22(1) ATA). After the receipt of this information, the requesting person can ask to inspect (inzage verkrijgen) the documents which gave rise to the inscription (Article 22(2) ATA).

The Bureau, as well as legal persons with full legal competence which aim to serve the interests of the registered professionals, or of the final consumers of the goods and services provided by those professionals, can claim the condemnation of those who use a title in violation of Article 23(1) ATA $^{41}$ (Article 23(2) ATA). This possibility is also open to every person who is entitled, according to paragraph one, to use a title, as long as the title used is the same as the one under which the claimant is registered (Article 23(3)). The district judge is competent to decide upon these claims in the first instance (Article 23(4)). As held by Article 23(5), Article 23(1-4) is not applicable to architects of yachts and nautical architects. The reason is that their working field falls outside the scope of the built environment. Therefore it is held that persons using the title of 'information architect' also falls outside the field of the Architects' Title Act. It follows that whenever this title is used, the Bureau will take the necessary measures to prevent it. If its warning does not cause the user to refrain from illegal use, a judicial procedure can be started and a daily fine of 5,000 Euros can be imposed.

${ }^{41}$ See paragraph 7.2.2. 
Article 9 ATA contains the requirements which need to be fulfilled before one can register. These will now be discussed. It should be noted that Article 9 ATA will be amended following the entry into force of the 2010 amendment to update the Architects' Title Act and to bring it in line with the modern educational programmes.

\section{Requirements for registration}

Subscription in the register will be granted to those who fulfil one of the following requirements:

\section{a. Dutch qualifications}

a. ${ }^{42}$ being in the possession of:

$1^{\circ}$ a Master' ${ }^{43}$ degree in the field of architecture obtained at a university mentioned in the annex to the Law on Higher Education and Scientific Research

$2^{\circ}$ a certificate of construction sciences ${ }^{44}$ in the field of the technique connected to a university mentioned in the annex to the Law on Higher Education and Scientific Research.

Since Dutch students often have the possibility to choose between a range of courses within a certain branch of education, the education received by these students can have a very different content while they all get the same or a comparable diploma. As held by Article 9(2) ATA, the VROM Minister can establish further rules on the direction which one who fulfils the requirements of Article 9(1) sub a or c, has to give to its education, in order to be able to register. At this moment the 'Detailed Regulation Organization Architect, Town planner, Garden- and Landscape-Architect and Interior Architect' ${ }^{45}$ of 14 April 2006 contains such additional rules. These more detailed rules enumerate the competences (knowledge, insights, skills) which new professionals should possess at the beginning of their career, and the VROM Minister is able to determine such requirements. It is up to the education institutes to adapt their curricula to the required criteria. The Detailed Rules contain a list detailing the graduation profiles which are deemed to fulfil these criteria. In this way, the Foundation Bureau Architect's Register does not have to judge upon each individual request as to whether a certain graduation profile, differentiation or branch entitles one to register. It should be noted however, that he Architects' Title Act does not contain the obligation to form detailed rules. It only foresees the possibility. Nevertheless, as stipulated in the explanatory memorandum to the

42 The letter-numbering uses the same letters as those used in the Architects' Title Act.

43 On 9 March 2006, the Law on the Modification of the Architects' Title Act in connection with the introduction of the Bachelor-Master structure of higher education was adopted. The Act was published in Official Gazette 188 of 20 April 2006 and was given retroactive effect as of 1 September 2002.

44 In Dutch this is called 'Bouwkunde'. Subsection a, $2^{\circ}$ will be deleted following the entry into force of the 2010 Act which updates Article 9 ATA. However, as held by Article 29 of the 2010 Act, a person can apply for registration if $s /$ he is (before the entry into force of the new Act) in the possession of Dutch qualifications that allowed him to register before the entry into force of the 2010 Act.

45 Ministerial Regulation of 14 April 2006, Stcrt, 2006, 87; in Dutch: Nadere Regeling inrichting opleidingen architect, stedenbouwkundige, tuin-en landschapsarchitect en interieurarchitect. Before, the regulation of 1 September 1988 created by the Minister of Education and Sciences, the Ministers of Housing, Spatial Planning and Environment and of Welfare, Public Health and Culture, contains more detailed rules on the institution of the education of architect, town planner and interior architect (Strct. 1988, 190) 
Detailed Rules of 1988, their creation was deemed necessary, since Article 9 ATA contains several general graduation profiles, differentiations or branches which do not all aim to prepare for the professions which are the subject of the Architects' Title Act. Since the Act does not contain sufficient guarantees to make sure that registration is reserved for experts, the creation of detailed rules was required.

The Detailed Rules of 2006 added a Master's education in the field of architecture to the educational programmes whose diploma or certificate gives rise to subscription in the architects' register, allowing the holders to use the title of architect. ${ }^{46}$ Article 2 of the Detailed Rules 2006 describes which requirements certainly have to be fulfilled to be registered as an architect. Article 3 enumerates specifically which diplomas or certificates are considered to be appropriate. ${ }^{47}$ Degrees indicating a successful completion of examinations with regard to the following educational programmes satisfy these requirements:

- Master in Architecture, Direction Architecture; Master in Architecture, Building and Planning, Direction Architecture; Master in Architecture, Urbanism and Building Sciences, Direction Architecture at Delft Technical University following the successful completion of a Bachelor's education in the field of building art, leading to the degree of Bachelor of Science or of another educational qualification which provides students with qualities (knowledge, insight, abilities) which are comparable to those gained after completion of the aforesaid Bachelor's education

- Master in Architecture, Building and Planning, direction Architecture at Eindhoven Technical University following the successful completion of a Bachelor's education

46 Due to the connection between the Act of 7 March 2006 on the modification of the Architects' Title Act in connection with the introduction of the Bachelor-Master structure of higher education and the more detailed rules 2006 (Detailed Rules 2006) the Detailed Rules should enter into force on the same date as the Act of 7 March 2005, or at least as soon as possible after it (Article 15 Detailed 2006). The Act of 7 March 2006 entered into force on 21 April 2006. The Detailed Rules entered into force on 6 May 2006. Both the provisions of the law as well as the regulations will have retroactive effect as of 1 September 2002. This is the date on which the Bachelor-Master structure was introduced into higher education.

47 Article 4 of the Detailed Rules enumerates old educational programmes at the Universities which also give holders the right to register (acquired rights). In this light, reference should be made to Article 10 of Directive 85/384/EEC which states that each Member State shall recognize the diplomas, certificates and other evidence of formal qualification set out in Article 11, awarded by other Member States to nationals of those Member States, where such nationals already possess these qualifications at the time of the notification of this Directive, or their studies leading to such diplomas, certificates and other evidence of formal qualifications commences during the third academic year at the latest following such notification, even if those qualifications do not fulfil the minimum requirements laid down in Chapter II, by giving them, as regards the taking up and pursuit of architectural activities and subject to compliance with Article 23 (right of establishment and freedom to provide services), the same effect within its territory as the diplomas, certificates and other evidence of formal qualifications which it awards in architecture. Since the starting point of the Nearer Regulation 1988 was that the education mentioned in Articles 10 and 11 of Directive 85/384/EEC allows one to be registered, they were also enumerated in Article 4 of the Detailed Rules. In the light of Articles 10 and 31 (1) of the Directive, which states that Member States shall take the measures necessary to comply with this Directive within 24 months of its notification (i.e. 5 August 1985), persons holding a diploma or certificate before or on this date, or who started the required education at the latest during the third academic year following this date, are eligible to be registered. The qualifications listed in Article 11 of Directive 85/384/EEC can now be found in Annex VI of Directive 2005/36/EC. See also Groeneveld, p. 134. 
in the field of building art, leading to the degree of Bachelor of Science or of another educational programme which provides students with qualities (knowledge, insight, abilities) which are comparable to those gained after completion of the aforesaid Bachelor's education.

It follows that graduates of such fulltime education as part of a five years' course of study at the Technological Universities of Delft and Eindhoven, obtain the Dutch academic title of 'construction engineer' and have access to the register. ${ }^{48}$ Practical training is recommended but is not compulsory. This is in line with Directive 2005/36/EC which, however, still refers to the old name for the diplomas (before the introduction of the BaMa structure). If is accompanied by a Declaration of the Bureau indicating that the education fulfils the requirements of Article 46 of the Directive, and that these qualifications have to be recognised automatically (see Annex V.7).

b. being in the possession of the final certificate 'Higher Building Art $t^{49}$ ' issued by Article 29 of the Industrial Education Law.

The Industrial Education Law was abolished in 1 August 1968. Subsection b is therefore only applicable to architects who received a certificate from an Academy of Building Art (not university level) before 1971. These qualifications have to be recognised in accordance with Annex VI to Directive 2005/36/EC. Subsection b will be deleted after the entry into force of the 2010 amendment. ${ }^{50}$

c. being in the possession of:

$1^{\circ}$. a Master's degree in the field of architecture obtained at an academy mentioned in the annex to the Law on Higher Education and Scientific Research

$2^{\circ}$. a final diploma issued by an Academy of Building Art based on Article 29 of the Law on Continued Education, the certificate of an education for professions in the field of architecture, and town planning as meant in Article 34(3) of the Law on Higher Professional Education or the certificate of a continued education in the field of building art connected to a college as meant in the Law on Higher Education and Scientific Research.

Training for the architectural profession can also be obtained by following a parttime education at an Academy of Architecture. Students at the academies are employed in an architects' office or similar practice during working hours. As part of their work, students are expected to become conversant with all the aspects of the building process. In this way their theoretical knowledge will be broadened and deepened at the same time. In the evening the students have to follow mandatory courses at the academy.

48 Bond der Nederlandse Architechten, The Architectural Profession in the Netherlands, leaflet, August 2006. See http://www.bna.nl/binaries/bna-downloads-3/infoblad-the-architectural-profession-in-nl.pdf, last visited 23 December 2009.

49 In Dutch this is called 'Hoger bouwkunst onderricht'.

50 Article 29 of the 2010 Act stipulates that a person can apply for registration if s/he is (before the entry into force of the new Act) in the possession of Dutch qualifications that allowed him to register before the entry into force of the 2010 Act. 
In this way, holders of the following qualifications ${ }^{51}$ can also be registered:

- Master in Architecture at the Academy of Amsterdam, issued by the Examination commission of the Academy of Building Art in Amsterdam

- Master in Architecture at the Academy of Rotterdam, issued by the Examination commission of the Academy of Building Art in Rotterdam

- Master in Architecture at the Fontys Academy in Tilburg, issued by the Examination commission of the Fontys Academy for Architecture and Town Planning in Tilburg

- Master in Architecture at the ArtEZ Academy for arts, issued by the Examination commission of the Academy of Building Art in Arnhem

- Master in Architecture at the Hanze Academy in Groningen, issued by Examination commission of the Academy of Building Art in Groningen

- Master in Architecture at the Zuyd Academy, issued by the Examination commission of the Academy of Building Art in Maastricht.

The training at such an Academy can only be followed after one has completed a specific technical Bachelor's education at an institute of higher education, that comprises four years full-time study. The Master's programme contains a combination of theory and practice. Graduates obtain the academic title Master in Architecture. ${ }^{52}$ Their qualifications have to be automatically recognised since they are listed in Annex V.7. of Directive 2005/36/EC. Other educations which are not enumerated in this Annex or in Annex VI will fall under the general system.

Subsection c, $2^{\circ}$ will be deleted following the entry into force of the 2010 amendment Act.

As has been noted before, Article 26(1) ATA holds that the VROM Minister is obliged to give those who are registered and fulfil the requirements as mentioned in Article 9(1) c, but do not fulfil the requirements of Article 47(2) of Directive 2005/36/EC, the opportunity to complete an Examination as meant in that Article of the Directive. This will be further discussed under $b$.

d. being in the possession of the certificate of a Continued Building Art education as meant in Article 29 of the Industrial Education Law.

As noted above, the Industrial Education Law was abolished in 1 August 1968. Subsection d is therefore only applicable to architects who received a certificate of an Academy of Building Art (not university level) until 1970. These qualifications have to be recognised in accordance with Annex VI to Directive 2005/36/EC. This subsection will also be deleted following the entry into force of the 2010 amendment Act. ${ }^{53}$

51 See Article 3 of the Detailed Rules of 14 April 2006.

52 Just as is the case with university education, Article 4 of the Detailed Rules enumerates old educational programmes at the Academies which also fulfil the requirements to be registered (acquired rights).

53 Again it should be mentionned that Article 29 of the 2010 Act indicates that a person can apply for registration if s/he is (before the entry into force of the new Act) in the possession of Dutch qualifications that allowed him to register before the entry into force of the 2010 Act. 
f. being in the possession of the diploma of the Foundation Institute for Architecture (F.I.A) which was issued after having completed an education organised by this Foundation of at least four years, which was started at the latest by 5 August 1988, and of an attestation delivered by the VROM Minister which indicates that the person involved successfully withstood the Minister's inquiry on the designs he made and executed during a factual practice of at least six years in the field of architecture or; being in the possession of the diploma issued by the Foundation Institute for Architecture (F.I.A.) which was obtained at the conclusion of an education which was started after 5 August 1988 if this education satisfies, according to the VROM Minister, the requirements of Articles 3 and 4 of Directive 85/384/EEC

Since the first part of requirement $\mathrm{f}$ is not applicable to those who have started their education now, it will not be further discussed. With regard to the second part, it must be stated that following research done by the Bureau in 1996, the VROM Minister decided in 1997 that the F.I.A. education did not fulfil the requirements of the Architects' Directive. Since this possibility is also mentioned in Annex VI of Directive 2005/36/EC, professionals fulfilling these requirements and in possession of this diploma not later than the reference academic year 1987/1988, should also be recognised automatically in other EU states. This subsection will also be deleted in the light of the 2010 Act which updates Article 9 ATA.

h. having successfully completed an education which is assigned by the VROM Minister after the professional organisations representing the architects have been heard on the matter.

This provision makes it possible to amend/supplement the requirements of the Architects' Title Act. Article 9(2) (c) of the 2010 amendment Act states that one is also allowed to register if one holds a certificate relating to an education in the field of architecture of which the VROM Minister has decided that the level is equal with that of a master education in the field of architecture in one of the above-mentioned universities or academies.

\section{b. Dutch examinations}

Next to those who obtained qualifications as mentioned under a.) persons who did not complete a certain educational programme but who passed the following examinations will also be allowed to register:

e. having passed the architect's examination instituted by the Council of Architects before the date on which the examination, as meant in sub $g$ of this Article, can be taken for the first time.

These examinations organised by the BNA existed until 1987, and will therefore not be discussed further. Since they are listed in Annex VI of Directive 2005/36/EC, they have to be recognised in terms of those who passed not later than during the academic year 1987/1988. Subsection e is thus not contained in the 2010 amendment. 
g. having passed the examination for architects as meant in chapter VI of this law, or having obtained exemption for this examination from the VROM Minister due to exceptional competence.

As held by Article 3(2), the Bureau provides administrative assistance with regard to the organisation of these examinations. Article 25 ATA gives architects who do not fulfil the requirements of the Architects' Title Act (no Dutch or foreign recognised diplomas) a chance to register by the successful completion of an examination. The possibility to register after having successfully completed an examination will be discussed in more detail under b.).

The Examination Decision Architects' Title Act of 20 November $1990^{54}$ contains more specific rules on the examinations described in Articles 25 and 26 ATA.

Article 2 of the Examination Decision Architects' Title Act indicates that only persons who have practised the profession for over seven years are allowed to take part in the examination. This is composed of two parts. This is also provided in Article $12 \mathrm{~b}$ of the 2010 Amendment Act. With regard to the first part of the examination, the architect has to present three of his designs to the Examination Commission, and give an oral explanation (Article 3(1)). Article 3(2) contains some criteria which are applied to test the professional's competence. With regard to the second part, candidates have to write a paper on a subject chosen by the Examination Commission and have to make a design which fulfils the Commission's criteria (Article 4(1). The criteria mentioned in Article 3 and 4 accord to the criteria mentioned in the Detailed Rules of 14 April 2006, and are the same as those which were listed in Article 3 of Directive 85/384/EEC and which are now listed in Article 46 of Directive 2005/36/EC. The candidate is only allowed to take part in the second part of the examination, if he succeeds in the first part. As held by Article 6(1), the Examination Commission can exempt candidates from the second part if they have already demonstrated in another way their ability to fulfil the requirements listed in Articles 3 and 4. Exemption from the second part can, for example, be granted to those who have already published in a professional magazine, as long as the publication gives a sufficient insight into the architect's qualities.

Article 25(2) AA foresees that the extent and the content of these examinations are determined by a general measure of administration (GMA) which will also regulate the requirements to get permission to complete the examinations, as well as those to get an exemption from certain parts. The Examination Decision Architects' Title Act carried this Article into effect. The examination rules, as well as their modifications, have to be approved by the VROM Minister (Article 25(3) ATA). As held by Article 26(2), Article 25(2) and (3) also apply to examinations falling under Article 26. Before 1998, the Bureau advised the Minister with regard to examination matters. Since 1998 this has be-

54 Decision of 20 November 1990, Official Gazette 1990, 577 modified by the decisions of 2 November 1993, Official Gazette 1995, 521 and 14 February 1998, Official Gazette 1998, 99. 
come the task of the Bureau Rijksbouwmeester ${ }^{55}$, since the Bureau did not think it was advisable to be involved in procedures in which candidates were involved, who were often already summoned by it for the illegal use of the architectural title. One can only participate in the examinations described in Articles 25 and 26 ATA after payment of the fee as noted in Article 7 (Article 27). As held by Article 14 Examination Decision Architects' Title Act, a candidate can object to a judgement on the examinations to the Examination Commission. The GMA does not foresee the possibility if instituting a higher appeal. This does not preclude the possibility that one can protest against the judgement of the Examination Commission before a civil court. Lastly, it should be mentioned that the examination Regulation of 29 September $1993^{56}$ on the examination for architects, as meant in Chapter II of the examination Decision of 20 November 1990, approved by the VROM Minister, contains more detailed rules on the institution of the examination. This will not be discussed further.

Article 26 jo. Article 9(1) (c) ATA

As noted earlier, Article 26 ATA stipulates that the VROM Minister is obliged to give those who are registered and who fulfil the requirements as mentioned in Article 9(1) c, but do not fulfil the requirements of Article 47(2) of Directive 2005/36/EC, the opportunity to complete an examination as detailed in that Article of the Directive. In this respect it should be repeated that in Article 46(1) Directive 2005/36/EC, training as an architect shall comprise a total of at least four years of full-time study or six years of study, at least three years of which is on a full-time basis, at a university or comparable teaching institution. The training must lead to successful completion of a universitylevel examination. As held by Article 47(2), by way of derogation from Article 46, recognition shall also be accorded to training which, as part of social betterment schemes or part-time university studies which satisfy the requirements referred to in Article 46, as attested by an examination in architecture passed by a person who has been working for seven years or more in the field of architecture under the supervision of an architect or architectural bureau. In this way, Annex VI of Directive 2005/36/EC indicates that the certificate stating that its holder has passed the degree examination in architecture awarded by the architectural academies which are recognised by the state, should be recognized by other Member States if professionals already possessed these qualifications no later than the reference academic year of 1987/1988 (entry into force of Directive 84/384/EEC). However, persons who did start such an education later do not fall under Annex VI. It follows that with regard to the diplomas awarded by the Staterecognized architectural academies, a complication arises since persons who followed such an education part-time, fulfil the criteria of the Architects' Title Act and can thus be registered, but do not fulfil the requirements of the Directive: they have not enjoyed a part-time education lasting six years of which at least three years were full-time (Article 46(1) Directive 2005/36/EC). Article 26 ATA gives these persons - as long as they started their education after academic year 1987-1988 - the opportunity to complete an

55 The Rijksbouwmeester advises the government on the architectural policy and national accommodation. It forms part of the VROM Ministry.

56 Stcrt. 1993, 192. 
additional examination so that they fulfil Article 47(2) at last. As stipulated in Article 6(2) Examination Decision Architects' Title Act, the Examination Commission will automatically exempt the registered candidate who fulfils the requirements of Article 9(1) c ATA, and has at least seven years of professional experience under the leadership of another architect, from the second part of the examination. This last provision refers in particular to Article 26(1) ATA.

Article 25 jo Article 9(1)(g) ATA

Article 25(1) ATA on the other hand, indicates that the VROM Minister is obliged to give persons the opportunity to complete these examinations at least once a year. As held by Article 3(2), the Bureau provides administrative assistance with regard to the organisation of these Examinations. These examinations are meant for those who did not enjoy an education as mentioned in Article 9, and who could not benefit from the temporary provisions of Chapter VII, but who are of the opinion that registration should follow due to their professional experience. The successful completion of an examination according to Article 25(1) ATA, gives them the possibility to register. As suggested above, only persons with a minimum of seven years of practical experience are allowed to sit the examinations. The VROM Minister who is competent to exempt persons from sitting the examination as described in Article 9(1) g, is obliged to give persons the opportunity to complete these examinations at least once a year. After successful completion of the required examination, the professionals are then allowed to register. Since the examinations are not listed in annex VII of the Directive, they will however not be recognised automatically, but will fall under the general system of recognition. Due to the experience that participants have enjoyed, they are likely to have gained enough knowledge so that they normally they do not have to take part in the second part of the Examination. It follows that the Examination for those professionals consists of verifying whether the candidate can exhibit seven years practical experience, and whether the designs presented to the Examination Commission is of sufficient quality. The number of persons who use this possibility is very low, while the number of successful participants is even lower. As indicated in Articles 9(1) (g) ATA and 25(1), it is the VROM Minister who is competent to exempt persons from completing the examination as described in Article 9(1) g. In this regard it should be mentioned that the Ministry of VROM has laid down certain criteria which can indicate that someone has such exceptional competence such as intense work in the field for at least ten years, so that the professional practice can guarantee that that person is able to function as a competent designer, publications in professional journals at a more than exceptional level, the recognition of the professional community that the work contributes in an exceptional way to the development of architecture, work of a consistent high level from an architect with a personal architectural vision, etc.

The possibility of the Minister to exempting persons for the need to sit these examinations in cases of exceptional competence is implemented in Article 5 of Directive 85/384/EEC which is now reflected in Article 48(2) Directive 2005/36/EC. 
If the candidate successfully completes the examination, he can be registered according to Article 9 ATA, and is allowed to use the professional title due to Article 23(1) ATA. This does not encompass that his qualifications will be automatically recognised at EU level.

\section{c. EC/EEA qualifications}

In the foregoing, mention has been made of Directive 2005/36/EC on several occasions. The Act of 12 June 2008 has amended the Architects' Title Act of 7 July 1987 in order to implement this Directive. With regard to EC qualifications Article 9(1) i and $j$ has now been amended, and replaced by subsections $\mathrm{i}, \mathrm{j}, \mathrm{k}, \mathrm{l}, \mathrm{m}, \mathrm{n}$ as follows:

Enrolment in the register as architect will be granted to those who are in the possession of:

- evidence of formal qualifications as an architect as determined in Article 21 of Directive 2005/36/EC issued by the competent body of another involved Member State and listed in Annex $V$, or

- $\quad$ an educational diploma as determined in Article 47(1) Directive 2005/36/EC (training provided by the German 'Fachhochschulen) satisfying the requirements of Article 46 and followed by a four year period of professional experience as attested by a certificate as meant in Article 47(1), or

- taking into account the requirements mentioned in Article 47(2) (i.e. training as part of social betterment schemes or part-time university studies which are passed by a person who has been working for seven years or more in the field of architecture under the supervision of an architect or architectural bureau), an attestation of a successful examination in architecture which satisfies the requirements of Article 46.

Article 9, i. is often used by Austrians who can only register themselves in their own state after having three years of professional experience. To be able to work as an architect immediately after obtaining their diploma, they register in the Netherlands. ${ }^{57}$

Since one can only register as an architect in Italy after having completed the necessary education as well as a state examination, an architect who did not fulfil this state examination cannot register in the Netherlands, since they are not fully qualified to register in their home state. The state examination is recognised at the EU level. The Austrians, even though they do not have any practical experience, have the required diploma, while the Italian diploma is not complete without succeeding in the state examination.

$j$.

evidence of formal qualifications as an architect as mentioned in Article 49(1) paragraph 1 of Directive 2005/36/EC (provision on acquired rights; listed in Annex VI point 6 of the Directive and awarded by another Member State and attesting a course of training which began no later than the reference academic year referred to

57 http://www.architectenwerk.nl/architectenpraktijk02/Architectendata, last consulted 9 November 2009. 
Public Law in the Netherlands

in that Annex, even if they do not satisfy the minimum requirements laid down in Article 46)

- evidence of a certificate as determined in Article 49(1) paragraph 2 of Directive 2005/36/EC (special provision regarding certificates issued by the Federal Republic of Germany)

- evidence of a confirming declaration as determined in Article 49(2) of Directive

2005/36/EC (certificates issued to nationals of Member States by the Member States which have enacted rules governing the access to, and pursuit of, the activities of an architect as of the following dates:

(a) 1 January 1995 for Austria, Finland and Sweden;

(b) 1 May 2004 for the Czech Republic, Estonia, Cyprus, Latvia, Lithuania, Hungary, Malta, Poland, Slovenia and Slovakia;

(c) 5 August 1987 for the other Member States).

$k$. an attestation giving access to the professional activities of architect as determined in Article 23(3) paragraph 1, (4) paragraph 1, (5) paragraph 1 accompanied by a certificate as meant in (3) paragraph 2, (4) paragraph 2 and (5) paragraph 2 (special provisions regarding evidence of formal qualifications issued by the former Czechoslovakia, the former Soviet Union and the former Yugoslavia).

l. a certificate as determined in Article 48(2) Directive issued by the competent authority of another Member State indicating that the professional has especially distinguished himself by the quality of his work in the field of architecture.

This subsection got its present form as a result of the law of 2 December 2004 on the amendment of several laws regarding the execution of the Agreement of 21 June $1999^{58}$ on the free movement of persons concluded by the EC and its member states on the one hand, and Switzerland on the other, and which concerns the adaptation of the Architects' Title Act due to a ruling of the ECJ on the freedom of establishment. Due to this amendment, community nationals in the possession of an architectural diploma which does not have to be recognized by the other member states in the light of the Architects' Directive, still have the possibility to be subscribed in the register. To be registered, the VROM Minister has to check the knowledge and ability of the requesting party, by comparing the level of education and the professional experience of the requesting party with the knowledge and qualifications of the holders of a national attestation which gives, following Article 9(1) a and c, the right to register.

m. evidence of formal qualifications as an architect issued by the competent authority of other Member States which are recognized by the Bureau after an inquiry, and in accordance with Articles 5 -13 General Act Recognition EC professional qualifications ${ }^{59}$.

This Act implements Chapter I of Title III (the general system) of Directive 2005/36/EC.

58 Agreement 21 June 1999, Luxemburg.

59 Act of 6 December 2007 holding general regulations on the recognition of EC-professional qualifications, Official Gazette 2007, 530 (General Act Recognition EC-professional qualifications). 
With regard to the free provision of services, reference should be made to Articles $27 \mathrm{~b}$ and $27 \mathrm{c}$ ATA which were added by the Act of 12 June 2008. These Articles implement Title II of Directive 2005/36/EC. As held by Article 27 b(1), a service provider shall provide his services in the Netherlands under the professional title of the Member State of establishment, in the official language(s) of that state. Furthermore, service providers can also use their academic titles (Article $27 \mathrm{~b}(2)$ ). The latter provision implements Article 54 of Directive 2005/36/EC. On request, the services provider can ask to be registered. He has to add a declaration that he is legally established in his Member State to pursue his professional activities, offer proof of his nationality and, if the profession is not regulated, proof that he has pursued the activity for at least two years during the previous ten years. Contrary to Article 7(2) of the Directive, the ATA does not demand that evidence of professional qualifications have also to be provided. A decision will be made within four weeks. Article 27 c ATA deals with the exchange of information between the Bureau and the competent authority of another Member State in the event of complaints by service receivers.

\section{d. Non EC/EEC qualifications}

After implementation of Directive 2005/36/EC, Article 9(1) i $3^{\circ}$ and $j$ are now replaced and amended as follows by Article 9(1) $\mathrm{n}$ and o:

Enrolment in the register as architect will be granted to those who are in the possession of:

n. a diploma, certificate or other title in the area of architecture issued by a third state which is recognized by the competent authority of a Member State in accordance with Article 2(2) of Directive 2005/36/EC. In this case, the person involved has to qualify as a migrating professional and be in the possession of a declaration which is issued by that competent authority, and which indicates that he has at least three years of professional experience in the area of architecture.

This subsection implements Article 3(3) of Directive 2005/36/EC. Since it is applicable if recognition is provided by another Member State in accordance with Article 2(2) of the Directive, it is only applicable to professionals holding the nationality of a Member State and not to third-country nationals.

o. a diploma, certificate or other title in the area of architecture which is issued by the competent authority of a third state in conclusion of an education which satisfies, according to the Bureau, the requirements of Article 46 Directive or, when it does not satisfy those requirements, is recognized by the Bureau after an inquiry, in accordance with Article 5-13 General Act Recognition EC professional qualifications.

As already indicated above, the General Act Recognition EC professional qualifications implements Chapter I of Title III (the general system) of Directive 2005/36/EC correctly. However subsection o is not limited to recognition in accordance with this General Act, but is applicable to all qualifications issued by a competent authority of a third state, even if the professional has the nationality of a third-state. It follows that subsection o can be invoked by third-country nationals in possession of the requisite 
architectural qualifications. Recognition should be granted if the qualifications satisfy the requirements listed in Article 46 of the Directive.

\section{Registration procedure}

Professionals wanting to register according to Article 9 ATA, have to fill in a request form, send over the evidence and pay the inscription fee (Article 13(1)). In this regard it should be mentioned that members of professional associations get a discount because these associations pay the registration fee of their members collectively. ${ }^{60}$ In the event of a request for recognition or a request for registration involving Article 9(1) (m), the Bureau needs to come to a decision within three months of it receiving all the necessary documents (Article 13(4) ATA). If compensation measures are necessary, the recognition decision can be postponed until these measures are completed by the applicant. A decision should be taken at the latest one month after completion of these measures (Article 13(5) ATA and Article 19(3) and (4) General Act Recognition EC professional qualifications).

As noted above, the General Administrative Act (Awb) is applicable to the practices of the Bureau. While Article 15 ATA foresees that registration will not be refused without the person concerned being heard by the Director or his substitute, the Article was amended due to the entry into force of the General Administrative Act. Now Article 4:7, 1 Awb states that an administrative organ has to give the applicant the opportunity to expound his view whenever it refuses his application in whole or in part, and when the refusal is based on data concerning the applicant which is different from those which the applicant provided himself. Furthermore, as held by Article 2:1 Awb, everyone can be assisted or can be represented by an authorised person in his relationship with public organs. Decisions need to be founded on solid grounds (Article 3:46, $1 \mathrm{Awb}$ ) and have to be delivered or sent to interested parties (Article 3:41, 1). The possibility to object to, or appeal the decision, must also be mentioned (Article 3:45 Awb).

The Bureau makes sure that after the decision to register has been made, the actual registration will follow as soon as possible (Article 14(1)). Registration will not be refused if the applicant did not have the opportunity to hand over extra evidence in support of his qualification.

Immediately after registration, as well as every following year, registered professionals have to pay a contribution (Article 16(1)). The Bureau will determine the amount which has to be paid (Article 7).

Article 17(1) ATA stipulates that the registration will be annulled in the following cases:

a. if, according to the provisions of this act, the registration took place unlawfully;

b. if the registered professional does not fulfil the obligation to pay the contribution as detailed in Article 16(1);

c. on request of the registered professional;

d. after the decease of the registered professional.

60 Priemus et al. 2001, p.53. 
As held by Article 17(2) jo 15(1), the decision to annul a certain registration based on Article 17(1) a, will only take place after the professional has been given the opportunity to hand over extra proof of his qualifications.

Such a decision based on Article 17(1) b will only take place four weeks after the professional was informed of the decision by which his registration was annulled (Article 17(3)).

Following Article 4:1 Awb, the request to be removed from the list as indicated in Article $17(1) \mathrm{c}$, has to be done in writing.

Every annulment based on Article 17(1) a-c will immediately be communicated to the person involved (Article 17(4)). This means that following Article 3:41 Awb, the decision will be sent or handed to the interested parties, including the applicant. The decision has to indicate that an appeal may be instituted to the Trade and Industry Appeals Tribunal within the period described in Article 21. This follows from Article 3:45 Awb.

In the case of Article 17(1) b and c, the interested parties will also be informed of the possibility for them to request the cancellation of the annulment (Article 17(4) jo Article 18(1)). This request, which has to be made in writing according Article 4:1 Awb, will only be taken into account after the inscription fee as detailed in Article 13(1) is paid, and after all the contributions as detailed in Article 16(1) and due before the request was made, have also been paid.

Four weeks after the reception of the request as per Article 18(1), the Bureau will cancel the annulment (Article 19(1)). The moment of cancellation of the annulment will be considered as the moment of registration, and the moment on which the fee which as described in Article 16(1) has to be paid (Article 20).

As indicated before, an appeal against a decision can be instituted by the interested parties. This will be based on the provisions of this act to the Trade and Industry Appeals Tribunal (Article 21(1)). Such an appeal is possible not only against the decisions of the Bureau Architects' Register, but also against decisions based on the Architects' Title Act taken by the responsible Ministers. ${ }^{61}$ Article 21(2) and (3) ATA contain some more specific rules. ${ }^{62}$

61 On 1 January 1994 the Act of 16 December 1993 (Official Gazette 1993, 650) modifying the Act on the Judicial Organisation, the General Code of Administrative Law, the Act on the Council of State, the Act of Appeal, the Act on the Civil Servants 1929 and other regulations, as well as revoking the Act Administrative Case Law Public Decisions (Arob-Act - 'Arob' being the abbreviation of the Dutch title of the Act: 'Wet Administratieve Rechtspraak Overheidsbeslissingen') entered into force. This Act is also known as the Act on the Completion of the first phase on the Revision of the Judicial Organisation. Before this Act entered into force, an appeal could be instituted against decisions of the Bureau Architects' Register before the Trade and Industry Appeals Tribunal. However, against decisions of the responsible Ministers, one could institute an 'Arob'-appeal. This meant that after an administrative objection or appeal, one had the possibility to institute an appeal to the Arob-judge. The administrative judge in the Arob-case was the Administrative Litigation Division of the Council of State. This Section was the first and only judicial instance which took a binding decision on the appeal. Due to the fact that the Section became overburdened very quickly, and due to the complex system of legal protection, the Section and the Arob-Act were abolished. In this regard it should be added that the Administrative Litigation Division of the Council of State which tenders only an advice to the Crown, was held not to fall within the definition of a 'tribunal' as 
The Architects' Title Act does not contain any provisions on fines which can be imposed on those who wrongfully use the title. Article 435 jo Article 23 of the Criminal Code holds that a pecuniary fine of 3,700 Euros will be imposed upon those who use the title of 'doctorandus' which used to be the title obtained by those who now hold a Master's degree. It should be noted that this Article only refers to academic titles, and not to the use of the professional title of architect. The District Court is competent to decide upon complaints (Article 23(4) AA).

\subsubsection{Turning the Architects' Title Act into a more powerful quality instrument}

The Architects' Title Act foresees that those registered by the Bureau are allowed to use the title. Registration is reserved for those who possess a certain qualification that is described in the Architects' Title Act. It follows that, in general, only one criterion is tested for registration: the diploma obtained. If one is in the possession of the required diploma, or can prove that one has passed a certain examination, one can be registered for the rest of one's life whether or not the profession is practised. It is held that this situation cannot guarantee professional competence and consumer protection during the whole period in which the architect practises his profession. Upon the request of the 1998 Rijksbouwmeester Prof. ir. Wytze Patijn in 2001, an evaluation on the effectives of the Act was conducted by the Research Institute for Housing, Urban and Mobility Studies of Delft University (OTB) ${ }^{63}$. It was concluded that overall the Act produced an exten-

meant in Article 6 (1) ECHR. Since the Crown, which was empowered to determine the dispute, does not qualify as an independent and impartial court, there was a violation of Article 6 (1) ECHR. See European Court of Human Rights, Application no. 8848/80, Benthem v. the Netherlands, paragraphs 40, 43-44.

62 If a recognition decision or an approval by the Minister as meant in Article 9 (1) (o) is considered as a general compelling regulation, a judicial appeal can be instituted to the Trade and Industry Appeals Tribunal contrary to Article 8:2 Awb which stipulates that an appeal cannot be instituted against general compelling regulations (Article21(3)). This would mean that only the civil judge would be competent to rule upon this decision. However, Article 21(3) indicates that the legislator holds the opinion that the administrative judge is competent to rule upon decisions as meant in the Architects' Title Act. This paragraph was added by the Act of 26 September 2002 (Official Gazette 2002, 526) which amended several regulations relating to the implementation of Directive 2001/19/EC, which is now replaced by Directive 2005/36/EC. See R. Seerden and F. Stroink, Administrative Law of the European Union, Its Member States and the United States, A Comparative Analysis, Intersentia, Antwerp-Groningen, 2002. It serves to execute the Directive and contains, in Article III B, the possibility to institute a higher appeal against the rejection of a request to recognize an architectural diploma which has not been obtained in a EU or EEA Member State, but which is recognized by a EU Member State. The same applies if no decision has been taken within three months (Article III B Act of 26 September 2002 included a new Article 9a in the ATA Act This Article has been abolished however by the Act of 12 June 2008 amending the Architects' Title Act and implementing Directive 2005/36/EC).

Lastly, it should be mentioned that Article 8:4 e Awb is applicable (Article 21 (2) ATA). This means that an appeal cannot be instituted against a decision containing a judgement on the knowledge and abilities of a candidate or student that has taken the examination, or has been tested in any other way, or containing the determination of requirements, standards or more detailed rules for this examination or test. This paragraph was added by the 'Leemtewet Awb' (Act of 26 April 1995, Official Gazette 1995, 250, entry into force on 17 May 1995). It precludes a higher appeal against decisions of the Commissions which are charged with the taking of the examination, as meant in Articles 25 and 26 of this law, to the Trade and Industry Appeals Tribunal.

63 Priemus et al., 2001. 
sive, transparent and reasonably functioning market for architectural services. However improvement was needed. The OTB report indicated that, in the light of consumer protection and quality, the imposition of a two year period in which professional experience should be gained was necessary as well as lifelong education for all architects. A code of conduct and a complaint procedure for consumers in the event that an architect violated this code were also recommended.

In the light of this advice, the 2004 VROM Minister, Mrs. S. Dekker, wrote in her letter of 23 Mach 2004 to the President of the Second Chamber of the Dutch Parliament, that she was aiming to make the Architects' Title Act a more powerful quality instrument. In its Action Programme Environment and Culture ${ }^{64}$ of May 2005, the Cabinet confirmed that the Architects' Title Act should become a more powerful quality instrument, certainly in the light of the new Directive 2005/36/EC. Some of these findings have already been implemented in the amended Architects' Title Act of 12 June 2008. Furthermore, as indicated above, very recently (on 4 Mach 2010) the Architects' Title Act was amended again to include a mandatory period of professional experience of two years before one is allowed to register. Some other changes were also introduced, such as an explicit recognition that also legal persons can use the title of architect. The 2010 Act has not yet entered into force. Article VIII states that a Royal Decree will indicate when this will take place. It is expected that the professional experience period will become obligatory from 2015 onwards.

\section{Lifelong learning}

The Act of 12 June 2008 which amended the Architects' Title Act introduced a new Article 27a into the ATA which implements Article 22 (b) of Directive 2005/36/EC. This Article indicates that, unless the Bureau is notified that one is no longer professionally active, all registered architects are obliged to keep abreast of professional development by continuing education for at least 16 hours per year. Architects who are also a member of the professional association BNA are, through their membership, subjected to more stringent rules: BNA members have to keep up with new developments by undertaking at least 30 hours of education per year. The Architects' Title Act does not foresee any sanctions if one does not fulfil this obligation, nor is there any supervision. ${ }^{65}$ This does not seem to be efficient. In this regard, the OTB also proposed to annul the registration of those professionals who have not been professionally active for a certain period of time. In this way the risk that consumers would engage an incompetent professional was also deemed to be limited. However, since this proposal can be qualified more as a form of professional protection instead of title protection, it has not been accepted.

\section{Two year period of practical experience}

The OTB report also advised that professionals should have two years of professional experience before they are able to register. In this regard, the 2003 Rijksbouwmeester, Jo Coenen, took the initiative for the Experiment with regard to the Professional Experi-

64 In Dutch: 'Actieprogramma Ruimte en Cultuur'.

65 Parliamentary Documents Lower House 2007/2008, 31.079, no. 10. 
ence of Young Architects to give newcomers in the profession the possibility to gain much more and much wider practical experience in the brief two-year period during which newly-qualified architects begin regular practice. In this way they would be prepared to fully enter the profession. The new architects were given an individual mentor and had to follow a common programme. The evaluations of the Experiment demonstrated that it was a much needed and necessary complement to regular education, and more in particular with the education provided by the Technical Universities. The transition from the TU-education to real practice is not particularly seamless since the education provides for scientific design competences and does not qualify as a 'professional' education. Therefore, it does not contain a period for traineeship, even though Article 7.6(3) Law on Higher Education and Scientific Research provides that an education which prepares individuals for particular professions have to include a practical preparation with regard to professional practice. Article 7.6(2) explicitly holds that this is also applicable to the profession of architect. It has been asked whether there is sufficient practical preparation in the educational process at this moment. Practical skills and insights into building regulations, procedures, building costs, etc. are subjects which have to be learned through practice. As noted in the OTB report, the obligatory traineeship period in Member States such as Belgium, Germany, the United Kingdom and France, should be taken as an example. In this regard it should be noted however that European legislation does not demand the completion of a professional experience period. However, the Architects' Title Act has recently been amended. In July 2009, the Dutch Council of Ministers has, upon request of VROM Minister Cramer, agreed to send the proposal to amend the Architects' Title Act to the Second Chamber. ${ }^{66}$ On 4 March 2010 the Act amending the Architects' Title Act was approved by the First Chamber as well. When the amended Act enters into force, the title of 'architect' can only be used after completion of a traineeship (Article 12d), while those who follow this traineeship can call themselves 'architects in training'. It is foreseen that the amended act will enter into force in the traineeship will become mandatory from 2015 onwards. Those who are already registered are not obliged to follow such a practical period, since they probably already have practised the profession. The Bureau has to implement and manage these amendments. ${ }^{67}$

\section{Professional liability insurance}

It was also proposed to introduce obligatory professional liability insurance since consumers have no guarantee that the architect is covered by professional liability insurance. In two Round Table Meetings (11 April 2005 and 21 June 2005) held by members of the professions, it was however held that a compulsory professional liability insurance was not desirable and that the creation of a deontological rule which states that architects have to communicate to their clients before the contract is concluded with regard to whether or not they are in the possession of such insurance, was a better solution.

66 See Parl. Doc. 2008-2009, 32016, nr. 3.

67 At this moment the Bureau advises the VROM Minister on the quality of architectural education. In the future its task in this field will probably be extended, with the organisation of the professional experience period and responsibility for its quality, as well as with the creation of a deontological code and a complaints procedure. 
Compulsory insurance was considered to give rise to market regulation, and to give consumers a false feeling of security, since not every professional act is covered by such insurance. At this moment, only BNA members are obliged to buy professional liability insurance (Article 6(2) BNA Articles of Association). However, as held in Part I of this thesis, Article 23 of Directive 2006/123/EC indicates that Member States may ensure that providers whose services present a direct and particular risk to the health or safety of the recipient, or a third person, or to the financial security of the recipient, subscribe to professional liability insurance. Since the design and supervision of buildings can cause severe damage in the event that it is not performed well, it can be argued that the Netherlands has failed to implement the Directive in this regard. In this regard it should be taken into account, however, that Dutch architects will usually apply standard conditions that require architects to insure their professional liability. This will be discussed in more detail in Chapter 13. Furthermore, Article 27a which will be included in the Architects' Title Act after the entry into force of the 2010 amendment, indicates that those who are included in the register will have an information obligation towards (potential) clients. This obligation means that the registered architect who is asked to submit a quotation, is required to inform his client of his expertise and professional competence, coverage of the work to be carried out by him through a professional liability insurance policy and of the rights and obligations of the client.

\section{Complaint procedures and a deontological code}

The OTB report also made a recommendation for a public basis for complaint procedures and a deontological code. Since, currently consumers have no opportunity to complain if an architect does not behave well - they can institute civil proceedings but this involves a long and difficult process - a deontological code would provide protection by giving them the possibility to complain. It should be possible that the registration of professionals who do not work in accordance with a deontological code, or who make other professional faults, can be annulled. Other sanctions can be a warning, a suspension or a fine. It is proposed that the civil judge remains the competent authority to determine possible damage compensation. The deontological code will be inspired by the code of the Architects Council of Europe. The Council of State has not (yet) supported this amendment, due to the fact that the competence to create such rules is not sufficiently clear and precise.

These were the most important findings of the Research Institute for Housing, Urban and Mobility Studies of Delft University. ${ }^{68}$ It can be concluded that the Architects' Act

68 Another proposed amendment is to change the Bureau into an independent agency of public law or a public agency for trade and industry. In this regard it should be noted that, on 2 November 2006, an Act was promulgated containing more detailed rules on independent agencies, also know as Framework Act independent agencies, Official Gazette 587, 30 November 2006. It is foreseen that this new Act will be made applicable to the Bureau. See Parl. Doc. 32 016. As held in paragraph 12.2.2.1 of this thesis, the Bureau is an independent agency of private law. An independent agency is an organisation which fulfils public tasks, but which is not directly subordinated to a Ministry. Since the Cabinet's policy with regard to independent agencies is to put public tasks as much as possible under ministerial control, there are some limits to their competences. In general, an independent agency can only make rules on administrative or technical matters. Special subjects can only be regulated insofar as the Minister gives his approval first. It 
already foresaw the permanent education Act of 12 June 2008 (Article 27a AA) while a bill is pending on a two year period in which professional experience should be gained (bill 18 July 2009). The other proposals have not yet been implemented.

\section{The Association of Dutch Architects}

As indicated in paragraph 12.1, the Association of Dutch Architects (BNA) set up a private register for architects stricto sensu in 1948. This should be distinguished from the public register which was created in 1988 and managed by the Bureau. As a result of public registration, the architectural title is protected. Since the profession is not protected, the public register generally only guarantees clients that a registered architect has followed the required professional education. The demands of competent professional practices however, are more exacting, and include, among others, practical experience, adherence to a Code of Conduct, enhancing skills by following courses and a liability insurance. ${ }^{69}$ Only membership of the BNA -which is the sole general professional association of Dutch architects- guarantees all these skills. Through the BNA, architects who are of the opinion that the legal protection is not sufficient to guarantee a proper fulfilment of professional services, can thereby still unite themselves more closely. Membership is not compulsory, but is open to all registered architects who have gained sufficient (two years) qualified practical experience. The BNA created deontological rules on the 'way' in which the profession should be practised. By becoming a member, the architect obliges himself to work in accordance with these rules. They have to be observed by all BNA Members and have a bearing on competence, independence (Article 2 Code of Conduct), responsibility and the loyalty of the architect as an adviser of his client, without disregard, however, of his responsibility to society as a whole, and of his collegiality towards his fellow professionals (Article 1 Code of Conduct). ${ }^{70}$ In this way, the Code obliges the members inter alia, to improve their own knowledge, take into account the consequences of their actions for society and the environment, and make agreements in which the rights and duties of themselves and their clients are laid down in a sound way. The BNA Code of Conduct does not contain any provision on price regulation or business structure. It seems thus that also BNA architects are allowed to associate with en-

would thus be problematic for a public agency to create rules on the professional experience period, the deontological code or on permanent education. The Bureau is a 'b-organ' as meant in Article 1:1 (1) (b) General Act Administrative Law since it is a private agency holding public authority. The Bureau has public authority since it registers new professionals and manages the register. Since this responsibility is held by a private agency which is, for the majority, composed of members of the profession, it can be seen as an independent institution. See Priemus et all, p. 35.

With regard to the independent public agency model, board members of the Bureau are appointed by the VROM Minister who disposes of a lot of instruments to effect his political responsibility, and to prevent practising professionals protecting themselves against newcomers (approval of the budget and the annual accounts, creation of policy rules regarding the execution of tasks by the independent public agency, annulment of a decision, subjecting of certain decisions to foregoing approval, ...). What the exact consequences will entail will become clear after the Architects' Act is amended to incorporate these changes.

69 Bond der Nederlandse Architechten, The Architectural Profession in the Netherlands, leaflet, August 2006 p. 5. See http://www.bna.nl/binaries/bna-downloads-3/infoblad-the-architectural-profession-in-nl.pdf, last consulted 23 December 2009.

70 Ibid., p. 6. 
trepreneurs in the Netherlands. With regard to publicity, Article 2(2) indicates that architects have the freedom to make their activities, expertise, experience and competence known to the public.

The statutes of the BNA foresee in Articles 11 and 12, that membership can be cancelled by the board when a member does not fulfil its obligations. There is a College of Supervision and a Council of Appeal where a member can fight such a decision. Furthermore, BNA members are obliged to insure their professional liability, and have to undertake permanent education of 30 hours per year. With this final requirement in mind, the BNA Academy was created. In this academy, architects can follow several courses as part of the process of permanent education. ${ }^{71}$

The main occupations of the BNA are limited to testing the quality of the architecture and of building techniques in terms of social developments; informing members about new (legislative) developments and changes; stimulating a high quality of education and practical training; discussing with the government and other actors in the building sector about the judicial and economic frameworks within which architects perform their tasks; drawing up general conditions for the relationship between architects and clients, architect-employers and architect employees; representing the architect-employers in trade-unions and cooperating with other professional organizations; promoting the role of the architect as businessman and emphasizing their role in economic society; etc.

It should be stressed however, that architects are not obliged to register with the BNA. At present the BNA has over 3,000 members, representing some 1,500 practices. ${ }^{72}$ Roughly $75 \%$ of Dutch practices are associated with the BNA through the membership of one or more of their architects. However, when looking at the individual number of architects, only one third is a BNA-member. It follows that most members are large bureaus.

\section{Conclusion}

In the Netherlands, the architectural profession has changed considerably over time. Due to the high population density, the complexity of building projects has increased, which means that most building projects are set up by building promotors. ${ }^{73}$ As of 1 October 1993, registered architects can officially be distinguished from other professionals in the building sector since they have the privilege to call themselves 'architect' to the exclusion of all others. The Architects' Title Act gives rise to the legal protection of the title of Architect in the Netherlands. The general requirement for registration is the possession of a recognized diploma/certificate, or the successful taking of an examination. In general, Dutch students can follow a five-year university education or a fouryear part-time training at an Academy, the latter after having completed a four-year

71 See http://www.bna.nl/nl/nieuws/persberichten,2008/02/bna-academie.html and http://www.bna.nl/ $\mathrm{nl} /$ nieuwsberichten,bna/2008/06/wet-arch-titel.html, last consulted 1 November 2009.

72 http://www.bna.nl/nl/overbna, last consulted 9 November 2009.

73 However, recently a project has been started in the municipality of Almere to encourage consumers to 'design' their own houses in conjunction with their own architect. See http://www.echo.nl/albu/wonen/redactie/836573/uniek.project.in.almere.poort/, last consulted 23 December 2009. 
Bachelor programme. It is also possible to use the title after successful completion of the examination instituted by the Council of Architects. In order to take this examination, a minimum of seven years of practical experience in the field of architecture is required. The VROM Minister can grant exemption on the basis of proven exceptional competence. Automatically recognised certificates are those issued by the universities or academies mentioned in the Architects' Title Act and those mentioned in Annex V.7 and VI of Directive 2005/36/EC. Other qualifications can be recognised under the Directive's general system which is incorporated in the Act of 6 December 2007, containing general rules on the recognition of EC qualifications. The 2010 Amendment Act of the Architecs' Title Act includes a mandatory period of two years in which professional experience has to be gained before one can be registered as a fully qualified architect. It is foreseen that the traineeship -which is currently only obligatory for BNA members- will become mandatory from 2015 onwards. Registered architects are not subject to a code of conduct and there is no mandatory insurance obligation. Also legal persons can register. The Architects' Act is in line with the provisions of Directive 2005/36/EC. However, since there is no mandatory insurance obligation except for members of the Association of Dutch Architects (BNA), it can be questioned whether this is contrary to recital 98 of Directive 2006/123/EC which states that any operator providing services involving a direct health, safety of financial risk for the recipient or a third person, should, in principle, be covered by appropriate professional liability insurance.

The Bureau is charged with the registration of architects. Legally registered architects who comply with the educational requirements may exercise their profession as private architect or as salaried architect in an architects' office, in the public service, in professional bodies such as housing corporations or pension funds, and in the building industry, and use the title. ${ }^{74}$

To protect the consumer and society as a whole, the Bureau is authorized to institute legal proceedings against persons who illegally use the title of architect. The Bureau also functions as the 'competent authority' as detailed in Directive 2005/36/EC for all matters relating to the implementation and administration of its provisions.

Registration offers only a confirmation that the architect has fulfilled the required education programme. It follows that title protection can give some information about the quality of architectural services, but that an architect has also practical experience can only be guaranteed by membership of the BNA. Architects with two years professional experience can voluntarily become a member of the BNA. These architects have to act in accordance with the BNA Code of Conduct. The Permanent Professional Training Regulations which apply as of January 2006, contains rules on the professional education of BNA-members and implies that these architects should spend at least thirty hours per year on professional training. ${ }^{75}$

\footnotetext{
74 Bond der Nederlandse Architechten, The Architectural Profession in the Netherlands, leaflet, August 2006 See http://www.bna.nl/binaries/bna-downloads-3/infoblad-the-architectural-profession-in-nl.pdf, last visited 23 December 2009.

75 Van Gulijk 2009, p. 33.
} 
The Dutch title protection does not present significant obstacles as far as competition within, or entry into, the profession is concerned, because it is not coupled with a professional monopoly ${ }^{76}$. It does not prevent others, without a title, from entering the market.

In the Netherlands there is no protection of the profession since many legal requirements already apply to the architect's design as well as to the construction process, which all aim to protect the quality of buildings. It follows that to exercise the profession of architect in the Netherlands, neither inscription in the register nor BNA membership are mandatory.

76 Maks \& Philipsen 2002, p. 73. 



\section{Chapter 8}

\section{CONTRACT LAW IN THE NETHERLANDS}

\section{Introduction}

The preceding chapters discussed the public regulation of architects in the Netherlands. It was demonstrated that, contrary to the Belgian situation, only the title of architect is protected, but not the practise of the profession. This means that the involvement of an architect is not mandatory for the design of plans and the supervision of building works. Furthermore, the professions of architect and entrepreneur can be practised by one and the same person. Whether this has any consequences within the relationship between the building master, the entrepreneur and the (person practising as) architect, will be investigated in this chapter. It should be noted however, that just as was the case with the Belgian situation, this thesis will not contain a detailed description of the construction process, since it only aims to discuss the regulation of architects. However, when discussing the tasks of architects, it is impossible not to refer to the presence of other building partners, since the tasks of these professionals are often interrelated. For the same reasons as were described earlier, the tasks of the architect will only be discussed within the ambit of the traditional construction process.

Since the new civil code of the Netherlands is based on the Code Napoleon of 1804, while Belgium still uses this Code with only some minor amendments, the contractual regulation of architects in both countries contains some similarities. It follows that when discussing a regulation which is similar in both countries, I will refer to my explanation in the Belgian chapter and will not describe the content of that regulation in detail again, except if the Dutch regulation contains a derogation. However, even though the provisions of the civil codes of both states are comparable on several points, it has to be noted that the Dutch regulation dealing with the tasks and liabilities of architects is not limited to the provisions of the Civil Code or to the provisions which have been expressly agreed upon in the architectural contract. ${ }^{1}$ This is due to the fact that, in the Netherlands, the professions have created their own sets of rules, called standard terms. These

Of course contracts do not only contain what has expressly been agreed upon, but also what is deemed to be included, in accordance with the nature of the agreement, by reasonableness and fairness, usage and the law (see Article 1134 Civil Code Belgium and Article 6:2 Dutch Civil Code) 
standard terms are generally accepted and even foreseen in special 'extra-judicial' arbitration authorities. ${ }^{2}$ In the majority of the cases, parties have agreed that these standard terms are applicable to their contract. This means that problems which arise in the event of a building containing a certain defect are mostly solved by these arbitration authorities. As noted above, in Belgium it is not at all common for building problems to be solved outside of the court. Generally accepted standard terms are also non-existent. It follows that the regulation of (the tasks and liabilities of) $\operatorname{architects}^{3}$ in both countries is not that similar at all. Since the exact ambit of the architectural tasks is generally laid down in a contract (or in standard conditions), the contractual liabilities of architects will also be discussed in relation to the tasks of the building master and other building partners. As noted in paragraph 6.1., it is, of course, possible that the architect is also liable in tort towards third parties (such as the entrepreneur, neighbours, persons renting a house, etc.). In this regard it should be noted that the extra-contractual responsibility will only be withheld if no contractual obligations are violated. Since the responsibilities and tasks of architects are determined by the contract, and since my analysis of case law on the liabilities of architects has demonstrated that the overall majority of cases holding architects liable are based on their contractual liability, I will not discuss the liability in tort of architects, or their criminal liability.

\section{The legal position of the architect}

\subsection{Liberal profession}

Dutch legislators have not created a legal definition of the concept 'liberal profession'. It is however presumed that free professionals are professionals who practise a regulated profession and personally provide intellectual services in an independent way, after having fulfilled the required education. They are personally responsible for their actions, often subscribe to a deontological code, have a relationship of trust with their clients, and pursue their clients' as well as the public interest. ${ }^{4}$

The profession of architect is considered to fulfil all these requirements and is enumerated on the list of free professions of the Chamber of Commerce.

\subsection{The legal classification of the architectural contract}

The Dutch Civil Code does not contain any specific provision on the representation of the building master by the architect. Nevertheless, the contract between the architect and the building master is mostly categorized as a 'contract of services' as explained in Article 7:400 CC 5 .

2 As held by Article 1020 Civil Proceedings Act, it should be laid down in writing that a dispute will be subject to arbitration.

3 As held before, when the profession of 'architect' is discussed in the following chapters, the persons allowed to use the title are referred to, except if I expressly state otherwise.

http://www.raadvoorhetvrijeberoep.nl/, last consulted 23 December 2009.

5 In Dutch: 'overeenkomst van opdracht'. 
As noted above, entrepreneurship was considered as a sort of rent of work in Roman law (locatio-conductio operis faciendi). The Code Napoleon did not break with this tradition. It followed that the Dutch Civil Code of 1838, which was heavily influenced by the Code Napoleon ${ }^{6}$, stated in Article 1583 of Title 7 of Book III, that there are two types of rent: the rent of goods and the rent of services, work and industry ${ }^{7}$. This can be compared to Articles 1708-1711 of the text of the Code Napoleon used in Belgium.

Nevertheless, in 1907, the Labour Agreement Act $^{8}$ broke with this tradition. It was held that only goods could be rented, as opposed to services, labour and industry. The content of Title 7 (now Title 4) was reduced to rent agreements, which therefore no longer included entrepreneurship agreements, labour agreements and agreements to fulfil certain services. These were brought under a new title, Title 7A on the 'Agreements to supply labour'. These agreements were thus no longer classified as a type of rent.

After several amendments, these types of agreements are no longer classified under the same title. The Labour Agreement Act is now codified in Title 10 of Book 7 of the Dutch Civil Code which only deals with labour agreements stricto sensu. ${ }^{10}$ This means that nowadays the entrepreneurship agreement is no longer classified under a common heading with other types of agreements, and has its own Title 12, which was created in 2003, but only entered into force on 1 September 2006. ${ }^{11}$ The difference between a labour and an entrepreneurship agreement is that there is no level of subordination between the entrepreneur and the one who engages him. Furthermore, in principle, agreements to fulfil services are regulated in Title 7 of the Civil Code, entitled 'Commis-

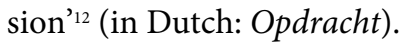

In the Netherlands, the contract concluded between an architect and his client is generally classified as a contract for services as defined in Article 7:400 CC (commission). The difference with the notion of mandate which is a type of commission agreement (Article $7: 414$ CC) is that in the event of a mandate, the architect fulfils legal actions for the account of the building master. However, in principle, the architect does not fulfil legal actions but only factual ones. ${ }^{13}$ Therefore the contract of the architect is qualified as a commission contract.

Until 1838 the Code Napoleon was applicable in the Netherlands.

In Dutch: 'huur van goederen, en huur van diensten, werk en nijverheid'.

Wet van 13 juli 1907 op de arbeidsovereenkomst, Stb. n. 193.

In Dutch: 'arbeidsovereenkomst'.

10 A labour agreement is an agreement by which one party engages himself to fulfil labour requirements for and at the service of another party, during a certain time, and against a certain wage: Article 7:610 CC

11 Act of 5 June 2003 to amplify title 7.1 (Purchase and Barter) of the new Civil Code with provisions on the purchase of immovables as well as the determination and introduction of title 7.12 (entrepreneurship), Official Gazette. 238. With regard to contracts to which the second section is applicable, the old regime has to be applied in the event that the contract has already been concluded before the entry into force of the new title on 1 September 2006. The first section is applicable to these contracts,.

12 In Dutch: 'overeenkomst van Opdracht'.

13 Van Zeben 1991, p.318. As held by Article 7.1 New Rules 2005, the architect is his client's mandatary if and insofar as his client has assigned him in writing for that purpose, or if the architect can prove that the client has otherwise explicitly given him permission. However, the lack of a written authorization cannot be brought in against the consultant, if and insofar as the consultant proves that the client has otherwise ex- 
As held in Article 7:400 CC.:

'1. The contract for services is an agreement to which one party, in the absence of an employment contract, fulfils services for the other party which do not constitute the erection of a material work, the preservation of things, the assignment of works or the transport of persons or things.'

In the event that Article 7:400 CC is applicable, the service provider fulfils certain tasks for his client for his own account. Since the architect does not normally fulfil legal actions for the account of his client, Articles 7:414-424 on mandate are, in principle, not applicable.

The difference with regard to Article 7:750 CC on entrepreneurship, on the other hand, is that the contract for services as meant in Article 7:400 CC does not concern the creation of a material, tangible work, while Article 7:750 CC only means materials creations. ${ }^{14}$ Since architects design plans and do not construct the building themselves, Article 7:750 CC is not applicable to them.

\subsection{The status of the architect}

Architects can practise their profession as a self-employed professional, as an employee or as an official of the state appointed by the administration. ${ }^{15}$ In the situation in which architects work as employees, they normally have concluded a labour agreement with their employer, and not a contract of services. It should be noted that in the Netherlands, architects can even be employed by entrepreneurs. However, since they practise a liberal profession, they always have to take into account the interests of the general public. Their intellectual independence cannot be affected.

Hereunder the tasks and responsibilities of the self-employed architect will be discussed in greater detail. The tasks of the other types of architects are generally the same.

\section{Parties to the architectural contract}

As held above, the relationship between the architect and the building master is qualified as a contract of services, and not as an entrepreneurial contract. The provisions in Title 12 on entrepreneurship do not refer to the architect at all. The reason is that the

plicitly given permission, or if and insofar these actions follow out of the given circumstances or the nature of the commission. The New Rules will be discussed in more detail hereunder. In general however, architects are not allowed to sign a contract with an entrepreneur on behalf of the client. If the architect exceeds his authority to act, he is strictly liable towards the entrepreneur if the latter suffers damages because of this.

14 According to Article 7:750 (1) CC, a contract for works is a contract whereby one party, the contractor, undertakes towards the other party, the client, otherwise than under a contract of employment, to create and to deliver works of a tangible nature, against a price in money to be paid by the client. The entrepreneur is thus obliged to erect the work and to deliver it to the building master, in accordance with the content and purpose of the agreement.

15 See for example Article 3(2) BNA Code of Conduct. 
involvement of an architect is not mandatory according to Dutch law. In the Netherlands, a building can therefore be constructed with or without the involvement of an architect. Since this thesis aims to describe the regulations relating to architects, it is obvious that the situation in which the building master decides to engage an architect will be under discussion.

In the traditional construction process the architectural contract is concluded between the architect and a non-professional building master. The architect performs services for the building master which exist in principle in the design of a plan and the supervision of the execution of the building works. In this thesis only the traditional building process will be discussed.

\section{Content of the architectural contract}

When a contract is concluded, parties generally discuss and agree on every specific aspect which is included in the agreement. In principle, contractual and liability matters are thus regulated by the Dutch Civil Code. This means that a valid contract is concluded between two or more consenting parties (Article 6:213 CC jo art. 3:33 CC) if its object does not violate public order and good morals, and the contractual obligations are determinable (Article 6:227 CC). If the agreement came into existence as the result of a threat (Article 3:44(2) CC), error, deceit (Article 3:44(3) CC) or the misuse of circumstances (Article 3:44(4) CC), or if one of the parties was not legally capable of binding itself (Article 3:34 CC), the agreement can be declared void. Contracts are form free and, in principle, do not have to be written.

The Civil Code provisions in Title 12 are not only applicable to building works, but to all types of entrepreneurship. Only Section 2 contains provisions which are explicitly applicable to building contracts. They aim to protect consumers and have coercive force. As has been stated previously, the professional groups in the Dutch building industry held that the stipulations of the Code Napoleon were too obsolete, and consequently have created their own rules, referred to as standard terms, which often replace the Civil Code provisions. Since the professional associations have created their own rules, the legislator considered it to be unnecessary to include more specific provisions relating to building construction in the Civil Code in 2003. Furthermore, if legislation which would cover all types of building projects had to be created, the regulation would be complex and extensive. There are situations in which the design is made by the building master himself, or by his architect, and situations in which the entrepreneur also acts as the designer. The execution of the work can be carried out with or without supervision, while the complexity of the building project can also require special rules. Since the building sector has demonstrated that it is able to foresee a differentiated system of regulations, the legislator has chosen not to create a special regulatory regime for building projects. Furthermore, the sector's own rules can be adapted more easily. Nevertheless, as noted above, the legislator did chose however to create a coercive regime in fa- 
vour of consumers, since there is a risk of imbalance and inequality of economic power in this area. ${ }^{16}$

The standard terms which are thus created by certain professional associations in the building industry, are therefore very popular. However parties always have to declare them applicable to the contract under consideration. The standard terms aim to regulate the contractual relationship of the building master and the entrepreneur, and the relationship between the building master and the architect. They constitute a part of the contract and have become generally accepted. Whenever standard terms are declared applicable to a certain contract, the contracting parties do not have to agree on every aspect separately. In this way, the contracts become more uniform, which brings about an easier situation for those involved in the building sector and their clients. It should be noted, however, that according to Article 6:233 CC, the applicability of the standard terms can be nullified if the user has not given the other party a reasonable opportunity to take notice of them. However, as held by Article 6:232 CC, the other party is bound by the general terms and conditions even if, at the time of entry into the contract, the user has understood or ought to have understood that the other party was not aware of its contents. Furthermore, in the event that the content of standard terms contract is unreasonably onerous, for example if the architect is released in whole or in part from a legal obligation to repair damage, it can be nullified. ${ }^{17}$

As noted above, in this way not only architectural standard terms, such as the Standard Regulation 1997 (SR 1997) and the New Rules 2005 (NR 2005), were created, but so too were entrepreneurial standard terms such as the Uniform Administrative Terms for the Execution of Works 1989 (UAV), the Uniform Administrative Terms for Integrated Contracts 2005 (UAV-GC 2005) and the General Terms for Entrepreneurship in the Building Company (1992 (AVA 1992).

Even though this thesis aims to discuss the regulation of architects, the importance of some of these entrepreneurial terms should not be underestimated. The reason is that some of them presume the presence of a 'director', which is deemed to be an architect, the building master or another expert. In this way, the UAV 1989 contain the most popular standardized contractual clauses when an architect is involved. ${ }^{18}$ They revised the Uniform Administrative Terms of 1968 and came into existence after deliberation between the organisations of building companies and the government. The UAV (and most of the other standard terms) are characterised by the fact that disputes between entrepreneurs and building masters are settled by the Council of Arbitration for the Building Industry which is not a judicial court. Its case law is quite uniform. The UAV

16 Asser-Van den Bergh 2007, p. 11.

17 See for example Article 60(2) Standard Regulation 1988 and 's-Gravenhage 22 November 2000, BR 2001, 599, annotated by M.A.M.C. van den Berg.

18 The UAV 1989 must be used for all projects commissioned by public authorities or subsidized by these. Bond der Nederlandse Architechten, The Architectural Profession in the Netherlands, leaflet, August 2006, p. 10. See http://www.bna.nl/binaries/bna-downloads-3/infoblad-the-architectural-profession-in-nl.pdf, last visited 23 December 2009. 
are applicable in the traditional situation in which the entrepreneur erects a building in accordance with a design created by the building master or by the latter's architect or advisor. They are therefore not applicable in the event that the entrepreneur created the design himself. Furthermore, the building is erected under the building master's supervision (direction) or under the supervision of a director (i.e. generally an architect, advisor or other expert).

The most important architectural standard terms on the other hand are the New Rules 2005 (NR) and the older Standard Regulation (SR) 1997. ${ }^{19}$ The NR define the general provisions and the obligations of the building partners with respect to the commission. As noted above, they are only applicable in a concrete case if parties agree upon this. The NR are created by the Royal Institution of Dutch Architects (BNA) and the Organisation of Consultant and Engineers Bureaus (ONRI), but can also be used by architects who are not BNA members. Several disciplines in the construction industry, active in the design, consultancy and management phases, aimed to obtain an integrated design so that contracts would be more uniform, which would be easier for all parties. ${ }^{20}$ In this way the NR contains standard regulations which are commonly used in the construction sector, and which are generally not contrary to fairness and good faith. The NR are accompanied by a standard contractual form in which the parties make concrete agreements with respect to the specific commission granted to the architect. The filling in of this basic contract differs as between projects, while the legal relationship remains the same. It should be noted, however, that the NR only regulate the relationship between the building master and the consultant (i.e. mostly an architect or engineer). The NR however do not describe the architect's tasks in detail, as the former SR $1997 \mathrm{did}$. The tasks and competences are now enumerated in the 'Explanatory Notes on the Legal Relationship client-architect, engineer and consultant NR 2005 Standard Form of Basic Contract'. It is important to note that, together with the NR, a 'Standard Task Specification' was created, which enumerates the tasks of the various consultants in detail. A new version was made in 2009. These will also be further discussed hereunder.

It follows that when inquiring about the tasks of the architect, not only the provisions of the Civil Code will have to be discussed, but also the NR which deal with the most recent architectural standard terms and the UAV 1989 which contain the most popular

19 It should be noted that since 1 September 2006, the Regulation Consumer-Architects exists. This contains simpler rules on the legal relationship between the architect and his (non-professional) client, and is applicable to smaller projects if parties agree so. In the event of a mistake by the architect, the building master can only obtain damage compensation to a maximum of 75,000 Euros. If the advisory costs are higher, the damage compensation can be 1,000.000 Euros at most. 75,000 Euros is also the maximum amount which can be obtained by client-consumers in the NR 2005 if the advisory costs are lower than 75,000 Euros. However, those who are not consumers can obtain a damage compensation of a maximum of $1,000.000$ Euros even if the advisory costs are lower than 75,000 Euros. It is important to note that in the event of a dispute, no arbitration is possible, and recourse has to be taken to the ordinary courts. See http://www.bna.nl/binaries/bna-downloads-3/02-algemene-voorwaarden-consument-architect.pdf, last consulted 17 November 2009.

20 The New Rules 2005, Explanatory notes on the legal relationship between client-architect, engineer and consultant DNR 2005, Standard Form of Basic Contract. 
entrepreneurial terms. This is due to the fact that the Civil Code does not discuss the tasks and liabilities of architects as such. Title XII on entrepreneurship presumes the absence of a 'direction', while Title VII on service contracts is applicable to the architectural contract but does not deal with it specifically. However, since the Civil Code does contain rules on the relationship between the building master and the entrepreneur, its provisions cannot be neglected, since the responsibility of the architect often starts where the responsibility of another contracting party ends. Furthermore, if standard terms are not applicable to a contract, the Civil Code provisions have to be consulted. Title 7.12 even contains a few provisions which have coercive force..$^{21}$

It is important to note that the UAV foresee that the building master is allowed to appoint one or more persons to 'direct' the work (\$3.1 UAV 1989). In this way architects, but also other specialists, can function as director. If the building master does not appoint someone, he will function as the director himself. The director will represent the building master in all matters related to the construction, except if the UAV provides that the building master is exclusively competent (\$3.4 UAV 1989). ${ }^{22}$ In the NR on the other hand, the architect is called a 'consultant' (see Article 1). The consultant is he who accepts the commission. This means that the NR are not only applicable to the architect practising as a free professional, but also to the architect-employee, and even to those who fulfil commissions without being in the possession of any educational qualifications..$^{23}$

Since this thesis aims to discuss the regulations with regard to architects, I will use the term 'architect' when the UAV refer to the 'director' and the NR to the 'consultant'.

Membership of the BNA does not have any influence on the applicability of the architectural terms which are created by the BNA, or on the contractual relationship between the building master and the architect. Parties can always agree as to whether or not the NR are applicable. This means that even architects who are not a BNA member can agree that these terms are applicable ${ }^{24}$, as well as those who practise the profession without being allowed to use the title ${ }^{25}$. Furthermore, the mere fact of being a BNA member does not automatically make the NR applicable. In any case, it should be noted that architectural terms cannot be applicable when there are no architectural actions (and,

21 Article 7:755 and 7:762 have coercive force, as well as section 2 of title 7.12.

22 See for example the Council of Arbitration for the Building Industry 2 April 1913, Jaarverslag 1913, nr. II, 6. Since the architect cannot represent the building master if the building master is specifically named in the UAV, he is, for example, not allowed to change or cancel the direction, prolong the period for delivery, agree on prices and changes with regard to the building specifications, put the entrepreneur in default, etc. In any case, the director is not allowed to adapt the building contract with the entrepreneur after its conclusion (Council of Arbitration for the Building Industry 1966, nr. 4712, Jaarverslag 1966, 49). If he did so, the building master would not be bound by the changes. Furthermore, the architect cannot raise the entrepreneur's honorarium without the consent of the building master. See Council of Arbitration for the Building Industry 26 August 1982, nr. 9878, BR 1982, 919. These matters do not fall under the architect's normal competence.

23 Van Wijngaarden \& Chao-Duivis 2004, part 7, p. 16.

24 Utrecht 15 January 1964, JAR 1964, 79; Arbitration Institute Architecture 25 March 1980, BR 1980, 641; TvA 1980/5, p. 124.

25 Council of Arbitration for the Building Industry 25 July 1973, BR 1973, 808. 
for example, only entrepreneurial actions) involved. ${ }^{26}$ Architectural standard terms are thus not necessarily applicable to every contract. In the event that they are not applicable, and a certain issue is not contractually regulated, they are not even considered to be automatically applicable with regard to that specific issue. In such a case, one will determine how the issue is generally regulated. Since architectural terms are mostly declared applicable by the contracting parties, the architect's competence as described in these standard terms, is often deemed to be the normal competence. It follows that, if no standard terms apply, and the building contract does not regulate a certain issue, one will look at the 'normal' solution which is, in general, presumed to be described in architectural terms, since they describe the tasks and liabilities architects incur in general. Furthermore, it should be noted that the rules of the Civil Code complement the standard terms, so whenever the applicable terms do not regulate a certain issue, the Civil Code has to be consulted.

If the NR 2005 are applicable, disputes between the building master and the architect have to be settled as amicably as possible, including the use of mediation. If no specific arrangements apply, the dispute will be settled by the ordinary civil judge applying the Code of Civil Legal Procedure. However, if parties agree that the settlement of disputes will take place by means of arbitration, then all disputes -including those regarded as such by only one of the parties- which arise between the client and the consultant or their legal successors or assignees as a result of the commission, shall be settled by arbitration. Article 44 of the SR 1997 foresees arbitration by the Arbitration Institute of Architecture ${ }^{27}$ which specifically deals with issues between architects and building masters, while the NR 2005 resort to the Council of Arbitration for the Building Industry ${ }^{28}$ when it comes to dealing with building problems. This is the same Council as that indicated in the UAV. The Council decides in accordance with the rules which are in force

Council of Arbitration for the Building Industry 20 September 1983, BR 1984, 535

This arbitration institute was set up in 1969 by the General Terms on the honoraria of architects and the contractual relationship between the building master and the architect (AR 1969) which was replaced by the SR 1988.

28 Due to the wish to have a more integrated system, the board of the Arbitration Institute of Architecture and the Council of Arbitration for the Building Industry is made up of the same persons. See http://www.arbitrageinstituutbouwkunst.org/curatorium/index.html, (last consulted 17 November 2009) and http://www.arbitrageinstituutbouwkunst.org/arbiters/index.html, (last consulted 17 November 2009). Arbitration by the Council of Arbitration for the Building Industry as stipulated in NR was inspired by the wish to have one 'general' arbitration institute for the building sector in the Netherlands. Most disputes are brought before the Council of Arbitration for the Building Industry: Van Wijngaarden \& Chao-Duivis 2004, part 8, p 14. A party in arbitral proceedings initiated with the Arbitration Board whose subject matter is linked to proceedings before another arbitration institute in the Netherlands, may request that these proceedings be completely joined, provided that the other proceedings are conducted subject to the applicability of rules providing for the possibility of a complete joinder of arbitral proceedings in a substantively corresponding manner. The chairmen of both arbitration institutes will jointly decide. See Article 19, Arbitration Regulation of the Arbitration Institute of Architecture and Article 17, Council of Arbitration Regulation. Each of the parties shall, in principle, be entitled to appeal against an award rendered by the Arbitration Board in the first instance. The appeal shall be handled by an Arbitration Tribunal. See Article 19, Arbitration Regulation of the Arbitration Institute of Architecture and Article 22, Council of Arbitration Regulation. 
on the day on which the dispute has been brought up. If parties have agreed on arbitration, the civil court does not have jurisdiction (Article 58 NR).

\subsection{Obligations of the architect}

Even though the Standard Task Specification by the NR, which describes the architect's tasks, is extremely detailed, hereunder the most important tasks which architects generally incur are summarised.

- Provide assistance and advice to the client

As held by Article 7:401 CC, the architect has to fulfil his commission ${ }^{29}$ with due care. This means that his services have to be carried out with the same diligence that society requires from other persons of the same profession and undertaking similar tasks. ${ }^{30}$ As stated in Article 7:403 CC, the architect has to inform his client ${ }^{31}$ about what he has done in order to fulfil his commission, and has to notify him immediately after completion of his task, in the event that his client was not aware of completion. Furthermore, the architect has to justify the way in which he has fulfilled his task. If he has used or received money for the account of his client as part of the fulfilment of his tasks, he also has to inform his client about this. It follows that Article 7:403 CC is a concretization of the duty of care obligation stipulated in Article 7:401 CC. This duty of care obligation is also contained in Articles 11.1 and 11.2 NR 2005 which state that the architect has to dispose of the required knowledge and competence, for the proper fulfilment of the commission, and has to carry out the commission in a proper and careful manner, assist the client independently in a position of trust, and conduct his services to the best of his knowledge and capacity. The architect should avoid everything that can prejudice the independence of his advice. The duty of care obligation which is an obligation of means, is not only applicable to the architect's advisory task but to the whole process.

The duty of care obligation also means that the architect keeps his client informed about the execution of the commission. He provides, to the best of his capacity, and in time, on request, all pieces of information, including information about the progress of the execution of the commission, alterations of (government) regulations or decrees, or alterations with respect to the financial aspects of the commission, the financial consequences of alterations thereof whether necessary or not, as well as information about agreements which he has concluded with third parties for the fulfilment of the commission (Article $11 \mathrm{NR}$ ). He also has to give advice on construction materials. Furthermore, it is obvious that the architect has to take into consideration the public and private regulations which are relevant to the commission, and has to inform the building master about the progress of the works, the existence of which may be considered as common knowledge among consultants (Article 1.4 and 1.5 NR). In this way the provisions of

29 In Dutch: 'opdracht'.

30 Supreme Court 18 June 1926, NJ 1926/1021; Supreme Court 9 June 2000, NJ 2000, 460

31 The client is 'de opdrachtgever'. 
(among others) the Housing Act and the Spatial Planning Act have to be taken into account, as well as private law rules relating to neighbourhood obligations.

Architects have an obligation of means in this regard, which means that they have to make a design which is suitable for obtaining a building permit, but they do not have to guarantee that such a permit will effectually be granted. If the design does not meet the legal requirements, architects are strictly liable however.

The architect also has to warn his client if the information given to him contains such shortcomings, or shows such deficiencies that he would act in defiance of standards of reasonableness and fairness should he proceed.

As held by Article 7:402 CC, the architect has to respect justified directions in relation to the performance of his commission, and which are given to him in due time. If he has reasonable grounds to refuse the fulfilment of his task in accordance with the directions given to him, he can terminate the contract if his client does not adapt these directions, and he can invoke serious grounds. However, if the commission contains certain faults, or if the date provided to him contains errors which are so serious that it would be contrary to reason to base his work on them, he has to inform the building master (Article 11.10 NR).

The architect also has to do what is necessary to obtain decent price offers from entrepreneurs with regard to the execution of the building project. However, the architect is not allowed to grant the commission to a particular entrepreneur. This is still the task of the building master. However, if the entrepreneur could rightfully trust the architect's power to grant him the work, the building master can be bound by this, even though no permission was given to this effect. ${ }^{32}$

\section{- Determination of the programme and the budget}

Article 3 NR 2005 states that the architect will advise his client to let him fulfil a preinvestigation if the client does not dispose of a list of demands which can be considered as the starting point for his activities, if he is not sure whether the execution of the client's demands is possible, or if he deems a pre-investigation to be desirable. If fulfilment of his client's wishes is possible, the architect draws up a written concept of the commission in consultation with the client, from which emerges what has been discussed, as well as the applicability of these rules (Article 4.1 NR 2005). As held by Article 4.2 NR 2005, the agreement is officially concluded if the architect confirms in writing to his client that he can execute this concept, or if such a written offer by the architect has been accepted by the client, or if that which has been laid down is agreed upon in another way, as long as it is in writing. It follows that if the client approves the concept in writing, the contractual obligations are set, and the contract has been entered in to. ${ }^{33}$ As indicated by the Explanatory Notes to the NR, if the architect has been asked to draw up estimates or budgets, he has to draw these up to the best of his ability. According to the

32 Council of Arbitration for the Building Industry 1948, nr. 1431, Jaarverslag 1948-1949, 16.

33 It should be noted that it is obligatory for an entrepreneurial contract to be in writing if it relates to the purpose of constructing a dwelling consisting of an immoveable thing or part, and is commissioned by a natural person not acting in the conduct of a profession or business (see Article 7:765). Section 2 of title 7 of book 7 has coercive force, and contains several provisions which all aim to protect consumers. 
Arbitration Institute of Architecture, architects are obliged to provide the client with cost estimates. ${ }^{34}$ This also falls under the proper and careful carrying out of the commission. The budget does not only include the real costs but also the architect's fee. In this regard it should be noted that chapter 12.8. of the NR contains rules on how the architects can calculate his fee, for example by percentage, that is on the basis of the value of the work to be done; by time, that is on the basis of the time spent; or by discretion, meaning that it is left entirely to the discretion of the parties. In this regard it should be noted that the SR 1997 used to indicate the fee basis by means of a reference to NEN 2631, which is a Dutch norm indicating how investment costs of building should preferably be calculated. A formula was drawn which led to the determination of a certain percentage which would then result in the fee. ${ }^{35}$ This formula left no room for price competition whatsoever and was often also used by architects which were no BNA members or to contracts to which the SR 1997 was not made applicable and was not only used by the Arbitration Institute Architecture but also by the ordinary courts. ${ }^{36}$ This form of price fixing was not taken over by the NR 2005.

\section{- Design of the plan}

As held by the Standard Task Specification by the NR, the architect is responsible for the design. Of course the design of the architect has to be of good quality and has to satisfy the building master's demands. As noted above, these demands have to be agreed upon first (Article 2(3) NR). Before the design can be made, the architect first has an obligation of means to investigate the soil, to see whether it is fit for constructing a building in accordance with the client's wishes. ${ }^{37}$

- Supervision of the execution of the building works

As held by $\$ 3.6 \mathrm{UAV}$, the architect supervises the execution of the building works and verifies whether the contractual obligations have been observed. This is also confirmed by the Standard Task Specification by the New Rules 2005 under the heading 'Executional Phase'. The architect has to check the quality of the work on a regular basis, and to determine whether they are fit for approval. Since the architect has to act with due care, he has an obligation of means. As to what the supervision of the execution exactly entails, I refer to Chapter 8.5. In any case, it should be noted that architects can engage experts to assist them during the verification of the building work.

\subsection{Obligations of the building master}

- Give the architect and the entrepreneur the opportunity to work

As held by Articles 12.1 and 12.2 NR, the building master has to behave as a good and careful building master in his relationship with the architect. This means that even though he is not obliged to control the latter's advice, he has to give him the opportunity

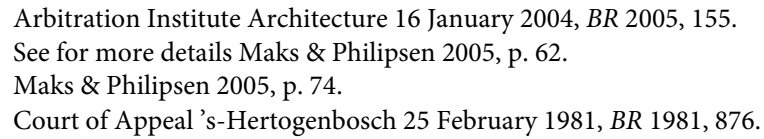


to fulfil his job. Towards the entrepreneur, the building master is not obliged to assist him with the execution of the building. Nevertheless, an obligation to cooperate can be written down in the contract or can be deduced from its purpose. In the literature it is said that such an obligation exists if the entrepreneur has a positive interest in the good performance of the contract. ${ }^{38}$. Of course this is the case with building contracts, since the entrepreneur wants to get a good reputation for his work and so gain new clients, and needs to have enough work to keep his employees in employment. Therefore the building master is obliged to give the entrepreneur the opportunity to fulfil the contract. An example of the cooperation obligation can be found in Article 12.4 NR which holds that if the building master actually detects a shortcoming, or should have been conscious thereof, he has an obligation to warn the architect in that respect. Furthermore, the building master has to hand over the permission to the entrepreneur and put the land at the entrepreneur's disposition ( $\$ 5 \mathrm{UAV}$ ). It follows that both parties have to take each other's interests into account.

- Provide all necessary information

The building master has to provide the architect will all information that is necessary to undertake the project. In the event that he notices, or should have noticed, a certain fault in the architect's plans, he has to warn the architect about this (Article 12.4 NR).

\section{- Pay the price}

As held by Article 7:405 CC, if the architect enters into the agreement within the practice of his profession or business (trade), his client has to pay him. If the amount is not determined, the client has to pay a regular or reasonable amount. In such a case, the regulation in standard terms is held applicable on this point, since its content is deemed to be generally known and customary ${ }^{39}$ The obligation to pay is also stipulated in Article 12.8 NR. It follows that if there is a conflict, and the judge cannot fall back on the provable presence of contractual dispositions between the architect and the client, he is charged with the duty to investigate the characteristic feature of the architect-principal relationship. He will look at standard terms to determine what belongs to the tasks of the architect and to determine a reasonable honorarium for the architect..$^{40}$

Of course the client also has to pay the service provider's costs which are related to the fulfilment of his commission, as long as these costs are not included in his honorarium. Furthermore the client also has to compensate for damage suffered by the architect in the event that a certain serious danger arose during the fulfilment of the task, for which the architect cannot be held accountable. In the event that the service provider was working within the practice of his profession or business, he only has to be compensated if that danger surpasses the risks which are normal within the execution of that profession or trade (Article 7:406 CC). It follows that, in the event that the danger constitutes a normal risk which has to be taken into account, the professional service provider will not get damage compensation. Most architects are insured for such risks. As

Asser-Hartkamp 4-I, 2004, nr. 281.

Amsterdam 7 March 1979, BR 1979, 801.

40 Adriaansen, Maks \& Philipsen 2005, p. 56. 
indicated in the previous chapter, Dutch architects are not (yet) obliged to buy professional liability insurance. This might be contrary to recital 98 of Directive 2006/123/EC which states that any operator providing services involving a direct health, safety of financial risk for the recipient or a third person, should, in principle, be covered by appropriate professional liability insurance.

- Approval and acceptance of the work

As held by Article 7:758 CC, in his relationship with the entrepreneur, the building master has to approve and accept the work if it seems that it has been carried out in a good and proper way. As held by $\$ 3.4 \mathrm{UAV}$ jo $\$ 9$ and 10 , the architect will approve and accept the work unless the building master has notified the entrepreneur that he will do this himself.

\section{Liabilities and risks of the architect and the entrepreneur}

\subsection{Introduction}

In the forgoing chapter, the most important tasks of the architect were briefly discussed. This chapter aims to discuss the main liabilities of architects in the event that a building suffers a certain defect. As held before, the Civil Code does not assume the presence of an architect. Therefore the general liability principles will apply, as well as the regulations laid down in the New Rules. Reference should also be made to the UAV, in which the presence of an architect to direct the work is made possible. It should be noted that the liability of the architect depends on the concrete circumstances of the case. In the following, I aim to provide the reader with the general liability principles which are applied when judges or arbitrators rule as to whether or not the architect has violated his contractual obligations. It should be noticed that this subject will only be discussed within the framework of the traditional construction process. Furthermore, only the contractual liability will discussed and not the architects' liability in tort or penal liability.

\subsection{Proof of liability}

As held by Article 6:74 CC, every failure in the performance of an obligation shall require the debtor to repair the damage which the creditor suffers because of this, unless the failure is not attributable to the debtor. If performance is not permanently impossible, the debtor has to be put in default before he is obliged to repair the damage.

With regard to the architectural responsibility, Article 13.1 NR holds more specifically that the architect is liable if he committed a culpable shortcoming (accountable fault) and that the building master has put him in default in writing and summoned him to repair the consequences of the shortcoming within a reasonable time, given that the architect has not (or not on time) repaired the consequences of these shortcomings. If follows that the architect who perpetrates a shortcoming is not, by definition, therefore 
liable. To be declared liable, the client must declare in writing that the architect is li$\mathrm{able}^{41}$, grant him a reasonable time to make good the consequences of the shortcoming, in the event that the architect has not, or not on time, complied with this summons. The architect is thus only liable for his culpable shortcomings at the moment that he has not answered the proof of default. This is also stipulated in Article 6:74 CC. ${ }^{42}$

Each case of not complying with an obligation following from the commission is a shortcoming. The shortcoming is culpable when the architect could, and should have, avoided the shortcoming. The criterion is that of a well and carefully acting architect who acted with normal attentiveness. The architect should be equipped with the required professional knowledge and means, while these requirements are related to the actual commission. ${ }^{43}$ The arbitrators will always verify whether a well and conscientiously operating consultant would have handled it in the same way. The architect is thus not liable for damage which could not be foreseen ${ }^{44}$, or when he did everything which could reasonably be expected from him. ${ }^{45}$ However, sometimes the architect will be answerable for a certain result. Calculations, for example, should not contain any mistakes. If the commission stipulates that an uncertain environment, for example a soil which cannot properly be investigated before the start of the execution activities, should be examined, then the consultant cannot be answerable for the result, but he has met his obligation to advise in a proper and careful manner if he has 'done his best' in the given circumstances. ${ }^{46}$

In the Netherlands, the Civil Code, but more importantly standard conditions, describe what the tasks of an architect really encompass. Court decisions, decisions of arbitration institutes and doctrine have often interpreted these tasks and determined their extent. I refer to paragraph 8.4. for some examples.

Overall, architects have an obligation of means towards the building master. As held by Article 11.1. NR 2005 he has to fulfil his commission with good care and assist the building master to the best of his knowledge and competence. It is clear that architects can be held liable in cases which they did not design with due care. The design should conform to the state of the art, which is an obligation of means. ${ }^{47}$ Architects have to advise their clients on the applicable legislation. Since they are obliged to know the relevant regulations, they can be held strictly liable if the design is not in conformity with these rules. Architects do not have to guarantee that a building permit will be granted. The design only has to be eligible to obtain such a permit, which indicates the existence

41 The proof of default does not have to be issued in all cases, for example if a term has been agreed on as fatal, the sole expiry of this date, without the work having been executed that should have been carried out, is enough to be in default.

42 Arbitration Institute Architecture, nr. 1200-0162, unpublished; Arbitration Institute Architecture 12 September 2003, nr. 1200-0204, unpublished. The purpose of a summons is to give the architect the opportunity to cure the consequences of the default within a reasonable time.

43 Explanatory Notes to the New Rules, Article 1.

44 Council of Arbitration for the Building Industry 27 January 1986, BR 1986,462.

45 Court of Appeal Amsterdam 29 May 1970, BR 1971, 421; Van den Berg, Bregnan and Chao-Duivis (et al) 2007, p. 266.

46 Explanatory Notes to the New Rules, Article 11 (2)

47 Bruggeman, Chao-Duivis \& Koning 2007, p. 44. 
of an obligation of means. ${ }^{48}$ If the architect exceeds his competence, it is possible that he binds his clients to third parties, which can lead to severe damages. It follows that in such a case, he will be strictly liable. ${ }^{49}$ Architects have to examine the building site to the best of their ability. This clearly is an obligation of means. The same is true with regard to the selection of building materials: the architect can be held liable in the event of improper advice, or if he was, or should have been, aware of the unfitness of the materials. ${ }^{50}$ An obligation of means also exists regarding the advice on construction costs. The budget determined by the architect has to be more or less equal to the real costs, since architects cannot predict every possible situation that can have an influence on the price. Since architects are not obliged to be present at the building site at all times, it can be said that they have also an obligation of means in this regard. In any case, architects are always allowed to engage experts such as engineers with regard to certain tasks. ${ }^{51}$ The architect will be liable if he should have noticed that the expert was not competent, or noticed this without taking any action.

Of course the client has to prove the culpable shortcomings of the architect. However, arbitrators are able to determine on their own whether a culpable shortcoming has been committed due to their experience and competence. Therefore, they do not often demand that the building master should fully prove his viewpoint. In this regard it should be noted that there are many limitations to the architect's liability. However since the introduction of SR 1988 they have become fewer in number, making them not unreasonably onerous as meant in Articles 6:236 and 6:237 CC

The entrepreneur, on the other hand, has to execute the works according to the plan provided to him by the building master or by the building master's architect ( $\$ 6.2$ $\mathrm{UAV}$ ). In such a case, the entrepreneur has to make sure that the work is executed in accordance with the plan and the directions of the architect. He is, in principle, not responsible for the fact that the work does not live up to the building master's expectations due to a fault in the plan, except if he neglected his duty to issue a warning ( $\$ 14$ UAV). ${ }^{52}$ Furthermore, it should be noted that the entrepreneur can only invoke his right

\footnotetext{
Van Gulijk 2009, p. 76; Arbitration Institute of Architecture 19 April 2005, No. 1200-0301, not published.

See Article 1 jo 7 NR 2005.

Council of Arbitration for the Building Industry, 21 September 2001, BR 2002, 149.

Arbitration Institute Architecture 3 February 2003, BR 2004, 75.

52 See 's-Gravenhage, 27 November 1952, NJ 1953/661. The entrepreneur is also obliged to warn the building master for any faults/defects in the building master's area of responsibilities, as long as he could/should have noticed them (7:754 CC). This duty does not encompass a full research of the obligations, but only refers to what is reasonably noticeable and is based on the principle that parties have to take each other's legitimate interests into account, even in the pre-contractual phase: See Supreme Court 15 November 1957, NJ 1958, 67 (Baris/ Riezenkamp). If the entrepreneur failed to issue a warning, he will normally only be held fully liable if he was aware of the fault in the design/instructions, and did not act upon it. If he was not aware of it, but could/should have been aware of it, the damage compensation will mostly be divided between parties in accordance with Article 6:101 (1) CC. The damage which has to be compensated for is mostly calculated as the difference between the costs which have to be made to repair the defect, and the costs which should have been made if the entrepreneur had issued a warning in time, and his warning would have been followed: See Council of Arbitration for the Building Industry, 14 May 1969, nr. 5487, BR
} $1969,454$. 
to the presence of a director to supervise the work if this was contractually agreed with the building master or in the case of exceptional circumstances. If afterwards it turns out that the entrepreneur is not sufficiently competent to do the job, he cannot demand that the building master hire an architect to repair his faults.

It is important to note that $₫ 44.3$ UAV 1989 states that, notwithstanding the liability of parties by virtue of the contract or the law, the entrepreneur is liable for damage to the work, unless this damage is the consequence of exceptional circumstances against which the entrepreneur did not have to take appropriate measures due to the character of the work, and it would be unreasonable to hold him liable for the damage. It seems therefore that the entrepreneur has a residual liability and will be held liable every time another party cannot be held responsible, based on the law or by contract.

Since the architect will be held liable in the event that he committed a culpable shortcoming within the framework of his tasks, while the entrepreneur will be held liable in the event of an attributable shortcoming in the execution of the work, in the Netherlands the professionals will not be held liable in solidum.

Of course parties are always allowed to insert exoneration clauses in the contract as long as these do not violate the true meaning of the contractual obligations, and do not exonerate deceit or malicious intent. This will be further discussed in paragraph 8.5.3.2.

\subsection{Liability before and after reception of the building work}

Constructions build by the entrepreneur under the supervision of the architect have to be approved and delivered to the building master (see Chapter IV UAV and Article 16.1 NR).

As held by Article 758(1) CC, the works will be delivered by the entrepreneur to the building master after the latter has accepted them. After the entrepreneur has indicated that he has finished the execution ${ }^{53}$, the building master has to react and approve or disapprove the work within a reasonable time period (dependent on the circumstances of the case). Silence is considered to be an acceptance. According to $\$ 9.1 \mathrm{UAV}$, the entrepreneur has to notify the architect in writing that he has completed the execution. Furthermore, $\$ 9$ contains precise time limits wherein the work has to be accepted if the building master wants to evade automatic acceptance ( $\$ 9$ and 10). In any case, small defects cannot be a reason to withhold approval ( $\$ 9.7 \mathrm{UAV})$. After approval, the building work will be delivered to the building master (\$10.1) UAV). Nevertheless parties can agree to foresee a maintenance period, in which the building master can test whether the

53 The entrepreneur has to fulfil the works and offer the construction within the agreed time period. In the event that this time period is not respected, a fine can be imposed (Article 6:91 CC) and the UAV may even foresee in a diminution of the contract price ( $\$ 42 \mathrm{UAV})$. In the event that the work cannot be offered due to force majeure or a fault of the building master, the time period can be prolonged. The Council of Arbitration for the Building Industry only applies this diminution if the building master has suffered damage. Furthermore the judge can soften the amount of the fine based on Article 6:94 CC if reasonableness requires this (coercive force). 
building is free from defect. Defects which are noticed within this period have to be repaired by the entrepreneur, with the exception of defects which are caused by construction or working methods which are proscribed by the building master, or by the building master's materials ( $\$ 11.2$ jo $\$ 5.2$ and $5.3 \mathrm{UAV}$ ). At the end of the maintenance period, the entrepreneur will ask the architect once more to verify and approve the work.

It is important to note in this regard that Article $11.3 \mathrm{NR}$ states that the architect has to buy professional indemnity insurance that offers at least the same cover as the skeleton policy, lastly and jointly decreed and published by the Royal Institute of Dutch Architects and the Organization of Consulting Engineers (ONRI). As noted before, architects who are a BNA member are obliged to buy insurance. Due to the NR, all architects, even those who are not a BNA member, have to buy professional liability insurance if they apply these NR.

As held by Article $15 \mathrm{NR}$, the damage to be compensated for by the architect, is limited per commission to a sum equal to the consultancy costs with a maximum of 1,000,000 Euros. As stated before, this is only the case if the NR 2005 are made applicable. However, in the case of commissions where the client is a consumer, and the consultancy costs per commission are lower than 75,000 Euros, the damage to be compensated for is limited to a maximum of 75,000 Euros. These limitations are, of course, only valid if the NR are applicable, and are only valid for 'professional' faults of the architect. If the architect voluntarily causes damage or was grossly negligent, it can be at odds with the principle of good faith to invoke this provision..$^{54}$

\subsubsection{Liability before reception of the building work}

As stated before, Title 12 of Book 7 of the Dutch Civil Code does not include the presence of an architect. Since this thesis aims to discuss the regulation of architects, it presumes the involvement of an architect, so that the provisions of the NR have to be referred to when discussing their liability as well as the provisions of the UAV which deal with the presence of a direction. However, to understand the ambit of the architects' liabilities, one also has to take into account the liabilities of the entrepreneur and the building master, as described in the Civil Code and the UAV, since the liability of one person often starts where that of another person ends.

As already noted, Article 13.1 NR holds that the architect is liable in the event that he has committed a culpable shortcoming, and the building master has put him in default in writing and has summoned him to repair the consequences of the shortcomings within a reasonable time, while the architect has not (or not on time) repaired these consequences. Since the architect is responsible for the supervision of the execution ( $\$ 3.6 \mathrm{UAV}$ ) as well as for the design of the plan (Standard Task Specification to the NR), while the entrepreneur is responsible for executing the work in accordance with the architect's design and directions ( $\$ 6.2$ and $6.4 \mathrm{UAV})$, -at least if these standard terms are

54 Council of Arbitration for the Building Industry 18 August 1997, BR 2000, 704, annotated by M.A.M.C. van den Berg. 
applicable- the respective professionals will be held liable in the event that they have committed an attributable shortcoming within the framework of their respective obligations, and were in default with regard to repairing the damage. In the case of force majeure, they can therefore not be held liable. As already noted above, it should be noted that the architect has, in principle, an obligation of means. This means that he has to fulfil his duty of care and act as a reasonable and prudent professional, in order to escape liability.

As noted above, in this thesis, the presence of an architect to supervise the building work is presumed. It should be noted that his supervision is meant as an extra guarantee for the building master, and not as a diminution of the entrepreneur's responsibilities.

However, even though supervision is not obligatory, this does not mean that the building master will never be liable for failing supervision towards the entrepreneur. If the entrepreneur does not receive any remarks about the work that has been executed by him, he will trust that his work is fulfilling the building master's requirements. If it then turns out that this is not the case, and that the entrepreneur found himself, due to the attitude of the architect, in a less favourable position, he can claim damage compensation from his contracting party, the building master. When determining the entrepreneur's liability for his respective culpable shortcomings, the attitude of the supervisor will only be taken into account if the entrepreneur was not aware of the fault, and he could not know that the supervision was insufficient. It follows that the building master will only be liable with regard to the entrepreneur for insufficient supervision, if the architect's attitude could reasonably let the entrepreneur believe that his work would be approved by the building master, while the entrepreneur's trust in the supervisor was justified and the damage was caused because the entrepreneur built upon this trust. ${ }^{55}$ Of course, the building master can always institute proceedings against the architect. The fact that the entrepreneur's trust in the supervisor has to be justified, does not leave much room for the entrepreneur to hold the building master accountable for faults with regard to the supervision. Since the supervisor cannot personally control every aspect of the building process, only evident faults or faults which occur repeatedly are considered to be faults which should have been noticed by the architect. Of course contracting parties can always agree otherwise.

The Civil Code and the UAV do contain some more specific liability rules with regard to defects in, or lack of fitness of, materials or tools used by the entrepreneur. These shall be for the account of the entrepreneur (Article 7:760(1) CC). This is confirmed by $\$ 17$ UAV 1989, which stipulates that the entrepreneur is responsible for the good quality of the building materials, their fitness for the intended purpose, and their timely delivery. It is important to note that the entrepreneur is not allowed to use building materials which are not approved. As held by $\$ 18.1 \mathrm{UAV}$, the materials have to be approved by the architect before they are incorporated into the construction. Materials which are put at the entrepreneur's disposal by the building master are deemed to have been approved.

55 Asser-Van Den Berg 2007, nr. 111. 
Nevertheless, in the event that the materials, including the land, are proscribed by the building master and contain a defect causing an improper performance of the work, the building master will be liable (Article 7:760(2) CC). This is also confirmed in $\$ 5.2,5.3$, 5.4 UAV 1989. Article 7:760(2) CC confirms the content of Article 6:77 CC which states that where, in the performance of an obligation, an object is used which is unfit for purpose, the resulting shortcoming will be attributed to the debtor, unless this would be unreasonably onerous in the light of the content and purpose of the legal action out of which the obligation arises, generally accepted principles and other circumstances of the case. It follows that, if an improper execution is due to defects or the use of inappropriate materials on the part of the building master, including the land, the latter will be responsible for the consequences, at least if the entrepreneur respected his warning duty and did not otherwise fail his duty of care. However, in the event that Article 7:760(2) CC applies, the entrepreneur will be liable in the event that he failed his duty to warn, as stipulated in Article 7:754 CC, or failed in his expertise or due care in another way. Paragraph 2 applies mutatis mutandis in the event of errors or defects in plans, drawings, calculations, specifications or executing directions provided by the building master (Article 7:760(3) CC). The extent of the entrepreneur's obligation to deliver a good and proper building, is therefore dependent on the amount of specifications given by the building master, and the amount of freedom of choice which is left to the entrepreneur. The building master is therefore responsible for his own choices. The consequences of these defects are therefore for the account of the building master, whether or not he can be blamed for these defects. ${ }^{56}$

\$5.2 UAV 1989 holds in this regard that the building master is liable for the construction demanded of him, and the working methods required by him (i.e. for the orders and directions given by him or in his name ${ }^{57}$ ). $\$ 5.3$ UAV extends his liability to building materials prescribed by him. This paragraph is an exception to $\$ 17$ which states that the entrepreneur is responsible for the quality of the building materials, and their fitness for their intended use. If the prescribed instructions of the building master, as well as the execution by the entrepreneur, contain defaults, both the building master and the entrepreneur can be held partially liable..$^{8}$

56 Explanatory Memorandum, Kamerstukken II 1992/93, 23, 095, nr. 3, p.32. In 1966, the Supreme Court held that in the event that the building master does not provide the materials himself, but orders which materials have to be used by the entrepreneur who then has to purchase them, the building master is liable in th event that they are defective, even if these materials are, in principle, fit for their intended use: Supreme Court 25 March 1966, NJ 1996, 279 (Moffenkit). The Explanatory Memorandum to Article 7:760 (2) CC departed from this viewpoint. In the event that certain types of materials, which are fit for their intended use, are prescribed by the building master, while the specific materials bought by the entrepreneur are accidentally unfit, the entrepreneur will be held liable. It was held that there is no reason to shift the risk to the building master since the entrepreneur could also be faced with this problem if there would not have been any direction at all as to the materials which have to be used. Only if the type of materials were unfit in any case, would the building master be responsible. In such a case, the instruction of the building master is qualified as a defective design choice (as opposed to $₫ 4 \mathrm{UAV}$ ).

57 It is, however, possible that the building master exonerates himself for any faults in the required construction: Council of Arbitration for the Building Industry 1934, nr. 954, aarverslag 1934, 15.

58 Council of Arbitration for the Building Industry 19 September 1918, Jaarverslag 1918, nr. 119, 93; Council of Arbitration for the Building Industry, Jaarverslag 1921, nr. XLIII, 87. 
To avoid liability as meant in Article 7:760(2) and (3), the entrepreneur must therefore warn the building master about inaccuracies in the agreed specifications at the moment the contract is concluded, or during the execution, to the extent that he was, or ought to have been, reasonably aware thereof. ${ }^{59}$ The entrepreneur does not have to investigate the instructions and directions, but has to warn of defects which are noticeable after a global inspection. ${ }^{60}$ The entrepreneur's warning duty is also stipulated in $\$ 6.14 \mathrm{UAV}$, which states that if it appears that the orders or directions contain defaults or omissions which are so serious that it would be against good faith for the entrepreneur to execute them without issuing a warning, the entrepreneur is liable if such a warning did not take place. In such cases, the building master has to prove that the entrepreneur failed in his warning duty.

When determining whether or not the entrepreneur is liable in the event that he failed his duty to warn, the Council of Arbitration for the Building Industry holds that the entrepreneur only has to do a marginal testing. ${ }^{61}$ The Council takes the level of expertise of the building master into account. In this way, it has often been held that if the entrepreneur is no expert, or if the building master has more expertise than the entrepreneur, the entrepreneur is not liable for specific technical issues and has no warning duty. The Supreme Court, on the other hand, only takes the level of expertise of the building master into account after having judged that the entrepreneur is liable, to determine the extent of the damage which has to be paid..$^{62}$ Furthermore, the Council of Arbitration for the Building Industry holds that if another expert is consulted by the building master, the entrepreneur can, in principle, trust the latter's advice and does not have to warn of any faults ${ }^{63}$. If the entrepreneur has not enough experience to undertake this task, he should hire an expert himself. On the other hand, when the entrepreneur is an expert in the field himself, he has to warn the building master/director as soon as possible. The more serious the fault is, the bigger his warning duty is ${ }^{64}$ In any case, it is important to note that the warning has to be given to the architect immediately after the fault is noticed (\$6.14 UAV 1989). In general, failure of notification brings about full liability. However, account has to be taken of the foreseeability of the damage.

In the event that the building master made a fault and the entrepreneur failed in his duty to issue a warning, the defect is, in the first place, still the risk of the building master. The reason is that if there was no defect in the materials, directions or design, the entrepreneur did not have to issue a warning for anything at all. If he had to issue a warning, this necessarily entails that there was already a defect which could have been prevented if the entrepreneur had respected his warning duty. The damage is therefore caused by both parties. In such a case, the damage can be divided in accordance with the respective

59 Council of Arbitration for the Building Industry 7 October 1983, BR 1984, 166; Council of Arbitration for the Building Industry 12 July 2000, nr. 21.273, BR 2000, 167.

60 Asser-Van den Berg 2007, nr. 101; Asser-Thunissen 1994, nr. 539.

61 Council of Arbitration for the Building Industry 1939, nr. 1206, Jaarverslag 1939, 27.

62 Supreme Court 18 March 1932, NJ 1932 (Mook/Sap III).

63 Council of Arbitration for the Building Industry 1958, nr. 2700, Jaarverslag 1964, 16.

64 Council of Arbitration for the Building Industry 1962, nr. 3828, Jaarverslag 1962, 104. 
mistakes of the parties concerned (Article 6:101 CC). However, the Council of Arbitration for the Building Industry often holds the entrepreneur liable for the entire damage, since \$6.14 UAV states that the entrepreneur is liable for the harmful consequences of his failure. According to the Council, this means that the entrepreneur's failure to warn caused the total damage. ${ }^{65}$ In any case, a division cannot take place if the entrepreneur was aware of the fault and did not warn the building master. If the architect made a design fault as well, the building master can institute proceedings against both professionals. In such a situation, the architect will only be held liable for his culpable shortcomings and will only have to pay for that part of the damage which is caused by him. ${ }^{66}$ The architect can therefore also be held partially liable for failure of supervision in such a case. It can be concluded that if there is a fault in the execution of the work, the entrepreneur has to cure it, or pay compensation for the damage caused. ${ }^{67}$ However, if a certain obvious fault which could not be overlooked by the architect is approved, it is possible that the entrepreneur may no longer be held liable. ${ }^{68}$ In any case, it should be noted that the architect will not be held liable in solidum together with the entrepreneur in the Netherlands. If the building master engaged an architect to design the plans and to give directions during the execution of the building work, and it turns out that the building suffers from a defect, the building master will, in general, turn to the entrepreneur instead of to the architect, even if the former failed in his duty to warn. ${ }^{69}$ The reason for this is that architects mostly use general conditions in which their liability is strongly limited, while the UAV foresee in $\$ 44.3$ that, notwithstanding the liability of parties by virtue of the contract or the law, the entrepreneur is liable for damage to the work, unless this damage is the consequence of exceptional circumstances against which the entrepreneur did not have to take appropriate measures due to the character of the work, and it would be unreasonable to hold him liable for the damage. It seems therefore, that the entrepreneur has a residual liability and will be held liable every time another party cannot be held responsible, based on the law or on the contract. In the event that the building master turns to the architect anyway, the architect can claim that, within the contractual relationship between the building master and the architect, the former is responsible for the entrepreneur's failure to warn, which jointly caused the damage. The damage can then be divided in accordance with the respective faults. If this division would not be reasonable due to the seriousness of the faults, and the circumstances of the case, it can still be corrected (Article 6:101 last sentence CC). This correction factor will often be used since the position of the architect as professional designer brings about that he has to design the building with the utmost accuracy, since he knows that the executor will place trust on his design. He can never speculate on the fact that a possible fault will be noticed by the entrepreneur, and can never trust on a 'double

65 Council of Arbitration for the Building Industry 7 October 1983, nr. 11.380, BR 1984, p. 166, annotated by H.O. Thunissen

66 Council of Arbitration for the Building Industry 16 November 2005, nr. 27.016, unpublished; Council of Arbitration for the Building Industry 1929, nr. 683, Jaarverslag 1929, 68.

67 Council of Arbitration for the Building Industry 15 December 1994, nr. 16.977, unpublished.

68 Council of Arbitration for the Building Industry 5 November 2003, nr. 23.526, unpublished.

69 Van Den Berg, Bregman, Chao-Duivis \& Langendoen 2004, pp. 282-293. 
check'. ${ }^{70}$ Even though the duty to warn is a duty in favour of the building master, the architect cannot presume that this duty will always be rightly fulfilled. In the relationship between the building master and the architect, the statement of the architect that the damage is jointly caused by the fact that the entrepreneur did not warn will, in principle, therefore not release him from his liability due to the reasonableness correction factor mentioned in the last sentence of Article 6:101 CC.

Article 7:760(1) CC and $\$ 17$ UAV can be compared to Article 1788 of the Civil Code as it is used in Belgium, while Article 1789 of the latter Code can be compared to Article 7:760(2) CC and 5.2-5.3-5.4 UAV.

Article 7:757 CC can be compared to Article 1790 of the Civil Code used in Belgium. It holds that if the object upon which, or to which the works have to be executed, perishes or gets lost, making the execution of the work impossible, while this cannot be attributed to the entrepreneur, the entrepreneur is entitled to a proportional payment of the agreed price based on the work he has already fulfilled and his costs. In the event of malicious intent or gross negligence on the part of the building master, the latter has to pay the full contract price less the entrepreneur's savings (Article 7:757(1) CC). In the event that the object ${ }^{71}$ was kept by the entrepreneur (i.e. in principle before reception), the building master does not have to make any payment unless the perishing or loss of the object was due to his fault (see Article 1790 CC Belgium). If this is the case, Article 7:757(1) is likewise applicable (Article 7:757(2)) CC). It follows that in the case of "normal' culpability, the entrepreneur has to be paid proportionally, while in the case of malicious intent or gross negligence, the contract price has to be paid fully, less his savings. The UAV do not contain an Article comparable to Article 7:757 CC. As noted above, according to the UAV, the work is, in principle, at the risk of the entrepreneur until the moment of delivery (\$6.4 UAV 1989), unless special circumstances occur $(\$ 44.3 \mathrm{UAV})$.

\subsubsection{Liability after receipt of the building works}

1. In principle: the architect can be held liable for five years after completion of the commission As noted before, Article $13 \mathrm{NR}$ states that the architect is liable towards his client if he committed a culpable shortcoming and the client has declared in writing that he is liable, and has summoned him to make good the consequences of the shortcoming within a reasonable period of time and the consultant has not, or not in time, complied with this summons. The architect is only liable for damage that directly results from his culpable fault or negligence (Article 13-14 NR).

\footnotetext{
Asser-Van den Berg 2007, nr. 106.

1 With regard to immovables, the 'object' is mostly not 'kept' by the entrepreneur. Buildings are normally constructed on the land of the building master who automatically becomes the owner.
} 
Even though the New Rules 2005 do not foresee specific provisions dealing with the exact content of the architect's liability after reception, they do foresee them during a prescribed period. ${ }^{72}$

According to Article 16 NR 2005, each liability of the architect expires five years from the day upon which the commission was terminated, either by completion or cancellation. The day on which the object is completed or is deemed to be completed is regarded as the day on which the commission is terminated in the event that this date took place before the day on which the architect was sent his final bill. Otherwise the date on which the final bill was sent counts as the starting point for the prescribed period. However, the legal claim on account of a culpable shortcoming is not admissible if the building master has not, with due diligence, declared in writing, and for good reasons, that the architect is in default after he has discovered the shortcoming or reasonably should have discovered it. This legal claim on account of a culpable shortcoming expires two years after the written a motivated notice of default. Furthermore, it is not admissible for this claim to be brought up later than five years from the day upon which the commission was terminated, either by completion or cancellation.

It follows therefore that the building master first has to put the architect in default, and has to institute a proceeding within two years of the written proof of default. In any case, each liability expires after five years, so if the building master puts the architect in default four years after the completion of the building works, but waits two years to institute proceedings, his claim will be inadmissible.

It is important to note that the architect can only be held liable by the building master during the five year period after completion of the building work in the event that it is proven that he committed a culpable shortcoming. In the Netherlands, the building master thus has to prove the architect's shortcoming with regard to each liability. There is therefore a heavier weight on the building master's shoulders.

It should be noted however, that Article $16 \mathrm{NR}$ is only applicable in the event that the New Rules 2005 have been made applicable to the contract. If this is not the case, the claim for damage will generally prescribe after twenty years (Article 3:306 CC). Article 3:310 CC is more specific, and holds that claims for damage due to shortcomings in the performance of a contract prescribe five years after the creditor discovered the shortcoming and is aware of the identity of the debtor. In the event that the creditor did not discover the damage, the liability period of ten years starts to run after the damage was caused. It follows that the New Rules limit the liability period as laid down in the Civil Code. $^{73}$

72 The former standard architectural terms used to foresee a liability was a period of ten years. Since this gave rise to extremely high insurance premiums, this was reduced to five years. See A. De Groot, BR 1989, p. 247.

73 It should be added that the New Rules also limit the extent of the architects' liability. As held by Article 15, the compensation which has to be paid by the architect for the damage caused to his client equals the advisory costs (advisor's fee, supervision costs and additional costs) with a maximum of 1,000,000 Euros. If 
2. The entrepreneur is in principle not liable for defects after delivery of the building works As noted before, after the entrepreneur has indicated that he has finished the execution of the building work, the building master has to react and approve or disapprove these works within a reasonable time period. After the acceptance by the building master, the entrepreneur will deliver the works. Just as in Belgium, parties often agree to establish a maintenance period in which the building master can test whether the building is free from defects. Defects which are noticed within this period have to be repaired by the entrepreneur for his own account, unless they are caused by construction or working methods which are proscribed by the building master or by the building master's materials ( $\$ 11.2$ jo $\$ 5.2$ and 5.3 UAV). At the end of the maintenance period, the entrepreneur will ask the architect to once more verify and approve the work.

As held by Article 7:758(2) CC, after delivery of the building work, the building master carries the risk for this work. This is confirmed by $\$ 12.1$ UAV which holds that after the day on which the work is delivered in accordance with $\$ 10.1$ or $10.2 \mathrm{UAV}$, the entrepreneur is no longer liable for defects in the work. It follows that, after delivery and reception of the work, the entrepreneur is, in principle, no longer liable for defects in the construction.

As held by $\$ 6.4$ UAV, the construction and its execution are for the account of the entrepreneur until the day on which the construction is delivered in accordance with $\$ 10$ UAV. The construction is considered to be delivered when it is approved or when it is deemed to be approved. The day on which the work is approved or is deemed to be approved is therefore the day on which the work is considered to be delivered. In the event that the entrepreneur has indicated that the work is ready to be delivered and the building master does not check the work and accepts it within a reasonable period (with or without reservations), nor disapproves of it, the building master is presumed to have tacitly accepted the work. If there is an explicit or implicit (for example by unconditional payment or unconditional use of the construction) approval, the works are considered to be approved by the building master and will be delivered by the entrepreneur. If the applicable standard terms do not contain a provision on acceptance, the unconditional use of the building counts at least as a presumption of approval ${ }^{74}$. If the building master does not accept the work, he has to give his reasons for refusal. If the entrepreneur agrees with these objections, he must repair them and subsequently ask for a new approval. If he does not agree, it is possible to bring the dispute before the Council for Arbitration. ${ }^{75}$

$\$ 9$ and 10 UAV contain more details about the formalities which have to be fulfilled before delivery can take place. These will not be discussed within this thesis.

these costs are less than 75,000 Euros, the compensation can be, at most, 75,000 Euros. It follows that, with regard to large projects, clients often still have to bear a considerable amount of the damages themselves.

74 See for example Council of Arbitration for the Building Industry 198, nr. 70.352, unpublished; Council of Arbitration for the Building Industry 9 May 2007, nr. 28.679, unpublished.

75 Council of Arbitration for the Building Industry 25 August 1999, nr. 70.422, unpublished. 
As held by Article 7:758(3) CC, there is one exception to the fact that the entrepreneur is no longer liable for defects after the reception of the work by the building master: since the entrepreneur is freed from liability for all defects which reasonably could/should have been noticed by the building master at the moment of delivery, he is still liable for damage caused by hidden defects. The entrepreneur is thus discharged from all liability for defects which the building master should have noticed at the moment of delivery. It is important to note that in the event that the works are not approved due to minor defects, it is possible that arbitrators may be called upon to verify whether or not the defects hinder the entrepreneur from using the building. The Council of Arbitration for the Building Industry has ruled a number of times that small defects do not hinder delivery as long as they do not impede the use of the building ${ }^{76}$ (see also $\$ 9.7 \mathrm{UAV}$ ).

It is important to note that $\$ 12 \mathrm{UAV}$ contains an additional exception. $\$ 12.2 . \mathrm{b} \mathrm{UAV}$ states that the entrepreneur is not freed from liability after delivery of the work in the event that the work or part of it contains a hidden defect which is due to a fault on the part of the entrepreneur, the fault of his supplier, sub-contractor or his workmen, and the entrepreneur has been notified of that defect within a reasonable time period after its discovery. Furthermore, the entrepreneur is still liable after reception if the situation described in Article 1645 Old CC takes place. This exception to the entrepreneur's liability, as well as others, will be discussed in detail hereunder (point 3., 4. and 5.).

As stipulated in Article 7:759(1) CC where, after delivery, the construction is found to contain defects for which the entrepreneur is liable, the building master must give the entrepreneur the opportunity to repair these defects within a reasonable period of time, unless this cannot be demanded from the building master in the given circumstances. This is, of course, without prejudice to the entrepreneur's liability for damage caused by the defective delivery.

The entrepreneur's possibility to repair the defects is based on the proportionality principle, and does not have to be granted to him if this would bring about considerable inconveniences for the building master, or in the event that a satisfying result is not expected, or cannot take place within a reasonable time period. If the costs of repair would be disproportional to the building master's interest, the entrepreneur does not have to repair the defects. It should be noted, however, that even if the entrepreneur cures the defects, he still has to indemnify the building master for the damage caused by his deficient delivery.77 Article 7:759 CC therefore takes the interests of both parties into account. The same principles can be found in $\$ 46.1,6.7$ and 11.2 UAV. As held by $\$ 46.1$ $\mathrm{UAV}$, if the entrepreneur does not repair the defects, the building master can repair them himself or have someone do this for the account of the entrepreneur. In the case of a serious defect, he can also resolve the contract in accordance with Article 6:265 CC.

76 See for example Council of Arbitration for the Building Industry 22 October 1917, Jaarverslag 1917, Nr. XIII, 55, W. 10.318; Council of Arbitration for the Building Industry 17 April 2003, nr. 25.113, unpublished; Council of Arbitration for the Building Industry 2 June 2003, nr. 23.438, unpublished Council of Arbitration for the Building Industry 11 May 2006, nr. 28.107, unpublished; Council of Arbitration for the Building Industry 17 Augustus 2006, nr. 27.297, unpublished.

77 Van Wijngaarden \& Chao-Duivis 2004, part 2, p 178. 
Parties often agree to put into place maintenance or experience period. In this period the building master is allowed to use the construction over a certain period to 'experience' whether or not the building suffers from defects. This possibility is not foreseen by law and thus has to be agreed upon explicitly, or has to be applicable by usage. In this regard it should also be noted that none of the standard terms which existed before 1945 contained any provision on maintenance periods. Nevertheless, the Council of Arbitration for the Building Industry often held that certain defects could still be repaired after a certain period during which the building master could test his building. It follows that an experience period is often deemed to be present due to usage, even if neither the contract, nor standard terms which proscribe such a period, are applicable to the contractual relationship. ${ }^{78}$ Even the UAV do not contain provisions for an experience period as such, but do give rules in the event that the building specifications prescribe such a period ( $\$ 12 \mathrm{UAV})$. If the UAV are applicable, parties thus have to come to a specific agreement about the existence of such a period, and its duration, which can therefore differ on a case by case basis.

The UAV do foresee, however, that the experience period starts to run after delivery of the building work and that the entrepreneur has to repair defects which become apparent during this period on his own account, with the exception of defects for which the building master is liable ( $\$ 11(2)$ UAV). Furthermore, as held by $\$ 11.4$ UAV, damage which arises within the maintenance period comes for the account of the building master, with the exception of damage which is a consequence of insufficient work performed by the entrepreneur.

Until the last day of the experience period, defects ${ }^{79}$ which were not visible at the moment of delivery, and which could therefore not have been indicated at that time, can be communicated to the entrepreneur. ${ }^{80}$ Within a reasonable period ${ }^{81}$ the entrepreneur has to repair these defects as well as possible consequential damage ${ }^{82}$ for his own account, except if it can be demonstrated that the building master is liable for the damage ${ }^{83}$ (par. 11.2 and 11.3 UAV). After reparation, the entrepreneur has to be paid. However, if the entrepreneur does not offer reparation or refuses it, or when arbitrators hold that the case is better solved without reparation in natura ${ }^{84}$, or when such reparation is impossi-

78 Council of Arbitration for the Building Industry 7 February 1996, nr. 17.177, unpublished; A.C. van Zeggelen, BR 1976, p. 221

79 Since the standard terms do not indicate which defects have to be repaired, every construction which is not in accordance with the building specifications or the requirements of good work, has to be repaired.

80 The defects have to become apparent during the experience period, not before it: par. 11 (2) UAV, Article 9 (2) AVA 1992

81 Council of Arbitration for the Building Industry 1923, Jaarverslag 1923, nr XXVIII, 124.

82 The building master does not have to prove that the defects are caused by the entrepreneur. Council of Arbitration for the Building Industry 7 November 1988, nr. 13.378, BR 1989, 222; Council of Arbitration for the Building Industry 4 July 1997, nr. 18.297, unpublished.

83 The building master can, for example, be liable if he puts building materials at the disposal of the entrepreneur which contain defects that could not be noticed by the latter (Par. 5 (2), (3) and (4) UAV, par. 6 (14) UAV; Council of Arbitration for the Building Industry 13 February 2006, 23.839, unpublished, or if he used the construction in an improper way.

84 For example when reparation in natura is extremely costly. 
ble, the entrepreneur can be condemned to pay a financial compensation to the building master instead, or a deduction of the entrepreneur's fee can take place. As noted before, the building master can also repair the defects himself, or have someone do this for the account of the entrepreneur. In the event of a serious defect, he can also resolve the contract in accordance with Article 6:265 CC. However, if the construction can be used, and the building master has sufficient certainty that the defects will be repaired within a reasonable time, ${ }^{85}$ arbitrators will not permit a deduction of the entrepreneurs' fee ${ }^{86}$.

In a situation in which receipt is refused, the entrepreneur will normally try to repair the defects as soon as possible, and will ask for a new approval. If this is the case, approval can only be refused by the building master if the first disapproved defects are not repaired. New defects can thus not be the reason for a second refusal ( $\$ 9.9 \mathrm{UAV}) .^{87}$

If parties agree that there shall not be an experience period, this means that after reception, the work is not allowed to contain any defects which could otherwise have been repaired during the experience period. ${ }^{88}$

Since Article 7:758 CC and $\$ 12$ UAV contain a transfer of risks from the entrepreneur (and the architect) to the building master, they bring about a reversal of the burden of proof: before delivery, the entrepreneur is liable unless he can prove differently; after delivery, damages are for the account of the building master unless he can prove that one of the exceptions is applicable.

From this moment onwards the prescription period starts to run, which limits the liability for defects in the building work. This will be further discussed hereunder.

The provisions which were discussed above all refer to the liability of the entrepreneur. The New Rules 2005 do not contain a special provision dealing with liability after receipt of the building works. For this reason, reference should be made again to Article 13 which holds that the architect is liable for culpable shortcomings if he did not, or not in time, comply with a written summons of his client. In this regard it should be noted that if the work is of such low quality that the entrepreneur could not reasonably have trusted in the architect's approval, the entrepreneur cannot invoke the architect's approval to escape from liability towards the building master. The representation power of the architect as described in $\$ 3.4 \mathrm{UAV}$, is thus limited to the situation that he works with due care and good faith. ${ }^{89}$ Once the works are approved however, the entrepreneur

85 See, for example, Council of Arbitration for the Building Industry 1925, nr. 499, Jaarverslag 1925, 112; Council of Arbitration for the Building Industry 1948, nr. 1467, Jaarverslag 1948-1949, 36.

86 Council of Arbitration for the Building Industry 1927, nr. 566, Jaarverslag 1927, 40.

87 Council of Arbitration for the Building Industry 16 December 1982, nr. 9473, TvA 1983/5, sub 2; Bloemlezing 1981-82, 132.

88 Council of Arbitration for the Building Industry 8 May 1992, nr. 15.616, unpublished; Council of Arbitration for the Building Industry 15 February 1985, nr. 11.366, unpublished.

89 Council of Arbitration for the Building Industry 7 January 1932, W. 12404. 
does not have to demonstrate that the approval was justified. In the event of a dispute, the building master has to prove that it happened incorrectly. ${ }^{90}$

3. The entrepreneur is liable for hidden defects after delivery

As noted above, Article 7:758(3) CC states that the entrepreneur is discharged from all liability for defects which could reasonably have been discovered by the building master at the time of delivery.

For a long time, the Council of Arbitration for the Building Industry held that the entrepreneur was not liable for defaults after the experience period, except if Article 1645 Old CC, which will be discussed hereunder, would be applicable. ${ }^{91}$ In 1957, the notion of 'hidden defect' was used for the first time by the Council of Arbitration for the Building Industry. ${ }^{92}$ The Civil Courts had used it previously in the 1920s, and often held that the entrepreneur would not be liable after approval of the work by the architect except for 'defects which could not have been discovered at the moment of reception'. ${ }^{93}$ It is important to note that not only the materials used can have hidden defects, but also the work executed by the entrepreneur ${ }^{94}$.

In 1930, the Supreme Court decided that the entrepreneur is liable for hidden defaults for a thirty year period (Mook/Sap (II) $)^{95}$. The Council of Arbitration for the Building Industry followed this judgment for quite some time. This meant that, after the experience period, the entrepreneur would still be liable for defects which could not have been noticed at the moment of reception, even if these defects did not lead to a collapse or perishing of the building as meant in Article 1645 Old CC. It follows that if the building master could have noticed the defect, his legal claim would not be confirmed.

In 1961, the Council of Arbitration for the Building Industry held that the amount of supervision is very important to determine whether or not a certain defect was hidden. It held that, whenever a director (for example an architect) supervised the execution of the building works, a defect would only be deemed hidden 'if it could not be noticed, even after proper supervision and inquiry by the direction'. The level of expertise of the building master, the involvement of an expert (architect) and the amount of supervision, were and are therefore very important in this regard. ${ }^{96}$ Since it is up to the building

90 Council of Arbitration for the Building Industry 15 February 1980, nr. 8933, BR 1980, 628.

91 See, for example, Council of Arbitration for the Building Industry 1954, nr. 2121, Jaarverslag 1954, 67.

92 Van Wijngaarden \& Chao-Duivis 2007, part 2, p. 59; Council of Arbitration for the Building Industry 1957, nr. 2328, Jaarverslag 1957, 19.

93 See for example Court of Appeal Arnhem 16 December 1924, NJ 1925/421; Groningen 28 October 1932, NJ 1934/1557.

94 Defects which were visible at the moment of reception, but of which the severity could not be comprehended by the building master, also constitute hidden defects: Council of Arbitration for the Building Industry 26 March 2007, nr. 71.059, unpublished.

95 Supreme Court 13 November 1930, NJ 1931, 247.

96 Roermond 10 January 1985, BR 1986, 145; Council of Arbitration for the Building Industry 28 April 2006, nr. 56.282, unpublished. 
master to prove that a certain defect is hidden, ${ }^{97}$ a defect is qualified as hidden more easily when the building master has no expertise in the field and is not assisted by an expert (architect).$^{98}$ Even though an expert should notice a particular defect more easily, in the Netherlands the entrepreneur is still considered to be the first person responsible. This means that, in the event of hidden defects in the execution of the building work, the architect can, in general, only be held liable together with the entrepreneur if he did not supervise the work properly.9 An improper supervision can therefore diminish the entrepreneur's degree of liability. ${ }^{100}$ However, it is possible for the entrepreneur to exonerate or limit his liability for hidden defects after reception, except if this recourse would be contrary to good faith. ${ }^{101}$ If only incidental supervision by the architect took place, a defect is qualified more easily as being hidden since, in such cases, the entrepreneur has a higher level of responsibility. ${ }^{102}$ However, the building master can be held liable as well in the event that his supervision is too lenient.

As noted above, in principle the building master should allow the entrepreneur to cure the defects for which he is accountable in accordance with Article 7:759 CC. It is obvious that this Article is applicable in the case of hidden defects. If the entrepreneur does not repair the defects, the building master can institute an action for reparation in natura, an action to get payment of the reparation costs, or an action based on a decrease in value. Consequential damages also have to be repaired.

However, as held by Article 7:762 CC, the liability of the entrepreneur for hidden defects that are known yet not disclosed by him, cannot be excluded or limited, and neither can it be made subject to shorter prescription periods than those provided for in Article 7:761 CC. As held by Article 6:89 CC, the creditor cannot invoke a defect in the performance if he did not protest within a short time after he noticed the defect, or should have noticed it. Any non-disclosure by the persons charged by the entrepreneur with the supervision of the performance of the work, shall be equated with non-disclosure by the entrepreneur. Non-disclosure of such defects by persons who are charged by the entrepreneur with the supervision of the execution of the work, shall be equated with his own non-disclosure. Even though Article 6:76 CC holds that the debtor who uses the services of other persons in the performance of an obligation is responsible for their conduct as if it was his own, non-disclosure by the entrepreneur's subordinates can therefore not be equated with his own non-disclosure. Article 7:762 CC has coercive force.

As stipulated in Article 7:761(1) CC, any right of action for a defect in works delivered prescribes the expiry of two years from the time the building master makes a com-

97 Council of Arbitration for the Building Industry 22 November 2004, nr. 26.444, unpublished.

98 Council of Arbitration for the Building Industry 8 September 1976, nr. 7637, BR 1977, 99; Bloemlezing, 1976-1981, 25.

99 Council of Arbitration for the Building Industry 22 August 2006, nr. 70.929/70.940, unpublished.

100 Council of Arbitration for the Building Industry 17 August 2005, nr. 25.084, BR 2006, 55.

101 Council of Arbitration for the Building Industry 8 September 1976, nr. 7618, BR 1976, 891; Bloemlezing 1976-1981, 23; Court of Appeal Arnhem 19 August 1997, BR 1998, 416.

102 Council of Arbitration for the Building Industry 7 January 1980, nr. 9329, BR 1980, 395, annotated by H.O. Thunnissen; Council of Arbitration for the Building Industry, 20 January 1994, nr. 14.859, BR 1994, 683, annotated by H.O. Thunnissen. 
plaint on the matter. If the client has set a period for the entrepreneur to cure the defect, the prescription period shall begin only at the end of that period, or so much earlier if the contractor has indicated that he will not cure the defect. In any event, the right of action is prescribed on the expiry of twenty years from the delivery in the case of the construction of buildings (Article 7:761(2) CC.

It can be concluded that when no standard terms are applicable, the entrepreneur stays liable for hidden defects for twenty years. ${ }^{103}$ However, if a complaint has been made, the action has to be instituted within two years. Article 7:761 CC contains, therefore, a double prescription period. Consequently, both Articles 6:89 and 7:761 CC force the building master to take the entrepreneur's interests into account.

In the event that the UAV are applicable, reference should be made to $\$ 12$ which states:

'1. The entrepreneur is not longer liable for defects in the work after the day on which the work is deemed to be delivered in accordance with $\$ 10(1)$ or (2).

2. This is different however

a....

$b$. if the work or any part of it contains a hidden default due to the fault ${ }^{104}$ of the entrepreneur, his supplier, his sub-contractor or his manpower, and this defect was mentioned to the entrepreneur within a reasonable time after its detection.

3. A defect as meant in (2b) is only hidden if it could reasonably not be noticed by the director during the supervision, or at the moment of delivery as meant in \$. 9(2)

4. The legal action based on hidden defaults has to be instituted within five years of the day mentioned in $\$ 10(1)$ or (2)

5. If the building specifications foresee in an experience period, the day after the end of the experience period will replace the day mentioned in $\$ 12(1) \ldots{ }^{\prime 105}$

Firstly, it should be noted that it follows from the wording of $\$ 12.4$ UAV that in the event that a hidden defect could not reasonably have been noticed by the director $(\$ 12.3$ UAV) but was known to the entrepreneur, a problem arises. This is due to the fact that $\$ 12.4$ UAV holds that the legal action has to be instituted five years after delivery, while Article 7:761(1) CC indicates that legal action should be instituted within two years after the protest of the building master and, at the latest, twenty years after the delivery (Article 7:761(2) CC). Since the liability of the entrepreneur for hidden defects which were known to him cannot be excluded or limited according to Article 7:762 CC which has coercive force, it seems that $\$ 12.4 \mathrm{UAV}$ is in violation of these provisions of the Dutch Civil Code.

103 Council of Arbitration for the Building Industry 1 August 1994, nr. 17.337 BR 1994, 880. The twenty year prescription period is in line with Article 3:306 CC which states that all rights for action prescribe after twenty years, except if the law provides otherwise.

104 By this is meant that the entrepreneur has a risk-liability: Council of Arbitration for the Building Industry 22 January 1990, nr. 13.592, BR 1990, 859, annotated by H.O. Thunnisen.

105 The rules of non-conformity in the Civil Code do not apply if the UAV are applicable: Council of Arbitration for the Building Industry, 1 December 2005, nr. 27.935, unpublished. 
Secondly, $\$ 12$ UAV contains a more extensive research obligation for the architect. After delivery, the entrepreneur is still liable for damages caused by defects which are his fault, or that of his supplier, sub-entrepreneur or manpower, and which could not have been noticed by the architect during the execution of the building work or at the moment of reception. It follows that the architect has to control and supervise the work during the whole execution period. If the defect could therefore be noticed during the execution, but not at the moment of delivery, the entrepreneur cannot be held liable. ${ }^{106}$ If the fault could have been noticed, the Council of Arbitration for the Building Industry often decides that within the relationship building master-entrepreneur, the building master has to carry his own damage. The building master is held liable for insufficient supervision, even though there is not even an obligation to supervise. ${ }^{107}$ The UAV therefore contains a liability limitation on the part of the entrepreneur compared to the Civil Code provisions. The definition of what constitutes a hidden fault in the UAV 1989, is the same as the definition applied by the Council of Arbitration for the Building Industry. ${ }^{108}$ It is up to the building master to prove the existence of the hidden fault. However, to verify whether a fault was hidden or not, account should be taken of the level of expertise of the building master and/or his architect. According to Asser/Van den Berge ${ }^{109}$, the rights of the building master are limited by this too much. They hold that a supervisor is engaged for the benefit of the building master, and not to diminish the entrepreneur's obligations. Therefore it is not reasonable to hold the building master liable in the event that he engaged a supervisor or supervised the works, while he cannot be held liable if no supervision took place. ${ }^{110}$ It is argued that the building master should only be held liable in a situation in which the entrepreneur could trust that he was executing the building works professionally, that his trust was justified and that the damage was partly caused by that trust. Only in such a case should the building master should be held liable, in accordance with Article 6:101(1) CC. If the entrepreneur could not trust on the silence of the building master or his supervisor, due to the seriousness of his fault, or if he had to understand that approval would never be granted, the entrepreneur should not be able invoke that the defect was not hidden, since the entrepreneur cannot be rewarded for his lack of good faith. However, as noted above, the Council of Arbitration for the Building Industry does not take into account the justified trust of the entrepreneur or the attitude of the supervisor. The Council only evaluates whether a more careful attitude on the part of the supervisor could have prevented the damage. If so, this is disadvantageous to the building master. Furthermore, whether the entrepreneur was aware of his defective construction or not is also not of importance as far as the Council is concerned.

106 As noted above, this is different if the UAV are not applicable. With regard to defects which the building master could but did not notice during the construction process, the entrepreneur is still liable in accordance with Article 7:758(3) CC. However if it becomes clear that the building master did notice the defect but did not act upon it, it could be contrary to reasonableness and fairness to hold the entrepreneur liable (see Article 6:248 and 6:101 CC).

107 Council of Arbitration for the Building Industry 11 February 2005, nr. 25.811

108 Van Wijngaarden \& Chao-Duivis 2007, part 2, p. 94.

109 Asser-Van den Berg 2007, nr. 114. As noted above, the UAV do not contain an obligation to engage a supervisor, but only the possibility (\$3.1 and 3.9 UAV).

110 Asser-Van den Berg 2007, nr. 116. 
It is important to note that after substantial reparation by the entrepreneur, a new period of five years starts to run regarding the repaired defects in accordance with $\$ 12.5$ UAV. ${ }^{111}$ Furthermore, it should be noted that it seems that with regard to defects known to the entrepreneur, the liability period as described in $\$ 12.4 \mathrm{UAV}$, can be overruled by the two year period as stipulated in Article 7:761(1) CC which starts to run from the moment the building master has made a protest. This means that if the building master has given a notice of default, he is obliged to institute his claim within two years after this notification.

4. The entrepreneur is liable after delivery for damage caused by the perishing of the building due to serious defects

As of 1 September 2003, the Civil Code's new title on entrepreneurship entered into force in the Netherlands. ${ }^{112}$ One of the most important changes was the abolition of old Article 1645 which stated:

"When a building, erected against a fixed price, perishes in whole or in part due to a default in its composition or the unsuitability of the land, the architect and the entrepreneur are liable for ten years."

As will immediately be noticed, Article 1645 (old) CC is a direct translation of Article 1792 of the Code Napoleon which was already discussed in the chapter on Belgium. ${ }^{113}$ It was included in the Dutch Civil Code of 1838 and was taken up in an unaltered form in Article 7A:1645 CC in 1992. At that time the new title on entrepreneurship was awaited for. Even though Article 7A:1645 CC was abolished when the new title on entrepreneurship entered into force in 2003. However, Article 1645 Old CC was still applicable up to 31 August 2006 for building contracts which were entered into prior to 1 September 2003. ${ }^{114}$ Moreover, the Article can still be applicable if parties agree to it. Since most of the present standard terms, such as the UAV 1989, still refer to the Article, Article 1645 Old CC is also applicable to the contracts concluded under the ambit of these standard terms. It should be noted that Article 1645 Old CC was not one of public order. This means that parties could contractually exclude its applicability.

$\$ 12$ UAV states:

'1. The entrepreneur is not longer liable for defaults in the work after the day on which the work is deemed to be delivered in accordance with \$10(1) or (2).

2. This is different however

a. when the case described in Article 1645 Old CC occurs

5. If the building specifications foresee an experience period, the day after the end of the experience period will replace the day mentioned in paragraph 1 ..."

111 Council of Arbitration for the Building Industry 8 December 1982, nr. 10.166, BR 1983, 160; TvA 1983/5, 175 sub 12.

112 Decision of 25 June 2003, Official Gazette 2003, p. 272.

113 Van den Berg 2003, p.181.

114 Article 7:217 Transitional Law. 
It follows that the entrepreneur is still liable for a ten year period for serious faults, even if these faults do not contain hidden faults if Article 1645 old CC is applicable.

Hereunder I will briefly discuss the content of Article 1645 CC again, and refer to Dutch case law to explain its scope.

The fact that the building must " for Article 1645 CC to apply, was taken quite literally by the Supreme Court in 1929. It held that Article 1645 CC means that the stability of the building should be infected in a way that the building has fallen down or is at risk of falling down. ${ }^{115}$ This risk means that the 'collapse process' should have started within ten years. ${ }^{116}$ This narrow interpretation of the Article has generally been followed by the Council of Arbitration for the Building Industry. However, in 1973, the Council took a broader approach, and held that a 'collapse' means that the building has defects which are so serious that its stability is in danger, and that this danger can only be averted by extraordinary and costly measures. ${ }^{117}$

As held by Article 1645 Old CC, the reason for the collapse has to be a fault in the building's composition or the unsuitability of the land. ${ }^{118}$ If the building master or the architect determined the composition of the building, the entrepreneur will not be held liable, except if he did not warn them with regard to defects he noticed, or should have noticed, during the construction process. ${ }^{119}$

This means that for the entrepreneur to be liable, he should have determined the composition of the building himself. The same goes for the unsuitability of the land. It should be noted that the liability for the 'collapse' of the building is not limited to the damage to the building itself, but is extended to other damage which is a consequence of the collapse, such as physical injuries to a person. ${ }^{120}$ Of course, as will be discussed hereunder, it is possible that the liability is divided between the entrepreneur and the building master or the architect. ${ }^{121}$

With regard to the ten year's responsibility, the civil courts hold that the collapse process should have started within ten years of delivery. ${ }^{122}$ The Council of Arbitration for the Building Industry holds that the claim has to be instituted within ten years of delivery. ${ }^{123}$

115 Supreme Court 14 November 1929, Mook / Sap, NJ 1929/1776, W. 12059. However, lower courts sometimes have a broader interpretation: e.g. The Hague 7 December 1926, NJ 1927/1015 and NJ 1928/1022.

116 Council of Arbitration for the Building Industry 19 August 1987, nr. 12.508, BR 1988, 217, annotated by H.O. Thunnissen.

117 Council of Arbitration for the Building Industry 15 August 1973, nr. 6566, BR 1973, 799, annotated by H.O. Thunissen; NJ 1974/305, annotated by P. Zonderland.

118 Van Wijngaarden \& Chao-Duivis 2007, part 2, p. 32; Court of Appeal Amsterdam 6 February 1925, W. 11347.

119 Den Bosch 15 February 1963, NJ 1963/296.

120 Zwolle 6 June 1990, BR 1990, 861.

121 Council of Arbitration for the Building Industry 13 June 1974, nr. 7117, BR 1974, 701; Jaarverslag 1974, 64; Council of Arbitration for the Building Industry 3 May 1976, nr. 7713, BR 1976, 728; Bloemlezing 1976$1981,29$.

122 Roermond 2 June 1983, BR 1985, 480; NJ 1985/147.

123 Council of Arbitration for the Building Industry 16 June 1986, nr. 12 219, BR 1987, 59. 
When the Uniform General Terms are applicable, the claim can also be instituted later, as long as the entrepreneur has been put in default within ten years. ${ }^{124}$

It follows that, if the UAV are applicable, the prescription period of twenty years as described in Article 7:761(2) CC is applicable for all defects in the received work which do not fall under the ambit of Article 1645 Old Civil Code, and do not constitute a hidden defect as meant in $\$ 12.2 b$ UAV 1989.

The most important consequence of Article 1645 Old CC is its reversion of the burden of proof. It is not the building master who has to prove that the 'collapse' arose due to the shortcoming of the architect/entrepreneur, but it is up to the architect/entrepreneur to prove that the collapse was caused by a circumstance for which he was not responsible $^{125}$ or for which he does not carry the risk ${ }^{126}$. Of course, after the expiry of the ten year period, the building master has to prove that the entrepreneur is responsible for the collapse. ${ }^{127}$ Article 1645 CC contains therefore a presumption of non-fulfilment on the part of the architect/entrepreneur. The building master therefore does not have to prove that the defect was caused by the architect's or the entrepreneur's shortcoming. The professionals, on the other hand, have to demonstrate that the perishing is caused by a circumstance which is not imputable to them. ${ }^{128}$

Finally it should be noticed that the liability period as described in Article 1645 old CC, can still be overruled by the two year period as stipulated in Article 7:761(1) CC which starts to run from the moment the building master has made a protest. This means that if the building master has given a notice of default, he is obliged to institute his claim within two years after this notification.

\section{Deceit}

Lastly it should be noted that the content of Article 12.4 UAV in which the liability of the entrepreneur is limited to five years after receipt in the event of hidden defects, can be contrary to reasonableness and fairness in case of deceit or malicious intent on the part of the entrepreneur. ${ }^{129}$ Of course, also in other instances the entrepreneur as well as the architect can be held liable after delivery in such cases, based on the principle of good faith.

\footnotetext{
124 Council of Arbitration for the Building Industry 11 December 1991, nr. 14.356, BR 1992, 332, annotated by H.O. Thunissen.

${ }^{125}$ Council of Arbitration for the Building Industry 19 August 1987, nr. 12.508, BR 1988, 217, annotated by H.O. Thunnissen.

126 Council of Arbitration for the Building Industry 3 December 1987, nr.12.541, B.R. 1989, 297; Council of Arbitration for the Building Industry 13 April 2005, nr. 24.753, unpublished.

127 Council of Arbitration for the Building Industry 19 July 1993, nr.15.252, BR 1993, 920, annotated by H.O. Thunnissen.

128 Supreme Court 13 November 1930, NJ 1931, 247, annotated by EM M (Mook/Sap II).

129 Council of Arbitration for the Building Industry 2 July 2002, nr. 22.740.
} 


\subsection{The liability of the architect for subordinates and sub-entrepreneurs}

As held by Article $5 \mathrm{NR}$, the architect is allowed to have other persons fulfil his tasks under his leadership. With regard to certain components of his work, he can even give leadership to these persons. Nevertheless, the architect himself is responsible for the good and proper fulfilment of the work concerned. This is confirmed by Article 13.2 $\mathrm{NR}$, which holds that the architect is likewise responsible for the shortcomings of these persons, as for his own, unless the involvement of such person is imposed upon him. Such persons are mostly involved due to their specific knowledge and specialism. In this regard it should be noticed that Article 11.8 states that the architect informs his client about the natural person or persons who are authorized to represent him, if necessary mentioning the limitations of his or their authority. Furthermore, since the architectural contract is a service contract, mention has to be made of Article 7:404 CC as well, which states that if a certain task is assigned with the eye on a specific person who works together with, or is subordinated to, the commissioner, that person has to fulfil the task personally, unless the task can be fulfilled by others under that specific person's responsibility, notwithstanding the commissioner's liability.

Since this thesis deals with the liability of the architect, the liability of the entrepreneur in terms of his manpower and sub-contractors as described in Article 7:751 CC should not be discussed.

\$6.26 UAV states however, that in a situation in which the UAV are applicable, the entrepreneur can only engage a sub-entrepreneur with the written permission of the architect. This means that the approval of the building master himself is not required..$^{130}$ Nevertheless, even if the architect approved the involvement of a certain sub-contractor, the entrepreneur is still solely responsible for this sub-entrepreneur in terms of the building master. ${ }^{131}$ This is a direct consequence of Article 6:76 CC which holds that where, in the performance of an obligation, the debtor uses the services of other persons, he is responsible for their conduct as if it was his own. Of course the subcontractor himself is liable in terms of the entrepreneur with whom he has a contractual relationship. ${ }^{132}$

\section{Liabilities of the specialists involved}

As held by Article 6.1 NR, if the proper realization of the project requires the appointment of one or more third-party-consultants, then the client shall not proceed to such action without prior consultation with the architect. If the architect is to work together with third-party-consultants, then the building master determines which participant is responsible for the co-ordination of the activities of the different consultants, and which participant is responsible for steering the progress of the activities of the different consultants (Article 6.2 NR). Of course, in such cases, the architect is not responsible for

\footnotetext{
130 Council of Arbitration for the Building Industry 2 April 1980, nr. 9415, BR 1980, 796.

131 's-Gravenhage 27 November 1952, NJ 1953/661. An exception arises when the subcontractor is appointed by the building master and the entrepreneur, who has given a task to a subcontractor, makes a protest, warning or reservation.

132 Council of Arbitration for the Building Industry 31 October 1968, nr. 5326, BR 1968, p. 608.
} 
damage caused by such a consultant. However, if the architect hires specialists himself who are working for him, he is liable for them himself (Article 5 jo Article 13(2) NR). ${ }^{133}$

\section{Conclusion}

In the Netherlands, the relationship between the architect and the building master is qualified as a contract of services (Article 7:400 CC) and not as an entrepreneurial contract. The provisions in Title 12 of the Civil Code which are applicable, not only to building works but also to all types of entrepreneurship, do not therefore regulate the relationship between the architect and his client. Entrepreneurial contracts only cover material works, while architects generally fulfil only intellectual tasks.

The obligations of architects can be summarised as the provision of assistance and advice to the clients, the determination of the programme and the budget, the design of the plans and the supervision of the building work. However, as noted in the preceding chapter, clients are not obliged to engage an architect for these tasks. These obligations are not laid down in the Civil Code, but are laid down in standard terms, case law and in the legal literature.

Architects are, in principle, liable for every failure in the performance of their obligations (Article 6:74 CC). In generally, they have an obligation of means, and have to act as a reasonable professional. They have to repair any damage which the creditor suffers because of their negligence, unless the failure is not attributable to them. If performance is not permanently impossible, the debtor has to be put in default before he is obliged to repair the damage.

Architects have a large contractual freedom. Several sets of standard terms exist in which the relationship between the architect and the building master is regulated. The most recent standard terms are the New Rules (NR) 2005. These standard terms are applicable if parties so agree, which is generally the case, and also contain an arbitration clause which generally has to be specifically agreed to.

With regard to the architectural responsibility, Article 13.1 NR holds more specifically that the architect is liable in the event that he has committed a culpable shortcoming (accountable fault) and that the building master has put him in default in writing, and has summoned him to repair the consequences of the shortcoming within a reasonable time, while the architect has not (or not on time) repaired the consequences of these faults.

As held by Article 7:758(2) CC, after delivery of the building work, the building master bears the risk for such work. The general prescription period for liability is twenty years (Article 3:306 CC). Article 3:310 CC holds that claims for damages due to shortcomings in the performance of a contract, prescribe five years after the creditor has discovered

133 See also Council of Arbitration for the Building Industry 31 May 1918, nr. 101, Jaarverslag 1918, Nr. IX, 37. 
the shortcomings and if he is aware of the identity of the debtor. In the event that the creditor did not discover the damage, the liability period of ten years starts to run after the damage has been caused.

Article 16 NR 2005 deviates from this rule and foresees a liability period of five years which starts the day upon which the commission has been terminated, either by completion or by cancellation. Next to the limitation of the liability period, architects often limit the extent of their liability as well. In this regard, the damage to be compensated by the consultant is limited per commission to a sum equal to the consultancy costs with a maximum of 1,000,000 Euros. In the case of commissions where the client is a consumer and the consultancy costs per commission are lower than 75,000 Euros, the damage to be compensated for is to a maximum of 75,000 Euros.

The UAV which are the standard terms applicable in the relationship between the entrepreneur and his client, do not contain many clauses limiting the liability of the entrepreneur. It follows that the liability for a possible shortcoming in design will more easily be laid by the entrepreneur if he did not warn about the fault in the design. In any case, the entrepreneur can be held liable for hidden defects after delivery (CC: twenty years; UAV: five years) and for damage caused by the perishing of the building due to serious defects (ten years). There does not exist an in solidum liability system to solve liability issues.

Architects are not obliged to buy professional liability insurance. This is different, however, for BNA members. Even though only one third of the architects are associated with the BNA, the majority of architects are insured, since the NR also require insurance if they are applied to a certain contractual relationship (Article 11.3 NR). 
C. THE REGULATION OF ARCHITECTS IN BELGIUM VS. THE NETHERLANDS 

Chapter 9

\section{COMPARISON OF THE SITUATION OF ARCHITECTS IN BOTH COUNTRIES}

The Belgian and Dutch architectural markets vary considerably, not only from a legal perspective but also in cultural terms. While it is often said that Belgians have 'een baksteen in de maag' and engage their own architect to construct a house of their personal taste, most projects in the Netherlands are built by large building developers who generally engage architects and entrepreneurs to realize their projects, and who then sell the houses/apartments to individuals. It follows that houses in the Netherlands often resemble each other.

\section{Right to use the title}

In Belgium, the Architects' Act lays down in detail who is allowed to use the title of architect.

In general, it can be said that Belgian and other EC/EEA nationals need to be in possession of a certain diploma obtained in Belgium, which requires five years of study. Persons who obtained their qualifications elsewhere in the EU/EEA are also allowed to use the title if these qualifications are listed in annex $1 \mathrm{a}$ and $2 \mathrm{~b}$ which implement annex V.7 and VI of Directive 2005/36/EC, which means that recognition should be granted automatically. If the qualifications do not conform to these requirements, it is possible to complete an aptitude test or undertake an adaptation period in accordance with the Act of 12 February 2008, instituting a new General Framework for the recognition of EC-qualifications which implements the general system mentioned in Chapter I of Title III of the Directive. Professionals who obtained their qualifications outside the EU can invoke Article $1 \$ 5,4^{\circ} \mathrm{AA}$ which equalises formal qualifications issued by a third state if the holder has three years of professional experience on the territory of the Member State which has recognized the formal qualifications Legal persons are not allowed to use the architectural title since they cannot be in the possession of the required qualifications.

In the Netherlands, as of 1 October 1993, registered architects can officially be distinguished from other professionals in the building sector since they have the privilege to

1 It is generally said that Belgians like to build. 
call themselves 'architect' to the exclusion of all others. The Architects Title Act gives rise to the legal protection of the title of Architect in the Netherlands. To use the title, one must be registered with the Foundation Bureau Architects' Register which is charged with the registration of architects. The general requirement for registration is the possession of a recognized diploma/certificate, or the successful taking of an examination. In general, Dutch students can follow a five-year university education or a fouryear part-time training at an Academy. In order to sit the examination, a minimum of seven years of practical experience in the field of architecture is required, while the VROM Minister can grant exemption on the basis of proven exceptional competence. Automatically recognised certificates are those issued by the universities or academies mentioned in the Architects' Act and those mentioned in Annex V.7 and VI of Directive 2005/36/EC. Other qualifications may be recognised under the Directive's general system which is incorporated in the Act of 6 December 2007 which contains general rules on the recognition of which EC qualifications are applicable (General Act EC professional qualifications). Even though the current Architects' Title Act does not specifically mention it, case law has indicated that legal persons may also use the title if certain conditions are fulfilled. This is confirmed by the 2010 amendment Act which has not yet entered into force.

BNA membership is only open to architects who have at least two year of professional experience. When the 2010 amendment Act enters into force, this condition will be extended to all architects. The Architects' Act will be amended to include a two year period in which professional experience has to be gained before one can be registered. It follows that the possession of such practical experience is a requirement for practising the profession in Belgium, and will be a requirement to use the title in the Netherlands. It is foreseen that the traineeship will become mandatory from 2015 onwards.

\section{Right to practise the profession}

Architects in Belgium have a monopoly with regard to designing houses and supervising building works for (almost) all constructions which require a building permit. Not only the title, but also the profession, is protected. To be able to practise the profession, architects have to register with the Architects' Order. To be registered on the tableau, a two year period in which professional experience has been obtained should have been completed. The Architects' Order issues the licence to practice, manages the architectural register, determines the duties and rights of architects, and is responsible for (the formulation and execution of) disciplinary rules. Only persons who are allowed to use the title can practise the profession, together with third country nationals in the event of the existence of reciprocal allowance by their state, or in the event that they got permission by Royal Decree. EC/EEA service providers will be registered in the Services Register in conformity with Article $8 \$ 2(1)$ AO. This Article implements Title II of Directive 2005/36/EC. Third country nationals will have to obtain the permission of the Council of the Order located in the area in which the service will be provided. Due to the Laruelle Act of 2006, legal persons can also practise the profession, and are allowed to fulfil architectural tasks. As indicated above, they are, however, not allowed to use the title. It can be said that this has improved the situation of architects since, in this way, they can 
secure their personal wealth. Instead of being personally liable, the legal person will be held responsible. Whether this is beneficial for their clients, can be seriously questioned and depends also on -the availability and content of- the liability insurance.

In the Netherlands, the profession of architect is not protected. It follows that everyone can perform architectural services as long as the title is not used by those who do not fulfil the requirements of the Architects' Title Act. It is said that the protection of the profession is not necessary since many legal requirements already apply to the architect's design, such as the provisions of the Housing Act and the Building Decree. Registered architects are not subject to a code of conduct. Only BNA members have to act in accordance with the BNA Code of Conduct. To these architects, the Permanent Professional Training Regulations are applicable as of January 2006. These contain rules on professional education of BNA-members and imply that BNA architects should spend at least thirty hours per year on professional training. The fact that more persons are allowed to practise the profession does not bring about a reduction in architects' salaries in the Netherlands. As demonstrated by the Mirza \& Nacey research in Chapter 2, architects in the Netherlands earn much more than their Belgian colleagues.

\section{Market conduct}

In Belgium there are currently no mandatory, minimum or maximum fee scales for architectural activities. In 2004 the European Commission held that the recommended fee scale that was created by the Belgian Architects' Order in 1967 and which got binding force by Royal Decree in 1985, violated EC competition law. The Commission estimated that recommended minimum tariffs are generally created to coordinate the conduct of architects so that architects whose costs are lower are dissuaded from lowering their prices. Consequently, the recommended fee scale was revoked by the Order.

In the Netherlands, the SR 1997 used to indicate the fee basis by means of a reference to NEN 2631, which is a Dutch norm indicating how investment costs of building should preferably be calculated. A formula was drawn which led to the determination of a certain percentage which would then result in the fee. This formula left no room for price competition whatsoever and was often also used by architects which were no BNA members or to contracts to which the SR 1997 was not made applicable and was not only used by the Arbitration Institute Architecture but also by the ordinary courts. This form of price fixing was not taken over by the NR 2005.

With regard to advertising, Article 13 of the Deontological Code in Belgium foresees that the architect is allowed to make his activities known to the public in an independent and discrete manner. Obtrusive publicity has to be avoided however. The architect has to take into account that his name and title are not used in an illegal way by others, or are used for commercial purposes by others. He is allowed to mention his title in books, and is even obliged to mention it on a plate at the building site during the construction work, and is allowed to have it mentioned afterwards.

In the Netherlands, there is no general regulation about advertising which is applicable for all architects. The disciplinary code of the BNA mentions, in Article 2(2), that 
architects have the freedom to make their activities, expertise, experience and competence known to the public.

Finally, with regard to structural restrictions in Belgium, mention should be made of Article $6 \mathrm{AA}$ and Article 10 of the Deontological Code, by which architects are not allowed to practise the profession of entrepreneur. Since architects should be independent (Article 4 Deontological Code) every association of an architect with an entrepreneur is forbidden. In the Netherlands there is no such prohibition. Even though it may be argued that architects should be independent, it might be questioned whether such a severe restriction is efficient, since the profession seems to function quite well in states in which there is no incompatibility between architects and entrepreneurs. In any case it should be noted that such restrictions prevent a single company from offering a total service package in which the building was designed and constructed by professionals who consider themselves as partners rather than adversaries.

\section{Insurance}

In Belgium, all architects, including legal persons, are obliged to buy insurance. In this way the building master has more certainty that he will receive damage compensation. This gives rise to more administration and higher premiums, and can bring about the situation that the quality of the work will diminish.

In the Netherlands, there is no mandatory insurance obligation except for BNA members. If standard conditions are used which prescribe professional liability insurance, architects also have to buy insurance. In this way it can be concluded that most architects are insured. However, since there is no legal obligation, the Dutch legislation might be contrary to recital 98 of Directive 2006/123/EC which states that any operator providing services involving a direct health, safety of financial risk for the recipient or a third person, should, in principle, be covered by appropriate professional liability insurance.

\section{Liability}

In Belgium, design contracts take the form of 'entrepreneurial contracts' which is a specification of the more general 'rent of labour'. As held by Article 1779 CC, the rent of work and services covers work provided by entrepreneurs performing in accordance with building specifications. The architect has to advise his client, design a plan, determine the programme and the budget, and supervise the building work. For the architect to be liable, a fault in the performance of his contractual activities, damage and a causal link must be proven. In this regard, architects are also liable if they engage an expert who lacks sufficient skills. The liability regime is next to the general provisions in the Civil Code and is specifically laid down in Articles 1787-1799 CC. In principle, the architect is no longer liable after the building work is accepted (received) by the building master. However, the architect is still liable for (small) hidden defects after receipt of the work. The same is true for serious defects, which cause the building to perish totally or 
partially (Article 1792 jo 2270 CC). These Articles are of public order since they are said to protect public safety, and cannot be contractually deviated from. It follows that the period in which the architect is liable cannot be limited.

Clauses that limit the extent are, in principle, void. Architects who hire specialists can limit their liability, but they are still liable if they discover any negligence on the part of these specialists. This gives protection to the building master. However the liability cannot be limited with regard to damages falling under Articles 1792 jo. 2270 CC).

It follows that standard terms are not commonly used in Belgium, and disputes are almost always settled by judicial courts. For certain defects, such as problems with the stability, insulation and water tightness, judges are sometimes more lenient towards the building master and hold that the architect has an obligation of means. However, the myriad of case law and the legal literature, indicates that Article 1792 CC does not contain a presumption of fault.

The architect is often held liable in solidum with the entrepreneur. If the entrepreneur has made a fault in the construction, the architect is often held liable as well due to his defective supervision. Since the architect is the only building partner who is obliged to buy professional liability insurance, including the decennial liability, he is the one who mostly suffers from huge liability claims. To cover their own losses as well as the losses of other building partners, clients often take out a Construction All Risks Insurance which covers damage during the realisation of the building work.

It can be concluded that the weight on the shoulders of architects is very heavy. This has been mitigated by the Laruelle Act which allowed legal persons to practise the profession of architect as well. This means that the creditors of the company can only claim compensation from the company's wealth, and the architect-natural person's wealth cannot be claimed against in order to obtain damage compensation.

In the Netherlands, the relationship between the architect and the building master is qualified as a contract of services (Article 7:400 CC) and not as an entrepreneurial contract. The provisions in Title 12 of the Civil Code which are applicable not only to building works, but to all types of entrepreneurship, therefore do not regulate the relationship between the architect and his client. Entrepreneurial contracts only cover material works, while architects generally fulfil only intellectual tasks. The obligations of architects can be summarised as the provision of assistance and advice to the clients, the determination of the programme and the budget, designing the plans and supervising the building work. These obligations are not laid down in the civil code, but can be written down in standard terms, case law and in the legal literature.

Architects are, in principle, liable for every failure in the performance of their obligations (Article 6:74 CC). In general, they have an obligation of means, and have to act as a reasonable professional in the same circumstances would do. They have to repair the damage which the creditor suffers due to their negligence, unless the failure is not attributable to them. If performance is not permanently impossible, the debtor has to be put in default before he is obliged to repair the damage.

In the Netherlands, architects have a large contractual freedom. Several sets of standard terms exist in which the relationship between the architect and the building master is regulated. The most recent standard terms are the New Rules (NR) 2005. These stan- 
dard terms are applicable if parties so agree, and contain an arbitration clause which generally has to be specifically agreed to as well. With regard to the architectural responsibility, Article 13.1 NR holds more specifically that the architect is liable in the event that he has committed a culpable shortcoming (accountable fault) and the building master has put him in default in writing and has summoned him to repair the consequences of the shortcoming within a reasonable time, while the architect has not (or not on time) repaired these consequences.

As held by Article 7:758(2) CC, after delivery of the building work, the building master bears the risk for such work. The general prescription period for liability is twenty years (Article 3:306 CC). Article 3:310 CC holds that claims for damage due to shortcomings in the performance of a contract, prescribe five years after the creditor discovered the shortcoming and is aware of the identity of the debtor. In the event that the creditor did not discover the damage, the liability period of ten years starts after the damage has been caused.

Article 16 NR 2005 deviates from this rule and foresees a liability period of five years which starts the day upon which the commission is terminated, either by completion or cancellation. Next to the limitation of the liability period, architects often limit the extent of their liability as well. In this regard, the damage to be compensated for on the part of the consultant is limited per commission to a sum equal to the consultancy costs with a maximum of 1,000,000 Euros. In the case of commissions where the client is a consumer and the consultancy costs per commission are lower than 75,000 Euros, the damage to be compensated for is up to a maximum of 75,000 Euros.

The UAV, which are the standard terms applicable in the relationship between the entrepreneur and his client, do not contain many clauses limiting the liability of the entrepreneur. It follows that the liability for a possible shortcoming of the design will be more easily laid by the entrepreneur if he did not warn about the fault in the design. In any case, the entrepreneur can be held liable for hidden defects after delivery and for damage caused by the perishing of the building due to serious defects. In solidum convictions are not used to solve liability issues. In the Netherlands, the building master thus has to prove the architect's shortcoming with regard to each liability. There is thus a heavier weight on the building master's shoulders. 
D. REGULATION OF ARCHITECTS IN OTHER EU MEMBER STATES 

Chapter 10

\section{COMPARISON OF THE SITUATION OF DUTCH AND BELGIAN ARCHITECTS WITH OTHER EU ARCHITECTS}

In Sections A) and B), the regulations relating to architects in Belgium and the Netherlands have been discussed in detail. In this section, I will give a brief overview of the most important aspects of (public) regulation in some other Member States of the European Union (old EU-15). In this way we can determine the extent to which the Belgian and Dutch regulations relate to the regulations in other States, and whether they are stronger or weaker or more or less comparable to them. The following conclusions are based on studies conducted by the OTB Research Institute for Housing, Urban and Mobility Studies of Delft University (paragraph 10.1.) as well as on a study of the Institute for Advanced Studies (Institut für Höhere Studien - IHS) in Vienna (paragraph 10.2). Note that these data relate to the situation of architects in the years 2003/2004.

\section{Studies conducted by the OTB Research Institute for Housing, Urban and Mobility Studies of Delft University}

The OTB Institute has conducted several studies with regard to the architectural profession. ${ }^{1}$ It came to the conclusion that the profession can be classified into five categories by taking into account whether or not there is title protection; whether or not the profession is protected; whether or not practical experience is required, and whether or not architects have to adhere to a disciplinary code. See Table 1.

\footnotetext{
1 Meijer \& Visscher 2006, pp. 1-10. See also Meijer \& Visscher 2008, pp. 1287-1298.
} 
Comparison of the Situation of Dutch and Belgian Architects With Other EU Architects

Table 1: Characteristics of the legal position of architects within the EU

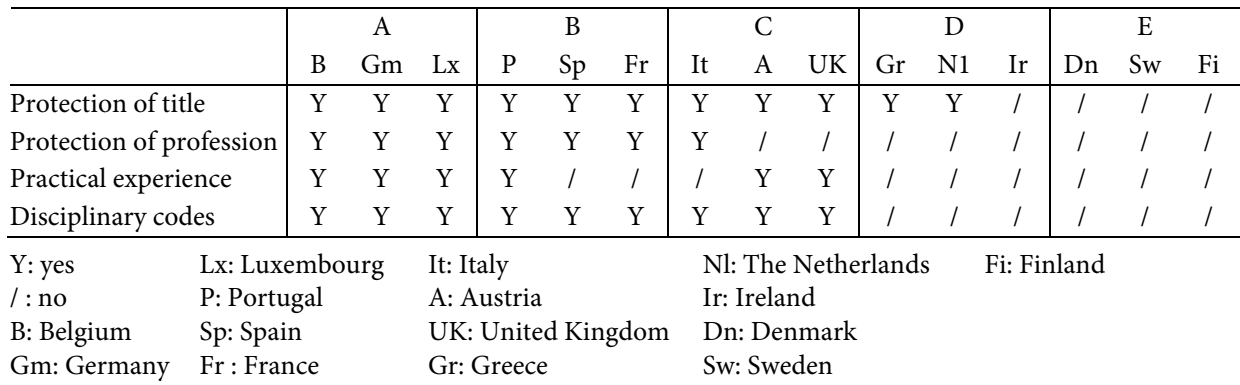

A. Title and profession are protected. There is a legal system of practical experience and disciplinary codes. There is thus a wide ranging regulatory system (Belgium, Germany, Luxembourg and Portugal).

B. Title and profession are protected. There is a legal system of disciplinary codes. Practical experience is, however, not required (Spain, France and Italy).

C. Title is protected. There is a legal system of disciplinary codes and practical experience. The profession itself is not protected however (Austria and the United Kingdom).

D. Title is protected. The profession is not protected. Other regulations are left to the relevant professional organizations (Greece and the Netherlands). There is thus no legal system of disciplinary codes or of practical experience ${ }^{2}$.

E. No legal regulations concerning architects (Denmark, Ireland, Sweden and Finland).

It is held that as long as the building accords with building regulations, it is not important who has designed them. The title is thus not even protected. Anyone can use the title of architect. ${ }^{3}$

It can be concluded that the architectural title is legally protected in most of the states under consideration. The purpose of such regulations is to give some basic quality assurance to consumers when hiring an 'architect'. As indicated in Part I, title protection also enables architects to work more easily in other EU states. However, in this regard, it should be noted that states do not have to introduce or maintain professional or title protection, or any other type of regulation. They only have to guarantee that no unjusti-

2 It should be noted that the Act of 4 March 2010 amending the Architects' Title Act (professional experience, life-long learning for town planners, garden and landscape architects en interior architects, amdements related to the Framework Act on Independent Agencies and some other amendments), Stb. 2010, 130, stipulates in Article 12d that a two year period of professional experience will be required before one is allowed to register. This Article has not yet entered into force however.

3 See for more information http://www.architectenregister.nl/pdf/01_sba.pdf, last consulted 10 November 2009. 
fied restrictions are imposed with regard to the recognition of qualifications which are obtained in Member States, and the free movement of architects. In this way, some states only require a particular education at an academy, while in others, registration can only follow after professionals have completed a certain period of practical experience. Furthermore, in some states, none of these requirements have to be fulfilled. Table 2 contains some more detailed data with respect to the architectural profession.

Table 2: Overview of the main characteristics of the legal position of building architects in the EU-15 in 2003/2004:

\begin{tabular}{lcccc}
\hline Group A & $\mathrm{B}$ & $\mathrm{Gm}$ & $\mathrm{Lx}$ & $\mathrm{P}$ \\
\hline Educational institutions: & $19^{4}$ & 72 & $/$ & 18 \\
- universities & 5 & 15 & $/$ & 14 \\
- academies & 14 & 57 & $/$ & 4 \\
Min years of study & 5 & 4.5 & $/$ & 5 \\
Protection of title & $\mathrm{Y}$ & $\mathrm{Y}$ & $\mathrm{Y}$ & $\mathrm{Y}$ \\
Protection of the profession & $\mathrm{Y}$ & $\mathrm{Y}$ & $\mathrm{Y}$ & $\mathrm{Y}$ \\
Obligatory registration & $\mathrm{Y}$ & $\mathrm{Y}$ & $\mathrm{Y}$ & $\mathrm{Y}$ \\
Internship required & $\mathrm{Y}: 2$ (years) & $\mathrm{Y}: 2 / 3$ & $\mathrm{Y}: 1$ & $\mathrm{Y}: 2$ \\
Disciplinary code & $\mathrm{Y}$ & $\mathrm{Y}$ & $\mathrm{Y}$ & $\mathrm{Y}$ \\
Insurance required & $\mathrm{Y}$ & $\mathrm{Y}$ & $\mathrm{Y}$ & $/$ \\
\hline & & & & \\
\hline Group B & $\mathrm{Sp}$ & $\mathrm{Fr}$ & $\mathrm{It}$ & \\
\hline Educational institutions: & 14 & 22 & 18 & \\
- universities & 14 & 22 & 14 & \\
- academies & $/$ & $/$ & 4 & \\
Min years of study & 5 & 6 & $5+$ & \\
Protection of title & $\mathrm{Y}$ & $\mathrm{Y}$ & $\mathrm{Y}$ & \\
Protection of the profession & $\mathrm{Y}$ & $\mathrm{Y}$ & $\mathrm{Y}$ & \\
Obligatory registration & $\mathrm{Y}$ & $\mathrm{Y}$ & $\mathrm{Y}$ & \\
Internship required & $/$ & $/$ & $/$ & \\
Disciplinary code & $\mathrm{Y}$ & $\mathrm{Y}$ & $\mathrm{Y}$ & \\
Insurance required & $\mathrm{Y}$ & $\mathrm{Y}$ &
\end{tabular}

4 It should be noted thatn due to the restructuring of the education system, these figures are not longer correct. See Chapter 5.2.2 for an updated overview. This is also possible with regard to the other states under consideration. 
Comparison of the Situation of Dutch and Belgian Architects With Other EU Architects

\begin{tabular}{|c|c|c|c|c|}
\hline Group C & $\mathrm{A}$ & UK & & \\
\hline Educational institutions: & 6 & 39 & & \\
\hline - universities & 5 & 18 & & \\
\hline - academies & 1 & 21 & & \\
\hline Min years of study & 5 & 5 & & \\
\hline Protection of title & $\mathrm{Y}$ & $\mathrm{Y}$ & & \\
\hline Protection of the profession & l & l & & \\
\hline Obligatory registration & $\mathrm{Y}$ & $\mathrm{Y}$ & & \\
\hline Internship required & 3 & 2 & & \\
\hline Disciplinary code & $\mathrm{Y}$ & $\mathrm{Y}$ & & \\
\hline Insurance required & $\mathrm{Y}$ & $\mathrm{Y}$ & & \\
\hline Group D & Gr & $\mathrm{Nl}$ & & \\
\hline Educational institutions: & 2 & 8 & & \\
\hline - universities & 2 & 2 & & \\
\hline - academies & 1 & 6 & & \\
\hline Min years of study & 5 & $4 / 5$ & & \\
\hline Protection of title & $\mathrm{Y}$ & $\mathrm{Y}$ & & \\
\hline Protection of the profession & 1 & l & & \\
\hline Obligatory registration & $\mathrm{Y}$ & $\mathrm{Y}$ & & \\
\hline Internship required & 1 & l & & \\
\hline Disciplinary code & 1 & l & & \\
\hline Insurance required & 1 & 1 & & \\
\hline Group E & $\mathrm{Ir}$ & Dn & Sw & $\mathrm{Fi}$ \\
\hline Educational institutions: & 2 & 2 & 3 & 3 \\
\hline - universities & 2 & l & 3 & 3 \\
\hline - academies & 1 & 2 & 1 & I \\
\hline Min years of study & 5 & 5 & 4.5 & 5 \\
\hline Protection of title & 1 & l & 1 & I \\
\hline Protection of the profession & 1 & l & I & l \\
\hline Obligatory registration & 1 & l & I & I \\
\hline Internship required & 2 & l & I & I \\
\hline Disciplinary code & 1 & l & I & I \\
\hline Insurance required & 1 & l & / & I \\
\hline
\end{tabular}

It can be concluded that among the 15 countries examined, the architect's title is protected in 11 cases. ${ }^{5}$ This does not mean that architects automatically have a monopoly in these countries. A monopoly only exists in 7 countries $^{6}$. One should distinguish between the monopolies limited to certain objects (in Portugal, for example, the monopoly is limited to instances where special regulations apply, such as in case of protection of historic sites). Furthermore, in certain legislations, the monopoly is retained exclusively

5 In this regard it should be noticed that, in some countries, the current rules apply to building architects, interior architects, landscape architects and urban planners. In other countries the legislation is confined to building architects and civil engineers. The demands on the professional practice of building architects are, however, not comparable to demands on those of interior architects.

6 This is in Belgium, France, Germany, Italy, Luxemburg, Portugal (to a lesser extent) and in Spain. 
by architects (as in France, Belgium) and in others it is shared with engineers (e.g. Italy or Luxemburg). Belgium appears to be the country where the monopoly is at its strongest, since it does not only deal with the creation of plans, but likewise with the control over the execution of work as well. ${ }^{7}$ As held by the Belgian Centre d'Etudes d'Assurance, across this heterogeneity, it appears that legislation which protects the architects' title and a fortiori legislation which supports a monopoly is stimulated by a wish to ensure the quality of construction, protection of the environment and public safety. ${ }^{8}$ Whether this is truly the case will be discussed in Part III of this thesis in which an economic analysis of the regulation of architects will be presented. In any case it should be noted that these differences have significant influence upon the appreciation of the specific nature of an architect in terms of liability and insurance. ${ }^{9}$ However, since the liability regimes in the different Member States are so diverse, and depend on the details of each specific case, it is not possible to categorise them into groups. ${ }^{10}$

Since it would be too much to discuss these data in more detail within the scope of this thesis, I will now turn to the findings of the Institute for Advanced Studies in Vienna. The IHS report not only discusses the differences in regulations, but also determines the level and extent of these regulations.

\section{Study conducted by the Institute for Advanced Studies in Vienna}

As stated in Part I of this thesis, the Lisbon European Council in 2000 adopted an economic reform programme to make the EU the most competitive and dynamic knowledge-based economy in the world by 2010. In the field of regulated professions, steps towards these goals have been taken by the Commission through initiatives based on competition policy on the one hand, and on internal market policy (freedom of establishment, freedom to provide services which led to the adoption of Directive 2005/36/EC and Directive 2006/123/EC) on the other. ${ }^{11}$

In the field of competition law, the European Commission initiated a research project to investigate whether all these regulations truly served the interests of consumers. A largescale project on competition in professional services was conducted by the Directorate General for Competition, and a first step was the investigation of an independent study carried out by the Institute for Advanced Studies in Vienna (IHS) in 2002/3 on the eco-

7 As held by the Belgian legislator, the architects' monopoly in Belgium is stimulated by "the necessities imposed upon the safety of inhabitants, hygiene of living areas, concern for the aesthetics of the construction, collaboration and conservation of country's artistic heritage, protection of the capitals invested in the construction by the project owners: See Doc. Parl. Ch., 1936-1937, No. 236, Exposé des motifs.

8 http://www.groupe-cea.com/upload/doc_stheme/Document_en/16/_liabilities_in_Europe.pdf , last consulted 10 November 2009.

9 See Title I and II of this Part.

10 For an overview I refer to http://www.ordredesarchitectes.be/nl/teksten/cea/TABEL.PDF, last consulted 15 November 2009.

11 As indicated in Part I of this thesis, the close relationship between the Treaty provisions on competition and those on free movement have been acknowledged by the ECJ in Wouters. The ECJ relied on the same arguments in order to conclude that competition rules, on the one hand, and Treaty rules on freedom to provide services and establishment on the other, had not been infringed: See Brumter 2004, p. 219. 
nomic impact of regulation in the field of liberal professions in different Member States $^{12}$. On the basis of the encouraging results of the study, the Commission launched an invitation to comment on the place of regulations in the liberal professions, consisting of a questionnaire addressed to professionals in all Member States which aimed to collect an insider's perception of the issue. Then, in October 2003, a public consultation took place involving consumers' representatives, members of the liberal professions and businesses, which concluded the research and information phase. ${ }^{13}$ Professional associations and Member States were called on to review critically the existing public and selfregulation, and to reform or eliminate rules if needs be. Successively, on 9 February 2004, the Commission presented its final report on competition in professional services, with the aim to summarise the findings of the research and consultation proceedings, and to provide guidance to the interested regulatory subjects as to the next steps towards modernisation in the liberal professions ${ }^{14}$. In its final report, the Commission identified the following main categories of potentially restrictive regulations relating to EU professions:

- entry requirements and reserved rights

- price fixing and recommended prices

- $\quad$ advertising regulations

- regulations governing business structure and multi-disciplinary practices.

This report used regulatory indices to compare and measure the level of regulation in the EU-15. The overall index ranged from 0 in the case of no regulation (for architects and engineers in five countries), to 12 in the case of maximum regulation ${ }^{15}$.

According to the study, countries with a high degree of regulation intensity for all professions are Austria, Italy, Luxembourg and, with some exceptions in the field of technical services, Germany, as well as France and possibly Greece (in Greece there was not much information available in the English language). Belgium, Spain (and possibly Portugal) were considered to be in the medium category, and the UK, Sweden (with the exception of pharmacists), the Netherlands, Ireland, Finland and Denmark (the latter with the exception of pharmacists) appeared to have more or less liberal regimes. Nevertheless, according to the report, the least regulated Member States are arguably the most sceptical with regard to the restrictions which still remain in their countries. See Table 3.

12 Contract No. COMP/2002/D3/S12.334490. IHS study: See Paterson, Fink, Ogus et al. 2003.

13 A conference on the regulation in the liberal professions was held on 28 October 2003, hosted by the DG Competition in Brussels. Commissioner Monti made the closing speech.

14 Report on Competition in Professional Services 9 February 2004, COM(2004) 83 final. A follow-up report was made in 2005 to update the first report,and a conference called 'Better Regulation of Professional Services' was held in Brussels. Furthermore, in December 2006, a conference on 'The Economic Case for Professional Services Reform' was organized.

15 This was the case for pharmacists in Sweden, where all pharmacies were until recently owned by one stateowned company. 


\begin{tabular}{lccccc}
\hline & Accountants & Legal & Architects & Engineers & Pharmacists \\
\hline Austria & 6.2 & 7.3 & 5.1 & 5 & 7.3 \\
Belgium & 6.3 & 4.6 & 3.9 & 1.2 & 5.4 \\
Denmark & 2.8 & 3.0 & 0 & 0 & 5.9 \\
Finland & 3.5 & 0.3 & 1.4 & 1.3 & 7.0 \\
France & 5.8 & 6.6 & 3.1 & 0 & 7.3 \\
Germany & 6.1 & 6.5 & 4.5 & 7.4 & 5.7 \\
Greece & 5.1 & 9.5 & $\mathrm{n} / \mathrm{a}$ & $\mathrm{n} / \mathrm{a}$ & 8.9 \\
Ireland & 3.0 & 4.5 & 0 & 0 & 2.7 \\
Italy & 5.1 & 6.4 & 6.2 & 6.4 & 8.4 \\
Luxembourg & 5 & 6.6 & 5.3 & 5.3 & 7.9 \\
Netherlands & 4.5 & 3.9 & 0 & 1.5 & 3.0 \\
Portugal & $\mathrm{n} / \mathrm{a}$ & 5.7 & 2.8 & $\mathrm{n} / \mathrm{a}$ & 8 \\
Spain & 3.4 & 6.5 & 4.0 & 3.2 & 7.5 \\
Sweden & 3.3 & 2.4 & 0 & 0 & 12 \\
Uk & 3.0 & 4.0 & 0 & 0 & 4.1 \\
\hline
\end{tabular}

With regard to the architectural profession in particular, the report concluded that, in general, market entry was heavily regulated in the Member States while market conduct was not. The maximum index was 6 in Italy while the average across the European Union was less than 3. For this reason, the IHS study identified the architectural profession as the least regulated among the professions examined. In respect of market entry, some countries showed rather restrictive licensing models (e.g. Austria, Germany, Italy, Luxembourg) while, in other states, certification with or without very limited exclusive tasks reserved to the professions was the standard model (e.g. Sweden, the UK, the Netherlands, Finland and Denmark). The IHS research demonstrated that in all the countries where reserved tasks for architects apply, membership of a professional association is compulsory. Moreover, a university degree is a basic requirement to enter the respective market in these countries, while a considerable degree of variation existed regarding mandatory professional exams and required professional practice. The conduct regulations for architects and engineers appeared to be less restrictive in most of the countries when compared to the regulations of other professions. Only Italy, Germany and Luxembourg had rather restrictive regulations in this respect. Furthermore, the study showed that, in most countries, there did not exist any binding price or fee system (exceptions were held to be Belgium ${ }^{16}$, Germany, Italy and Luxembourg (with regard to public works only)). In most countries, only moderate regulations existed concerning advertising and on forms of business and inter-professional co-operation. Furthermore, the studies found that, in recent years, a development could be seen in the countries with a high degree of regulation to more liberal regimes, especially with regard to conduct regulations. See Table 4.

16 It has been held previously that the Belgian Deontological Norm No 2 is held to restrict competition law and is no longer used by the Belgian Architectural Association as the recommended standard. 
Comparison of the Situation of Dutch and Belgian Architects With Other EU Architects

Table 4: Technical Services (Architects): IHS Regulation indices. See IHS report, Part 1, p. 64.

\begin{tabular}{lcccc}
\hline & Entry & Conduct & Total & Rank \\
\hline Italy & 3.2 & 3.0 & 6.2 & 1 \\
Luxembourg & 2.6 & 2.7 & 5.3 & 2 \\
Austria & 3.9 & 1.2 & 5.1 & 3 \\
Germany & 1.8 & 2.7 & 4.5 & 4 \\
Spain & 3.2 & 0.8 & 4.0 & 5 \\
Belgium & 2.4 & 1.6 & 3.9 & 6 \\
France & 2.2 & 0.9 & 3.1 & 7 \\
Portugal & 2.2 & 0.6 & 2.8 & 7 \\
Finland & 1.4 & 0.0 & 1.4 & 9 \\
Denmark & 0.0 & 0.0 & 0.0 & 10 \\
Ireland & 0.0 & 0.0 & 0.0 & 10 \\
Netherlands & 0.0 & 0.0 & 0.0 & 10 \\
Sweden & 0.0 & 0.0 & 0.0 & 10 \\
United kingdom & 0.0 & 0.0 & 0.0 & 10 \\
Greece & $\mathrm{n} / \mathrm{a}$ & $\mathrm{n} / \mathrm{a}$ & $\mathrm{n} / \mathrm{a}$ & $\mathrm{n} / \mathrm{a}$ \\
\hline
\end{tabular}

\section{Conclusion}

A detailed analysis of the regulation of architects in all EU states (except for Belgium and the Netherlands) would be outside the scope of this thesis. This Title was added to the research, to give the readers an idea about the regulation of architects in other states. Whether and how the findings of the two studies mentioned above correspond, will not be discussed. In this regard it should be noted that deviations are possible since the OTB research only determined whether disciplinary codes have to be adhered to, whereas the IHS study also looked at the conduct of these rules. Furthermore, the IHS report received a lot of criticism from legal and economic scholars. The criticism was however not that much on the calculation of the regulation indices but more on the empirical analyses in the following chapters. This will be discussed in more detail in Part III of this thesis.

In any case it can be concluded that, compared with other EU states, Belgium has a rather restrictive regime with regard to architects, whereas the Netherlands exhibits a more lenient situation. 


\section{PART III}

\section{ECONOMIC ANALYSIS OF THE REGULATION OF ARCHITECTS}



Chapter 11

\section{THE ARCHITECTURAL PROFESSION: AN ECONOMIC APPROACH}

\section{Objectives of the economic analysis of law}

Even though this thesis deals with the liberal profession of architect -the world 'liberal' literally meaning 'free from restraint'- it has been demonstrated in the preceding chapters that the architectural profession is (certainly in Belgium) heavily regulated. This chapter aims to compare the Belgian and Dutch regulatory systems as discussed in Part II of this thesis, from an efficiency perspective. To achieve this end, a law and economics analysis of the regulation of the architectural profession in those two countries is used.

The law and economics approach to legal and regulatory issues -also called the economic analysis of law- unites the field of law and the field of economics, and aims to bring about a better understanding of both. As will be clarified in this chapter, economics provides a scientific theory to predict how people respond to changes in law, and what the effects of legal sanctions on behaviour are. In other words, microeconomic theory offers an explanation about how legislation and other regulations affect the choices of individuals. In this way, laws constitute incentives for changing behaviour, and can be instruments for achieving important social goals (efficiency -i.e. the cheapest means- and distribution) and/or paternalistic goals while economics predicts their effects on efficiency, and on the distribution of income and wealth. As held by Cooter and Ulen, because of these qualities, laws can be seen as implicit prices. ${ }^{1}$ In this regard, this part of the thesis discusses how the decisions of architects (producers) and their clients (consumers) are coordinated through movements in market price, taking account of the fact that consumers and producers will always try to maximize their utility. This means that they will always choose the best alternative when making a decision. ${ }^{2}$ Producers will therefore choose to provide those goods or services which maximise their profits, i.e. the goods and services for which the difference between the price per unit that consumers are willing to pay and the cost of production of these units is the largest. Competition among producers will therefore force these producers to minimise their costs of produc-

Cooter \& Ulen 2003, p. 4.

Ibid. 
tion and sales prices. Consumers, on the other hand, will try to choose goods or services with the best quality-price ratio. The decisions of consumers and firms must be made consistent in the sense that somehow the two sides must agree about the quantity and price of the good or service that will be produced and consumed. ${ }^{3}$ When these consumption and production decisions are consistent in this sense, the market is said to be in equilibrium. In this part of the thesis, it will be explained that, in general, the market for architectural services, as many others, is not in equilibrium at all, as a result of certain problems. Law and economics theory aims to describe these problems, and to offer solutions for them. In order to determine the effects of the existence and absence of laws on the goals of efficiency and distribution, judges and other lawmakers must have a method of evaluating these effects. An economic analysis of law provides an objective method for evaluating which legal rules are to be preferred. ${ }^{4}$ In this way, it may help to establish which combination of regulation or non-regulation options is likely to lead to more efficient outcomes.

\section{Methodology and structure}

In this chapter the general theory of the economic analysis of law will be described, and it will be demonstrated that economics is not only linked with taxation, regulation of markets or competition law, but is a behavioural science that more generally analyses human behaviour, even if this is not strictly market orientated. ${ }^{5}$ Different possibilities will be discussed which are used to internalize externalities such as moral persuasion (paragraph 11.3.2), the Coase theorem (paragraph 11.3.3), taxes (paragraph 11.3.4), liability rules (paragraph 11.3.5) and regulation (paragraph 11.3.6). Even though Part II of this thesis only discusses contractual liabilities, since the relationship between the architect and the building master is in principle regulated by a contract, it can be said that the economic analysis of tort law is interesting since architects always have to act with a minimal amount of due care to prevent the occurrence of any harm. The tort law analysis is highly relevant since it presupposes a situation in which there is no regulation. This analysis will be offset against the regulation of behaviour via government regulation. The criteria for regulation will be discussed from a public as well as a private interest perspective (paragraph 11.3.6.1), followed by an overview of the 'authors' who generally create regulation next to the specific contracting parties: the government and self-regulating agencies such as professional associations (paragraph 11.3.6.2). In this regard it should be noted that, through the legal analysis of contract law which is provided for in Part II of this thesis, I aim to determine whether the intensity of contract law is linked to the intensity of regulation. This will be further discussed in paragraph 11.3.7. However, this research does not contain an economic analysis of contract law and further research is recommended in this area. Finally, this thesis will contain a brief discussion of insurance theory (paragraph 11.4.) and its importance for architects.

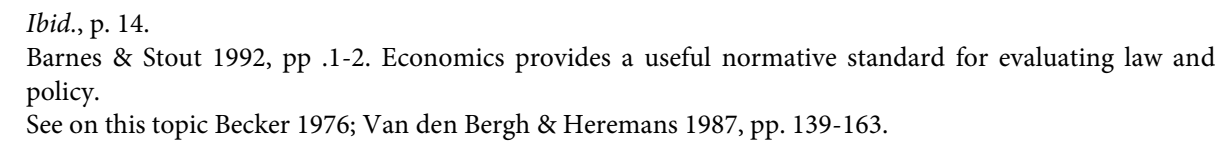


While each paragraph refers to the architectural profession, an economic analysis of the regulation of architects in Belgium and the Netherlands will be presented in paragraph 11.3.6.4. Finally, a conclusion will be provided in paragraph 11.5. It should be noted that this thesis cannot extensively deal with all problems of economic analysis (it will, for example, not discuss whether or not it is better (i.e. more efficient) to have EU legislation to uniformly regulate (harmonize) the architectural profession), but aims to demonstrate that law and economics can be a useful method for analysing architectural law and policy.

\section{The internalization of externalities}

\subsection{Introduction}

As demonstrated in Part II of this thesis, the architectural profession is surrounded by difficult tasks and responsibilities. It is obvious that architects have to work with due diligence and seriousness because it is crucially important that the buildings they design are safe and secure. When a decision causes costs or benefits to individuals or groups other than the person making the decision, the decision has caused external effects, also called externalities.

If an externality occurs, the decision-maker does not bear himself all the costs (such as pollution from cars - a negative externality) or enjoy all the gains (such as improved health care reducing absenteeism - a positive externality) from his action. In a free market, i.e. a market without regulations, externalities are not internalised in the decisionmaking process of the suppliers. As a result, too much or too little of the good will be consumed from the point of view of society: if the costs to the world exceed the costs to the individual making the choice (e.g. pollution, crime) then the good will be overconsumed from society's point of view; if the world around the person making the decision benefits more than the individual does (e.g. education, safety), then the good will be underconsumed by individual decision makers.

With regard to the provision of services by architects in particular, externalities can appear if the quality of the service rendered by the architect is not high, since this can cause huge losses for private parties and for society as whole. A badly constructed or poorly designed apartment building may cause casualties and does not only constitute a problem for the owner of the building and the individuals who rent the apartments, but also for the public security in general (for example, visitors, people walking by ... ). Due to possible third party effects, society becomes a second client: one that does not pay directly, but one that fears to 'pay' indirectly for bad or biased services. ${ }^{6}$ On the other hand, every individual can enjoy the sight of a beautiful building and safely visit it, which certainly can be qualified as a positive externality.

6 Geens 2004, p. 290. 
In this thesis I will discuss a variety of legal instruments that can be used to internalize externalities. However it should first be determined whether legal rules are needed at all to achieve such internalization. For this reason, a variety of instruments which can be used to prevent the injurer of damages with appropriate incentives to prevent/reduce harm will be analysed. It will be demonstrated that, next to moral persuasion, negotiations and taxes and liability rules and regulation can lead to the prevention of damage. Since the latter two options are most common, this part of the thesis mainly focuses on liabilities and regulations. The reader should note, however, that this thesis does not provide an economic analysis of contract law, but aims to offer an economic analysis of tort law and regulation. This might seem odd at first instance since neither in Part I nor in Part II was liability in tort discussed from a legal point of view, while the regulation and the contractual liability of architects was presented. However, by presenting an economic analysis of tort law and regulation, the main possibilities through which socially optimal behaviour and thus the prevention of damages can be obtained, are included. Indeed, injurers are likely to take due care in order to prevent damages when faced with the threat of liability rules. Regulation, on the other hand, can also be used to provide incentives for prevention in the event that liability rules are not able to achieve the desired results. The private law which was discussed in Part II of this thesis will serve to determine whether the intensity of contract law is linked to the intensity of regulation.

\subsection{Moral persuasion}

In the absence of regulation, there will be no incentives for architects to take into account possible damages caused by, for example, a faulty design to third parties. However, not only can legal rules provide incentives to internalise the externality by forcing the architect to take into account the damage caused, but it is possible that such internalisation can also be achieved through moral persuasion of the architect, pointing at his liability to society as a whole. This might lead to voluntary compliance, although the efficacy of such an approach has been questioned. ${ }^{7}$

\subsection{Coase theorem}

Another way for private parties to internalize external effects is through negotiation, except in cases where transaction costs are prohibitive. In this way, the externality is internalized in a contract. Coase referred to the reciprocal nature of harm. In this way it can be said that harm is not just caused by an architect who designed a high apartment block which spoils the view of the neighbours, but also by the presence of those living next-door. In such a case, it should be decided whether the rights of the architect and the building master or those of the neighbours should be limited. This will depend on who can take precautions to reduce or prevent the harm. According to the Coase theo-

7 Oates \& Baumol 1975, pp. 95-128. 
$\mathrm{rem}^{8}$, in the absence of, or in a situation of very low transaction costs, the outcome of negotiations will be economically efficient, regardless of how the government allocates property rights, because the interested parties will bargain privately to maximise their joint utility and social welfare and, in this way, correct the externality. Through bargaining, parties can therefore internalize the externality, for example by including a risk premium in the prices for professional services. ${ }^{10}$ However, even though a premium may be included in the prices for professional services, in markets for professional services the transaction costs are generally too high. ${ }^{11}$ Nevertheless, since professionals find it possible to pass their increased liability on to their clients by increasing their prices, the Coase theorem has not lost its relevance in the professional services market. Indeed, since it is possible that the architect is held liable in tort by the owners of the neighbouring building if they suffer damage caused by the construction works, this will be taken into account when the contract is created. The price charged to the building master reflects the division of risks as agreed between the architect and his client.

\subsection{Pigouvian tax}

Another theoretical solution for the problems caused by negative externalities can be found in the imposition of a tax (the so-called Pigouvian $\operatorname{tax}^{12}$ ) on all activities that generate external costs, thereby reducing the incentives to take part in such activities. Not only private parties can internalize external effects through negotiations, but also government can achieve this by means of taxes and subsidies. This tax should be equal to the amount of the external costs. Optimally, for each harmful activity, the marginal tax rate should be equal to the marginal costs caused by it. However, as suggested by Philip$\operatorname{sen}^{13}$, this solution does not seem practical in markets for professional services. It is difficult to calculate what level of tax would counterbalance the negative externality. Hence some form of quality regulation and/or liability rules are needed to cure the problem of negative externalities in the professions.

8 Coase 1960, pp. 1-44.

9 These are the costs associated with the time and effort needed to search out, negotiate, and consummate an exchange.

10 As will be explained in the next paragraph, due to the information asymmetry problem (one of the parties to a contract has information that is not available to the other) in markets for professional services, transaction costs are usually very high, so that the Coase theorem will mostly not deliver the desired results. In the relationship between architects and clients, transaction costs include, for example, the client's costs associated with finding an appropriate architect, negotiating with the architect on the design assignment, drawing up a design contract, and bringing a claim before a judge in event of the architect's breach of duty. Van Gulijk 2009, p.159.

11 Philipsen 2009, forthcoming. Advance access online since 21 April 2009, last consulted 23 December 2009.

12 Pigou 1954.

13 Philipsen 2008, p. 96. 
The Architectural Profession: an Economic Approach

\subsection{Liability rules}

\subsubsection{Prevention of accident costs}

As indicated earlier, the professional task of architects is very complex. For this reason, the right incentives have to be created to make sure that architects take good care. Generally speaking, a lot of professional activities can be carried out in a very safe way. It follows that the increase in value they bring to society is often larger than the costs of the damage they cause. ${ }^{14}$ Since the influence of damages on people's behaviour should only extend to the point where the costs of accidents are acceptable for society, it is of no use prohibiting these activities. However, in today's market, consumers are in need of effective and independent redress mechanisms when things go wrong. In this regard, the classic economic analysis of law starts from the assumption that, by exposing the costs of their actions through liability rules, parties will be motivated to take optimal care to prevent accidents. The result would be a reduction in the total social cost of accidents, since it is at the level of care that the costs of prevention and expected damage are minimised. ${ }^{15}$ It follows that economists tend to stress the deterrent function of tort law, as opposed to the compensation goal to which lawyers mostly refer. ${ }^{16}$ In the famous book The Costs of Accidents, Calabresi proposed a law and offered an economic analysis of the deterrent function and the compensation goal of tort law, and made a distinction between primary, secondary and tertiary accident costs. ${ }^{17}$

Primary accident costs are the costs of accident (tort) avoidance and the damage that finally occurs. More specifically, they are the costs associated with the reduction of the number of accidents and the severity of such accidents (prevention costs), as well as the costs of accidents that are not prevented because preventing them is more costly than letting them occur (costs of damages). As held by Calabresi, the principal function of accident law is to reduce the sum of the costs of (avoiding) accidents. ${ }^{18}$ The reduction of the social costs of accidents was thus the central role of tort law. Since there is a tradeoff because some damage is very costly to prevent, Calabresi has argued that the primary cost reduction goal is to minimize the sum of the costs of prevention and the costs of damage.$^{19}$ It follows that primary costs include the costs of accidents that are not prevented, because preventing them is more costly than letting them occur. With regard to the architectural profession, it can be said that primary costs include the professional's costs associated with the creation of his design; the costs to architects of hiring other experts to make sure the design contains no faults; the costs related to the study of books and articles to learn the characteristics of certain building materials, etc. As indicated by Calabresi, the costs of prevention and the costs of damage can be reduced by taking an adequate level of care. The more prevention there is, the lower the level of damages will

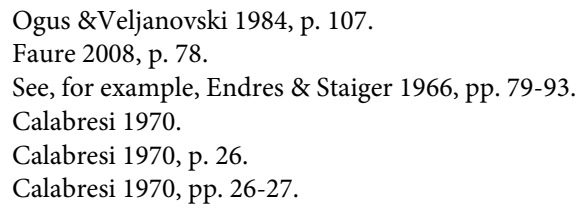


be. According to the Learned Hand rule ${ }^{20}$, the injurer has to weigh his costs of prevention against the costs of damage for the injured party. ${ }^{21}$ The injurer of the damage is liable for negligence if the prevention costs are less than the expected benefit. Therefore, the injurer has to make prevention costs that, at most, equal his expected benefit. As indicated before, often rules are created to indicate that the architect should observe a minimum level of care. Furthermore, the costs of prevention and damage can be reduced by performing a certain level of activity: the higher the level of dangerous activities, the more damage will occur. An optimal activity level will be achieved if the expected utility derived from the activity at least equals the expected damages as a result of the activity.

Secondary costs, on the other hand, refer to the equitable spreading of loss. An example can be found in the taking out of insurance. ${ }^{22}$ As indicated in Part I of this thesis, architects are mostly covered by professional liability insurance. Sometimes this is even imposed by law. Obviously, the secondary cost reduction goal only comes into the picture after earlier measures to prevent or reduce primary costs have failed. With regard to this second type of costs, it should be investigated as to whether architects, as injurers or victims, are better capable to bear the costs of liability in a certain situation. The one who is most capable is considered to be the cheapest risk bearer. Usually the damage is placed on the wealthy in order to bring about a just distribution, regardless of whether or not this involves financial spreading, since they will be in the best situation to pay for the damages. Therefore, the wealthy are often considered to be the cheapest risk bearers. ${ }^{23}$

Tertiary costs are the costs of administering the legal system. They are administrative costs such as the verification costs of insurance companies, negotiation costs, lawyer's costs, costs of using the courts, costs of administering punishment, and other administrative costs. The purpose of this tertiary cost reduction goal is to question whether the attempt to reduce accident costs, either through primary or secondary cost reduction, does not cost more than it actually saves. ${ }^{24}$ If the administrative costs of the prevention and compensation of damages exceed the actual prevention and compensation costs, prevention and compensation may not be worthwhile.

\subsubsection{Strict liability vs. negligence}

To minimise the above-mentioned social costs in terms of harm, a certain level of care has to be taken. Cost-benefit analyses have demonstrated that the optimal level of care is that where the marginal costs of care taking equal the marginal benefits of accident reduction. ${ }^{25}$ Liability law should provide parties with incentives to adopt this optimal

Cooter \& Ulen 2004, p. 331f; Shavell 2004, p. 191

Van den Bergh 2001, p. 116; Van Gulijk 2009, p. 161.

Calabresi 1970, p. 51

23 Calabresi 1970 , p. 21 , pp. $27-28$. Calabresi mentions three variables that may indicate that a party is the superior risk bearer: if he is in the best position to prevent the risk; if he can best insure himself; if he can take out insurance at the lowest cost.

24 Calabresi 1970, p. 28; Van Gulijk 2009, p. 163.

25 Shavell 1987, p. 7; Landes \& Posner 1981, p. 870. 
care level. In this regard two main liability systems exist: strict liability and negligence. Which of these systems provides parties with incentives to take optimal care depends on whether one deals with a unilateral or a bilateral accident situation.

In a unilateral accident situation - i.e. a situation in which the victim cannot influence the accident risk - with negligence rules, the injurer will take optimal care if the due care which is required in accordance with the negligence rule is equal to the optimal care as defined above. ${ }^{26}$ This is due to the fact that the injurer will not take more care than is necessary, since he escapes liability as soon as he complies with the due care standard. Taking higher care will be more expensive for him, while taking lower care will lead to a duty to compensate for the damage. Liability for negligence does not provide incentives to adopt an optimal actively level however. The same is true in the case of strict liability. The level of care taken by the injurer will equal the optimal care, since this will lead to a minimization of the total expected accident costs. It should be noted however, that even though both the negligence and the strict liability rules lead to a minimization of the social costs of accidents, secondary and tertiary costs may be different within the two liability systems. With regard to the secondary costs, an injurer who follows the due care level will never have to compensate the victim, while if strict liability applies, the reverse is true as soon as damage has arisen. Since, in negligence systems, the victim has to convince the judge of an insufficient level of care taking on the part of the injurer, high administrative costs are present. It follows that the judge has to make an extra effort to determine what the marginal costs and benefits of care taking lie. ${ }^{27}$ In strict liability systems, these costs do not exist. However, a legal case will follow as soon as the victim has suffered injury, since compensation is always due. Since the optimal activity level is not incorporated in the due care standard which is applied by the court, negligence rules will not give optimal incentives to the injurer to adopt an optimal activity level..$^{28}$ Under a strict liability rule, the injurer has an incentive to adopt an efficient activity level since this is the way to minimize the total expected accident costs.

In a bilateral accident setting, victims will only have incentives to take due care in the case of negligence. Indeed, if the injurer is only subjected to a negligence rule, the victim carries his damage as long as the injurer has taken due care. For this reason, the victim also has an incentive to adopt an optimal activity level. In the event that the injurer is held strictly liable, on the other hand, the victim will receive compensation anyway. In a strict liability regime combined with a contributory negligence defence, the victim will not receive compensation if he did not take the efficient level of care. If this is the case, both the injurer and the victim will take efficient care to avoid liability. ${ }^{29}$ In such a case, the victim has no incentive to adopt an optimal accident level since it will not be taken into account by the judge to determine whether the victim was negligent or not. Another possibility is the combination of negligence with a contributory negligence defence, in which the injurer does not have to pay the victim if the latter was negligent, not even if the injurer did not take due care. Finally, also, a comparative negligence rule

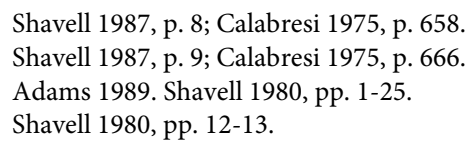


can provide incentives for care taking to the injurer as well as the victim. If both parties failed to take due care, the victim can only claim compensation which is proportional to the amount of damage caused by the injurer.

Since Part I of this thesis focuses on the liability of architects, I will not discuss this bilateral accident situation in further detail. Within the relationship of architectbuilding master, there is normally no liability in tort, but instead a contractual liability. Liability in tort is possible however, in the relationship architect-entrepreneur, at least if they did not regulate their tasks and obligations in a contract. ${ }^{30}$ It should be noted however, that when the entrepreneur can influence the accident risk, for example by warning the architect in time with regard to a certain problem, a liability rule should be chosen which gives an incentive for care taking on the part of the entrepreneur as well. This can be found in cases of negligence, strict liability with a contributory negligence defence, negligence with a contributory negligence defence and a comparative negligence rule. However, in a regular situation, it is not the entrepreneur that truly suffers from a fault of the architect or vice-versa, but the building master with whom the professionals have a contractual relationship.

In any case, when having to make a choice between strict liability and negligence ${ }^{31}$, it is often argued that strict liability eases the victim's burden of proving fault in order to obtain compensation. However, as has been discussed above, the principal aim of tort law is not to provide for damage compensation, but to deter injurers from causing damage in the first place. Furthermore, if often occurs that legal systems qualify every violation of a regulation as a fault, so that victims only have to prove this violation, a causal relationship and damage. Whether strict liability is thus more beneficial for the victim can be questioned. This is even more so, since strict liability regimes often contain several derogations to this regime. ${ }^{32}$ However, strict liability does impose upon the injurer, not only the incentive to take efficient care, but also to adopt an optimal activity level. The injurer will be held liable, regardless of the victim's behaviour. In a system of strict liability with a contributory or comparative negligence defence, the victim's behaviour also becomes important since the latter is in a position to limit the damage by taking due care. From the perspective of damage prevention, we should avoid the situation in which the actions or inactions of the victim are not taken into account as well.

Another factor that should be taken into account is that strict liability does not bring about high information costs for the judge..$^{33}$ As opposed to a negligence system, the judge does not have to decide what the optimal level of care in a concrete situation should have been. The judge only has to 'punish' the one who did not obtain a certain

30 It should be repeated that in Belgium, a contract between an architect and an entrepreneur is often scrutinised extremely closely, since it argued that it might harm the independence of architects.

31 It should be noted that the above-mentioned analysis is based on a situation in which both parties are risk neutral. As pointed out by Endres and Schwarze, strict liability is only efficient if, in some way, risk can be removed from the risk averse injurer, for example through insurance: Endres \& Schwarze 1991, pp. 1-25

32 See for example Brans 1994, pp. 61-67 and pp. 85-91.

33 Polinsky 1988, pp. 139-147. 
result by holding him liable. ${ }^{34}$ It follows that in a strict liability system the injurer will take all efficient precautions to avoid the accident, even if the judge is not able to determine the negligence standard. With regard to the architectural profession, it can be said that strict liability gives architects incentives to take efficient care. However, since the architect has to deal with very complex and different matters, and provides intellectual services, he is mostly held liable if due care was not taken. Indeed, architects often do their utmost to prevent harm, but it is always possible that damage occurs anyway. As has been demonstrated in Part I of this thesis, for this reason architects in Belgium and the Netherlands are mostly held liable for negligence. Only in certain specific circumstances is a stricter liability regime applied if it is presumed that the architects should be able to guarantee a certain result with regard to a particular task in a building project. ${ }^{35}$

\subsubsection{Caps}

It is possible that financial limits (caps) are placed on the amount that has to be paid by the injurer. Limits are often created by public regulations, but are also present in (insurance) contracts. The insurability of the damage is often seen as a reason of the imposition of such caps, as well as the pressure of interest groups ${ }^{36}$ who want to lower their risks. However, if this is the case, the level of care taken by the injurer will diminish, since he will only take the level of care which is needed to avoid an accident which equals the statutory limited amount, as opposed to the level which is needed to reduce the total accidents costs efficiently. ${ }^{37}$ As has been demonstrated above, not only the extent of the damage can be limited, but also the liability period. This will lead to underdeterrence and also undermines the principle of the full compensation of victims. ${ }^{38}$ In this regard it should be noted that the limitations on architectural liability as formulated in the Belgian Civil Code (Article 1792 and 2270 CC) and the Dutch New Rules (Article 15 and $16 \mathrm{NR})^{39}$ are only applicable in the contractual relationship between the architect and the building master. They therefore do not fall within the ambit of tort law. However it must be said that the same risk of underdeterrence exists, since architects will consider the harm-causing event as one with a limited maximum cost and do not have the incentive to take due care which would reduce all accident costs efficiently, nor will they aim to prevent/minimise costs which may arise after the maximum liability period has passed. A limitation on the amount of damage that will be covered by insurance however, does not mean that the injurer himself will have to pay the excess on the insurance. Nevertheless, in such cases, the victim bears the risk that the injurer may be insolvent.

34 Another factor which is relevant when opting for strict or negligence liability is the insolvency risk of the injurer. In case of strict liability, a problem arises if the amount of the damages is higher than the injurer's wealth. If this is the case, the injurer will take less than the optimal care (underdeterrence). Faure \& Hartlief 2003, p. 43.

35 The imposition of a very high standard of care under negligence is often referred to as absolute liability. See Faure \& Skogh 2003, p. 247.

36 In paragraph 12.3.6 the aims and effects of interest groups will be further discussed.

37 Landes \& Posner 1984, p. 419.

38 Hartlief \& Tjittes 1994.

39 See chapters 6 and 8 of this thesis. 
Chapter 11

\subsubsection{Conclusion}

It can be concluded that the economic analysis of tort law indicates that liability rules provide incentives to parties to engage in careful behaviour. This means that tort law is not primarily seen as a system to compensate victims for damage, but rather to deter injurers from causing damage in the first place. Different liability rules can be applied. The most important ones are negligence and strict liability. As indicated above, strict liability brings about certain advantages: the costs are shifted to the injurer who will have to try to achieve the optimal care level as well as an optimal activity level since he is deterred more easily; judges have no costs to determine the due care standard; victims do not have to prove fault. However, if the victim also has influence on the risk by taking due care, a contributory or comparative negligence defence to the strict liability rule should be added. In this way all accident costs can best be prevented/limited, at least in risk neutral situations. Since the relationship between the architect and the building master which has been discussed in Part II of this thesis does not, in principle, fall under tort law but under contract law, it should be noted that the architect will not be held liable in tort to the building master, either under a negligence rule or a strict liability rule. Since generally architects and entrepreneurs are third parties with regard to one another, they can resort to tort law to obtain damages. However it should be noted that it is mostly the building master who suffers damage due to a fault on the part of one of these professionals. Nevertheless, it can be argued that since liability for negligence and strict liability are also used in contract law, the economic criteria presented above in relation to negligence and strict liability in tort law may also have relevance for the contractual liability.

\subsection{Regulation}

As indicated above, for liability rules to work effectively, there must be a victim and an identifiable injurer who is able to pay compensation. Furthermore, concrete damage has to be determinable. This is not always the case, which means that other possibilities have to be considered.

Especially since the early 1990s, the regulation of liberal professions has received a lot of attention in the law and economics literature. ${ }^{40}$ Traditionally, architecture has not been subjected to the competitive forces that are present in commercial sectors. The policy of distinguishing professional practice from commercial trade reflects a rational concept that, due to the specialized, personal and important nature of the professional services and the need to uphold and preserve the quality and integrity of the professions, competition would not guarantee a socially optimal outcome. ${ }^{41}$ As has been discussed earlier in this thesis, Member States and professional associations have created many regulations to 'control' the architectural profession, so that competition is often restricted. As opposed to liability rules, these regulations are anticipatory interventions which are used by the government or a professional association to prevent undesirable

40 See, for example, Ogus 1994

$41 \quad$ Van den Bergh 1999, p. 89. 
actions or outcomes in markets, or to direct market activity towards desirable ends. It is thus regulation that is created in advance to any action. As will be explained hereunder, ex ante regulation is often present in the form of entry regulations and conduct regulations. In this part of the thesis, we will investigate whether these regulations are really necessary to achieve efficient outcomes. To answer this question we first need to explain why regulation is created in the first place, and whether it provides any benefits. In this regard, the law and the economics literature addresses two opposing views which explain the creation of regulation: the public interest approach and the private interest approach. These theories will now be discussed.

\subsubsection{The Public Interest Approach}

According to the public interest approach, regulation is justified in terms of the perceived shortcomings of the market system when it comes to dealing with certain problems. Public interests are involved if the government takes upon itself the responsibility to protect social interests in the belief that these interests would otherwise not be properly protected. Public interests are therefore a sub-collection of social interests. ${ }^{42}$ As suggested by Hameleers, when discussing public interest theory, the starting point is an economic analysis of (trans)actions in a market without government intervention. ${ }^{43}$ Public interests are at stake when transactions between market players, or the actions of one market player, do not take into account the consequences for other stakeholders who are not involved in that transaction or action. As a consequence, private interests served by that (trans)action do no coincide with social interests, and negative externalities may result. ${ }^{44}$ In such cases, the transaction mechanism does not function well. In economic terms this is referred to as a 'market failure' which means that the sum of the net benefits of a certain activity to producers and consumers is below the maximum attainable with the existing level of resources in the economy, so that the socially efficient level of output is not attained. To compel stakeholders to compensate third parties for these negative externalities, the government can use statutory or other measures. ${ }^{45}$ Regulations formulated by government agencies should pursue the public interest in correcting for market failure. ${ }^{46}$ In this way they aim to improve social welfare by erasing issues which prevent an economically efficient outcome, and to realise a politically acceptable distribution of income, i.e. the financial accessibility of the service. What ex-

42 Dutch Scientific Council for Government Policy, Het Borgen van Publiek Belang, The Hague, 2000; Teulings, Bovenberg \& Van Dalen 2003.

43 Hameleers 2004, p. 86.

44 Negative externalities appear if a decision causes costs to individuals or groups other than those making the decision. The concept of 'externalities' will be discussed hereunder.

45 The government has a comparative advantage compared to the market since it is the only party that can use public compulsion to force all interested parties to participate.

46 Posner 1974, pp. 335-358; Noll 1989, pp. 1253-1287.

It must be noted, however, that the presence of asymmetric information which entails that one party has more information at its disposal than another party, does not guarantee that the market will fail. What matters is whether the asymmetric information brings about a different outcome than the outcome that would exist if there was symmetric information. If this occurs, then the case for market failure can be made: Arnold 2004, p.726. This will be discussed in detail hereunder. 
actly constitutes the public interest is not a constant, but varies according to time, place and the specific values held by a particular society. ${ }^{47}$ In any case, the public interest approach holds that regulation might be necessary to circumvent the shortcomings of the market when it has to deal with certain problems leading to less social welfare. However, regulation may fail if the efficiency gains to which it gives rise are outweighed by increased transaction costs or misallocations in other sections of the economy. ${ }^{48}$

As suggested by economic theory ${ }^{49}$, to obtain a general equilibrium in an economy with perfect competition wherein it is possible to enlarge someone's welfare without diminishing the other's utility ${ }^{50}$, four conditions have to be fulfilled:

1. In every market there should be many small and identical producers, who cannot significantly influence the price level, and who sell homogeneous products in their respective markets.

2. There should be perfect information in that economy, meaning that all market participants are informed about all (equilibrium) prices and characteristics of goods.

3. There are no external effects.

4. The products are private goods.

If one of these conditions is not fulfilled, one can speak of a certain degree of market failure: a situation in which the market does not provide the ideal or optimal amount of a particular good or service. In practice, there will always be some distortions in the market. I will now discuss these conditions in more detail. ${ }^{51}$

\section{A lack of competition}

An industry in which there are so many firms that no one of them can influence the market price by its individual decisions, and in which there are so many consumers that the individual utility-maximizing decisions of no single consumer can affect the market price, is called a perfectly competitive industry. Market power, on the other hand, results either from the existence of monopolies and related market structures or from cartellike behaviour on the part of a group of firms/suppliers. In contrast to firms under perfect competition, who sell their products at the level where price equals marginal costs ${ }^{52}$

47 Ogus 1994, p. 29; Speech of Kroes, Better Regulation of Professional Services, UK Presidency Seminar, Brussels, 21 November 2005. It can be said, however, that $\mathrm{p}$ ublic interests in the liberal professions relate to the quality of the service (i.e. efficiency) and the financial accessibility of the service (i.e. equitable distribution of income)

48 Ogus 1994, p. 30.

49 See for example Maks \& Philipsen 2005, p.12-13.

50 This is also known as a Pareto-efficient situation. Maintaining freedom of trade is, in principle, ParetoImproving, because voluntary exchange transactions make all participants better off.

51 Paternalistic or distributive arguments for intervention in the market will not be discussed in this thesis.

52 If a producer wants to determine whether his initial level of production is his maximum, he can make very small (marginal) changes away from his initial level. The costs associated with this small increase are called marginal costs. The benefits of producing more are called marginal benefits. As long as the marginal benefits exceed the marginal costs of the change, the producer will continue to make more small changes. When benefits and costs are equal he will stop making changes, and the producer has reached his maxi- 
equals minimum average costs, a monopolist will sell its (smaller) output at a higher price level: where its marginal costs of producing equals its marginal benefits. ${ }^{53}$ It follows that a monopolist always operates in a Pareto inefficient manner. ${ }^{54} \mathrm{~A}$ situation is said to be Pareto-efficient or allocatively efficient if it is impossible to change it so as to make at least one person better off without making another person worse off. The abuse of market power is a problem which causes market failure. In these situations, regulation (in the form of competition law) may offer a solution to avoiding abuse of dominance and to combat cartel-like behaviour. ${ }^{55}$ This will be discussed in more detail hereunder. It should be observed however, that the costs of correcting market failure by means of regulation have to be smaller than the efficiency gains derived from the regulation, and that the regulation has to be in proportion to the said failure.

The market for professional services is - at least before the formation of self-regulating bodies - characterized by many small and identical producers, who cannot significantly influence the price level, and who offer more or less homogeneous services in their respective markets. It follows that, at least at first sight, the formation of monopolies and a lack of competition should not be feared in the architectural profession. The competitive process which generates efficiency requires that no single producer of a good or service (or group of co-ordinated producers) controls a sufficiently large share of that market that it can determine, by its own decision, the equilibrium combination of price and output for the market. If this was not the case, prices would be higher and output would be lower than in a truly competitive market. However monopolistic situations do not only exist when there are only a few professionals active in a certain market. They can also be created when a relative large number of professionals are active, but is only allowed to do so after fulfilling certain heavy requirements meaning that the number of active professionals is still much smaller than when no such requirements were imposed. As indicated in the previous chapters, both the Netherlands and Belgium impose certain requirements upon architects. In both countries, architects have to be registered before they can use their title. Registration is only possible after certain education and training requirements are fulfilled. The number of active architects is therefore smaller than if no requirements were imposed. Moreover, in Belgium, only persons in possession of the architectural title can practise the profession with regard to buildings for which a building permit is required, while in the Netherlands, anyone can practise the profession. It follows that Belgian architects possess a real monopoly in the construction market with regard to designing and supervising the construction of buildings.

\footnotetext{
mum utility. The optimum for nearly all decisions occurs thus at the point at which marginal benefit equals marginal cost.

53 Maks \& Philipsen 2005, p. 14.

54 Varian 1984, pp. 79-85.

55 It should be noted that regulation should not be used to create as much competition as possible, but that it may be used in the public interest to regulate cartels and the abuse of dominance. In certain situations it might even be better to have only one or a few producers instead of many small firms. This is the case when the costs of producing certain goods by one or a few producers are smaller than the costs of separate production by many smaller producers. Such monopolies or oligopolies are called 'natural' monopolies or 'natural' oligopolies.
} 


\section{Information asymmetry}

a. Experienced clients vs. professionals

Asymmetric information is present when one of the parties to a contract (generally the professional) has information which is not available to the other party (the client). Since professionals generally know more about the quality of the service they provide - their services mostly involve the application of their human capital to judge individual cases than their clients, professional services are often characterized by information asymmetry. The problem of information asymmetry occurs particularly in cases where one is dealing with experience goods ${ }^{56}$ or trusts goods ${ }^{57}$ as opposed to search goods ${ }^{58}$. Professional services fall under the first two categories since the quality of the services provided can, at best, only be determined after consumption or use. It follows that information problems are almost always present. This is strengthened by the fact that most consumers of architectural services will only turn to an architect once (or for a very limited number of times). In this regard it should be noted that the reputation of an architect is very important with regard to attracting new clients: future business often depends on the satisfaction of previous clients. ${ }^{59}$ Furthermore, the level of client sophistication ordinarily will determine how a client selects an architect. Most clients are uninformed about which qualifications are important, and do not know how to assess the qualifications, which means that they cannot make good use of their options. Furthermore, if costs are associated with interviewing and evaluating more than one architect, this can constrain a client's ability to perform a meaningful personal evaluation. ${ }^{60}$ Building companies or promoters, on the other hand, are normally repeat buyers, and are more equipped to judge the quality of the services provided. However, as suggested by Stephen, the fact that individual clients lack expertise and information on quality does not mean that the market will inevitably fail. If such information can be transferred between purchasers, reputation will play a role in disciplining suppliers. If repeat purchasers can easily transfer their experience to inexperienced clients by acting on their behalf in the selection of the professional, or via a list of approved professionals, infor-

56 Experience goods are goods or services the properties of which can only be assessed after consumption or after experience. This means that if these goods are bought regularly, consumers may learn about their quality through the repeat purchase mechanism.

57 Trust goods are goods or services the properties of which can only be determined after applying highly technical standards, and for which there is no learning through the repeat-purchase-mechanism, meaning that the properties of these goods cannot be assessed either before or after the transaction. They are also called credence-goods. Since a profession can be defined as an occupation with the following characteristics: specialized skills, skills that are particularly or fully acquired by intellectual training, the service calls for a high degree of integrity, and it involves direct or fiduciary relations with clients - also services performed by free professionals can be described as being 'objects of trust'. The consumer - who mostly cannot fully control the quality of the service rendered - has to rely on the expertise of the professional in order to assess whether or not it has the desired level of quality.

58 In the case of search goods, consumers know already where they can obtain each of the options available to them, but they have to evaluate the utility of each option first on price and quality.

59 Reputational concerns can serve as a disciplinary force. See Reagan 1998, p. 559. Such concerns may render the need for certain traditional rules unnecessary if the architect is already concerned with maintaining his reputation consistent with the rules. See Zacharias p. 34.

60 Zacharias 2007, p. 176. 
mation asymmetry may be overcome. ${ }^{61}$ The reputation of an architect therefore plays a significant role with regard to attracting new clients. As suggested by Zacharias, reputations can be earned through performance that is reported in some relatively neutral way, or observed and recounted by people qualified to judge the performance (such as previous clients, other professionals, evaluating institutions). ${ }^{62}$ In this regard he noted that wealthy, experienced and sophisticated clients are likelier to know how to identify earned reputation and to make the effort to identify the reputations of potential architects, since they know what questions to ask and how to interpret the information received. For such clients, there is less need to regulate. Inexperienced or untutored consumers, on the other hand, may not know where to look or know what information is important. If they seek information on earned reputation, they are most likely to rely on word of mouth from other individuals who have had limited experience in evaluating the professional. Reputations can also be created, either by a professional himself, or by a third party (for example the press), who may have a financial or other incentive to publicize particular perceptions about the professional. In this way the professional can generate publicity to create a good name. Obviously, such a reputation tends to be less objective, and mainly targets potential clients who have limited resources for identifying useful information on their own, and is mainly self-serving. Furthermore, advertisements mostly only mention surface facts instead of providing real core information. However, the characterization of reputation as earned or manufactured does not automatically determine how accurate a reputation is, who can access it, and whether it is meaningful. Since lay consumers are mostly not well equipped to determine the quality of a building design, reputations developed by them may be less accurate than those developed by independent professional evaluators. The question can then be asked whether the need for regulation in markets with infrequent purchasers justifies that regulation be extended to markets where purchasers are experienced. ${ }^{63}$ In this regard Stephen holds that public policy towards markets for professional services should become more differentiated than in the past, differentiated by profession and by consumer type within each market. ${ }^{64}$

In any case, it should be noted that since free markets will only achieve efficient outcomes if a significant number of consumers is able to make purchase decisions on the basis of complete and undistorted price-quality judgements, free markets for professional services will not produce efficient outcomes. ${ }^{65}$ Professionals may not wish to communicate certain information, and are likely to act only in their own interests, with-

61 Stephen 2004, p. 148. Stephen holds that there is a potential for oversupply in the professional service markets for those categories of service sought by infrequent purchases, where the mechanism of reputation or the use of experienced agents does not operate. He indicates that regulation is needed to achieve efficient levels of output and prices.

62 Zacharias 2007, p. 185, pp. 190-192 and p. 195

63 In this regard Gilson concludes that over time, "information asymmetries" have decreased because, among other reasons, sophisticated clients have learned to use in-house counsel to select representation, and these in-house counsels are in a position to assess both quality and reputation. This, essentially, has shifted the power in the relationship to the demand side of the equation. See: Gilson 1990, p. 888.

64 Stephen 2004 , p. 149.

65 Stephen \& Love 2000, nr. 5860. 
out taking account of their clients' best interests. ${ }^{66}$ Since quality control by consumers is often impossible, and monitoring the quality of architectural services is difficult due to lack of knowledge, the ignorant clients of the professionals pay anyway, without knowing whether the price is reasonable. ${ }^{67}$ In this regard it should be noted that architecture is an exceedingly complex craft and there are myriad ways in which the architect's integrity is put to the test. As suggested by Skolimwski, the practice is immoral if the architect cuts corners and produces shoddy designs and buildings, when the client expects otherwise. The client is the innocent, while the architect retains power and can subtly manipulate the client in so many ways. ${ }^{68}$

b. Adverse selection

Furthermore, as proposed by economic theory, serious information asymmetries can culminate in a market for lemons ${ }^{69}$, i.e. a market on which only goods of inferior quality are offered. If the consumer is not able to judge the quality of the service provided, he will not be willing to pay a higher price for higher quality, so that providers of higher quality products or services charging higher prices will be driven out of the market. This results in a market with sub-optimal quality services. This process is also known as adverse selection. Adverse selection is possible every time a party on the market is in the possession of information which is not known by the other parties (for example the services rendered is of lower quality than normally to be expected) and makes a decision (for example a single used price will emerge for a certain type of task) that adversely affects the others. As already noted, since consumers cannot evaluate the properties of the supplied products/services, nor control whether a certain professional has the right knowledge and know-how to do a job, professionals have no incentives to guarantee a high level of quality. As a result, consumers tend to compare the costs instead of the quality of the services offered. Suppliers of high quality products, however, will not be satisfied with an average price and consequently will be driven out of the market, thereby reducing the average quality of suppliers in the market. Furthermore, since they cannot evaluate quality, the price that consumers are willing to pay for the services will be lower than that which they would be willing to pay to a high quality provider if they could identify one. Their choice of professionals is therefore limited. This all leads to quality deterioration and a reduction in the market price, possibly generating a race to the bottom or a 'lemons market'. ${ }^{70}$ The public interest theory holds that regulation might be able to convert this 'equilibrium' of low quality and low prices into a market outcome characterised by high quality and a reasonable price. ${ }^{71}$ For example, by setting and polic-

66 Addison, Barrett \& Sieben 1997, p. 69.

67 It should be noted that e ven when consumers do possess all the necessary information, perfect rationality can break down under complications. Beyond a certain complicatedness, our logical apparatus ceases to cope - our rationality is bounded - and economic theory holds that in such cases, consumers process the information only up to a point where the marginal benefit of the information equals the marginal cost of processing more information. See Simon 1987. Due to these problems, the market usually fails to produce the socially optimal quantity and quality of the professional service. Garoupa 2004, p. 4 . .

68 Skolimowski 1993, p. 497.

69 Akerlof 1970, p. 487.

70 Akerlof 1970.

71 Maks \& Philipsen 2002, p. 17. 
ing a minimum quality standard, the adverse selection problem can be reduced. ${ }^{72}$ On the other hand it has been argued that when a professional such as an architect operates in a field in which a reputation for client-centred behaviour is imperative - architectural services are credence goods and architects often 'depend' on the publicity made by former clients - the need for rules against self-dealing and even negligence is diminished, because the market will enforce similar standards. ${ }^{73}$

\section{c. Moral hazard}

Information asymmetry can also cause a moral hazard problem. This arises after a client has selected a professional and remains when one party to a transaction (e.g. the architect) changes his behaviour (e.g. he buys an insurance ${ }^{74}$ ) in a way that is hidden from and costly to the other party (the client) (there are no or fewer incentives to do his utmost to create good plans to avoid the collapse of the building). Moral hazard therefore arise when the behaviour of the insured changes after the purchase of insurance, leading to the probability of loss or the size of the loss increasing. A moral hazard problem arises when the architect and his client have differing individual objectives, and the client

72 Leland 1979, pp. 1328-1346. However professional bodies often set this quality standard above the socially desirable level.

73 Zacharias 2008, p. 180. Zacharias, who studied the situation of lawyers (p. 184), suggested that information about lawyers' reputations casts light on the degree to which lawyers, or groups of lawyers, will care about, and adhere to, specific kinds of rules, and how they will implement regulatory leeway.

74 Insurance theory predicts that concluded insurance contracts influence the insured's behaviour, and that the decision to insure is invariably consistent and commensurate with the insured's risk aversion. People are inclined to choose insurance to avert possible financial losses they do not want to bear themselves. Since insurers mostly have less information on the magnitude of the risk to which the insured is exposed, they want to inform themselves of the risk attributes of the insured and adjust their premiums accordingly to avoid adverse selection. This is even more so since those running the bigger risk are assumed to have a proportionate demand for insurance, causing an ever increasing claims rate for insurers. See Van Boom 2008, p.253. However, some argue that the opposite phenomenon is happening, and that those who have the least need for insurance are most likely to by it. See, for example, Hemenway 1990, pp. 1063-1069 and Chiappori \& Salanie 2000, pp. 56-78. Insurance demand is not always perfectly rational. In legal systems where motor liability insurance is not compulsory, it has been found that those who do not take out insurance are more accident-prone than others. This is called advantageous or propitious selection. As held by Van Boom, there is little evidence as to whether propitious selection is a weaker or stronger driver in insurance market failure than adverse selection. See Van Boom 2008, p. 259. In any case, economic theory predicts that individuals shielded from financial loss by insurance coverage will demonstrate adapted behaviour and will thus actually increase the risk of the insured loss. See Shavell 2005, pp .63-77; Graf von der Schulenbrug 2005, p. 282 and Parsons 2003, pp. 448-471. In this way, research has shown a positive correlation between the increase of sickness coverage and the amount of sick leave. See Johansson \& Palme, pp. 1879-1890. To cure this problem, insurers try to fix the right premium level at the beginning of the insurance contract, by collecting information from the insured. However, the costs of monitoring the insured during the running period of the contract are usually considered to be excessive compared to the expected benefits thereof. See Baker \& Griffith 2007, pp. 487-544. As suggested by Van Boom 2008, p. 262, it follows that less energy is spent on monitoring the insured, but this does not mean that this is an inefficient state of affairs: the cost of controlling moral hazard and avoiding adverse selection must be set off against the expected benefits. As Van Boom rightly holds, some degree of moral hazard and adverse selection can be efficient, provided that the insurance market in question is itself functioning properly. Too little effort by the insurance industry may result in an inefficient level of precaution, and may eventually cause adverse selection and uninsurability. Legislators should, however, be careful with introducing compulsory insurance since it is possible that insurers are then bound to apply less risk and premium differentiation than would be advisable. See Cohen \& Dehejia 2004, pp. 357-393. 
cannot easily determine whether the architect's actions are being taken in pursuit of his goals, or are self-interested misbehaviour. ${ }^{75}$ Since the client is not able to control the architect's efforts, he cannot sanction the architect's negligent attitude. ${ }^{76}$ An example of this moral hazard behaviour can be found in the principal-agent problem of demand generation, which means that professionals render extra services or services of a higher quality than is necessary, which consumers would not have wanted if they have been fully informed. ${ }^{77}$ The producer thus has an incentive to over-supply quality in order to charge higher prices, even if the client would be better served with a lower quality at a more reasonable price, or the producer supplies services the client does not need. In these circumstances a market for professional services is likely to generate a level of professional services which is above the optimal (or efficient) level, and thus there will be market failure. If all of its members were to behave in such a way, this could harm the reputation of the profession. Each member of the profession would individually like to cheat, but if all members cheat, then they will all be worse off in the end. Indeed, since the market price reflects only the average quality level, and will thus attract average quality sellers, cheating would lead to a reduction in the average level of quality as perceived by consumers, a further reduction in market prices, and a further reduction of quality. Due to information asymmetry, consumers are not able to recognize high quality products or services. (Self)-regulation can be seen as a solution to this 'free rider' problem ${ }^{78}$. Regulation may not be needed for professional clients who are not at an informational disadvantage.

From the above it follows that the regulation of professional services can improve the market equilibrium: the benefits of regulation include a decrease in search costs, improvements in service quality, more adequate supply of information concerning the quality of professional services, and a reduction in risk..$^{79}$ Furthermore, since rules can

5 Milgrom \& Roberts 1992, p. 170.

Somers 2005, p. 83.

77 This is called supplier-induced demand. If consumers remain dependent on the prescriptions of service providers, and are risk averse (clients will pay money to avoid having to face uncertain outcomes; they can purchase insurance from an insurance company or may self-insure and incur expenses to minimize the probability of an uncertain event to arise, or to minimize a certain monetary loss (e.g. buying smoke detectors). It is also possible to reduce the price one is willing to pay), the increased uncertainty they have to face regarding the price and quality of the service offered, may partially offset the benefits from the enhanced competition.

As suggested by Jenny, in some professions in France, the auditing of the prescriptions or the services furnished by service providers by auditing agencies has emerged. They check the services rendered by professionals to diminish their strategic behaviour. He suggests that promoting independent auditing of service providers' prescriptions may not be a perfect solution, since the quality of the service rendered by the auditors and their independence may also be difficult to assess, but at least it has the potential of making it more difficult for members of the professions to strategically use the fact that they provide their clients both with a prescription and with the services rendered. According to Jenny, such auditing therefore seems a necessary complement to the elimination of the most blatantly anticompetitive provisions of regulatory codes, and self-regulations used by the professions. See Jenny 2004, p. 139.

78 Fletcher 2004, p. 74.

79 Garoupa 2004, p. 6. Furthermore, another information problem that might provide an argument for the regulation of professional services is bounded rationality. This means that potential tortfeasors may respond less appropriately to incentives given by the tort system than is expected, due to fact that actors of- 
introduce minimum quality standards, confidence can be increased so that the relationship between the consumer and the professional is more easily based on trust generated by regulation. ${ }^{80}$

\section{External effects}

As noted in paragraph 11.3.1., an externality occurs when a decision leads to costs or benefits to individuals or groups, other than the person making the decision. Since, in a free market, externalities are not internalised in the decision-making process of the suppliers, too much or too little of the good will be consumed from the point of view of society. In the latter case, the inclusion of external economies in the competitive model causes the social benefits of an activity to be higher than its private costs, at the margin. ${ }^{81}$ It follows that if the price mechanism does not take into account the full social costs and social benefits of production, consumption externalities can cause market failure.

Negative externalities can also appear in the architectural market every time the quality of the service rendered by the architect is not high, since this can cause huge losses for private parties and for society as a whole. However, since everyone can enjoy and visit certain buildings, positive externalities are also created.

As suggested by Arruñada, the provision of private services usually goes together with the provision of external effects or, in other words, with public services..$^{82}$ These externalities stem from both the nature of the private services and from political decisions, which obliges certain private service providers to also provide certain public services. Arrunada holds that in this way, the production of private and public services by a single professional can be defined as an economy of scope or joint production, which is less costly than if different service providers are involved, due to the use of joint information - the human capital or general knowledge as well as specific knowledge relating to the customer or the case in question - and contractual resources. However, as Arruňada rightly indicates, assigning the production of externalities to professionals achieves economies of scope, but poses a serious problem in that, in principle, the professional has no incentives to produce the (positive) externalities, as these are services for which he is not paid, and for which he might even have to incur a certain cost. ${ }^{83}$ It follows that there must be strong incentives to make the professional independent of the customer who is paying him, even considering that, if the services are refused, the professional risks losing the customer. Arruňada concludes that achieving suffcient incentives for such a high degree of independence will be costly; in particular, it will require suppressing or restraining competition. It follows that regulation is needed to overcome quality

ten take shortcuts in making decisions that frequently result in choices that fail to satisfy the utility maximisation prediction. The limits of human cognitive abilities make it often impossible to follow a utility maximising strategy. This will not be further discussed in this thesis. For more information, see Faure 2008, pp. 75-102.

$80 \quad$ Meyer \& Rowan 1991, p. 44.

81 Addison, Barrett \& Sieben 1997, p. 67.

82 Arruňada 2004, p. 53.

83 Ibid. 
deterioration caused by negative externalities. In this way, the existence of individual liabilities provides incentives for service providers to deliver high quality work. Academic education and training are also defence mechanisms against the negative externalities which can arise due to low quality services. External effects can also be internalized by private parties through negotiation, except in cases where transaction costs are prohibitive. In this way, the externality is internalized in a contract. According to the Coase theorem ${ }^{84}$, in the absence of, or in the case of very low transaction costs ${ }^{85}$, the outcome of such negotiations will be economically efficient, regardless of how the government allocates property rights, because the interested parties will bargain privately to maximise their joint utility and social welfare and, in this way, correct the externality. Through bargaining, parties can therefore internalise the externality, e.g. by including a risk premium in the prices for professional services. However, due to the information asymmetry in markets for professional services, transaction costs are usually very high, so that the Coase theorem will mostly not deliver the desired results. In the relationship between architects and client, transaction costs include, for example, the client's costs associated with finding an appropriate architect, negotiating with the architect on the design assignment, drawing up a design contract, and bringing a claim before a judge in the event of the architect's breach of duty. ${ }^{86}$

\section{Public goods}

As stated before, the provision of private services often goes hand in hand with externalities or, in other words, with public services, since private services can have consequences for society. Externalities thus deal with the effects of services on the public at large. The concept of 'public goods' which will now be discussed, refers to the service itself. Street signs are examples of public goods since they are non-excludable and nonrival in consumption. Non-rivalrous consumption implies that consumption of the good by one person is not at the expense of another person. Non-excludability means that it is either impossible, or too expensive (for a private profit-maximising firm), to exclude people from consumption of the good. It follows that public goods generate important positive externalities which are of great value for society in general. As already explained, the same can be said of public services. Professional services can be classified as public goods since, once advice has been given, it can be passed on for free. Information can therefore be seen as a public good. The danger exists therefore that professionals under-provide socially valuable information because it may cost them more to provide this information than it is worth to consumers. ${ }^{87}$ However, the nonrivalrous nature may be limited to the extent that advice is so specific that another client with slightly different circumstances may not be able to use the same advice. ${ }^{88}$ For this

84 Coase 1960, pp. 1-44.

85 These are the costs associated with the time and effort needed to search out, negotiate, and consummate an exchange.

86 Van Gulijk 2009, p. 159. Transaction costs can also be reduced by making information available or defining standard provisions in contracts ('normative Coase theorem')

87 Maks \& Philipsen 2002, p. 20.

88 RBB Economics 2003, p. 2. See http://www.ccbe.org/fileadmin/user_upload/NTCdocument/rbb_ihs_critique_en1_1183706206.pdf, last consulted 23 December 2009. 
reason the services of an architect can generally not be qualified as a public good. Even though it can be argued that every member of the public can profit from a high quality urban environment designed by an architect (positive externalities), while the architect does not get a reward from every person making use of his project so that he might not be willing to supply the services asked for, or that he will supply them inadequately, the plan that is designed by him is generally based upon the desires of his client and dependent on the specific characteristics of the soil, the surface of the land, building regulations, the available budget, etc. It follows that it is said that a free rider ${ }^{89}$ problem which would result in undersupply, does not seem to occur in markets for professional services.

\subsubsection{The Private Interest Approach}

The public interest approach to regulation holds that regulations are created by government agencies to serve the public interest by correcting market failures. The private interest approach, on the other hand, holds that regulation is not only an answer to market failure but also a result of rent-seeking behaviour on the part of interest groups. In economics, rent seeking is the process by which an individual or firm seeks to gain through the manipulation of the economic environment rather than through trade and the production of added wealth. Rent seeking generally implies the extraction of uncompensated value from others without taking actions which improve productivity, such as by imposing regulations or other government decisions harming consumers. As indicated by Olson, these interest groups which try to maximise their utility are most successful in appropriating rent if they are small, single-issue oriented and well organized. ${ }^{90}$ With regard to this first criterion, it can be said that smaller coalitions with a strong community of interest will tend to have stronger political voices, because each group member has a larger financial stake in the outcome, given that the potential gains will be divided among fewer individuals. Therefore, a group will become an effective lobby if it is small enough in number, and if the financial interests are sufficiently concentrated so that the potential benefits from organizing and lobbying for government favours will exceed the associated costs. ${ }^{91}$ Since consumer interests are more diffused, and the costs of organizing consumers to avoid wealth transfers are relatively high and will exceed the expected gains, small cohesive groups are often successful in obtaining wealth transfers at the expense of the general public..$^{22}$ Through compulsory membership in professional bodies, interest groups are able to cope with the free riding problem. ${ }^{93}$ In this way, rents are generally generated and protected through effective limitations on entry and competition in the liberal professions sector. ${ }^{94}$ Interest groups also satisfy the

89 Free riders hope to benefit at no cost to themselves, from the payment of others.

90 Olson 1965, pp. 587-602.

91 Ibid.

92 Van den Bergh 1999, p. 113.

93 On the free riding problem (i.e. advantages also flow to outsiders who do not bear the costs of lobbying) see Olson 1965.

94 The asymmetry in the quality of checks of entrants and of established members of the profession is an example of attempts at monopoly rent protection. 
last two criteria mentioned by Olson: they are mostly very well organised and especially concentrated in their profession.

The private interest approach is based on three economic theories: the public choice theory, the capture theory and the economic theory of regulation. These theories will now be discussed.

The public choice theory is directed towards the study of politics based on economic principles. It explains how individual preferences are reflected in the voting procedures of public institutions. The theory holds that self-interest produces nothing but pathology in political decisions. ${ }^{95}$ In this way, politicians are sensitive to the whims and desires of voters and interest groups, since they strive for the maximisation of votes in order to be re-elected and to maximise their budget or prestige. Coalitions of voters who have a big stake in a benefit, often join together to seek special advantages from the state in order to have favourable legislation enacted. Because of their large interests, they are more likely to take effective action than the taxpayers at large, over whom the costs are spread. This may give rise to inefficient regulation. The public choice theory predicts therefore that the outcomes of the regulatory process will tend to favour the regulators instead of either businesses (capture theory) or the public (public interest theory).

The capture theory emphasises the pressure or influence exerted by private persons or interest groups on government to have regulations enacted in their private interest, rather than in the public interest. In other words, no matter what the motive is for the initial regulation and the establishment of the regulatory agency, eventually the agency will be captured by the special interests of the industry that is being regulated. Industries find it beneficial to exert influence or even bribe regulatory agencies because each firm has a lot at stake. A common way of doing this is to have former or future employees in the industry temporarily work for the regulatory agency. In any case, the private interests of the persons subject to regulation may be served more by the regulation than is the public interest.

The economic theory of regulation was described for the first time by Stigler. ${ }^{96}$ According to this theory, it is the industry itself that asks for regulation. Regulation originates where the benefits are concentrated (the industry) and the costs can be divided over a large group (consumers). In this way, wealth is transferred from the population as a whole to small groups of professionals. The economic theory of regulation assumes that the government is the supplier of regulation while the demand side consists of interest groups looking for protective regulation. Stigler held that the power of the state to coerce its citizens provides the possibility for the utilization of the state by an industry to increase its profitability. Every branch of industry which has enough power to do this, will lobby the government for the creation of barriers to entry with regard to the industry, or for conduct barriers in order to keep the number of suppliers low, so that the

95 Starr 1988, pp. 6-41; Ogus 1994, pp. 58-71; Posner 1998, pp. 572-576.

96 Stigler 1971 , pp. $3-21$ 
insiders can sell their products at high prices. Since the government is often pressured by these professionals, it does not always take the interests of the public into account. In this way interest groups aim, for example, for professional licensure to decrease the supply of professionals below the social optimum, increase the prices charged by professionals, and increase existing professionals' incomes beyond their marginal productivity, thus generating rents and quasi-rents. ${ }^{97}$ The government is thus the supplier of regulation which is acquired by the industry, designed and operated primarily for its benefit. When the industry seeks political power, it will make contact with the appropriate seller, i.e. the political party, and must be prepared to pay with the two things a party needs: votes and resources. It does not come as a surprise that the demand will be very high when the potential benefits of restricting competition cannot be obtained by the industry itself, for example by means of cartel formation. In 1976, Petlzman supported Stigler's conclusions, but added that the gain obtained by the winning group through political action, will not necessarily be maximised as it is within the power of the political process to grant it, because other interest groups and voters will be influential as well, and politicians will distribute favours and disfavours to maximise their chances of being re-elected. ${ }^{98}$ Political equilibrium depends on the efficiency of each pressure group in terms of producing pressure, the effect of additional pressure (from other interest groups) on their influence, the number of persons in different groups, and the deadweight costs of taxes and subsidies. ${ }^{99}$ According to Becker, it is not the existence of wellorganised pressure groups that may be harmful to the economy, but the unequal distribution of political power across these groups. In any case, Stigler's famous paper marked the beginning of the end of the widely accepted assumption that regulation was introduced and applied to remedy market imperfections, and to pursue widely accepted public interest goals. ${ }^{100}$

The private interest approach ${ }^{101}$ is a combination of the three theories described above and warns against rent seeking behaviour by interest groups, especially in cases of selfregulation, because it can constitute an incentive for the government to issue regulations which are not in the interest of the public as a whole. An example is that when applying the private interest theory, regulation not only fails to counter monopoly pricing, but is, on the contrary, used to sustain it through state intervention. It follows that rent-seeking is unproductive from a social welfare point of view because, as a result of the decrease in competition, wealth will be redistributed from consumers to producers. To analyse the extent to which regulation in a particular profession serves private interests rather than the public interest, a quantitative empirical analysis in needed. Architectural associa-

\footnotetext{
Hadfield 2000, pp. 953-1006; Kleiner \& Kudrle 2000, pp. 547-582.

Peltzman 1976, p. 221.

Becker 1975, pp. 421-447.

100 Joskow 2005, pp. 169-193.

${ }_{101}$ A lthough there are definitely some indications in the - mostly US based - empirical literature backing up the private interest approach and its rent-seeking hypothesis, there is no real consensus in the literature on the actual incidence and consequences of rent-seeking behaviour in the professions: See Philipsen 2008, p. 98. There still seems to be relative lack of empirical results as opposed to the volume of theoretical literature.
} 
tions can, in general, be qualified as successful interest groups. As explained in Chapters 5 and 7, the Belgian Architects' Order and the Dutch BNA enjoy public law status and can determine who may use the professional title. Furthermore, they can impose punishments on individuals not complying with the deontology, and ask for financial contributions as a condition of membership. The private interest approach may explain why progress on the programmes to harmonize national systems for professional qualifications has been painfully slow. As noted in Chapter 3, it took more than seventeen years before the Architects' Directive saw the light of day due to substantial differences in the way the profession was regulated, not only with regard to training conditions and professional qualifications, but also with regard to architectural obligations and liabilities. As pointed out in paragraph 3.3.1.1., for this reason some Member States and certain professional associations were of the opinion that the Directive should only apply to persons holding a university degree, others such as Germany and the Netherlands also wanted to approve non-university education in cases where practical experience complemented the theoretical knowledge up to university level. The length of the education was also a point of conflict. The Dutch Architectural Association wanted to regulate the profession as strictly as possible since it was held to be harder for Dutch architects to find work in another state than vice versa, which stimulated the Association to claim regulation and title protection. ${ }^{102}$ The different objectives and desires of the Member States and their professional associations, and the increasing conflicts, led to a situation of deadlock that lasted for almost two decades. This indicates that these associations are quite influential and were successful in preventing the creation of legislation that was not in their interests. Before the creation of Directive 85/384/EEC, architects who wanted to practise their profession in another Member State had to rely upon the general free movement principle and the case law of the Court of Justice of the European Union. Since discrimination on nationality was (and still is) prohibited, Member States had to allow nationals of other Member States - and later also certain third-country nationals - to establish themselves, or provide services on its territory, under the same conditions as its own nationals. The qualifications of architects obtained in other states were generally not exactly the same, while Member States were allowed to impose restrictions for reasons of public policy, public security and public health. It followed that a certain level of qualifications was generally demanded before one was allowed to practise the profession while using the architectural title. Since there was no specific legislation until 1985 dealing with the situation of architects in particular, due to the national disagreements described above, EU architects faced a situation of legal uncertainty due to the lack of clear rules with regard to the recognition of their qualifications. In this regard, it might be argued that the architectural associations were successful rent seekers.

102 Dankelman 1999, p. 115. 
The Architectural Profession: an Economic Approach

\subsubsection{Producers of regulation}

1. Public regulation vs. self-regulation

The term 'public regulation' describes the traditional regulatory system: the public authority being the all-embracing regulator, setting the relevant legislative or regulatory rules, monitoring compliance with them and enforcing them by imposing sanctions. ${ }^{103}$ The aim of the public authority is to implement public policy. By virtue of the principle of subsidiarity (Article 5(2) EC), it is up to Member States to decide whether they wish to regulate the professions directly through national rules, or allow self-regulation by professional bodies. As we have seen before, in Belgium and the Netherlands, the regulation of the architectural profession has been achieved through a combination of direct government regulation (public regulation) and rules adopted by professional associations. Indeed, although some aspects of self-regulation have their origins in spontaneous ordering from within a profession, it is argued that self-regulation is often created after a deliberate delegation of the state's law-making powers to an agency, whose membership is composed of representatives of the profession itself. ${ }^{104}$ It is therefore also possible that the government does not leave the whole process of elaboration, supervision and control to the professional groups, but creates the framework and the conditions under which the professional associations can elaborate and execute the professional regulations: this is the so-called conditioned self-regulation in which the professionals will be involved more closely, so that there will be greater effectiveness and performance. ${ }^{105}$ These associations, generally called 'Orders', are composed of practising professionals and enjoy public law status. The competence of professional associations to regulate a profession was confirmed by the Court of Justice of the European Union in Arduino. In this case the Court held that Member States have the right to regulate a profession. Due to the absence of harmonisation at the European level, Member States have the primary responsibility for defining the framework in which professions operate. When doing this, they are allowed to involve professional associations to create rules, as long as they do not abdicate their powers without clear instruction and control. ${ }^{106}$ As long as Member States retain (in principle ${ }^{107}$ ) the decision-making powers, and establish sufficient control mechanisms, they can involve professional bodies in this task. ${ }^{108}$ Self-regulation in

103 Palzer \& Scheuer 2004. T he government has the power to directly supervise the level and content of information provided by professionals. It can prohibit false information or oblige professions to disclose data and facts in relation to the price, composition, quantity or quality of a certain service.

104 Paterson, Fink \& Ogus 2003, p. 15.

105 Somers 2005, pp. 84-85. In the professional sector, self-regulation has been characterised as an institution of trust: a social contract between society and the profession that mitigates the moral hazard problem arising from information asymmetry. Dingwall \& Fenn 1987, pp. 51-64.

106 See also the Speech of Mario Monti for the Bundesanwaltskammer in Berlin on 'Competition in Professional Services: New Light and New Challenges' 21 March 2003. This was also confirmed by the European Parliament in its resolution on follow-up to report on Competition in Professional Services, 12 October 2006, (2006/2137/(INI)). The Parliament held that The Member States should be responsible for monitoring the scope of self-regulation to ensure that it does not impact negatively on consumer interests or the general interest.

107 See Case C-309/99 Wouters.

108 In a mature democracy it would not be justified if professional groups could be freed of control by the democratically elected Parliaments. 
the architectural profession transforms architectural associations into public bodies since entry and performance can be regulated by the profession itself. It contains some degree of collective restriction, other than constraints imposed by the government or state, to affect outcomes that would not be obtained by individual market behaviour alone. ${ }^{109}$

As noted above, an important incentive for regulation -and, in particular, state regulation- is the protection of consumers of professional services against abuse. By getting acquainted with the relevant regulation, a consumer can verify exactly what he can expect from a provider, and he can protect himself against non-qualified professionals and fraudulent behaviour. Due to the fact that more information is available as to what the provider has to live up to, common standards are introduced. Professional associations often impose their own regulations on their members to bring the governmental control to the lowest level possible. To achieve their objectives, they draw up their own regulations and take full responsibility for monitoring compliance with them. One of the main problems of self-regulation amongst professionals is that there is no competition between self-regulatory structures, as each profession enjoys a monopoly over a certain market. ${ }^{110}$ However, as indicated before, a greater output is produced under conditions of perfect competition than under a monopoly. ${ }^{111}$ The difference in these two output levels is the deadweight loss of monopoly ${ }^{112}$. Accordingly, considering that it is not the market but the state and/or a professional association which determine(s) the conditions under which a professional can operate, one can conclude that the price and quality of services are less dependent on supply and demand. ${ }^{113}$ This is to the benefit of the service providers and constitutes an(other) incentive for self-regulation: the more regulation they create, the more difficult it is for new professionals to enter the market, and the easier it is to establish a monopoly. However, in general, both types of regulation are liable to restrict competition between professionals and their enterprises. ${ }^{114}$

To give the reader a better knowledge of the implications of a self-regulatory regime, I will now discuss the main arguments for and against self-regulation.

\section{a. Public interest arguments in favour of self-regulation}

The main arguments in favour of self-regulation are elaborated by Miller ${ }^{115}$. He states that the specific knowledge of professionals with regard to quality and risks will lead to lower costs. In contrast to the government agencies -which have to recruit costly experts (often members of the profession) in order to obtain the necessary facts and data- pro-

109 Black 1996, pp. 699-711.

110 Arrunada 2004, p. 56.

111 If the market is perfectly competitive, the demand curve is the same as the marginal revenue curve.

112 A deadweight loss is a loss of economic efficiency that can occur when equilibrium for a good or service is not Pareto optimal. In other words, either people who would have more marginal benefit than marginal cost are not buying the product, or people who would have more marginal cost than marginal benefit are buying the product.

113 Larson 1977, p. 13.

114 Paterson, Fink \& Ogus 2003, p. 8

115 Miller 1985, pp.897-903. See also Van den Bergh 1999, p. 110. 
fessional associations have the relevant information or can get it at lower cost. ${ }^{116}$ Thanks to the information advantages of self-regulatory agencies, monitoring and enforcement costs are also reduced since the professions are more committed to rules protecting the high standard of the profession enacted by themselves than to statutory regulation on quality. As concluded by Baggott and Harrison, self-regulation will not only minimise information costs but may also avoid the counterproductive results that can emanate from an adversarial relationship between the professions. ${ }^{117}$

Another advantage of self-regulation is that it is more flexible, since there are, in general, no long bureaucratic processes that have to be followed to change the professional rules. The argument goes that for this reason, innovation is less likely to be stifled, and consumer choice is not that easily excessively limited.

The third argument advanced by Miller in favour of self-regulation is that it is the profession itself which bears the costs of the regulation, not the government. Therefore the professional will do whatever it takes to keep those costs as low as possible. Because this saves consumers many costs (fewer taxes), self-regulation is more easily accepted. Due to the efficiency gains, professional rules are less difficult to monitor and, in this way, monitoring and enforcement costs are reduced. ${ }^{118}$

\section{b. Private interest arguments against self-regulation}

Most of Miller's arguments cannot be reconciled with the private interest approach. It is a well-known fact that professionals belong to special interest groups, aiming to exclude competition rather than to improve quality. Since professionals want to make optimal profits, they do not hesitate to keep information secret, and to let individuals pay for services they do not need. Furthermore they often impose very high quality standards or entry restrictions and might only reveal the information which is in their interests and, if they are powerful, they can even influence the government to do what they prefer. The result will be a decrease in the level of social welfare, and a redistribution of wealth from consumers to suppliers. ${ }^{119}$

Another disadvantage of self-regulation is its lack of democratic legitimacy. As suggested by Van den Bergh, 'self-regulatory bodies are not accountable through normal democratic channels such as democratically elected Parliaments and third parties usually do not participate in establishing the self-regulatory regime. Moreover, the selfregulatory bodies often combine representative and regulatory powers. If a profession is entrusted with powers to pursue the general interest, democratic legitimacy seems to require that an independent public authority supervises the professional body and (dis)approves its self-regulatory rules.' ${ }^{120}$

Furthermore, the flexibility of self-regulation can be questioned. Since professionals will always try to obtain rents, they will resist changes in regulation that generate more opportunities for competition. Problems like information asymmetry and negative ex-

\footnotetext{
116 X., Een blik op het vrije beroep, KB-Weekberichten, 1998, n³2, p. 6.

117 Baggott \& Harrison 1986, pp. 143-160

118 Miller 1985, pp. 897-903.

119 Maks \& Philipsen 2002, p. 34. As will be discussed hereunder, the IHS Report on Regulation of Professional Services has not, however, been entirely successful in demonstrating the predicted welfare losses.

120 Van den Bergh 2004, p. 156.
} 
ternal effects will therefore not be solved by self-regulation. Even though professionals make the rules themselves, this does not mean that all regulatory costs are paid for by the profession itself: the costs can be externalized and translated in the form of higher prices, so that consumers still pay for them.

The above-mentioned public interest arguments in favour of self-regulation are actually, at the same time, arguments against public regulation. The challenge is to profit optimally from the advantages of self-regulation, while trying to control the danger of rent-seeking behaviour.

As explained above, professionals can -through the creation of market 'shelters' ${ }^{121}$ and monopolies in professional service provisions- secure autonomy, job security, high income and status, and collective social mobility. ${ }^{122}$ However, nowadays the clients of professionals do not hesitate to institute proceedings against professionals. Consequently, professional associations themselves impose more regulations and monitor their members strongly to bring the need for governmental control to the lowest level possible. It can be said that they have a certain decentralized regulatory control within states. ${ }^{123}$ Therefore, one can conclude, along with Van den Bergh ${ }^{124}$, that professions have a dual character. ${ }^{125}$ On the one hand, it is argued that they constitute self-interested occupational monopolies whose anticompetitive effects distort the social and economic organization of a society. On the other hand, through internal regulatory mechanisms and socialization practices, they promote certain values of moral obligation and public service, altruism and a special relationship of trust with clients. Self-regulation may thus both improve market performance and reduce competition. However, often its negative consequences in terms of restrictions of competition outweigh any potential benefits. For this reason, Van den Bergh argues that the state should create an institutional framework under which it becomes possible to fully profit from the advantages of selfregulation while, at the same time, minimizing its disadvantages. He suggests that the delegation of regulatory powers to self-regulatory bodies in markets for professional services should allow them to adequately cure the existing market imperfections without, at the same time, giving them the scope to reduce economic welfare again by creating a disproportionate distortion of competition. At the same time, the lack of democratic legitimacy should be remedied. ${ }^{126}$ To render self-regulation more efficient, Van den Bergh introduced two different institutional choices concerning the organization of selfregulatory powers so that self-regulation becomes more efficient: co-regulation and competitive self-regulation. These methods ${ }^{127}$ will now be discussed.

121 Freidson 1994.

122 Larson 1997, p. 1

123 Dingwall \& King, 1995, pp. 14-24.

124 Van den Bergh 2004, pp. 156-157.

125 Krause 1996

126 Van den Bergh 2004, pp.156-157.

127 The description of these methods is specifically based on the above-mentioned Article of Van den Bergh. See also Ogus 2000, nr. 9400. 
The Architectural Profession: an Economic Approach

\section{Co-regulation}

One speaks of co-regulation when public policy objectives are achieved through the combination of a certain degree of self-regulation and traditional public regulation. When jurisdictions adopt co-regulation, self-regulatory bodies enact rules, but public authorities hold some oversight with regard to ratifying those rules. ${ }^{128}$ This is also called mixed regulation. In this way the legislator can, for example, create rules on how a selfregulatory body must function, but without itself becoming involved in the determination of the rules of entry and conduct ${ }^{129}$. As indicated by Palzer and Sheuer, 'in the context of co-regulation, the state or competent authority will play a significant role, setting the legal framework and monitoring the functioning of the system by assuming responsibility for initially checking self-regulatory bodies, having a say on the monitoring of results and, if necessary, requesting that adaptations be implemented. Thus, the achievement of public policy goals is not relinquished to societal control entirely; the responsibility remains with the state. ${ }^{130}$ The state has therefore the last word on the contents of rules that will govern entry into a profession and its performance, and subjects self-regulatory rules to a public interest test. ${ }^{131}$ It follows that member States should not unconditionally delegate regulatory powers to private economic operators enabling them to create anti-competitive rules. Public regulators should maintain a margin of discretion in assessing whether such rules are in conformity with the public interest. As put forward by Van Den Bergh, 'A key element of a co-regulatory regime is thus the self-contained development of binding rules by the co-regulatory organization and its liability for these rules. In a co-regulatory-system, non-compliance with the given rules is directly or at least indirectly (for example in the form of possible revocation of a licence) sanctioned by the state (public authority). However, bearing in mind that state authorities may intervene in the case of an alleged malfunctioning of a co-regulatory institution, this will necessitate, at least to some extent, the doubling of institutional structures, which leads to the conclusion that more efficiency, in particular in terms of costs is not to be expected in the short-term.' ${ }^{132}$

Co-regulation is regarded by many as a means to achieve better regulation, and to accomplish both coping with the increasing risk of failure of traditional regulatory concepts, and handing back responsibility to society where that seems appropriate. ${ }^{133}$ It is

128 Grabosky \& Braithwaite 1986.

129 Evans 2004, pp. 524-525.

130 Palzer \& Scheuer 2004

131 Van Den Bergh 2004, p. 163. The co-regulatory approach has been recognized as an essential and, possibly, sufficient way of implementing existing provisions by the European Community, e.g. with regard to the review of the Television Without Frontiers Directive and the Recommendation on the Protection of Minors and Human Dignity on the Internet. See Palzer \& Scheuer 2004, p. 10.

132 Van Den Bergh 2004, p.163.

133 The co-regulatory approach has been recognized as an essential and, possibly, sufficient way of implementing existing provisions by the European Community in the course of reviewing existing legal instruments, e.g. with regard to the review of the Television Without Frontiers Directive and the Recommendation on the Protection of Minors and Human Dignity on the Internet. See also Alexander Sheuer: "The Portrayal of Violence in the Media: the respective roles of public regulation, media self-regulation and coregulation", contribution to the Council of Europe Expert Seminar "Violence in Everyday Life", held in Strasbourg, 11 June 2003, http://www.emr-sb.de/EMR/Portrayalofviolence_media.pdf, last consulted 29 November 2009. 
also held to be more democratic. However, protagonists of self-regulatory bodies articulate the fear that their established voluntary system might be 'captured' by the state and made into a co-regulatory system, and raise questions concerning the legitimization of this phenomenon, which is sometimes referred to as a shift to governance. State regulators and private watchdogs, on the other hand, voice the concern that partially empowering the industry to regulate itself might put the fox in charge of the henhouse. ${ }^{134}$ In any case, the adoption of co-regulatory systems remains a free decision of individual Member States. As suggested in Part I of this thesis, European competition law does not explicitly require Member States to subject self-regulatory rules of professional bodies for which they bear the final responsibility, to a public interest test. There is therefore no clear and unconditional requirement that Member States must justify restrictions on public interest grounds, and show that the instruments chosen are proportionate to achieve such goals. However, states are not totally immune from liability since such rules may be challenged on the grounds that they have a restrictive effect on the free movement provisions of the Treaty.

For this reason it is doubtful that co-regulation will always lead to efficient outcomes.

\section{Competitive self-regulation}

The concept of competitive self-regulation refers to competition between different professional bodies. ${ }^{135}$ When the government delegates its powers to professional bodies, it gives them the power to restrict supply (allowing them to create a monopoly situation) and/or to charge above-competitive prices. To cure this problem, monopolies have to be eliminated by forcing the self-regulatory bodies to compete with each other. According to Van Den Bergh this can be achieved in two ways: by creating competition between different professions offering the same professional service (inter-professional competition) and by abolishing the exclusive right to control supply within a single profession (intra-professional competition). As shown by empirical research done by Paterson et al. in $1988^{136}$ and $1994^{137}$, in the area of conveyancing and legal services in England and Wales, inter-professional competition will not necessarily benefit consumers. The reason is that when the number of rival professions is low and a limited range of homogeneous services is provided, removing a monopoly does not lead to lower prices. On the other hand, when there is a sufficiently large number of professional bodies, and when

134 Van den Bergh 2004, p. 163. Furthermore, there are three reasons why control by the state might remain ineffective. First of all, the concept of 'public interest' may not be clearly defined and instruments to assess whether public interest goals are achieved may be insufficiently developed. Second, the scope of control by the state may be too narrow, so that not all restrictions on competition are subjected to a public interest test. Third, the professional bodies keep their monopoly in the field of enforcement with the risk that they will use their margin of discretion in an anticompetitive way. For these reasons, Van Den Bergh holds that control should take place ex ante.

135 Van den Bergh 2004, p. 174; Ogus 2000, nr. 9400. In this regard it should be noted that competition between different professional bodies is possible within a single Member State, but also across Member States.

136 Paterson, Farmer \& Love 188, pp. 361-373.

137 Stephen, Love \& Paterson 1994, pp. 102-118. 
services are sufficiently heterogeneous, the risk of cartelization may be contained. ${ }^{138}$ Inter-professional competition may then act as a powerful deterrent to the lowering of professional standards. Since the current compartmentalization prevents the creation of alternative markets, for example for the provision of simple or routine services, interprofessional competition can create tension between different professions, and may be helpful in discovering abuses and in improving efficiency, by introducing a new division of labour. ${ }^{139}$ Even though a lot of measures have been taken to promote interprofessional competition, no steps have been taken yet to make intra-professional competition possible ${ }^{140}$, at least not in the area of architecture. Even though different professional organisations do exist (for example the Association of Flemish Architects, the Association of Architects of the Province of Limburg, the Union of Architects, etc. in Belgium), the Belgian Order of Architects is still the only institution of which membership is mandatory for a professional to be able to practise the profession in Belgium. ${ }^{141}$ The monopolies of the different Orders of Architects have not been abolished, while the creation of more Orders within the same territory to enhance competition has not been allowed. Nevertheless this 'liberalization' could bring about some positive effects: rents could be eliminated while the benefits of self-regulation could be preserved. As concluded by Van Den Bergh ${ }^{142}$, legislative measures leaving the largest possible scope for competition between legal rules should be preferred due to the likelihood of market failure caused by monopolies.

\section{Authors of regulation in Belgium and the Netherlands}

The legal relationship between the architect and his client is generally characterised by a skilled professional on the one hand, and inexperienced individuals on the other. For this reason, there will mostly be some degree of information asymmetry. As noted in Chapter 2 of this thesis, according to the sector study conducted by Mirza and Nacey for the Architects' Council of Europe in 2008, the largest single sector of the architectural market concerns individual houses. Private individuals are architects' principal client type, accounting for almost half (47\%) of architectural practices' revenue. This clearly mirrors the importance of individual housing as the largest market sector. However, even though Stephen argues that public policy towards markets for professional services should become more differentiated by profession and by consumer type, some caution should be maintained. Even though households might benefit from regulation which guarantees a certain quality, while business users might want to achieve flexibility or innovation (for example outsourcing, undertaking in-house certain categories of activities, being able to choose and mix service providers ... ) which is more easily obtained if certain regulatory restrictions are removed, in my opinion, the creation of different sets of regulations for different types of consumers would be a time consuming and costly occupation, since both types of consumers have, in the end, the same wish: to have a building that is fit for purpose of a good quality and for a good price. For this reason,

\footnotetext{
138 Van den Bergh 2004, p. 174.

139 Van den Bergh 1999, p. 123.

140 Ogus 1995, p. 97-108.

141 As noted in Part II of this thesis, certain exceptions exist for non EC/EEA nationals.

142 Van den Bergh 1999, p. 174.
} 
regulation can be an instrument to cure market failure, not only with regard to the information asymmetry problem, but also because of the external effects that can be caused by the activities of architects. As has been demonstrated in Part II of this thesis, the creation of monopolies can also be of some concern in the architectural market. In Belgium, the Architects' Act (AA) and the Architects' Order Act (AO) determine who can use the title and practise the profession of architect. This is therefore clearly public regulation. The Deontological Code of 29 April 1983 which was created by the Architects' Order and determines how architects should practise their profession, was ratified by Royal Decree on 18 April 1985. Article 39(1) AO holds that the King (i.e. the government) can give legal force to the deontological rules, and the regulations concerning traineeship, by means of a decision discussed in the Council of Ministers at the request of the National Council of Architects. With regard to the principles laid down in the deontological code, it can therefore be said that there is some form of co-regulation. Since there is only one Order (of course with territorial sub-divisions), and since architects hold a monopoly to design buildings which require a building permit, there is no real intra- or inter-professional regulatory competition. In this regard it should be noted however, that different professional organisations do exist (for example the Association of Flemish Architects, the Association of Architects of the Province of Limburg, the Union of Architects, etc. in Belgium). However the Belgian Order of Architects is still the only institution of which membership is mandatory for a professional to be able to practise the profession in Belgium. ${ }^{143}$ It follows that the monopoly of the Order of Architects with regard to registering new members and thus determining who is allowed to practise the profession, has not been abolished.

In the Netherlands, the Architects' Title Act (ATA) determines who can use the architectural title. This is public regulation. The Act determines that architects should register with the Foundation Bureau Architects Register, which is not a professional association but a public authority appointed by the Minister. Architects are not bound by a deontological code after registration. Only those who become members of a professional association such as the BNA are bound by their self-regulatory rules. In the Netherlands there is therefore no co-regulation to which all architects have to adhere. Since there is no Order at all, there can be no competitive self-regulation between different Orders. However, just as in Belgium, different professional associations do exist. It can be said that in this regard there is some intra-professional competitive self-regulation. Furthermore, since architects have no monopoly to provide architectural services, some level of inter-professional competition can also be present. However, since architects are not obliged to become a member of such an organization, the effects of any intra- or interprofessional competition are difficult to predict.

\section{Conclusion}

From the above it can be concluded that both self-regulation and public regulation have advantages as well as disadvantages. To reduce most of the disadvantages, two approaches have been suggested by Van den Bergh: co-regulation and competitive self-

${ }^{143}$ As noted in Part II of this thesis, certain exceptions exist for non EC/EEA nationals. 
regulation. Both these approaches maintain intact the information benefits and the benefits concerning the reduction of enforcement costs of self-regulation. A problem with co-regulation is, however, that the monopoly power of professional bodies is maintained unbroken. As noted above, European competition law does not explicitly require Member States to justify self-regulatory rules that restrict competition on public interest grounds, and to provide evidence that the rules are proportionate to achieving such goals. Van den Bergh therefore came to the conclusion that to achieve efficient outcomes, existing methods of supervision should be improved upon. ${ }^{144}$ In this way procedures should be developed to analyse whether the professional rules can be justified in the public interest, and impose no restrictions on competition that go further than necessary to achieve that goal. A system of competitive self-regulation may create scope for competition between different professions offering the same service. It may also remove compulsory membership of monopolistic professional associations, and thus initiate competition within a single profession. However, as suggested by Evans, co-regulation and competitive self-regulation can also bring about disadvantages, such as a duplication of resources, confused consumers due to multiple standards, etc. ${ }^{145}$ Experiments with these types of mixed regulation are needed to obtain more knowledge about the efficiency gains associated with these methods. As noted above, regulation is often created to cure market failure. Market failure can be caused by information asymmetry, externalities, public goods and lack of, or restrictions on, competition. On the other hand, states and self-regulatory bodies such as professional associations can also create rules which cause market failures and contravene competition law.

Since architectural associations are often keen on restricting competition in order for their members to have more power, the market will generate sub-optimal outcomes. Regulation in the form of competition law may offer a solution to avoiding the abuse of dominance or restrictive behaviour. The ultimate goal of competition policy is to promote an efficient allocation of resources. ${ }^{146}$ It is often argued by representatives of the liberal professions that self-regulation should not be subject to the competition rules at all, because that would endanger the profession's independence, or because selfregulation is in the public interest, not in the interest of the profession. However, a correct application of the competition rules would not endanger the practitioners' independence; they would still be free to provide their services in any way they want, as long as they do not use restrictive or abusive means. In any case, there is no guarantee that professional associations -which can easily be tempted to neutralize competition- will not introduce certain rules in their own favour. The democratically elected legislator is supposed to further all individual interests in an equal fashion to define what constitutes public interest. ${ }^{147}$ In general, there is less risk -but still some risk exists- that competition is distorted by public regulation.

\footnotetext{
144 See also Van Boom, Faure, Huls \& Philipsen 2009.

145 Less competition often leads to reductions in quality. See Evans 2004, p. 526

146 The importance for competition in the liberal professions is acknowledged by the European Parliament by its Resolution of 16 December 2003 on Market Regulations and Competition Rules for the Liberal Professions, 3 OJ C 91 E, 15.4.2004, p. 126.

147 Gilliams 2003.
} 


\subsubsection{Types of regulation}

\section{Market entry regulation}

a. Educational requirements, registration or membership of a professional association, nationality and establishment requirements, numerus clauses, etc.

Entry regulations define the conditions that have to be fulfilled before one is allowed to practise a profession and can therefore also be called qualification requirements. Typical market entry regulations are the demand for formal qualification certificates (e.g. university degrees, length of practice and/or professional examinations) or membership of a professional body, nationality ${ }^{148}$ requirements, or economic needs tests (such as the fixing of a numerus clausus so that only a pre-determined number of practitioners is permitted per territory). Professional associations often use such entry regulation to limit the flow of new entrants into profitable markets. Diploma requirements are often created by the public legislator and supplemented by the profession with a mandatory traineeship, or an establishment policy. In general it must be stated that entry requirements are often used by existing members of a profession to restrict supply and thereby to earn supra-competitive rents. On the other hand, the entry requirements may be seen as attempts to meet the problem of information asymmetry as described above. If the quality of services cannot be assessed by the consumer, the problem of adverse selection arises, since this attracts professionals who offer low quality services. Market entry requirements have the advantage that one can deal with this problem ex ante. However, being in the possession of certain educational requirements, or being a member of a professional association, does not necessarily guarantee that one is competent to practise the profession several years after the qualifications were obtained. This is certainly the case with regard to the architectural profession, since it is characterised as evolving rapidly due to new technologies. It follows that there is not necessarily a correlation between these entry requirements and the level of quality. The same goes for the imposition of a numerus clausus. If there are information deficiencies with respect to the quality of services, less intrusive steps should be applied first, such as the regulation of information or the regulation of the quality of the service itself. This will be discussed next. For concrete examples of entry regulation, I refer to Part I and II of this thesis.

\section{b. Information regulation and quality standards}

As noted above, information asymmetry is likely to occur in the market for architectural services. This can cause adverse selection, meaning that the quality of the services will be lower than the social efficient level which, in its turn, can lead to negative externalities. Different instruments can be used to uphold a sufficient level of quality. The obligatory provision of information (for example by means of advertising) and the prohibition of misleading publicity, can offer information on the quality of services. Furthermore, the government can also create minimum quality standards which have to be achieved by professionals when performing services: if these products or services do not live up to the standard expected, they are excluded from the market. Through the regulation of the

${ }^{148}$ A former French law of 31December 1940 stated that only persons holding the French nationality could use the title of architect. 
quality of services, social welfare can be enhanced in cases of information asymmetry or external effects by increasing the consumer surplus or decreasing the deadweight loss. ${ }^{149}$ In other words, the opportunity costs of entering the market increase with quality. ${ }^{150}$ Nevertheless, as held by Shapiro, the existence of low quality products is not a problem if there is demand for them, and they do not cause negative externalities, but if the quality is too low from a social welfare point of view, standards may solve the problem. ${ }^{151}$

There are three different types of standards. ${ }^{152} \mathrm{~A}$ target standard imposes (criminal) liability for eventual harmful consequences arising from the output of a supplier after it is brought on the market. Performance standards are helpful with regard to checking the quality of a product or service before it comes on the market, without intervening in the production process of the supplier. Finally, a specification standard forces or prohibits suppliers from using certain production methods or materials. However, since the governments do not have at their disposal a sufficient amount of knowledge to set such a standard, in the area of professional services it must be assumed that one is dealing with performance standards. Minimum quality standards have the advantage that consumers with limited education are protected against low-quality services. Nevertheless, as noted above, the risk exists that certain goods or services which would have been bought by certain consumers if they would have been available, may be excluded from the market. It follows that the imposition of standards interferes more with the market than does the supervision of the level and content of information. ${ }^{153}$ Furthermore, the introduction of standards brings certain costs with it. The direct costs consist of administrative costs and compliance costs. Administrative costs are the costs which occur as part of the process of defining, monitoring and enforcing the quality standard. Compliance costs are costs made to fulfil the minimum quality standards, for example buying new equip-

149 Maks \& Philipsen 2002, p. 38.

150 Leland 1979, pp. 1328-1346.

151 Shapiro 1983, p. 678. However, in the case of minor risks for third parties, standards may not be necessary if liability rules can offer the desired level of protection. This will be further discussed hereunder.

152 Ogus 1994, pp. 150-151.

153 In a survey by the Organisation for Economic Cooperation and Development (OECD), several countries mentioned that quality standards do not work only as entry barriers for trade between developed and developing countries, but even in developed markets, either because they are too high, or are non-uniform. See Analysis of non-tariff measures: the case of export duties, Working paper of the Trade DirectorateTrade Committee, 2003. As suggested by Boom, an importing country has incentives to impose a Minimum Quality Standard (MQS) slightly above the lowest quality produced in an unregulated market. It increases quality and equates domestic salaries to world levels, so that the domestic welfare increases. See Boom, 1995. A pure importing country with no domestic production, imports both high and low quality services (goods). However, in the event that the importing country also produces services (goods), the developed countries protect their own economies, and impose standards that may work as entry barriers for imports from developing countries. Therefore, a MQS imposed by a pure importing country with no domestic production or by an importing country that has high quality domestic firms, always results in blocked access for the low quality firm. Hernán \& Kujal, 2004. A country choosing an MQS will maximize welfare for a high enough MQS so that the market is only served by a foreign monopolist. To solve this problem, Hernán and Kujal propose the use of Flexible Quality Standards (FQS) which are less restrictive than MQS as they permit the sale of the good if the quality of the good is below the limit set by the standard: if a firm invests above the FQS it is exempt from paying the import tariff, otherwise, it pays the tariff. In this way the government has an instrument for quality (an FQS) and an instrument for output (a tariff). Both firms will stay in the market and the government will obtain greater domestic welfare than under an MQS or under free trade. 
ment. Indirect costs, on the other hand, are the often unintended side effects of regulation. In this regard standards can create inefficiency or act as a brake on technical change. ${ }^{154}$ Another problem associated with standards is that professionals will not hesitate to lobby so that the government will impose quality levels with which they already comply (no compliance costs). In this way they are protected against new competitors.

\section{c. Reserved rights: certification and licensing}

As noted above, entry restrictions are, in many cases, coupled with reserved rights to provide certain services. If this is the case, only practitioners with appropriate qualifications can carry out certain tasks. Not only can the government create such legislation but also many professional associations have internal rules establishing conditions for membership, and use qualitative as well as quantitative entry restrictions. In this way, licenses or certificates can be issued to increase consumer welfare by guaranteeing an adequate quality of goods and services if certain requirements are fulfilled (for example, disposing of a certain education level). As indicated by Shapiro, this holds only if consumers value high quality significantly compared to the costs of providing quality on the part of suppliers. ${ }^{155}$

If certification is issued, every individual can perform the services related to the regulated profession, but these individuals are not allowed to use the protected title without the relevant certificate. ${ }^{156}$ As mentioned above, title protection constitutes a form of certification, and indicates that the specific service is (or at least should be) of good quality. As mentioned before, after a person obtains an academic title, he can use it freely. However to be entitled to use a professional title, it is often necessary to be registered on the list of a professional association. The advantage of certification is that consumers still have the choice between certified and uncertified services, which will not be the case in a licensed market. ${ }^{157}$ However, professionals might be inclined to invest too much in education in order to indicate high quality levels. ${ }^{158}$ On the other hand, it has been argued that if membership of a professional association, which signals good quality to the consumer, is not compulsory, professional associations would have to work hard to maintain their members and their clients, and would therefore have an incentive to maintain high quality, more than is currently the case. ${ }^{159}$ If there is insufficient demand for uncertified services, and if the number of certified professionals is not very high, the effects of certification come close to those of licensing. It follows that, contrary to monopoly protection (comparable to the licence system), where offering a certain service is reserved for certain professionals only, in the case of title protection, the consumer is free to choose to hire a professional, with or without a title.

In case of licensing, services can only be performed by those professionals who have a credential issued by the regulator, which indicates competence in some profession. In

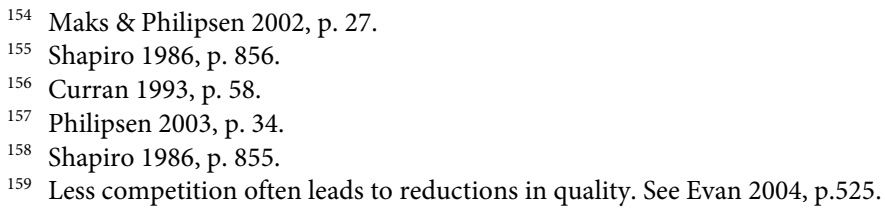


this way, the entry into the profession is restricted. With a licence system, the information asymmetry problem fades away. Due to the exclusion of poorly-educated suppliers, the average level of quality of a market will rise. However, this is only so if there is a sufficient relationship between the educational level of the supplier and the marginal costs of providing high quality. ${ }^{160}$ As pointed out by Shapiro, if high quality is important to consumers so that the relationship between human capital and high quality is positive, consumers' welfare can be enlarged by licensing or by certification, if suppliers can build their reputations over time by providing high quality goods or services. ${ }^{161}$ Social welfare can be improved through the use of licences because they alter the incentives of professionals by reducing the marginal cost of their quality provision. ${ }^{162}$ However, in choosing optimal minimum standards, a professional group or industry seeks to maximize its net gains. As with any monopoly, extra profits can be achieved by a lower level of total supply than is socially optimal, motivating the profession to set the optimal standards too high. ${ }^{163}$ Furthermore a Pareto-improvement will never be obtained, because there will always be consumers who would rather have bought low quality goods or services at a lower price. Empirical research has shown that in some cases, excessive licensing restrictions have led to higher prices without ensuring higher quality, while in some countries the loosening of restrictions in some professions has led to lower prices without any apparent reduction in quality. ${ }^{164}$ In any case, licensing laws which contain discriminatory rules can form a greater restriction on the freedom to provide services for non-nationals than for nationals, but also non-discriminating rules can cause this effect indirectly when they contain requirements which foreigners cannot meet as easily as nationals. Licensing intervenes further in the market process than certification does, but risk-averse ${ }^{165}$ consumers are better insured by it against possible harmful consequences of bad service due to the exclusion of suppliers who do not meet certain standards. ${ }^{166}$ In this way, 'quacks' are excluded from the market. In fact, with regard to professional services, licensing may function as a minimum standard of quality. In this regard it should be noted however, that a study concerning the free professions in Belgium, including the profession of architect, showed that higher degrees of licensing restrictiveness was related to higher prices and higher earnings. ${ }^{167}$ It follows that there is

160 If an individual's human capital increases because of increased license requirements, it seems at first sight plausible that his marginal cost of providing high quality decreases. See Maks \& Philipsen 2002, p. 29.

161 Shapiro, 1986, p. 856.

162 Ibid.

163 Leland 1997, p. 1338

164 Cox Foster 1990, pp. 26-27.

165 A person is said to be risk-averse if he considers the utility of a certain prospect of money income to be higher than the expected utility of an uncertain prospect of equal expected monetary value.

166 Philipsen 2003, p. 3

167 Maks, Philipsen \& Faure 2001. Due to disproportionate quantitative and qualitative entry controls, and the giving of reserved rights causing there to be a smaller number of professionals, higher prices are likely to arise. A negative consequence is that once new professionals succeed in entering the market, they often work in partnerships and have to be satisfied with a minimum wage, even though they have successfully concluded studies of long duration. In this regard, the European Commission accepts that each Member State should be allowed to determine the level of qualification needed for entry to a profession in that country, but holds that such entrance requirements should be proportionate and reflect what is actually required to be able to perform the relevant service to an acceptable standard. However Button and Fleming 
a real danger that consumers resort to cheaper alternatives -at least if this is possible- in the event that they think that professionals are overtrained and their services overpriced. ${ }^{168}$

\section{d. Market entry regulation in Belgium and the Netherlands}

In Chapters 5 and 7, the Belgian and Dutch regulation of architects was discussed. It was concluded that in Belgium, the title as well as the profession of architects are protected. Since only registered architects are allowed to design buildings for which a building permit is required, Belgian architects have a monopoly in the industry in this regard. This means that they have a license to practise, and consumers have no choice between a registered architect and another service provider.

In the Netherlands, on the other hand, architects can use their title after being registered. However, non-registered persons can also perform architectural services, as long as they do not use the title of architect. It follows that registered persons are certified and not licensed, and that there is therefore more competition since there is no professional monopoly as in Belgium. Furthermore, membership of a professional association is not even required in the Netherlands, while in Belgium every architect is a member of the Architects' Order. Only after registration at the Foundation Bureau Architects Register can one use the title in the Netherlands, but membership of the BNA is not necessary in order to be allowed to use the title. Since membership of a professional association is therefore not required in the Netherlands, it should be questioned why such membership is required in Belgium. In this regard it might be questioned whether the Belgian compulsory membership is the consequence of successful rent seeking behaviour on the part of the Belgian Architectural Association, and whether it is more efficient to replace this compulsory membership by optional membership in competing organisations.

In general, it has to be determined whether the Belgian and Dutch regulations are an appropriate answer to market failure and are proportional, or whether they create more problems (leading to higher costs) than they solve.

With regard to the monopoly situation in Belgium, it should be noted that even though, on the one hand, regulation is deemed to be needed in order to cure problems caused by the abuse of dominance, information asymmetry, externalities, and a non-optimal supply of public goods, ${ }^{169}$ while on the other hand it is argued that deregulation is necessary

studied the licensing of architects in the UK but found no conclusive evidence of an impact on incomes, while other studies have come up with mixed conclusions. See Button \& Fleming 1992, pp. 95-116. Lueck, Olson and Ransom concluded, in a thorough empirical study, that there was little support for the view that licensing restrictions affect the price of legal services. Their evidence suggests that it is what they describe as 'market forces' which are most important. See Lueck, Olsen \& Ransom 1995, pp. 63-83. Olsen, (in a review of the empirical literature on licensure in medical professions, focussing on the USA) concluded that the evidence is mixed, and varies across both time and the professions covered. See Olsen 2002, pp. 10181054.

168 Shapiro 1986, pp. 855-856.

169 The European Commission also holds the opinion that many of these regulations (e.g. regulation of fees, restrictions on advertising, deontological rules) unnecessarily restrict competition and states that it is im- 
to liberalize the market in order to rule out or limit the existence of professional monopolies. Since architects are more often consulted by developers in the Netherlands, and are mostly consulted by individual clients in Belgium, it is expected that the problem of information asymmetry is more serious is in Belgium. However, since the Dutch situation demonstrates that other ex ante tools such as the Housing Act and the Building Decree which contain detail requirements which buildings need to satisfy can also protect the quality of buildings without the negative effects as far as the restriction of competition is concerned, it might be assumed that, according to the public interest theory, the tool used in Belgium to cure market failure goes too far. Since market competition is already restricted to those who are allowed to use the title, the cure might be worse than the disease.

From a private interest point of view, it must be stated that it is impossible to enter the market in Belgium without registration by the Architects' Order, which brings about acceptance of its deontological code. Since architects have to be insured, insurance companies also have an important say with regard to market access. Since good quality designs and buildings can also be obtained by other means, it can be said that the monopoly does not serve the public interest, but rather serves to limit the number of market participants. This is likely to generate rents for architects who are already registered.

Furthermore, it should be noted that economic theory, and more specifically the law of supply and demand, has consistently predicted that prices will rise if the number of producers is limited. The question can then be asked whether the prices of architectural services are higher in Belgium than in the Netherlands due to the monopoly with regard to Belgian architects. In this regard, it should be noted that, in 2009, there are 12,714 architects registered in Belgium ${ }^{170}$ and 13,182 in the Netherlands. ${ }^{171} 75 \%$ of the architects registered in the Netherlands are architects in the narrow sense, meaning that they are not interior architects, town planners, or garden and landscape architects. ${ }^{172}$ There are thus $+/-9,886.50$ architects in the narrow sense registered in the Netherlands. ${ }^{173}$ The difference is not considerable when taking into account the fact that the Netherlands is a larger country with a larger population. The 2008 research conducted by Mirza \& Nacey for the Architects' Council of Europe ${ }^{174}$ concluded that there are only 11,500 architects in Belgium and 9,100 architects in the Netherlands. These numbers are therefore lower. ${ }^{175}$ What is important however, is that, in Belgium, there are fewer persons holding the architectural title than in the Netherlands.

portant to determine what is meant by the public interest in different markets. See Communication of 5 September 2005, COM (2005) 405 final, nos. 29 and 11.

170 Number on 17 September 2009, Architects' Order Belgium (interview by telephone 28 September 2009).

171 Number on January 2009, Foundation Bureau Architects' Register the Netherlands.

172 As noted before, in Belgium, interior architects, town planners and garden and landscape architects are not registered.

173 See http://www.architectenregister.nl

174 Mirza \& Nacey 2008. I refer to Chapter 2 for a description of how this research was carried out. For tables and charts I also refer to Chapter 2.

175 As indicated in Chapter 2, the Mirza \& Nacey research was based on various sources. The starting point was the research publication produced by COAC - Architectural Practice Around the World research by the Collegi d'Arquitectes de Catalunya (COAC), based on information supplied by national institutes and 
According to the Mirza \& Nacey research, the market revenue of Belgian architects was 327,108,000 Euros (28,444 Euros per architect) and for Dutch architects it was 901,558,000 Euros (99,072 Euros per architect), the market size referring to the architectural market as measured as the sum of the revenues earned by private architectural practices. The value of the Dutch architectural market is therefore much higher than that of the Belgian market: see Table 7 and Chart 2 in Chapter 2). The average revenue/earnings of Dutch architects is highest in all European countries (see Table 12 and Chart 8 in Chapter 2). The average hourly rate charged by Belgian architects is 60 Euros for principals and 47 Euros for architects who are not principals, while in the Netherlands, principals charge 116 Euros per hour and other architects 92 Euros (See Tables 14 and 15 and Chart 7 in Chapter 2). This is quite surprising when looking at the economic theory discussed earlier, certainly if one notes that the architects working for the Dutch government aside, architects in the Netherlands (sole principals, partners/directors, salaried architects, freelance architects, ... ) work fewer hours per week than their colleagues in Belgium (See Table 17 in Chapter 2).

The Mirza \& Nacey research does not explain why Dutch architects earn more and charge higher prices. Indeed, Dutch and Belgian architects do not necessarily calculate their fees in the same way (see Table 13 in Chapter 2) but the question still remains as to why there is such a big difference. Since Belgian architects hold a monopoly, one would anticipate that they would be the big profit makers. A possible explanation might be found in the fact that it is because there is no monopoly in the Netherlands, there are fewer 'real' architects in the Netherlands compared to Belgium. Since individuals who are interested in making designs and supervising building works are allowed to carry out this activity without having to register, and thus also without using the title -they may even not have earned the title of architect- the number of possible suppliers is, in the end, much higher, so that there is more competition in general. Furthermore, in the Netherlands, there is no reason for entrepreneurs and building promotors not engaging in drafting designs as well, since the legislator has not created incompatibilities as in Belgium. Since not everyone interested in and capable of drafting designs is obliged to register to be able to carry out such work, there is less competition among 'real' architects, which might, in turn, explain the fact that 'real' architects charge higher prices. Of course consumers can choose whether to turn to a registered architect or another service provider. It may be argued that since most individuals only build once in their lives, and since this will probably be their most important spending decision ever, they are often inclined to choose for the 'surety' of the competences of someone holding a real degree and belonging to an Order. The same goes for business clients, since they also want to engage the best professionals for their projects. Since their financial assets are much greater than that of regular individuals, they have the possibility to turn to more expensive architects. On the other hand, the Dutch building market is characterised by large projects carried out by building promotors who are engaged by public authorities to

associations of architects of the individual countries. Further data was collected by ACE in Phase I of this research. The researchers indicated that they attempted to verify all figures using a mixture of primary and secondary sources including Member Organisations' websites, telephone / email. Different sources produced conflicting figures, sometimes substantially different. Final figures are their best estimates based on these several different sources. All figures used were the latest available at the time. 
construct numerous identical houses in a certain area. Architects who are engaged in such projects can earn large profits with minimal investment, as opposed to their Belgian colleagues where such projects are not so popular. For this reason it might be argued that fewer architects are needed in the Netherlands which seems to be confirmed by the fact that only a small number of graduated architects work independently (see Table 11 Chapter 2). It is also possible that there is a tendency to charge modest prices in Belgium due to the fact that architects are, in general, not actively involved in politics so that the profession is not represented by professionals seeking rents. Empirical research is needed to confirm these findings.

In this regard, reference should be made to Van den Bergh and Montangie ${ }^{176}$ who studied the abolishment of the solicitors' monopoly for conveyancing services in England and Wales ${ }^{177}$ and the deregulation of the Dutch notary profession ${ }^{178}$, and concluded that liberalization does not guarantee lower prices ${ }^{179}$, so that increased competition is therefore not guaranteed either. They even found with regard to the Dutch notaries, that there is a justified concern that competition may decrease quality and jeopardize the notary's integrity. ${ }^{180}$ Just as is the case with fixed fees, Van den Bergh and Montangie concluded that regulation may be justified even in the case of monopolies, as long as effective instruments to control and monitor quality are not (yet) in place. In this way, it can also be argued that if everybody can perform architectural services, quality may deteriorate, which will lead to more legal claims at high prices, at least if no other mechanisms exist to guarantee quality. As noted above, buildings designed by architects can also harm third parties (negative externalities), can cause positive externalities (also for persons renting the house, their visitors as well as persons walking by can enjoy the feeling of being safe in, or next to, the building) and the advice of architects or the plans designed by them can be passed on for free. However with regard to this latter point, it should be noted that clients often have personal demands and building constructions are dependent on the circumstances and surface of the land being used. Since in the Netherlands everyone can perform architectural services -as long as only those who are registered use the title - it can be asked whether this does not have a negative impact on quality. The answer to this question will depend on whether there are other mechanisms in the Netherlands which guarantee a sufficient level of quality. Whether the restrictions on competition resulting from exclusive rights (architectural monopoly in Belgium) do

176 Van den Berg \& Montangie 2006, p. 189.

177 Non-solicitors were admitted to offer conveyancing services in competition with solicitors. This solution has led for the first time to a reduction of fees by solicitors in this field as a response to the threat of new entrants in the market. However fees have then increased after the introduction of this form of competition. This finding is another confirmation of the fact that the issue of the introduction of competition in the market for legal services is still open and gives rise to many contrasting problems that are difficult to solve.

178 To be brief, the monopolies of the notaries with regard to making up deeds for specific legal transactions are maintained, but there are no fixed fees, and anybody who has the necessary qualifications to become a notary has the right to be appointed as a notary in a certain area, provided that that person has a feasible business plan. The numerus clausus was therefore abolished.

179 The Dutch 'Commissie Monitoring Notariaat' argues that the cause for the increase in notary fees is a result of low price elasticity in this sector, too little countervailing power on the part of consumers, and the fact that there is still too little competition between notaries.

180 Intense price competition may also lower the respect for ethical rules. 
not go further than necessary to achieve the goals of public interest, we require a costbenefit analysis which compares the architectural monopoly in Belgium with the architectural title protection in the Netherlands. Such analysis will not be presented in this thesis, but it is assumed that the protection of the architect's function is better replaced by legal requirements on quality and safety of the design, such as clauses on these issues in Building Decrees. Such requirements also protect safety, quality and the public order interests of clients and society in general, which was the reason in the first place for Belgian legislators attempting to protect the function of architects. ${ }^{181}$

\section{e. Conclusion}

Entry regulation may lead to an increase in service quality. As pointed out by Fletcher, ex ante entry restrictions can do this in at least three ways: 'Firstly, they can alleviate the risk of parties offering services they are not competent to carry out by ensuring that the professional's knowledge is appropriate to the services offered. Secondly, such restrictions can reduce the incentives to cheat by lowering the cost of providing good quality. A highly trained professional needs to put in less effort in order to do a good job, and thus the benefits of shirking are lower. Third, they can reduce the incentives to cheat by raising the cost of being 'struck off. When a substantial investment is required in order to gain entry to a profession, the returns to membership will be high, and thus the cost of losing membership will also be high. ${ }^{182}$ However, entry regulations generally restrict competition. When the rules are set higher than necessary to achieve the abovementioned objectives in order to create monopoly rents and restrict competition, entry restrictions will not produce welfare. As demonstrated by Shapiro, if the relationship between human capital and high quality is positive, and if suppliers can build a reputation over time by providing high quality, consumer welfare can be increased by the use of instruments such as licensing or certification. This however holds only if consumers significantly value high quality compared with the costs of providing quality on the part of suppliers. Licensing will never lead to a Pareto improvement since there will always be consumers who would rather have obtained low-quality goods or services at a lower price. Furthermore, even though entry regulation can have a positive influence on quality, this is not necessarily the case. As indicated by Cox and Foster who reviewed several empirical studies on the effects of entry regulation on quality and fees, the resulting quality is often unaffected. Djankov et al. even hold that higher levels of regulation of entry are in accordance with the public choice view associated with larger unofficial economies and no measurable benefits in terms of the quality of products. ${ }^{183}$

It follows that, due to the high costs caused by the protection of the function of architect in addition to the protection of the title, the protection of the function (monopoly) can better be replaced by legal requirements on quality and safety of the design. Curing market failure by licensing does therefore not seem to be the most efficient solution. In the case of certification, clients still have choice when it comes to engaging an

181 Van Gulijk 2009, p. 205.

182 Fletcher 2004, p. 75.

183 Djankov \& Purrell, pp. 739-792; Djankov, La Porta, Lopes-de Silanes \& Shleifer 2002; Fisman 2004, p.2, see http://www2.gsb.columbia.edu/faculty/rfisman/regulationentry.pdf, 1 ast consulted on 30 November 2009; Cox \& Foster 1990, pp. 26-27. 
architect. Those who turn to a professional who is allowed to use the title are sure that the latter does have a certain educational background and/or some professional experience. Licensing therefore intervenes further in the market process than certification, but a licensing system insures risk-averse consumers better against possible harm caused by low quality services.

\section{Market conduct}

Conduct regulations cover all rules that directly regulate the conduct of professionals. Typical conduct regulations are regulation of prices and fees (fixed prices, minimum and/or maximum prices, etc.), regulation of advertising and marketing, regulation of location and diversification (geographical restrictions on offering services, restrictions on establishing branch offices) and restrictions on inter-professional co-operation or restrictions on forms of business (for example whether incorporation is allowed and under what preconditions). ${ }^{184}$ They can often be found in deontological codes formulated by professional associations and can also intervene in the market. It should be noted however that the regulatory instruments which are used to restrict entry can also be applied by self-regulating bodies.

\section{a. $\quad$ Price regulations}

Price fixing aims at the elimination of a real variable for competition, namely the possibility of introducing price reductions. It follows that consumers will not get the products or services at the lowest price possible. ${ }^{185}$ However, this does not mean that all competition is ruled out, since other types of competition are still present, such as the competition in service quality.

Professional associations have argued that fixed prices protect the quality of services. They indicate that without fixed prices professionals are going to get into a race to the bottom to attract more clients with low prices. In this regard it must be noted that if consumers cannot judge the quality of services provided by professionals, they will base their decision to purchase certain services mainly on price. However, due to their lack of knowledge, they will not be willing to pay higher prices for higher quality. If fees remain unregulated, providers of higher quality services may be driven out of the market, and

184 Paterson, Fink \& Ogus 2003, p. 2.

185 Fixed prices automatically entail cross subsidisation. 'Cross-subsidisation involves the transfer of value from one business to another. It often occurs where an undertaking uses profits it makes in one sector, where it has market power (a company will be in a dominant position if it has "market power", which is defined as the ability to act independently of competitors, customers and, ultimately, of consumers.) to support low prices in other markets where it faces more competition. Competition law does not normally forbid cross-subsidisation. Cross-subsidisation is likely to be a problem where an undertaking operates as a monopoly, or is otherwise dominant in one market, and uses its power in that market to support its activities in another market, for example to gain market share in that other market. Cross-subsidisation can therefore be an issue for regulated utilities, and often occurs alongside other abusive practices such as predatory pricing and selective price cutting/discriminatory pricing, which are prohibited by competition law.' See M. Johsnon, Cross-subsidisation, Competition Focus 2004, available at http://www.martineauuk.com/publication_event/updates/crosssubt_full.pdf, last consulted 23 December 2009. Crosssubsidisation is usually specifically prohibited by licence conditions, without any requirement for market dominance. 
entry of new high-quality service providers may be discouraged by the low income levels. This may result in a market with sub-optimal quality services. ${ }^{186}$ It follows that fixed fees may overcome the problem of adverse selection since then consumers will not compare the costs but rather the quality of products, at least if they are able to distinguish quality. ${ }^{187}$ As indicated above, Van den Bergh and Montangie studied the deregulation of the Dutch notary profession and came to the conclusion that liberalization does not guarantee lower prices. They hold that due to the serious information asymmetry in the market for notarial services, and due to the fact that quality assessment does not yet reach the minimum level required to avoid adverse selection, minimum fees might be preferable to price competition. ${ }^{188}$ Conversely, a maximum fee schedule may be helpful in dealing with the problem of moral hazard, since consumers cannot estimate the desired price/quality level and risk that producers oversupply quality to charge higher prices. A maximum fee schedule may therefore protect consumers against excessive charges. Even though recommended fees can also limit competition and are also liable to create market failure, they can also inform consumers of the average fees to be paid and can alleviate the burden of drafting offers and/or negotiating individual fees. In this way they can reduce transaction costs and lead to lower fees. According to these authors, a flat rejection of regulated fees does not do justice to the fact that these may be useful instruments for coping with adverse selection, moral hazard, and high transaction costs. ${ }^{189}$ In this regard, the Architects' Council of Europe (ACE) holds that adequate charging systems should be established, since these can give the client enough information to understand what scope of service to expect. ${ }^{190}$ For this reason, all types of charging systems that are covered by law, and/or delegated to a professional organisation under agreed rules, and which fulfil the requirements for protection of the public interest, or are founded on them, should be accepted, according to the ACE. It should be questioned however, whether the conclusions of Van den Bergh and Montangie with regard to fee regulations for the notary profession are also applicable to the profession of architect. As noted above, regulation is needed to guarantee efficient outcomes due to the presence of information asymmetry and negative externalities in a free market for professional services. If the consumer is not able to judge the quality of the service pro-

186 Paterson, Fink \& Ogus 2003, p. 211.

187 As held by Caron, private clients certainly need different levels of protection from business clients. The latter will actually gain more from intra-professional competition, as they need less protection in terms of quality guarantees, since they are repeat purchasers of the services and, in this case, reputation can work as a mechanism for maintaining high quality standards. However this is not the case for private purchasers of services. See Caron 2008, p. 68.

188 As proposed by Van den Bergh, policy makers should be fully aware of the adverse selection problem and refrain from introducing price competition as long as instruments to assess quality have not been sufficiently developed and set in place. See Van den Bergh \& Montangie 2006, p. 211.

189 Another advantage of fee regulation according to Van den Bergh lies in the fact that fee regulations may also be used as an instrument to prevent public goods from being undersupplied. Since higher prices imply lower output, it can be presumed that fewer persons involve an architect. If losses (e.g. no new buildings/old, dangerous buildings) exceed the benefits of the price reductions in the real property practice, a price ceiling may be justified from a global welfare perspective. See Van den Bergh \& Montangie 2006, pp. 211-212.

190 See K. Nilsson, Former President of the Architects' Council of Europe in 2003, speech at the European Conference on Regulation and the Liberal Professions, Brussels, 28 October 2003. 
vided, adverse selection will take place since he will not be willing to pay a higher price for higher quality, so that providers of higher quality charging higher prices will be driven out of the market. Furthermore, the professional has an incentive to over-supply quality in order to charge higher prices to the detriment of his consumer who might be better served with a lower quality at a more reasonable price (moral hazard). As suggested above, the seriousness of the information problems may be mitigated by the repeat purchase mechanism. As demonstrated in Chapter II, according to the Mirza \& Nacey research, individual houses account for $31 \%$ of the architectural market. This is the largest single sector. However, most architectural tasks are situated in other areas such as public housing, private housing (flats and housing developments), industry or commerce. Even though private individuals seem to be the architects' principal client type, the public sector and building developers provide architects with most of their commissions. The latter categories can be qualified as clients using the repeat purchase mechanism. It seems that most consumers of the notary profession, on the other hand, are one-time-shoppers. The information asymmetry problem in the market for architectural services is present, but probably less strong than in the notary market. It can therefore be argued that adverse selection takes place with regard to notary services rather than with regard to the services provided by an architect. It follows that excessive price competition caused by adverse selection that results in an overall reduction in the quality of the services provided, might therefore be less present in the architectural market. Accordingly, the regulation of fees is not as necessary in the architectural market in order to guarantee quality. In this regard it should be noted that, in any case, the requirement to be in the possession of certain professional qualifications aims to prevent quality deterioration in the architectural market.

With regard to externalities, the Latin notary creates benefits for the parties involved, but also for third parties who will get more and correct information concerning a certain transaction. As suggested by Van den Bergh and Montangie, regulation is needed to make sure that an optimal level of benefits for third parties (positive externalities) is achieved. ${ }^{191}$ The notary provides information and advice to prospective buyers and sellers about the legal aspects of the transaction, and acts as a neutral, impartial professional avoiding any conflict of interest. Authenticating legal documents on the transfer of property is important for the proper functioning of the whole economy, as they determine ownership of valuable assets and connected liabilities. The notary drafts a public document (notarial deed) that will be registered and has evidentiary power. As held by the aforementioned authors, the services provided by a notary have the characteristics of a public good. ${ }^{192}$ Indeed, third parties also benefit from notarial deeds, for example when they want to buy property. In this regard it can be held that fee regulations may be used as an instrument to prevent public goods from being undersupplied. However, it should be noted that even though notaries provide services from which the general public can benefit, it can be questioned whether they are truly non-rivalrous in nature. Notaries will only perform services if they are compensated for the work done. If

191 Van den Bergh \& Montangie 2006, p. 196.

192 Ibid., p. 191 
everyone could benefit from these services without there being someone to pay, they would refrain from making deeds and contracts since they also want to make profits.

The architect, on the other hand, acts in the interests of the building master. Of course he has to take into account public legislation, and has to make sure that the building is safe, but if his client wishes it, he will design an apartment building even if that destroys the neighbours' quality of life. Even though every member of the public can profit from a high quality urban environment designed by an architect (positive externalities), the plan that is designed by him is generally based upon the desires of his client, and dependent on the specific characteristics of the soil, the surface of the plot, building regulations, the available budget, etc. Price regulation is therefore less required in the architectural market as a means of safeguarding quality.

From the above, it might be concluded that even though intense price competition may decrease the legal quality of notarial services, this is not necessarily the case with regard to the architectural profession, due to the different characteristics of each profession.

Furthermore, fixed prices are liable to cause a reduction in quality since it is mostly not possible to provide high quality services at very low prices. ${ }^{193}$ Moreover, fixed prices cannot prevent unscrupulous practitioners from offering poor quality services, nor do they remove the financial incentives for practitioners to reduce quality and costs. Professions may still abuse their position by accepting rewards for their monopoly without enforcing high standards. ${ }^{194}$ It follows that there is not necessarily a causal effect between the level of fees charged and the quality of services supplied. ${ }^{195}$ With prices higher than the minima, collective fixing would not prevent the provision of poor-quality services with impunity. ${ }^{196}$ Even the circulation of recommended tariffs by a trade organization is liable to prompt the relevant undertakings to align their tariffs irrespective of their costs.

193 A certain degree of price-fixing has been accepted by the Commission if the aim and result of such pricefixing is to ensure quality control. See, for example, Commission Decision 87/480/EEC of 13 July 1987, Baltic International Freight Futures Exchange Ltd., OJ [1987] L 222/24.

194 In this regard, as early as 1970, the Monopolies and Mergers Commission of the United Kingdom argued that price competition in the supply of a professional service is likely to be the most effective single stimulant to greater efficiency and to innovation and a variety of services. In the meantime, numerous studies led to the same conclusion. Almost thirty years later, Article 4 (a) of Commission Regulation (EC) No 2790/1999 of 22 December 1999 on the application of Article 81(3) of the Treaty to categories of vertical agreements and concerted practices, indicates that that the restriction of the buyer's ability to determine its sale price, without prejudice to the possibility of the supplier's imposing a maximum sale price or recommending a sale price, provided that they do not amount to a fixed or minimum sale price as a result of pressure from, or incentives offered by, any of the parties, falls under the scope of Article 81(1) EC. This principle can also be found in Article 5 (d) of Commission Regulation (EC) No 2659/2000 of 29 November 2000 on the application of Article 81(3) of the Treaty to categories of research and development agreements. Recital 17 states explicitly that, in principle, certain severe anti-competitive restraints should be excluded from the benefit of the block exemption in Article 1, which exempts certain agreements from the scope of Article 81(1). These are limitations on the freedom of parties to carry out research and development in a field unconnected to the agreement, the fixing of prices charged to third parties, limitations on output or sales, allocations of markets or customers, and limitation on effecting passive sales for the contract products in territories reserved for other parties.

195 OECD 1985, paragraph 199. See also the opinion of Advocat General Léger in Arduino.

196 Commission Decision 95/188/EC of 30 January 1995 relating to a proceeding under Article 81 of the EC Treaty (IV/33.686 - Coapi), OJ 1995, L 122/37 [1995] 5 CMLR 468, paragraph 41. 
Such a method dissuades undertakings whose costs are lower from lowering their prices, and thus creates an artificial advantage for undertakings which have the least control over their production costs. ${ }^{197}$ In the event of advisory prices, professionals are, in theory, therefore still free to set their prices, although the risk of collective pricing behaviour is rather high. ${ }^{198}$ As suggested by the (then) Competition Commissioner Mario Monti in 2004, recommended prices can mislead consumers as to what is a reasonable price for the service they are receiving, and as to whether this recommended price is negotiable. As shown by the Commission Staff Working Document of September 2005, 'The key justifications given for maintaining recommended fee scales centre on the need to provide a guide to consumers on likely costs and protect against what is termed 'unfair' competition between practitioners. However, recommended fees and reference scales can still act to facilitate price co-ordination.'

It follows that, since price regulations are liable to restrict competition, tariff regulations imposed by professional associations should, in principle, be prohibited, since their object constitutes an appreciable restriction on the freedom of professional action, more exactly on the freedom to fix their individual scales of charges for payment for services to clients, and are thus at odds with the economic freedom of professionals. ${ }^{199}$ Price restrictions prevent consumers from benefiting from services at lower prices which more efficient agents could provide, and form a disincentive for agents to seek to alter their working practices to enable them to reduce their costs. The restrictions therefore fail to allow consumers a fair share of the benefits, and do not improve the distribution of services or promote technical or economic progress. ${ }^{200}$ Fixed prices therefore constitute an agreement having, as its object, the establishment of scales of charges for clients and, as such, are contrary to Article 101(1) (a) TFEU (Article 81(1) EC). ${ }^{201}$ As stated

197 Commission Decision 96/438/EC of 5 June 1996 relating to a proceeding pursuant to Article 81 of the EC Treaty (IV/34.983 - Fenex), OJ L 181, 20 July 1996, pp. 28-36. See also the 2003 study of Paterson, Fink \& Ogus and the OECD reports on competition in professional services.

198 Philipsen 2003, p. 36.

199 In this regard it can be added that, in 2008, the Belgian Competition Council decided that the Association of Interior Architects of Belgium (not a regulated profession) had infringed the competition rules by adopting and publishing a deontological norm with a scale of minimum fees. However the European Parliament seems to have taken another view on fee scales. The European Parliament, in point 9 of its Resolution of 5 April 2001 on scale fees and compulsory tariffs for certain liberal professions and, in particular lawyers, and on the particular role and position of the liberal professions in modern society, OJ C $21 \mathrm{E}$, 24.1.2002, p.364 that: only compulsory tariffs established by professional bodies or Associations of all Members of a given profession may, according to circumstances, be regarded as decisions adopted by Associations of undertakings submitting to competition rules. Apparently, for the European Parliament, non-binding fees are not under the control of the competition authorities. See: Resolution of the European Parliament of 5 April 2001 on scale fees and compulsory tariffs for certain liberal professions, in particular lawyers, and on the particular role and position of the liberal professions in modern society. Furthermore, on 23 March 2006, the European Parliament has adopted a resolution on the legal professions and the general interest in the functioning of legal systems. The European Parliament considered that fee scales or other compulsory tariffs for lawyers and other legal professions are justified by the pursuit of a legitimate public interest (when) Member States actively supervise the involvement of private operators in the decision-making process.

200 Commission Decision 95/188/EC, paragraph 43.

201 Ibid. 
above, recommended prices can also have this effect where compliance with a recommendation by the undertakings to which it is addressed has an appreciable influence on competition in the market in question. ${ }^{202}$ Indeed, the fixing of prices, even those which merely constitute a target, affects competition, since such target prices enable all the participants in a cartel to predict, with a reasonable degree of certainty, what the pricing policy pursued by their competitors will be.

Even though fee restrictions can restrict competition, they can be a useful tool to prevent the problem of adverse selection if consumers are able to distinguish on quality. Furthermore, it is possible that public interest objectives can justify the fixing of minimum prices, for example to prevent professionals from offering services below price, causing quality to deteriorate. Under conditions of asymmetric information, advertising will focus on aspects that consumers can easily access, such as prices or commercial quality features (location of the notary's offices and availability of parking space, free cup of coffee, etc.) and may thus be a useful complementary tool to prevent adverse selection, which leads to excessive price competition among professionals and results in an overall reduction of the quality of the services provided. ${ }^{203}$ However the quality of services can be guaranteed by measures of a different type. Less restrictive mechanisms such as licensing, certification, quality standards and information regulation can already empower consumers to make more informed purchasing decisions and support highquality services. ${ }^{204}$ Furthermore, active monitoring by consumer associations on pricing, and the collection and publication of survey-based historical price data by independent organisations, can provide consumers with more information. ${ }^{205}$ It follows that the regulation of fees in combination with limitations on entry is dysfunctional in terms of improving quality, since it is precisely the facilitation of market entry that raises the chances of a successful quality-enforcing policy.

As concluded by Van den Bergh, as clients often cannot reliably evaluate service quality, even after treatment (credence goods), there seems to be a case for more comprehensive quality-enforcing regulation. ${ }^{206}$

\section{$b \quad$ Advertising restrictions}

Advertising may facilitate competition by informing consumers about different products and allowing them to make better informed purchasing decisions. Advertising is therefore generally permitted, provided that it is true and objective, and conforms to basic principles such as integrity and compliance with professional secrecy. ${ }^{207}$ Objective information satisfies the need among consumers to find their way in an often unknown, complex and new territory. Advertising restrictions may reduce competition by constraining the flow of information, and increasing the costs of gaining information about

202 This has been confirmed in several rulings of the ECJ. Case C-96/82, IAZ. For more information on the application of competition law to the liberal professions I refer to Wendt 2009.

203 Van den Berg \& Montangie 2006, p. 210.

204 Case C-35/99, opinion of Advocat General Léger, paragraph 117.

$205 \operatorname{COM}(2005) 405$ final p. 21

206 Van den Bergh 1999, p. 105.

207 Commission decisions of 7 April 1999, relating to a proceeding to Article 81 of the EC Treaty (IV/36.147 EPI code of conduct), 1999/267/EC, OJ L 106, 23.04.1999, p. 14. See also Bicho 1999/2, pp. 24-25. 
different products. ${ }^{208}$ If advertising is banned, the established professionals have a clear competitive advantage and newcomers are disadvantaged. ${ }^{209}$ This results in a limited choice for consumers since it is more difficult to shop around for a good price and service, and this may have adverse effects on employment. Advertising is thus a means for existing firms to reaffirm their strengths by discouraging clients from searching for other products. Since newcomers are more likely to charge lower prices to gain consumers' trust, and may have to spend more on advertising, to the advantage of existing firms, restrictions on advertising can protect them by enabling them to compete. ${ }^{210}$

In this regard, Stephen and Love after reviewing seventeen studies on advertising, came to the conclusion that restrictions on advertising increase the fees charged for the profession's services and that the more advertising there is, the lower the fees. ${ }^{21}$ There is therefore a connection between advertising and sellers' individual price elasticity. ${ }^{212}$

As suggested by Caron, in markets for relatively homogeneous products, advertising will stimulate consumers' search activity for low-prices, which will cause the demand curve facing each firm to become more price elastic. ${ }^{213}$ This means that a greater degree of price comparison by consumers will lead to greater reductions in sales for any seller who raises prices, and this will lead to lower prices in the presence of advertising. ${ }^{214}$ In markets for relatively non-homogeneous goods, advertising will help consumers gather information for quality comparisons by increasing consumers' familiarity with a wider variety of market options, again causing increases in the own-price elasticity of the demand curve. In the case of search goods, this will be accomplished by directly informing consumers of the availability and qualities of alternative seller's products and, in the case of experience goods, advertising will indirectly increase consumer information by encouraging experimentation with more market brands. ${ }^{215}$

Just like legal services which are discussed by Caron, architectural services are never fully routine and fully standardized. If we consider them as non-homogeneous products, the full application of the view envisaging a relationship between advertising and increased price elasticity will be harder. It can, in fact, hold for search and experience goods, whose quality can be ascertained prior to, or after, purchase, but not for credence

208 The prohibition of advertising can also constitute a restriction on the free movement of persons/freedom of establishment. See Case C-405/98 Konsumentombudsmannen (KO) v. Gourmet International Products $A B(G I P)$ [2001] ECR I-1795.

209 Comments and concluding remarks of Commissioner Monti at the Conference on Professional Regulation, European Commission Centre Broschette, Brussels, 28 October 2003.

${ }^{210}$ Caron 2008, p. 36. Restraints on advertising enhance the ability of professionals to sustain collusive prices or, at least, to charge significantly above cost.

211 Stephen \& Love 2000, no. 5860. These findings are based on several academic studies. See also Benham 1972, pp. 337-352; Cady 1976, pp. 493-510. See in this regard also Cox, De Serpa \& Canby 1982, pp.305318 who conclude that advertisers have lower fees.

212 Comanor \& Wilson 1979, pp. 453-476.

213 Caron 2008, p. 33. It should be noted that a person selling a homogeneous product or providing a homogenous service in a perfectly competitive market is not likely to advertise because this would have costs and no benefits for him. Nevertheless, the industry as a whole may advertise in the hope of shifting the market demand curve to the right.

214 Stigler 1961, pp. 213-225.

215 Nelson 1974, pp. 729-754. 
goods, the quality of which may not be judged even after purchase. Thus, advertising of credence goods on the part of the seller may be more misleading than informative. ${ }^{216}$

As indicated by Maks and Philipsen, on the one hand, if the availability of price information was increased through advertising, this could discourage quality competition and could lead to a degradation of quality on the market. ${ }^{217}$ However, American and Canadian empirical studies provide a good deal of evidence that advertising does not adversely affect quality. ${ }^{218}$ It has been shown that even if price can communicate no information directly about quality, it can do so indirectly, because price serves as a positive signal of quality, when price advertising is allowed. Price advertising is therefore welfare enhancing, because it improves consumer choice. However, a problem arises if price advertising is undertaken exclusively, or at least principally, by low-price/lowquality suppliers, since in these cases price advertising becomes an adverse signal on quality. As pointed out by Rizzo and Zeckhauser, since professionals are keen to avoid such adverse signals on quality, price advertising will be uncommon in most professions. ${ }^{219}$ Therefore not only may advertising have an effect on quality, perceptions of quality may have an effect on the form of advertising chosen by professionals. ${ }^{220}$

On the other hand, the prohibition of advertising will lead to higher search costs and higher fees. ${ }^{221}$ As an instrument to prevent quality degradation that results from adverse selection, advertising restrictions seem to be disproportional. ${ }^{222}$ It follows that obliging the producers/service providers to furnish information about the quality of the goods/services concerned would therefore be fruitful. However, as stated above, in the area of professional services, the disclosure of such information is a complicated matter, due to the fact that almost every service provision is different in nature. The 'repeat buying by consumers mechanism' provides incentives for suppliers of experience goods to produce goods and services of above minimum quality and to disclose information on quality voluntarily. ${ }^{223}$ If consumers are satisfied with their purchase, a further relationship with the professional is based on this positive experience, and they are likely to lead to good publicity for other consumers. Therefore, advertising is important to persuade consumers to a first buy. ${ }^{224}$ For products and services which are bought repeatedly, information regulation is not needed, because consumers can go to a different supplier the next time. Since the 'repeat purchase mechanism' is mostly not applicable to architectural services, there is a risk also that low quality products will be advertised in a

${ }^{216}$ Cox 1989, p. 135. In the case of search goods, there is no ground to forbid price advertising, since advertising will lower search costs and fees

217 Maks \& Philipsen 2002, p. 24.

218 See for example Muris \& McChesney 1979, pp. 179-207.

219 Rizzo \& Zeckhauser, pp. 381-421.

220 Stephen 2004 , p. 148. A ccording to the public interest approach, it is necessary to regulate the provision of information if professionals abuse their reputation by lowering the quality of his services. The higher the quality is, the higher the opportunity costs are. See Leland 1979, p. 1331.

221 Stephen \& Love 2000, p. 997.

222 Bond, Kwoka, Phelan \& Whitten 1980

223 Cave 1985, p. 343.

224 This of course does not count for providers who only intend to make big profits in the short run. Shapiro calls this a 'fly-by-night-strategy': Shapiro 1983, pp. 659-680. 
possibly fraudulent way. The prohibition of misleading -but not all- advertising, is thus certainly beneficial in these cases.

c. Structural restrictions

In the $19^{\text {th }}$ Century and earlier, membership of a profession entailed that the practitioner was regarded as having personal responsibility for the integrity and validity of the advice or the service which he provided. Therefore, they were expected to practise primarily as sole practitioners, the only form of combination permitted being that of an unincorporated partnership, where all members of the firm took joint and several responsibility for one another. Practising behind the shield of incorporation with limited liability was regarded as fundamentally inconsistent with the status of professional practitioner. 225

In today's market for professional services, there is a need for forms of cooperation between professionals and, more specifically, for multi-disciplinary practise. This is a consequence of all sorts of technological developments bringing about complex issues which require highly specialized service providers. Since it is impossible to be specialized in all these issues, cooperation is necessary. Furthermore, due to globalization, multidisciplinary business are needed and wanted by multinational firms, to deal with complex cross-border transactions.

States and professional associations often restrict such forms of cooperation since they fear that the independence and objectivity of the professionals is in danger. They argue that conflicts of interests can arise between architects who 'should' practise their profession with honour and dignity, and entrepreneurs who only have a pecuniary interest. Unreserved and unlimited authorization of multi-disciplinary partnerships between different professions can lead to an overall decrease in the degree of competition prevailing in the market as a result of the substantial reduction of undertakings present in that market. However, business structure regulations restrict the ownership structure of professional services companies, the scope for collaboration with other professions, and the opening of branches, franchises or chains. This may have a negative impact if providers are inhibited from developing new services or cost-efficient business models. Just like the other restrictions discussed, structural restrictions are an ex ante method of dealing with an ex post problem.

As proposed by Fletcher, the creation of large corporate entities can arguably reduce the tendency to provide poor quality service, and can limit stimulation for unnecessary demand. She refers to the example of a professional working in a large firm who will only receive a share of the profits (if anything) as a result of any extra business he or she obtains from the client, whereas a professional working as an individual receives the full benefit of induced demand. ${ }^{226}$ The latter has therefore presumably increased incentives to engage in such behaviour. Furthermore, one of the most common market-based methods of solving asymmetric information issues is the creation of a reputation. A corporation will have a strong incentive to control the behaviour of its staff, such that

${ }^{225}$ Cooke 2004, p. 230.

${ }^{226}$ Fletcher 2004, p. 77. 
this reputation is not tarnished. ${ }^{227}$ Moreover, since professional services result in a wide variety of external effects which stem from both the nature of the private services and from political decisions which oblige certain private service providers to also provide certain public services, the production of private and public services by a single professional implies economies of scope or joint production. It follows that it is less costly if a professional produces both private and public services with regard to the same cases. ${ }^{228}$ Because of these characteristics, it is argued that professional services are better produced and sold within organizational formulas -such as professional associations, professional firms or hybrids- which are quite different from those of neoclassical abstractions of firms and markets. ${ }^{229}$ A range of services can then be provided, since one-stopshopping is easy and less costly for consumers, increases efficiency and increases income. In the case of bigger corporations, there will be a better division of labour with more specialization, so that there are fewer costs. For example, there may be a division between architects designing industrial buildings and those designing private houses.

As proposed by the European Commission, business structure regulations appear to be less justifiable in professions where there is no overriding need to protect practitioners' independence. ${ }^{230}$ The architectural and engineering professions, for example, function effectively without these regulations in most Member States. It therefore appears unlikely that business structure regulations are essential to protect consumers of these services. This is confirmed in 1990 by the research by Cox and Foster who reviewed a large amount of empirical literature on the effects of regulation on quality and fees and came to the conclusion that a majority of the studies finds quality to be unaffected by licensing or business practice restrictions associated with licensing. ${ }^{231}$ Business structure regulations appear to be more justifiable in markets where there is a strong need to protect practitioners' independence or personal liability. There might, however, be alternative mechanisms for protecting independence and ethical standards which are less restrictive in terms of competition. In some markets, stringent ownership restrictions might therefore be replaced, or partially replaced, by less restrictive rules. ${ }^{232}$

Fletcher 2004, p. 76

28 It is less costly to produce a set of goods in one firm than it is to produce that set in different firms.

229 Arruňada 2004, pp. 54-58.

${ }^{230}$ In this regard reference should also be made to Directive 2006/123/EC which hols in Article 25 that Member States shall ensure that providers are not made subject to requirements which oblige them to exercise a given specific activity exclusively or which restrict the exercise jointly or in partnership with different activities. Nevertheless, providers practising a regulated profession may be made subject to such requirements: in so far as this is justified in order to guarantee compliance with the rules governing professional ethics and conduct, which vary according to the specific nature of each profession, and is necessary in order to ensure their independence and impartiality. Furthermore, in the event that multidisciplinary activities between these providers are authorised, Member States have to ensure that conflicts of interest and incompatibilities between certain activities are prevented; that the independence and impartiality required for certain activities is secured, and that the rules governing professional ethics and conduct for different activities are compatible with one another, especially as regards matters of professional secrecy.

231 Cox \& Foster 1990.

${ }^{232}$ Communication from the Commission - Report on Competition in Professional Services, $/{ }^{\star} \mathrm{COM} / 2004 /$ 0083 final $^{*}$ / 
The Architectural Profession: an Economic Approach

\section{d. Market conduct regulation in Belgium and the Netherlands}

As indicated in Part II of this thesis, the Belgian deontological code aims to regulate the conduct of architects practising in Belgium. All architects are subject to the provisions of this Code since once a professional is registered (which is necessary to practise the profession unless Article 8(2) or (3) AO is applicable) he automatically becomes a member of the Order, which entails that the deontological code is applicable. In the Netherlands there is no mandatory deontological code. Only architects who voluntarily became a member of the BNA are subject to the BNA's rules of conduct. However, standard terms often regulate the relationship between architects and their clients. By the creation of defaults rules, transaction costs can be reduced.

With regard to the architectural profession specifically, one can say that there are currently no mandatory, minimum or maximum fee scales for architectural activities in Belgium and the Netherlands. ${ }^{233}$ Nevertheless, in both countries, prices are often calculated as a percentage of construction costs. Such a system is liable to undermine the incentives for architects to design in a way that reduces unnecessary construction costs. Furthermore, there is a lot of uncertainty as to the price which the client has to pay for the services provided by the representative for a long time. This precludes transparency as to the price payable by the user.

While in the late 1990s, recommended prices were abolished for architects in France $^{234}$ and while in the United Kingdom, the Office of Fair Trading came to the conclusion that the Royal Institute of British Architects' (RIBA) indicative fee guidance could facilitate collusion ${ }^{235}$, in 2003 the European Commission sent the Belgian Architects' Association a warning that its recommended minimum fee scale could constitute a violation of EU competition rules. ${ }^{236}$ In 1967, this fee scale found its origin in Article 12 of the Association's Code of Ethics, which new version was given binding force by Royal Decree in $1985 .{ }^{237}$ After becoming aware of the fee scale's difficult and disputed status, in 2002 the Belgian Architectural Association made a statement indicating that, since both

233 In its 2005 communication to the Council, the European Economic and Social Committee and the Committee of the Regions, the Commission concluded that several Member States were making progress to abolish fixed tariffs. Only four Member States (Cyprus, Greece, Italy and Luxembourg) still had fixed prices for architects and engineers at that time. See COM(2005) 405 final, pp. 12-20. The minimum scale which was legally enforced in Germany did not result in significant incomes for architects: see the ACE Document on Competition Policy and Professional Practice of Architects, http://www.mo.org/tr./UIKDocs\%5Cacecompetitionpolicy.pdf, last consulted 5 September 2009.

234 The French Conseil de la Concurrence also prohibited the French Architects' Association from further elaborating and distributing fee scales: see Decision no. 97D45 of 10 June 1997 and Communication from the Commission - Report on Competition in Professional Services $/{ }^{*} \mathrm{COM} / 2004 / 0083$ final ${ }^{*} /$

235 However, the Office of Fair Trading adopted the RIBA's new fee guidance based on historical information and the collation of price trends that do not provide a lead on the current year's prices.

236 On other occasions, the Commission also held that Article 81 EC (101 TFEU) fully applies if a Member State gives authority to a professional association to fix prices, thereby violating Article 3 (g), 10 and 81 EC. See e.g. Consiglio nazionale degli spedizionieri doganali: Decision of 30 June1993. [1993] OJ L 203; Colegio Oficial de AGhentes de la Propriedad Industrial: Decision of 30 January 1995 [1995] OJ L 122. When professional associations promulgate fee schedules on the basis of such authority, they will not be immune from antitrust scrutiny. In both decisions, price fixing was held to be illegal.

237 Article 39 of the Architects' Order Act empowers the Crown, at the National Council's request, to give binding force to the Code of Ethics by means of a Royal Decree discussed in Cabinet. This happened on 5 July 1967 while the new Code of Ethics was given force by Royal Decree in 1985. 
the Belgian Competition Council and the Court of Justice of the European Union seem to be taking a particular interest in the compatibility with the competition rules of fee scales drawn up by regulated professions, the fee scale should merely be understood as a guideline. ${ }^{238}$ This did not stop the Commission from finding that the fee scale had violated EC competition law. While it is true that the cost of the work is a determining factor in the insurance premium to be paid by the architect, the Commission decided that there was no other direct link between the cost of the work and the architect's costs, or any necessary link with the value added by his services. According to the Commission, fees charged for professional service should reflect the architect's skills, efficiency and costs, and perhaps his fame or notoriety, and should not be dependent solely on the value of the works or the price of the entrepreneur. Since the circulation of recommended tariffs by a professional organisation is liable to prompt the relevant undertakings to align their tariffs, irrespective of their cost prices, such a method dissuades undertakings whose costs are lower from lowering their prices, and thus creates an artificial advantage for undertakings which have the least control over their production costs. ${ }^{239}$ Furthermore, recommended prices can mislead consumers as to what is a reasonable price for the service they are receiving, and as to whether this recommended price is negotiable. ${ }^{240} \mathrm{~A}$ scale that imposes or recommends minimum fees is unlikely to protect consumers against excessive fees. Furthermore, such a scale does not prevent unscrupulous architects from offering poor-quality services. As indicated above, the fee scale can even protect them by guaranteeing a minimum fee. Since the fee scale was liable to discourage architects from working in a cost-efficient manner, reducing prices, improving quality or innovating, it was decided that it violated Article 101(1) TFEU. ${ }^{241}$

In the Netherlands, the SR 1997 used to indicate the fee basis by means of a reference to NEN 2631, which is a Dutch norm indicating how investment costs of building should preferably be calculated. A formula was drawn which led to the determination of a certain percentage which would then result in the fee. This formula left no room for price competition whatsoever and was often also used by architects which were no BNA members or to contracts to which the SR 1997 was not made applicable and was not only used by the Arbitration Institute Architecture but also by the ordinary courts. This form of price fixing was not taken over by the NR 2005.

It follows that the absence of price fixing leaves open the possibility of introducing price reductions which, in turn, generates more competition. However the fixing of prices as a percentage of the construction costs, does not seem to be cost-efficient.

238 Important in this regard is that Article 12 stipulated that an architect may incur disciplinary penalties if he infringes the 1985 Code of Ethics.

239 See on this matter also Case C-8/72 Vereeniging van Cementhandelaren, paragraph 21 . As held by the ECJ in Case C-246/86 Belasco, even though fixed prices might not have been observed in practice, the decisions fixing them have the object of restricting competition. In this regard it should therefore be noted that while a professional association may, in certain circumstances, legitimately pronounce ex post on the level of fees being claimed, it is not allowed to attempt to harmonise the level of fees ex ante.

240 As noted above, shortly after the scale was drawn up, the Association drafted a standard contract in which the only option for determining fees was a reference to the scale; this too attests to its intention to restrict competition on prices between its members, by drawing up a minimum fee scale. It circulated this standard contract for eighteen years.

241 The Belgian Architectural Association was condemned by the European Commisson in June 2004. 
With regard to advertising, Article 13 of the Deontological Code in Belgium foresees that the architect is allowed to make his activities known to the public in an independent and discrete manner. Obtrusive publicity has to be avoided however. The architect has to take into account that his name and title are not used in an illegal way by others, or are used for commercial purposes by others. He is allowed to mention his title in books, and is even obliged to mention it on a plate at the building site during the construction work, and is allowed to have it mentioned afterwards. In the Netherlands, there is no general regulation about advertising which is applicable for all architects. The disciplinary code of the BNA mentions, in Article 2(2), that architects have the freedom to make their activities, expertise, experience and competence known to the public.

Since there are no restrictions on advertising in Belgium and the Netherlands, consumers can be informed adequately about the services offered by architects in order to come to a decision. However, since architectural services are often all different in nature, the disclosure of information is complicated, meaning that advertising might mislead consumers. It follows that advertising is quite important with regard to persuading clients in terms of a first buy, while the repeat buying mechanism should provide incentives to provide a good price-quality ratio.

Finally, with regard to structural restrictions in Belgium, mention should be made of Article 6 AA and Article 10 of the Deontological Code, by which architects are not allowed to practise the profession of entrepreneur. Since architects should be independent (Article 4 Deontological Code) every association of an architect with an entrepreneur is forbidden.

In the Netherlands there is no such prohibition. Even though it may be argued that architects should be independent, it might be questioned whether such a severe restriction is efficient, since the profession seems to function quite well in states in which there is no incompatibility between architects and entrepreneurs.

In any case it should be noted that such restrictions prevent a single company from offering a total service package in which the building was designed and constructed by professionals who consider themselves as partners rather than adversaries. Such cooperation can lead to higher levels of efficiency since there are fewer negotiation and transaction costs (the architect contracts with one company) while the professionals involved are more likely to cooperate from the beginning, and to seek solutions together in the event of a problem with the design or the construction work. From a public interest perspective, it might therefore be argued that negative externalities can be detected more easily. It follows that, from an efficiency point of view, the Dutch system should be preferred.

\section{e. Conclusion}

It can be concluded that price regulations (fixed and recommended prices), advertising restrictions and restrictions on business structure, can all limit competition between professionals within the profession, but also with other professions. They can often be found in the professional codes and the rules of conduct of professional associations. Even though regulation might be needed to cure market failure, the least restrictive 
mechanism should be chosen to guarantee quality (proportionality). In any case, the costs of correcting market failure by means of regulation need to be smaller than the efficiency gains derived from the regulation.

\section{Findings of the European Commission}

As indicated in Part I, the Lisbon European Council in March 2000 adopted an economic reform programme to make the EU the most competitive and dynamic knowledge-based economy in the world by 2010. In improving the competitiveness of the EU economy, professional services were held to play an important role. A large-scale research project on competition in professional services was conducted by the European Commission. In this way, the Commission aimed to determine whether the current regulation of professional services serves the interests of consumers, and is therefore the most efficient and least restrictive of competition, or whether better regulation, more adapted to the modern world, could help spur economic growth, and deliver better services and value for consumers. ${ }^{242}$ The Commission based this research on an independent study which was carried out by the Institute for Advanced Studies in Vienna which contained a schematic overview of regulation in the then $15 \mathrm{EU}$ member States for six professions, including architects. For each of these professions, an overview was presented of all the rules restricting entry to the profession, and the rules restricting market conduct. A 'regulation index' was used which represented the degree of regulation between 0 and 12 . In this way, regulations concerning price fixing, recommended prices, advertising regulations, entry requirements and reserved rights and regulations governing business structure and multi-disciplinary practices as categories of regulation which are possible to restrict competition, were identified. ${ }^{243}$

${ }^{242}$ See http://ec.europa.eu/comm/competition/sectors/professional_services/overview_en.html, last consulted 1 December 2009.

${ }^{243}$ In its report, the Commission also mentioned the reactions of the respondents to the findings of the IHS With regard to architects, the majority of respondents supported appropriate entry regulation to ensure that architects are competent to carry out their functions and respect safety standards. However, the Commission argued that few respondents commented in detail on the extent to which licensed or certified architects should hold exclusive or reserved rights. Likewise, very few discussed the regulatory framework in countries such as Denmark, Ireland and the Netherlands, where unqualified practitioners are permitted to offer a range of architectural services. The Architects' Council of Europe, for example, commented that control mechanisms are essential because the quality of architectural services is only discernible after the construction process.

With regard to price fixing, the majority of the respondents argued in favour of price regulation and recommended prices for architectural services. Most suggested that these regulations are necessary to ensure quality. Unrestricted price competition would force prices to levels at which it would be impossible to ensure quality and safety standards. According to the Architects' Council of Europe, for example, reasonable fixed prices are necessary to ensure that professionals compete on quality rather than on price. Without fixed prices, service providers would be tempted to offer the lowest price in order to gain contracts, leading to a reduction in the quality of construction. The Architects' Order of Belgium argued that fixed prices are necessary to allow architects to make a reasonable profit and to exercise their functions with honour and dignity. They suggested that price competition would force architects to use inferior material that would reduce the strength and security of buildings. In the Commission's view, however, none of the respondents explained why price regulation, as opposed to other mechanisms such as planning permission procedures, construction standards and monitoring, should offer an effective means of quality control. No reason was given to indicate why price regulation should be expected, in itself, to improve or safeguard construction standards, nor was any explanation given as to why architects subject to price regulation would not have 
After making a comparative analysis of nearly all EU Member States in terms of key economic variables and indicators (ratios which are calculated based on the number of firms in a country, their turnover, employment levels, population, GDP, the number of practising professionals, etc.), the IHS came to the conclusion that, with regard to technical services - under which architectural services can be qualified, - the existence of relatively higher numbers of larger firms, employing greater numbers of persons, could be associated with a low degree of regulation, and seemed to be a clear result of firms having the scope to merge. A higher degree of regulation was associated with a relatively low number of professionals, lower values of volume per employed person (lower productivity) and lower volume per firm, which means that firm size, i.e. expressed as volume of business, is higher in less regulated countries. Furthermore, it was held that there was a real risk that the advantages which would result from an optimal size of firm (economies of scale) were not utilized fully in more regulated branches on account of missing incentives - with less competition there is less incentive to exploit a potential increase in productivity. These findings point in the direction of effects predicted by the private interest theory of regulation. However, research showed that the volumes of output in a country with a high degree of regulation tend to be higher than expected, and are often comparable to the volumes of output in a country subject to a lower degree of regulation, due to the economic strength of the branch in that country. In any case, the research demonstrated that the level of professional regulation differs widely from country to country. The architectural and engineering professions were found to be among the least regulated professions.

Taking into account all these findings, the main conclusion of the IHS in its research report was that a reduction of regulation is possible without having to fear the risk of a

strong motivations to reduce quality in order to maximise profits.

No evidence was provided to suggest that standards are higher in the minority of Member States that have minimum or fixed fees. A large majority of respondents were also in favour of recommended prices for architectural services. However, few commented in detail on the justification for this type of regulation. As held by the Commission, few of the respondents commented on the concern that recommended prices may facilitate collusion. Likewise, they did not explain why consumers should need recommended prices for architectural services, despite the fact that they do not rely on recommended prices when purchasing other complex products. In this regard, the Bundesarbeitskammer, an Austrian consumer organisation, even suggested that the Austrian professions sometimes lead consumers to believe that recommended prices are fixed prices in order to avoid giving discounts. They added that Austrian architects face few incentives to reduce prices and costs.

With regard to advertising, the majority were of the opinion that architects should be free to engage in truthful advertising.

Finally, as far as business structure and inter-professional cooperation is concerned, the majority believed that there is a need for regulation to ensure transparency of ownership with regard to architectural services companies, and to preserve architects' independence from other groups. In this way, the Architects' Council of Europe argued that, given the complex nature and potential impact of architectural services, it is important for clients to be aware of the ultimate ownership of architectural services companies. The Council also suggested that architects' independence should not be compromised as a result of cooperation with other groups. However, the Commission considered that the respondents did not comment on the potential economic advantages of cooperation between architects and other groups such as engineers and builders. Nor did they comment on service provision in the majority of EU Member States where there are no significant regulations restricting architects' participation in multi-disciplinary practices. 
market breakdown. ${ }^{244}$ The report thus concluded that the lower regulation strategies which work in one Member State might be made to work in another, without decreasing the quality of professional services, and for the ultimate benefit of the consumer. ${ }^{245}$ It was held that there is no indication of malfunctioning of markets in relatively less regulated countries. This might suggest that some rules are unnecessary. It was concluded that there is no link between the density of professional regulation and the protection of consumers, and that a high regulatory density is not very efficient. On the contrary, according to the report, low regulation is not a hindrance, but rather a spur to overall wealth creation. The report also led to the conclusion that less regulated countries have relatively lower revenues per professional, but a proportionally higher number of active professionals who generate a relatively higher overall turnover. This all suggests that more freedom in the professions is not a hindrance, but rather a spur to overall wealth creation. Since professional regulation may eliminate or limit competition, this can lead to decreased efficiency and innovation and can reduce the incentives to lower prices and increase quality. ${ }^{246}$ The Commission indicated that it would like to see the regulatory restrictions in Member States reviewed and, where they are not objectively justified, removed or replaced by less restrictive rules.

Whilst pointing out that the best way to achieve overall change would be by voluntary action of those responsible for setting the existing restrictions, primarily by means of reviewing the existent regulation through a proportionality-based approach ${ }^{247}$, the

244 Paterson, Fink \& Ogus 2003, I, p. 104, p. 111, p. 119 and p. 127.

245 Ibid.

246 Communication of 9 February 2004, COM (2004) 83 final, no. 23. As noted above, this was already acknowledged by the ECJ in its landmark Wouters decision where it held that certain types of regulation, even when they restrict competition, may be necessary for the proper practice of certain professions and should therefore be permitted. However, as held by Van den Berghe, the Commission's policy line is a moderate one since it still holds that some level of regulation may be needed to cure the existence of information asymmetry, externalities and public goods in professional services while total de-regulation may not be required to enhance consumer welfare. See Van den Berg \& Montangie 2006, p. 197. According to the Commission, some form of less restrictive re-regulation may suffice, so that some exceptions to the competition rules should therefore be allowed

247 In this regard it should be noted that a proportionality test is not in line with the ECJ's case law in Arduino. In the case law concerning Member States' liability under Article 3 (1) (g) jo 10 (2) and 81 (1) EC, there is no mention at all of the need for state measures to be proportional to the achievement of the public interest. Even though the ECJ mentions, in paragraph 109 of Wouters, that it does not appear that the effects go beyond what is necessary, the Court also stated that the fact that less restrictive rules may be applicable in certain Member States does not mean that a more restrictive rule in force in another Member State infringes EC competition law. This is due to the fact that, in the absence of specific EC legislation in this field, each Member State remains in principle free to regulate the exercise of the legal profession within its territory. The Court thus held that bar associations have a margin of discretion to decide what they deem appropriate and necessary to protect the proper practice of the profession in their respective Member States. See Wouters, paragraph 105 and 108. Accordingly, different States may consider different core values and/or different means to protect them as being necessary for the proper exercise of the profession, so that professional regulations may significantly differ from one Member State to another. See Wouters, paragraph 99 and 108. It would therefore be contrary to EC competition law to unduly limit the margin of discretion through a proportionality principle (the most appropriate solution is not necessarily the least restrictive one). There is currently therefore, no basis in EC competition law for the public interest and the proportionality test proposed by the Commission in paragraph 88 of its Report, so that Member State are under no compulsion to amend their existing restrictive regulations in order to comply with such a test. See Siragusa 2004, p. 587. 
Commission made clear that a simple elimination of anti-competitive mechanisms may not be enough to bring about more competition to this sector, and therefore that both regulatory authorities and professional bodies should explore the need to use procompetitive accompanying mechanisms which increase transparency and enhance consumer empowerment. Such mechanisms include active monitoring by consumer associations, collection and publication of survey-based historical data or public announcements of the abolition of tariffs. The distinction between rules which are covered by competition law and rules which are not has to be decided on a case by case basis or more to the point, rule by rule, profession by profession. ${ }^{248}$ In any case, through coordination in the European Competition Network the Commission will keep monitoring the regulatory progress. ${ }^{249}$

However, the study of IHS and thus also the Commission's report got a lot of criticism.

With regard to the fact that the IHS report holds that a connection may be surmised between volume of business per professional and excess profit which means high profits for a smaller number of professionals are associated with higher regulation indices while low regulation is associated with higher employment and greater overall wealth creation, ${ }^{250}$ Van den Bergh and Montangie ${ }^{251}$ hold that this conclusion seems farfetched ${ }^{252}$, since higher volume (turnover adjusted for differences in price levels and GDP) does not equal higher profit. They argued that, by assuming that turnover is an indicator of profits, the IHS researchers have overlooked the fact that the costs of professional services are not necessarily the same for all countries ${ }^{253}$, which means that higher turnover does not imply higher supra-competitive profits. Turnover in a heavily regulated profession may be higher because the bureaucratic costs and prices are higher, or because professionals in highly regulated Member States work harder than in other Member States. It is also possible that prices are higher because of a higher service quality. The report assumes a reasonable homogeneity of quality of professional services across EC Member States, which is a very strong assumption given the heterogeneity of preferences (concerning price/quality relationships and the views on the scope of public goods

248 Competition in Professional Services: New Light and New Challenges, Speech by Commissioner Monti to the Bundesanwaltskammer, Berlin 21 March 2003.

249 National competition authorities have been active and a step change has been seen in their activity, with the majority reporting begin engaged in work in this field during 2004/05. The Commission found that the findings which could be drawn based on the fifteen 'old' Member States could equally be applied to the 10 new Member States. Competition authorities in Denmark, Ireland, the Netherlands and the United Kingdom have well established programmes in this sector - Denmark as part of a wider governmental regulatory reform programme. Authorities in Belgium, Estonia, Hungary, Poland and Slovenia also initiated structured work to bring reform to professions. In this way, architects in Belgium are now allowed to form incorporated firms. See Commission Staff Working Document, Progress by Member States in reviewing and elimination of restrictions to Competition in the area of Professional Services COM(2005) 405 final.

250 Paterson, Fink \& Ogus 2003, nr. 22, p. 4.

251 Van den Berg \& Montangie 2006, p. 199.

252 RBB Economics 2003, p. 17.

253 Turnover in a heavily regulated profession may be higher because the bureaucratic costs are higher as are the prices charged. Turnover can also be higher because professionals in highly regulated Member States work harder than in other Member States, or because the quality of the services is higher, leading to higher prices. 
to be provided by the professions) and the concomitant differences in the scope of the professional monopoly. It should also be taken into account that high incomes may also reflect appropriate quality rents. As held by Van Den Bergh, as long as quality measurement does not form part of the empirical work, strong policy conclusions do not seem warranted. It is thus concluded that the IHS Report does not take account of the potential effect of regulation on the quality of professional services. The magnitude of the costs and benefits of self-regulation is thus ultimately an empirical issue.

Furthermore, the report does not fully control for the risk of spurious correlation: the correlation between the degree of regulation (as indicated by the regulation index) and the level of employment (or total wealth) may be caused by a third variable linked to the two others (for example: gross domestic product) that is not controlled for.

Another criticism made by Van den Bergh and Montangie is that empirical work shows that deregulation does not automatically achieve the results desired by the policy makers, and may even provoke counterproductive effects. The Commission's reports and the IHS study do not contain any traditional competition law analysis or an economic empirical analysis, but base their decision with regard to the deregulation of prices on the fact that there does not seem to be market failure in states where prices are not, or are less, regulated. For this reason, the report assumes that price fixing does not form an essential regulatory instrument for the free professions. As pointed out above, studies on the effects of the liberalization of notarial services in the Netherlands show that prices may increase rather than decrease after deregulation, and that quality may be negatively affected by it. As suggested above, the IHS study does not consider the impact of regulation on quality. Furthermore, there is no convincing evidence that regulation of professional services decreases welfare. ${ }^{254}$ Furthermore, since the liberalization of professions is associated with a higher number of professionals, meaning that each architect has more competitors, it will be more difficult to earn a lot of money in a certain period of time. Certainly an architect established in a rural area feels the difference in his pocket when another architect settles in the same area, since people who are planning to build a house have suddenly the choice between two architects. If the prices they charge are about the same, the potential number of clients for each architect can be halved. This is not an attractive situation, since small areas contain only a small number of potential clients, and are thus not very profitable. Of course prices can be lowered to attract clients. However, the danger exists that a race to the bottom will take place, causing the architects to earn less money than if they worked in a big city. In a big city, bigger projects arise which are likely to generate more money. It follows that most architects are concentrated in areas with high population density to the detriment of rural areas. ${ }^{255}$ Consequently, persons living in rural areas do not have a lot of choice when it comes to professionals, unless they go all the way to a bigger city to find more architects so that

254 Van den Berg \& Montangie, 2006, p. 199.

255 An example of this theory can be seen in Iceland. Iceland liberalised pharmacy services in 1996 with the aim of increasing competition, cutting costs and improving the service to citizens. The result was that national expenditure in pharmaceuticals increased, and pharmacies became concentred in areas with high population densities to the detriment of the rural areas. See PGEU Presentation, Brussels 28 October 2003. 
they are able to compare between the services they offer. It can therefore be argued that the objective of improving services to citizens is not achieved. ${ }^{256}$

It should also be noted that the Commission did not look at reduced transaction costs and increased legal certainly brought about by regulation, and did not pay enough attention to market imperfections that such measures may cure (information asymmetry, etc.) or other goals of public interest (financial accessibility of services, guaranteed fixed prices). ${ }^{257}$

With regard to the architectural profession in particular, Katarina Nilsson, President of the Architects' Council of Europe (ACE) in 2003, held that even though the profession of architect turns out to be the least regulated profession of all the professions examined, in order to really compare differences, the different types of regulation of the profession must be put in the context of different building regulations in the respective countries. Therefore, it is important to be well informed of the range and type of services provided by the architect. In this regard, according to Nilsson, a seriously limiting factor in the IHS Study is the fact that it merely focused on the service provided by the profession and not, in any respect, on the effects of the service on society, of the context in which the service is used, and the scope of the service. ${ }^{258}$ In this regard, it should be mentioned that even though the IHS Study claims that fees are lower when professions are not regulated - which might be true in certain cases - the scope of the services charged for can vary, certainly when it comes to architectural services, and this also has a major impact on prices. In regulated countries, architects often have to take on more responsibilities than in less regulated ones in which the authorities' control of the built environment is more extensive.

Criticism was also put forward by the Architects' Council of Europe which did not agree with the deregulation plans of the Commission with regard to registration. It held that registration does not hinder competition since the professional bodies for architects are open to any professional that meets the requirements of qualification and training, and do not discriminate in their decisions. ${ }^{259}$ For architects, the only conditions to registration or membership are education, length of practice and that the professionals undertake to comply with the Codes of Conduct of the organization. According to the $\mathrm{ACE}$, none of these conditions could be said to hinder competition. They were created in the interest of consumers who have a clear and justified interest in knowing that anyone who is an architect will comply with certain standards which have been established to meet the needs of society and the individual consumer.

256 See for criticism of the IHS report with regard to the legal profession: Henssler \& Kilian 2003.

257 Van den Bergh \& Montangie 2006, p. 213.

258 Nilsson, former ACE President, Speech at the European Conference on Regulation and the Liberal Professions, Brussels, 28 October 2003. Reference was made to Case C-292/6 Gullung v. Conseil de l'Ordre des Avocats au Barreau de Colmar et al., Judgement of 19 January 1988, ECR, 1988, 111. The ECJ held that a registration requirement is not incompatible with Article $43 \mathrm{EC}$, and that a lawyer who was denied access to the Bar in a Member State other than his own, due to a failure to fulfil the necessary conditions of good character, could not rely on Community law to work as a lawyer in the other Member State. The role of the Bar as the final supervisor of entry into the profession was thus confirmed.

259 Nillson 2003. 
In any case, as pointed out by Philipsen, despite the inherently subjective process of assigning weights to different forms of regulation, it seems safe to conclude that the IHS regulation indices provide at least a reasonable indication of the level of regulation in EU Member States circa 2003, because a relatively large shift in the weights often leads to a relatively small change in the value of the index. ${ }^{260}$

\section{Conclusion}

Not only do states create regulation, but also self-regulatory systems make a combined use of the regulatory techniques described above: registration to become a member; certification to enjoy protection of the title; duty to comply with ethical rules; control of performance (sanctions), licensing, etc. ${ }^{261}$ From the analysis above, it follows that price fixing is the strictest regulatory instrument, followed by licensing, certification, imposing quality standards and information regulation. All these instruments can be applied by the government as well as by self-regulating groups. On the one hand, government or professional associations often use entry restrictions, restrictions on advertising, on fees or on conduct, to obtain a certain level of quality. Ex ante regulation is often created to increase the incentives to avoid the situation that professionals might otherwise have to offer poor quality service or induce unnecessary demand (moral hazard). On the other hand, professional groups themselves are likely to set standards too high in order to push competitors out of the market or to use licenses as an entry barrier. In this way, a strict regulatory system could lead to a monopolistic situation and monopolistic advantages for the professions concerned. As pointed out above, the creation of such monopolies can undermine competition. ${ }^{262}$ Therefore, many groups of professionals do not refuse, and even aim at a strong professional regulation. ${ }^{263}$

A lot of these restrictions are already removed by EU legislation and the case law of the Court of Justice of the European Union on the one hand, and initiatives at Member State level on the other. The public and private interest approaches to regulation as described above, and the empirical literature examining various forms of regulations in the professions, often lie at the heart of the action undertaken by the legislator. Research conducted by Van den Bergh and Montangie with regard to the abolishment of the solicitors' monopoly for conveyancing services in England and Wales, and the deregulation of the Dutch notary profession, indicates however that liberalization does not necessarily guarantee lower prices, so that increased competition is not guaranteed by it. They even found with regard to the Dutch notaries that there is a justified concern that competition might decrease quality and jeopardize the notary's integrity. Since this might be a result of the special characteristics of the notary profession, research is needed to determine whether this also applies to architects. Furthermore, the research indicates that regulation may be justified, even in a monopoly situation, as long as effec-

260 Philipsen 2008, p. 103. In this regard it should be noted that although the criticism of the IHS report is justified and correct, the criticisms mainly concerns the empirical analysis, with regard to which the IHS has already stated that it is merely a first attempt. The European Commission took these conclusions one step further however.

261 Van den Bergh 1999, p. 120.

262 Van den Bergh 1999.

263 Van Der Krogt 1981. 
tive instruments to control and monitor quality are not (yet) in place. It can likewise be questioned whether quality will deteriorate if everybody is allowed to perform architectural services, as is the case in the Netherlands, since it can be argued that if persons are engaged in designing a building but who are not 'real' architects, there is more uncertainty and possibly higher transaction costs, while in the case of regulation, there are reduced transaction costs. The answer to this question will depend on whether there are other mechanisms in the Netherlands which guarantee a sufficient level of quality. Van Gulijk concluded in this regard that the protection of the architect's function is better replaced by legal requirements with regard to the quality and the safety of the design, such as the requirements that have been established in the Dutch Building Decree. Such requirements also protect the safety, quality and public order interest of clients and of society in general, which was the reason in the first place for Belgian legislators wishing to protect the function of architects. Furthermore, whether the restrictions on competition resulting from exclusive rights (architectural monopoly in Belgium) and fixed prices do not go further than necessary to achieve goals of public interest, would require a cost-benefit analysis which compared the architectural monopoly in Belgium with the architectural title protection in the Netherlands. More empirical research is needed to solve this issue. It follows that, in any case, the most efficient regulatory instrument(s) should be chosen, and account should be taken of the effects of regulation on consumer surplus, producer surplus and the deadweight of welfare loss. ${ }^{264}$ In this regard it should be noted that it is important for regulation not be disproportionate to cure the market failure under consideration. In recent years, there is a trend to more pro-active forms of consumer protection and quality management, implying a lower degree of anticompetitive effects. In several countries, professional indemnity insurance has been made obligatory or broadened for a number of professions, while in others, obligatory continuing education, facilities for specialisation or specific voluntary certification and/or benchmarking systems have arisen. ${ }^{265}$ Looking at the interaction between the European Commission, national regulators, and national competition authorities, there have been bottom-up ${ }^{266}$ effects as the Commission is influenced by the developments at the Member State level, as well as top-down effects.

According to Philipsen, to find out whether regulations are liable to bring about benefits, the general conditions for exemption of a restrictive agreement under EC competition law, as defined in Article 101(3) TFEU (Article 81(3) EC), seems to provide a useful scheme. ${ }^{267}$ It should be noted, however, that this is therefore not an economic test but a legal test. These four conditions are: (1) the agreement, decision or concerted practice must improve the production or distribution of goods or promote technical or economic progress; (2) it must allow consumers a fair share of the resulting benefit; (3) it must not impose restrictions on the undertakings that are not indispensable to the attainment of the objectives; and (4) it must not afford the undertakings the possibility of

\footnotetext{
264 Adriaans, Maks \& Philipsen 2005, p. 72.

265 Paterson, Fink \& Ogus 2003, 1, p. 90.

266 Especially in the UK, Ireland and the Netherlands, national competition authorities undertake activities to identify restrictions to competition.

267 Philipsen 2003, p. 43.
} 
eliminating competition in respect of a substantial part of the product. As suggested by Philipsen, 'If one substitutes the word 'regulation' for the phrase 'agreement, decision or concerted practice' the following observation can be made: Condition (1) states that we only need regulation if social welfare is improved by this regulation, just as public interest theory suggests by its focus on market failure. Condition (2) adds to this that the consumer surplus must be given sufficient weight. Conditions (3) and (4) require that competition should not be restricted more than necessary (also because of the danger of rent seeking). One has thus to choose the optimal form or regulation. ${ }^{268}$ According to Philipsen, regulation of a profession should preferably be measured against this scheme, and should thus meet all its requirements.

\subsection{Regulation vs. liability}

It is obvious that safety issues have to be taken into account when providing services. In particular, the architectural profession involves difficult tasks and responsibilities. Architects have to work with due diligence and seriousness because it is of great importance that the buildings that are designed are safe and secure. The right incentives have to be created to make sure that architects take the utmost care. As indicated above, this can be done by means of different instruments such as liability regimes, regulation, taxes, etc. Because in general, a lot of professional activities can be carried out in a very safe way, the increase in value they bring to society is often larger than the costs of the damages they bring about. ${ }^{269}$ Since the influence of damages on people's behaviour should only extend to the point where the costs of accidents are acceptable for society, it is of no use to prohibit these activities completely. However, in today's market, consumers are in need of effective and independent redress mechanisms when things go wrong.

Liability rules are used separately or jointly with ex ante regulation to remedy market failure. Calabresi ${ }^{270}$ and Shavell ${ }^{271}$ made a comparison between ex ante regulations, which are categorized as 'specific deterrence', and ex post liability which is categorized as 'general deterrence'.

The specific deterrence method stipulates that government regulates a certain level of activities and care, and decides who should perform these activities and how these should be done. The main reason for this approach is that people are said not to know what is best for them..$^{272}$ When persons do not live up to these governmental rules ${ }^{273}$, they will be punished. It follows that their behaviour is influenced directly by regulation, since it is generally independent of the actual occurrence of harm.

268 Phlipsen 2003, pp. 43-44

269 Ogus \& Veljanovski 1984, p. 107

270 Calabresi 1970, pp. 95-107.

271 Shavell 1984, pp. 363-383.

272 For example, a collective judgement on whether cars of a particular type are desirable, is better than a series of individual judgements to buy or not to buy a particular car, which would be preferred under the general deterrence approach.

273 Specific deterrence can achieve primary loss reduction by undertaking detailed activities, but it can only be effective for a very limited number of acts or activities. 
According to the general deterrence method, it is the market which determines up to what level, and in what way, activities have to be carried out in view of the costs. Individuals have the freedom to engage in these activities and are in a position to take the possible accident costs into account. The regulator does not impose particular behaviour, but links predetermined consequences to certain behaviour. It follows that professionals only come into contact with these consequences once they have caused damage, or are accused of having made a professional mistake. Individuals are held liable for the damages they have caused and are deterred by a tort suit in cases of damage ${ }^{274}$, so that this method therefore works indirectly. As opposed to the specific deterrence regime which is enforced by public law and criminal law, liability is enforced by private law. ${ }^{275}$

The crucial difference between both systems is that, in the general deterrence method, there is no room for an ex ante decision about the desired number of accidents that a society is willing to bear. This method means that the behaviour of an individual is not regulated by governmental legislation, but is determined by the individual himself. ${ }^{276}$ Furthermore, in liability regimes, liability is based upon the damage caused to the victim. The victim is compensated for the consequences of certain acts or omissions, so that he will be put in the same position as that in which he found himself before the damage-causing event. As opposed to this, the specific deterrence method emphasizes the punitive nature of criminal regulation. Damage compensation is 'paid' not to an individual victim, but to society as a whole. When opting for the specific deterrence method, different assumptions are taken into account. In the first place, individuals are not able to determine their own benefits. Secondly, damage-causing events can also have non-pecuniary consequences. Thirdly, the specific deterrence method presupposes that individuals take moral decisions which cannot be expressed in terms of costs or benefits. Fourthly, there are income differences between the different market actors. In the fifth place it is held that there are dangerous activities which cannot be regulated through the market mechanism. These presumptions have to be reversed if one opts for the general deterrence method. ${ }^{277}$

Contrary to liability, regulation is, in general, independent of the actual occurrence of harm. ${ }^{278}$ While liability is enforced by private law, regulation is enforced by public and criminal law. ${ }^{279}$

As maintained by Shavell, when choosing between tort law and regulation as instruments for controlling risky activities, there are four criteria which should be taken into account: information, insolvency risk, the threat of a liability suit and administrative costs.

The first determinant is the possibility that private parties and the government have different views concerning hazardous activities. In the event of information asymmetry

274 There is a threat of ex post punishment.

275 Shavell 1984, p. 357.

276 Deben \& Vereeck 2003, p. 101

277 Ibid., p. 100.

278 Shavell 1984, p. 358.

279 Ibid., p. 357. 
between the government and private parties, information problems can justify governmental intervention through regulation. However, according to Shavell, it has to be determined who can acquire the information at the least cost - the government or the parties involved. When private parties have more information at their disposal than the government, it is better for them to make their own assessment concerning the control of risks, the advantages of the activity, the costs of lowering the risks and the damage possibilities. Otherwise, the chance would exist that the legislator would make arbitrary rules, or rules which are not the most suitable to regulate the problem. In this case, liability rules will have more advantages because the information which is available ex post, and which can take into account all the (detailed) circumstances of the case, will lead to a better cost allocation than the allocation which is made by the legislator, ex ante. ${ }^{280}$ In the event that the government has better information, or if the parties do not readily appreciate all the risks, regulation should be preferred. ${ }^{281}$

As mentioned earlier, when considering professional activities which mostly involve trust goods, the professionals themselves rather than government agencies have specific knowledge on quality and risks. ${ }^{282}$ For this reason, self-regulation can be preferred over state regulation. However, since consumers of professional services can also be qualified as private parties, there is normally also an information asymmetry between the private parties themselves. Even though a liability regime leads to efficient results, in these cases a regulatory regime will nevertheless direct the problem better, since it puts consumers in a better position to know ex ante which services and which minimum level of quality they may expect.

Regarding the insolvency risk or inability to pay for the harm done - i.e. the ability of the person who caused the damage to indemnify the victim for the entire loss ${ }^{283}$ - Shavell indicates that if the potential damages are higher than the wealth of the injurer, liability rules will not incline injurers to take optimal care. This is due to the fact that injurers cannot pay more than what they actually have, unless they are insured, of course. If the sufficient level of care is determined by ex ante regulation on the other hand, the potential injurer has to comply with this regulation, irrespective of his wealth. ${ }^{284}$ The inability to pay is thus not of any relevance within the specific deterrence system. Unwanted behaviour is forbidden, whatever the costs are.

With regard to the liberal professions, a combination of ex ante regulation and liability rules seems optimal. Since bad quality services provided by architects can have major effects, not only for the building master, but also for persons renting the building, or third parties walking by, ex ante regulation is needed to determine issues like the desired educational level of professionals and the desired level of quality. In this way, professionals who are, at first sight, not competent, are already ruled out so that the situation is immediately safer. However, if professionals who do possess the desired educational level were not at risk of being sued, they might not have the necessary in-

280 Ibid. 1984, p. 359.

281 Ibid.

282 Philipsen 2003, p. 22; Van den Bergh 2004, p. 158; Ogus 2000, nr. 9400.

283 Van Velthoven \& Van Wijck 2001, p. 376.

284 Shavell 1984, pp. 360-363. 
centives to deliver good quality. In this regard, the insurance coverage is important. ${ }^{285}$ Liability regimes can be attractive because, by lowering the insurance premium when the risks are low, individuals have incentives to keep the level of care as high as possible. However, a liability regime will not suffice, since bad quality services may have huge consequences, and the professional might not be able to pay for all the damages caused. It follows that a combination of ex ante and ex post regulation is needed to ensure that the optimal level of care is taken.

According to Shavell, the possibility of a liability suit (third determinant) is not that high if the individual harm is small, or if the harm occurred a while ago before the damage became apparent, or if it is difficult to establish a causal link between the actions of the injurer and the damage. If this is the case, a law suit may not be started, which implies that a tort system will have no deterrent effect since the party causing the damage does not experience negative consequences from its behaviour. ${ }^{286}$ It follows that if there is no threat of a liability suit, an ex ante safety regulation has to ensure that a sufficient level of care is taken by the potential injurer. ${ }^{287}$ The chance of getting caught is therefore an issue to be taken into account in the case of regulation: due to the overload of cases which the courts have to deal with, and due to the resulting policy to set aside numerous less important cases, private parties tend to calculate their risk of having to pay for their wrongs. Problems in liability regimes concern the fact that there can also be legal wrongs without a victim, that there is often a lack of evidence, or that the damage done to each individual is so small that no one takes the effort to institute proceedings. It is important for the well-functioning of society that these wrongs are also punished. ${ }^{288}$ Furthermore, if individuals are afraid to institute proceedings against very powerful parties, or if they are not able to indicate the person who caused the damage, a liability regime is not the best solution. Prior approval, such as licensing or certification, on the other hand, can ex ante exclude manifest incompetence which can give rise to high social costs.

With regard to the liberal professions, the chance of escaping a lawsuit is linked again to the information asymmetry argument, and the fact that professional services are often experience or trust goods. Since consumers are often not able to determine whether a professional has delivered poor quality services, while this is in any case often hard to prove, this implies that they may not have sufficient incentives to hold the service provider accountable. This is even more so since, in many markets, the outcome of a professional's work depends not only on his own service, but also on a variety of other factors, such as whether the entrepreneur obeyed the architect's instructions. Since only a proportion of consumers are likely to institute claims, the redress in one case is often not appropriate punishment for certain misconduct. It follows that at least some level of ex ante regulation is needed, since there is a serious enforcement problem. When comparing liability with self-regulation, it should be noted that self-regulatory associations

285 Ibid., p. 361

286 Eatwell, Milgate \& Newman 1998, p. 143, Shavell 1984, p. 363

287 Shavell, 1984, p. 363.

288 Van Velthoven \& Van Wijck 2001, p. 376. 
have normally greater knowledge about a certain problem than judges. However, under a tort system, judges may also hire experts -usually members of the regulated profession- to assist them in the assessment of negligence. The question is then whether the savings resulting from combining the judges' and the experts' roles into one are greater than the potential losses due to over-inclusive self-regulation. This can be determined by empirical research. Even though this determinant does not seem to have a strong influence on the choice between liability and regulation for the specific case of the liberal professions ${ }^{289}$, a regulatory regime is generally favourable, since the information asymmetry problem makes it difficult for consumers to determine what exactly caused harm. To be held liable, a causal link between a fatal accident involving a badly constructed or badly designed building and the involvement of the architect or engineer therein, should always be established.

Finally, a comparison must be made between the administrative costs of a liability regime and an ex ante regulatory system. For ex ante systems to function, public costs with regard to passing and enforcing the regulation, as well as private costs of compliance, have to be incurred..$^{290}$ Liability systems demand for public expenses of the legal system itself (fees of judges, building of court houses, electricity in court houses, etc.), as well as for private costs of time, effort and legal expenses borne by the parties (lawyers' costs). The costs, or at least most of the costs of a liability system, only seem to be present in the event that harm has actually happened. As noted by Philipsen, a lot of accidents will be prevented by the deterrent effect of being held liable and having to pay damages to the victim. ${ }^{291}$ In the case of regulation however, the costs of passing and enforcing the regulation are always there, irrespective of the actual occurrence of an accident. These costs are not borne by the individuals causing the biggest risk - which is often the case in liability regimes - but by society as a whole..$^{292}$

It can be concluded that -if private parties have more and better information- information asymmetry favours a liability regime in general. If this is not the case, regulation can take care of the information asymmetry problem. The same is true with regard to administrative costs. On the other hand, the incapacity to pay for harm done, as well as the possibility of a law suit, favour ex ante regulation. Indeed, regulation might be needed to prevent externalities causing large losses, for which professionals may be insolvent or for which there is lack of evidence. When applying these determinants specifically to the regulation of professions in order to determine whether regulation or liability is needed to cure a problem caused by market failure, it can be said that the criteria seem to apply, especially to the cases of externalities and information asymmetry, while they do not seem to be applicable at all to cases involving market failure caused by the market power of public goods. ${ }^{293}$ In this regard it should be noted that liability rules can also be created by self-regulatory associations, so that they can design

289 Philipsen 2003, p. 23.

290 Shavell 1984, pp. 363-364.

291 Philipsen, 2003, p. 22.

292 Shavell 1984, p. 364.

293 Philipsen 2003, p. 22. 
punishment regimes specifically to achieve the incentivisation required for their members to achieve good quality. However, as noted above, self-regulatory regimes may not provide the correct incentives to set appropriate levels of punishment or redress. ${ }^{294}$ It follows that a complete solution to the problem of risk control should involve the joint use of liability and regulation, with the balance of them reflecting the importance of the determinants. ${ }^{295}$ After all, regulation is rather static (inflexible) and can more easily be influenced by rent-seeking behaviour. ${ }^{296}$ Moreover, there may be problems of enforcement. The creation of an independent monitoring and regulatory committee may be the solution to controlling risky activities.

Even though professionals would have acted in accordance with all applicable legislation, it is still possible that a loss may be caused to third parties. Their rights on compensation may not be impaired simply because the professional lived up to the regulation. As indicated above, the observance of these rules is just a minimum; the professional still has to take all possible precautions which are deemed necessary under tort law to avoid the possibility that his activities cause harm to third parties. ${ }^{297}$

\section{Compensation for damage}

\subsection{Insurance: general principles}

Notwithstanding the use of liability rules, regulation or other instrument damage can still occur. In this paragraph I will discuss the traditional compensation mechanism: insurance.

The utilitarian approach with respect to insurance demonstrates that risk creates a disutility for risk averse persons. Their utility can be increased through loss spreading, or if the small probability of a large loss is taken away from the injurer, in exchange for the certainty of a small loss being the payment of a premium. ${ }^{298}$ This last option is the rationale behind insurance. Insurance can also be used to reduce transaction costs since it has been decided ex ante who will intervene if damage occurs.

As pointed out in paragraph 11.3.6.1, the behaviour of the insured party will change as soon as the risk is removed from him (moral hazard) since there are no incentives for care taking which used to be present due to the deterrent effect of having to pay compensation in the event of damage. Shavell has indicated that there are two ways of controlling this problem: firstly by an appropriate adaptation of the premium; secondly by partially exposing the insured to a risk. ${ }^{299}$

However, the determination of the appropriate premium is not easy, since information on the insured is not readily available to the insurance company which has to invest

294 Evans 2004, p. 525.

295 Shavell, 1984, p. 365.

${ }^{296}$ However, professionals may also lobby in favour of a financial cap on liability, thus transferring a rent from potential victims.

297 Shavell 1984, p. 365; Faure \& Van den Bergh 1987, p. 110.

298 Arrow 1965; Borch 1961, pp. 245-255.

299 Shavell 1979, pp. 541-562. 
costs to obtain some knowledge. Furthermore in the event of a partial exposure to the risk, some risk aversion will still remain. Often a combination of both systems is applied to control moral hazard. It follows that the incentives for care taking are, in that case, no longer based upon liability law since the threat of having to compensate a victim is shifted to the insurance company.

Since insurance is based on a system of loss spreading, risk pools have to be constructed as narrowly as possible, so that the average premium corresponds with the risk of most pool members. If this is not the case, and parties would not disclose their risk profile appropriately, the narrowing of the risk pools might be endangered, meaning that the average premium would be relatively high for low risk members who would then leave the group (adverse selection). ${ }^{300}$ As noted by Priest, the adverse selection problem can thus only be cured by an appropriate risk differentiation. ${ }^{301}$

Compulsory liability insurance is often advanced as a means of protecting the innocent victim. In this way the victim is protected against the insolvency of the injurer. However, liability insurance is also an instrument to increase the utility of a risk averse injurer. It can thus be argued that insurance is not only beneficial for the architect's client, but also for the architect. However a duty to buy insurance might be inefficient if it forces persons to purchase liability insurance while they actually have no need for it. Since insurance does not increase everyone's expected utility (big architectural firms might not have a need to insure for a loss of 25,000 Euros, while a single architect might have this need), a general insurance obligation might create a social loss. Even those who have no demand for insurance are still obliged to pay premiums in situations in which professional liability insurance is mandatory. Since parties have different attitudes towards risk, and hence different needs, it seems that an insurance obligation is generally not welfare increasing. In this regard it should be noted that, even without such obligation, those who are risk averse will probably buy insurance anyway. However, since parties are not always able to make an accurate assessment of the risk they are exposed to, insurance can protect them against underestimation of possible damages. Another justification for compulsory insurance is the protection of the victim against the insolvency of the injurer. If, due to the extent of the damage, the wealth of the injurer is exceeded, the victim can still be compensated via insurance. On the other hand, insolvency may cause problems of underdeterrence. If the expected damage is lower than the injurer's assets, he will only purchase liability insurance up to the amount of his assets, since he cannot lose more than he owns in a liability suit. ${ }^{302}$ The underdeterrence and underinsurance problems can be cured by compulsory liability insurance. ${ }^{303}$ If this is the case, the insurer has incentives to control the insured's actions, and to check whether he has taken the necessary care to avoid damages. ${ }^{304}$ It follows that there might

300 Wagner 1996, pp. 105-106.

301 Priest 1987, p. 1521, pp. 1524-25.

302 In this way harm will be externalized, since the costs will not be born by the injurer. Insurance internalizes these costs.

303 Jost 1996, pp. 259-276.

304 This is only beneficial if the moral hazard can be controlled adequately, and insurers have appropriate incentives to do so. 
be a case for compulsory insurance in the event of insolvency. However it should be questioned whether this is the best way to remedy the insolvency problem, certainly having regard to the fact that there will always be a moral hazard problem with liability insurance. Other possibilities, such as first party insurance, might cure the problem at lower cost and thus be more proportional to achieving the objective. This will not be further discussed within this thesis. However, it should be noted that, in the event of compulsory liability insurance, often the total risk is shifted to the insurer, which strengthens the moral hazard and brings about higher premiums. Furthermore, in insurance markets which are not fairly competitive, the insurer will have fewer incentives to align the premium with the insured's individual behaviour. Even though the government can decide that professionals are obliged to buy insurance, this does not mean that insurance companies are willing to cover the risks. Indeed, between the insurer and the professional, a contractual relationship will arise, but parties are not obliged to enter into an agreement. It follows that the insurance company has a lot of power, certainly if professionals are not allowed to practise their profession without being insured. This is questionable from a policy point of view. ${ }^{305}$ As noted by Faure, the creation of a duty for insurance companies to accept coverage seems like an extremely dangerous path to follow, given the importance of an effective control of moral hazard. ${ }^{306} \mathrm{He}$ argues that the monitoring of the risk ex ante is an important instrument with regard to controlling moral hazard. This could ultimately lead an insurance undertaking to the decision that it considers the risk to be too high. To have an optimal control of moral hazard, insurance companies should be able to decide freely whether or not they want to insure a party. Finally, another problem exists in the fact that the insurer cannot invoke defences against the third party beneficiary of insurance, since these are not opposable to third parties. This means that the insurer has to compensate the victim, but can institute proceedings against the insured to claim the money back. This will only lead to results if the insured is not insolvent.

\subsection{Professional liability insurance in Belgium and the Netherlands}

In Belgium, all registered architects are obliged by law to buy professional liability insurance. It follows that insurers are at least certain that those who are mandatorily insured are professionals with the required qualifications. Of course, other persons are also allowed to buy insurance, but these are not allowed to engage in architectural activities for buildings requiring a building permit. Since architects are the only professionals in the building industry who are obliged to buy insurance, while they are often held liable in solidum with the entrepreneur, it appears that the risk is shifted to those with the deepest pockets. Liability insurance increases the utility of risk averse architects. Since architects are thus held liable quite often (see Chapter 6), the insurance premium is quite high. Mandatory insurance also brings about high transaction costs every time a contract is concluded. At first sight, this might also have an effect on the premium to be paid by the architect, which architects, in their turn, can include in the price their clients

305 Rogge 1996, p. 40.

306 Faure 2002, p. 314 
have to pay for their services. In this regard it should be noted that architects who are not risk-averse, and hence have no demand for insurance, have to pay the premium as well. ${ }^{307}$ Another potential danger of liability insurance is that there will always be a moral hazard problem. It follows that insurers should be able to cure this problem by monitoring the insured, which does not seem to be easy and might be very costly. This, in turn, might lead to higher premiums for architects and higher prices for clients. It follows that higher premiums are not a necessary corollary of a mandatory insurance obligation.

On the other hand, it is possible that the architect is not able to make an accurate assessment of the risk he is exposed to, and the benefits of buying liability insurance (information problems). In a situation in which he underestimates the risk and does not buy insurance, compulsory liability insurance might be a solution to safeguard his own assets and those of his client in the event that the architect is insolvent. Insolvency may pose a problem of underdeterrence. As stated above, if the expected damage exceeds the architect's assets, the architect will only have incentives to purchase liability insurance up to the amount of his own assets. Since the damage caused by a fault in a design or a fault in the supervision of the building work is generally quite substantial, a duty to purchase insurance coverage for the amount of the expected loss protects the building master (and certain third parties) better than when he is confronted with an insolvent and uninsured architect. Insolvency may cause architects to externalize harm by providing services that might cause harm which largely exceeds their assets. By buying insurance, these costs can be internalized (Coase) if the insurer cures the moral hazard problem, for example by setting appropriate policy conditions and asking an adequate premium. In this way the costs will not be carried by society at large. Compulsory insurance might therefore remedy problems of underdeterrence and undercompensation.

In the Netherlands, on the other hand, there is no insurance obligation, except for members of the BNA. Membership of the BNA provides the assurance that the professional has the required qualifications to use the title of architect. Other persons who are not architects can also buy insurance for damage that can occur during their design/supervision activities. Furthermore, standard conditions also often impose the obligation to be insured. This also brings about transaction costs. Since this is all based upon contract law, insurers are generally free to decide whether or not they want to insure someone. It seems logical that they are more likely to insure professionals holding a diploma or certificate than those lacking any qualifications.

It follows that there is a trade-off between the benefits and costs of compulsory insurance for architects and their clients. Since the damage caused by a fault in the design or the supervision of the building works is generally quite high, mandatory liability insurance might be more in the interests of society (and thus more efficient with regard to compensating for damage) than liability rules without mandatory insurance. There is a real risk that the magnitude of the damage exceeds the architect's assets. However, it is also possible to force the architect ex ante to provide a certain compensation, bank guarantee or other kind of payment as guarantee of compensation in the event that damage occurs. In such cases, architects are still liable in the event that the damage is

307 Faure \& Van den Bergh 1989, pp. 109-111 
attributable to them, but are not obliged to buy insurance. This would be a flexible solution provided that it enables that damage is compensated adequately ex post, since the architect can choose any market solution..$^{308}$

\section{Conclusion}

Since activities carried out by an architect can cause harm, architects need incentives to take good care. Externalities can be internalized in different ways: moral persuasion, taxes, liability rules and regulation. Furthermore, contracting parties may also agree themselves that certain rules are applicable within their relationship, in addition to the rules created by the state or the professional association (Coase theorem).

In this regard, the classic economic analysis of law starts from the assumption that, by exposing the costs of their actions to liability rules, parties will be motivated to take optimal care to prevent accidents. In this way, a reduction in the total social costs of accidents can be achieved, since it is at the level of care that the costs of prevention and expected damage are minimised. However, for liability rules to work effectively, there must be a victim and an identifiable injurer who is able to pay damage compensation. This is not always the case, which means that other possibilities have to be resorted to, such as regulation, either by the government or by self-regulating organizations. The architectural profession is characterized by high levels of regulation. This is often a mix of State regulation, self-regulation and custom and practice, which has evolved over a number of years. In spite of all the regulation policies, standard economic theory predicts that, in a 'perfect market', an unregulated outcome is optimal, in that consumer welfare can only be improved to the detriment of producer welfare, and vice versa. ${ }^{309} \mathrm{It}$ follows that there is a certain tension between, on the one hand, the need for a certain level of regulation in the professions and, on the other, competition law. However, in the liberal professions which are characterized by high levels of information asymmetry, there will always be a problem of market failure and some degree of regulation will always be necessary. As suggested by Miller, governmental regulation is not always cost efficient, since the government is not always the party with the best knowledge on a certain matter. ${ }^{310}$ Furthermore public regulatory regimes are not that flexible, while the costs of regulation are spread over society as a whole.

In this thesis it has been demonstrated that the regulation of the architectural title should be preferred over the regulation of the profession, since the latter can be replaced by other mechanisms to guarantee high quality. Even though a professional monopoly might be justified to protect quality, it is not proportional, and is likely to benefit predominantly the professionals themselves. It has been demonstrated also that price fixing, advertising restrictions (except those aimed at false and misleading advertising), and restrictions to business structure, are not cost-efficient. In this regard it can be

\footnotetext{
308 Faure \& Hartlief 1996, pp. 321-326.

309 If the advantages of a regulatory system do not balance the disadvantages, or if the advantages of regulation are smaller than those of a free market for this profession, it is argued that it is better to abandon the professional regulation. See Somers, p. 102.

310 Miller 1985, pp. 897-903.
} 
stated that the entry to the profession is more heavily regulated in Belgium than in the Netherlands. Indeed, since only registered architects are allowed to design buildings for which a building permit is required, Belgian architects have a monopoly to design such buildings. It follows that more competition is possible in the Netherlands since there is no professional monopoly as in Belgium. Since the Dutch situation demonstrates that other ex ante tools such as the Building Decree can also protect the quality of buildings, without the negative effects as far as the restriction of competition is concerned, it might be assumed that, according to the public interest theory, the tool used in Belgium to cure market failure goes too far. Since market competition is already restricted to those who are allowed to use the title, the cure might be worse than the disease. Curing market failure by licensing does therefore not seem to be the most efficient solution. Certification is recommended over licensing since clients still have the choice with regard to engaging an architect. Those who turn to a professional who is allowed to use the title of architect, are sure that the latter does have a certain educational background and/or some professional experience. A less extreme option to deal with the monopoly problem, next to its abolishment, can be found in the extension of the monopoly to other experts who also have the relevant knowledge and know-how. ${ }^{311}$ This might even be the case for certain entrepreneurs.

Furthermore, even though the prohibition of architects associating with entrepreneurs in Belgium might be justified for public interest reasons, since the architect should be able to work in total independence, it might be questioned whether this restriction, which does not exist in the Netherlands, is proportional. In any case, cost-benefit analyses have demonstrated that business restrictions bring about more costs.

My research aimed to determine whether the intensity of regulation is linked to the intensity of contract law which entails that I wanted to determine whether a higher level of regulation entails a less stringent contract law system of contract law with a lesser degree of contractual responsibilities and liabilities.

As pointed out in Part II, architects and their clients generally lay down their respective rights and obligations in a written contract. These contracts are concluded since regulations are often weak, and cannot always be enforced. Contracts can be a useful (complementary) tool with regard to curing market failure. ${ }^{312}$ However, concluding private agreements brings about high transaction costs, since parties have to negotiate the content of the contract. In this regard, standard conditions can be created which only bring about high transaction costs at the time of creation, and which can be adapted to the specific needs of every new situation. Especially in the Netherlands, standard conditions with an arbitration clause, often form part of the agreement. It follows that self-regulation also has an influence on private law. Arbitration is popular since disputes will be resolved by a body which is composed of professionals in the building industry (entrepreneurs, architects, engineers) but also of building masters, who have a better knowledge than regular judges with regard to design/construction problems. It

311 De Caluwe 1997, pp. 20-22.

312 Contract law provides the default rules, in case transaction costs (search and information costs, barganing and decision costs and policing and enforcement costs) are too high. 
follows that there are fewer administrative costs which means that disputes can be resolved more quickly and less expensively. Arbitrators' verdicts may be more accurate and predictable than those of a court, since arbitrators possess industry expertise. Of course when arbitrators have to decide upon complex or novel cases, it is also difficult to predict the decision. ${ }^{313}$ As noted by Van den Bergh, alternative dispute settlement between private parties is only desirable if they increase society's wealth and are democratically legitimized. ${ }^{314}$ This desirability depends on the absence of information asymmetry and negative external effects. If parties decide ex ante to resort to dispute settlement by means of arbitration, one can assume that this is useful for them so that this agreement has to be honoured, but this does not mean that the state has to encourage alternative dispute settlement. ${ }^{315}$ In a situation of possible information asymmetry and possible negative externalities, a further cost benefit analysis is required before the desirability of an alternative dispute settlement can be determined. ${ }^{316}$

Due to the regulatory differences with regard to the architectural profession between Belgium and the Netherlands, one might expect that parties which are subjected to the Dutch legislation which is more lenient when it comes to professional qualifications, registration, mandatory insurance, etc. impose heavier requirements in their contracts in order to guarantee quality and limit externalities. With regard to the contractual liability of architects, it seems that both in Belgium and the Netherlands, architects are generally liable for negligence. Furthermore, the ten year liability principle which is laid down by Belgian public regulation, and which is of public order, cannot be contractually deviated from, and thus always forms part of the contract as well. It follows that this principle is a heavier burden for architects than the five year liability period which is generally laid down in the Dutch standard regulations. The heavier burden on architects in Belgium is strengthened by the fact that they are often held liable in solidum with entrepreneurs. Furthermore, Dutch architects are also allowed to limited the extent of their liability (see Article $15 \mathrm{NR}$ ), while clauses that limit the extent of the architect's

313 As held by Bernstein, the settlement of disputes through arbitration is taken a step further in the diamond industry in which all dealers of diamonds must sign an agreement to submit all disputes arising from the diamond business between dealers to the club's arbitration system. Arbitration awards are kept strictly secret to protect the reputation of those who are subject to a procedure. Since the system is based upon trust, members are not allowed seek redress in regular courts. Behaviour which does not fulfil the social values of the Jewish society is sanctioned informally. In this way the diamond industry has been able to use reputation at a cost low enough to create a system of private law, enabling most transactions to be consummated and most contracts enforced completely outside the legal system. See Bernstein 1992, pp. 115-157. It should be noted however, that this cannot be compared to the Dutch arbitration system as discussed before, since parties are free to decide whether or not disputes will be settled by arbitration. Furthermore, the arbitration procedure in the diamond industry, as discussed by Bernstein, only refers to procedures between professional dealers, while the Dutch Council of Arbitration and the Arbitration Institute for the Building Industry often deal with disputes between professionals and consumers.

314 Van den Bergh 2008, p. 795. See also Shavell 1995, p. 3.

315 Van den Bergh 2008, p. 795; Shavell 1995, p. 8: 'If parties have inadequate information about the benefits of alternative dispute resolution and this information cannot be effectively communicated to them, the promotion of alternative dispute resolution can be justified. The same is true if alternative dispute resolution might positively affect third parties.'

316 An alternative dispute resolution agreement between the building master and the architects might not give proper attention to the rights of the entrepreneur or of third parties who suffered damage. 
liability are, in principle, void in Belgium. It can therefore be concluded that in Belgium and the Netherlands, the intensity of contractual liability is not linked to the intensity of regulation.

With regard to compulsory liability insurance, it can be held that there is a trade-off between the benefits and costs for both architects and their clients. Since the damage caused by a fault in the design or the supervision of the building works is generally quite high, mandatory liability insurance might be more in the interests of society (and thus more efficient when it comes to compensating for damage) than liability rules without mandatory insurance. However, it is also possible to force the architect ex ante to provide certain compensation, a bank guarantee or another kind of payment as guarantee of compensation in the event that damage occurs. In such a case, architects are still liable in the event that the damage is attributable to them, but are not obliged to buy insurance. This would be a flexible solution provided that it enables damage to be compensated for adequately ex post, since the architect can choose any market solution.

Even though the underdeterrence and underinsurance problems can be cured by compulsory liability insurance, it should be questioned whether this is the best way to remedy the insolvency problem, certainly having regard to the fact that there will always be a moral hazard problem with liability insurance. In a situation of compulsory liability insurance, often the total risk is shifted to the insurer, since the legislator often limits the possibilities to expose the insured to risk. In this way the duty to insure is often equal to the total amount of liability which strengthens the moral hazard and brings about higher premiums. Other possibilities, such as first party insurance, might cure the problem at a lower cost, and thus may be more proportional to achieve the objective. Since architects are obliged by law to buy professional liability insurance in Belgium, while this only is the case for BNA members in the Netherlands, it can be said that the Belgian system is not efficient, since architects who are not risk averse have to pay the premium as well. Furthermore, since architects are the only professionals in the building industry who are obliged to buy insurance, while they are often held liable in solidum with the entrepreneur, it appears that the risk is shifted to those with the deepest pockets. However, since BNA members have to buy insurance, and since standard terms often also contain an insurance obligation, it can be said that there is not such a big difference between the two states. In any case, as pointed out in Part II, the limitation of architectural liability by means of a private company with limited liability, is cheaper than the limitation of liability through contractual clauses. However, while this might be beneficial for architects, it is not desirable from a society's point of view since an architect can 'hide' behind a legal person to safeguard his personal wealth. In this way only the capital of the company is at risk whenever a professional fault occurs, while the professional's personal wealth is exempted from any claims. This again brings about problems of underdeterrence of architects and undercompensation of victims, and is thus not efficient in terms of compensating for possible damage. 

Chapter 12

\section{FINAL CONCLUSIONS}

\section{SUMMARY}

The profession of architect embraces a myriad of skills, abilities and know-how, and is a multi-layered proficiency. Architects do not only create a design for certain construction activities, but also provide a broad selection of services such as preparing and monitoring construction activities, applying for planning permission, land surveying, the issuing of planning permission applications, holding feasibility studies, guiding clients, integrating technical, social and economic problems that arise in connection with building works, etc. However, due to the new technological developments and the high demands of clients, individual architects often specialize in a certain field, and engage other specialists such as engineers to help them with more technical issues.

In the European Union, the architectural profession is practised by approximately 436,280 persons. Due to the creation of the internal market, these professionals should be able to practise their profession in the EU without facing unjustified or disproportional restrictions. Due to the general non-discrimination principle contained in Article 18 TFEU (ex Article $12 \mathrm{EC}$ ) and the free movement rights of Union citizens (Article 21 TFEU - ex Article 18 EC), and of workers (Article 45 TFEU - ex Article 39 EC) and selfemployed professionals in particular (Articles 49 and 56 TFEU - Articles 43 and 49 EC), Member States are not allowed to impose unjustified or disproportional restrictions that are directly or indirectly based upon the architects' nationality. Since States (and professional organisations) could not reach an agreement about the content of architectural studies due to the substantial differences in the national architectural educations, there is no minimum harmonization of architectural educations at EU level. However, a Directive on mutual recognition of professional qualifications of architects was created in 1985 (Directive 85/384/EEC) and is now replaced and updated by Directive 2005/36/EC. This Directive indicates that Member States are not allowed to restrict the free provision of architectural services, and several cases were decided by the ECJ on the basis of this Directive. With regard to the freedom of establishment, the Directive provides, in Chapter III of Title III, for the automatic recognition of qualifications of EU nationals if these satisfy the requirements enumerated in Articles 46 or 47 . All national qualifications 
which are enumerated in annex V.7 to the Directive, fulfil these requirements. If a diploma is not listed in one of the annexes, Chapter I of Title III of the Directive can be relied on if certain conditions are fulfilled with regard to the level of the qualifications obtained. If the duration of the training in the home Member State is at least one year shorter than that required by the host Member State, or if the training in the home state covers substantially different matters than that in the host state, recognition can be granted if certain compensation measures in the form of an aptitude test or an adaptation period are fulfilled. Overall, it can be held that Directive 2005/36/EC contains a clear system that allows EU architects to move and practise in another Member State. The qualifications of EU architects who do not fulfil the requirements of the Directive should also be examined by the Member States before taking a decision in accordance with the Gebhard and Vlassopoulou rulings of the ECJ. Experience gained in another Member State should be taken into account, as well as the experience and qualifications obtained in a third-country (Haim, Hocsman). Directive 2005/36/EC is, as such, not applicable to third-country nationals. However, in Gül, the ECJ held that the professional qualifications of certain third-country nationals should also be taken into account in accordance with the Vlassopoulou ruling.

With the 1999 Treaty of Amsterdam, the Member States established a legal basis in Title IV of the EC Treaty to create a common European immigration policy within an 'Area of Freedom, Security and Justice'. Since then, several initiatives have been undertaken which centre on the rights of legally residing third-country nationals. Directives have been issued which provide architects holding the nationality of a third country with certain free movement rights if a number of conditions are fulfilled. Furthermore, association and partnership agreements have been concluded by the EU and several thirdcountries. However the situation of third-country nationals is still far from being equal or comparable to that of EU architects, since their rights are generally provided within the limits provided for by the national legislation of the host state.

The recognition of professional qualifications has to be distinguished from academic recognition. Academic recognition still falls within the Member States' sovereign powers (Article 165 TFEU). However, over time, the ECJ has developed case law which does not necessarily respect this strict division of power, and is applicable to those who are in the process of becoming a fully-fledged professional. Member States have decided to standardize rules in this area within the Bologna process that takes place outside the realm of the EU at intergovernmental level, and aims to create convergence, yet not the standardisation of European higher education. The Lisbon Recognition Convention, which was created within the framework of the Council of Europe, aims to give every applicant appropriate access to an assessment of his/her foreign academic qualifications, and adopts the idea of acceptance unless there are substantial educational differences, but does not foresee the harmonisation of architectural studies. It remains to be seen whether this Convention will genuinely contribute to free movement.

This thesis has revealed that the architectural profession is characterized by quite a high level of regulation. This is often a mix of State regulation, self-regulation created by the 
professional associations and custom and practice, and has evolved over a number of years.

Compared with other liberal professions, the regulatory situation of architects is bipolar in that the market entry regulations in some countries of the EU are relatively broad and rigid (e.g. in Belgium, Austria, France, Germany, Italy, Spain, Portugal, Greece and Luxembourg) where in other countries the regulations are comparatively liberal (e.g. in the Netherlands, Sweden, Finland, Denmark, England/Wales and Ireland). Market conduct regulation is generally very limited.

Next to the fact that regulations can limit the free movement of professionals, they can also restrict free competition in the European Union. EU competition law can be applicable to rules created by architectural associations if the rules have an impact on the EU market and affect trade between Member States. Next to market entry restrictions, price fixing, structural restrictions and advertising restrictions are able to hinder free competition.

The discussion of the situation of architects in Belgium and the Netherlands has revealed that there are crucial differences with regard to the right to use the title (professional qualifications) and the right to practise the profession. While in Belgium only those who are in the possession of the required qualifications are allowed to practise the architectural profession and the customer is even obliged to engage an architect for all constructions requiring a building permit, in the Netherlands anyone can practise the profession. The use of the title is reserved only for those holding the necessary diploma. As indicated by research conducted by Mirza \& Nacey, the architectural clientele, as well as the revenue of architects, differ considerably between states. In Belgium, architects are more often consulted by private individuals than in the Netherlands, while architects are more often engaged by developers and local governments in the Netherlands than in Belgium. This is also noticeable in the building landscape which, in Belgium, is characterized by houses built in different styles, while the Dutch building environment is, due to public policy, recognised by whole villages containing more or less the same houses.

Architects in Belgium earn less than their Dutch colleagues.

With regard to contractual obligations and liabilities, it should be noted that in both states the main tasks of architects are the design and supervision of building work. In Belgium, after the reception of the building work, the architect is only liable for hidden defects and in the event of deceit. Furthermore, there is a ten year liability period with regard to serious defects which have caused the building to perish totally or partially. There is no possibility of limiting this prescription period. Since defects in the design or supervision of building works are generally liable to cause severe damage, building masters frequently invoke the ten year responsibility of architects.

Architects are often held liable. The Dutch Civil Code indicates that claims for damage due to shortcomings in the performance of a contract, prescribe five years after the discovery of the defect and, in the event of no discovery, ten years after the damage has been caused. However, it is possible to contractually deviate from these prescription periods. This is often done by the use of standard conditions that mostly provide for a 
five year liability period. In the Netherlands, architects can also contractually limit the extent of their liability.

Since activities carried out by an architect can cause harm, architects need incentives to take good care. In this regard, the classic economic analysis of law starts from the assumption that, by exposing the costs of their actions to liability rules, parties will be motivated to take optimal care to prevent accidents. However, for liability rules to work effectively, there must be a victim and an identifiable injurer who is able to pay damage compensation. This is not always the case, which means that other possibilities have to be resorted to, such as regulation, either by the government or by self-regulating organizations. However, when a building contains a certain default, the building master always has the possibility to turn to the architect who is - next to the entrepreneur and other building partners - immediately identifiable as a possible injurer. After all, the building master has concluded a contract with these professionals. Even third parties will probably not have to make much effort to become acquainted with the identity of the architect: there might be publicity on the building site, they can ask neighbours or the building master who will probably not hesitate to refer the injured parties to the architect to escape any responsibility himself. Nevertheless, due to the problem of information asymmetry, the building master is generally not in the position to determine the level of quality that should be provided, or the respective responsibilities of the engaged building partners. It follows that regulation is still needed to cure this market failure.

Standard economic theory has predicted that, in a perfect market, an unregulated outcome is optimal. It follows that there is a certain tension between, on the one hand, the need for a certain level of regulation in the professions and, on the other, competition law. According to the public interest theory, four conditions need to be fulfilled in order to obtain a general equilibrium in an economy with perfect competition: there are many small and identical producers who cannot significantly influence the price level, and who sell homogeneous products in their respective markets; there is perfect information in such an economy, so that all market participants are informed about all (equilibrium) prices and the characteristics of goods; there are no external effects; the products are private goods. Since the advice and service provided by an architect is generally so specific that another client in slightly different circumstances may not be able to use it, architectural services can, in principle, not be qualified as public goods. However Member States and professional associations often impose requirements upon architects before they can enter the profession. In Belgium, architects even possess a monopoly in the construction market with regard to designing and supervising buildings. In this regard it should be noted that the architectural profession is -certainly within the traditional construction process in which the architect's clients are generally one-time consumers - characterized by a high level of information asymmetry. This can lead to adverse selection: consumers cannot evaluate the properties of the supplied services, and professionals are inclined to provide low quality services which are then bought by the consumers. Furthermore, a moral hazard problem arises: clients are not able to determine whether the architect is working in their best interests, and are not able to sanction the architect's attitude. It follows that a problem of market failure is present within the architectural services market so that some degree of regulation will always be necessary. 
This is strengthened by the fact that negative externalities can appear every time the quality of the service rendered by the architect is not high, and damages are caused.

However, even though market failure, consumer protection and a high quality of the building environment seem to be valid reasons for entry regulation, the Dutch situation demonstrates that other ex ante tools such as the Dutch Building Decree can also protect the quality of buildings without the negative effects relating to the restriction of competition. It follows that it can be argued that, according to the public interest theory, the licensing system in Belgium goes too far in terms of curing market failure, since it seems that less restrictive measures -and thus more proportionate tools - are able to obtain the same effect: a high quality building environment. The same might be said of the prohibition of Belgian architects when it comes to practising the profession of entrepreneur. It should be noted however, that even though there is no monopoly in the Netherlands, the prices for 'Dutch' architectural services are higher. Liberalization does not guarantee lower prices or increased competition.

The private interest approach, on the other hand, indicates that regulation is not an answer to market failure, but the result of rent-seeking behaviour by interest groups. The Belgian Architects' Order and the Dutch Bureau can determine who may use the professional title. The Order and the Dutch BNA, of which membership is not mandatory, can impose punishments on individuals not complying with the deontology and ask for financial contributions as a condition of membership. These institutions have therefore influential powers over their members and persons wanting to enter the profession.

This thesis has revealed that, with regard to the architectural profession, a combination of ex ante regulation and liability rules seems optimal. Since bad quality services provided by architects can cause harm to the building master and third parties, ex ante regulation is needed to determine the desired level of professional qualifications and the desired level of quality. However, if professionals who do fulfil these requirements cannot be sued, liability rules are also needed. Since a liability regime will not provide for sufficient incentives if the architect is not able to pay for the damage caused, his insurance coverage is important. A potential danger of liability insurance is the presence of a moral hazard problem if only the insurer pays for the damage caused. This problem can be solved by an appropriate adaptation of the premium and/or by exposing the insured partially to the risk. In this regard compulsory liability insurance is often advanced as a means to protect the innocent victim. A trade-off exists between its benefits and costs for both architects and their clients. Compulsory insurance might remedy problems of underdeterrence and undercompensation, since the prospective costs can be internalized if the insurer cures the moral hazard problem, for example, by setting appropriate policy conditions and asking for an adequate premium. Since the damage caused by a fault in the design or the supervision of the building works is generally quite high, mandatory liability insurance might be more in the interests of society (and thus more efficient when it comes to compensating damage) than liability rules without mandatory insurance. If the architect is not able to make an accurate assessment of the risk he is exposed to, compulsory liability insurance might be a solution to safeguard his own assets and those of his client in the event of insolvency. In Belgium, all registered archi- 
tects are obliged by law to buy professional liability insurance. In this way the problem of underdeterrence caused by insolvency can be cured, so that the victim can be protected against possible bankruptcy of his architect. It follows that compulsory liability insurance internalizes these negative external effects. However, since architects in Belgium are the only professionals in the building industry who are obliged to buy insurance, while they are often held liable in solidum with the entrepreneur, it appears that the risk is shifted to those with the deepest pockets. This might also have an effect on the premium to be paid by the architect, who, in turn, can include it in the price their clients have to pay for their services. In the Netherlands, there is no insurance obligation, except for members of the BNA (more than 3,000 architects, that is approximately onethird of all architects). Standard terms generally also provide for mandatory insurance, with the result that the majority of architects are covered by insurance. Even though it might be argued that the Belgian system is not cost-efficient, since architects who are not risk-averse have to pay the premium as well, while there will always be a moral hazard problem, it should be noted that this conclusion should be considered in the light of the number of architects who risk insolvency. Empirical research is needed to determine the number of architects belonging to this category. If the risk of underdeterrence is considerable, the Dutch system might also be inefficient. In any case, other possibilities with regard to providing compensation, such as a bank guarantee, should also be considered.

After this brief summary, I will now answer my research questions, and the problem definition formulated in Chapter 1.2 of this thesis.

\section{RESEARCH QUESTION 1}

\section{Is there legislation or case law at EU level that determines who should be allowed to use the title of architect or to practise the profession and how the profession should be practised?}

Due to the fact that discrimination on grounds of nationality is prohibited within the scope of the Treaty, and due to the free movement rights of workers and self-employed professionals (Articles 18, 45, 49 and 56 TFEU), the Union has provided EU architects with a legal framework to move within the EU, without having to face unjustified or disproportional restrictions that are directly or indirectly based upon their nationality. After almost eighteen years of negotiation, Directive 85/384/EEC on the mutual recognition of architectural qualifications was created. This has now been updated and replaced by Directive 2005/36/EC that regulates the freedom of establishment, and the freedom to provide services on the part of EU architects. Title II of Directive 2005/36/EC deals with the freedom to provide services, and holds that Member States are not allowed to restrict the free provision of services. However, service providers are subject to the professional rules which are applicable in the host Member State. With regard to the freedom of establishment, the Directive contains an automatic recognition system in Chapter III of Title III of the qualifications of EU architects if these qualifications satisfy the requirements enumerated in Article 46 or 47 . The qualifications enumerated in annex V.7 to the Directive are all considered to satisfy the necessary re- 
quirements of Article 46. Article 49 deals with specific qualifications (listed in Annex VI.6) which do not satisfy the minimum requirements laid down in Article 46, but which also have to be recognized. It follows that Belgian architects in the possession of a diploma in one of the Annexes are allowed to practise and use their title in the Netherlands (and any other Member State) and vice versa. If a certain diploma is not listed in one of the annexes, Chapter I of the Directive can be relied on if certain conditions are fulfilled, and recognition should also be granted. In the case of substantial differences, compensation measures can be demanded in the form of an aptitude test or an adaptation period. These have to be proportional, and must take into account the experience and knowledge already gained. It can be held that Directive 2005/36/EC contains a clear and useful system which EU architects can invoke when moving to another Member State. As held by Article 2(2) of the Directive, each Member State may permit Member State nationals' in possession of evidence of professional qualifications not obtained in a Member State, to pursue a regulated profession on its territory, in accordance with its rules. It follows that under the Directive, Member States are not obliged to let such professionals carry out activities in their territory. However, evidence of formal qualifications issued by a third country shall be regarded as evidence of formal qualifications if the holder has three years' professional experience in the profession concerned, on the territory of the Member State which recognised these formal qualifications in accordance with Article 2(2) (see Article 3(3)). Due to the case law of the ECJ, the qualifications of EU architects who cannot rely upon the Directive should also be examined by the Member States before taking a decision (Gebhard, Vlassopoulou). Even if one cannot invoke the Directive, one can still try to rely on the principles provided for by the Court of Justice of the European Union in Gebhard and Vlassopoulou. It follows that Member States are obliged to examine whether the work experience gained in another Member State corresponds to the experience required under national law. The same goes for qualifications obtained in a third country (see, for example, Haim and Hocsman).

Directive 2005/36/EC is not applicable to third-country nationals as such. These can invoke the Court's ruling in Gül in which it was decided that certain third-country nationals are entitled to access to employment and equal treatment as if they were an EU citizen. Furthermore, Directive 2004/38/EC on the right of citizens of the Union and their family members to move and reside freely within the territory of the Member States, confers extensive rights upon certain third-country family members of EU citizens who made use of their free movement rights. Family members that have the right of residence or the right of permanent residence in a Member State are entitled to take up employment or self-employment and shall enjoy equal treatment with the host Member State's nationals within the scope of the Treaty (Article 23 and 24). It follows that third-country architects who fall within the ambit of Directive 2004/38/EC, and hold a certain qualification obtained in a Member State, should be able to rely on Directive 2005/36/EC to obtain access to the same profession as exercised in that country under the same conditions as nationals of the host Member State. If such third-country nationals are in the possession of a specific qualification listed in Annex V.7, automatic recognition should take place in accordance with Chapter III of Title III of the Directive. If this is not the case, recognition can possibly be granted in accordance with the general system as described above. It should be noted, however, that if the Union citizen has not 
made use of his free movement right, one deals with a purely internal situation in which national law prevails. In such a case, the non-discrimination principle and the principle of equal treatment (on the basis of nationality) do not apply. It is more likely, however, that a third-country national spouse is in the possession of a third-country qualification. If this is the case, Article 24 of Directive 2004/38/EC, which imposes equal treatment, and Article 3(3) of Directive 2005/36/EC, should be jointly used. It follows that the evidence of formal qualifications issued by a third country has to be regarded as evidence of formal qualifications of an EU holder, if the individual has three years' professional experience in the profession concerned, on the territory of the Member State which recognised that evidence of formal qualifications. In all other cases, the third-country national has to rely on the case law of the ECJ in Haim and Hocsman and Gül. It follows that all qualifications, even those obtained outside the EU, should be taken into account by comparing the specialized knowledge, abilities and experience certified, with the knowledge and qualifications required by national law.

After the entry into force of the Treaty of Amsterdam, legislation is created regarding the legal migration of third-country nationals to the EU on the basis of five Directives and one draft Directive: Directive 2003/86/EC on the right of family reunification; Directive 2003/109/EC on the status of long-term residents; Directive 2004/114/EC on the conditions of admission of students, pupils, unremunerated trainees and volunteers; Directive 2005/71/EC on a specific procedure for admitting third-country national researchers; Directive 2009/50/EC on the conditions of entry and residence of thirdcountry nationals for the purposes of highly qualified employments; draft Directive on a single permit and a common set of rights. All these Directives contain a right for thirdcountry nationals to participate in the labour market of the host Member States after a certain period of time and/or under certain conditions. It is doubtful, however, that there is genuine equal treatment of these third-country nationals. Even though the Directives have led to the development of certain minimum standards which need to be respected by Member States, national implementing measures are rather restrictive and are, in some cases, even lowered to the minimum standards provided for in the Directives. The absence of a general policy for all types of workers demonstrates the unwillingness of Member States to give up their sovereignty in immigration matters. However, with the entry into force of the Lisbon Treaty, which provides for qualified majority voting in this area, it is expected that more legislation will be created granting thirdcountry nationals stronger rights. Furthermore, the Union has also concluded special Agreements with certain third-country states which provide for broader free movement rights. In this regard, the Association Agreement between the EC and Iceland, Liechtenstein and Norway (European Economic Area), the EEC-Turkey Association Agreement, the Partnership and Cooperation Agreements with Russia and other ex-Soviet states, the Euro-Mediterranean Association Agreement, the Cotonou Agreement and the Stabilization and Association Agreements with the Balkan States, all foresee certain free movement rights for third-country nationals. These agreements grant more or less extensive equal treatment rights to third-country nationals who are legally resident and employed in a Member State. However, with the exception of EEA and Swiss nationals, the condi- 
tions governing the right to entry fall entirely within the competence of the Member States.

Finally mention should also be made of Directive 2006/123/EC which aims to simplify procedures, and provides professionals with a more flexible regime when providing services in another EU state. The core provision of Directive 2006/123/EC is Article 16(1) which provides that Member States have to respect the right of providers to provide services in a Member State other than that in which they are established. The Directive strikes a certain balance between guaranteeing the rights of service providers to free access and free exercise of a service activity, whilst allowing Member States the right to invoke their most essential requirements in certain clearly-defined circumstances. It is said that this will definitively improve legal certainty for service providers and consumers. The Directive is underpinned by obligations on Member States to co-operate with, and assist, one another to ensure that businesses are properly and efficiently supervised across the EU, whilst avoiding the duplication of controls. Since the Directive makes it easier to establish anywhere in the EU, saving time and money, it provides a welcome boost to cross-border service provision. However, the list of limitations and exceptions to its scope can be expected to have heavily reduced the integrative potential of this instrument.

\section{RESEARCH QUESTION 2}

Which national regulations and self-regulatory measures issued by professional associations exist in Belgium and the Netherlands with regard to the architectural profession?

- Market entry

In Belgium, the Architects' Act lays down, in detail, who is allowed to use the title of architect. In September 2009, 12,714 architects were registered in Belgium. In general, it can be said that Belgian and other EC/EEA nationals need to be in the possession of a particular diploma obtained in Belgium which requires five years of study. The architectural specialisation within civil engineering education leads to the title of 'civil engineerarchitect' (university) while successful completion of the education at an academy (nonuniversity) leads to the title of 'architect'. For persons who obtained their qualifications elsewhere in the EU/EEA, they are also allowed to use the title if these qualifications are listed in annex 1a and 2b which implement annex V.7 and VI of Directive 2005/36/EC. Under such circumstances, recognition should be granted automatically. If the qualifications do not conform to these requirements, it is possible to complete an aptitude test or adaptation period in accordance with the Act of 12 February 2008, instituting a new General Framework for the recognition of EC-qualifications which implements the general system mentioned in Chapter I of Title III of the Directive (Article $1 \$ 5 \mathrm{AA}$ ).

Professionals who obtained their qualifications outside the EU can invoke Article $1 \$ 4$ AA which holds that the competent Belgian authorities will examine the qualifications which fall under the ambit of Directive 2005/36/EC, but which are obtained outside the EU if they were recognized by another Member State. The training/experience obtained 
in another Member State will also be taken into account. As held by Article $1 \S 5,4^{\circ}$, formal qualifications issued by a third state have to be equalized with EU qualifications if the holder has three years of professional experience on the territory of the Member State which has recognized the professional qualification, and confirms this professional experience. This is the implementation of Article 2(2) jo 3(3) of Directive 2005/36/EC.

In Belgium, everyone who is allowed to use the title can practise the profession of architect. However, the profession can also be practised by certain categories of engineers who are not allowed to use the title of architect (Article $2 \$ 1$ AA). Furthermore, as held by Article 8(1) AA, non EC-EEA nationals can only practise the profession if reciprocal benefits are granted, or if a Royal Decree has allowed this practice (Article 8(2) AA). These requirements render the free movement of third-country nationals who are in the possession of the necessary qualifications useless if there is no reciprocity. This is not in line with the provisions of Directive 2004/38/EC or with the principles laid down in the Directives on legal migration as discussed in paragraph 3.2.2 and 3.3.2 of this thesis which do not require any reciprocity. Indeed, third-country nationals to whom one (or more) of these Directives is applicable should be treated equally with EU nationals. It follows that if an EU national in the possession of a third-country diploma is allowed to practise the profession of architect due to the application of Article 3(3) jo 2(2) of Directive 2005/36/EC, a third-country national who falls within the scope of Directive 2004/38/EC, or one of the other Directives dealing with the integration of third-country nationals in the EU (or one of the Association Agreements), should be treated equally if these Directives provide for equal treatment with regard to access to the profession. Account has to be taken of the qualifications and experience obtained by third-country nationals, even if these are obtained outside the EU (Gül).

Since the entry into force of the Laruelle Act on 1 July 2007, legal persons are also allowed to fulfil architectural tasks. They are, however, not allowed to use the title. It is argued that a company can, in principle, better survive the troubles of life of a natural person, such as illness or death. Legal persons are, however, not allowed to use the architectural title since they cannot be in the possession of the required qualifications. All architects, both natural and legal persons, have to adhere to the Deontological Code. According to Article 10 of this Code and Article 6 AA, the profession of architect cannot be practised by an entrepreneur, and vice versa.

Architects in Belgium have a monopoly when it comes to designing houses and supervising building works for (almost) all constructions which require a building permit. Not only the title, but also the profession, is protected. To be able to practise the profession, architects have to register with the Architects' Order. To be registered on the tableau, two years of professional experience has to be obtained. The Architects' Order issues the licence to practice, manages the architectural register, determines the duties and rights of architects, and is responsible for the formulation and execution of disciplinary rules. EC/EEA service providers will be registered in the Services Register in conformity with Article $8 \$ 2(1)$ AO. This Article implements Title II of Directive 
2005/36/EC. Third country nationals will have to get permission of the Council of the Order located in the area in which the service is to be provided.

It can be said that Belgium has implemented Directive 2005/36/EC well, although too late. However, neither the Architects' Act, the Architects' Order Act or the Deontological Code contain any provision on permanent education as meant in Article 22 (b) of the Directive.

In the Netherlands, registered architects can officially be distinguished from other professionals in the building sector, since they have the privilege to call themselves 'architect' to the exclusion of all others, as of 1 October 1993. On 1 January 2008, 9,100 architects were registered in the Netherlands. The Architects' Title Act gives rise to the legal protection of the title of Architect in the Netherlands. To use the title, one must be registered with the Foundation Bureau Architects Register, which is charged with the registration of architects. The general requirement for registration is the possession of a recognized diploma/certificate, or the successful taking of an examination. In general, Dutch students can follow a five-year university education leading to the title 'construction engineer' or a four year part-time Masters training at an Academy which follows a specific technical Bachelors education at an institute of higher education that comprises four years of full-time study. It is also possible to use the title after successful completion of the examination instituted by the Council of Architects. In order to participate in this examination, a minimum of seven years of practical experience in the field of architecture is required. The VROM Minister can grant an exemption on the basis of proven exceptional competence. Automatically recognised certificates are those issued by the universities or academies mentioned in the Architects' Act, and those mentioned in Annex V.7 and VI of Directive 2005/36/EC. Other qualifications (including thirdcountry qualifications) can be recognised under the Directive's general system which is incorporated in the Act of 6 December 2007 containing general rules on the recognition of EC qualifications (General Act EC professional qualifications). Third-country qualifications of architects who have already practised the profession in another Member State that has recognized the qualifications for three years, will also have to be recognized in the Netherlands. Even though the Architects' Title Act does not specifically mention it, case law has indicated that legal persons can also use the title if certain conditions are fulfilled.

At this moment in time, one can say that generally, only the academic grade is required for a person to use the title in the Netherlands. BNA membership is only open to architects who have at least two year of professional experience. When the Act of 4 March 2010 amending the Architects' Act will enter into force, the title of 'architect' can only be used after completion of a traineeship (Article 12d), while those who follow this traineeship can call themselves 'architects in training'. It is foreseen that the traineeship will become mandatory from 2015 onwards. It follows that the possession of such practical experience -a requirement to practise the profession in Belgium- will also become a requirement to use the title in the Netherlands. 
In the Netherlands, anyone can practise the profession. It follows that the profession of architect is not protected, which means that anyone can perform architectural services as long as the title is not used by those who do not fulfil the requirements of the Architects' Title Act. It is said that the protection of the profession is not necessary since many legal requirements already apply to the architect's design such as the provisions in the Building Decree and the Housing Act. Furthermore, Welstandscommissies which are composed of architects, town planners and regular citizens, advise municipalities and decide whether buildings are of sufficient quality and fit within the surroundings. Registered architects are not subject to a code of conduct. Only BNA members have to act in accordance with the BNA Code of Conduct. The Permanent Professional Training Regulations which apply, as of January 2006, contain rules on the professional education of BNA-members, and imply that these architects should spend at least thirty hours per year on professional training.

\section{- Market conduct}

There are no mandatory, minimum or maximum fee scales for architectural activities in

Belgium. Nevertheless, prices are often calculated as a percentage of construction costs. Such a system is liable to undermine the incentives for architects to design in a way that reduces unnecessary construction costs. Furthermore, there is a lot of uncertainty as to the price which the client has to pay for the services provided by the representative for a long time. This precludes transparency as to the price payable by the user. In 2004 the European Commission held that the recommended fee scale that was created by the Belgian Architects' Order in 1967 and which got binding force by Royal Decree in 1985, violated EC competition law. The Commission estimated that recommended minimum tariffs are generally created to coordinate the conduct of architects so that architects whose costs are lower are dissuaded from lowering their prices. Furthermore, recommended prices can mislead consumers as to what is a reasonable price for the service they are receiving, and as to whether this recommended price is negotiable. A scale that imposes or recommends minimum fees is unlikely to protect consumers against excessive fees. It also does not prevent unscrupulous architects from offering poor-quality services. Since the fee scale was liable to discourage architects from working in a costefficient manner, reducing prices, improving quality or innovating, it was decided that it violated Article 101(1) TFEU.

In the Netherlands, the SR 1997 used to indicate the fee basis by means of a reference to NEN 2631, which is a Dutch norm indicating how investment costs of building should preferably be calculated. A formula was drawn which led to the determination of a certain percentage which would then result in the fee. This formula left no room for price competition whatsoever and was often also used by architects which were no BNA members or to contracts to which the SR 1997 was not made applicable and was not only used by the Arbitration Institute Architecture but also by the ordinary courts. This form of price fixing was not taken over by the NR 2005.

It follows that the absence of price fixing leaves open the possibility of introducing price reductions which, in turn, generates more competition. However the fixing of prices as a percentage of the construction costs, does not seem to be cost-efficient. 
With regard to advertising, Article 13 of the Deontological Code in Belgium foresees that the architect is allowed to make his activities known to the public in an independent and discrete manner. Obtrusive publicity has to be avoided however. The architect has to take into account that his name and title are not used in an illegal way by others, or are used for commercial purposes by others. He is allowed to mention his title in books, and is even obliged to mention it on a plate at the building site during the construction work, and is allowed to have it mentioned afterwards.

In the Netherlands, there is no general regulation about advertising which is applicable for all architects. The disciplinary code of the BNA mentions, in Article 2(2), that architects have the freedom to make their activities, expertise, experience and competence known to the public.

Since there are no restrictions on advertising in Belgium and the Netherlands, consumers can be informed adequately about the services offered by architects in order to come to a decision. However, since architectural services are often all different in nature, the disclosure of information is complicated, meaning that advertising might mislead consumers. It follows that advertising is quite important with regard to persuading clients in terms of a first buy, while the repeat buying mechanism should provide incentives to provide a good price-quality ratio.

Finally, with regard to structural restrictions in Belgium, mention should be made of Article 6 AA and Article 10 of the Deontological Code, by which architects are not allowed to practise the profession of entrepreneur. Since architects should be independent (Article 4 Deontological Code) every association of an architect with an entrepreneur is forbidden.

In the Netherlands there is no such prohibition. Even though it may be argued that architects should be independent, it might be questioned whether such a severe restriction is efficient, since the profession seems to function quite well in states in which there is no incompatibility between architects and entrepreneurs.

\section{RESEARCH QUESTION 3}

What are the tasks, obligations and liabilities of architects in Belgium and the Netherlands?

In Belgium, design contracts are qualified as 'entrepreneurial contracts' which is a specification of the more general 'rent of labour'. As held by Article 1779 CC, the rent of work and services covers work provided by entrepreneurs performing in accordance with building specifications. The architect has to advise his client, design a plan, determine the programme and the budget, and supervise the building work. For the architect to be liable, a fault in the performance of his contractual activities, damage and a causal link must be proven. In this regard, architects are also liable if they have engaged an expert who lacks sufficient skills. The liability regime is next to the general provisions in the Civil Code specifically laid down in Articles 1787-1799 CC. In principle, the architect is not liable beyond the time that the building work is accepted (received) by the building master. Only for (small) hidden defects is the architect still liable after recep- 
tion. The same is true for serious defects, which cause the building to perish totally or partially (Article 1792 jo 2270 CC) and for which the architects is liable for a ten year period. These Articles are public orders since they are said to protect public safety and cannot be contractually deviated from, so that the liability period cannot be limited. This gives protection to the building master. Furthermore, clauses that limit the extent of the architect's liability are, in principle, void in Belgium. It follows that standard terms are not commonly used in Belgium, and disputes are almost always settled by judicial courts. For certain defects, such as problems with the stability, insulation and water tightness, architects have an obligation of result. However, the myriad of case law and legal literature indicates that Article 1792 CC does not contain a presumption of fault, which means that the one who holds the architect liable for a certain defect should prove the latter's error. Architects are not liable just because there is damage.

In Belgium, the architect is often held liable in solidum with the entrepreneur. This means that if the entrepreneur is responsible for a certain defect in the construction, the architect is often held liable as well, since it is often claimed that he supervised the building work insufficiently or incorrectly. Building masters almost always ask for an in solidum conviction, since all architects, including legal persons, are obliged to buy insurance. In this way, the building master has more certainty that he will receive damage compensation in the event of a defect. Since the architect is the only building partner who is obliged to buy professional liability insurance, including the decennial liability, he mostly suffers from huge liability claims. To cover their own losses as well as losses of other building partners, building masters often take out a Construction All Risks Insurance which covers damage during the realisation of the building work. The heavy weight on the shoulders of architects has been mitigated by the Laruelle Act, which also allows legal persons to practise the profession of architect. This means that the creditors of an architectural company can only claim compensation from the company's assets and that the architect-natural person's assets cannot be claimed against by way of damage compensation.

In the Netherlands, the relationship between the architect and the building master is qualified as a contract of services (Article 7:400 CC) and not as an entrepreneurial contract. The provisions in title 12 of the Civil Code which are applicable, not only to building works, but also to all types of entrepreneurship, therefore do not regulate the relationship between the architect and his client. Entrepreneurial contracts only cover material works, while architects generally carry out only intellectual tasks. The obligations of architects can be summarised as providing assistance and advice to clients, determining the programme and the budget, designing the plans and supervising the building work. These obligations are not laid down in the civil code, but are written down in standard terms, in case law and in the legal literature. Architects are, in principle, liable for every failure in the performance of their obligations (Article 6:74 CC). In general, they have an obligation of means, and have to act in the same way as a reasonable professional would have acted in these particular circumstances. They have to repair the damage which the creditor suffers because of their negligence, unless the failure is not attributable to them. If performance is not permanently impossible, the debtor has to be put in default before he is obliged to repair the damage. In the Netherlands, there is a large contractual free- 
dom with regard to architectural contracts. Several sets of standard terms exist in which the regulation between the architect and the building master is regulated. The most recent standard terms are the New Rules (NR) 2005. These standard terms are applicable if parties so agree, and contain an arbitration clause which generally has to be specifically agreed to. With regard to the architectural responsibility, Article $13.1 \mathrm{NR}$ holds that the architect is liable if he committed a culpable shortcoming (accountable fault) while the building master has put him in default in writing and has summoned him to repair the consequences of the shortcoming within a reasonable time and the architect has not (or not on time) repaired these shortcomings. As held by Article 7:758(2) CC, after delivery of the building works, the building master bears the risk for the building works. The general prescription period for liability is twenty years (Article 3:306 CC). Article 3:310 CC holds that claims for damage due to shortcomings in the performance of a contract, prescribe five years after the creditor discovered the shortcoming, while he is acquainted with the debtor. In a situation in which the creditor did not discover the damage, the liability period of ten years starts to run after the damage is caused. Article 16 NR 2005 deviates from this rule and foresees a liability period of five years which starts the day upon which the commission is terminated, either by completion or cancellation. Next to the limitation of the liability period, architects often limit the extent of their liability as well. In this regard, the damage to be compensated for by the consultant is limited per commission to a sum equal to the consultancy costs with a maximum of $1,000,000$ Euros. In the case of commissions where the client is a consumer, and the consultancy costs per commission are lower than 75,000 Euros, the damage to be compensated is to a maximum of 75,000 Euros.

The UAV, which are the standard terms applicable in the relationship between the entrepreneur and his client, do not contain many clauses limiting the liability of the entrepreneur. It follows that the liability for a possible shortcoming of the design will be more easily laid with the entrepreneur if he did not warn about faults in the design. In any case, the entrepreneur can be held liable for hidden defects after delivery, and for damage caused by the perishing of the building due to serious defects. In solidum convictions are not used to solve liability issues. Since there is no strict liability with regard to the design and supervision of the building works by the architect (architects are, in principle, only strictly liable if they exceed their powers or gave incorrect advice on the applicable building legislation), the building master has to prove the architect's shortcomings with regard to the liability of all the actors involved. There is therefore a heavier weight on the building master's shoulders. In the Netherlands, there is no mandatory insurance obligation except for BNA members (more than 3,000 members, more or less a third of all architects). If standard conditions are used which prescribe professional liability insurance, architects also have to buy insurance. In this way it can be concluded that most architects are insured.

The extent and duration of the architectural liability is much higher in Belgium than in the Netherlands. It follows that not only public law relating to market access and market conduct, but also private (contract) law, may affect the free movement of architects. Even though empirical research is still needed with regard to the effects of private law legislation on architects, it is possible that Dutch architects feel reluctant to work in 
Belgium since their professional liability lasts in general, twice as long as in the Netherlands. However, since this extended liability period can be covered by insurance, the fact that, in general, architects earn less in Belgium, will probably be a more compelling reason for Dutch architects not to establish in Belgium.

\section{RESEARCH QUESTION 4}

What does economic theory teach us about (self-)regulation in the professions?

When choosing between tort law and regulation as instruments for controlling risky activities, Shavell indicates that four criteria should be taken into account: information, insolvency risk, the threat of a liability suit and administrative costs. Due to the fact that private parties have more and better information at their disposal, information asymmetry favours a liability regime, since then they can make their own assessments concerning the control of risk. If this is not the case, regulation can take care of the information asymmetry problem. The same is true with regard to administrative costs: most of the costs of a liability system seem to be present in the event that harm has actually occurred. On the other hand, the inability to pay for harm done, as well as the possibility of a law suit, favour regulation, since regulation might be needed to prevent externalities causing large losses which professionals may not be able to cover due to insolvency or for which there is a lack of evidence.

Even though liability rules may inspire architects to take due care, regulation may be needed to cure market failure. Since activities carried out by an architect can cause harm, architects need incentives to take good care. Contracting parties may agree between themselves that certain rules are applicable within their relationship, in addition to (or instead of) the rules created by the state or by the professional association (Coase theorem). Externalities can be internalized in different ways: moral persuasion, taxes, liability rules and regulation. In this regard, the classic economic analysis of law starts from the assumption that, by exposing the costs of their actions through liability rules, parties will be motivated to take optimal care to prevent accidents. In this way, a reduction in the total social costs of accidents can be achieved, since it is at this level of care that the costs of prevention and expected damage are minimised. For liability rules to work effectively, there must be a victim and an identifiable injurer who is able to pay damage compensation. This is not always the case, which means that other possibilities have to be resorted to, such as regulation, either by the government or by self-regulating organizations. However, when a building contains a certain default, the building master will have no difficulty identifying the architect as a possible injurer, since these parties have entered into a contract. Nevertheless, due to the problem of information asymmetry, the building master is generally not in the position to determine the level of quality that should be provided, or the respective responsibilities of the engaged building partners. It follows that regulation is still needed to cure this market failure. Since the customer has less information at his disposal than the professional, he is not able to determine whether the design/building possesses the required quality level and is free from any defects. Due to the information asymmetry problem, regulation is needed in the architectural profession to safeguard quality. 
In fact, the architectural profession is characterized by high levels of regulation. This is often a mix of State regulation, self-regulation and custom and practice, which has evolved over a number of years. As suggested above, in spite of all the regulation policies, standard economic theory predicts that in a 'perfect market', an unregulated outcome is optimal, in that consumer welfare can only be improved at the detriment of producer welfare, and vice versa. It follows that there is a certain tension between, on the one hand, the need for a certain level of regulation in the professions and, on the other, competition law. Indeed, as noted above, national regulations are not only liable to restrict the free movement of professionals, but also free competition in the EU.

In economic theory, different approaches exist to explain why regulation has been created. According to the public interest approach, regulation is needed to cure market failure. Market failure might exist if there is no, or restricted, competition, if there is information asymmetry, if there are negative external effects and if the produced goods are public goods. Regulation is able to overcome these 'problems'. The private interest approach, on the other hand, indicates that regulation is not only an answer to market failure, but also the result of rent-seeking behaviour on the part of interest groups. By manipulating the economic environment rather than through trade and the production of wealth, these interest groups seek gain. Regulation can be created by the government or by the private associations themselves. Since the government is not always the party with the best knowledge of a certain matter, government regulation is not always costefficient. Furthermore, public regulatory regimes are not particularly flexible, while the costs of regulation are spread over society as a whole. However, according to the private interest approach, professional associations, which lack democratic legitimacy, will rather exclude competition than improve quality. In this regard the role of the Court of Justice of the European Union should be to filter out those rent-seeking practices which amount to protectionism of the national market as against foreigners.

Since both approaches towards regulation are surrounded with difficulties, some other forms of regulation are suggested by Van den Bergh: co-regulation (public policy objectives are achieved through the combination of a certain degree of self-regulation and traditional public regulation) and competitive self-regulation (competition between different professions offering the same service). Experiments with these types of mixed regulation are needed to gain more knowledge about the efficiency gains of these methods which bring into play the information benefits and the benefits concerning the reduction of enforcement costs of self-regulation.

As suggested above, liability rules can be used separately or jointly with ex ante regulation to remedy market failure. Calabresi and Shavell made a comparison between ex ante regulations, which are categorized as 'specific deterrence' and ex post liability which is categorized as 'general deterrence'. In the specific deterrence method, the government regulates a certain level of activities and care, decides who should perform certain activities, and in which way this should be done. This is due to the fact that people are said not to know what is best for themselves. When individuals do not live up to these government rules, they will be punished, and their behaviour is thus directly influenced by regulation. According to the general deterrence method, the regulator does not impose a particular type of behaviour, but links predetermined consequences to certain behav- 
iour. It follows that professionals come only into contact with these consequences once they have caused damage or are accused of having been at fault professionally. In liability regimes, the victim is therefore compensated for the consequences of certain acts or omissions, so that he will be put in the same position as he found himself in before the damage causing event. As opposed to this, the specific deterrence method emphasizes the punitive character of criminal regulation.

Finally it should be noted that, notwithstanding the use of liability rules, regulation or other instruments, damage can still occur. Insurance can increase the utility of risk averse persons, and can reduce transaction costs, since it is decided ex ante who will intervene in the event that damage occurs. However, this might bring about the situation that the behaviour of the insured party will change as soon as the risk is removed from him (moral hazard). As pointed out by Shavell, this can be solved by an appropriate adaptation of the insurance premium, and by exposing the insured partially to a risk, or a combination of both. Compulsory liability insurance is often advanced as a means of protecting the innocent victim. With regard to compulsory liability insurance, it can be suggested that there is a trade-off between the benefits and costs for both architects and their clients. Since the damage caused by a fault in the design or the supervision of the building work is generally quite high, mandatory liability insurance might be more in the interest of the building master and injured parties, than would be liability rules without mandatory insurance. Due to the problem of underdeterrence caused by insolvency, the victim can be protected against the possible bankruptcy of the architect. However, if architects are the only professionals in the building industry who are obliged to buy insurance, it is very likely that the injured party will first turn to the architect in order to obtain damage compensation, so the risk is shifted to those with the deepest pockets. In this regard it should be noted that it is also possible to force the architect ex ante, to provide certain compensation, a bank guarantee or another kind of payment as guarantee of compensation in the event that damage occurs. In such a case, architects are still liable in situations in which the damage is attributable to them, but are not obliged to buy insurance. This would be a flexible solution, provided that it enables the damage to be compensated adequately ex post, since the architect can choose any market solution.

\section{RESEARCH QUESTION 5}

\section{Is there any market failure in the Belgian and Dutch markets for architectural services which might justify regulation?}

As proposed by the public interest theory, a lack of competition might cause market failure. As demonstrated by the answer to research question 2, both Belgium and the Netherlands impose requirements upon architects before they can enter the profession. Belgian architects even have a monopoly with regard to designing and supervising building works. It follows that there is a higher level of competition in the Netherlands than in Belgium. This is because monopolists sell their output at a higher price level and can abuse their market power, which results in market failure. 
Negative externalities can also cause market failure. These appear in the architectural market every time the quality of the service rendered by the architect is not high, and damage is caused. This can bring about huge losses for private parties and for society as a whole: a poorly designed apartment building may collapse and cause damage, not only to the client, but also to visitors, neighbours, etc. It follows that regulation may be needed to obtain high quality buildings. However, even though consumer protection and a high quality of the built environment seem to be valid reasons for entry regulation, the Dutch situation demonstrates that other ex ante tools such as the Dutch Building Decree, can also protect the quality of buildings without the negative effects relating to the restriction of competition. Furthermore, Welstandscommissies, which are composed of architects, town planners and regular citizens, advise the municipality. They have to approve building applications and decide whether the proposed constructions are of sufficient quality and fit within the surroundings. It follows that it can be argued that according to the public interest theory, the tool used in Belgium to cure market failure goes too far. Since market competition is restricted to those who are allowed to use the title, the cure might be worse than the disease, and does not seem to be the most efficient solution to market failure. The Dutch certification process is recommended over licensing, since clients still have the choice with regard to engaging an architect. Furthermore, those who turn to a professional who is allowed to use the title can be sure that the latter does have a certain educational background and/or some professional experience. A less extreme option to dealing with the monopoly problem, next to the abolishment of it, can be found in the extension of the monopoly to others who also have the relevant knowledge and know-how. This might even be the case for certain entrepreneurs. Even though the prohibition of architects from associating with entrepreneurs in Belgium might be justified on public interest grounds since the architect should be able to work in total independence, it might be questioned whether this restriction, which does not exist in the Netherlands, is proportional. In any case, costbenefit analyses have already demonstrated that business restrictions bring about more costs than benefits.

The Mirza \& Nacey research revealed that Dutch architects earn more and charge higher prices than Belgian architects. Even though they do not necessarily calculate their fees in the same way, it is still striking to notice that there is a big income difference. A possible explanation might be found in the fact that it is just because there is no monopoly in the Netherlands, and there are fewer 'real' architects in the Netherlands compared to Belgium. Since individuals who are interested in making designs and supervising building works are allowed to carry out this activity without having to register, and thus also without using the title -they may even not have earned the title of architect- the number of possible suppliers is ultimately much higher, so that there is more competition in general. Furthermore, in the Netherlands, there is no reason for entrepreneurs and building promotors not to engage in drafting designs as well, since the legislator has not created incompatibilities as exist in Belgium. Since not everyone interested in, and capable of, drafting designs is obliged to register to be able to carry out this work, there is less competition among 'real' architects -those who are allowed to use the title, which might, in turn, explain the fact that 'real' architects charge higher prices. Of course con- 
sumers can choose whether to turn to a registered architect or another service provider. It might be argued that since most individuals only build once in their lives, and since this will probably be their most important spending decision ever, they are often inclined to choose based on the 'surety' of the competences of someone holding a relevant degree and belonging to an Order. The same goes for business clients since they also want to engage the best professionals for their projects. Since their financial assets are much higher than that of regular individuals, they have the possibility to turn to more expensive architects. On the other hand, on the Dutch building market, there are more large construction projects in which building promotors are engaged by public authorities to construct numerous identical houses in a certain area. Architects who are engaged in such projects can earn large profits with minimal investment, as opposed to their Belgian colleagues where such projects are not so popular. For this reason it might be argued that fewer architects are needed in the Netherlands. In any case it should be noted that a study conducted by Van den Bergh and Montangie with regard to the abolishment of the solicitors' monopoly for conveyancing services in England and Wales, and the deregulation of the Dutch notary profession, demonstrates that liberalization does not guarantee lower prices, so that increased competition is not guaranteed as a result of it. In this regard, mention should be made of the fact that even though the intensity of regulation in the Netherlands is lower with regard to entry to the profession, Dutch architects generally earn more than their Belgian colleagues.

The states and professional organisations often hold that the obligation to hold professional qualifications is needed to enhance consumer protection, since the architectural profession is characterized by a high level of information asymmetry, which can cause market failure. This is especially the case within the traditional construction process in which the architect's clients are generally one-time consumers, due to the fact that a house is considered to be a long and expensive investment. This can lead to adverse selection: since consumers cannot evaluate the properties of the supplied services, architects can be inclined to provide low quality services which are then bought by their clients. Furthermore, a moral hazard problem arises since clients are not able to determine whether the architect is working in their best interests, and are not able to sanction the architect's attitude. For these reasons, regulation may be necessary. Since architects are more often consulted by developers in the Netherlands, and are mostly consulted by individual clients in Belgium, it is expected that the problem of information asymmetry is more serious is in Belgium. Furthermore, it can be said that since the advice and services provided by an architect are generally so specific that another client with slightly different circumstances may not be able to use it, architectural services can, in principle, not be qualified as public goods, so that there is, in principle, no free rider problem for which regulation is warranted.

Even though the public interest theory explains that regulation can be necessary to cure the problem of information asymmetry which is certainly present with regard to the architectural profession, one needs to keep in mind that this regulation needs to be proportionate. Furthermore, situations in which regulation generates more costs than benefits (regulatory failure) should be avoided. Reference should also be made to the 
private interest approach that indicates that regulation is not always an answer to market failure, but the result of rent-seeking behaviour on the part of interest groups. Professional groups are likely to set standards too high, in order to push competitors out of the market or use licenses as an entry barrier which, in its turn, can lead to a monopolistic situation and monopolistic advantages for the professions concerned, and can undermine competition. The Belgian Architects' Order and the Dutch BNA -membership of the latter is not mandatory- enjoy public law status, and can determine who may use the professional title. Furthermore, they can impose punishments on individuals not complying with the deontology, and ask for a financial contribution as a condition of membership. Since good quality designs and buildings can also be obtained by other means, it can be said that the Belgian monopoly does not serve public interest, but rather serves to limit the number of market participants. This is likely to generate rents for architects who are already registered. Furthermore, the private interest approach may also explain why progress on the programmes to harmonize national systems for professional qualifications was painfully slow. As stated before, it took more than seventeen years before the Architects' Directive saw the light of day due to substantial differences in the way the profession was regulated, not only with regard to training conditions and professional qualifications, but also with regard to architectural obligations and liabilities. While Belgium held that Directives should only apply to persons holding a university degree, the Netherlands also wanted to approve non-university education in cases where practical experience complemented the theoretical knowledge up to university level. Since it took such a long time before agreement could be reached, it can be said that the architectural associations have defended their position fiercely.

\section{RESEARCH QUESTION 6}

Is the intensity of public regulation related to the intensity of the contractual obligations and liabilities of architects in Belgium and the Netherlands?

Since bad quality services provided by architects can have major effect, not only for the building master, but also for persons renting the building or third parties walking by, ex ante regulation is needed to determine issues like the desired educational level of professionals and the desired level of quality. In this way, professionals who are, at first sight, not competent, are already ruled out, so that the situation is already safer. However, if professionals who do possess the desired educational level were not at risk of being sued, they might not have the necessary incentives to deliver good quality.

With regard to the profession of architect in Belgium and the Netherlands, the intensity of regulation is not linked to the intensity of contract law. As held in the answer to research question 2, the entry to the architectural profession is more heavily regulated in Belgium than in the Netherlands, since architects have a monopoly in Belgium. Next to market entry regulation, market conduct regulation has an influence on the behaviour of architects in Belgium and the Netherlands. In this regard it must be stated that all architects practising in Belgium are subject to the deontological code, since they all have to be registered by the Order. In the Netherlands, on the other hand, there is no mandatory association with any professional organisation, so that deontological rules are not applicable unless one voluntarily chooses to become a BNA member. There are 
no mandatory, minimum or maximum fee scales in Belgium and the Netherlands. The fee scale which used to exist in Belgium was withdrawn after the European Commission held it to be incompatible with EU competition law. Nevertheless, in both countries, prices are often calculated as a percentage of construction costs. Such a system is liable to undermine the incentives for architects to design in a way that reduces unnecessary construction costs, and is therefore not cost-efficient. There are no restrictions on advertising in Belgium and the Netherlands, as long as this happens in a discrete manner (Belgium). With regard to structural restrictions, it has to be noted that architects are not allowed to practise the profession of entrepreneur, and vice versa. This prohibition is created to ensure the independence of the architect, and to guarantee quality. In the Netherlands there is no such prohibition. Since the profession seems to function quite well in the latter state, it might be questioned whether such a severe restriction is efficient with regard to curing any market failure. In any case, such restrictions prevent any one company from offering a total service package in which the building is designed and constructed by professionals who consider themselves as partners rather than adversaries. Such cooperation can lead to higher levels of efficiency since there is less negotiation and transaction costs, while the professionals involved are more likely to cooperate from the beginning and seek joint solutions in the event of a problem with the design or the construction of the work. From a public interest perspective, it must therefore be argued that negative externalities can be detected more easily.

Architects and their clients generally lay their respective rights and obligations down in a written contract. These contracts are entered into since regulations are often weak and cannot always be enforced. Contract law can be a useful (complementary) tool to dealing with market failure. However, concluding private agreements brings about high transaction costs, since parties have to negotiate the content of the contract. In this regard, standard conditions can be created which only bring about high transaction costs at the time of creation, and which can be adapted to the specific needs of every new situation. Especially in the Netherlands, standard conditions with an arbitration clause often form part of the agreement. It follows that self-regulation also has an influence on private law. Arbitration is popular, since disputes will be resolved by a body which is composed of professionals in the building industry (entrepreneur, architects, engineers) but also of building masters all of whom have a better knowledge than regular judges of design/construction problems. It follows that there are fewer administrative costs, which means that disputes can be resolved more quickly and less expensively. Arbitrators' verdicts may be more accurate and predictable than those of a court, since arbitrators possess industry expertise. Of course, when arbitrators have to decide upon complex or novel cases, it is also difficult to predict the decision. The desirability of alternative dispute settlement depends on the absence of information asymmetry and negative external effects. If parties decide ex ante to resort to dispute settlement by means of arbitration, one can assume that this is useful for them, so that this agreement has to be honoured, but this does not mean that the state has to encourage alternative dispute settlement procedures. In the event of information asymmetry and negative externalities, a further cost benefit analysis is required before the desirability of an alternative dispute settlement can be determined. 
Compared with other EU states, Belgium has a rather restrictive regime with regard to architects, while the Netherlands belongs to the group of more lenient states. Due to the regulatory differences, one might expect that parties in the Netherlands include heavier requirements in their contracts in order to guarantee quality and limit externalities. However, with regard to the contractual liability of architects, it seems that both in Belgium and the Netherlands, architects are generally liable for negligence. Furthermore, the ten year liability principle which is laid down by Belgian public regulation, and which is a public order, cannot be contractually deviated from, and thus always forms part of the contract. In the Netherlands, on the other hand, parties often deviate from the legal liability clauses in the Dutch Civil Code by means of standard conditions, which generally reduce the liability period to five years. It follows that the ten year liability principle in Belgium constitutes a heavier burden for architects than the five year liability period which is generally laid down in the Dutch standard regulations. The heavier burden on architects in Belgium is strengthened by the fact that they are often held liable in solidum with entrepreneurs, and by the fact that architects in Belgium are generally strictly liable for defects relating to the stability, insulation, waterproofing and sound insulation of the work. Furthermore, Dutch architects are also allowed to limit the extent of their liability (see Article 15 NR), while clauses that limit the extent of the architect's liability are, in principle, void in Belgium. It can be concluded that in Belgium and the Netherlands, the intensity of contractual liability is not linked to the intensity of regulation.

\section{CENTRAL RESEARCH QUESTION}

\section{Is the Dutch or the Belgian combination of regulations and contract law provisions most cost-efficient from an economic point of view?}

In this thesis it has been demonstrated that the regulation of the architectural title should be preferred over the regulation of the profession, since the latter can be replaced by other mechanisms to guarantee quality. Even though a professional monopoly might be justified to protect quality, it is not proportional, and is likely to benefit only the professionals themselves. It has been demonstrated also that price fixing, advertising restrictions (except those aimed at false and misleading advertising) and restrictions to business structure, are not cost-efficient. In this regard it can be stated that the entry to the profession is more heavily regulated in Belgium than in the Netherlands. Indeed, since only registered architects are allowed to design buildings for which a building permit is required, Belgian architects have a monopoly with regard to designing such buildings. It follows that more competition is possible in the Netherlands since there is no professional monopoly as in Belgium. Since architects are mostly consulted by individual clients in Belgium, it is expected that the problem of information asymmetry is more serious is in Belgium. However, since the Dutch situation demonstrates that other ex ante tools such as the Building Decree can also protect the quality of buildings without the negative effects as far as the restriction of competition is concerned, it might be assumed that, according to the public interest theory, the tool used in Belgium to cure market failure goes too far. Since market competition is already restricted to those who 
are allowed to use the title, the cure might be worse than the disease. Curing market failure by licensing does thus not seem to be the most efficient solution. Certification is recommended over licensing, since clients still have the choice to engage an architect. Those who turn to a professional who is allowed to use the title, are sure that such an individual does have a certain educational background, and/or some professional experience. However, to determine whether the restrictions on competition resulting from exclusive rights (e.g. the architectural monopoly in Belgium) does not go further than necessary to achieve public interest goals, a cost-benefit analysis which compares the architectural monopoly in Belgium with the architectural title protection in the Netherlands is required. More empirical research is needed to solve this issue. It follows that in any case, the most efficient regulatory instrument(s) should be chosen, and account should be taken of the effects of regulation on consumer surplus, producer surplus and the deadweight welfare loss. In this regard it should be noted that it is important for regulation not be disproportionate to curing the market failure under consideration.

A less extreme option when it comes to dealing with the monopoly problem, next to its abolishment, can be found in the extension of the monopoly to other experts, who also have relevant knowledge and know-how. This might even be the case for certain entrepreneurs. Furthermore, even though the prohibition of architects associating with entrepreneurs in Belgium might be justified in terms of the public interest, since the architect should be able to work in total independence, it might be questioned whether this restriction, which does not exist in the Netherlands, is proportional and thus efficient to cure market failure. As indicated before, such restrictions prevent one company from offering a total service package in which a building is designed and constructed by professionals who consider themselves as partners rather than adversaries. Such cooperation can lead to higher levels of efficiency, since there are fewer negotiation and transaction costs, while the professionals involved are more likely to cooperate from the beginning and seek joint solutions in the event of a problem with the design or the construction work appearing. Defects can be detected more easily by mutual monitoring. It follows that, from an efficiency point of view, the Dutch system should be preferred. In any case, cost-benefit analyses have demonstrated that business restrictions bring about more costs.

This thesis has revealed that, with regard to the architectural profession, a combination of ex ante regulation and liability rules seems optimal. Since bad quality services provided by architects can cause harm to the building master and to third parties, ex ante regulation is needed to determine the desired level of professional qualifications, and the desired quality level. However, this is not enough if professionals who do fulfil these requirements cannot be sued. Therefore liability rules are also needed. In this regard it should be emphasized that the differences in the Belgian and Dutch liability regimes may also negatively influence the free movement of architects. However, it has been demonstrated that the intensity of public regulation is not related to the intensity of the contractual obligations, which means that architects in Belgium are subject to more burdensome public law requirements as regards access to the profession, but also to more onerous liability rules. Since it has been held that the monopolistic situation is not cost-efficient, the heavier private law responsibilities of architects can hardly be justified 
from an economic perspective. Since Belgian architects face heavy claims, and are often held liable in solidum with the entrepreneur, problems of underinsurance and underdeterrence due to insolvency can be 'cured' by the introduction of compulsory liability insurance. Since architects in Belgium are the only professionals in the building industry who are obliged to buy insurance, they are often held liable in solidum with the entrepreneur. Consequently, it appears that the risk is shifted to those with the deepest pockets. It should be questioned whether this is the best way to remedy the insolvency problem, certainly having regard to the fact that there will always be a moral hazard problem with liability insurance. In the event of compulsory liability insurance, often the total risk is shifted to the insurer, since the legislator often limits the possibilities of exposing the insured to risk. In this way, the duty to insure is often equal to the total amount of liability, which strengthens the moral hazard and brings about higher premiums. Other possibilities, such as first party insurance, might cure the problem at lower cost and thus be more proportional to attaining the objective. In the Netherlands, only BNA members are obliged to buy insurance. However, standard terms generally also demand mandatory insurance, with the result that the majority of architects are covered by insurance, so that the Dutch and Belgian systems do not differ that much in practice when it comes to professional liability insurance. Even though it might be argued that the Belgian system is not cost-efficient, since architects who are not risk-averse have to pay the premium as well, while there will always be a moral hazard problem, it should be noted that this conclusion should be considered in the light of the number of architects who risk insolvency. Empirical research is needed to determine the number of architects belonging to this insolvency category. If the risk of underdeterrence is considerable, the Dutch system might also not be efficient. In any case, other possibilities exist for providing compensation such as a bank guarantee, and this should also be considered.

Finally, it should be noted that even though the limitation of the architectural liability by means of a private company with limited liability, which is possible in Belgium and the Netherlands, is cheaper than the limitation of liability by contractual clauses, and might be beneficial for architects, it is not desirable from a societal point of view, since the architect can 'hide' behind a legal person to safeguard his personal assets. In this way, only the capital of the company is at risk whenever a professional fault occurs, while the professional's personal wealth is exempt from any claims. This again brings about problems of underdeterrence of architects and undercompensation of victims, and is thus not efficient when it comes to compensating for possible damage.

Since the Belgian system is not proportionate when it comes to entry regulations to the profession, it can be concluded that, at least on this point, the Dutch system is more cost-efficient than the Belgium system.

\section{Policy recommendations}

In the spirit of the above-mentioned conclusions, I would like to propose the following recommendations with regard to the regulation of architects:

- When discussing the free movement of professionals in and to the EU, more account should be taken of differences in liability systems, since it is possible that these may hinder free movement. 
- The monopoly of architects in Belgium should be abolished, or at least extended to other experts such as experienced and qualified entrepreneurs. Since EU law does not forbid licensing systems as such, and since professional monopolies are, in principle, allowed unless they are not justified in the public interest and are disproportionate to the objective pursued, it can be argued that the Belgian situation is disproportional to achieving consumer protection and a high quality in terms of the built environment.

- The practice of the profession of architect should not be incompatible with the practice of the profession of entrepreneur.

- Architects should be given the choice between purchasing compulsory liability insurance or the provision of a certain compensation ex ante, such as a bank guarantee or other kind of payment as a guarantee of compensation in the event that damage is occurring.

- If architects are obliged to buy compulsory liability insurance, this obligation should also be extended to other building professionals, certainly in the light of the Belgian in solidum liability.

\section{Points for further research}

This thesis demonstrates that a law and economics approach towards regulation can be a useful method to analyse architectural law and policy. Economic theory has been applied to determine whether there is market failure within the Belgian and Dutch architectural markets, and to indicate to what extent it is efficient when it comes to regulating the architectural profession from both a public interest and a private interest perspective. The collection of empirical evidence of this market failure, and whether or not the Belgian and Dutch architectural regulation is the result of rent-seeking behaviour on the part of architects, might be useful to obtaining a better insight in this analysis. Information on the number of building defects caused by architects in Belgium and the Netherlands might provide useful insights regarding the presence and scope of negative externalities in both states.

In the introduction it was stated that this thesis only deals with the traditional construction process in which a client engages an architect and an entrepreneur by himself. However, more complex relationships have arisen in the construction industry, and alternative construction processes can be recognized in which the building master signs an agreement with a promoter, and can only have a minimum amount of influence. Whether or not the same conclusions can be drawn for such alternative processes, especially with regard to the liability of architects, is an interesting point for further research.

This thesis has described the contractual obligations and liabilities of architects from a legal point of view. An economic analysis of these private law principles might reveal some interesting insights to determine whether the Dutch or the Belgian private law system is more cost-efficient. A comparison of the architects' liability in tort, and his criminal liability, might also offer some interesting insights. Furthermore, empirical research may determine why the income of Dutch architects is higher than that of Belgian architects, and whether the explanations I suggested for this are correct.

Finally, it should be noted that this thesis has not discussed whether it is better according to economic theory to have EU legislation to uniformly regulate (harmonize) 
the architectural profession. Reference was made to the Draft Common Frame of Reference and the PEL SC neither of which are legally enforceable, while a legal analysis of the regulation of architects in the European Union was provided in Part I of this thesis, which contains an effectiveness study to determine whether architects can practise their profession in other EU states without unjustified impediments. By applying the economics of federalism, further research could demonstrate whether it would be more efficient to uniformly regulate the profession.

Architecture is a fundamental feature of our history, our culture and of our future. The combined effect of competition rules and common market rules should lead to better functioning of a common market, and to an increase in competition. Through the geographical mobility of architects, cultures and architecture itself will be enriched. Even though building promoters are the leading figures in the Dutch market, architects are still engaged to make a design. The architectural profession is thus certainly not 'dead', but is rather in its infancy, due to new technologies which are developing with immense speed. As suggested by Frank Lloyd Wright, (architect 1869-1959), 'The mother art is architecture. Without an architecture of our own we have no soul of our own civilization.' 


thans vervangen is door Richtlijn 2005/36/EG. Deze richtlijn betreft professionele en niet academische erkenning, daar ze van toepassing is op personen die reeds volledig gekwalificeerd zijn als architect en hun beroep in die hoedanigheid reeds uitoefenen terwijl academische erkenning in principe een kwestie betreft die enkel onder de verantwoordelijkheid van de lidstaten valt en niet onder die van de EU.

In principe kan worden gesteld dat de kwalificaties van architecten die vermeld worden in Annex V.7 van Richtlijn 2005/36/EG automatisch erkend dienen te worden door de andere lidstaten, zolang deze opleiding in totaal ten minste, hetzij vier jaar studie op voltijdse basis, hetzij zes jaar studie waarvan ten minste drie jaar voltijds, aan een universiteit of een vergelijkbare onderwijsinstelling bevat (Titel III van Hoofdstuk III). Ter afsluiting van deze opleiding dient met goed gevolg een examen op universitair niveau te worden afgelegd en dient de verwerving van de in de richtlijn genoemde kennis en bekwaamheid te zijn gewaarborgd. Ook de driejarige opleiding aan de Duitse 'Fachhochschulen' dient te worden erkend voor zover deze opleiding wordt aangevuld met een periode van beroepservaring van vier jaar in Duitsland. Indien een diploma niet vermeld wordt in Annex V.7 kan ook het algemeen systeem neergelegd in Titel I van Hoofdstuk III van de Richtlijn worden toegepast als bepaalde voorwaarden zijn vervuld wat betreft het niveau van de behaalde beroepskwalificaties. Indien de duur van de opleiding ten minste één jaar korter is of indien de inhoud van de opleiding wezenlijk verschillend is, kan een aanpassingsstage of een proeve van bekwaamheid worden geëist door de ontvangende lidstaat. Het Europees Hof van Justitie (EHJ) heeft in dit opzicht geoordeeld dat rekening dient te worden gehouden met elke genoten opleiding en al de ervaring van de kandidaat (Vlassopoulou), ook indien die in een andere lidstaat werd verkregen (Haim, Hocsman). In dit opzicht stelt Richtlijn 2005/36/EG dat lidstaten de kwalificaties van EU-burgers behaald buiten de Unie mogen aanvaarden indien de bepalingen van de Richtlijn worden nageleefd doch zij zijn hiertoe slechts verplicht indien een eerste lidstaat de kwalificaties reeds heeft erkend en de kandidaat drie jaar professionele ervaring heeft. Ook al werd door het EHJ geoordeeld in Gül dat ook bepaalde personen die niet de nationaliteit bezitten van een EU-lidstaat het erkenningsregime zoals neergelegd in Vlassopoulou kunnen inroepen, zijn de artikelen uit het verdrag en Richtlijn 2005/36/EG in principe niet van toepassing op derdelanders. Richtlijn 2004/38/EG verleent echter aan bepaalde familieleden van EU-burgers, zelfs indien zij niet de nationaliteit bezitten van een EU-staat, het recht op gelijke behandeling. Daarenboven werden er na de inwerkingtreding van het Verdrag van Amsterdam vijf Richtlijnen gecreëerd alsook één ontwerprichtlijn die een aantal rechten verlenen aan bepaalde categorieën van derdelanders. Ook associatie- en partnerakkoorden met staten die niet behoren tot de EU werden gesloten. De situatie van architecten uit derde landen is ver van gelijk of vergelijkbaar met de status van EU-architecten.

Het beroep van architect wordt vaak niet enkel gereguleerd door de lidstaten doch ook door de beroepsorganisaties. Deze reguleringen kunnen niet enkel het vrij verkeer van architecten hinderen, doch kunnen er ook voor zorgen dat de vrije mededinging wordt gelimiteerd. Regels betreffende de toegang en de uitoefening van het beroep, alsook regels die prijzen vastleggen, publiciteit verhinderen of samenwerkingsvormen verbie- 
den, zijn in dit opzicht gekende voorbeelden. Dit boek bespreekt wanneer zulke regels een inbreuk vormen op het Europese mededingingsrecht.

Niet enkel de situatie van architecten op EU-niveau wordt besproken in dit boek. Er wordt tevens een analyse van de Belgische en Nederlandse regulering geboden. Zowel in België als in Nederland mogen in principe enkel zij die de gepaste opleiding hebben genoten de titel van architect voeren. $\mathrm{Na}$ registratie door de Orde van architecten zijn deze personen ook exclusief bevoegd om het beroep van architect uit te oefenen wat betreft bouwwerken waarvoor een bouwvergunning is vereist in België. Dit betekent aldus dat de Belgische architecten een monopoliepositie hebben, daar niemand anders de taken van de architect mag uitvoeren. In Nederland daarentegen mag iedereen het beroep uitoefenen en wordt enkel het gebruik van de titel beperkt tot zij die het vereiste diploma bezitten. Dit betekent dat de Nederlandse architect niet over een monopolie beschikt wat betreft het maken van een plan of het houden van toezicht. Nederlandse architecten dienen zich te laten registreren door de Stichting Bureau Architectenregister. Deze stichting is geen beroepsorde zodat zij ook geen deontologische beroepscode heeft uitgewerkt zoals de Belgische Orde. Enkel architecten die zich apart laten registeren door de Bond der Nederlandse Architecten (BNA) dienen de code van deze professionele organisatie te respecteren.

Onderzoek heeft aangetoond dat er in beide staten ook verschillen zijn wat betreft het cliënteel en de inkomsten van architecten: in België worden architecten vaker ingeschakeld door gewone consumenten terwijl in Nederland architecten vaker werken voor projectontwikkelaars of gemeenten. Dit is ook merkbaar in het bouwlandschap dat in België gekarakteriseerd wordt door een aaneenschakeling van verschillende soorten woningen terwijl in Nederland hele wijken bestaan uit hetzelfde soort huizen. Architecten in Nederland verdienen daarenboven aanzienlijk meer dan hun Belgische collega's.

Naast de 'publieke' regelgeving die ondermeer regelt wie de titel mag voeren en wie het beroep mag uitoefenen, bespreekt dit boek ook de situatie van architecten onder het Belgische en Nederlandse contractenrecht met betrekking tot het traditionele bouwproces. In dit opzicht dient te worden opgemerkt dat er geen afdwingbaar Europees contractenrecht bestaat dat werd onderschreven door de lidstaten van de EU.

Een eerste belangrijke vaststelling is dat waar in België de verhouding tussen de architect en de bouwheer in principe geregeld wordt door de specifieke inhoud van het contract en de relevante bepalingen van het Burgerlijk Wetboek, deze verhouding in Nederland zeer vaak beheerst wordt door Standaardvoorwaarden zoals 'De Nieuwe Regeling 2005' (NR). Deze voorwaarden bevatten een door de BNA uitgewerkte regeling inzake de verplichtingen, aansprakelijkheden en rechten van de architect en de bouwheer en worden zeer vaak toegepast, zelfs indien de betreffende architect geen lid is van de BNA. De Nieuwe Regeling voorziet daarenboven in de beslechting van geschillen door de Raad van Arbitrage voor de Bouw. Wat betreft de aansprakelijkheid van architecten in het bijzonder voorziet de Belgische wetgeving dat architecten niet meer aansprakelijk zijn na oplevering van de werkzaamheden. Dit is enkel anders indien het gebouw geheel of gedeeltelijk teniet gaat door een gebrek in de bouw waarvoor architecten en aannemers gedurende tien jaren aansprakelijk zijn, alsook in het geval van bedrog 
en bij verborgen gebreken. Het Nederlandse Burgerlijk Wetboek stelt dat een rechtsvordering tot vergoeding van schade door verloop van vijf jaren verjaart na de aanvang van de dag waarop de benadeelde met de schade en met de daarvoor aansprakelijke persoon bekend is geworden. Krachtens de NR vervalt elke aansprakelijkheid van de architect door verloop van vijf jaren vanaf de dag waarop de opdracht is geëindigd. Het is aldus duidelijk dat de periode waarin de architect doorgaans aansprakelijk kan worden gehouden half zo kort is in Nederland ten opzichte van in België. De aannemer die in beginsel niet meer aansprakelijk kan worden gehouden na oplevering, blijft in Nederland toch aansprakelijk voor verborgen gebreken (de rechtsvordering verjaart door verloop van twee jaren na protest van de opdrachtgever en is in ieder geval verjaard door verloop van twintig jaren na de oplevering). Indien de Uniforme Administratieve Voorwaarden (UAV) worden toegepast die in het algemeen de relatie tussen de bouwheer en de aannemer regelen, kan de aannemer gedurende tien jaar aansprakelijk worden gehouden indien het gebouw geheel of gedeeltelijk teniet is gegaan. Daarenboven wordt ook de omvang van de aansprakelijkheid van de architect in Nederland beperkt door de NR, terwijl dit in België niet is toegestaan. Hierbij komt nog dat in België architecten doorgaans in solidum aansprakelijk worden gesteld tezamen met de aannemer. Zowel in België als in Nederland zijn ook rechtspersonen in de mogelijkheid het beroep uit te oefenen. Op deze manier kan de Belgische architect sinds kort ook zijn persoonlijke aansprakelijkheid beperken. Het is duidelijk dat de intensiteit van de regulering (in België: monopolie; in Nederland: geen monopolie) niet gerelateerd is aan de intensiteit van de aansprakelijkheid van architecten (in België: tien jaar voor gebreken die de stevigheid van het gebouw aantasten, geen beperking van de omvang van de aansprakelijkheid mogelijk, in solidum aansprakelijkheid mogelijk; in Nederland doorgaans vijf jaar; beperking van de omvang van de aansprakelijkheid mogelijk, geen in solidum aansprakelijkheid).

Aangezien architecten door het uitvoeren van hun taken schade kunnen veroorzaken, is het van belang dat zij als een goede huisvader te werk gaan. De klassieke economische analyse van het recht stelt dat aansprakelijkheidsregels er voor kunnen zorgen dat men goede zorg draagt om schade te voorkomen. Vaak zijn zulke regels evenwel niet voldoende en is regulering nodig opdat architecten en andere beroepsbeoefenaars werk van hoge kwaliteit afleveren. De reden hiervoor is dat de architectenmarkt gekenmerkt is door informatieasymmetrie waarbij cliënten vaak leken zijn die niet in staat zijn om te beoordelen of het werk al dan niet aan de gestelde vereisten voldoet of wie aansprakelijk is voor eventuele schade. Ex-ante regulering kan bepaalde eisen stellen waaraan steeds dient te worden voldaan door de beroepsbeoefenaar. De standaard economische theorie voorspelt echter dat in een perfecte markt waarin er onbelemmerde marktwerking is, de afwezigheid van regulering optimaal is. Een algemeen evenwicht wordt bereikt indien er vele kleine en identieke producenten zijn die niet in staat zijn het prijsniveau beduidend te beïnvloeden en die homogene producten verkopen; er perfecte informatie is zodat iedereen geïnformeerd is over de prijs en eigenschappen van de producten; er geen externe effecten zijn en de producten private goederen zijn. Zoals aangegeven rijst er zeer vaak een probleem van informatieasymmetrie. Dit kan leiden tot antiselectie waarbij cliënten kiezen voor goedkope diensten die van slechte kwaliteit blijken te zijn omdat zij 
niet in staat zijn de kwaliteit te beoordelen alsook tot een moreel risico waarbij een architect zich anders gaat gedragen en slechtere kwaliteit of extra (onnodige) diensten zal leveren daar hij weet dat zijn cliënten minder of geen kennis van zaken hebben. Daarenboven kunnen zich negatieve externe effecten (schade, ook aan derden) voordoen indien de architect niet met voldoende zorg zijn werkzaamheden heeft uitgevoerd. Aangezien voornoemde voorwaarden die vervuld dienen te zijn om een evenwicht te bereiken in een perfecte markt in principe niet (allen) vervuld zijn wat betreft de diensten verleend door architecten en er alzo marktfalen is, stelt de economie van het publiek belang dat regulering nodig is om dit marktfalen te herstellen. Dit brengt met zich mee dat er een spanningsveld is tussen enerzijds de regulering van het beroep en het mededingingsrecht anderzijds. Er dient echter op toegezien te worden dat regulering niet verder gaat dan nodig om het doel van het waarborgen van voldoende kwaliteit te bereiken. Zoals aangegeven beschikken architecten in België over een professioneel monopolie. In Nederland worden andere instrumenten gebruikt om kwaliteit te waarborgen: het Nederlands Bouwbesluit bevat bepalingen waaraan de gebouwen dienen te voldoen en Welstandscommissies adviseren de gemeente inzake de geschiktheid en kwaliteit van een voorgestelde constructie. Volgens de theorie van het publiek belang gaat het monopoliesysteem in België dan ook te ver. Desalniettemin zijn de prijzen in België toch lager dan in Nederland zodat kan worden gesteld dat (partiële) liberalisatie niet noodzakelijk leidt tot lagere prijzen. De theorie van het private belang stelt aan de andere kant dat regulering het resultaat is van het gedrag van belangengroeperingen die winst zoeken (rentseeking) en de politici proberen te overtuigen regulering in hun voordeel te creëren. Om te bepalen of de beroepsorganisaties van architecten succesvolle rent-seekers zijn is een empirische analyse nodig.

Dit boek heeft aangetoond dat wat betreft het beroep der architect, een combinatie van ex-post aansprakelijkheidsregels en ex-ante regulering optimaal is. Ex-ante regulering, zoals regulering betreffende de vereiste beroepskwalificaties, is nodig om het niveau te bepalen van de gewenste kwaliteit. Aangezien ook architecten die aan de diplomavereisten voldoen aansprakelijk moeten kunnen worden gesteld indien er zich toch schade voordoet, is een aansprakelijkheidsregime eveneens nodig. Aangezien zulk regime niet voldoende prikkels biedt indien de architect niet in staat is de schade te vergoeden, is de dekking die door zijn verzekering wordt geboden van belang. Echter, bij verzekering rijst wederom het moreel risico: het is mogelijk dat de architect minder zorg aan de dag zal leggen indien hij weet dat zijn verzekering toch de eventuele schade zal dekken. Daarom dient de premie die betaald moet worden voldoende aangepast te zijn aan zijn gedrag en de geleverde kwaliteit en is het nuttig de architect zelf ook gedeeltelijk aan het risico bloot te stellen. Een systeem van verplichte verzekering wordt vaak beschouwd als de oplossing om de bouwheer te beschermen. Terwijl in België alle architecten verplicht zijn een aansprakelijkheidsverzekering af te sluiten, is dit in Nederland enkel het geval voor BNA-leden. In België wordt de bouwheer aldus beschermd tegen het eventuele faillissement van de architect. Aangezien de architect evenwel de enige bouwpartner is die bij wet verplicht is zich te verzekeren en aangezien architecten doorgaans in solidum aansprakelijk worden gesteld tezamen met de aannemer, wordt het risico gelegd bij degene met het grootste vermogen. Dit kan een effect hebben op de premie die betaald 
dient te worden en die architecten nadien kunnen doorrekenen aan de bouwheer. Hoewel gesteld kan worden dat het Belgisch systeem niet kostenefficiënt is daar ook architecten die weinig risico lopen verplicht zijn zich te verzekeren en er steeds een moreel risico kan zijn, moet deze conclusie gezien worden in het licht van het aantal architecten dat insolvabel zou zijn. Empirisch onderzoek is nodig om te bepalen hoeveel architecten tot deze categorie behoren. Indien er te weinig afschrikking is wat betreft het insolventierisico waardoor de kans op insolventie groter is, kan worden gesteld dat het Nederlandse systeem in dit opzicht ook niet efficiënt is. Om deze reden dienen andere mogelijkheden om schade te vergoeden, zoals een bankgarantie, ook overwogen te worden. 

négociations que la Directive 85/384/CEE concernant la reconnaissance mutuelle des diplômes, certificats et autres titres du domaine de l'architecture et comportant des mesures destinées à faciliter l'exercice effectif du droit d'établissement et de libre prestation de services, est entrée en vigueur. Celle-ci est actuellement remplacée par la Directive 2005/36/CEE. Il faut remarquer que cette Directive concerne la reconnaissance professionnelle et non pas la reconnaissance académique puisqu'elle est applicable aux personnes qui ont déjà été admises à exercer la profession d'architecte et qui exercent déjà la fonction. La reconnaissance académique est en principe une affaire appartenant seulement à la responsabilité des États membres.

En ce qui concerne la Directive, on peut avancer que les États membres sont obligés de reconnaître les qualifications dans le domaine d'architecture nommées dans l'annexe V.7. automatiquement si le demandeur a suivi une formation contenant en total au moins quatre ans à plein temps ou six ans dont au moins trois ans à plein temps dans une université ou dans un autre établissement d'enseignement (Titre III du Chapitre III). Il faut qu'à l'issue de cette formation le demandeur ait réussi un examen au niveau universitaire et qu'il ait gagné toutes les connaissances et compétences indiquées dans la Directive. Aussi la formation dispensée par les 'Fachhochschulen' allemands qui dure trois ans doit être reconnue si elle est suivie d'une période d'expérience professionnelle de quatre ans en Allemagne. Si un diplôme n'est pas mentionné dans l'Annexe V.7., il est possible de se servir du système général codifié dans Titre I du Chapitre III de la Directive si les conditions concernant le niveau des qualifications sont remplies. Si la durée de la formation suivie est inférieure au moins d'un an à celle requise dans l'État membre d'accueil ou lorsque la formation qu'il a reçue porte sur des matières substantiellement différentes de celles couvertes par le titre de formation requis dans l'État membre d'accueil, l'État membre d'accueil a le droit d'exiger du demandeur qu'il accomplisse un stage d'adaptation pendant trois ans au maximum ou qu'il se soumette à une épreuve d'aptitude. A cet égard la Cour de Justice de l'Union européenne a décidé que les autorités nationales sont tenues d'examiner dans quelle mesure les connaissances et qualifications attestées par le diplôme acquis par l'intéressé dans son pays d'origine correspondent à celles exigées par la réglementation de l'État d'accueil (Vlassopoulou). En outre les qualifications obtenues dans un autre État membre doivent être prises en considération (Haim, Hocsman). Par contre, la Directive 2005/36/CE indique que chaque État membre peut permettre sur son territoire, selon sa réglementation, l'exercice d'une profession réglementée aux ressortissants des États membres titulaires de qualifications professionnelles qui n'ont pas été obtenues dans un État membre. Néanmoins, tout titre de formation délivré dans un pays tiers doit être assimilé à un titre de formation obtenu dans l'Union dès lors que son titulaire a, dans la profession concernée, une expérience professionnelle de trois ans sur le territoire de l'État membre qui a reconnu ledit titre conformément.

Bien que la Cour ait jugé dans le cas Gül que certaines personnes qui ne disposent pas de la nationalité d'un État membre sont également autorisées à invoquer le système de reconnaissance comme établi dans Vlassopoulou, en principe les articles du traité et de la Directive 2005/36/CE ne sont pas applicables aux personnes qui ont la nationalité d'un tiers pays tiers. Par contre, la Directive 2004/38/CE confère à certains membres de la famille des ressortissants de l'UE même s'ils ne disposent pas de la nationalité d'un 
État membre, le bénéficie de l'égalité de traitement. En outre, après l'entrée en vigueur du Traité d'Amsterdam, cinq Directives ont été créées ainsi qu'un projet de Directive qui confèrent certains droits aux quelques catégories de personnes des états tiers en vue de l'intégration dans l'Union. Aussi des accords d'association et de partenariat ont été conclus avec des états qui n'appartiennent pas à l'Union. Néanmoins, la situation des architectes venants des pays tiers n'est ni identique, ni comparable au statut des architectes de l'UE.

Souvent la profession d'architecte n'est pas seulement régulée par les États membres mais aussi par les associations professionnelles. Il est possible que ces régulations ne dérangent pas seulement la circulation libre des architectes mais aussi la libre concurrence. Des réglementations concernant l'accès à et l'exercice d'une profession et les règles qui imposent des prix, interdisent la publicité ou des formes de coopération sont des exemples connus. Ce livre examine, également, les violations des règles européennes par certaines de ces réglementations

Ce livre ne traite pas seulement la situation des architectes au niveau de l'UE. Il contient aussi une analyse des régulations belges et néerlandaises. En principe, dans ces deux pays les architectes sont seulement autorisés à l'emploi du titre d'architecte après avoir achevé la formation nécessaire. En Belgique ces personnes sont -après l'enregistrement à l'Ordre des architectes- exclusivement compétentes pour exercer la profession quant aux ouvrages exigeants un permis de constructions. Cela implique que les architectes belges ont un monopole puisque personne d'autre n'a le droit d'exercer la profession. Par contre, aux Pays-Bas tout le monde a le droit d'exercer la profession. C'est seulement l'utilisation du titre qui est réservée à ceux qui possèdent le diplôme nécessaire. Aux Pays-Bas les architectes ne jouissent pas d'une position monopolistique pour le dessin du plan et la supervision des travaux de construction. Aux Pays-Bas les architectes sont obligés de s'enregistrer auprès de la 'Fondation Bureau Registre des Architectes'. Cette fondation n'est pas un Ordre professionnel et n'a donc pas crée de code professionnel comme l'Ordre belge. Seuls les architectes qui sont enregistrés spécialement chez 'l'Association des Architectes Néerlandais' (BNA) sont tenus de respecter la déontologie de cette organisation professionnelle.

Des études ont démontré qu'il y avait des différences dans les deux états en ce qui concerne la clientèle et le revenu des architectes : en Belgique les architectes sont plus souvent consultés par des consommateurs individuels tandis qu'au Pays-Bas les architectes travaillent plutôt pour les promoteurs de construction ou pour les municipalités. A cet égard le paysage de construction belge est caractérisé par une chaîne de maisons de toutes sortes alors que les quartiers remplis d'habitations plus ou moins identiques sont courants aux Pays-Bas. En plus, aux Pays-Bas les architectes ont un revenu considérablement plus haut que celui de leurs collègues en Belgique.

A côté de la réglementation publique qui détermine qui a le droit d'utiliser le titre et qui peut exercer la profession, ce livre traite aussi la situation des architectes par rapport au droit du contrat belge et néerlandais dans le processus de la construction traditionnelle. 
A cet égard il faut remarquer qu'il n'existe pas de droit européen des contrats contraignant souscrit par les États-membres de l'UE.

Une première constatation importante est que comme la relation entre l'architecte et le maître d'ouvrage est en principe réglé par le contenu spécifique du contrat et par les articles relevant du Code Civil en Belgique, aux Pays-Bas cette relation est fréquemment réglée par les conditions types comme La Nouvelle Régulation' (NR). Ces conditions règlent les obligations, les responsabilités et les droits de l'architecte et du maitre d'ouvrage. Elles sont créées par le BNA et sont appliquées le plus souvent, même si l'architecte n'est pas membre du BNA. En outre, la Nouvelle Régulation prévoit les règlements de contentieux par le Conseil d'Arbitrage de la Construction. En ce qui concerne la responsabilité des architectes en particulier, la législation belge indique que les architectes ne sont plus responsables après la réception des travaux. Néanmoins si l'édifice construit à prix fait ou s'il y a la possibilité qu'il menace de périr en tout ou en partie par le vice de construction, même par le vice du sol, l'architecte et l'entrepreneur sont responsables pendant dix ans. Comme une faute commise par un architecte a souvent des conséquences sérieuses, la responsabilité décennale est souvent invoquée. La période de responsabilité est aussi prolongée en cas de dol et de défauts cachés. Le Code Civil néerlandais stipule que l'action en justice pour obtenir des dommages est couverte par la prescription de cinq ans à partir du jour où la victime a pris de connaissance de l'identité du responsable. Le NR indique que toute responsabilité s'éteint cinq ans après le jour où les travaux sont finis. Il est clair que la période lors de laquelle l'architecte peut habituellement être tenu responsable aux Pays-Bas ne représente que la moitié de la période en Belgique. En principe, l'entrepreneur n'est plus responsable après la réception de travaux sauf pour les défauts cachés (l'action en justice se prescrit deux ans après la protestation du maitre d'ouvrage et s'est en tout cas prescrit vingt ans après la réception). Si les Conditions Administratives Uniformes (UAV) qui règlent en général la relation entre le maître d'ouvrage et l'entrepreneur, sont appliquées, l'entrepreneur peut être tenu responsable pendant dix ans si l'édifice a périt en tout ou en partie. En outre, l'étendue de la responsabilité de l'architecte aux Pays-Bas est limitée par le NR, tandis que cela n'est pas permis en Belgique. Il faut ajouter qu'en Belgique les architectes sont généralement tenus responsable in solidum avec l'entrepreneur. En Belgique comme aux Pays-Bas les personnes morales ont la possibilité d'exercer la profession. De cette manière l'architecte belge peut depuis récemment limiter sa responsabilité. Il est clair que l'intensité de la régulation (en Belgique : situation monopolistique; aux Pays-Bas: pas de monopole) n'est pas liée à l'intensité de la responsabilité des architectes (en Belgique : dix ans pour les défauts qui atteignent la fortitude de l'édifice, pas de limites sur l'étendue de la responsabilité, couramment responsabilité in solidum; aux Pays-Bas généralement cinq ans ; limitation du volume de la responsabilité possible, pas de responsabilité in solidum).

Puisque les architectes peuvent causer des dommages en exerçant leur profession, il est important qu'ils travaillent avec la prudence d'un bon père de famille. L'analyse économique du droit classique détermine que les règles de la responsabilité peuvent contribuer à la prévention du dommage. Néanmoins, souvent ces règles ne sont pas suffisantes de sorte que l'on a besoin des régulations pour s'assurer que le travail des architectes et 
des autres professionnels garantit d'une qualité élevée. La raison est que le marché d'architectes est connu par l'asymétrie de l'information puisque les clients sont généralement des profanes qui ne sont pas capable de juger si l'ouvrage satisfait aux conditions nécessaires ou qui est responsable pour un dommage éventuel. La régulation ex ante peut exiger des qualités que le professionnel doit satisfaire. Néanmoins, la théorie d'économie standard expose que dans un marché parfait dans lequel il y a une concurrence illimitée, l'absence des régulations est optimale. Un équilibre général est atteint quand il y a beaucoup de petits producteurs identiques qui ne sont pas capables d'influencer le niveau des prix significativement et qui vendent des produits homogènes ; il y a une information parfaite de sorte que tout le monde est bien informé du prix et des qualités des biens ; il n'y a pas d'effets externes et les produits sont des biens privés. Comme indiqué ci-dessus, le problème d'asymétrie de l'information se présente souvent sur le marché des architectes. Cela peut aboutir sur l'anti-sélection ce qui implique que les clients choisissent des services moins chers de mauvaise qualité puisqu'ils ne sont pas capables de juger la qualité ainsi qu'à un risque moral causant qu'un architecte change son comportement et fournit des services de mauvaise qualité ou des services superflues puisqu'il sait que ses clients ont moins ou pas de connaissance en la matière. En outre, il est possible que des effets externes négatifs (dommage, aussi aux tiers) se présentent si l'architecte n'a pas travaillé avec assez de soins. Comme les conditions qui doivent être satisfaites pour atteindre un équilibre sur un marché parfait ne sont, en principe, pas remplies dans le domaine des services rendus par un architecte ce qui implique qu'il y a défaillance du marché, la théorie de l'intérêt public indique qu'il faut de la régulation pour rétablir cette défaillance. Il s'ensuit qu'il y a une zone de tension entre la régulation de la profession d'une part et le droit de la concurrence d'autre part. Néanmoins il faut veiller à ce que la régulation n’aille pas plus loin que nécessaire pour atteindre la garantie d'une qualité suffisante. Comme indiqué ci-dessus, en Belgique les architectes disposent d'un monopole professionnel. Par contre, aux Pays-Bas d'autres instruments sont utilisés pour garantir la qualité : le Décret de la Construction néerlandais contient les conditions auxquelles les édifices doivent satisfaire et des Services d'Urbanisme conseillent les municipalités sur l'aptitude et la qualité d'une construction proposée. Cela signifie que d'après la théorie de l'intérêt publique la situation monopolistique n'est pas proportionnelle. Néanmoins, les prix en Belgique sont plus bas qu'aux Pays-Bas ce qui peut indiquer que la libéralisation (partielle) ne mène pas nécessairement à des prix plus bas.

D’autre part, la théorie de l'intérêt privé stipule que la régulation est le résultat du comportement des groupements d'intérêts qui cherchent du profit (rent-seeking) et essaient de convaincre les politiciens de créer des règles à leur avantage. Afin de déterminer si les associations professionnelles des architectes sont des 'rent-seekers' réussis il faut une analyse empirique.

Ce livre a démontré que, en ce qui concerne la profession d'architecte, une combinaison des règles de responsabilité ex post et de la régulation ex ante est optimale. La régulation ex ante, comme la régulation des qualifications professionnelles nécessaires, est nécessaire pour déterminer le niveau de la qualité désirée. Puisqu'il faut que les architectes qui satisfont les conditions des qualifications professionnelles soient 
également tenus responsables en cas de dommage, il faut de plus un régime d'imputabilité. Étant donné qu'un tel régime n'offre pas assez de stimulations si l'architecte n'est pas dans la possibilité d'indemniser la victime, le paiement par son assurance est une affaire d'importance. Cependant l'assurance facilite à nouveau les problèmes de hasard moral : il est possible que l'architecte soit moins sérieux dans son travail s'il sait que son assurance sera responsable financièrement pour le dommage. Voilà ce qui explique pourquoi la prime doit être adaptée suffisamment à son comportement et à la qualité fournie et pourquoi il est utile d'exposer l'architecte luimême partiellement au risque. Un système d'assurance obligatoire est souvent vu comme solution pour protéger le maitre d'ouvrage. Pendant qu'en Belgique tous les architectes sont obligés de se couvrir avec une assurance de responsabilité, aux Pays-Bas seulement les membres du BNA y sont tenus. Il s'en suit qu'en Belgique le maitre d'ouvrage est donc protégé contre la faillite éventuelle de l'architecte. Comme l'architecte est le seul partenaire du processus de construction qui est obligé par loi de s'assurer et comme les architectes sont généralement responsables in solidum avec les entrepreneurs, le risque est mis chez le plus fortuné. Cela peut avoir un effet à la prime que les architectes peuvent inclure dans le prix à payer par le maître d'ouvrage. Même si on peut estimer que le système belge n'est pas efficace en termes de coûts puisque les architectes qui ne courent pas vraiment de risques sont également obligés de payer une assurance et attendu qu'il y aura toujours un problème de hasard moral, il faut que cette conclusion soit lu par rapport au nombre d'architectes risquant l'insolvabilité. Des études empiriques sont nécessaires afin de déterminer combien d'architectes appartiennent à cette catégorie. Si les architectes sous-estiment les risques qu'ils encourent de sorte que le risque d'insolvabilité sera plus grand, on peut soutenir que le système néerlandais n'est pas efficace non plus à cet égard. Pour cette raison des autres possibilités pour indemniser le dommage, comme une garantie bancaire, doivent être considérées. 


\section{BIBLIOGRAPHY}

\section{Literature}

\section{Adams 1989}

Adams, M., 'New Activities and the Efficient Liability Rules', in: M. Faure \& R. Van den Bergh, Essays in Law and Economics. Corporations, Accident Prevention and Compensation for Losses, Antwerp: Maklu, 1989.

Addison, Barrett \& Siebenass 1997

Addison, J.T, Barrett C.R. \& Sieben, W.S., Labour Markets in Europe, Issues of Harmonization and Regulation, London: Dryden Press, 1997.

Adriaansens, Maks \& Philipsen 2005

Adriaansens, C.A., Maks, J.A.H. \& Philipsen, N.J., 'A Law and Economic Approach of the Regulatory Framework for Architects in the Netherlands', in: E. Crals \& L. Vereeck (Eds.), Regulation of Architects in Belgium and the Netherlands. A Law and Economics Approach, Leuven: LannooCampus, 2005.

Akerlof 1970

Akerlof, G., 'The Market for Lemons', Quarterly Journal of Economics, 84, pp. 487-500.

Alajääskö \& Blackburn 2004

Alajääskö, P., \& Blackburn, O., 'Architectural and Engineering Activities and related Technical Consultancy', Statistics in Focus, European Commission, Eurostat, 11/2004.

Allsopp 1993

Allsopp, B., 'Patronage and professionalism', in: B. Farmer \& H. Louw (eds.), Companion to Contemporary Architectural Thought, London and New York: Routlegde, 1993, pp. 33-38.

Arnold 2004

Arnold, R.A., Economics, Ohio: Thomson South-Western, 2004.

Arrow 1965

Arrow, K., Aspects of the Theory of Risk-Bearing, Helsinki: Yrjö Jahnssonin Säätiö, 1965.

Arruňada 2004

Arruňada, B., 'Managing Competition in Professional Services and the Burden of Inertia', C.-D. Ehlermann and I. Atanasiu (eds.), European Competition Law Annual, Oxford/Portland Oregon: Hart Publishing, 2004, pp. 51-72.

Asser - Hartkamp 2004

Asser, C. - Hartkamp, A.S., Handleiding tot de beoefening van het Nederlands Burgerlijk Recht, Verbintenissenrecht, De verbintenis in het algemeen, Deventer: Kluwer 2004.

Asser -Thunissen 1994

Asser, C. - Thunissen, H.O., Handleiding tot de beoefening van het Nederlands Burgerlijk Recht, Bijzondere Overeenkomsten, deel 5-III, Aanneming van Werk, Zwolle: Kluwer 1994.

Asser-Van den Berg 2007

Asser, C. \& Van Den Berg, M.A.M.C., Handleiding tot de beoefening van het Nederlands Burgerlijk Recht. Bijzondere overeenkomsten, deel IIIC, Aanneming van Werk, Deventer: Kluwer, 2007. 


\section{Aubry, Rau, Zachariä \& Bartin 1907}

Aubry, F.C., Rau, C, Zachariä, K.S. \& Bartin, A., Cour de droit civil français : d'après la méthode de Zachariae, Paris: Marchal \& Billard, 1907.

Baert 2001

Baert, G., Aanneming van werk, Antwerp: E. Story-Scientia, 2001.

Baggott \& Harrison 1986

Baggott, R. \& Harrison, L.J., 'The Politics of Self-Regulation: the Case of Advertising Control', Policy and Politics, 14, 1986, pp. 143-160.

Baker \& Griffith 2007

Baker, T. \& Griffith, S.J., 'Predicting Corporate Governance Risk: Evidence from the Directors' \& Officers' Liability Insurance Market', University of Chicago Law Review, 74, 2007, pp. 487-544.

Barnes \& Stout 1992

Barnes, D.W. \& Stout, L.A., The Economics of Contract Law, Minneapolis: West Group 1992.

Becker 1975

Becker, G.S., 'A Theory of Competition Among Pressure Groups for Political Influence', in: Quaterly Journal of Economics, 18, 1975, pp. 421-447.

Becker 1976

Becker, G.S., The Economic Approach to Human Behavior, Chicago: University of Chicago Press, 1976.

Benham 1972

Benham, L., 'The Effect of Advertising on the Price of Eyeglasses', Journal of Law and Economics, vol. 15, 1972, pp. 337-352.

Berman 2002

Berman, G.S., The Morphing of the Architect's Role and How it is Impacting the CM, Construction Management Association of America, National Conference \& Trade Show, Loews Coronado Bay Resort, San Diego, CA, October 13-15, 2002, p. 5.

\section{Bernstein 1992}

Bernstein, L., 'Opting out of the Legal System: Extralegal Contractual Relations in the Diamond Industry', in: The Journal of Legal Studies, vol. 21, no. 1, 1992, pp. 115-157.

Bicho 1999

Bicho, M.-J., 'Professions liberales: aspects essentiels de l'action de la Commission en matière d'application des règles de concurrence', Competition Policy Newsletter 1999/2.

Black 1996

Black, J., 'An Economic Analysis of Regulation: One view of the Cathedral', Oxford Journal of Legal Studies, vol. 16, nr. 4, 1996 , pp. 699-711.

Bond, Kwoka, Phelan \& Whitten 1980

Bond, R., Kwoka, J., Phelan, J. \& Whitten, I., Effects of Restrictions of Advertising and Commercial Practice in the Professions: The Case of Optometry, Washington: Federal Trade Commission, 1980.

Bond der Nederlandse Architecten 2006 Bond der Nederlandse Architecten, The Architectural Profession in the Netherlands, leaflet August 2006.

Boom 1995

Boom, A., 'Asymmetric international minimum quality standards and vertical differentiation', Journal of Industrial Economics, vol. 43, nr. 1, 1995.

Borch 1961

Borch, K., 'The Utility Concept Applied to the Theory of Insurance', The Austin Bulletin, 1961, pp. 245255.

Brans 1994

Brans, E.H.P., Liability for Ecological Damages under the 1992 Protocols to the Civil Liability Convention and the Fund Convention and the Oil Pollution Act of 1990, Tijdschrift voor Milieuaansprakelijkheid, 1994, pp. 61-67 and 85-91.

Bricmont 1971

Bricmont, G., La responsabilité des architecte et entrepreneur, $3^{\text {rd }}$ ed., Brussels: Larcier, 1971.

Bruggeman, Chao-Duivis \& Koning 2007

Bruggeman, E.M, Chao-Duivis, M.A.B. \& Koning, A.Z.R., Praktijkboek contacteren in de bouw, Den Haag: Instituut voor Bouwrecht, 2007. 


\section{Brumter 2004}

Brumter, P., 'Freedom of Establishment and Freedom to Provide Services for Regulated Professions in the Internal Market: New Initiatives by the Commission', in: C.-D. Ehlermann and I. Atanasiu (eds.), European Competition Law Annual, Oxford/Portland Oregon: Hart Publishing, 2004, pp. 219-228.

Buchanan 1995

Buchanan, J. M., 'Federalism as an Ideal Political Order and an Objective for Constitutional Reform' Publius, vol. 25, 1995, pp. 19-27.

Buchanan, Tollision \& Tullock 1980

Buchanan, J.M., Tollison, R.D. \& Tullock, G. (eds), Towards a Theory of Rent-Seeking Society, Texas: A\&M University Press, 1980.

Burssens 2001

Burssens, F., Aannemingsrecht in Hoofdlijnen, Anwerp-Apeldoorn: Maklu, 2001.

Burssens 2007

Burssens, F., 'Het voeren van de titel en de uitoefening van het beroep van architect na de Wet van $15 \mathrm{Fe}-$ bruari 2006', in: Burssens, F., Daelman, S., Gielis, M., Ruysschaert, S. \& Joosten, L., De Architectenvennootschap, Antwerp: Maklu, 2007, pp. 11-30.

Button \& Fleming 1992

Button, K. \& Fleming, M., 'The Effect of Regulatory Reform on the Architectural Profession in the United Kingdom', International Review of Law and Economics, vol. 12, pp. 95-116.

Cady 1976

Cady, J., 'An Estimate of the Price Effects of Restrictions on Drug Price Advertising', Economic Inquiry, vol 14, 1976, pp. 493-510.

Calabresi 1970

Calabresi, G., The Costs of Accidents. A Legal and Economic Analysis, New Haven: Yale University Press, 1970.

Calabresi 1975

Calabresi, G., 'Optimal Deterrence and Accidents', Yale Law Journal, 1975, pp. 656-671.

Caron 2008

Caron, A., The legal profession between regulation and competition, LUISS Guido Carli Working Paper, 2008.

Cave 1985

Cave, M., 'Market Models and Consumer Protection', Journal of Consumer Policy, 1985, pp. 336-351.

Chiappori \& Salanie 2000

Chiappori P.A. \& B. Salanie, B., 'Testing for Asymmetric Information in Insurance Markets', The Journal of Political Economy, 108, 2000, pp. 56-78.

Claessens 2008

Claessens, S., Free Movement of Lawyers in the European Union, Nijmegen:Wolf Legal Publishers, 2008.

Coase 1960

Coase, R., 'The Problem of Social Cost', Journal of Law and Economics, 3, 1960, pp. 1-44.

Coble \& Blatter 1999

Coble, R.J. \& Blatter, R.L., 'Concerns with Safety in Design/Build Process', Journal of Architectural Engineering, col. 5, nr. 2, June 1999, pp. 44-48.

Cohen \& Dehejia 2004

Cohen, A. \& Dehejia, R., 'The Effect of Automobile Insurance and Accident Liability Laws on Traffic Fatalities', Journal of Law and Economics, 47, 2004, pp. 357-393

Comanor \& Wilson 1979

Comanor, W. \& Wilson, T., 'The Effect of Advertising on Competition: A Survey', Journal of Economic Literature, vol. 17, 1979, pp. 453-476.

Cooke 2004

Cooke, J.D., 'Vocation as a Commodity', in: C.-D. Ehlermann and I. Atanasiu (eds.), European Competition Law Annual, Oxford/Portland Oregon: Hart Publishing, 2004, pp. 229-238

Cooter \& Ulen 2003

Cooter, R. \& Ulen, T., Law and Economics, $4^{\text {th }}$ ed., Pearson, Addison-Wesley, 2003.

Cordinanzi, Lang \& Nascimbene 2008

Cordinanzi, M., Lang, A. \& Nascimbene, B., Citizenship of the Union and Free Movement of Persons, 2008. 


\section{Cordinanzi, Lang \& Nascimbene 2008}

Cordinanzi, M., Lang, A. \& Nascimbene, B., Citizenship of the Union and Free Movement of Persons, Martinus Nijhoff Publishers, 2008.

Cox 1989

Cox, S., 'Advertising Restrictions among Professionals: Bates v. State Bar of Arizona', in: J. Kwoka \& L. White (eds.), The Antitrust Revolution: The Role of Economics, Glenview: Scott Foresman, 1989, pp. 134159. .

Cox \& Foster 1990

Cox, C. \& Foster, S., The Costs and Benefits of Occupational Regulation, Bureau of Economics Staff Report to the Federal Trade Commission of the United States, 1990.

Cox \& De Serpa 1982

Cox, S., De Serpa, A. \& Canby, W., 'Consumer Information and the Pricing of Legal Services', Journal of Industrial Economics, vol. 30, 1982, pp.305-318.

Craig \& De Burca 2003

Craig, P. \& De Burca, G., EU Law, Text, Cases and Materials, Oxford: Oxford University Press, 2003.

Curran 1993

Curran, C., 'The American Experience with Self-Regulation in the Medical and Legal Professions', in: M. Faure, J. Finsinger, J. Sieger \& R. Van den Bergh (eds), Regulation of Professions: A law and economics approach to the regulation of attorneys and physicians in the US, Belgium, the Netherlands, Germany and the U.K., Antwerp: Maklu, 1993, pp. 47-87.

Dabin \& Lagasse 1955

Dabin, J. \& Lagasse, A., 'Examen de Jurisprudence (1951-1955): La responsabilité délictuelle et quasi délictuelle', Revue Critique de Jurisprudence belge, 1955, pp. 216-278.

Daelman 2007

Daelman, S., 'De verzekeringstechnische aspecten m.b.t. de wettelijk verplichte verzekering (Wet Laruelle 15/2/2006)', in: in: Burssens, F., Daelman, S., Gielis, M., Ruysschaert, S. \& Joosten, L., De Architectenvennootschap, Antwerp: Maklu, 2007, pp. 31-70.

Dankelman 1999

Dankelman, S., Europa geschaakt! De Europese erkenning van architecten en ingenieurs, Delft: Eburon, 1999.

Day \& Powell

Day, R. \& Powell, J., 'The vision, the potential and the virtual reality: technologies to inform architectural design', in: B. Farmer \& H. Louw (eds.), Companion to Contemporary Architectural Thought, London and New York: Routlegde, 1993, pp. 166-173.

De Becker 1941

De Becker, A., La protection du titre et de la profession d'architecte, Brussels: Larcier, 1941.

Deben \& Vereeck 2003

Deben, L., Rechtseconomische theorie van verkeersaansprakelijkheid en regulering, Diepenbeek: Steunpunt Verkeersveiligheid, Diepenbeek, 2003.

De Caluwé 1989

De Caluwé, A., 'L’exercice en société des professions libérales. La professions d'architecte'; in R. Valkeneer and P. Deahn (eds.), L'exercice en société des professions libérales, Brussels : Bruylant, 1989, pp. 1-28.

De Caluwé 1997

De Caluwé, A., 'Un monopole en question: Est-ce vraiment le cas?', in: X, Liber amicorum Yvon Hannequart et Roger Rasir, Diegem: Kluwer 1997, pp. 17-34.

De Caluwe \& Devogele 1967

De Caluwe, A. \& Devogele, H., 'Interférence des responsabilités de l'architecte et de l'ingénieur', Journal des Tribunaux, 1967, pp. 587-589.

De Graeve 2009

De Graeve, M., Een werkelijk vrij verkeer van diensten voor architecten, in: Tijdschrift voor Wetgeving 2009, 2, p. 181.

Dekkers 1955

Dekkers, R., Précis de droit civil belge, II, Brussels: Bruylant, 1955.

Delvaux 1968

Delvaux, A., Traité juridique des bâtisseurs, Brussels : Bruylant, 1968. 
Deketelaere, Schoupas \& Verbeke 2004

Deketelaere, K., Schoups, M. \& Verbeke A., Handboek Bouwrecht, Antwerp: Intersentia 2004.

De Page 1957

De Page, H., Traité élémentaire de droit civil belge, principes-doctrine-jurisprudence, $2^{\text {nd }}$ edition, Brussels: Bruylant, 1951.

De Witte 2007

De Witte, B., 'Setting the Scene, How did Services get to Bolkestein and Why?', European University Institute Law Working Paper, no. 2007/20, (also published as Mitchell Working Paper 3/2007 (Europa Institute, University of Edinburgh).

Diephuis 1889 Diephuis, G., Het Nederlandsch Burgerlijk Regt, XII, 1889.

Dingwall \& Fenn 1987

Dingwall, R. \& Fenn, P., 'A Respectable Profession? Sociological and Economic Perspectives on the Regulation of Professional Services', International Review of law and Economics, 1987, 7, pp. 51-64.

Dingwall \& King 1995

Dingwall, R. \& King, M.D., 'Herbert Spencer and the professions: occupational ecology reconsidered', Sociological Theory, 13, 1995, pp. 14-24.

Dirix 1984

Dirix, E., Obligatoire verhoudingen tussen contractanten en derden, Antwerp: Kluwer, 1984.

Divis 2004

Divis, J., The international labour market: professional recognition of qualifications, presentation at the expert meeting on the Impact of Globalization on Higher Education, UNESCO, Paris 2001.

Djankov, La Porta, Lopes-de-Silanes \& Schleifer 2002

Djankov, S., La Porta, R., Lopes-de Silanes, F. \& Shleifer, A., 'The Regulation of Entry', Quarterly Journal of Economics, vol. 117, 2002, pp. 1-37.

Djankov \& Purrell 2002

Djankov, D. \& Purrell, P., 'Enterprise restructuring: a quantitative survey', Journal of Economic Literature, vol. 40 , no. 3,2002 , pp. $739-792$.

Dougan 2001

Dougan, M., 'Free Movement: The Workseeker as Citizen', in: Cambridge Yearbook of European Legal Studies, 2001

Duranton 1844

Duranton, M., Cours de droit français suivant le Code Civil, Paris : Thorel, 1844.

Eatwell, Milgate \& Newman 1984

Eatwell, J., Milgate, M., Newman, P., The New Palgrave, a Dictionary of Economics, Hampshire: Palgrave Publishers, 1998.

Ehlermann 1993

Ehlermann, C.D., 'Concurrence et professions libérales: antagonisme ou compatibilité', Revue du marché commun et de l'union européenne, 1993, pp. 136-144.

Endres \& Staiger 1966

Endres, A. \& Staiger, B., 'Ökonomische Aspeckte des Umwelthaftungsrecht', in: M. Ahrens \& J. Simon (eds.), Umwelthaftung, Risikosteurerung und Versicherung, Berlin: Erich Schmidt Verlag, 1966, pp. 79-93.

Endres \& Schwarze 1991

Endres, A. \& Schwarze, R., 'Allokationswirkungen einer Umwelthaftpflicht-versicherugn', Zeitschrift für Umweltpolitik und Umwelrecht, 1991, pp. 1-25

Evans 2004

Evans, L., 'Professional Services: Recent EU Developments and Work in Progress' , in: C.-D. Ehlermann and I. Atanasiu (eds.), European Competition Law Annual, Oxford/Portland Oregon: Hart Publishing, 2004, pp. 517-528

Farmer 1993

Farmer, B., 'Introduction', in: B. Farmer \& H. Louw (eds.), Companion to Contemporary Architectural Thought, London and New York: Routlegde, 1993, pp. 1-3. 


\section{Faure 2008}

Faure, M.G., 'Legal Harmonisation from the Perspective of the Economic Analysis of Law', in: M. G. Faure, H. Koziol and S. Puntscher-Riekmann (eds.), Vereintes Europa - Vereinheitliches Recht? Die Rechtsvereinheitlichung aus rechtsökonomischer, privatrechtlicher and politikwissenschaftlicher Sicht, Vienna: Verlag der Österreichischen Akademie der Wissenschaften, 2008, pp. 11-46.

\section{Faure 2003}

Faure, M.G., 'How Law and Economics May Contribute to the Harmonisation of Tort Law in Europa', in: R. Zimmerman (ed.), Grundstrukturen des Europäischen Deliktsrechts, Baden-Baden: Nomos 2003, pp. 3182

\section{Faure 2002}

Faure, M.G., 'Environmental Damage Insurance in Theory and Practice', in: T. Swanson (Ed.), An Introduction to the Law and Economics of Environmental Policy: Issues in Institutional Design, 2002, pp. 282 328

Faure \& Hartlief 2003

Faure, M.G. \& Hartlief, T., Insurance and Expanding Systemic Risks, Paris: Organisation for Economic Cooperation and Development, 2003.

Faure \& Skogh 2003

Faure, M. \& Skogh G., The Economic Analysis of Environmental Policy and Law: an introduction, Cheltenham: Edward Elgar Publishing, 2003.

Faure \& Hartlief 1996

Faure, M. \& Hartlief, T., 'Compensation Funds versus Liability and Insurance for Remedying Environmental Damage', Review of European Community and International Environmental Law, 1996, pp. 321326.

Faure \& Van den Bergh 1987

Faure, M. \& Van den Bergh, R., 'Negligence, Strict Liability and Regulation of Safety under Belgian law: An Introductory Economic Analysis', The Geneva Papers on Risk and Insurance, 1987, pp. 95-114.

Faure \& Van den Bergh 1989

Faure, M.G. \& Van den Bergh, R.J., Objectieve aansprakelijkheid, verplichte verzekering en veiligheidsregulering, Antwerp: Maklu 1989.

Faure 2008

Faure, M., 'Calabresi and Behavioural Tort Law and Economics', Erasmus Law Review, volume 01, 2008 pp. $75-102$

Fenet 1827

Fenet, P.A., Receuil complet des travaux préparatoires du Code civil, 14, Paris: Videcoq, 1827.

First 2004

First, H., 'Liberal or Learned? European and US Antitrust Approaches', in: C.-D. Ehlermann and I. Atanasiu (eds.), European Competition Law Annual, Oxford/Portland Oregon: Hart Publishing, 2004, pp. 239 270.

Fisman \& Sarria-Allende 2004

Fisman, R. \& Sarria-Allende, V., Regulation of Entry and the Distortion of Industrial Organization, NBER Working Paper no. 10929., 2004.

Flamme 1975

Flamme, M.-A., 'Du partage des responsabilités dans la construction', in: Responsabilité Professionnelle et assurance des riques professionnels, Brussels 1975.

Flamme \& Lepaffe 1966

Flamme, M.-A., \& Lepaffe, J., Le contrat d'entreprise, Brussels: Bruylant, 1966.

Fletcher 2004

Fletcher, A., 'The Liberal Professions: Getting the Regulatory Balance Right', in: C.-D.Ehlermann and I. Atanasiu (eds.), European Competition Law Annual, Oxford/Portland Oregon: Hart Publishing, 2004, pp. 73-84.

Fontaine 1996

Fontaine, M., Droit des assurances, Brussels: Larcier, 1996.

Fontein 1988

Fontein, E.M., De rechtspositie van de architect 1850-1985, Delft: Delfse Universitaire Pers, 1988. 


\section{Forrester 2004}

Forrester, I.S., 'Where Law Meets Competition: Is Wouters Like a Cassis de Dijon or a Platypus?' , in: C.-D. Ehlermann and I. Atanasiu (eds.), European Competition Law Annual, Oxford/Portland Oregon: Hart Publishing, 2004, pp. 271-294.

Freidson 1994

Freidson, E., Professionalism Reborn: Theory, Prophecy and Policy, Cambridge: Polity Press 1994.

Fries \& Shaw 1998

Fries, S. \& Shaw, J., 'Citizenship of the Union: First steps in the European Court of Justice', in: European Public Law 4, 1998.

Garben 2008

Garben, S., 'The Bologna Process From a European Law Perspective', European University Institute Law Working Paper, no. 2008/12.

\section{Garoupa 2004}

Garoupa, N., Regulation of Professions in the US and Europe: A Comparative Analysis; American Law \& Economics Association Annual Meetings, The Berkeley Electronic Press, 2004.

\section{Geens 2004}

Geens, K., 'Vrij beroep en mededinging: deontologie is een remedie tegen, tucht dikwijls een gevolg van marktfalen', in: Liber Amicorum Tijdschrift voor Privaatrecht en Marcel Storme, Story, 2004, pp. 283-296.

Ghykca 1938

Ghyka, M.C., Essai sur le rythme, Paris: Gallimard, 1938.

Gilliams 2003

Gilliams, H., Self-regulation by liberal professions and the competition rules. Paper presented at Regulation of Professional Services conference organized by the European Commission, Brussels, 2003.

Gilliams 2004

Gilliams, H., 'Competition Law and Public Interest: Do we Need to Change the Law for the (Liberal) Professions?', in: C.-D. Ehlermann and I. Atanasiu (eds.), European Competition Law Annual, Oxford/Portland Oregon: Hart Publishing, 2004, pp. 395-334.

Gilson 1990

Gilson, R.J., 'The Devolution of the Legal Profession: A Demand Side Perspective', Maryland Law Review, 49, 1990, pp. 869-916.

Glanville 2004

Glanville, H., 'Provisional Notes on the Professional Recognition of Foreign Qualifications', CARDS Project Higher Education Mobility: Diploma Recognition Policy and Legislation, 2004.

Grabosky \& Braithwaite 1986 Grabosky, P. \& Braithwaite, J., Of Manners Gentle: Enforcement Strategies of Australian Business Regulatory Agencies, Melbourne: Oxford University Press, 1986.

Greenbie 1993

Greenbie, B.B., 'Harmonizing the human habitat', in: B. Farmer \& H. Louw (eds.), Companion to Contemporary Architectural Thought, London and New York: Routlegde, 1993, pp. 82-88.

Groeneveld 2007

Groeneveld, H.A., Wet op de Architectentitel, Deventer: Kluwer, 2007.

Gropius 1965

Gropius, W., The New Architecture and the Bauhaus, Cambridge, MA: The MIT Press, 1965.

Gyselen 2004

Gyselen, L., 'Anti-Competitive State Action in the Area of Liberal Professions: An E.U./U.S. Comparative Law Perspective', in: C.-D.Ehlermann and I. Atanasiu (eds.), European Competition Law Annual, Oxford/Portland Oregon: Hart Publishing, 2004, pp. 353-396.

Hadfield 2000

Hadfield, G., 'The Price of Law: How the Market for Lawyers Distorts the Justice System', Michgan Law Review, 98, 2000, pp. 953-1006.

Hailbronner 1999

Hailbronner, K.,'The Treaty of Amsterdam and Migration Law', European Journal of Migration and Law 1(1), 1999. 


\section{Hameleers 2004}

Hameleers, M., 'Towards a Smarter Protection of Public Interests in the Liberal Professions', in: C.D.Ehlermann and I. Atanasiu (eds.), European Competition Law Annual, Oxford/Portland Oregon: Hart Publishing, 2004, pp. 85-100.

Hartlief \& Tjittes 1994

Hartlief, T. \& Tjittes, R.P.J.L., Verzekering en Aansprakelijkheid, Deventer: Kluwer, 1994.

Hemenway 1990

Hemenway, D., 'Propitious Selection', The Quarterly Journal of Economics, 105, 1990, pp. 1063-1069.

Henssler \& Kilian 2003

Henssler, M. \& Kilian, M., Economic Impact of Regulation in the Field of Liberal Professions in Different Member States, Position Paper, Cologne, 2003.

Herbots 1980

Herbots, J.H., 'De aannemingsovereenkomst', in: Bijzondere overeenkomsten. Actuele problemen. Postuniversitaire lessenreeks januari-april 1980, Antwerp: Kluwer, 1980.

Herbots, Pauwels \& Degrootte 1997

Herbots, J.H., Pauwels, C. \& Degrootte, E, 'Overzicht van Rechtspraak (1988-1994). Bijzondere overeenkomsten’, Tijdschrift voor Privaatrecht 1997, pp. 647-776.

Heremans 2010

Heremans, T., Professional Services in the EU Internal Market: Quality Regulation and Self-Regulation, thesis defended at Leuven University on 19 March 2010, to be published.

Hernán \& Kujal 2004

Hernán, R. \& Kujal, P., Market Access and Minimum Quality Standards, Economics Working Papers, Madrid University, 2004.

Hitchcock \& Johnson

Hitchcock, H.-R. \& Johnson, P., The International Style, 1997, New York; W. W. Norton \& Company, 1997.

International Monetary Fund 1997

International Monetary Fund, World Economic Outlook, Washington, 1997.

Jansen 1998

Jansen, C.E.C., Towards a European Building Contract Law, Deventer: W.E.J. Tjeenk Willink, 1998.

Jenny 2004

Jenny, F., 'Regulation, Competition and the Professions', in: C.-D.Ehlermann and I. Atanasiu (eds.) European Competition Law Annual, Oxford/Portland Oregon: Hart Publishing, 2004, pp. 131-142.

Johansson \& Palme 2005

Johansson, P. \& Palme, M., 'Moral Hazard and sickness insurance', Journal of Public Economics, 89, 2005, pp. 1879-1890.

Jones 2006

Jones, C.B., The Role of the Architect: Changes of the Past, Practices of the Present, and Indications of the Future, Doctoral thesis (unpublished), Brigham Young University, 2006.

Jones \& Sufrin 2001

Jones, A. \& Sufrin, B., EC Competition Law- Text, Cases and Materials, Oxford: Oxford University Press, 2004.

Joskow 2005

Joskow, P.L., 'Regulation and Deruglation After 25 Years: Lessons Learned for Research in Industrial Organization', International Review of Industrial Organization, 26, 2005, pp. 169-193.

Jost 1996

Jost, J., 'Limited liability and the requirement to purchase insurance', International Review of Law and Economics, 1996, pp. 259-276.

Kadelbach 2003

Kadelbach, S., 'Union citizenship', in: J.H.H. Weiler \& A. Von Bogdandy (eds.), European Integration: The New German Scholarship, Jean Monnet Working Paper 9/03, NYU School of Law and Max Planck Institute for Corporative Public Law and International Law, 2003.

Kapteyn \& Verloren van Themaat 1989

Kapteyn, J.P.G. \& VerLoren van Themaat, P., Introduction to the Law of the European Communities, $2^{\text {nd }}$ edition, Deventer: Kluwer, 1989. 


\section{Kerber \& Van den Bergh 2008}

Kerber, W. \& Van den Bergh, R., 'Mutual Recognition Revisited: Misunderstandings; Inconsistencies, and a Suggested Reinterpretation', Kyklos, 61, Blackwell Publishing, 2008, pp. 447-465.

\section{Keune 2004}

Keune, R.V., Applicability of the Accountancy Disciplines to other Professional Serces, Presentation at the Workshop on Domestic Regulation, World Trade Organization, Geneva, 29 March 2004.

\section{King 1991}

King, A.D., Global Cities: Post-Imperialism and the Internationalisation of London, London: Routledge.

Kleiner \& Kudrle 2000

Kleiner, M. \& Kudrle R.L., 'Does Regulation Affect Economic Outcomes? The Case of Dentistry', $w$ and Economics, 43, 2000, pp. 547-582.

Kluyskens 1952

Kluyskens, A., Beginselen van Burgerlijk Recht, IV, Antwerp: Standaard, 1952.

Kohl 2006

Kohl, B., 'Aspects récents des conditions d'exercice de la profession d'architecte', Droit de la Construction, Liège: Editions de Jeune Barreau de Liège, 2006, pp. 7-43.

Kohl 2009

Kohl, B., 'European Construction Law and the Draft Common Frame of Reference : Selected Topics', European Review of Private Law, Aspen Publishers Inc., 2009, pp. 675-702.

\section{Kox, Lejour \& Montizaan 2004}

Kox, H., Lejour, A, \& Montizaan, R. 4. 'The free movement of services within the EU', CPB Documents 69, The Hague: Netherlands Bureau for Economic Policy Analysis, 2004.

Krause 1996

Krause, E.A., Death of the Guilds: Professions, States and the Advance of Capitalism, 1930 to the Present, New Haven: Yale University Press, 1996.

Lamon 2006

Lamon, H., 'Beperking van aansprakelijkheid voor architectenvennootschappen', Balans 2006, nr. 541, pp. 1-3.

Landes \& Posner 1981

Landes, W \& Posner, R., 'The positive economic theory of tort law', Georgia Law Review, vol. 15, 1981, pp. 851-924.

Landes \& Posner 1984

Landes, W. \& Posner, R., 'Tort Law as a Regulatory Regime for Catastrophic Personal Injuries', Journal of Legal Studies, 1984, pp. 417-471.

Larson 1977

Larson, M.S., The Rise of Professionalism: A Sociological Analysis, Berkeley: University of California Press, 1977.

Laugier 1753

Laugier, M.-A., Essai sur l'Architecture, Paris 1753, trans. W. \& A. Herrmann, An Essay on Architecture, Los Angeles: Hennessey \& Ingalls, 1977.

Laurent 1887

Laurent, F., Principes de Droit Civil, Brussels: Bruylant, 1887.

Le Corbusier 1927

Le Corbusier, C.E., Vers une Architecture, 1927.

Leland 1979

Leland, H.E., 'Quacks, Lemons and Licensing: A Theory of Minimum Quality Standards', Journal of Political Economy, vol. 87, 1979, pp. 1328-1346.

Lenaerts 1988

Lenaerts, H., Inleiding tot het sociaal recht, Brussels, Story, 1988.

Lewis 2002

Lewis, R.K., 'Will Forces of Globalization Overwhelm Traditional Local Architecture?', Washington Post, November, 2002.

Liet-Veaux 1963

Liet-Veaux, G., La Profession d'Architecte: Statut juridique, Paris : Masson, 1963. 


\section{Locré 1803}

Locré, J.G., Procès-verbaux du Conseil d'Etat, contenant la discussion du projet de Code Civil, Paris: Imprimerie de la République, 1803.

\section{Louveaux 2001}

Louveaux, B., 'De persoonlijke aansprakelijkheid van de architect - een anachronisme in de markteconomie?', $A R-C O$, january 2001, p. 26.

Lueck, Olsen \& Ransom 1995

Lueck, D., Olsen, R. \& Ransom, M., 'Market and Regulatory Forces in the Pricing of Legal Services', Journal of Regulatory Economics, vol. 7, 1995, pp. 63-83.

Lund 1993

Lund, N., 'Educational objectives in architecture', in: B. Farmer \& H. Louw (eds.), Companion to Contemporary Architectural Thought, London and New York: Routlegde, 1993, pp. 477-480.

Mahgoub 2004

Mahgoub, Y., Global and Local Requirements for an Objective Evalution System for Architectural Competence: the Case of Kuwait, Paper presented at the $9^{\text {th }}$ World Conference on Continuing Engineering Education, Tokyo, 15-20 May 2004.

Maks \& Philipsen 2002

Maks, J.A.H., \& Philipsen, N.J., 'An economic analysis of the regulation of professions', in: L. Vereeck (ed.), The Regulation of Architects, Antwerp: Intersentia, 2002.

Maks, Philipsen \& Faure 2001

Maks, J.A.H., Philipsen, N.J. \& Faure, M.G. '(Zelf-)Regulering van de Apothekersmarkt in Nederland', Maandschrift Economie, 65, 2001, pp. 208-227.

Markus 1993

Markus, T.A. 'Buildings as social objects', in: B. Farmer \& H. Louw (eds.), Companion to Contemporary Architectural Thought, London and New York: Routlegde, 1993, pp. 15-20.

Mast, Dujardin, Vandamme \& Vandelanotte 1999

Mast, A., Dujardin, J., Vandamme, M. \& Vandelanotte, J., Overzicht van het Belgisch administratief recht, Antwerp: Kluwer 1999.

Maurin 2002

Maurin, P., 'De Ervaring met de Franse Wet van 4 januari 1978, genaamd de wet Spinetta', in: AR-CO, 2002, pp. 1-65.

Mazeaud \& Mazeaud 1960

Mazeaud, H.L. \& Mazeaud, J., Leçons de droit civil, Paris: Montchrestien, 1960.

Meijer \& Visscher 2006

Meijer, F.M. \& Visscher, H.J., 'The legal position of architects in the European Union', in :A Balsswin, E Hui \& F Wong (Eds.), Proceedings of the CIB W89 International Conference on Building Education and Research, Hong Kong: Hong Kong Polytechnic University; Dept. Building \& Real Est., 2006.

Meijer \& Visscher 2008

Meijer, F.M., \& Visscher, H.J., 'The meaning of the protection of the architects title in European countries', in: R. Haigh \& D. Amaratunga (Eds.), Building Resilience, Salford, UK: School of the Built Environment, University of Salford, UK, 2008, pp. 1287-1298

Meulemans 2005

Meulemans, D., 'De twee regimes inzake aanneming', in: D. Meulemans (ed.), Een pand bouwen en verbouwen, Leuven: Acco 2005, pp. 66-76.

Meyer \& Rowan 1991

Meyer, J. \& Rowan, B.,'Institutionalized Organizations; Formal Structure as Myth and Ceremony', in: W. Powell en P. Dimaggio (eds.), The New Institutionalism in Organizational Analysis, Chicago: The University of Chicago Press, 1991, p. 44.

Milgrom \& Roberts 1992

Milgrom, P. \& Roberts, J., Economics, Organization and Management, Englewood Cliffs, Prentice-Hall International, 1992.

Miller 1985

Miller, J., 'The FTC and Voluntary Standards; Maximizing the Net Benefits of Self-Regulation', The Cato Journal, 4, 1985, pp. 897-903. 


\section{Minvielle 1921}

Minvielle, G., Histoire et condition juridique de la profession d'architecte, Paris: Y. Cadoret, 1921.

Mirza \& Nacey

Mirza, V. \& Nacey, A., The Architectural Profession in Europe - A Sector Study Commissioned by the Architects' Council of Europe, final, 2008.

Mitchell 1990

Mitchell, W.J., The Logic of Architecture, Design, Computation and Cognition, Cambridge, MA: The MIT Press, 1990.

Montgomery 1989

Montgomery, R., 'Architecture invents new people' in R. Ellis and D. Cuff (eds.), Architects' People, Oxford: Oxford University Press, 1989, pp. 260-281.

Muris \& McChesney 1979

Muris, T.J. \& McChesney, F.S., 'Advertising and the Price and Quality of Legal Services: The Case for Legal Clinics', American Bar Foundation Research Journal, 1979, pp. 179-207.

Nackaerts 2005

Nackaerts, W., 'De architect', in D. Meulemans (ed.), Een pand bouwen en verbouwen, Leuven: Acco, 2005, pp. 93-145.

Nederlands Centraal Planbureau 2008

Nederlands Centraal Planbureau, Architecten- en ingenieursbureaus (Brancebeschrijving 2000-2006), 2 October 2008

Nelson 1974

Nelson, P., 'Advertising as Information', Journal of Political Economy, vol. 82, 1974, pp.729-754.

Nilsson 2003

Nilsson, K., Speech at the European Conference on Regulation and the Liberal Professions, Brussels, 28 October 2003

Noll 1989

Noll, R., 'Economic Perspectives on the Politics of Regulation', in: R. Schmalensee and R. Willig (eds.), Handbook of Industrial Organization II, Amsterdam: Elsevier 1989, pp. 1253-1287.

Nuttgens 1993

Nuttgens, P., 'The nature of architecture', in: B. Farmer \& H. Louw (eds.), Companion to Contemporary Architectural Thought, London and New York: Routlegde, 1993, pp. 4-8.

Oates \& Baumol 1975

Oates, W. \& Baumol, W., 'The instruments for environmental pollution', in: E. Mills (ed.), Economic Analysis of Environmental Problems, New York: Columbia University Press, 1975, pp. 95-128.

OECD 1985

OECD, Politique de la concurrence et professions libérales, Paris, 1985

Ogus \& Veljanovski 1984

Ogus, A.I. \& Veljanovski, C.G., Readings in the Economics of Law and Regulation, Oxford: Clarendon Press, 1984.

Ogus 1994

Ogus, A.I., Regulation: Legal Form and Economic Theory, Oxford: Clarendon Press, 1994.

Ogus 1995

Ogus, A., 'Rethinking Self-Regulation', Oxford Journal of Legal Studies, 15, 1995, pp. 97-108.

Ogus 2000

Ogus, A.I., 'Self-Regulation', in: B. Bouckaert and G. De Geest (eds.), Encyclopedia of Law and Economics, 2000, Cheltenham: Edward Elgar nr. 9400.

Ogus \& Veljanovski 1984

Ogus, A.I., Veljanovski, C.G., Readings in the Economics of Law and Regulation, Oxford: Clarendon Press, 1984

Olsen 2002

Olsen, R.N., 'The Regulation of the Medical Professions', in: B. Bouckaerts and G. De Geest (eds.), Encyclopaedia of Law and Economics, vol. III, Regulation of Contracts, Aldershot: Edward Elgar, 2002, pp. 1018-1054. 


\section{Olson 1965}

Olson, M., The Logic of Collective Action: Public goods and the theory of groups: Cambridge: Harvard University Press, 1965.

\section{Orbasli \& Worhington 1995}

Orbasli, A. \& Worthington, J., Architecture and Town Planning Education in the Netherlands: A European Comparison, York: Institute of Advanced Architectural Studies, 1995.

Palzer \& Scheuer 2004

Palzer, C. \& Scheuer, A., 'Self-Regulation, Co-Regulation, Public Regulation', in: UNESCO Clearinghouse (ed.), Yearbook 2004, 2004. PLACE OF PUBLICATION?

Parsons 2003

Parsons, C., 'Moral Hazard in Liability Insurance', The Geneva Papers on Risk and Insurance, 28, 2003, pp. 448-471.

Paterson, Farmer \& Love 1988

Paterson, A., Farmer L. \& Love, J., 'Competition and the Market for Legal Services', Journal of Law and Society, 1988, pp. 361-373.

Paterson, Fink \& Ogus 2003

Paterson, A., Fink M. \& Ogus, A., Economic Impact of Regulation in the Field of Liberal Professions in Different Member States: Regulation of Profession Services, Study for the European Commission 2003.

Peers 2006

Peers, S., EU Justice and Home Affairs, Oxford: Oxford University Press, 2006

Peltzman 1976

Peltzman, S., 'Towards a More General Theory of Regulation', Journal of Law and Economics, 19, 1976, pp. 211-240.

Philipsen 2003

Philipsen, N.J., Regulation of and by Pharmacists in the Netherlands and Belgium: An Economic Approach, Antwerp: Intersentia.

Philipsen 2008

Philipsen, N.J., 'Regulation of professions: a European perspective', in: M. Faure \& F. Stephen (eds.), Essays in the Law and Economics of Regulation in honour of Anthony Ogus, Antwerp, Oxford, Portland: Intersentia, 2008, pp. 93-114.

Philipsen 2009

Philipsen, N.J., 'Regulation of Liberal Professions and Competition Policy: Developments in the EU and China', 6 Journal of Competition Law and Economics, 2, 2010, pp. 203-231.

Pigou 1954

Pigou, A.C., 'Some Aspects of the Welfare State', Diogenes, 1954, vol. 2, nr. 7, pp. 1-11.

Plato 360 BC

Plato, Timaeus, trans. B. Jowett, New York: Random House, 1937.

Polinsky 1988

Polinsky, A.M., 'Optimal Liability when the Injurer's Information about the Victim's Loss is Imperfect', International Review of Law and Economics, vol. 7, no. 2, 1988, pp. 139-147.

Posner 1974

Posner, R.A., 'Theories of Economic Regulation', Journal of Economics and Management Science, 5, 1974 pp. 335-358.

Posner 1998

Posner, R.A., Economic Analysis of Law, $5^{\text {th }}$ edition, New York: Aspen Law \& Business, 1998, p. 572-576.

Pothier 1766

Pothier, R.J., Traité Du Contract De Louage, Paris: Debure, 1766.

Pourvoyeur 2000

Pourvoyeur, S., 'De rol van de verschillende betrokkenen bij het bouwproces en hun aansprakelijkheid voor het bouwwerk', T.Aann. 2000, pp. 100-112.

Priemus et al. 2001

Priemus, H., Meijer, F.M., Visscher, H.J., Grouwstra, S.V.A., Lubach, D.A., Boxem J.L. \& Winter, H.B., Architect en Titelwet, Rotterdam: 010 Publishers, 2001. 


\section{Priest 1987}

Priest, G.L.,'The Current Insurance Crisis and Modern Tort Law', The Yale Law Journal, vol. 96, 1987, pp. 1521-1590.

\section{Ramboer, Evens \& Van Daele 2002}

Ramboer, I., Evens, M. \& Van Daele, N., 'Aansprakelijkheid en verzekerbaarheid in de bouwsector', in: Handels-en Economisch Recht, 17, 2002.

\section{Ramboer 2008}

Ramboer, I., 'De verzekering beroepsaansprakelijkheid ingevolge de wet van 15 februari 2006 en het uitvoeringsbesluit van 25 april 2007', in: Uytterhoeven, K., Vandekerkchove, E., Devloo, M., Ramboer, I. \& Heyvaert L., De uitoefening van het beroep van architect in het kader van een vennootschap, KortrijkHeule: UGA, 2008, pp. 107-136.

RBB Economics 2003

RBB Economics, Economic Impact of Regulation in Liberal Professions, A Critique of the IHS Report RBB, Economics, 2003.

Reagan 1998

Reagan, M.C., 'Professional Reputation: Looking for the Good Lawyer', South Texas Law Review, 39, 1998, pp. 549-560.

Ribstein \& Kobayashi 1996

Ribstein, L.E. \& Kobayashi, B.H., 'An Economic Analysis of Uniform State Laws, Journal of Legal Studies, vol 25, 1996, pp. 131-199.

Rigaux 1975

Rigaux, P., L'Architecte - Le Droit de la Profession, Brussels: Maison Ferdinand Larcier, 1975.

Rigaux 1993

Rigaux, P., Le droit de l'architecte. L'évolution des 20 dernières années, Brussels: Larcier, 1993.

Rizzo \& Zechauser 1992

Rizzo, A. \& Zeckhauser, R.J., 'Advertising and the Price, Quantity and Quality of Primary Physician Services', Journal of Human Resources, vol. 28, 1992, pp. 381-421.

Rogge 1996

Rogge, J., Les assurances en matière d'environnement, Diegem : Kluwer, 1996.

Rybczynski 2001 Rybczynski, W., The Look of Architecture, Oxford: Oxford University Press, 2001.

Schneider 1995

Schneider, H., Die Anerkennung von Diplomen in der Europäischen Gemeinschaft, Antwerp: Intersentia, 1995.

Shapiro 1983

Shapiro, C., 'Premiums for High Quality Products as Rents to Reputation', Quarterly Journal of Economics, 983, pp. 659-680.

Shapiro 1986

Shapiro, C., 'Investment, Moral Hazard and Occupational Licensing', Review of Economic Studies, 53 , 1986, pp. 843-862.

Shavell 1979

Shavell, S., 'On Moral Hazard and Insurance', Quarterly Journal of Economics, 1979, pp. 541-562.

Shavell 1980

Shavell, S., 'Strict Liability versus Negligence', Journal of Legal Studies, 1980, pp. 1-25.

Shavell 1984

Shavell, S., 'Liability for Harm versus Regulation of Safety', Journal of Legal Studies, 13, 1984, pp. 363-383.

Shavell 1987

Shavell, S., Economic Analysis of Accident Law, Cambridge: Harvard University Press, 1987.

Shavell 1995

Shavell, S., 'Alternative Dispute Resolution: An Economic Analysis', 24 Journal of Legal Studies 1, 1995 pp. 1-28.

Shavell 2004

Shavell, S., Foundations of economic analysis of law, Cambridge/London: Harvard University Press, 2004. 
Bibliography

\section{Shavell 2005}

Shavell, S., 'Minimum Asset Requirements and Compulsory Liability Insurance As Solutions to the Judgement-Proof Problem', Rand Journal of Economics, 36, 2005, pp. 63-77

Simon 1987

Simon, H.A., 'Bounded rationality', in: J. Eatwell, M. Millgate \& P. Newman (eds.): The New Palgrave: A Dictionary of Economics, London and Basingstoke: Macmillan, 1987.

Simont \& Degavre 1970

Simont, L. \& Degavre, J., 'Examen de jurisprudence', R.C.J.B., 1970, pp. 113-184.

Siragusa 2004

Siragusa, M., 'Critical Remarks on the Commission's Legal Analysis in Its Report on Competition in Professional Services', in: C.-D.Ehlermann and I. Atanasiu (eds.), European Competition Law Annual, Oxford/Portland Oregon: Hart Publishing, 2004, pp. 583-590.

Skolimowski 1993

Skolimowski, H., 'Architecture and morality', in: B. Farmer \& H. Louw (eds.), Companion to Contemporary Architectural Thought, London and New York: Routlegde, 1993, pp. 496-499.

Soinne 1969

Soinne, B., La responsabilité des architecte et entrepreneur après la réception des travaux, Paris : Librairie générale de droit et de jurisprudence, 1969.

Somers 2005

Somers, E., 'Towards a New Regulation of Architects in Belgium? An Example of a Progressive Regulation of Professions in an International Dimension', in: E. Crals \& L. Vereeck, Regulation of Architects in Belgium and the Netherlands - A Law and Economics Approach, Tielt: Lannoo 2005.

Starr 1988

Starr, P., The Meaning of Privatization, Yale Law and Policy Review, 6, 1988, pp. 6-41.

Stephen 2004

Stephen, H., 'The Market Failure Justification for the Regulation of Professional Service Markets and the Characteristics of Consumers', in: C.-D.Ehlermann and I. Atanasiu (eds.), European Competition Law Annual, Oxford/Portland Oregon: Hart Publishing, 2004, pp. 143-154.

Stephen \& Love 2000

Stephen, F. \& Love, J., 'Regulation of the Legal Profession', in: B. Bouckaert \& G. De Geest (eds), Encyclopedia of Law and Economics, Cheltenham: Edward Elgar, 2000.

Stephen, Love \& Paterson 1994

Stephen, F., Love, J. \& Paterson, A., 'Deregulation of Conveyancing Markets in England and Wales', Fiscal Studies, 15, 1994, pp. 102-118.

Steyaert, De Ganck \& De Schrijver 1990

Steyaert, J., De Ganck, C. \& De Schrijver, L., Arbeidsovereenkomst, Brussels: E. Story-Scientia, 1990.

Stigler 1961

Stigler, G.J., 'The Economics of Information', Journal of Political Economy, vol. 69, 1961, pp.213-225.

Stigler 1971

Stigler, G.J., 'The Theory of Economic Regulation', Bell Journal of Economics and Management Science, 2, 1971, pp. $3-21$.

Teulings, Bovenberg, Van Dalen 2003

Teulings, C.N., Bovenberg A.L. \& Van Dalen, H.P., De Calculus van het Publieke Belang, The Hague, April 2003.

Thirion 2000

Thirion, N., 'Libéralisation et concurrence: l'impulsion du droit communautaire et ses conséquences, récentes ou à venir, dans l'ordre juridique belge', in : Le point sur le droit commercial, Liège, Ed. Formation permanente, January 2000, p. 219-317.

Tiesdell \& Oc 1993

Tiesdell, S. \& Oc, T, 'Architecture and People', in: B. Farmer \& H. Louw (eds.), Companion to Contemporary Architectural Thought, London and New York: Routledge, 1993, pp. 44-51.

Tilleman 1997

Tilleman, B., Lastgeving, Antwerp: Kluwer, 1997.

Tullock 1969

Tullock, G., 'Federalism and Problems of Scale, Public Choice, vol. 6, 1969, pp. 19-29. 
Bibliography

\section{Uytterhoeven 2004}

Uytterhoeven, K., 'De aansprakelijkheid van de architect die zijn beroep uitoefent in het kader van een professionele of multiprofessionele vennootschap of associatie', Tijdschrift voor Bouwrecht en Onroerend Goed, Intersentia 2004, p. 193-197.

Uytterhoeven 2008

Uytterhoeven, K., 'De uitoefening van het beroep van architect door een rechtspersoon en de aansprakelijkheid van de architect na de wet van 15 Februari 2006', in: Uytterhoeven, K., Vandekerkchove, E., Devloo, M., Ramboer, I. \& Heyvaert L., De uitoefening van het beroep van architect in het kader van een vennootschap, Kortrijk-Heule: UGA, 2008, pp. 11-43.

Van Boom 2008

Van Boom, W.H., 'Insurance Law and Economics: An Empirical Perspective', in: M. Faure and F. Stephen (eds.), Essays in the Law and Economics of Regulation in Honour of Anthony Ogus, Antwerp-OxfordPortland: Intersentia, 2008, pp. 253-276.

Van Boom, Faure, Huls \& Philipsen 2009

Van Boom, W.H., Faure, M.G., Huls, J.J.H. \& Philipsen, N.J., Handelspraktijken, reclame en zelfregulering, Den Haag: Boom Juridische uitgevers, 2009.

Van den Berg 1998

Van den Berg, M.A.M.C., Bewerking van hoofdstuk VI, deel B, 'Aanneming van bouwkundige werken', Supplement 56, in: A.P.A. de Klerk-Leenen \& B. Wessels (Eds.), Bijzondere Contracten (pp. VI.B-1-.B.1646-8), Deventer: Kluwer, 1998.

Van den Berg 2003

Van den Berg, M.A.M.C., 'Naar een nieuwe regeling in de UAV van de aansprakelijkheid van de aannemer na oplevering van het werk', in: M.A.M.C van den Berg, M.A.B. Chao-Duivis, \& H. Langendoen (Eds.), Aangenomen werk, Liber Amicorum prof.mr. M.A. van Wijngaarden). Deventer: W.E.J. Tjeenk Willink, pp. 181-197.

Van Den Berg 2004

Van den Berg, M.A.M.C., Bregman,A.G, Chao-Duivis, M.A.G. . \& Langendoen, H., Bouwrecht in kort bestek, Deventer: Kluwer, 2004.

Van den Bergh \& Heremans 1987

Van den Bergh, R. \& Heremans, D., 'Recht en Economie', Tijdschrift voor Economie en Management, 1987, pp. 139-163.

Van den Bergh et al. 1993

Van den Bergh, R., Curran, C., Faure, M.G., Swennen, H., Hellingman, K., Den Hertog, J., Herrmann, H., Trautwein, H-M. \& Rönnau, A., Ogus, A.I., Bowles, R., Finsinger, J., in: M.G. Faure, J. Finsinger, J. Siergers \& R. Van den Bergh (eds.), Regulation of Professions - A Law and Economics approach to the regulation of attorneys and physicians in the US, Belgium, The Netherlands, Germany and the UK, Antwerp: Maklu, 1993.

Van den Bergh 1994

Van den Bergh, R., 'The Subsidiarity Principle in European Community Law: Some Insights from Law and Economics', Maastricht Journal of European and Comparative Law, 1, 1994, pp. 337-366.

Van den Bergh 1998

Van den Bergh, R., 'Subsidiarity as an Economic Demarcation Principle and the Emergence of European Private Law', Maastricht Journal of European and Comparative Law, 5, 1998, pp. 129-152.

Van den Bergh 1999

Van den Bergh, R., Self-regulation of the medical and legal professions: remaining barriers to competition and EC Law, in: Organized Interests and Self-Regulation, An Economic Approach, B. Bortolotti and G. Fiorentini (eds), Oxford, New York, Oxford University Press, 1999, pp. 89-130.

Van den Bergh 2001

Van den Bergh, R., 'Gronden en grenzen van aansprakelijkheid: Rechtseconomische kanttekeningen', in Aansprakelijkheid: Gronden en Grenzen, Verslagboek tweede Grotius lustrum, Deventer: Kluwer, 2001, pp. $111-142$

Van den Bergh 2004

Van den Bergh, R. 2004, 'Towards Efficient Self-regulation in Markets for Professional Services', in: C.D.Ehlermann and I. Atanasiu (eds.), European Competition Law Annual, Oxford/Portland Oregon: Hart Publishing, 2004, pp. 155-176. 


\section{Van den Bergh 2008}

Van den Bergh, R., 'De maatschappelijke wenselijkheid van gedragscodes vanuit rechtseconomisch perspectief, Weekblad voor Privaatrecht, Notariaat en Registratie, 2008, pp. 792-798.

Van den Bergh \& Montangie 2006

Van den Berg, R. \& Montangie, Y., 'Competition in Professional Services Markets: Are Latin Notaries Different?', Journal of Competition Law and Economics 2(2), 2006, pp. 189-214.

Van den Bossche 2004

Van den Bossche, A.M.A.P., 'Het vrije beroep in Europees Perspectief: storm op zee?', in: T.P.R. 2004 Liber Amicorum, Gent: Story Scientia, pp. 795-833.

Van Der Krogt 1981

Van Der Krogt, T., Professionalisering en collectieve macht: een conceptueel kader,The Haghue: Vuga, 1981.

Van Eeckhoutte 2007

Van Eeckhoutte, W., Sociaal Compendium Arbeidsrecht, met fiscale notities, 2007-2008, Mechelen: Kluwer, 2007.

Van Gulijk 2009

Van Gulijk, S., European Architect Law - Towards a New Design, Apeldoorn/Antwerp: Maklu, 2009.

Van Velthoven \& Van Wijck 2001

Van Velthoven, B.J.C. \& Van Wijck, P.W., Recht en efficiëntie, Deventer: Kluwer, 2001.

Van Wijngaarden \& Chao-Duivis 2004-2007

Van Wijngaarden, M.A, Chao-Duivis, M.A.B., Hoofdstukken Bouwrecht, Deventer: Kluwer, 2004-2007.

Van Zeben 1991

Van Zeben, C.J., Parlementaire Geschiedenis van het Nieuwe Burgerlijk Wetboek, Deventer,1991.

Varian 1984

Varian, H.R., Microeconomic Analysis, $2^{\text {nd }}$ edition, New York: Norton 1984, pp. 79-85.

Verbist 2003

Verbist, H., 'Arbitrage in bouwzaken en aanbestedingsdossiers : aspecten bekeken vanuit een Belgisch en Europeesrechtelijk perspectief, Tijdschrift@ipr.be - Revue@dipr.be, nr. 4, October 2003, pp.76-87.

Vergauwe 1991

Vergauwe, J.P., Le droit de l'architecture, Brussels: De Boeck-Wesmael, Brussels, 1991.

Von der Schulenburg 2005

Graf von der Schulenburg, J.M., Versicherungsökonomik, Karlsruhe: Verlag Versicherungswirtschaft, 2005.

Wagner 1996

Wagner, G., 'Versicherungsfragen der Umwelthaftung', in: J. Simon and M. Ahrens (eds.), Umwelthaftung, Risikosteuerung und Versicherung, Berlin 1996, pp. 97-146.

Wendt 2009

Wendt, I., The Tension Between Rules Regulating the (Liberal) Professions and EC Competition Law, Maastricht: Datawyse, 2009.

Wiesbrock 2009

Wiesbrock, A., Legal Migration to the European Union - Ten Years After Tampere, Nijmegen: Wolf Legal Publishers, 2009.

Wigney 1952

Wigny, P., Droit Constitutionnel. Principes et droit positif, Brussels: Bruylant, 1952.

Woods 1999

Woods, M.N., From Craft to Profession: The Practice of Architecture in Nineteenth-Century America, Berkeley: University of California Press, 1999.

Wotton 1624

Sir Wotton H., The Elements of Architecture, London: John Bill, 1624.

Zacharias 2008

Zacharias, F.C., 'Effects of Reputation on the Legal Profession', Washington \& Lee Law Review, 2008, pp. 173-214. 


\section{Case Law}

Case law of the Court of Justice of the European Union

Case C-19/61 Mannesmann AG v High Authority of the European Coal and Steel Community [1962] ECR 675.

Case C-26/62 NV Algemene Transport en Expeditie Onderneming van Gend en Loos v. Nederlandse Administratie der Belastingen [1963] ECR 1

Case C-75/63 Hoekstra (née Unger) v. Bestuur der Bedrijfsvereniging voor Detailhandel en ambachten [1964] ECR 177.

Case C-6/64 Flaminio Costa v. ENEL [1964] ECR 585

Joined Cases C-56/64 and C-58/64 Établissements Consten S.A.R.L. and Grundig-Verkaufs-Gmbh v. Commission of the European Economic Community [1966] ECR 299.

Case C-32/65 Italian Republic v. Council of the European Economic Community and Commission of the European Economic Community (“Challenge to Regulation 19/65”) [1966] ECR 389.

Case C-56/65 Société Technique Minière (L.T.M.) v. Maschinenbau Ulm Gmbh (M.B.U.) [1966] ECR 235.

Case C-10/69 Portelange v. Smith Corona Marchant International [ 1969] ECR 309.

Case C-8/72 Vereeniging van Cementhandelaren v. Commission of the European Communities [1972] ECR 977.

Case C- 114/73 Suiker Unie and Others v Commission of the European Communties [1975] ECR 1663.

Case C-2/74 Jean Reyners v. Belgium State [1974] ECR 631.

Case C-8/74 Procureur du Roi v. Dassonville et al., [1986] ECR 3713.

Case C-33/74 Van Binsbergen v. Bestuur van de Bedrijfsverenging voor de Metaalnijverheid [1974] ECR 1299.

Case C-36/74 Walrave and Koch v. Association Union Cyclise Internationale [1974] ECR 1405.

Case C-71/74, Frubo v. Commission, [1975] ECR 563.

Case C-175/75 R. v. Saunders [1979] ECR 1129.

Case C-13/76 Donà [1976] ECR 1333.

Case C- 26/76 Metro SB-Großmärkte GmbH \& Co. KG v. Commission of the European Communities [1977] ECR 1905.

Case C-415/93 Union Royal Belge des Sociétés de Football Association ASBL \& others v. Jean-Marc Bosman [1995] ECR I-4921.

Case C-71/76 Thieffry v. Conseil de l'Ordre des Avocats à la Cour de Paris [1977] ECR 765.

Case C-5/77 Tedeschi v. Denkavit [1977] ECR 1555.

Case C-11/77 Patrick v. Ministre des Affaires Culturelles [1977] ECR 1199.

Case C-106/77 Amministrazione delle Finanze dello Stato v Simmenthal S.p.A. [1978] ECR 629.

Case C-22/78 Hugin v. Commission [1979] ECR 1869.

Case C-120/78 Rewe-Zentrale AG v. Bundesmonopolverwaltung für Branntwein [1979] ECR 649.

Cases 209 to 215 and 218/78 Van Landewyck and Others v. Commission [1980] ECR 3125.

Case C- 251/78 DenkavitFuttermittel v Minister für Ernährung, Landwirtschaft und Forsten des Landes Nordrhein-Westfalen [1979] ECR 3369.

Case C-102/79 Commission v. Belgium [1980] ECR 1473.

Case C-127/79 BRT and SABAM [1974] ECR 51.

Case C-172/80 Züchner [1981] ECR 2021.

Case C-246/80 Broekmeulen v. Huisarts Registratie Commissie [1981] ECR 2311.

Case C-279/80 Webb [1981] ECR 3305.

Cases C-35/82 and 36/82 Morson and Janjan v. Netherlands ECR 3723.

Case C-96/82 NV IAZ International Belgium and others $v$ Commission of the European Communities [1983] ECR 3369.

Cases C-286/82 \& 26/83 Luisi and Carbone v. Ministero del Tesoro [1984] ECR 377.

Joined Cases 29 and 30/83 Compagnie Royale Asturienne des Mines and Rheinzink [1984] ECR 1679.

Case C-107/83 Ordre des Avocats v. Klopp [1984] ECR 2971.

Case C-123/83 Bureau National Interprofessional du Cognac v Guy Clair [1985] ECR I-391.

Case C-152/83 Sandro Forcheri and his wife Marisa Forcheri, née Marino v. Belgian State and asbl Institut Supérieur de Sciences Humaines Appliquées - Ecole Ouvrière Supérieure [1983] ECR 02323. 
Case C-180/83 Moser [1984] ECR 2539.

Case C-293/83, Françoise Gravier v. City of Liège [1985] ECR 00593.

Case C-365/93 Commission v Greece [1995] ECR I-499.

Case C-161/84 Pronuptia [1986] ECR 353.

Case 45/85 Verband der Sachversicherer [1987] ECR 405.

Case C-66/85 Lawrie-Blum v. Land Baden-Württemberg [1986] ECR 2121.

Joined Cases C- 89, 104, 114, 116, 117 and 125 to 129/85 A. Ahlström Osakeyhtiö and others v Commission of the European Communities [1988] ECR 5193.

Case C-96/85 Commission v. France [1986] ECR 1475.

Case C-118/85 Commission v. Italy [1987] ECR 2599.

Case C-131/85 Emir Gül v Regierungspräsident Düsseldorf [1986] ECR 1573.

Case C-168/85 Commission v Italy [1986] ECR 2945.

Case C-427/85 Commission v. Germany [1988] ECR 1123.

Case C-12/86 Demirel [1987] ECR 3719.

Case C-222/86 UNECTEF v. Heylens [1987] ECR 4097.

See Case 246/86 Belasco [1989] ECR 2117.

Case C-263/86 Belgium v. Humbel [1988] ECR 5365.

Case C-267/86 Van Eycke [1988] ECR 4769.

Case C-30/87 Bodson [1988] ECR 2479.

Case C-38/87 Commission of the European Communities v Hellenic Republic [1988] ECR 4415.

Case C-190/87 Oberkreisdirektor des Kreises Borken and Another v Moormann [1988] ECR 4689.

Case C-266-267/87 The Queen v. Association of Pharmaceutical Importers, ECR 1295.

C-379/87 Groener v. Minister for Education [1989] ECR 3967.

Case C-18/88 Régie des télégraphes et des téléphones v. GB-Inno-BM SA [1991] ECR I-5941.

Case C-316/88 Centre Public d'Aide Sociale v Lebon [1987] ECR I-2811.

Case T-4/89 BASF v. Commission of the European Communities [1991] ECR II-1523.

Case T-7/89 SA Hercules Chemicals NV v. Commission of the European Communities [1991] ECR II-1711.

Case T-148/89 Tréfilunion v Commission [1995] ECR II-1063.

Case C-154/89 Commission v France [1991] ECR I-659.

C-180/89 Commission v Italy [1991] ECR I-709.

Case C-192/89 Sevince v. Staatssecretaris van Justitie [1990] ECR I-3461.

C-198/89 Commission v Hellenic Republic [1991] ECR I-727.

Case C-234/89 Delimites [1991] ECR I-935.

Case C-282/89 R. V. Immigration Appeal Tribunal ex parte Antonissen [1991] ECRI-00745.

Case C-340/89 Vlassopoulou v. Ministerium für Justiz, Bundes- und Europaangelegenheiten BadenWürttemberg [1991] ECR I-2357.

Case C-357/89 Raulin v. Netherlands Ministry of Education and Science [1992] ECR I-1027.

Case C-41/90 Höfner and Elser c. Macrotron [1991] ECR I-1979.

Case C-76/90 Manfred Säger v. Dennemeyer \& Co. Ltd. [1991] ECR I-4421.

Case C-296/90 Commission v Italy [1991] ECR I-03847.

Case C-309/90 Commission v Hellenic Republic [1991] ECR I-5311.

Case C-310/90 Nationale Raad van de Orde van Architecten v Ulrich Egle [1992] ECR I-177.

Case C-328/90 Commission v. Hellenic Republic [1992] ECR I-00425.

Case C-369/90 Micheletti and others v. Delegación del Gobierno en Cantabri [1992] ECR I-4239.

Case C-370/90 The Queen v. Immigration Appeal Tribunal \& Surinder Singh, ex parte Secretary of State for Home Department [1992] ECR I-4265.

Joined Cases C-159/91 and C-160/91 Poucet and Pistre [1993] ECR I-637.

Case C-166/91 Bauer v. Conseil National de l'Ordre des Architectes [1992] ECR I-02797.

Case C-185/91 Reiff [1993] ECR I-5801

Case C- 19/92 Kraus v. Land Baden-Württemberg [1993] ECR I-1663

Case C-49/92 Commission of the European Communities v Anic Partecipazioni SpA [1999] ECRI-04125.

Case C-199/92 Hüls v. Commission of the European Communities [1999] ECR I-4287.

Case C-250/92 Gottrup-Klim v Dansk LandbrugsGrovvareselskab AmbA [1994] ECR I-5641.

Case C-319/92 Salomone Haim v. Kassenzahnärztliche Vereinigung Nordrhein [1994] ECR I-425.

Case C-364/92 Sat Fluggesellschaft [1994] ECR I-43.

Case C-153/93 Delta Schiffahrts- und Speditionsgesellschaft [1994] ECR I-2517. 
Case C-154/93 Tawil-Albertini [1994] ECR I-451.

Case C-399/93 Oude Luttikhuis and Others v. Coberco [1995] ECR I-4515.

Case C-415/93 Union Royale Belge des Sociétés de Football Association and others v. Bosman [1995] ECR I4921.

Case C-447/93 Dreesen v Conseil national de l' Ordre des Architectes [1994] ECR I-4087.

Case T-513/93 Consiglio Nazionale degli Spedizionieri Doganali v. Commission of the European Communities, [2000] ECR II-01807.

Case C-55/94 Gebhard v. Consiglio dell'Ordine degli Avvocati e Procuratori di Milano [1995] ECR I-4165.

Case T-77/94 VGB and Others v. Commission [1997] ECR II-759.

Case C-96/94 Centro Servizi Spediporto [1995] ECR I-2883.

Case C-107/94 Asscher v. Staatsecretaris van Financiën [1996] ECR I-3089.

Case C-164/94 Aranitis v. Land Berlin [1996] ECR I-135.

Case C-237/94 O'Flynn v. Adjudication Officer [1996] ECR I-2617.

Case C-244/94 Fédération française des sociétés d'assurances and Others [1995] ECR I-4013.

Joined Cases T-374/94, T-375/94, T-384/94 and T-388/94 European Night Services and Others v. Commission of the European Communities [1998] ECR II-3141.

Case C-3/95 Reisebüro Broede [1996] ECR I-6511.

Case C-7/95 John Deere v Commission of the European Communities [1998] ECR I-3111.

Case C-18/95 F.C. Terhoeve v. Inspecteur van de Belastingdienst Particulieren/Ondernemingen Buitenland [1999] ECR-I-345

Case T-25/95 Cimeteries CBR SA et al. V. Commission of the European Communites [2000] ECR II-491.

Case C-96/95 Commission v. Germany [1997] ECR I-1653.

Case C-282/95 P Guérin Automobiles v. Commission [1997] ECR I-1503.

Case C-299/95 Kremzow [1997] ECR I-2629.

Case C-343/95 Diego Cali \& Figli [1997] ECR I-1547.

Case C-35/96 Commission v. Italian Republic (CNSD II) [1998] ECR I-3851.

Case C-36/96 Günaydin [1997] ECR I-5143.

Case C-55/96 Job Centre (II) [1997] ECR I-7119.

Joined Cases C-64/96 and 65/96 Uecker and Jacquet [1977] ECR I-03171.

Case C-67/96 Albany International BV v. Stichting Bedrijfspensioenfonds Textielindustrie [1999] ECR I-5751.

Case C-85/96 Martinez Sala v. Freistaat Bayern [1998] ECR I-2691.

Case C-274/96 Criminal Proceedings against H.O. Bickel and U. Franz [1998] ECR I-7637.

Case C-306/96 Javico [1998] ECR I-1983.

Case C-369/96 \& C-376/96 Arblade [1999] ECR I-8453.

Case C-112/97 Commission v Italy [1999] ECR I-1821.

Case C-124/97 Läärä and Others [1999] ECR I-6067.

Case C-234/97 Fernandez de Bobadilla v. Museo Nacional del Prado, Comité de Empresa del Museo Nacional del Prado, Ministerio Fiscal [1999] ECR I-4773.

Case C-337/97 C.P.M. Meeusen v. Hoofddirectie van de Informatie Beheer Groep [1999] ECR I-3289.Case C340/97 Nazli [2000] ECR I-957.

Case C-387/97 Criminal Proceedings against Florus Ariel Wijsenbeek [1999] ECR I-6207.

Case C-49/98 Finalarte Sociedade Construçao Civil v. Urlaubs-und Lohnausgleichskasse der Bauwirtschaft [2001] ECR I-7831.

Case C-238/98 Hugo Fernando Hocsman v. Ministre de l'Emploi et de la Solidarité [2000] ECR I-6623.

C-281/98 Roman Angonese v. Cassa di Riparmio di Bolzano SpA [2000] ECR I-4139.

Case C-355/98 Commission v. Belgium [2000] ECR I-1221.

Case C-421/98 Commission v. Spain [2000] ECR I-10375.

Case C-35/99 Arduino [2002] ECR I-1529.

Case T-144/99 Institute of Professional Representatives before the European Patent Office [2001] ECR II-1087.

Case C-145/99 Commission v Italy [2002] ECR I-2235, paragraphs 22 and 23.

Case C-184/99 Rudy Grzelczyk v. Centre Public d'Aide Sociale d'Ottignies-Louvain-la-Neuve (CPAS) [2001] ECR I-6193.

Case C-192/99 R. v. Secretary of State for the Home Department ex parte Kaur [2001] ECR I-1237.

Case C-221/99 Giuseppe Conte v. Stefania Rossi [2001] ECR I-09359.

Case C-267/99 Christiane Urbing-Adam c. Administration de l'enregistrement et des domaines [2001] ECR I7467. 
Case C-298/99 Commission v. Italy [2002] ECR I-03129

Case C-309/99 Wouters, Savelbergh, Price Waterhouse Belastingsadviseurs NV and Algemene Raad van de Nederlandse Orde van Advocaten [2002] ECR I-1577.

Case C-413/99 Baumbast and R. v. Secretary of State for the Home Department [2002] ECR I-7091.

Case C-31/00 Conseil National de l'Ordre des Architectes v. Dreesen [2002] ECR I-663.

Case C-60/00 Mary Carpenter v. Secretary of State for the Home Department [2002] ECR I-6279.

Cases C-162/00 Pokrzeptowics-Meyers [2002] ECR I-1049.

Case C-188/00 Kurz [2002] ECR I-10691.

Case C-438/00 Seutscher Handballbund [2003] ECR I-4135.

Case C-198/01 Consorzio Industrie Fiammiferi (CIF) [2003] ECR I-08055.

Case C-285/01 Isabel Burbaud v. Ministère de l'Emploi et de la Solidarité [2003] ECR I-08219.

Case C-313/01 Christine Morgenbesser v. Consiglio dell'Ordine degli avvocati di Genova [2003] ECR I-13467.

Case C-200/02 Kunqian Catherine Shu and Man Lavette Chen v. Secretary of State for the Home Department [2004] ECR I-09925.

Case C-456/02 Michel Trojani v. Centre public d'aide sociale de Bruxelles (CPAS) [2004] ECR I-7573.

Case C-471/02 Commission of the European Communities v. Hellenic Republic [2004] ECR I-7973.

Case C-65/03 Commission v. Belgium [2003] ECR I-6427.

Case C-140/03 Commission v Hellenic Republic [2005] ECR I-3177.

Case C-147/03 Commission v. Austria [2005] ECR I-5969.

Case C-152/03 Ritter-Coulais [2006] ECR I-1711.

Case C-209/03 R (Dany Bidar) v. London Borough of Ealing and Secretary of State for Education and Skills [2005] ECR I-2119.

Case C-250/03 Ministero della Giustizia and Commissione per gli esami di avvocato presso la Corte d'appello di Milano [2005] ECR I-01267.

Case C-265/03 Simentukov [2005] ECR I-2579.

Joined Cases C-94/04 and C-202/04 Federico Cipolla v. Rosaria Fazari, née Portolese and Stefano Macrino and Claudia Capodarte v. Roberto Meloni [2006] ECR I-1 1421.

Case C-109/04 Karl Robert Kraneman v. Land Nordrhein-Westfalen, [2005] ECR I-02421.

Case C-97/05 Gattoussi [2006] ECR I-11917.

Case C-287/05 Hendrix [2007] ECR I-6906.

Case C-291/05 Eind [2007] ECR I-10719.

Case C-43/06 Commission of the European Communties v. Republic of Portugal [2007] ECR I-73.

Case C-527/06 Renneberg [2008] ECR I-7735.

Case C-345/08 Krzysztof Peśla v. Justizministerium Mecklenburg-Vorpommern, OJ C 24, 30.01.2010, p. 10.

Case C-469/08 Commission of the European Communities v. Kingdom of Belgium, OJ C 6, 10.01.2009, p. 14

Case C-119/09 Robert Koller v. Rechtsanwaltsprüfungskommission beim Oberlandesgericht Graz, to be published.

Case law of national courts

\section{BELGIUM}

\section{Constitutional Court}

Constitutional Court 10 October 2001, A.A. 2001, afl. 4, 1663; A.J.T. 2001-02, 781; Official Gazette 1 December 2001; Cah. dr. immo 2002, afl. 1, 10; JLMB 2001, afl. 42, 1816 annotated by B. Louveaux, Juristenkrant 2001 afl. 36, 4; R. J. I. 2001, 106; Burssens 2001, no. 106

Constitutional Court 10 July 2002, R.W. 2002-03, 857.

Constitutional Court 12 July 2007, A.GrwH 2007, afl. 3, 1163

\section{Supreme Court}

Supreme Court 6 November 1959, unpublished.

Supreme Court 25 April 1960, R.J.I., p. 311; Pas.1960, I, 988.

Supreme Court, 17 November 1960, Pas. 1962, I, 334

Supreme Court 18 May 1961, R.W. 1961-62, 1961. 
Supreme Court, 3 October 1961, Pas. 1962, I, 142.

Supreme Court 6 October 1961, R.W. 1961-62, 783; Jur. Comm. Brux. 1963, 186; Pas. 1962, I, 152; R.C.J.B. 1963, 5 annotated by Lagasse; R.G.A.R. 1962, nr. 6905; R.G.A.R. 1962, nr. 6927; R.J.I. 1962, 383 and 1964 331.

Supreme Court 11 January 1962, Pas. 1962, I, 571; T.S.R. 1962, 366.

Supreme Court 24 October 1963, Pas. 1964, I, 197.

Supreme Court, 12 November 1964, Pas., 1965, I, 254.

Supreme Court, 20 May 1965, Pas., I, 1010.

Supreme Court 9 September 1965, J.T., 1965, 577.

Supreme Court 30 March 1967, Pas., 1967, I, 895.

Supreme Court 18 December 1967, Pas., 1968, I, 516.

Supreme Court 27 March 1968, R.C.J.B., 1970, 78.

Supreme Court 17 October 1968, Pas., 1969, I, 181

Supreme Court 17 February 1969, Pas., 1969, I, 536 ; J.T., 1969, 480.

Supreme Court 20 February 1969, R.J.I. 1969, 273.

Supreme Court 21 April 1969, Arr. Cass. 1969, 779; J.T. 1969, 565; Pas. 1969, I, 730 ; R.J.I. 1970, 7.

Supreme Court 16 October 1969, R.C.J.B., 1971, 390, annotated by Glansdorff.

Supreme Court 9 April 1970, Arr.Cass. 1970, 725.

Supreme Court, 4 May 1970, Pas., 1970, I, 753.

Supreme Court 23 June 1970, Arr.Cass. 1970, 1000; R.W. 1970-71, 603; Pas. 1970, I, 942.

Supreme Court 19 November 1970, T. Aann. 1971, 43, annotated by M.A. Flamme.

Supreme Court 9 February 1971, Arr.Cass. 1971, 555; R.W. 1971-72; Pas. 1971, I, 527; R.J.I. 1973.

Supreme Court 15 February 1971, R.J.I., 1972, 141.

Supreme Court27 September 1972, unpublished.

Supreme Court 29 September 1972, Arr.Cass. 1973, 121.

Supreme Court 23 March 1973, Arr.Cass. 1973, 736 - 738; Pas. 1973, I, 700.

Supreme Court 25 June 1973, J.T. 1974, 247.

Supreme Court 7 December 1973, Arr. Cass. 1974, 395.

Supreme Court 13 December 1973, J.T. 1974, 60.

Supreme Court 3 May 1974, J.T., 1974, 568-569.

Supreme Court 8 January 1976, R.J.I. 1976, 115.

Supreme Court 24 September 1976, Arr.Cass. 1977, 98; R.W. 1976-77, 2269; Pas. 1977, I, 101 ; J.T. 1977, 471 ; Rev. not. b. 1977, 602 .

Supreme Court 4 March 1977, Arr.Cass. 1977, 730.

Supreme Court 26 January 1978, Arr.Cass. 1978, 780 ; R.W. 1978-79, 665 ; T. Aann. 1979, 416, annotated by Flamme; Pas. 1978, I, 759.

Supreme Court 23 February 1978, Arr.Cass. 1978, 743; Pas. 1978, I, 723.

Supreme Court 3 March 1978, Arr.Cass. 1978, 780; R.W. 1978-79, 711; T. Aann. 1981, 262, annotated by Krings; J.T. 1979, 28, annotated by Krings; Pas. 1978, I, 759; R.C.J.B. 1982, 176, annotated by M. Alexandre; R.J.I. 1979, 7.

Supreme Court 31 May 1978, T. Aann. 1983, 30.

Supreme Court 11 September 1978, J.T.T. 1979, 200.

Supreme Court 2 February 1979, R.W. 1979-80, 51.

Supreme Court 2 February 1979, Arr.Cass. 1978-79, 626; T. Aann. 1981, 212, annotated by K. Ver Berne; Pas. 1979, I, 629.

Supreme Court 21 September 1979, Arr.Cass. 1979-80, 84.

Supreme Court 24 September 1981, R.W, 1982-83, 1062.

Supreme Court 1 April 1982, R.W. 1984-1985, 603; Arr.Cass. 1981-82, 963; Pas. 1982, I, 909; Bull. 1982, 909; Credoc 1983, ed. April, 7; J.T. 1983, 309.

Supreme Court 14 January 1983, Arr.Cass. 1982-83, 657; Bull. 1983, 579; Pas. 1983, I, 579; R. W. 1982-83, 2544. Supreme Court 2 June 1983, Arr.Cass. 1982-83, 1217; Bull. 1983, 1005; J.T. 1984, 298; Pas. 1983, I, 1105; R.W. 1983-84, 2047.

Supreme Court 18 November 1983, R.W. 1984-85, 47; Arr.Cass. 1983-84, 323; Pas. 1984, U, 303; J.T. 1984-549.

Supreme Court 28 February 1984, unpublished.

Supreme Court 21 June 1984, T. Aann. 1997, 323. 
Bibliography

Supreme Court 25 October 1985, T. Aann. 1986, 240, annotated by J. Embrechts; Arr.Cass. 1985-86, 270; R.W 1988-89, 670, annotated by C. Van Schoubroeck; Pas. 1986, I, 226; J.T. 1986, 438.

Supreme Court 11 April 1986, Arr.Cass. 1985-86, 1088.

Supreme Court 18 May 1987, R.W. 1988-89, 1124.

Supreme Court 12 June 1987, Arr.Cass. 1986-87, 1258; Bull. 1133; Pas. 1987, I, 1133; T.R.V. 1988, 57, annotated by S. Raes.

Supreme Court 8 April 1988, Arr.Cass. 1987-88, 1000

Supreme Court 2 November 1989, Arr.Cass. 1989-90, 298; Bull. 1990, 262; Pas. 1990, I, 262; R.W. 1989-90, 924.

Supreme Court 25 April 1991, Arr.Cass. 1190-91, 873.

Supreme Court, 12 May 1993, Bull civ I, nº 25.

Supreme Court 15 September 1994, R.A.C. 1995, 29; R.W. 1995-96, 454; Arr.Cass.1994, 748.

Supreme Court 1 December 1994, Arr.Cass. 1994, 1038; Bull. 1994, 1031; J.L.M.B. 1995, 1078, annotated by F. Moises; J.T. 1995, 316; Pas. 1994, I, 1031; R.W. 1994-1995, 1377.

Supreme Court 28 September 1995, R.W. 1995-96, 932.

Supreme Court 15 December 1995, J.L.M.B. 1986, 780; Arr.Cass. 1195, 1135.

Supreme Court 1 February 1996, Arr.Cass. 1996, 145; Bull. 1996, 164; Pas. 1996, I, 164; R.W. 1996- 97, 330.

Supreme Court 9 June 1997, Arr.Cass. 1997, 625 ; Bull. 1997, 649 ; Fiskoloog 1998, ed. 646, 1 : J.L.M.B. 1997, 1276.

Supreme Court, 7 November 1997, Arr.Cass 1997, 457.

Supreme Court 27 November 1997, Arr.Cass. 1997, 1233; Bull. 1997, 1292; Pas. 1997, I, 1292.

Supreme Court 21 December 2001, Pas. 2001, I, 22007; T.B.H. 2002, 443, annotated by W. Derijcke.

Supreme Court 22 September 2005, Juristenkrant, 2005, ed. 118, 11.

Supreme Court 10 April 2006, T.B.O. 2007, ed. 2, 113, annotated by W. Mertens, R.A.B.G., 2006, ed. 11, 795, annotated by B. Maes.

\section{Council of State}

Council of State 10 December 1952, Arr. R. v. St. 1952; R.A.C.E. 1952; Pas. 1954, IV, 41; R.J.I. 1953, 159.

Council of State 24 January 1955, R.J.I., 263.

Council of State 25 January 1962, Arr. R.v.St. 1962; R.A.A.C.E. 1962; La Construction 1962, 48; Pas. 1963, IV, 4; R.J.D.A. 1962, 155; R.J.I. 1962, 172.

Council of State 21 February 1962, Arr. Et Avis Cons. Etat, 1962, 150.

Council of State 18 January 1966, Arr. Et Avis Cons. Etat, 39.

Council of State 8 December 1967, Arr. R. v. St. 1967; T.B.P. 1969, 125; R.A.C.E. 1967; Pas. 1968, IV, 70; R.J.D.A. 1968, 202; R.J.I. 1969, 123; R.J.I. 1971, 39; Rev. dr. commun 1968, 16. 1970; L'Entreprise et le Droit, 1972, 257, annotation De Caluwé.

Council of State 9 June 1970, L'Entreprise et le Droit, 1972, 257, annotation De Caluwé.

Council of State 23 June 1970, Arr. Et Avis Cons. Etat, 1970, 645.

Council of State 4 August 1970, Arr. Et Avis Cons. Etat, 1970, 758.

Council of State 9 February 1971, R.J.I. 1973, 165.

Council of State 18 January 1974, T. Aann. 1974, 30, annotated by Flamme; T.B.P. 1975, 102; Pas. 1976, IV, 19. Council of State 22 January 1974, Arr. Et Avis. Cons. Etat, arrêt n ${ }^{\circ} 16204$.

Council of State 1 June 1979, A.P.M. 1979, 3; Arr. R. v. St. 1979, 648; R.J.I. 1980, 11; T.B.P. 1980, 69.

Council of State 28 April 1981, Pas. 1984, IV, 43; Arr. R. v. St. 1981, 582; R.A.C.E. 1981.

Council of State, 20 June 1985, R.W., 1985-86, 880; Arr. R. v. St. 1985.

Council of State 26 June 1986, R.A.C.E., 1986.

Council of State 13 October 1987, Arr.R v.St. 1987.

Council of State 24 May 1988, A.P.M. 1988, 86; Arr. R. v. St. 1988; T.B.P. 1989, 259.

Council of State 27 April 1994, Arr. R.v.St. 1994; R.A.C.E. 1994.

\section{Courts of Appeal}

Ghent 12 August 1864, B.J. 1965, 919.

Ghent 16 January 1886, Pas. 1886, II, 108.

Brussels 22 May 1902, Jur.Comm.Brux. 1906, 392. 
Ghent 9 December 1913, Pas. 1914, II, 47.

Liège 25 May 1955, J.T. 1955, 680.

Brussels 20 January 1956, R.J.I. 1957, 3496.

Brussels 30 October 1957, J.T. 1958, 22.

Brussels 2 December 1959, R.J.I., 1959, 379

Brussels 10 June 1960, R.J.I., 1960, 267.

Brussels 20 June 1960, J.T., 188.

Brussels 31 October 1961, Pas., 1962, II, 267.

Brussels 22 January 1962, J.T., 1963, 11.

Brussels 22 February 1963, Pas. 1963, II, 274; J.T., 315.

Liège 3 January 1964, R.J.I., 1964, 193.

Ghent 5 February 1966, R.W., 965-66, col. 1952.

Brussels 13 May 1966, R.J.I., 341.

Ghent 1 April 1966, R.W., 1965-1966, col. 1855.

Brussels 27 February 1967, unpublished.

Brussels 25 March 1970, Pas., 1970, II, 155, J.C.B., 1973, I, 161.

Brussels 13 May 1970, J.T., 1670, 547.

Brussels 19 April 1971, R.J.I., 1971, 113.

Brussels 14 June 1971, B.R.H. 1971, 568; J.C.B., 1971, I, 568.

Brussels 24 January 1972, T. Aann. 1980, 187, annotated by De Nève.

Brussels 3 February 1972, J.C.B., 1972, I, 416.

Brussels 13 May 1972, unpublished.

Ghent 23 February 1973, L'Entreprise et le droit, 1974, 153.

Brussels 6 October 1973, J.T., 1974, 43.

Brussels 15 November 1973, R.J.I., 1966, nº 4268.

Brussels 23 January 1975, T. Aann. 1975, 146.

Brussels 23 January 1975, T. Aann. 1975, 151

Brussels 25 November 1976, T. Aann. 1981, 261.

Antwerp 7 November 1977, Limb. Rechtsl. 1979, 73.

Brussels 28 June 1978, R.J.I. 1979, 139.

Brussels 26 September 1979, J.T. 1980, 26.

Brussels 22 May 1981, R.J.I. 1981, 269.

Anwerp 24 May 1983, R.W. 1985-86, 2718.

Ghent 8 February 1984, R.J.I. 1990, 237.

Ghent 1 March 1984, R.J.I. 1984, 331.

Brussels 11 December 1984, Ann dr. $\lg 1986,128$, annotated by Y. Hannequart.

Liège 29 October 1985, R.R.D. 1985, 339.

Brussels 25 June 1986, R.J.I. 1988, 5.

Brussels 3 February 1988, R.J.I. 1988, 275.

Liège 22 February 1988, J.L.M.B. 1988, 1284, annotated by R. De Briey.

Brussels 20 January 1989, R.G.A.R. 1991, nr. 11.764.

Brussels 8 February 1990, R.J.I. 1990, 179.

Bergen 8 October 1990, J.T 1991, 585; RGAR 1993, nr. 12.171

Antwerp 9 October 1990, T. Aann. 1997, 164, annotated by J. Embrechts.

Bergen 25 June 1991, J.L.M.B. 1992, 758, annotated by B. Louveaux.

Bergen 30 October 1991, R.R.D. 1992, 52.

Liège 6 May 1992, J.T. 1992, 797; J.L.M.B. 1992, 1268, annotated by B. Louveaux.

Ghent 9 November 1993, A.J.T. 1994-95, 67, annotated by B. De Temmerman; Pas. 1993, II, 18; R.W. 1993-94, 1235.

Antwerp 16 March 1994, Limb. Rechtsl. 1994, 21.

Brussels 22 September 1994, J.L.M.B. 1996, 1476, annotated by J. Henrotte.

Brussels 25 October 1994, R.J.I. 1995, 91.

Ghent 9 December 1994, R.W. 1995-1996, 90.

Liège 23 January 1995, J.T. 1995, 385; Pas. 1994, II, 3; R.R.D. 1995, 40.

Ghent 26 January 1995, A.J.T. 1995-96, 49.

Brussels 4 May 1995, A.J.T. 1995-96, 101. 
Brussels 15 February 1996, J.L.M.B. 1996, 1482.

Liège 20 June 1996, J.L.M.B. 1997, 382.

Ghent 20 September 1996, A.J.T. 1997-1998, 280, annotated by P. De Smedt.

Brussels 14 November 1996, J.L.M.B. 1997, 9; Jb. Hand.Med. 1996, 816; T. App. 1997, ed. 4, 30; T.B.H. 1997, 66.

Liège 26 March 1997, T. Aann. 1998, 263.

Brussels 10 April 1997, T. aann. 1997, 343.

Ghent 18 April 1997, A.J.T. 1999-00, 41.

Ghent 24 April 1997, A.J.T. 1998-99, 894.

Antwerp 13 May 1997, T. Aann. 1998, 366.

Brussels 30 September 1999, T. Aann. 2000, 146.

Antwerp 10 November 1999, A.J.T. 1999-00, 969.

Brussels 12 October 2001, A.J.T. 2001-02, 740, annotated by G. Ballon; J.L.M.B. 2002, ed. 17, 718

Liège 22 October 2001, J.L.M.B. 2002, ed. 17, 725 .

Bergen 3 June 2002, R.G.A.R. 2003, nr.13765.

Liège 28 June 2002, R.R.D. 2002, ed. 105, 458; T.Aann. 2003, ed. 8.

Brussels 18 October 2002, R.J.I. 2003, 195; Antwerp 14 October 2003, N.J.W. 2003, 1266, annotated by W. Goossens.

Antwerp 14 November 2002, R.W. 2005-2006, ed. 17, 667; T. Aann. 2003, ed. 2, 114

Antwerp 4 December 2002, N. .J.W. 2003, ed. 43, 1000, annotated by W. Goossens.

Antwerp 14 October 2003, N.J.W. 2003, ed. 50, 1266, annotated by W. Goossens; R.W. 2005-06, ed. 22, 863; TBO 2005, ed. 2, 110, annotated by M. Debaene and A. Van Grunderbeek.

Brussels 17 March 2004, R.R.D. 2004, ed. 113, 333.

Ghent 18 June 2004, T.B.O. 2004, 238.

Brussels 28 September 2004, Jb.Hand.Med. 2004, 925.

Ghent 9 June 2006, N.J.W. 2007, ed. 156, 134, annotated by K. Vanhove.

Liège 15 May 2008, R.G.A.R. 2008, afl. 10, nr. 14448 ; T. Aann. 2990, afl. 1, 70.

\section{Courts of First Instance}

Brussels 21 January 1958, R.J.I., 275.

Brussels 6 April 1964, Pas., III, 25.

Bruges 24 February 1966, T. Aann. 1966, 161; Res Jur. Imm. 1966, 161.

Leuven 21 February 1968, R.W., 1971-1972, col. 276.

Dendermonde 26 April 1968, T. Aann. 1972, 12, annotated by R. Moors.

Liège 27 September 1968, R.J.I., 1971, 35.

Arlon 28 November 1972, J.L., 1972-1973, 213.

Brussels 18 April 1989, J.T. 1989, 733.

Liège 25 June 1996, T.Aann. 1997, 222

Brussels 1 September 1998, T.B.B.R. 2000, 56.

Bergen 26 March 1999, Cah. dr. immo 2000, ed. 2, 19, annotated by J. Henrotte.

Dendermonde 21 June 2001, T. Aann. 2002, ed. 2, 159.

\section{Court of Commerce}

Court of Commerce Ghent, 26 October 1923, J.C.Fl. 1925, 72, annotated by E. Vrebos.

Court of Commerce Brussels 27 November 1970, B.R.H. 1971, 203.

Court of Commerce Brussels 24 September 1972, J.C.B., 1973, 263.

Court of Commerce Brussels 23 November 1982, T.B.H. 1983, 594.

Court of Commerce Antwerp 22 March 1985, La Construction, 11 April 1986, 7, annotated by Ph. Flamme.

\section{Labour courts}

Labour Court Bergen 23 March 1976, T.S.R. 1976, 340.

Labour Court Bergen 9 July 1979, R.G.A.R. 1982, nr. 10.454. 


\section{President competition council}

President of the Council of Competition 31 October 1995, A.J.T. 1995-1996, annotated by J. Billiet; J.L.M.B. 1996,263, annotated by J. Vergauwe; J.T. 1996, 346

\section{THE NETHERLANDS}

\section{Supreme Court}

Supreme Court 18 June 1926, NJ 1926/1021.

Supreme Court 14 November 1929, NJ 1929/1776, W. 12059.

Supreme Court 13 November 1930, NJ 1931, 247, annotated by EM M.

Supreme Court 18 March 1932, NJ 1932.

Supreme Court 15 November 1957, NJ 1958, 67.

Supreme Court 25 March 1966, NJ 1996, 279

Supreme Court 9 June 2000, NJ 2000, 460.

Supreme Court 15 December 2000, NJ 2001, 57; RvdW 2001, 8.

\section{Courts of Appeal}

Court of Appeal Arnhem 16 December 1924, NJ 1925/421.

Court of Appeal Amsterdam 6 February 1925, W. 11347.

Court of Appeal Amsterdam 29 May 1970, BR 1971, 421.

Court of Appeal 's-Hertogenbosch 25 February 1981, BR 1981, 876.

Court of Appeal Arnhem 19 August 1997, BR 1998, 416.

Court of Appeal 's-Gravenhage 18 July 2003, 02/325, unpublished.

Court of Appeal Amsterdam 8 January 2004, 1529/02, unpublished.

\section{District Courts (arrondissementsrechtbanken)}

The Hague 7 December 1926, NJ 1927/1015 and NJ 1928/1022.

Groningen 28 October 1932, NJ 1934/1557.

's-Gravenhage, 27 November 1952, NJ 1953/661.

Den Bosch 15 February 1963, NJ 1963/296.

Utrecht 15 January 1964, JAR 1964, 79.

Amsterdam 7 March 1979, BR 1979, 801

Roermond 2 June 1983, BR 1985, 480; NJ 1985/147.

Roermond 10 January 1985, BR 1986, 145.

Zwolle 6 June 1990, BR 1990, 861 .

Nijmegen 13 September 1996, nr. 4432/95/21, unpublished.

Harderwijk 18 September 1996, nr. 603/96, unpublished.

Zutphen 10 July 1997, nr. 9303 HA ZA 97-214, unpublished.

Wageningen 21 January 1998, nr. 79784 CV 1272/1996, unpublished.

Utrecht 13 May 1998, nr. 94 416-CV-97-116, unpublished.

Breda 28 October 1998, nr. 100 924/CV/98-1834, unpublished.

Almelo 12 June 2002, nr. 46570 HA ZA 773-2001, unpublished.

's-Gravenhage 22 November 2000, BR 2001, 599, annotated by M.A.M.C. van den Berg.

Eindhoven 5 June 2003, case nr. 259612, 3603/02, unpublished.

Alkmaar (Den Helder) 8 July 2004, 153390, unpublished.

Council of Arbitration for the Building Industry

Council of Arbitration for the Building Industry 2 April 1913, Jaarverslag 1913, nr. II, 6.

Council of Arbitration for the Building Industry 22 October 1917, Jaarverslag 1917, Nr. XIII, 55, W. 10.318.

Council of Arbitration for the Building Industry 31 May 1918, nr. 101, Jaarverslag 1918, Nr. IX, 37.

Council of Arbitration for the Building Industry 19 September 1918, nr. 119, Jaarverslag 1918, 93.

Council of Arbitration for the Building Industry 1921, Jaarverslag 1921, nr. XLIII, 87.

Council of Arbitration for the Building Industry 1923, Jaarverslag 1923, nr XXVIII, 124.

Council of Arbitration for the Building Industry 1925, nr. 499, Jaarverslag 1925,112. 
Bibliography

Council of Arbitration for the Building Industry 1927, nr. 566, Jaarverslag 1927, 40. Council of Arbitration for the Building Industry 1929, nr. 683, Jaarverslag 1929, 68. Council of Arbitration for the Building Industry 7 January 1932, W. 12404.

Council of Arbitration for the Building Industry 1934, nr. 954, Jaarverslag 1934, 15.

Council of Arbitration for the Building Industry 1939, nr. 1206, Jaarverslag 1939, 27.

Council of Arbitration for the Building Industry 1948, nr. 1431, Jaarverslag 1948-1949, 16

Council of Arbitration for the Building Industry 1948, nr. 1467, Jaarverslag 1948-1949, 36.

Council of Arbitration for the Building Industry 1954, nr. 2121, Jaarverslag 1954, 67.

Council of Arbitration for the Building Industry 1957, nr. 2328, Jaarverslag 1957, 19.

Council of Arbitration for the Building Industry 1958, nr. 2700, Jaarverslag 1964, 16.

Council of Arbitration for the Building Industry 1962, nr. 3828, Jaarverslag 1962, 104.

Council of Arbitration for the Building Industry 1966, nr. 4712, Jaarverslag 1966, 49.

Council of Arbitration for the Building Industry 14 May 1969, nr. 5487, BR 1969, 454.

Council of Arbitration for the Building Industry 25 July 1973, BR 1973, 808.

Council of Arbitration for the Building Industry 15 August 1973, nr. 6566, BR 1973, 799, annotated by H.O. Thunissen; NJ 1974/305, annotated by P. Zonderland.

Council of Arbitration for the Building Industry 13 June 1974, nr. 7117, BR 1974, 701; Jaarverslag 1974, 64.

Council of Arbitration for the Building Industry 3 May 1976, nr. 7713, BR 1976, 728; Bloemlezing 1976-1981, 29.

Council of Arbitration for the Building Industry 8 September 1976, nr. 7618, BR 1976, 891; Bloemlezing 19761981, 23.

Council of Arbitration for the Building Industry 8 September 1976, nr. 7637, BR 1977, 99; Bloemlezing, 19761981, 25.

Council of Arbitration for the Building Industry 7 January 1980, nr. 9329, BR 1980, 395, annotated by H.O. Thunnissen.

Council of Arbitration for the Building Industry 15 February 1980, nr. 8933, BR 1980, 628

Council of Arbitration for the Building Industry 2 April 1980, nr. 9415, BR 1980, 796.

Council of Arbitration for the Building Industry 26 August 1982, nr. 9878, BR 1982, 919.

Council of Arbitration for the Building Industry 8 December 1982, nr. 10.166, BR 1983, 160; TvA 1983/5, 175, sub 12.

Council of Arbitration for the Building Industry 16 December 1982, nr. 9473, TvA 1983/5, sub 2; Bloemlezing 1981-82, 132

Council of Arbitration for the Building Industry 20 September 1983, BR 1984, 535.

Council of Arbitration for the Building Industry 7 October 1983, nr. 11.380, BR 1984, 166, annotated by H.O. Thunissen.

Council of Arbitration for the Building Industry 15 February 1985, nr. 11.366, unpublished.

Council of Arbitration for the Building Industry 27 January 1986, BR 1986, 462.

Council of Arbitration for the Building Industry 16 June 1986, nr. 12 219, BR 1987, 59.

Council of Arbitration for the Building Industry 19 August 1987, nr. 12.508, BR 1988, 217, annotated by H.O Thunnissen.

Council of Arbitration for the Building Industry 3 December 1987, nr.12.541, B.R. 1989, 297.

Council of Arbitration for the Building Industry 7 November 1988, nr. 13.378, BR 1989, 222.

Council of Arbitration for the Building Industry 22 January 1990, nr. 13.592, BR 1990, 859, annotated by H.O. Thunnisen.

Council of Arbitration for the Building Industry 11 December 1991, nr. 14.356, $B R$ 1992, 332, annotated by H.O. Thunissen.

Council of Arbitration for the Building Industry 8 May 1992, nr. 15.616, unpublished.

Council of Arbitration for the Building Industry 19 July 1993, nr.15.252, BR 1993, 920, annotated by H.O. Thunnissen.

Council of Arbitration for the Building Industry 20 January 1994, nr. 14.859, BR 1994, 683, annotated by H.O. Thunnissen.

Council of Arbitration for the Building Industry 1 August 1994, nr. 17.337 BR 1994, 880.

Council of Arbitration for the Building Industry 15 December 1994, nr. 16.977, unpublished.

Council of Arbitration for the Building Industry 7 February 1996, nr. 17.177, unpublished.

Council of Arbitration for the Building Industry 4 July 1997, nr. 18.297, unpublished. 
Bibliography

Council of Arbitration for the Building Industry 18 August 1997, BR 2000, 704, annotated by M.A.M.C. van den Berg.

Council of Arbitration for the Building Industry 16 November 1998, nr. 70.352, unpublished.

Council of Arbitration for the Building Industry 25 August 1999, nr. 70.422, unpublished.

Council of Arbitration for the Building Industry 12 July 2000, nr. 21.273, BR 2000, 167.

Council of Arbitration for the Building Industry 21 September 2001, BR 2002, 149.

Council of Arbitration for the Building Industry 8 April 2002, nr. 21.877, unpublished.

Council of Arbitration for the Building Industry 2 July 2002, nr. 22.740, unpublished.

Council of Arbitration for the Building Industry 17 April 2003, nr. 25.113, unpublished.

Council of Arbitration for the Building Industry 2 June 2003, nr. 23.438, unpublished.

Council of Arbitration for the Building Industry 5 November 2003, nr. 23.526, unpublished.

Council of Arbitration for the Building Industry 22 November 2004, nr. 26.444, unpublished.

Council of Arbitration for the Building Industry 11 February 2005, nr. 25.811, unpublished.

Council of Arbitration for the Building Industry 13 April 2005, nr. 24.753, unpublished.

Council of Arbitration for the Building Industry 17 August 2005, nr. 25.084, BR 2006, 55.

Council of Arbitration for the Building Industry 16 November 2005, nr. 27.016, unpublished.

Council of Arbitration for the Building Industry 13 February 2006, 23.839, unpublished.

Council of Arbitration for the Building Industry 28 April 2006, nr. 56.282, unpublished.

Council of Arbitration for the Building Industry 11 May 2006, nr. 28.107, unpublished.

Council of Arbitration for the Building Industry 17 Augustus 2006, nr. 27.297, unpublished.

Council of Arbitration for the Building Industry 22 August 2006, nr. 70.929/70.940, unpublished.

Council of Arbitration for the Building Industry 26 March 2007, nr. 71.059, unpublished.

Council of Arbitration for the Building Industry 9 May 2007, nr. 28.679, unpublished.

\section{Arbitration Institute Architecture}

Arbitration Institute Architecture 25 March 1980, BR 1980, 641; TvA 1980/5, 124

Arbitration Institute Architecture 4 December 2002, nr. 1200-0162, unpublished.

Arbitration Institute Architecture 3 February 2003, BR 2004, 75.

Arbitration Institute Architecture 12 September 2003, nr. 1200-0204, unpublished.

Arbitration Institute Architecture 16 January 2004, BR 2005, 155. 
Bibliography

\section{Internet links}

http://ec.europa.eu/comm/competition/sectors/professional_services/overview_en.html http://ec.europa.eu/competition/sectors/professional_services/studies/studies.html $\mathrm{http}: / /$ ec.europa.eu/education/policies/rec_qual/recognition/in_en.html http://ec.europa.eu/internal_market/qualifications/docs/future/faq_en.pdf $\mathrm{http} / /$ ec.europa.eu/internal_market/qualifications/docs/future/platforms_en.pdf http://ec.europa.eu/internal_market/services/docs/services-dir/explanatory/completing_UE_SM_for_services_en.pdf

http://ec.europa.eu/internal_market/smn/smn39/docs/specialfeature_en.pdf

http://ec.europa.eu/internal_market/top_layer/index_19_en.htm

http://europa.eu.int/rapid/pressReleasesAction.do?reference=IP/02/393\&format=HTML\&aged=1\&language=

EN\&guiLanguage $=$ en

http://europa.eu/rapid/pressReleasesAction.do?reference=SPEECH/06/687

http://europa.eu/scadplus/leg/en/cha/c11065.htm.

http://www.abgs.gov.tr/tarama/tarama_files/03/SC03DET_mutual_recognition.pdf

http://www.ace-cae.org/

http://www.arbitrageinstituutbouwkunst.org/arbiters/index.html

http://www.arbitrageinstituutbouwkunst.org/curatorium/index.html

http://www.architectenregister.nl

http://www.architectenregister.nl/pdf/01_sba.pdf

http://www.architectenwerk.nl/architectenpraktijk02/Architectendata

http://www.architekton.com

http://www.bna.nl/binaries/bna-downloads-3/infoblad-the-architectural-profession-in-nl.pdf

http://www.bna.nl/binaries/bna-downloads-3/02-algemene-voorwaarden-consument-architect.pdf

http://www.bna.nl/nl/nieuws/persberichten,2008/02/bna-academie.html

http://www.bna.nl/nl/nieuwsberichten,bna/2008/06/wet-arch-titel.html

http://www.bna.nl/nl/overbna

http://www.ccbe.org/fileadmin/user_upload/NTCdocument/rbb_ihs_critique_en1_1183706206.pdf

http://www.cepani.be/NL/

http://www.eaae.be/eaae2/info.php?mainType=about\&help=about

http://www.echo.nl/al-bu/wonen/redactie/836573/uniek.project.in.almere.poort/

http://www.emr-sb.de/EMR/Portrayalofviolence_media.pdf

http://www.enhsa.net

http://www.entemp.ie/trade/marketaccess/singlemarket/servicesDirective.htm

http://www.europarl.eu.int/oeil/resume.jsp?id=220062\&eventId=53758\&backToCaller=NO\&language=en

http://www.europarl.europa.eu/activities/committees/studies/download.do?language $=$ fr $\&$ file $=27071$

http://www.europarl.europa.eu/facts_2004/3_2_3_en.htm

http://www.fab-arch.be/architectuur/historische_context.php

http//www.fab-arch.be/architectuur/historische_geboorte.php

http://www.fenca.org/uploads/Surveys/codeconduct_en.pdf

http://www.groupe-cea.com/upload/doc_stheme/Document_en/16/_liabilities_in_Europe.pdf

http://www.interfidesko.be/archit.htm

http://www.jssgallery.org/Essay/Ecole_des_Beaux-Arts/Ecole_des_Beaux-Arts.htm

http://www.martineau-uk.com/publication_event/updates/crosssubt_full.pdf

http://www.mo.org/tr./UIKDocs\%5Cacecompetitionpolicy.pdf

http://www.nav.be/site2/interview-detail.php?id=13

http://www.oecd.org/document/30/0,3343,en_2649_34111_38979998_1_1_1_1,00.htm

http://www.ordredesarchitectes.be/nl/teksten/cea/TABEL.PDF

http://www.pinakes.be/static/pinakes_checklistoverheidsopdrachten.aspx

htpp://www.protect.be/_CLIENTS/Protect/Documenten/2007-2-27-(121511)_De\%20Tijd.pdf

http://www.raadvoorhetvrijeberoep.nl/

http://www.tobb.org.tr/abm/haberler/09ilerleme/Tarama\%20Raporu.pdf

http://www.uia-architectes.org/texte/england/Menu-1/0-pourquoi-new.htm

http://www2.gsb.columbia.edu/faculty/rfisman/regulationentry.pdf

http://ec.europa.eu/internal_market/qualifications/regprof/index.cfm?fuseaction=stats.ranking\&services=false 


\section{CURRICULUM VITAE}

Sarah Schoenmaekers (1983) studied law at the European Law School of Maastricht University. She participated at the René Cassin European Human Rights Moot Court Competition in Strasbourg in 2005 in which her team was qualified as the best nonnative French speaking European team. After graduating in 2005 she took the Flemish Bar Exam and began her career as a lawyer in Belgium. During her traineeship Sarah Schoenmaekers started to write a $\mathrm{PhD}$ about the regulation of architects in Belgium and the Netherlands. Since 2009 she is teaching several courses, under which substantive European Union law, at Maastricht University and Hasselt University. She is a full member of the Bar of Tongeren (Belgium). 



\section{IUS COMMUNE EUROPAEUM}

A peer-reviewed book series in which the common foundations of the legal systems of the Member States of the European Community are the central focus.

The Ius Commune Europaeum series includes horizontal comparative legal studies as well as studies on the effect of treaties within the national legal systems. All the classic fields of law are covered. The books are published in various European languages under the auspices of METRO, the Institute for Transnational Legal Research at the Maastricht University.

Editorial Board: Prof.Dr. J. Smits (chair), Prof.Dr. M. Faure, Prof.Dr. Chr. Joerges, Prof.Dr. J. Du PLESSIS and Prof.Dr. E. Vos.

Recently published:

Volume 76: European Cooperation between Financial Supervisory Authorities, Tax Authorities and Judicial Authorities, M. LUCHTMAN

Volume 77: Access to Justice and the Judiciary: Towards New European Standards of Affordability, Quality and Efficiency of Civil Adjudication, A. UzELAC and C.H. VAN RHEE (eds.)

Volume 78: The European Private Company (SPE): A Critical Analysis of the EU Draft Statute, D.F.M.M. ZAMAN, C.A. SChWARZ, M.L. LenNarTS, H.-J. DE Kluiver and A.F.M. DORRESTEIJN (eds.)

Volume 79: Constitutions Compared. An Introduction to Comparative Constitutional Law (2nd edition), A.W. HeRINGA and Ph. KIIVER

Volume 80: Rechtsbescherming en overheidsovereenkomsten, K. WAUTERS

Volume 81: Derden in het contractenrecht, I. SAMOY

Volume 82: The Right to Specific Performance. The Historical Development, J.H. DoNDORP and J.J. HALLEBEEK (eds.)

Volume 83: Financial Supervision in a Comparative Perspective, M. РОтО

Volume 84: Enforcement and Enforceability - Tradition and Reform, C.H. VAN RHEE and A. UZELAC (eds.)

Volume 85: Fact-Finding in Civil Litigation. A Comparative Perspective, R. VERKERK

Volume 86: The Making of Chinese Condominium Law. A Comparative Perspective with American and South African Condominium Laws, L. CHEN

Volume 87: Effective Criminal Defence in Europe, E. CAPE, Z. NAMORADZE, R. SMitH and T. SPRONKEN 